\title{
Project Report for the Commercial Disposal of Mixed Low-Level Waste Debris
}

\author{
G. Andrews \\ V. Balls \\ T. Shea \\ T. Thiesen
}

Published May 1994

\section{Idaho National Engineering Laboratory \\ EG\&G Idaho, Inc. Idaho Falls, Idaho 83415}


• 


\section{DISCLAIMER}

This report was prepared as an account of work sponsored by an agency of the United States Government. Neither the United States Government nor any agency thereof, nor any of their employees, make any warranty, express or implied, or assumes any legal liability or responsibility for the accuracy, completeness, or usefulness of any information, apparatus, product, or process disclosed, or represents that its use would not infringe privately owned rights. Reference herein to any specific commercial product, process, or service by trade name, trademark, manufacturer, or otherwise does not necessarily constitute or imply its endorsement, recommendation, or favoring by the United States Government or any agency thereof. The views and opinions of authors expressed herein do not necessarily state or reflect those of the United States Government or any agency thereof. 


\section{DISCLAIMER}

Portions of this document may be illegible in electronic image products. Images are produced from the best available original document. 


\section{EXECUTIVE SUMMARY}

This report summarizes the basis for the commercial disposal of Idaho National Engineering Laboratory (INEL) mixed low-level waste (MLLW) debris and the associated activities. Mixed waste is radioactive waste plus hazardous waste as defined by the Resource Conservation and Recovery Act (RCRA). The critical factors for this project were DOE 5820.2A exemption, contracting mechanism, NEPA documentation, sampling and analysis, time limitation and transportation of waste. This report also will provide a guide or a starting place for future use of Envirocare of Utah or other private sector disposal/treatment facilities, and the lessons learned during this project.

Initially 90 drums/containers of INEL MLLW were identified that could potentially meet Envirocare of Utah's radiological waste acceptance criteria (WAC). This list was then reduced to 29 drums/containers (580 cf) of MLLW debris that represented 14 waste streams (after laboratory analysis these were consolidated to 10 waste streams) that met three final criteria:

1. Candidate waste had to meet the "debris" definition given by EPA. All of the waste streams were visually inspected to ensure compliance with this criterion.

2. The waste appeared to meet Envirocare of Utah's waste acceptance criteria (WAC) based on existing waste documentation.

3. Existing documentation had to provide adequate information to allow safe sampling.

Sampling and follow-on laboratory analysis were performed on 29 drums/containers in accordance with the project Sample Analysis Plan, Site Work Release and Envirocare of Utah's material acceptance criteria procedures. Envirocare of Utah's permit only allows "Utah-certified" laboratory data for waste characterization. The laboratory analyses provided data required by the Envirocare of Utah RCRA Part B permit and NRC license for a complete waste profile. With this data, 15 drums $(100 \mathrm{ct})$ of the 29 drums/containers $(580 \mathrm{ct})$ were identified to fully comply with Envirocare of Utah's WAC. Of the $480 \mathrm{cf}$ that did not meet Envirocare of Utah's WAC, approximately $200 \mathrm{cf}$ had been "conservatively" classified by the generator as MLLW based on "process knowledge" and incomplete sampling. This waste will be reclassified as LLW that can be disposed of at the Radioactive Waste Management Complex (RWMC) at the INEL. Approximately $280 \mathrm{cf}$ of waste exceeded the upper limits of the Envirocare of Utah radiological WAC and remains in storage at the Mixed Waste Storage Facility (MWSF) at the INEL.

An unexpected result of this project is confirmation of industry and regulatory agency concern over the quality, cost, and complexity of characterizing heterogeneous debris waste streams. As noted above, only $1 / 6$ of the waste originally believed to meet the Envirocare of Utah waste acceptance criteria was disposed at Envirocare. 
Conclusions derived from this commercial disposal of MLLW debris project include:

- Future planning for these waste streams must consider the impact of additional characterization, time, and cost.

- With the high storage costs of MLLW and the limited storage space available, conservative classification of LLW as MLLW is expensive when compared to initial sampling and analysis costs at the time waste is generated.

- Disposal of DOE waste at offsite facilities should be considered as an alternative. The volume of waste treated or disposed should be maximized for every project to reduce the overall costs per unit volume.

The major accomplishment of the project is the accurate disposition of 580 cf of MLLW debris and disposal of $300 \mathrm{cf}$ of this waste. Approximately $200 \mathrm{cf}$ will be disposed at the RWMC and $100 \mathrm{cf}$ at Envirocare of Utah.

Based on this project, the two primary recommendations are (1) the generators of MLLW should be required to prepare a plan for storage, treatment, and disposal prior to generation of waste, and (2) the General Plant Project (GPP) to provide for sampling facilities at the MWSF should be given a high priority. Sampling at alternate temporary facilities requires site-specific procedures, schedules, and learning curves. A designated sampling facility will provide routine procedures and dedicated personnel to perform this work at a lower cost. 


\section{CONTENTS}

EXECUTIVE SUMMARY $\ldots \ldots \ldots \ldots \ldots \ldots \ldots \ldots \ldots \ldots \ldots \ldots \ldots \ldots \ldots \ldots \ldots \ldots$ iii

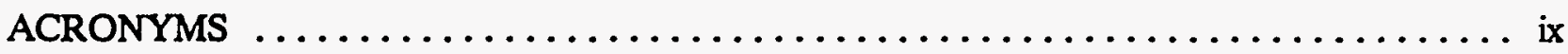

1. INTRODUCTION $\ldots \ldots \ldots \ldots \ldots \ldots \ldots \ldots \ldots \ldots \ldots \ldots \ldots \ldots \ldots \ldots$

2. PROJECT BASIS $\ldots \ldots \ldots \ldots \ldots \ldots \ldots \ldots \ldots \ldots \ldots \ldots \ldots \ldots \ldots \ldots \ldots$

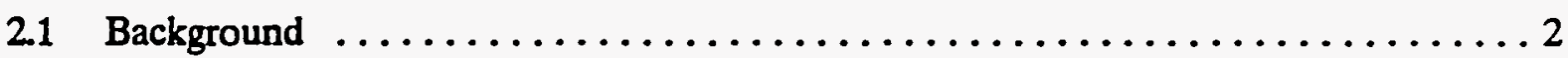

22 Preliminary Project Definition $\ldots \ldots \ldots \ldots \ldots \ldots \ldots \ldots \ldots \ldots \ldots \ldots \ldots \ldots \ldots \ldots \ldots \ldots$

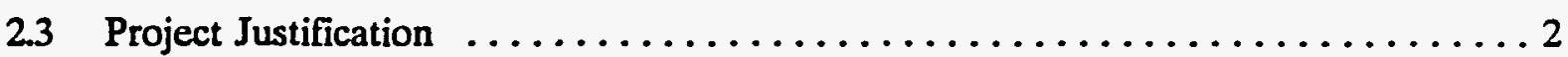

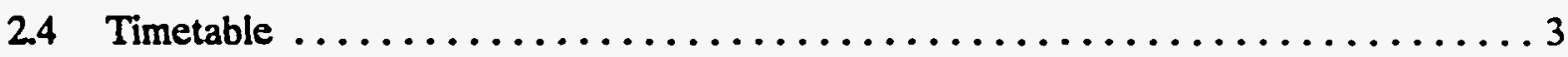

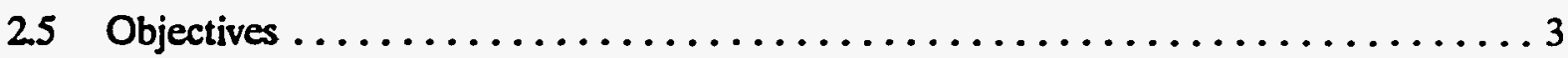

3. PROJECT MANAGEMENT PLAN $\ldots \ldots \ldots \ldots \ldots \ldots \ldots \ldots \ldots \ldots \ldots \ldots \ldots \ldots \ldots \ldots \ldots \ldots \ldots$

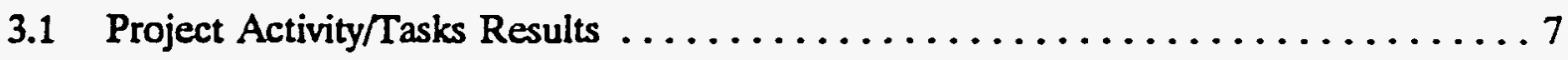

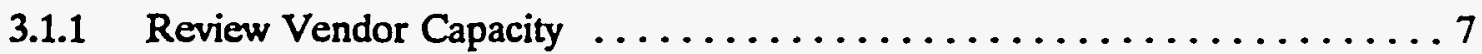

3.1.2 Review Army Corps of Engineers (COE) Contract ............. 7

3.1.3 Review INEL MLLW and Vendor WAC $\ldots \ldots \ldots \ldots \ldots \ldots \ldots \ldots$

3.1.4 Review MLLW Packaging for Transportation ............... 8

3.1.5 Prepare NEPA Documentation, Environmental Checklist (EC) and

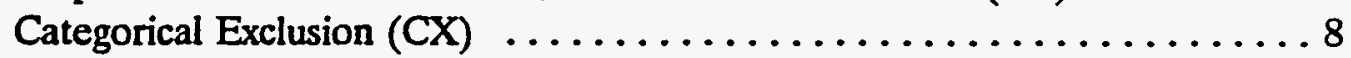

3.1.6 Formulate Waste Disposal PIan $\ldots \ldots \ldots \ldots \ldots \ldots \ldots \ldots \ldots \ldots \ldots$

3.1.7 DOE CX Approval ..........................

3.1.8 Review of Disposal Plan by EG\&G Idaho, Inc., and DOE $\ldots \ldots \ldots \ldots .8$

3.1.9 Secure Facility to Take Samples and Repackage $\ldots \ldots \ldots \ldots \ldots \ldots .9$

3.1.10 Prepare Sample Analysis Plan (SAP) .................... 9

3.1.11 Contract for Laboratory Sample Analysis $\ldots \ldots \ldots \ldots \ldots \ldots \ldots . \ldots$

3.1.12 Prepare Papers and Ship to Sampling Facility ................

3.1.13 Prepare SWR to Take Samples and Repackage $\ldots \ldots \ldots \ldots \ldots \ldots \ldots$

3.1 .14 DOE-ID Approval $\ldots \ldots \ldots \ldots \ldots \ldots \ldots \ldots \ldots \ldots \ldots$

3.1.15 Take Samples ........................... 10

3.1.16 Send Samples to Laboratory and Envirocare of Utah $\ldots \ldots \ldots \ldots \ldots 10$

3.1.17 Laboratory Analysis and Return Results .................. 10

3.1.18 Prepare Waste for Shipping (Packaging and Labels) $\ldots \ldots \ldots \ldots \ldots \ldots 10$

3.1.19 Fill Out Envirocare of Utah Forms .................. 10

3.1.20 Send Envirocare of Utah Forms and Lab Profiles for Approval ........ 10

3.1.21 Envirocare of Utah Sends Notice of Transport .............. 10

3.1.22 Prepare DOE/COE Contract Delivery Order $\ldots \ldots \ldots \ldots \ldots \ldots \ldots$ 
3.1.23 Notify Envirocare of Utah of Shipping Date $\ldots \ldots \ldots \ldots \ldots \ldots \ldots 11$

3.1.24 Envirocare of Utah Approves Shipping Date $\ldots \ldots \ldots \ldots \ldots \ldots \ldots 11$

3.1.25 Prepare Manifest and Fax to Envirocare of Utah ............. 11

3.1.26 Load and Transport Waste to Envirocare of Utah $\ldots \ldots \ldots \ldots \ldots 11$

3.1.27 Waste Disposal .............................. 11

4. EPA PERMTTS AND DOE REGULATIONS $\ldots \ldots \ldots \ldots \ldots \ldots \ldots \ldots \ldots \ldots \ldots$

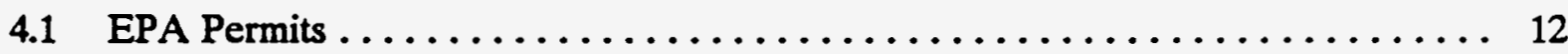

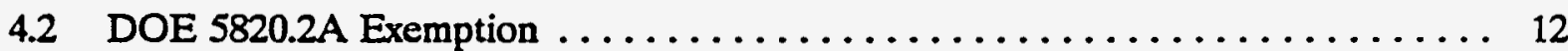

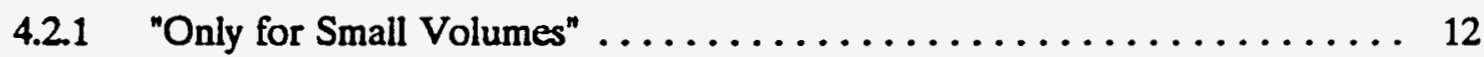

4.2.2 "Appropriate NEPA Documentation Shall Be Prepared" ........... 12

4.2.3 "Appropriate CERCLA, RCRA, TSCA Documentation Shall

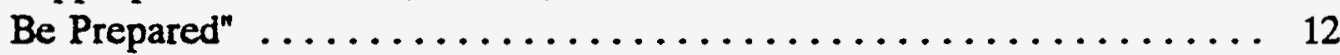

4.24 "Appropriate Procurement or Contracting Documents Shall Be Prepared" ................................ 12

4.2.5 "Review of Disposal Facility Permits, Licenses, Approvals, and Regulatory Records" ........................ 12

4.2.6 Treatment Necessary for Land Disposal" ................. 12

4.2.7 "LLW Compact and State Acceptance of DOE Waste" ........... 13

4.2.8 "All Wastes that are Land Disposal Restricted Shall Meet Best Demonstrated Available Technology" ................... 13

4.2.9 "Notify EM-33 Prior to Each Shipment Campaign" ............. 13

4.2.10 The Regulatory Status of the Disposal Facility Shall Be Confirmed" .... 13

4.2.11 "Periodic Reviews of the Disposal Facility Shall Be Conducted" ...... 13

5. PROJECT GO OR NO-GO ISSUES $\ldots \ldots \ldots \ldots \ldots \ldots \ldots \ldots \ldots \ldots \ldots \ldots \ldots \ldots$

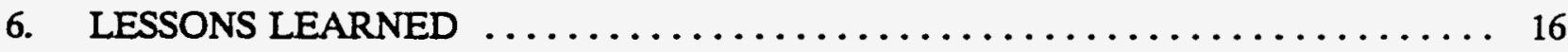

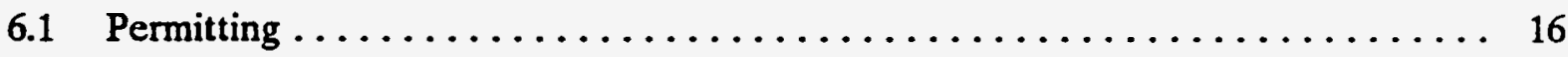

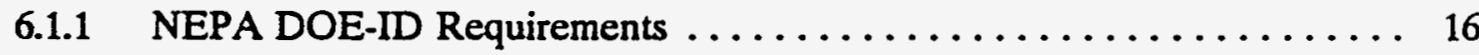

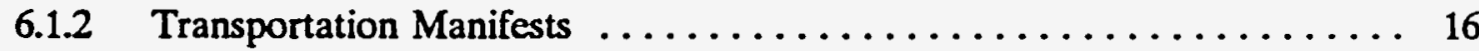

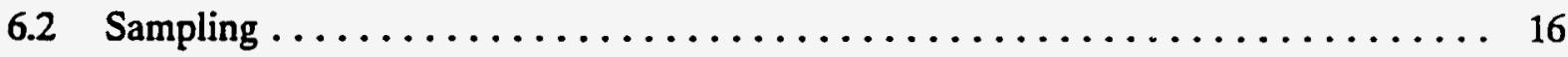

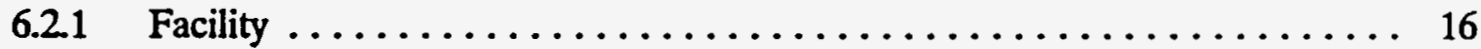

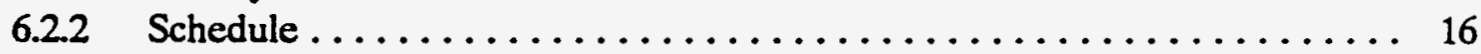

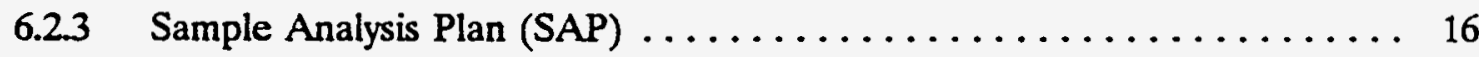

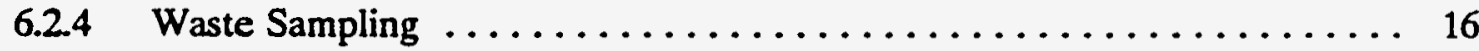

6.3 Laboratory Analysis $\ldots \ldots \ldots \ldots \ldots \ldots \ldots \ldots \ldots \ldots \ldots \ldots \ldots \ldots \ldots \ldots \ldots \ldots$

6.3.1 Contracting and Schedule $\ldots \ldots \ldots \ldots \ldots \ldots \ldots \ldots \ldots \ldots \ldots \ldots \ldots$ 


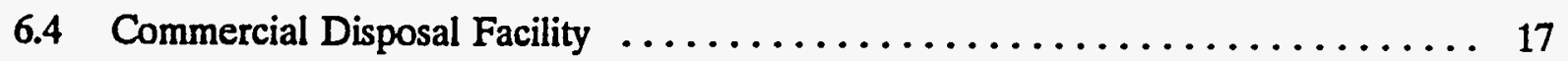

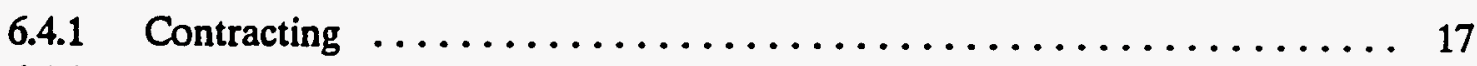

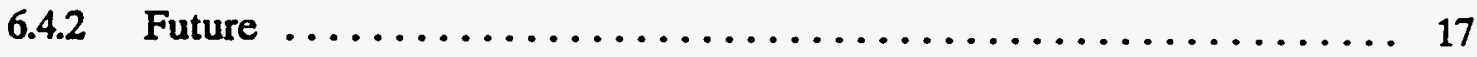

7. CONCLUSIONS/ACCOMPLISHMENTS $\ldots \ldots \ldots \ldots \ldots \ldots \ldots \ldots \ldots \ldots \ldots$

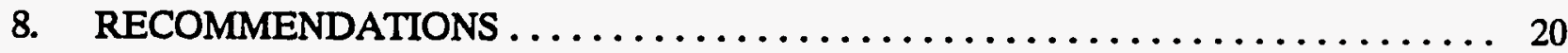

9. PROJECT COST SUMMARY $\ldots \ldots \ldots \ldots \ldots \ldots \ldots \ldots \ldots \ldots \ldots \ldots \ldots \ldots \ldots \ldots \ldots$

Appendix A-Case-by-Case Variance Extension $\ldots \ldots \ldots \ldots \ldots \ldots \ldots \ldots \ldots \ldots \ldots \ldots \ldots \ldots \ldots \ldots$

Appendix B-Project Management Plan $\ldots \ldots \ldots \ldots \ldots \ldots \ldots \ldots \ldots \ldots \ldots \ldots \ldots \ldots \ldots \ldots \ldots \ldots \ldots$

Appendix C-ESH\&Q Liability Assessment Report $\ldots \ldots \ldots \ldots \ldots \ldots \ldots \ldots \ldots \ldots \ldots \ldots \ldots \ldots$

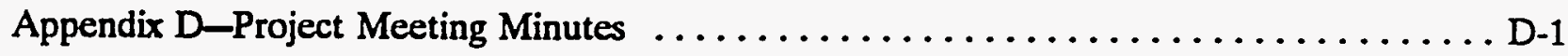

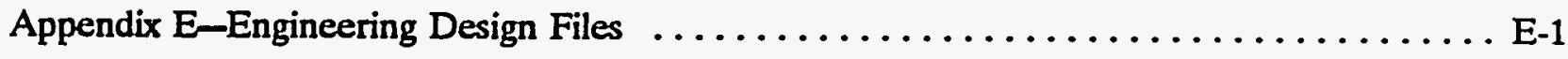

Appendix $\mathrm{F}-$ Categorical Exclusion and DOE 5820.2A Exemption Requirements ........ F-1

Appendix G-Sample Analysis Plan $\ldots \ldots \ldots \ldots \ldots \ldots \ldots \ldots \ldots \ldots \ldots \ldots \ldots \ldots \ldots \ldots \ldots \ldots \ldots$

Appendix H-Laboratory Analysis Contracts $\ldots \ldots \ldots \ldots \ldots \ldots \ldots \ldots \ldots \ldots \ldots \ldots \ldots \ldots \ldots$

Appendix I-U.S. Army Corps of Engineers Contract $\ldots \ldots \ldots \ldots \ldots \ldots \ldots \ldots \ldots \ldots$ I-1

\section{TABLE}

1. Interim transport and disposal schedule

$\ldots 5$ 
, 


\section{ACRONYMS}

CERCLA Comprehensive Environmental Response, Compensation, and Liability Act

cf

cubic feet

CFA Central Facilities Area

COE Corp of Engineers

CX categorical exclusion

DOE U.S. Department of Energy

DOE-ID Department of Energy Idaho Operations Office

EC environmental checklist

EDF Engineering Design File

EPA Environmental Protection Agency

ESH\&Q Environmental Safety, Health, and Quality

GPP General Plant Project

INEL Idaho National Engineering Laboratory

LDR land disposal restriction

LLW low-level waste

MLLW mixed low-level waste

MWSF Mixed Waste Storage Facility

NEPA National Environmental Policy Act of 1969

NRC Nuclear Regulatory Commission

PSPI Private Sector Participation Initiative

RCRA Resource Conservation and Recovery Act

RWMC Radioactive Waste Management Complex

SAP Sampling and Analysis Plan 
SOP Standard Operating Procedure

TSCA Toxic Substances Control Act

WAC waste acceptance criteria

WERF Waste Experimental Reduction Facility

WERF TAA Waste Experimental Reduction Facility Temporary Accumulation Area

WINCO Westinghouse Idaho Nuclear Corporation

WROC Waste Reduction Operations Complex 


\section{Project Report for the Commercial Disposal of Mixed Low-Level Waste Debris}

\section{INTRODUCTION}

This report summarizes the efforts to dispose of MLLW debris at a commercially operated mixed waste disposal facility. The text fully describes the project, including the schedule. The appendices contain copies of the key documents and reports generated and referenced by this project. This information has been assembled in this manner to provide other similar projects with a point of reference and to share lessons learned. 


\section{PROJECT BASIS}

\subsection{Background}

The INEL has been generating and storing mixed low-level waste (MLLW) at the INEL. The disposal of this waste is regulated under RCRA, NRC and DOE orders. Most of this waste now requires treatment prior to disposal to meet standards specified by the EPA. Once these wastes meet the established standards, they may be disposed in an appropriate landfill. The Radioactive Waste Management Complex (RWMC) Subsurface Disposal Area is a nonpermitted landfill unit. In fact, the INEL does not operate a permitted hazardous or mixed waste landfill. DOE at Hanford has constructed a landfill, but permitting has not been completed.

The DOE 5820.2A requirements generally prohibit disposal of DOE RCRA-regulated LLW wastes at a commercial facility. However, the Assistant Secretary of the Department of Energy has recently allowed an exemption for the offsite disposal of small quantities of mixed wastes. Envirocare of Utah, an offsite permitted land disposal unit, was identified and can accept some INEL wastes. This project was initiated to establish a contract mechanism, and to develop the necessary interfaces and INEL expertise to demonstrate safe, proper disposal of mixed waste as required under current DOE and EPA regulations.

\subsection{Preliminary Project Definition}

A meeting was held on November 22, 1993, to discuss and outline this project. Waste Reduction Operations Complex (WROC) Technical Programs requested the Private Sector Participation Initiative (PSPI) unit to assist with the contract preparation and project management of the commercial disposal of mixed low-level waste debris.

\subsection{Project Justification}

The following is an itemized criteria list that formed the basis for this project.

- The INEL is running out of MLLW storage facilities, with the potential for exceeding the INEL allowable storage capacity for MLLW.

- Direct land disposal of the debris waste prior to enforcement of land disposal restriction (LDR) treatment standards is allowed (prior to the May 8, 1994 deadline).

- DOE has no Subtitle $\mathrm{C}$ disposal facility for disposal of such waste.

- Even with waste treatment, there are no permitted DOE disposal sites.

- Oak Ridge is negotiating a contract with Envirocare of Utah. (April 1994, Oak Ridge Laboratory awarded a \$23 M subcontract for waste disposal services with Envirocare of Utah that could be extended to $\$ 350 \mathrm{M}$ over five years.)

- $\quad$ MLLW storage costs ( $\$ 75 / \mathrm{cf} / \mathrm{yr})$ would be eliminated. 
- Treatment costs would be avoided because the waste was not required to be treated prior to disposal.

- Estimated treatment costs are $\$ 200,000$ per waste stream.

- In summary, the project was justified by the prospect of eliminating $\$ 22,500$ per year storage costs, treatment costs, and treatability testing costs.

\subsection{Timetable}

The Environmental Protection Agency allowed an extension of direct land disposal of MLLW until May 8, 1994 (see Appendix A). This extension was allowed to provide time to search and develop possible treatment processes. Direct land disposal was predicated on assurance that no treatment process was available at the time of disposal. This project was started and scheduled to allow the maximum time to develop treatment processes. On March 21, 1994, treatment process development was again investigated. No approved processes were available. Shipment was then approved to Envirocare of Utah and completed on March 29, 1994. See Table 1 for interim schedule. See Appendix B for a complete project schedule and associated logic.

\subsection{Objectives}

The objective of this project is to demonstrate successful disposal of INEL MLLW debris at an offsite commercial disposal facility. 
Table 1. (continued).

\begin{tabular}{|c|c|}
\hline 2 & REVIEN YENOCA CAPACITY \\
\hline 4 & REYIEN COE CONTRAGT \\
\hline & REVIEN INE KLI E VENOA XAC \\
\hline & REVIEX WLY PACKAGING FOA TRANSFARTABILITY \\
\hline
\end{tabular}

$\operatorname{confit} \operatorname{coses}$

$\begin{array}{lll}20 & 1 & \text { Y } \\ 15 & 1 & \text { V } \\ 25 & 1 & \text { SNM } \\ 15 & 1 & \text { Y }\end{array}$

IHANSHUHI ANU L

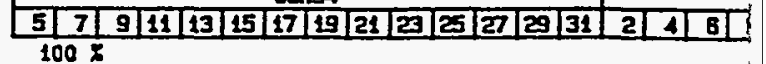

5 Jan

5 Jan

5 Jan

5Jan$$
100 x
$$

$100 \times$

$100 x$

17Jan

$100 x$ 
SPUSAL UF INEL MLLW

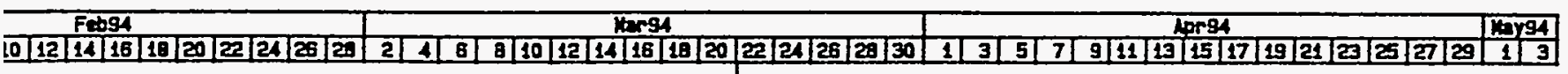

BFeb $T F=0$

Data Date

2110er

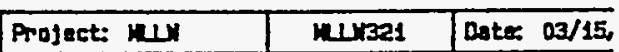

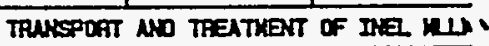

\begin{tabular}{|l|l}
\hline Page 1 & Vandell Ba11:
\end{tabular} 


\section{PROJECT MANAGEMENT PLAN}

\subsection{Project Activity/Tasks Results}

The following is a summary of the results of each project task. The order of discussion follows the logic shown on the schedule in Appendix B.

\subsubsection{Revlew Vendor Capacity}

A two-day waste acceptance training session at Envirocare of Utah was scheduled for January 25-26, 1994, and attended by the required team members. This training session was the first time the sampling and analysis requirements were fully identified for this project. The project schedule was accelerated by five weeks to allow third party analysis and validation of our sampling process by Envirocare of Utah. Backing up from the May 8, 1994, disposal deadline, a "drop dead" shipping date of March 29, 1994, was required. An additional project meeting was held to identify any "project fatal" activities and obtain commitment to the new accelerated schedule. It was agreed that it would be very difficult to meet this schedule but there were no "project fatal" activities identified.

An ESH\&Q audit of Envirocare of Utah was performed by EG\&G Idaho, Inc., for another project and was used for this project (see Appendix $\mathrm{C}$ for a copy and further details).

\subsubsection{Review Army Corps of Engineers (COE) Contract}

Two methods for contracting were discussed: (1) using an existing government contract or (2) negotiating a new contract. With the time constraint and past experience in establishing contracts of this nature, it was decided to use an existing government contract. DOE Oak Ridge had begun negotiating a contract with Envirocare of Utah early in 1993 but didn't expect to have it finalized until spring or summer 1994. The COE was in the final stages of negotiating a government-wide contract with Envirocare of Utah. Westinghouse Idaho Nuclear Corporation (WINCO) had been working with DOE-ID and was in the final stages of establishing an interagency agreement with the Corps of Engineers (COE) to access this contract. A meeting was held on December 15, 1993, with DOE-ID personnel with agreement that use of the COE contract was acceptable and to proceed in this manner. The interagency agreement between DOE-ID and the Army COE was finalized February 1, 1994.

Copies of the COE contract were distributed and reviewed by selected legal and environmental personnel at EG\&G Idaho, Inc., A review meeting was held on January 21, 1994. There were no major "no-go" issues; however, some concerns were noted and documented in the meeting minutes (See Appendix D).

\subsubsection{Review INEL MLLW and Vendor WAC}

This activity formed the basis for the quantity of INEL MLLW to be sampled and sent to Envirocare of Utah. The methods and results of this activity are documented in EDF WROC-EDF-220 (See Appendix E). Existing waste profile data were researched for compliance 
with Envirocare of Utah's WAC and the COE contract provisions. This list was then further refined to contain only waste that met the three final criteria:

- Candidate waste had to meet the "debris" definition given by EPA. All of the waste streams were visually inspected to ensure compliance with this criterion.

- The waste appeared to meet Envirocare of Utah's WAC, based on existing waste documentation.

- Existing documentation had to provide adequate information to allow safe sampling.

A project meeting was held to establish a final list of adequately documented waste streams to safely perform the sampling activities. This then became the final list for the sampling and follow-on analysis activity.

\subsubsection{Review MUW Packaging for Transportation}

On January 18, 1994, an inspection of every identified waste stream container for transportability was performed. Only two packages were noted with any work needed prior to shipping.

\subsubsection{Prepare NEPA Documentation, Environmental Checklist (EC) and Categorical Exclusion (CX)}

An Environmental Checklist (EC) and Categorical Exclusion (CX) were prepared by EG\&G Idaho, Inc., for DOE-ID approval (see Appendix F). DOE-ID had been working with WINCO on a similar effort and they decided to modify their EC and CX to include all of the INEL contractors. This task was completed two weeks ahead of schedule as a result of this action. The EC and CX prepared by this project were filed as additional documentation.

\subsubsection{Formulate Waste Disposal Plan}

This project report constitutes the waste disposal plan and will document and fulfill the requirements in the Grumbly letter addressing the case-by-case variance of DOE 5820.2A. The exemption criteria to DOE 5820.2A is discussed in Section 4.2. The work package in Appendix B is the project Waste Disposal Plan.

\subsubsection{DOE CX Approval}

See Section 3.1.5 above.

\subsubsection{Review of Disposal Plan by EG\&G Idaho, Inc., and DOE}

This activity was the final review of the process used to date with verified concurrence prior to shipment. 


\subsubsection{Secure Facillty to Take Samples and Repackage}

Test Area North (TAN) building \#607 and the Waste Experimental Reduction Facility (WERF) were contacted to provide a sampling area for this project. WERF had an area and could respond in the timeframe given. The WERF Temporary Accumulation Area (TAA) was identified as the sampling area. See Section 6 Lessons Learned for recommendations on sampling.

\subsubsection{Prepare Sample Analysis Plan (SAP)}

Developing a sample analysis plan usually takes one to two months. The project team completed this in two weeks through a series of team meetings and developed a through and successful Sample Analysis Plan. Sampling homogeneous materials in itself is difficult to ensure that a "representative" sample is obtained. The problem faced in sampling debris is the random nature and the lack of documented procedures or recommendations. Existing recommendations on how to obtain samples were reviewed and adapted where applicable. A series of team meetings where held to discuss the issues and develop guidelines for sampling debris waste (see Appendix G).

\subsubsection{Contract for Laboratory Sample Analysis}

The EG\&G Idaho, Inc., Sample Management unit was responsible for establishing a laboratory contract, sample management, and report data (see Appendix H). Turnaround time for sample analysis is typically 30 to 60 calendar days. Existing master task contracts and contract incentives were used to establish the contract with a 16-day turnaround time. This proved very successful and returned the analysis data in $\mathbf{1 0}$ days, six days ahead of schedule. This was a critical path activity and was an important factor in the success of this project.

\subsubsection{Prepare Papers and Ship to Sampling Facility}

Shipping of radioactive waste or material is a routine activity at the INEL. This activity had well established procedures and was completed without incident two days ahead of schedule.

\subsubsection{Prepare SWR to Take Samples and Repackage}

A safe work release for sampling and packaging was completed. This work at WERF was very successful and problems/issues were resolved in a very professional manner. WERF is a production facility and the personnel here were familiar with this type of work.

\subsubsection{DOE-ID Approval}

DOE-ID approval of the NEPA and project baseline was completed ahead of schedule. This project required extensive coordination and commitment from upper management and DOE-ID personnel. Precedent required schedules to allow two to three weeks or longer for DOE-ID actions. This project's DOE-ID counterpart was very proactive and on all issues was ahead of the schedule. This type of participation and level of involvement is the primary factor for success of this project. 


\subsubsection{Take Samples}

Samples were taken in accordance with the sample analysis plan (See Appendix $H$ for sampling requirements). Sampling and follow-on laboratory analysis was performed in accordance with the project SAP, project Site Work Release and Envirocare of Utah's material acceptance criteria procedures. Envirocare of Utah requires the generator to send them "fingerprint" samples for qualitative testing for use in the notice to transport. Preparation for sampling and the actual sampling of the waste was the single most expensive part of this project. If proper sampling were performed at the time waste is generated, this cost could be greatly reduced.

\subsubsection{Send Samples to Laboratory and Envirocare of Utah}

Samples were transported in accordance with the SAP and laboratory criteria.

\subsubsection{Laboratory Analysis and Return Results}

The laboratory analysis data was received six days ahead of the scheduled 16-day turnaround.

\subsubsection{Prepare Waste for Shipping (Packaging and Labels)}

This activity was performed by WROC technical program personnel and is a routine function for this unit.

\subsubsection{Fill Out Envirocare of Utah Forms}

Review of all the laboratory data for compliance with Envirocare of Utah's WAC required a larger effort than originally anticipated. WROC technical program personnel worked overtime to accomplish this activity in the time scheduled.

\subsubsection{Send Envirocare of Utah Forms and Lab Profiles for Approval}

Envirocare of Utah requires review of all data and comparison with the qualitative tests that they perform on the "fingerprint" samples. This provides an indication of the quality of sampling and testing efforts. All data and paperwork was in order and approval was given.

\subsubsection{Envirocare of Utah Sends Notice of Transport}

Envirocare of Utah gave verbal notice to transport March 25, 1994, and sent the official notice to transport April 1, 1994.

\subsubsection{Prepare DOE/COE Contract Delivery Order}

The Delivery Order is the document that the Corps of Engineers (COE) delivers to Envirocare of Utah for payment. This activity was started five weeks before it was due and the COE still didn't have it in place when scheduled. Envirocare of Utah has a policy to not accept waste unless this Delivery Order is in place. Envirocare of Utah conceded this requirement due to our tight schedule. This activity needs constant attention on future contracts. 


\subsubsection{Notify Envirocare of Utah of Shipping Date}

Envirocare of Utah requires 72-hour advanced shipping notice at the disposal facility.

\subsubsection{Envirocare of Utah Approves Shipping Date}

Envirocare of Utah employs a full-time scheduling person to coordinate all daily shipments at the Clive Utah site. This process works well and no delays or confusion was noted when the shipment was received.

\subsubsection{Prepare Manifest and Fax to Envirocare of Utah}

This shipping manifest is the EPA document that controls the custody of the waste. This document was faxed to Envirocare of Utah and reviewed prior to shipping so there were no problems when the truck arrived. This preapproval is required by Envirocare of Utah.

\subsubsection{Load and Transport Waste to Envirocare of Utah}

One hundred cf of MLLW debris was delivered and unloaded at Envirocare of Utah on March 29, 1994, without incident or question. All paperwork was in order and return manifest copies have been received at the INEL.

\subsubsection{Waste Disposal}

One hundred cf of MLLW debris was disposed of on May 5, 1994. 


\section{EPA PERMITS AND DOE REGULATIONS}

\subsection{EPA Permits}

An ESH\&Q audit performed by EG\&G Idaho, Inc., addresses all of the ESH\&Q issues associated with Envirocare of Utah. Between this report and the Army COE contract, all Federal and state permits required of Envirocare of Utah are listed and documented. See Appendix C and I for details.

\subsection{DOE 5820.2A Exemption}

Appendix F contains a copy of the exemption memorandum from Thomas P. Grumbly. This memorandum is an approved exemption to DOE 5820.2A for small quantities of mixed waste on a case-by-case basis. The major requirements and how these were met for this project are listed below.

\subsection{1 "Only for Small Volumes"}

This project will ship $100 \mathrm{cf}$ of MLLW debris. Future shipments will be addressed on a case-by-case basis.

\subsection{2 "Appropriate NEPA Documentation Shall Be Prepared"}

Completed as discussed in Section 3.1.5.

\subsection{3 "Appropriate CERCLA, RCRA, TSCA Documentation Shall Be Prepared"}

Only RCRA documentation applied to the waste streams submitted under this project. See 2.2 .5 above.

\subsection{4 "Appropriate Procurement or Contracting Documents Shall Be Prepared"}

See Appendix I for a copy of the Interagency Agreement with the COE and a copy of the Standard Operating Procedures (SOP) for the contract with Envirocare of Utah.

\subsection{5 "Review of Disposal Facility Permits, Licenses, Approvals, and Regulatory Records"}

See Appendix C and I.

\subsubsection{Treatment Necessary for Land Disposal"}

See Appendix E for RCRA treatment listings and results. 


\subsection{7 "LW Compact and State Acceptance of DOE Waste"}

There is an outstanding issue on the acceptance of LLW with the Northwest compact. However this project deals with MLLW only and this is not an issue for this project.

\subsection{8 "All Wastes that are Land Disposal Restricted Shall Meet Best Demonstrated Available Technology"}

WROC Technical Programs performed an extensive search to establish the availability of treatment processes for the waste streams considered for this project (See Appendix E).

\subsection{9 "Notify EM-33 Prior to Each Shipment Campaign"}

Notification was faxed to EM-33 by DOE-ID on March 16, 1994.

\subsubsection{The Regulatory Status of the Disposal Facility Shall Be Confirmed"}

As of March 16, 1994, EG\&G Idaho, Inc., indicated that the report contained in Appendix $C$ is current. Envirocare of Utah is responsible to notify EG\&G Idaho, Inc., of "any change in regulatory status."

\subsubsection{1 "Periodic Reviews of the Disposal Facility Shall Be Conducted"}

EG\&G Idaho, Inc., will keep the report in Appendix C current on an as-needed basis. The frequency of future audits will be based on the use of this disposal facility. 


\section{PROJECT GO OR NO-GO ISSUES}

From the beginning of this project there were many "go" or "no-go" issues. These were largely the result of the accelerated schedule and required immediate resolution and coordination of issues to ensure the "drop dead" shipping date would be met. Selected issues are listed below to emphasize the magnitude of the coordination and cooperation that was required from 16 individual units within the Waste Management Program.

- Legal liabilities

- Disposal contract in place by February 1, 1994

- Environmental checklist

- Categorical exclusion

- DOE-ID approval of CX

- Envirocare of Utah requirements and capacities

- Envirocare of Utah material acceptance training

- $\quad$ Project priority

- Personnel availability

- $\quad$ Sampling

- How to sample debris

- Sample requirements

- $\quad$ Existing waste profile data

- Candidate list of waste for disposal

- Facility in which to perform sampling

- Personnel

- Sampling plan

- Support personnel and availability

- Laboratory analysis

- Locate and contract with a Utah-certified laboratory 
- Sample analysis turnaround time

- Sample requirements

- Shipping requirements

- Acceptance procedures

- Waste profile data

- Verification of sampling procedures by the disposal facility

- Existing treatment capabilities. 


\section{LESSONS LEARNED}

The accelerated schedule placed a high emphasis on communication and teamwork for project success. As a result, many tasks were accomplished in much less time than usual. Some personal hardships were noted; however these could be avoided in future projects. Aggressive schedules should be pursued just short of causing personal hardships. The support from line and department management and the teamwork between the many different units in the EG\&G Idaho Waste Management Department was a critical factor for this project's success.

\subsection{Permitting}

\subsubsection{NEPA DOE-ID Requirements}

In the past, NEPA compliance has been the major project roadblock. NEPA documentation for this project was completed ahead of schedule. It is critical to have aggressive support from the project DOE-ID counterpart and open communication within the project team.

\subsubsection{Transportation Manifests}

It is important to involve transportation personnel from the project inception. This eliminated delays at shipment time.

\subsection{Sampling}

\subsubsection{Facility}

This project emphasized the importance for a sampling facility or modifications to the Mixed Waste Storage Facility for orderly characterization of the waste stored there.

\subsubsection{Schedule}

A double work shift for the sampling effort is highly recommended due to the time required to comply with safe work procedures. Most of the actual sampling work was completed on the second shift.

\subsubsection{Sample Analysis Plan (SAP)}

After preparing a draft SAP, a concentrated group meeting to finalize and comment on the SAP provided better quality and was more cost-effective than soliciting independent written comment and review. This should be the standard company procedure.

\subsubsection{Waste Sampling}

6.2.4.1 It was very important to have experienced personnel performing the sampling process. This was especially true for debris waste and the constant judgements that need to be 
made to assure a "representative sample." Sampling and project support personnel need to be familiar with the laboratory analysis test procedures.

6.2.4.2 Expect the Unexpected. The sample analysis plan had provisions to accommodate unexpected events such as surprises in the waste contents, radiation levels and waste types.

6.2.4.3 Don't use tape seal as secondary custody control on sample containers. On two of the ten containers an adhesive seal we used during handling was broken. Use a drilled bolt with wire seal.

\subsubsection{Always take lots of pictures.}

6.2.4.5 For sampling and associated analysis work it is recommended to keep waste streams separate when the contents are not fully known. This keeps one higher-level waste stream from contaminating a lower-level waste stream and possibly eliminating these waste streams from meeting the disposal facility WAC. Combining of waste streams is recommended after all of the laboratory data has been reviewed.

6.2.4.6 Correct weight is critical to analysis procedures. Samples must be scale-weighed to ensure the required analysis test weight. This problem resulted from some low density material, where the volume appeared adequate but was short on weight.

\subsection{Laboratory Analysis}

\subsubsection{Contracting and Schedule}

Contracting personnel used incentives to get laboratory results returned in ten working days. This project used a "Master Task List" which had prenegotiated prices based on a 30- to 60-day turnaround. However EG\&G Idaho agreed to a surcharge for a 15-day turnaround and also made provisions for a $10 \%$ early delivery incentive. This proved very successful in meeting this critical path activity and results were delivered ahead of schedule.

\subsection{Commercial Disposal Facility}

Training on disposal or treatment facility waste acceptance criteria should be the first scheduled project activity. Get these requirements "down cold".

\subsubsection{Contracting}

Understanding the terms and conditions of all contract details is very important. This requires personal one-on-one communication with all contracting personnel involved.

\subsubsection{Future}

Sampling and knowledge of the existing waste is critical and the most costly part of this project. The WAC requirements and paperwork imposed by Envirocare of Utah through the 
State of Utah may become the norm for Federal and commercial waste disposal in the future. The State of Utah is in the forefront of state-administered RCRA programs for these land disposal units. They have a "Utah state laboratory certification" program that could possibly be adopted wholly or in part as other states start administering their environmental programs in the 1990's. 


\section{CONCLUSIONS/ACCOMPLISHMENTS}

The following are some of the important conclusions and accomplishments of the INEL Commercial Disposal of MLLW debris project.

\section{Conclusions:}

- Future planning for these waste streams must consider the impact of additional characterization, time, and cost.

- With the high storage costs of MLLW and the limited storage space available, conservative classification of LLW as MLLW is expensive when compared to initial sampling and analysis costs at the time waste is generated.

- After future treatment processes have been developed and waste treatment has been performed, disposal of MLLW at Envirocare of Utah will still be a viable option.

- This project reaffirmed the need and importance of the Mixed Waste Storage Facility (MWSF) Handling Booth project. The Handling Booth project will provide facility capability to perform sampling verification, repackaging and associated profiling of waste for appropriate storage, treatment and disposal.

- Disposal of DOE waste at offsite facilities should be considered as an alternative. The volume of waste treated or disposed should be maximized for every project to reduce the overall costs per unit volume. The final total disposal cost per cubic foot of waste disposed at Envirocare of Utah was $\$ 294 / \mathrm{cf}$ in this project. This includes all material, labor, analysis work, transportation and disposal costs, including the work on LLW that will be disposed at the RWMC and the MLLW that remains in storage at the INEL.

\section{Accomplishments:}

- Five hundred eighty cf of MLLW debris were accurately dispositioned, with $300 \mathrm{cf}$ of this waste disposed. Approximately $200 \mathrm{cf}$ will be disposed at the RWMC and $100 \mathrm{cf}$ at Envirocare of Utah.

- The project identified a contracting mechanism that is established for at least three more years with Envirocare of Utah. Another contracting mechanism with Envirocare of Utah is now available through the DOE Oak Ridge Laboratory.

- The project established a standard for waste profile data required to commercially treat or dispose of LLW and MLLW at Envirocare of Utah. 


\section{RECOMMENDATIONS}

Based on this project, it is recommended that the following issues be addressed:

1. The generators of MLLW should be required to prepare a plan for storage, treatment and disposal prior to generation of waste. This plan must provide: (a) the quality of data required by each entity that will be handling the waste after generation, (b) identification and documentation of waste analysis needs that not only address the hazardous waste determination requirements of 40 CFR 262.11, but also satisfy, to the extent practicable, analytical requirements peculiar to the receiving facilities. If process knowledge is allowed, and is used to provide some or all of the required characterization data, it must be well-documented and defensible. Ideally, the generator should acquire the necessary permits, licenses, and criteria of the intended disposal facility to reduce the number of times that the waste must be handled and sampled. If all acceptance criteria, permits, and licenses are not available, it must be assumed that additional work will have to be performed that may include additional or new analyses, waste verification, and possibly waste repackaging. Such activities will have a significant impact on cost and schedules and must be anticipated. For wastes that have not yet been generated, it is prudent to establish a reasonable laboratory analysis standard to be performed when the waste is generated to reduce future sampling, storage, treatment, and disposal costs. For wastes currently in storage, existing characterization data should be reviewed to identify potential data gaps and determine whether additional analysis should be performed to satisfy anticipated needs or wait until all disposal requirements are known.

2. The General Plant Project (GPP) to provide for sampling facilities at the MWSF should be given a high priority. Sampling at alternate temporary facilities requires site-specific procedures, schedules and learning curves. A designated sampling facility will provide routine procedures and dedicated personnel to perform this work at a lower cost.

3. Direct shipping of debris from the point of generation will minimize the cost of characterization, handling, storage, treatment and disposal. Environmental remediation, decontamination, and decommissioning activities that expect to generate debris wastes should be required to consider direct shipping as a part of their planning and program management plan. 


\section{PROJECT COST SUMMARY}

This cost summary is based on the costs per cubic foot to dispose of $100 \mathrm{cf}$ of INEL MLLW debris at Envirocare of Utah. These costs also include costs for evaluating an additional $480 \mathrm{cf}$ that was not sent to Envirocare. The total project costs are based on waste that has been in storage for some time and had limited waste profile data available. As the generators are required to provide better profile data and incur these costs as the waste is generated, a higher emphasis will be placed on waste minimization. Sampling and performing laboratory analysis when the waste is generated will significantly reduce the overall cost per cubic foot for storage, treatment and disposal.

- Project Management, Documentation, Engineering, NEPA, Legal and Other.

$$
(\$ 49,981 / 580 \mathrm{cf})=
$$

$\$ 86.01 / \mathrm{cf}$

- Sampling.
$(\$ 59,000 / 580 \mathrm{cf})=$
$\$ 101.70 / \mathrm{cf}$

- Laboratory Analysis.

$(\$ 21,460 / 380 \mathrm{ct})=$

$\$ 56.50 / \mathrm{cf}$

- Shipping/Transportation. $(\$ 800 / 100 \mathrm{cf})=$ $\$ 8.00 / \mathrm{cf}$

- Disposal at Envirocare of Utah (estimated).

$\$ 56.00 / \mathrm{cf}$

- Total Project Costs as of May 8, 1994. $(\$ 49,981+59,000+21,460+800)=$

- Estimated Total Project Cost at Completion.

$\$ 135,000$

Totals

- Cost per cf to Dispose of $100 \mathrm{cf}$ of MLLW at Envirocare of Utah.

$$
(\$ 86.01 / \mathrm{cf}+\$ 101.7 / \mathrm{cf}+\$ 56.5 / \mathrm{cf}+\$ 8.0 / \mathrm{cf}+\$ 56.0 / \mathrm{cf})=\$ 308.21 / \mathrm{cf}
$$

- Total Cost directly associated with disposal of $100 \mathrm{cf}$ of MLLW at Envirocare of Utah.

$$
(\$ 308.21 / \mathrm{cf} \times 100 \mathrm{cf})=
$$




\section{Appendix A}

\section{Case-by-Case Variance Extension}

A-1 


\title{
INEL REPORT FOR THE RENEWAL OF THE HAZARDOUS DEBRIS CASE-BY-CASE CAPACITY VARIANCE EXTENSION
}

\author{
Prepared by: \\ Department of Energy \\ DOE Field Office, Idaho \\ 785 DOE Place \\ Idaho Falls, Idaho 83401-1562
}

LOCATION: Idaho National Engineering Laboratory Idaho Falls, Idaho

EPA Identification No. ID4890008952 (INEL site) ID6890190089 (Idaho Falls)

August 12, 1993 


\section{INEL REPORT FOR THE RENEWAL OF THE HAZARDOUS DEBRIS CASE-BY-CASE CAPACITY VARIANCE EXTENSION}

The purpose of this report is to meet the requirements specified in the Environmental Protection Agency (EPA) conditional case-by-case variance extension for hazardous debris, thus making the extension applicable to the Idaho National Engineering Laboratory (INEL). The effective termination date of this variance is May 8, 1994. This report covers only those mixed waste streams covered by the Land Disposal Restrictions (LDR) Third Third listing. Typically these will be characteristic wastes, but may include listed wastes also subject to the LDR Third Third listing, or even F-list codes where the waste meets the F-listed treatment standard.

This report provides estimates of the Third Third LDR mixed debris inventory and generation rate during the course of the variance period (May 8, 1993 to May 8, 1994). An extension is necessary for key functions, projects, and research to proceed at the INEL during the renewal period. This report addresses the information necessary to qualify for the variance renewal as required in Federal Register, Vo1. 58, No. 92, Friday, May 14, 1993.

Requirement 1: The name, mailing address, location and EPA identification number of the facility.

The INEL is a U.S. Department of Energy (DOE) owned and operated facility (EPA Identification Number ID4890008952). The INEL site is located on an 890-square mile area of desert about 40 miles west of Idaho Falls, Idaho (See Figure 1). Some support facilities are located in Idaho Falls (EPA Identification Number ID6890190089). The INEL mailing address is 785 DOE Place, Idaho Falls, Idaho, 83402-1103. 


\section{IDAHO NATIONAL ENGINEERING LABORATORY}

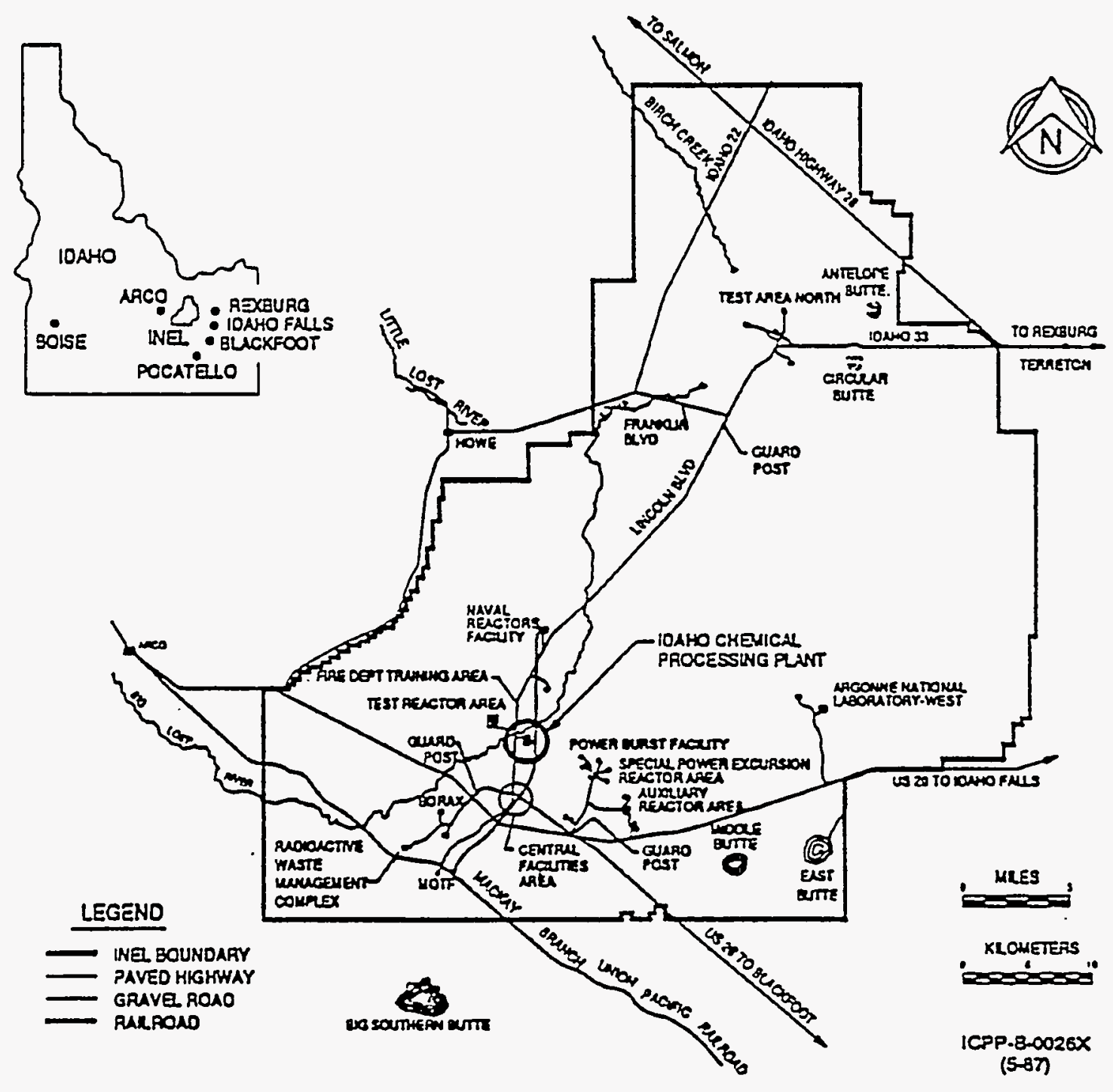

Figure 1 
Requirement 2: A description of the hazardous debris waste stream, including the RCRA waste code(s).

The term "mixed debris" in this report refers to hazardous debris, as defined in the May 14, 1993, Federal Register (58 FR 28506), that is also contaminated with radionuclides controlled under the Atomic Energy Act by DOE. Mixed debris is generated during ongoing waste management activities, from maintenance activities associated with plant projects at existing facilities, during upgrades to meet Resource Conservation and Recovery Act (RCRA) standards such as those for containment buildings, during the decontamination and decommissioning (D\&D) of older facilities, during environmental restoration activities, and from miscellaneous projects.

Table I lists the types of debris that will be generated, proposed treatment methods, proposed facilities for handling the particular waste types, and the anticipated dates of availability. Appendix I lists the storage facilities, building locations, current permitting status of the facilities, waste codes for the debris to be stored, the design capacity of the facilities, and current inventories.

Requirement 3: Waste generation rates (cu. m./yr.) and estimated inventories (cu. m.).

Appendix II lists the debris sources and the expected quantities to be generated. The estimated total quantity of debris expected to be generated during the existing variance extension is approximately 268 cubic meters. The. INEL has nine interim storage facilities, not including high efficiency particle air (HEPA) filter storage areas, totaling about 1630 cubic meters of container storage capacity. This capacity will accommodate the estimated mixed debris expected to be generated from all of the facilities and projects. Current generation rates of waste other than debris are not expected to have a significant impact on storage capacity. Existing inventories total approximately 28 percent of storage capacity. HEPA filters, which are stored separately, have a storage capacity of approximately 167 cubic meters (and a current inventory of approximately 19 cubic meters). 


\begin{tabular}{|c|c|c|c|}
\hline Waste Type? & Proposed $: \cdots$ & $\begin{array}{l}\therefore \text { Proposed } \\
\text { Facflity }\end{array}$ & $\begin{array}{l}\text { Oate Treatment } \\
\text { Available. }\end{array}$ \\
\hline $\begin{array}{l}\text { COMBUSTIBLES: } \\
\text { HEPA FIIters (LLW), } \\
\text { Wood. Paper. Cloth. } \\
\text { Rubber. Plastic }\end{array}$ & $\begin{array}{l}\text { Incineration or 0ther } \\
\text { Approved Treatment }{ }^{2}\end{array}$ & $\begin{array}{l}\text { WERF, NHCF Decon } \\
\text { Facility or Other } \\
\text { Approved Facility }\end{array}$ & $\begin{array}{l}\text { WERF - } 1994 \\
\text { HWCF - Currently } \\
\text { Ava i lable }\end{array}$ \\
\hline $\begin{array}{l}\text { HON-POROUS: } \\
\text { Metal Objects, Some } \\
\text { Plastics }\end{array}$ & $\begin{array}{l}\text { High Pressure Stean and } \\
\text { Kater Wash }\end{array}$ & $\begin{array}{l}\text { NWCF Decontamination } \\
\text { Facility }\end{array}$ & Current ly Ava i lable ${ }^{3}$ \\
\hline $\begin{array}{l}\text { Inherent ly Hazardous } \\
\text { (IH) Metals }\end{array}$ & $\begin{array}{l}\text { Decontamination or } \\
\text { Imobilization/Macroen- } \\
\text { capsulation (IH Metais) }\end{array}$ & WEDF Misc. Units & WEDF - 1994 \\
\hline $\begin{array}{l}\text { Reactive Hetal. } \\
\text { Contaminated Debris }\end{array}$ & $\begin{array}{l}\text { Deactivation/Chemical } \\
\text { Extraction }\end{array}$ & RSWPF & 2000 \\
\hline $\begin{array}{l}\text { POROUS MATERIALS: } \\
\text { Brick. Concrete, } \\
\text { Rock. Pavement, Some } \\
\text { Plast ics }\end{array}$ & $\begin{array}{l}\text { Abrasive Blasting or } \\
\text { Chemical Extraction }\end{array}$ & HWCF Decon Facility & Currently Availables \\
\hline Asbescos & $\begin{array}{l}\text { Macroencapsulation } \\
\text { Followed by Land } \\
\text { Oisposal }\end{array}$ & $\begin{array}{l}\text { Encapsulation by } \\
\text { Generator and } \\
\text { Oisposal at } \\
\text { Envirocare of Utah. } \\
\text { Inc. }\end{array}$ & Currently Available \\
\hline $\begin{array}{l}\text { HEPA Filter (HLH or } \\
\text { TRU) }\end{array}$ & $\begin{array}{l}\text { Chemical Extraction } \\
\text { (HEPA Filters) }\end{array}$ & $\begin{array}{l}\text { NWCF HEPA Filter } \\
\text { Leaching System }\end{array}$ & $1994^{7}$ \\
\hline
\end{tabular}

1. Example materials are included, but are not limited to those shown below each waste type.

2. Other approved treatments include, but are not limited to, acid or water washing. or other extraction or destruction technologies set forth in the Final Hazardous Oebris Rule.

3. Existing facility will need some modifications prior to treating some types of debris.

4. IH metals refers to Inherently Hazardous metals such as cadnium and silver solids. If possible, IH metals will be decontaminated and recycled: otherwise. IH metals will be imnobilized.

5. Modification to Decon facillty will be required prior to abrasive blasting.

6. Contract procurement with Envirocare is underway and is anticipated to be in place by the fall of 1993.

7. Testing of the WWCF HEPA Filter Leaching System will be conducted in the fall of 1993 . It is anticipated that the system will be modified and on line in 1994. 
Requirement 4: The owner/operator or generator must demonstrate that good-faith effort has been made to locate and contract with treatment or recovery facilities to manage the waste in accordance with the effective date of the applicable restriction in order to utilize this variance. The documentation of this effort must be submitted to EPA.

No operating commercial mixed debris treatment facilities have been identified. The market has given no indications that facilities will be available by May 8, 1994. Only one commercial facility with mixed debris disposal capacity has been identified to date (Envirocare of Utah, Inc.). Furthermore, the existing facilities at the INEL are not capable of treating all of the mixed debris types, without design modifications, or of meeting additional RCRA requirements.

In preparation for its national case-by-case mixed waste variance, DOE conducted a search (the results of which were submitted to the EPA in November 1991) for potentially available commercial facilities for the management of mixed waste. DOE contacted potentially suitable facilities to gather additional information on each facility's qualifications and capabilities. DOE evaluated the information to determine whether the facilities could actually provide treatment capacity for DOE case-by-case applicable mixed waste. The results of the DOE search revealed that commercial capacity for DOE mixed waste is inadequate. In general, the search demonstrated that very little treatment capacity was available. This lack of available treatment capacity has prevented DOE from locating and contracting with treatment or disposal facilities for its mixed waste.

Supporting DOE's aforementioned efforts, in December 1991 the National LowLevel Waste Management Program report published by DOE-Idaho regarding availability of treatment, documented the lack of available treatment:

"There are no facilities nationwide that are commercially, technically, or legally capable of treating all types of mixed waste. ...DSSI [Diversified Scientific Services Inc.] in Oak Ridge, Tennessee is permitted and licensed to treat aqueous solutions. [sic] characteristic mixed waste by incineration. NSSI [Nuclear Scientific Services, Inc.] 
in Houston, Texas, is permitted and licensed for chemical fixation and stabilization, chemical oxidation reduction precipitation, and charcoal adsorption. These facilities use technologies best suited to aqueous solutions. Scientific Ecology Group (SEG) expects to expand its existing LLW incinerator operations to allow a phased receipt of mixed wastes. The first phase is incineration of characteristic waste and the second is incineration of listed wastes. As part of the second phase, a delisting petition is expected to be submitted to EPA for selected waste codes."

In addition to contacting these companies, in July 1992, the INEL published a request in the Commerce Business Daily for expressions of interest by the commercial sector with regard to treating INEL's mixed waste. Although several firms expressed an interest in developing treatment, essentially no debris treatment capacity was expected to be available during the variance period of May 1992 to May 1993.

DOE then conducted another survey and located a facility permitted for disposal of solid (no free liquids) low-level mixed waste. On August 13, 1992, DOE published notice in the Commerce Business Daily of its intent to award a sole-source contract to Envirocare of Utah for disposal of solid DOE mixed waste (which includes mixed debris). No other firm that met the permitting requirements for disposal of mixed waste and mixed debris came forward by the September 14, 1992 deadi ine. This confirmed previous DOE efforts and conclusions regarding available treatment and disposal facilities. It should be noted that Envirocare is only permitted for disposal, and not treatment, of mixed waste or debris. Furthermore, Envirocare's permit only allows for disposal of very lowlevel radioactively contaminated solid mixed waste.

DOE's proposed contract with Envirocare will be for the permanent disposal of solid mixed waste. DOE expects its contract with Envirocare to be finalized and in place by the fall of 1993.

In a continuing effort to identify available treatment and disposal capacity, SEG and DSSI were contacted a second time in the fall of 1992. Both companies 
confirmed they cannot treat INEL mixed debris for the following reasons: SEG is only permitted to trea: hazardous waste as well as radioactive waste, but not hazardous and radioactive waste (i.e., mixed waste). While SEG has permits pending to do so, the permits had not been granted yet.

DSSI, like SEG, cannot treat INEL mixed debris because they are only permitted to incinerate solvents contaminated with radiological constituents. The feed for the DSSI incinerator must meet a minimum British Thermal Unit (BTU) content and must be in liquid form (because INEL mixed debris does not qualify, further communications were not performed regarding the mixed debris).

In a continuing good-faith effort to locate and contract treatment or recovery facilities to manage the mixed debris in accordance with the effective date of the applicable restriction, the Hazardous Waste Treatment Council (HWTC) was contacted on May 25, 1993. The HWTC searched their database for members that may be permitted to treat or dispose of INEL's mixed debris. The results of the search were negative, therefore, they sent notices to their membership inquiring whether they may have plans to treat or dispose of mixed debris in the future. Four member companies were contacted with the following results:

- Nor-True - cannot treat or dispose of INEL mixed debris.

- USPCI - cannot treat or dispose of INEL mixed debris.

- Highway 36 - cannot treat or dispose of INEL mixed debris.

- Cyanochem - cannot treat or dispose of INEL mixed debris. Recommended contacting "Quadrex" and "Asbestos."

Six other companies, including those recommended by Cyanochem, were contacted as follows:

- Quadrex - cannot treat or dispose of INEL mixed debris.

- Asbestos - cannot treat or dispose of INEL mixed debris. Recommended contacting APTUS.

- APTUS - cannot treat or dispose of INEL mixed debris.

- DSSI - cannot treat or dispose of INEL mixed debris. 
EG - cannot treat or dispose of INEL mixed debris because their permits or mixed waste are still pending.

SSI - will not treat or dispose of INEL mixed debris.

se refer to Appendix III for documentation and full description of the cations and associated circumstances for all of the companies contacted research for treatment and disposal capabilities. 
uirement 5: Certification as required under 40 CFR 268.5(b).

$\therefore$

I certify under penalty of law that I have personally examined and am familiar $\rightarrow$ the information submitted in this document and all attachments and that, əd on my inquiry of those individuals immediately responsible for obtaining information, I believe that the information is true, accurate, and complete. 1 aware that there are significant penalties for submitting false information, iuding the possibility of fine and imprisonment.

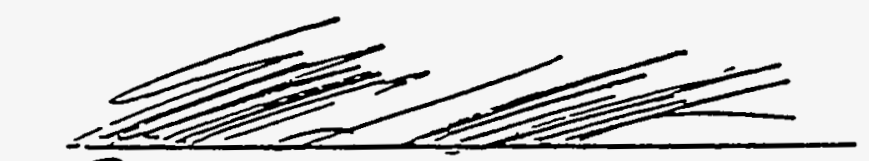

An A.A.P.TROLO

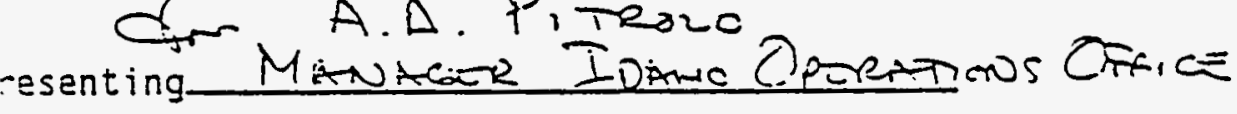

$\underline{2}$

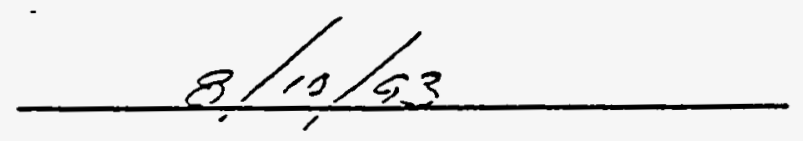


APPENDIX I 


\section{APPENDIX I}

IDAHO CHEMICAL PROCESSING PLANT (ICPP), INEL

Page 1 of 12

UNIT: New Waste Calcining Facility HEPA Filter Storage

WASTE TYPE: Radioactive and Hazardous Mixed Debris

CURRENT STATUS: Interim Status - RCRA

PROCESS CODES: SOI - Container Storage

SO3 - Waste Pile Storage

OTHER PERMITS: None

PROCESS DESIGN CAPACITY: SO1 - 56 Cubic Meters

SO3 - 85 Cubic Meters

CURRENT INVENTORY: 17 Cubic Meters

WASTE CODES:

\begin{tabular}{|c|c|c|c|c|c|}
\hline D CHAR. & F LISTED & $K$ LISTED & P LISTED & \multicolumn{2}{|c|}{$U$ LISTED } \\
\hline $\begin{array}{l}0004-0011 \\
0018-0019 \\
0021-0022 \\
0026 \\
0028 \\
0032 \\
0034-0036 \\
0038-0040\end{array}$ & $\begin{array}{l}\text { F001-F002 } \\
\text { F005 }\end{array}$ & $N / A$ & $\begin{array}{l}P 005 \\
P 012 \\
P 022 \\
P 024 \\
P 027-P 028 \\
P 030-P 031 \\
P 056 \\
P 073 \\
P 075 \\
\text { P077 } \\
\text { P098 } \\
\text { P104-P106 } \\
\text { P113 } \\
\text { P116 } \\
\text { P119-P120 }\end{array}$ & $\begin{array}{l}\text { U003-U004 } \\
\text { U007 } \\
\text { U009 } \\
\text { U012 } \\
\text { U014 } \\
\text { U019-U020 } \\
\text { U032 } \\
\text { U037 } \\
\text { U044 } \\
\text { U048 } \\
\text { U052 } \\
\text { U069 } \\
\text { U079 } \\
\text { U080-U081 } \\
\text { U083-U084 } \\
\text { U102-U0103 } \\
\text { U108 } \\
\text { U116 } \\
\text { U118 } \\
\text { U120 } \\
\text { U122-U123 } \\
\text { U127-U128 } \\
\text { U131 } \\
\text { U133-U135 } \\
\text { U138 } \\
\text { U140 } \\
\text { U144-U145 } \\
\text { U147 } \\
\text { U151 } \\
\text { U159 } \\
\text { U162 } \\
\text { U165 }\end{array}$ & $\begin{array}{l}\text { U169-U171 } \\
\text { U182 } \\
\text { U188 } \\
\text { U190-U191 } \\
\text { U196 } \\
\text { U201 } \\
\text { U204 } \\
\text { U207-U208 } \\
\text { U210-U211 } \\
\text { U215 } \\
\text { U217-U220 } \\
\text { U225-U228 } \\
\text { U239 } \\
\text { U328 }\end{array}$ \\
\hline
\end{tabular}




\section{APPENDIX I}

IDAHO CHEMICAL PROCESSING PLANT (ICPP), INEL

Page 2 of 12

UNIT: CPP-666 FAST HEPA Filter Storage

WASTE TYPE: Radioactive and Hazardous Mixed Debris

CURRENT STATUS: Interim Status - RCRA

Part B Permit Application submitted in July 1993.

PROCESS CODES: SO1 - Container Storage

OTHER PERMITS: Prevention of Significant Deterioration No. 0340-0001-300 Fuel Processing Restoration Facility

PROCESS DESIGN CAPACITY: 25 Cubic Meters

CURRENT INVENTORY: 1.5 Cubic Meters

WASTE CODES:

\begin{tabular}{|c|c|c|c|c|c|}
\hline D CHAR. & F LISTED & K LISTED & P LISTED & \multicolumn{2}{|c|}{ U LISTED } \\
\hline $\begin{array}{l}D 004-0011 \\
D 018-0019 \\
0021-0022 \\
D 026 \\
0028 \\
D 032 \\
D 034-0036 \\
0038-0040\end{array}$ & $\begin{array}{l}\text { F001-F002 } \\
\text { F005 }\end{array}$ & N/A & $\begin{array}{l}P 005 \\
P 012 \\
P 022 \\
P 024 \\
P 027-P 028 \\
\text { P030-P031 } \\
\text { P056 } \\
\text { P073 } \\
\text { P075 } \\
\text { P077 } \\
\text { P098 } \\
\text { P104-P106 } \\
\text { P113 } \\
\text { P116 } \\
\text { P119-P120 }\end{array}$ & $\begin{array}{l}\text { U003-U004 } \\
\text { U007 } \\
\text { U009 } \\
\text { U012 } \\
\text { U014 } \\
\text { U019-U020 } \\
\text { U032 } \\
\text { U037 } \\
\text { U044 } \\
\text { U048 } \\
\text { U052 } \\
\text { U069 } \\
\text { U079 } \\
\text { U080-U081 } \\
\text { U083-U084 } \\
\text { U102-U0103 } \\
\text { U108 } \\
\text { U116 } \\
\text { U118 } \\
\text { U120 } \\
\text { U122-U123 } \\
\text { U127-U128 } \\
\text { U131 } \\
\text { U133-U135 } \\
\text { U138 } \\
\text { U140 } \\
\text { U144-U145 } \\
\text { U147 } \\
\text { U151 } \\
\text { U159 } \\
\text { U162 } \\
\text { U165 }\end{array}$ & $\begin{array}{l}\text { U169-U171 } \\
\text { U182 } \\
\text { U188 } \\
\text { U190-U191 } \\
\text { U196 } \\
\text { U201 } \\
\text { U204 } \\
\text { U207-U208 } \\
\text { U210-U211 } \\
\text { U215 } \\
\text { U217-U220 } \\
\text { U225-U228 } \\
\text { U239 } \\
\text { U328 }\end{array}$ \\
\hline
\end{tabular}


UNIT: CPP-633 Waste Calciner Facility (WCF) HEPA Filter Storage

WASTE TYPE: Radioactive Mixed Waste

CURRENT STATUS: To be closed under interim status

Closure plan was submitted on May 5, 1993.

PROCESS CODES: SO3 - Waste Pile Storage

OTHER PERMITS: None

PROCESS DESIGN CAPACITY: Less than 1 Cubic Meter ( .84 Cubic Meter)

CURRENT INVENTORY: .56 Cubic Meter

WASTE CODES:

\begin{tabular}{|c|c|c|c|c|c|}
\hline D CHAR. & F LISTED & K LISTED & $P$ LISTED & \multicolumn{2}{|c|}{ U LISTED } \\
\hline $\begin{array}{l}0004-0011 \\
0018-0019 \\
0021-0022 \\
0026 \\
0028 \\
0032 \\
0034-0036 \\
0038-0040\end{array}$ & $\begin{array}{l}F 001-F 002 \\
F 005\end{array}$ & $N / A$ & $\begin{array}{l}P 005 \\
P 012 \\
P 022 \\
P 024 \\
P 027-P 028 \\
P 030-P 031 \\
P 056 \\
P 073 \\
P 075 \\
P 077 \\
P 098 \\
P 104-P 106 \\
P 113 \\
P 116 \\
P 119-P 120\end{array}$ & $\begin{array}{l}\text { U003-U004 } \\
\text { U007 } \\
\text { U009 } \\
\text { U012 } \\
\text { U014 } \\
\text { U019-U020 } \\
\text { U032 } \\
\text { U037 } \\
\text { U044 } \\
\text { U048 } \\
\text { U052 } \\
\text { U069 } \\
\text { U079 } \\
\text { U080-U081 } \\
\text { U083-U084 } \\
\text { U102-U0103 } \\
\text { U108 } \\
\text { U116 } \\
\text { U118 } \\
\text { U120 } \\
\text { U122-U123 } \\
\text { U127-U128 } \\
\text { U131 } \\
\text { U133-U135 } \\
\text { U138 } \\
\text { U140 } \\
\text { U144-U145 } \\
\text { U147 } \\
\text { U151 } \\
\text { U159 } \\
\text { U162 } \\
\text { U165 }\end{array}$ & $\begin{array}{l}\text { U169-U171 } \\
\text { U182 } \\
\text { U188 } \\
\text { U190-U191 } \\
\text { U196 } \\
\text { U201 } \\
\text { U204 } \\
\text { U207-U208 } \\
\text { U210-U211 } \\
\text { U215 } \\
\text { U217-U220 } \\
\text { U225-U228 } \\
\text { U239 } \\
\text { U328 }\end{array}$ \\
\hline
\end{tabular}




\section{APPENDIX I}

IDAHO CHEMICAL PROCESSING PLANT (ICPP), INEL

Page 4 of 12

UNIT: CPP-1617 Radioactive Mixed Waste Staging Facilițy (RMWSF)

WASTE TYPE: Hazardous and Radioactive Mixed Debris

CURRENT STATUS: Interim Status - RCRA

PROCESS CODES: SO1 - Container Storage

OTHER PERMITS: None

PROCESS DESIGN CAPACITY: 134,640 gal. (509.6 Cubic Meters)

CURRENT INVENTORY: 47 Cubic Meters

WASTE CODES:

\begin{tabular}{|c|c|c|c|c|c|}
\hline D CHAR. & F LISTED & K LISTED & P LISTED & \multicolumn{2}{|c|}{ U LISTED } \\
\hline $\begin{array}{l}0001-0011 \\
0014-0043\end{array}$ & $\begin{array}{l}F 001-F 003 \\
F 005 \\
F 027\end{array}$ & N/A & $\begin{array}{l}P 005 \\
P 012 \\
P 022 \\
P 024 \\
P 027-P 028 \\
P 030-P 031 \\
P 056 \\
P 073 \\
P 075 \\
P 077 \\
P 098 \\
F 104-P 106 \\
\text { P113 } \\
\text { P116 } \\
P 119-P 120\end{array}$ & $\begin{array}{l}\text { U002-U004 } \\
\text { U007-U009 } \\
\text { U012 } \\
\text { U014 } \\
\text { U019-U020 } \\
\text { U031-U032 } \\
\text { U037 } \\
\text { U044 } \\
\text { U048 } \\
\text { U052 } \\
\text { U055-U057 } \\
\text { U069-U072 } \\
\text { U079-U081 } \\
\text { U083-U084 } \\
\text { U098 } \\
\text { U102-U103 } \\
\text { U108 } \\
\text { U112-U113 } \\
\text { U116 } \\
\text { U118-U120 } \\
\text { U122-U123 } \\
\text { U125 } \\
\text { U127-U128 } \\
\text { U131 } \\
\text { U133-U135 } \\
\text { U138 } \\
\text { U140 }\end{array}$ & $\begin{array}{l}\text { U144-U145 } \\
\text { U147-U148 } \\
\text { U151 } \\
\text { U154 } \\
\text { U159 } \\
\text { U161-U162 } \\
\text { U164-U165 } \\
\text { U169-U171 } \\
\text { U182 } \\
\text { U187-U188 } \\
\text { U190-U191 } \\
\text { U196 } \\
\text { U201 } \\
\text { U204 } \\
\text { U206-U208 } \\
\text { U210-U211 } \\
\text { U215 } \\
\text { U217-U220 } \\
\text { U225-U228 } \\
\text { U239 } \\
\text { U328 } \\
\text { U353 }\end{array}$ \\
\hline
\end{tabular}




\section{APPENDIX I}

IDAHO CHEMICAL PROCESSING PLANT (ICPP), INEL

Page 5 of 12

UNIT: CPP-1619 Hazardous Chemical and Radioactive Haste Storage Facility (HCRWSF)

WASTE TYPE: Hazardous and Radioactive Mixed Debris

CURRENT STATUS: Interim Status - RCRA

PROCESS CODES: SO1 - Container Storage

OTHER PERMITS: Permit to Construct application (P-920302) submitted.

PROCESS DESIGN CAPACITY: 12,000 gal. (45.42 Cubic Meters)

CURRENT INVENTORY: 29 Cubic Meters

WASTE CODES:

\begin{tabular}{|c|c|c|c|c|c|}
\hline D CHAR. & F LISTED & $K$ LISTED & $P$ LISTED & \multicolumn{2}{|c|}{ U LISTED } \\
\hline $\begin{array}{l}0001-0011 \\
0014-0043\end{array}$ & $\begin{array}{l}F 001-F 003 \\
F 005 \\
F 027\end{array}$ & $N / A$ & $\begin{array}{l}P 005 \\
P 012 \\
P 022 \\
P 024 \\
P 027-P 028 \\
P 030-P 031 \\
P 056 \\
P 073 \\
P 075 \\
P 077 \\
P 098 \\
F 104-P 106 \\
P 113 \\
P 116 \\
P 119-P 120\end{array}$ & $\begin{array}{l}\text { U002-U004 } \\
\text { U007-U009 } \\
\text { U012 } \\
\text { U014 } \\
\text { U019-U020 } \\
\text { U031-U032 } \\
\text { U037 } \\
\text { U044 } \\
\text { U048 } \\
\text { U052 } \\
\text { U055-U057 } \\
\text { U069-U072 } \\
\text { U079-U081 } \\
\text { U083-U084 } \\
\text { U098 } \\
\text { U102-U103 } \\
\text { U108 } \\
\text { U112-U113 } \\
\text { U116 } \\
\text { U118-U120 } \\
\text { U122-U123 } \\
\text { U125 } \\
\text { U127-U128 } \\
\text { U131 } \\
\text { U133-U135 } \\
\text { U138 } \\
\text { U140 }\end{array}$ & $\begin{array}{l}\text { U1 44-U145 } \\
\text { U147-U148 } \\
\text { U151 } \\
\text { U154 } \\
\text { U159 } \\
\text { U161-U1 } 62 \\
\text { U164-U165 } \\
\text { U169-U171 } \\
\text { U182 } \\
\text { U187-U188 } \\
\text { U190-U191 } \\
\text { U196 } \\
\text { U201 } \\
\text { U204 } \\
\text { U206-U208 } \\
\text { U210-U211 } \\
\text { U215 } \\
\text { U217-U220 } \\
\text { U225-U228 } \\
\text { U239 } \\
\text { U328 } \\
\text { U353 }\end{array}$ \\
\hline
\end{tabular}


UNIT: Mixed Waste Storage Facility (MWSF)

WASTE TYPE: Radioactive Mixed Waste

CURRENT STATUS: Interim Status - RCRA

Part B Permit Application scheduled for submittal in 1993.

PROCESS CODES: SO1 - Container Storage

OTHER PERMITS: Permit to Construct/Prevention of Significant Deterioration (PTC/PSD) National Emission Standards for Hazardous Air Pollutants (NESHAPS)

PROCESS DESIGN CAPACITY: $34,000 \mathrm{gal}$. (129 Cubic Meters)

CURRENT INVENTORY: $11,502 \mathrm{gal}$. (44 Cubic Meters)

WASTE CODES:

\begin{tabular}{|c|c|c|c|c|}
\hline D CHAR. & F LISTED & $K$ LISTED & P LISTED & $\checkmark$ LISTED \\
\hline $0001-0043$ & $\begin{array}{l}F 001-F 012 \\
F 019-F 024 \\
F 026-F 028 \\
F 039\end{array}$ & $\begin{array}{l}\text { K001 } \\
\text { K015 } \\
\text { K069 } \\
\text { K100 }\end{array}$ & $\begin{array}{l}P 001-P 018 \\
P 020-P 024 \\
P 026-P 031 \\
P 033-P 034 \\
P 036-P 051 \\
P 054 \\
P 056-P 060 \\
P 062-P 078 \\
\text { P081-P082 } \\
\text { P084-P085 } \\
\text { P087-P089 } \\
\text { P092-P099 } \\
\text { P101-P116 } \\
\text { P118-P123 }\end{array}$ & $\begin{array}{l}\text { U001-U012 } \\
\text { U014-U039 } \\
\text { U041-U053 } \\
\text { U055-U064 } \\
\text { U066-U099 } \\
\text { U101-U103 } \\
\text { U105-U174 } \\
\text { U176-U194 } \\
\text { U196-U197 } \\
\text { U200-U223 } \\
\text { U225-U228 } \\
\text { U230-U240 } \\
\text { U242-U244 } \\
\text { U246-U249 } \\
\text { U328 } \\
\text { U353 } \\
\text { U359 }\end{array}$ \\
\hline
\end{tabular}




\section{APPENDIX I}

SPECIAL POWER EXCURSION REACTOR TEST (SPERT) IV, INEL

Page 7 of 12

UNIT: MWSF Portable Storage Units

WASTE TYPE: Hazardous and Radioactive Mixed Waste

CURRENT STATUS: Interim StatUS - RCRA

PROCESS CODES: SO1 - Container Storage

OTHER PERMITS: Permit to Construct/Prevention of Significant Deterioration (PTC/PSD) National Emission Standards for Hazardous Air Pollutants (NESHAPS)

PROCESS DESIGN CAPACITY: 62,500 ga1. (237 Cubic Meters)

CURRENT INVENTORY: 47,359 gal. (179 Cubic Meters)

WASTE CODES:

\begin{tabular}{|c|c|c|c|c|}
\hline D CHAR. & F LISTED & $K$ LISTED & P LISTED & U LISTED \\
\hline $0001-0043$ & $\begin{array}{l}F 001-F 012 \\
F 019-F 024 \\
F 025-F 028 \\
F 039\end{array}$ & $\begin{array}{l}K 001 \\
K 015 \\
K 069 \\
K 100\end{array}$ & $\begin{array}{l}P 001-P 018 \\
\text { P020-P024 } \\
P 026-P 031 \\
\text { P033-P034 } \\
P 036-P 051 \\
P 054 \\
P 056-P 060 \\
P 062-P 078 \\
P 081-P 082 \\
P 084-P 085 \\
P 087-P 089 \\
P 092-P 099 \\
P 101-P 116 \\
P 118-P 123\end{array}$ & $\begin{array}{l}\text { U001-U012 } \\
\text { U014-U039 } \\
\text { U041-U053 } \\
\text { U055-U064 } \\
\text { U066-U099 } \\
\text { U101-U103 } \\
\text { U105-U174 } \\
\text { U176-U194 } \\
\text { U196-U197 } \\
\text { U200-U223 } \\
\text { U225-U228 } \\
\text { U230-U240 } \\
\text { U242-U244 } \\
\text { U246-U249 } \\
\text { U328 } \\
\text { U353 } \\
\text { U359 }\end{array}$ \\
\hline
\end{tabular}


TEST AREA NORTH (TAN), INEL

Page 8 of 12

UNIT: WERF Waste Storage Building

WASTE TYPE: Hazardous and Radioactive Mixed Waste

CURRENT STATUS: Interim StatuS - RCRA

PROCESS CODES: SO1 - Container Storage

OTHER PERMITS: Permit to Construct/Prevention of Significant Deterioration (PTC/PSO) National Emission Standards for Hazardous Air Pollutants (NESHAPS)

PROCESS DESIGN CAPACITY: $70,000 \mathrm{gal}$. (265 Cubic Meters)

CURRENT INVENTORY: 0 gal. (O Cubic Meters)

WASTE CODES:

\begin{tabular}{|c|c|c|c|c|}
\hline D CHAR. & F LISTED & K LISTED & P LISTED & U LISTED \\
\hline $0001-0043$ & $\begin{array}{l}\text { F001-F012 } \\
\text { F019-F024 } \\
\text { F026-F028 } \\
\text { F039 }\end{array}$ & $\begin{array}{l}\text { K001 } \\
\text { K015 } \\
\text { K069 } \\
\text { K100 }\end{array}$ & $\begin{array}{l}P 001-P 018 \\
\text { P020-P024 } \\
\text { P026-P031 } \\
\text { P033-P034 } \\
\text { P036-P051 } \\
\text { P054 } \\
\text { P056-P060 } \\
\text { P062-P078 } \\
\text { P081-P082 } \\
\text { P084-P085 } \\
\text { P087-P089 } \\
\text { P092-P099 } \\
\text { P101-P116 } \\
\text { P118-P123 }\end{array}$ & $\begin{array}{l}\text { U001-U012 } \\
\text { U014-U039 } \\
\text { U041-U053 } \\
\text { U055-U064 } \\
\text { U066-U099 } \\
\text { U101-U103 } \\
\text { U105-U174 } \\
\text { U176-U194 } \\
\text { U196-U197 } \\
\text { U200-U223 } \\
\text { U225-U228 } \\
\text { U230-U240 } \\
\text { U242-U244 } \\
\text { U246-U249 } \\
\text { U328 } \\
\text { U353 } \\
\text { U359 }\end{array}$ \\
\hline
\end{tabular}




\section{APPENDIX I}

TEST AREA NORTH (TAN). INEL

Page 9 of 12

UNIT: Building-647 Waste Storage Facility

WASTE TYPE: Hazardous and Radioactive Mixed Waste

CURRENT STATUS: Interim Status - RCRA

PROCESS CODES: SOI - Container Storage

OTHER PERMITS: Permit to Construct/Prevention of Significant Deterioration (PTC/PSD) National Emission Standards for Hazardous Air Pollutants (NESHAPS)

PROCESS DESIGN CAPACITY: $27,500 \mathrm{gal}$ (104 Cubic Meters)

CURRENT INVENTORY: $27,302 \mathrm{gal}$. (103 Cubic Meters)

WASTE CODES:

\begin{tabular}{|c|c|c|c|c|}
\hline D CHAR. & F LISTED & K LISTED & $P$ LISTED & U LISTED \\
\hline $0001-0043$ & $\begin{array}{l}F 001-F 007 \\
F 021-F 022 \\
F 027-F 028 \\
F 039\end{array}$ & N/A & $\begin{array}{l}\text { P001-P018 } \\
\text { P020-P024 } \\
\text { P026-P031 } \\
\text { P033-P034 } \\
\text { P036-P051 } \\
\text { P054 } \\
\text { P056-P060 } \\
\text { P062-P078 } \\
\text { P081-P082 } \\
\text { P084-P085 } \\
\text { P087-P089 } \\
\text { P092-P099 } \\
\text { P101-P116 } \\
\text { P118-P123 }\end{array}$ & $\begin{array}{l}\text { U001-U012 } \\
\text { U014-U039 } \\
\text { U041-U053 } \\
\text { U055-U064 } \\
\text { U066-U099 } \\
\text { U101-U103 } \\
\text { U105-U174 } \\
\text { U176-U194 } \\
\text { U196-U197 } \\
\text { U200-U223 } \\
\text { U225-U228 } \\
\text { U230-U240 } \\
\text { U242-U244 } \\
\text { U246-U249 } \\
\text { U328 } \\
\text { U353 } \\
\text { U359 }\end{array}$ \\
\hline
\end{tabular}




\section{APPENDIX I}

TEST AREA NORTH (TAN), INEL

Page 10 of 12

UNIT: Hazardous Waste Storage Area (SMC) Building 628

WASTE TYPE: Radioactive Mixed Waste

CURRENT STATUS: Interim Status - RCRA

PROCESS CODES: SO1 - Container Storage

OTHER PERMITS: None

PROCESS DESIGN CAPACITY: 125 Cubic Meters $(33,000$ gallons)

CURRENT INVENTORY: 0 Cubic Meters

HASTE CODES:

\begin{tabular}{|c|c|c|c|c|}
\hline D CHAR. & F LISTED & K LISTED & P LISTED & U LISTED \\
\hline $0001-00011$ & F001-F003 & H/A & N/A & N/A \\
\hline
\end{tabular}


UNIT: Radioactive Scrap and Waste Facility (RSWF) Building 771

WASTE TYPE: Radioactive Mixed Waste

CURRENT STATUS: Interim Status - RCRA

PROCESS CODES: MisCellaneous Unit

OTHER PERMITS: None

PROCESS DESIGN CAPACITY: 193 Cubic Meters (51,000 gal.)

CURRENT INVENTORY: 41.5 Cubic Meters

WASTE CODES:

\begin{tabular}{|c|c|c|c|c|}
\hline D CHAR. & F LISTED & K LISTED & P LISTED & U LISTED \\
\hline 0001 \\
0003 \\
0005 \\
0006 \\
0007 \\
0008
\end{tabular}


UNIT: Radioactive Sodium Storage Facility (RSSF) Building 797

WASTE TYPE: Radioactive Mixed Waste

CURRENT STATUS: Interim Status - RCRA

PROCESS CODES: SOI - Container Storage

OTHER PERMITS: None

PROCESS DESIGN CAPACITY: 19 Cubic Meters (5000 gal.)

CURRENT INVENTORY: 9.6 Cubic Meters

WASTE CODES:

\begin{tabular}{|c|c|c|c|c|}
\hline D CHAR. & F LISTED & K LISTED & P LISTED & U LISTED \\
\hline 0001 & H/A & N/A & H/A & H/A \\
0003 & & & & \\
\hline
\end{tabular}


APPENDIX II 
APPENDIX II

MIXED DEBRIS GENERATION ESTIMATION

(Units in Cubic Meters)

ESTIMATE FOR MAY 8, 1993 TO MAY 7, 1994

Page 1 of 2

\begin{tabular}{|c|c|c|c|c|}
\hline GENERATING FACILITY/PROJECT/HASTE STREAM & COMBUSTIBLE DEBRIS & POROUS DEBRIS & HOH-POROUS DEBRIS & TOTAL VOLUME \\
\hline YASTE CALCINING FACILITY (HCF) STABILIZATION ACTIVITIES & 11 & 1 & 2 & 14 \\
\hline ACID RECYCLE PROJECT & 1 & 0 & 1 & 2 \\
\hline CPP-604/605 ASBESTOS ABATEMENT PROJECT & 2 & 1 & 13 & 16 \\
\hline MODIFY CPP-649 INSTRUMEMTATIOH PROJECT & 2 & 0 & 1 & 3 \\
\hline UPGRADE DVB C-37, C-12, ANO C-32 PROJECT & 2 & 0 & 2 & 4 \\
\hline NUCF VALVE BOX UPGRADE PROJECT & 3 & 1 & 3 & 7 \\
\hline FILIER LEACH MOOS PROJECT & 3 & 0 & 3 & 6 \\
\hline DRILLING AMO SAMPLING PROJECT & 1 & 1 & 0 & 5 \\
\hline HLLK EVAPORATOR UPGRAOE & 2 & 1 & 6 & 9 \\
\hline ISOLATE ML-102 & 1 & 0 & 4 & 5 \\
\hline REPLACE IR-101 & 3 & 1 & 1 & 5 \\
\hline CPP-604 EMBEDDEO LINES & 1 & 1 & 0 & 2 \\
\hline HUCF EMBEDDED LINES & 1 & 2 & 3 & 6 \\
\hline FUEL IIANOL ING & 5 & 1 & 4 & 10 \\
\hline IRC AHALYTICAL & 1 & 0 & 1 & 2 \\
\hline ANALYIICAL 602,627 & 4 & 0 & 2 & 6 \\
\hline ARALYIICAL CMEH. & 2 & 0 & 6 & 8 \\
\hline PRODUCTION (2300) & 3 & 0 & 2 & 5 \\
\hline FASI & 0 & 0 & 3 & 3 \\
\hline GASEOUS KASTE & 17 & 6 & 8 & 31 \\
\hline
\end{tabular}


APPENDIX II

MIXED DEBRIS GENERATION ESTIMATION

(Units in Cubic Meters)

ESTIMATE FOR MAY 8, 1993 TO MAY 7, 1994

Page 2 of 2

\begin{tabular}{|c|c|c|c|c|}
\hline GENERATING FACILITY/PROJECT/HASTE STREAM & COMBUSTIBLE DEBRIS & POROUS OEBRIS & NON-POROUS DEBRIS & TOTAL VOLUME \\
\hline NHCF TURMAROURD & 18 & 11 & 18 & 47 \\
\hline ACID CALCINER MODIFICAIION DEBRIS & 0 & 0 & 1 & 1 \\
\hline MONACIDIC LIQUID WASTE SYSTEM (EVAPORATOR UNITS) & 0 & $\mathbf{0}$ & 2 & 2 \\
\hline DBD OF ACIO EICH SYSTEH & $\underline{0}$ & 0 & 8 & 8 \\
\hline DVB REPAIR & 0 & 1 & 0 & 1 \\
\hline EVAPORATOR MESH & 0 & $\mathbf{0}$ & 3 & 3 \\
\hline REBORDER TUBE BUNDLE & 0 & 0 & 3 & 3 \\
\hline RF PROBE REPLACEMENT & 1 & 은 & 0 & 1 \\
\hline RII INSPECTION & 0 & o & 1 & 1 \\
\hline HEPA FILTERS & 0 & 7 & $\underline{0}$ & 1 \\
\hline B\&H HISC. PROJECT DEBRIS & 3 & 0 & 0 & 3 \\
\hline ANL-W HISC. PROJECT OEBRIS & 0 & 0 & 5 & 5 \\
\hline ELECTRONIC COMPONENTS & 6 & 0 & 0 & 6 \\
\hline EG\&G MISC. PROJECT DEBRIS & 13 & 2 & 8 & 23 \\
\hline IMEL HISC. PROJECI DEBRIS & 2 & 2 & 2 & 6 \\
\hline CASK OISHANILEMENT DEBRIS & 0 & 0 & 2 & 2 \\
\hline TOTAL VOLUME & 108 & 42 & 118 & 268 \\
\hline
\end{tabular}


APPENDIX III 
Form WINCO 5027

WESTINGHOUSE IDAHO

NUCLEAR COMPANY, INC.

\section{MEMO OF CONVERSATION}

$: 25 / 25 / 93$ Time $10 m$ Commitment Made $x$ Yes _ No Date

rson Calling Craia L. Porter Person Called Hazardous Waste Treatment Council Eli Eilbott 202-783-0870

:presenting INEL Representing

Irpose of Conversation Determine if any of the commercial hazardous treatment facility wners represented by HWTC can handle mixed debris.

ext of Conversation I described the types and quantities of mixed debris the INEL Enerates. ETi checked the HWTC database to see if there were any matches. No one on heir current database handled mixed debris.

El $i$ indicated that some of the members may have future 0 lans or have knowledae of gossible sources of commercial treatment. She committed to send the information to the membership. Any interested parties would contact me directly, (see attached copy of fax which was distributed to HWTC members). 


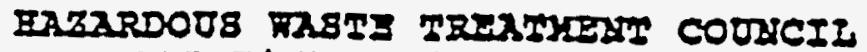 \\ 915 Fifteenth Stzeet, NW \\ Fifth Floor \\ Washington, DC 20005
}

VIX PACSIXIIE

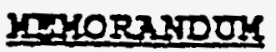

\author{
TO: Membership \\ EROM: EII D. Eilbott \\ DATE: $\quad$ May 25,1993 \\ RE: Generator Request for. Treatment of Hazardous Debris
}

Today we were contacted by 2 generator seeking treatment oi hazardous debris. The relevant information appears below. I advised the generator that I would circulate this information, and that he should expect lollow-up calls from ore or more iritc members.

Generztor Heme:

Sito Location:

contzet:

Debris rype:

Contaminant Type:
FINCO, a suicortractor at DOE's Idaho National Engineering Lab.

Near Idaho Falls, Idaho

Craig porter 208/526-310I

Asbestos piping insulation, rags; personal protective clothing and equipment, concrete, soil, tools.:

Trace Ievels of toxic metals and organics mixed with radioactive wastes at levels ranging from several MR/hr on contact to several R/ar on costact.

Please feel Iree to contact this generator directiy, and/or call me if you have any guestions. 
ate $5 / 27 / 93$ Time 10:15 Commitment Made _ Yes $x$ No Date

erson Calling Rich Powals

Person Called

Craig Porter

iepresenting _. Nor-True

Representing

INEL

Jurpose of Conversation Mixed Debris Treatment

Text of Conversation Rich called to indicate that they could not treat our mixed debris. 
7,1993

ig Porter

stinghouse Idaho Naclear Company, Inc.

1. Box 4000 jects Deparment

10 Falls, ID 83415-5119

I Mr. Porter:

hway 36 Iand Development Company is pleased that you have considered us to help you with your Irdous debris disposal needs. I have enclosed technical literature on the Frighway 36 Iand Development apany's Subttile C landfill.

we discussed, Fighway 36 has a part B RCRA permit for hazardous waste treatment but cannot recsive ed waste. All waste received at our facility can. not exceed our background radiation level of 25 roRoentgens per hour.

uld you have any questions, or require additional information, please feel free to contact me at 800-3926.

y traly yours,

1

i2 stal Eorst

2A Services Mañages

losures

: EWTC

\begin{tabular}{|c|c|}
\hline \multicolumn{2}{|c|}{ 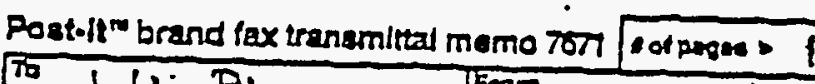 } \\
\hline Julie Piper & From Crasis Parter \\
\hline$\infty_{2} \cdot 2+2$ & $\infty$ \\
\hline Popt. & Prane $6-3 \mid<1$ \\
\hline Fax? & Faxक \\
\hline
\end{tabular}


Form WINCO 5027

WESTINGHOUSE IDAHO

NUCLEAR COMPANY, INC.

MEMO OF CONVERSATION

$\Xi 6 / 18 / 93$ Time 2:150m Comnitment Made _ Yes $\underline{x}$ No Date

son Calling Dave Asoitarte Person Called Craig L. Porter

resenting USPCI (208) $939-4428$ Representing INEL

pose of Conversation Hazardous debris treatment

st of Conversation Dave explained that USPCI has an existing RCRA/TSCA Iandfill at assy Mt. Utah. They have built an incinerator across the hiohway in Clive. Ut, which is ieduled for test burn in October with commercial operation in early 1994. The Einerator is being oermitted for RCRA/TSCA. Some NORM and mavbe dioxin. Dave confirmed. at they could not accept asbestos contajminated with both hazardous and radioactive ntituents. Requested mailino address and oromised to send company literature.

Signed

निद्र

Date

$4 / 8 / 93$ 
Form WINCO 5027

WESTINGHOUSE IDAHO

NUCLEAR COMPANY, INC.

MEMO OF CONYERSATION

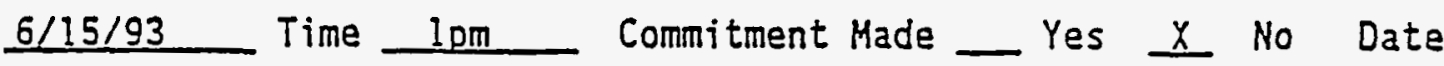

I Calling Craig L. Porter

Person Called Kathy Schiaufman

senting

Representing Cvanochem (313) 559-5900

se of Conversation Return call from Kathy (6/3) reaardina mixed debris.

of Conversation Kathy indicated that Cyanochem had received information from the dous Waste Treatment Council regarding our asbestos debris. She queried me regarding usiness and the types of waste we generated. I exolained what we do at the INEL and L that we generate radioactive, mixed, and hazardous waste. I pointed out that the oniy waste was small in volume compared to the other two categories. She offered to literature so they could be considered for our hazardous only waste. Although Tchem is onTy germitted for RCRA waste she suggested I contact the following comoanies possible treatment source for our mixed waste: ASBESTOS (801) 265-2323; 4120 S. 500 Murray, UT 84123 or QUADREX (615) $482-5532 \%$ David Rr.y. D.S. When I called ESTOS" Hestinahouse Environmental Remediation answered the ohone and sugaested I act APTUS at 531-4200:

Signed

Date $6 / 15 / 45$ 
te $6 / 18 / 93$ Time 10:30 Commitment Made _ Yes $\underline{x}$ No Date

srson Calling Craig L. Porter Person Called David Rry (615) $482-5532$

?presenting INEL Representing QUADREX Irpose of Conversation Determine if OUADREX is licensed to treat or disoose of mixed abris.

ext of Conversation I explained to Mr. Rry that he had been referred by Kathy chlaufman of Cyanochem as a possible source for mixed debris treatment or disoosal. I xolained that our debris is contaminated both radioloaically and with numerous RCRA haractistics and listed hazardous constituents. I also explained that our biagest roblem was assocjated with asbestos that is contaminated with RCRA waste and levels of adioactivity exceeding the disposal facility's (Envirocare) license. - Mr. Rry indicated their license prohibits RCRA waste. He indicated that their Gainesvilie acility can accept RCRA waste contaminated with xylene or toluene only. Mr. Rry said he would check some other possibilities and aet back with me if he found any possible sources Eor treatment/disposal of our mixed asbestos waste. 
Form HINCO 5027

WESTINGHOUSE IDAHO

NUCLEAR COMPANY, INC.

MEMO OF CONYERSATION

6/17/93 Time 2:30 Commitment Made — Yes $\underline{x}$ No Date

In Calling Craig L. Porter

Person Called Grea (801)531-4200

esenting

INEL

Representing

APTUS

ose of Conversation

Discuss asbestos debris contaminated with hazarjous and oactive constituents.

. of Conversation

Grea confirmed that they operate an incinerator. He indicated.

have been discussing asbestos and have decided to stay away from it due to the due oroblem. He also confirmed that their license does not include anv radionuclides.

signed

Date $\frac{C / 17 / 93^{\circ}}{1 / 1}$ 


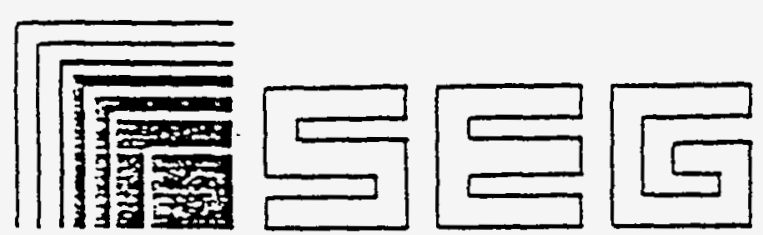

SCIENTIFIC ECOLOGY GROUP, INC.

iNay 15,1993

Rod Sidwell

WINCO

P. O. Box 4000

MS-5115

Idaino Falls, Idaho

Subject: $\quad$ Mixed Waste

Dear Mr. Sidwell:

Per your request to Wayne Norwood, please find enclosed for your files and information, a copy of the Scientific Ecology Group, Inc. (SEG) "Capabilities to Provide Comprehensive Radioactive Waste Management Services".

P!ease note that included, as an attachment to this document, is a copy of the SEG RCRA Part A Application. This application lists the processes to be permitted and the waste codes which SEG would process.

SEG bas prepared two (2) RCRA Part B Applications as a result of this Part A. The first Part B will enable SEG to receive and store materials and to apply treatment processes except for incineration. The incineration of materials is contained in the second Part B Application because the testing requirements will extend the permiting process by at least six (6) months for a test burn.

The first Part $B$ has been submitted to the State of Tennessee and other regulatory and public agencies. To date, we have received the approval of the Oak Ridge Environmental Quality Board. Also, during the first public review meeting, the State and SECr received no negative comonents from the public on our appliciston. Based on our progress made to date, we are hopeful the first Part B permit will be granted to SEG in lare 1993 or early 1994.

We hope that you will find this information usetul in planning your mixed waste processing strategy. If you .. bave any questions, please contact the undersigned at (615) 376-8032.

Very truly yours,

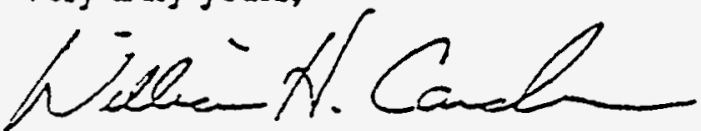

Williarn H. Carder

Manager, Government Marketing

WHC/js-93-027 


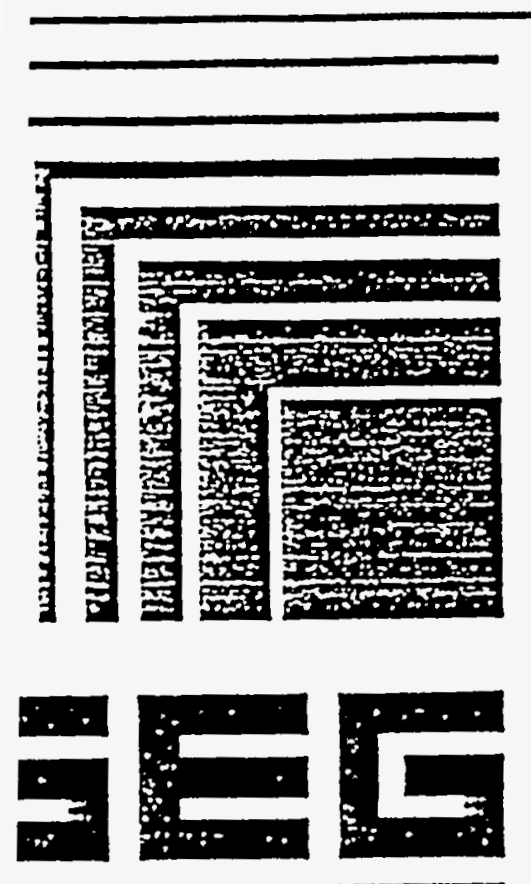

ITIFIC ECOLOGY GROUP. INC.

The World Leader 'adwaste Processing and Management

\section{Mixed Naste}

or more information contoct: SEG

P.O. BOX 2530

1560 Bear Creek Road Oak RIdge, TN 37830

(615) 481-0222

SEG is a wholv owned WOSOCY OF WESTINGHOUSE

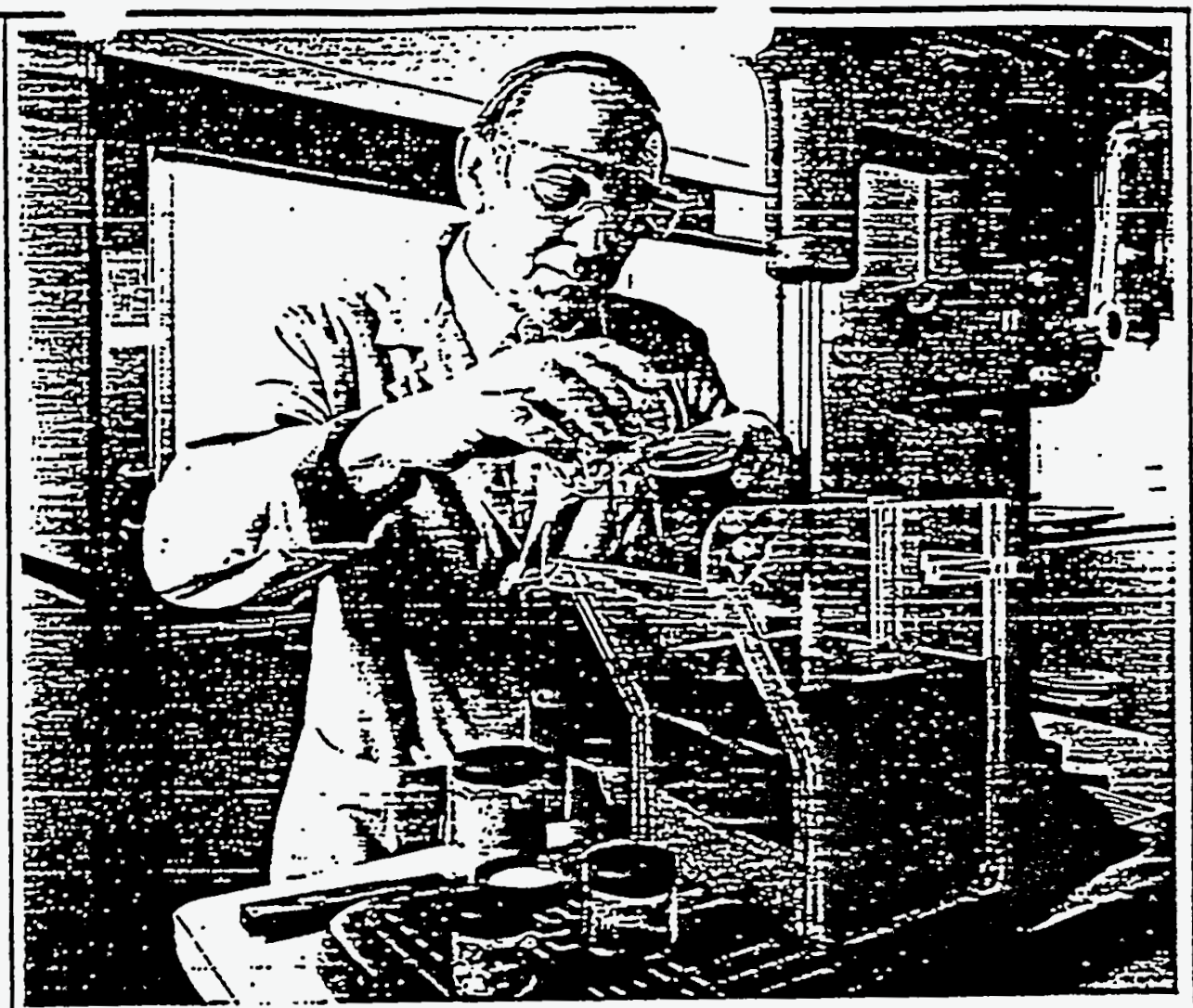

\section{SEG CAN SOIVE YOUR MIXED WASTE PROBLEMS}

- TREATABILITY STUDIES FOR

- Listed

- Characteristic

$\because$ MIXED WASTE STORAGE FACILITY

(due soon)

- SOIL DECONTAMINATION

- PCB's

- Hg (mercury)

3 METALS

- Lead

- Mg-Th (magnesium thorium) 
Form WINCO 5027

WESTINGHOUSE IDAHO

NUCLEAR COMPANY, INC.

MEMO OF CONVERSATION

ite $7 / 20 / 93$ Time 11:11 Commitment Made _ Yes $\underline{x}$ No Date zrson Calling Craig L. Porter Person Called Bob Gallacher (713) 641-0391 epresenting INEL Representing NSSI(NuClear Source \& SvCS. Inc.) urpose of Conversation Explore capabilities of NSSI to treat mixed debris.

ext of Conversation Bob indicated that they have treated minimal quantities of mixed ebris. primarily stabilization. NSSI is a fully permitted (Part B) TSD. Mixed waste is ncluded in the permit as lona as they maintain their rad license. Treatment capabilities Il lowed by the permit are very broad. i.e.. oxidation, reduction. chemical separation. stc. Basically, each request is handled on a case-by-case basis. Having said all this, 30 then made it very clear that they have found they cannot work with DOE. Have attempted treatina DOE waste four different times and essentially have only stored waste Cause DOE would never qive the aporoval to treat. NSSI typically no-bids proposals creater than $1 / 4^{n}$ thick and DOE is usually in the $11 / 2^{n}$ range. Their current staff of 30 zeople would have to triple to meet DOE requirements in addition to changing accounting systems and every other system - a terrible expense not warranted by DOE business. Summarized conversation by statina that NSSI has the facilities and capabilities but not the mentality to treat $O O E$ mixed waste. Thanked me for lettina him aet it off his chest. Date $7:=01-3$ 
Costs for treatment of conyeational bazardous wastes are provided in Seation 43.1 , where the impac: of ocher factors is also diseused.

\subsubsection{Costs of Technolegies for Conventlonal Applleatlons}

In Section 4.1 and 42 several tecteologies were discussed as beisg forgieally fessiole for destroying the bazardous componeats of mired waste or separating the radionetive sod barardaus componeats. The actual methods employed degead on the form of tbe waste, the ideatity of the radioactive and bazardous congounds, the volume of waste, and ocher bactors.

Costs for teeboologies for disposing of conventional (nonradioactive) bazardous wastes bave besa develoged for facilities processigg compasatively large volumes of waster generzlly over thourzads of gallons of liquid waste or tons of solid waste. Such costs ate presented in Twble 42 These costs are based on large amounis of convestional bazardous waste, ind are not directly applieable to the relacively small volumes of mixed waste. The raueb stasiller quantities of mixed waste requiring trestreneas will inc:ease the unit cost wor each of these techoologies.

Tabla 4-2. Representative treatmeat costs for conventional bazardous waste.

\begin{tabular}{|c|c|c|}
\hline Texinsology & Liquid Wasta & Solid Waste \\
\hline 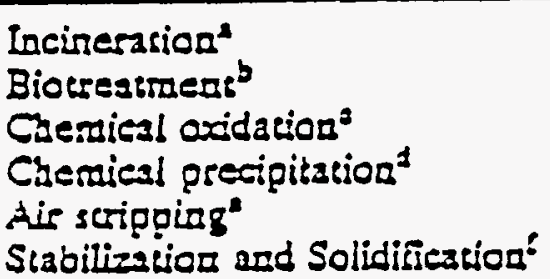 & $\begin{array}{l}\text { S600/55-gal dr2an } \\
50.02 \cdot 50.50 / 1,000 \mathrm{gal} \\
50.10-50.50 / 1,000 \mathrm{gal} \\
50.10-50.20 / 1,000 \mathrm{gal} \\
\text { S0.02-50.10/1,000 gal } \\
\text { NA }\end{array}$ & $\begin{array}{l}S 400+100 \\
\$ 50-S 150 / 200 \\
N A \\
N A \\
N A \\
S 80-5200 / 100\end{array}$ \\
\hline
\end{tabular}

2 Personad communicsion with Allen Xitto, Chemical Wasio Management, Juse 1991

b. Nyer,'1988

c. Berrardia. Froelich, 1985

d. Krsus, 1982

e Schriling, 1985

E Noyes Data, 1991

\subsubsection{Avallabllty of Treatrient Facllthes}

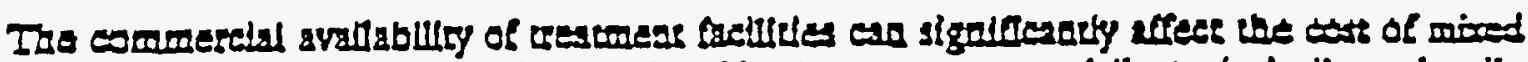
waste trencment There are no facilities nxtionwide that are commensially, techenically, or legally copable of treatiog all types of mixed waste In zddition to companies providiag trestment of

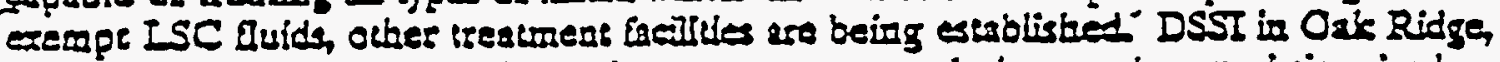
Tesnessee is peraitied and liessued bo treat aqueous solulioes characteristic moced wasta by

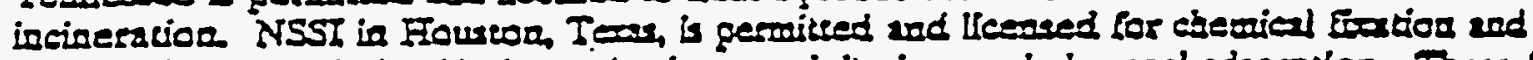

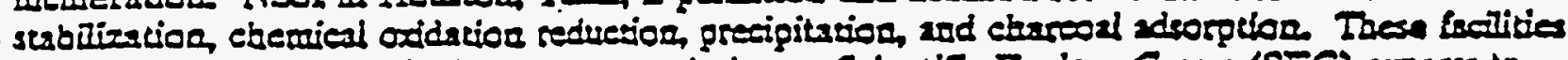
use technologies best suited to aqueous solutions Scieatifie Eoologs Group (SEG) epess to

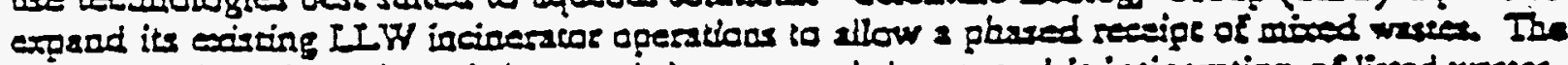

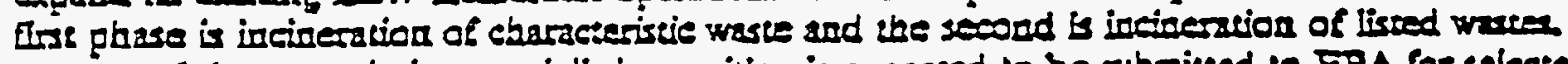

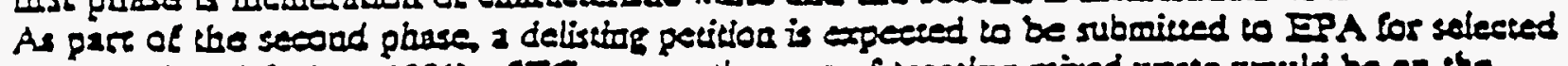

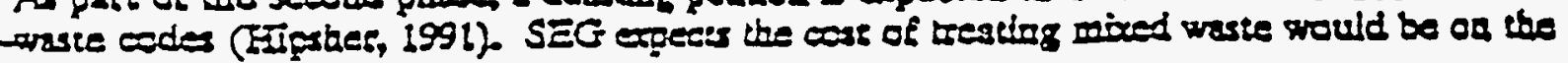


By signing this form, I indicate that I have reviewed the information included in this document and Appendices I, II, and III (INEL TSD Facilities, Mixed Debris Estimates, and Memos of conversations) and it is, to the best of my knowledge and belief, true, accurate, and complete in those'areas in which I have responsibility or expertise with respect to EG\&G Idaho operations.

(Ingaturef

Ii. V. Davis

ER\&WM Regulatory Compliance

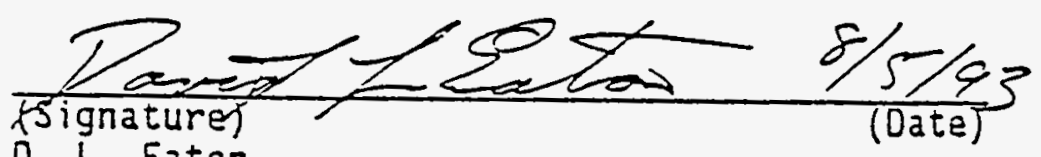

D. L. Eaton

EG\&G Environmental Technical Support
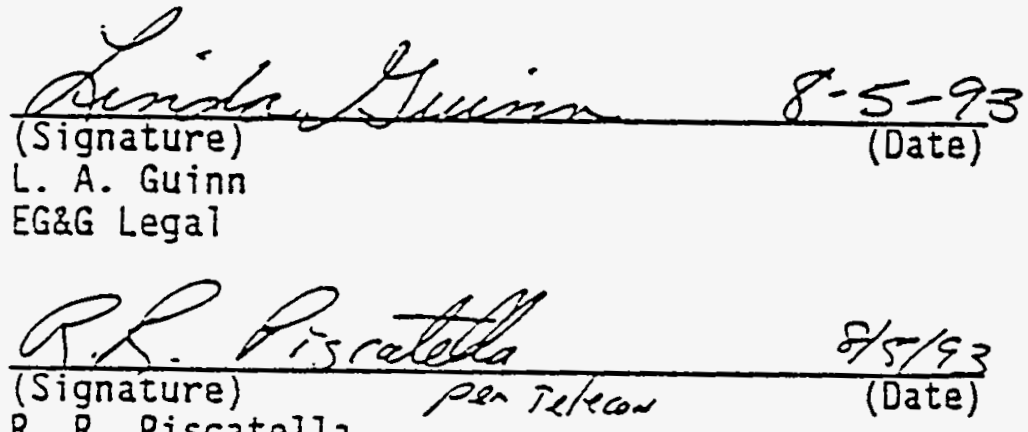

R. R. Piscatella

MLLW Waste Type Manager

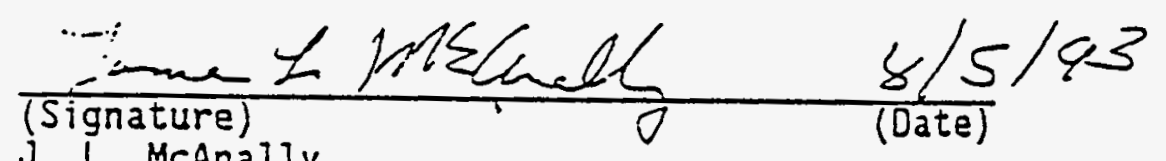

J. L. Mcanatly

Environmental Restoration \& Waste Management 
INCL REPORT FOR THE RENEWAL OF THE HAZARDOUS DEBRIS CASE-BY-CASE CAPACITY VARIANCE EXTENSION

By signing this form, I indicate that I have reviewed all the information in this document and all attachments (Appendix of Facility Inventories, Memos of Conversations) and it is, to the best of my knowledge and belief, true, accurate, and complete in those areas in which I have responsibility or expertise.

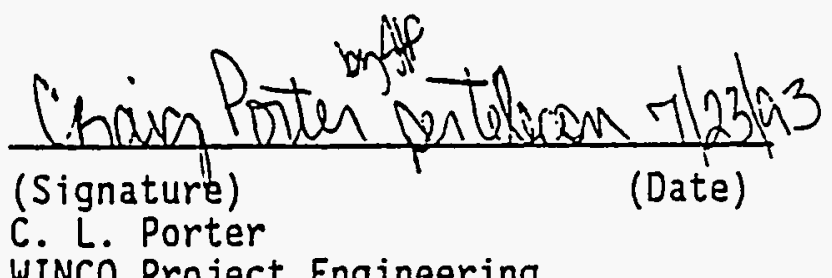

WINCO Project Engineering

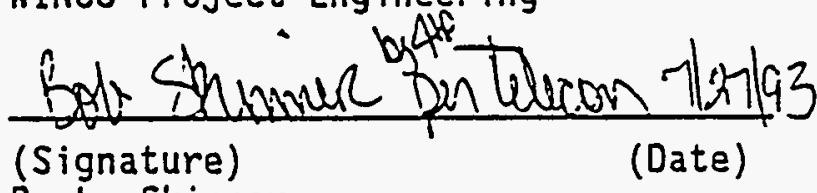

R. L. Skinner

WINCO Shipping and Materials

Management Manager

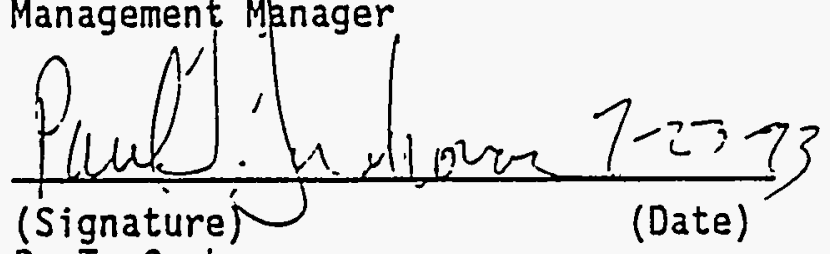

P. T. Grahovac

Law Department, wINCo

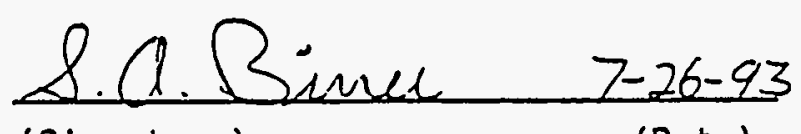

(Signature)

S. A. Borer

WINCO RCRA Compliance Manager

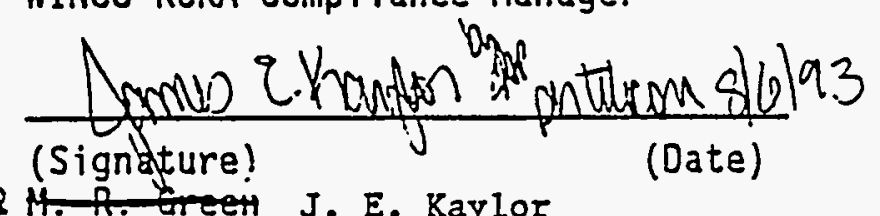

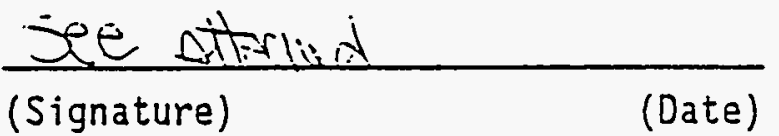

D. L. Eaton

EG\&G RCRA Compliance

Sesatinchid

(Signature)

(Date)

B\&W

$\overline{\text { (Signature) } \quad \text { (Date) }}$

M. T. Wall ace

Argonne

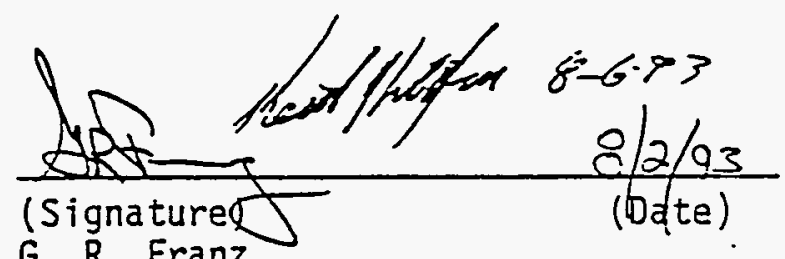

G. R. Franz

WINCO Environmental Permitting and Regulations Manager

(Signature)

(Date)

W. J. Johnson, Executive Vice President

Waste Processing

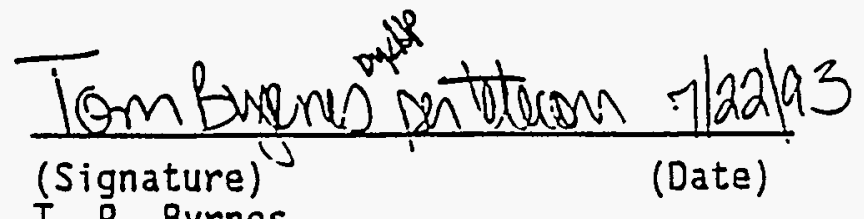

T. R. Byrnies

WINCO FAST Operations

$\because$ 
Requitrment 5: Cartification as required under 40 CrR 268.5(b).

I cartlify that I have personally examined and am familiar with the information submitted in this document and all attachments and that, based on my inquiry of those individuals immediately responsible for obtaining the information, I belfeye that the information is true, accurate, and completa to the best of my knowledge. I am aware that there are significant penalties for submitting ialse information, including the possibility of fines and imprisonment.

Signed

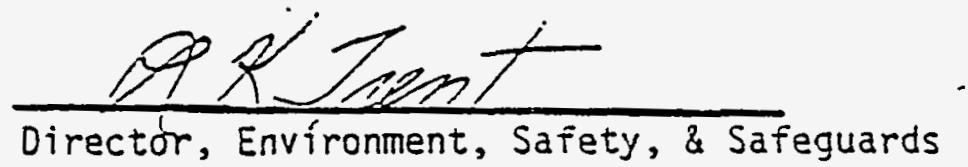

Representing Babcock dletilcat lutoto

Data

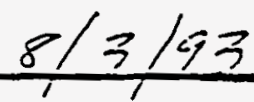


INEL REPORT FOR THE RENEHAL OF THE HAZAROOUS DEBRIS CASE-BY-CASE CAPACITY YARIAKCZ EXTEHSIOH

By signing this form, I indleate that I haye reviawed all the information in this documant and 11 attachments (Apoend1x of Facllity Inventories, Hemos of Conversatfons) and (t is, to the best of ny knowledge and bellef, trua, acsurata, and compiete in those araas in which I have responstbility or oxparttse.

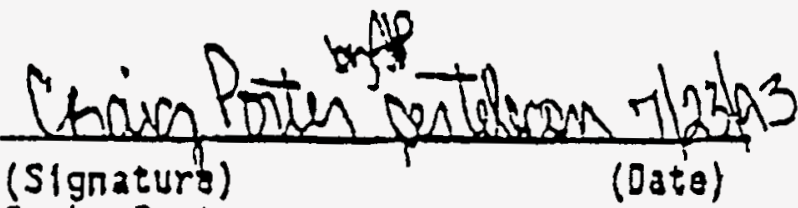

C. L. Porter

WLYCO Project Enginesring

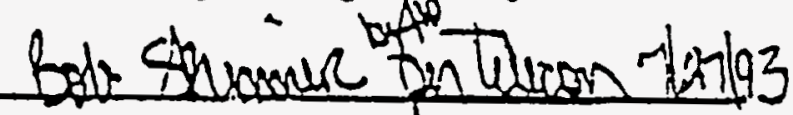

(Signetura)

(Dato)

R. L. Skinner

WINCO Shipoing and Matortals

Managament Manager

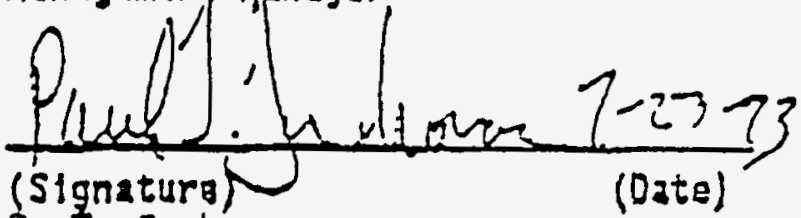

P. 7 . Grahavac

Law Department, wixco

(Date)

\section{4}

jee strind

(signatura)

o. L. Ezton

(axta)

EGLG RCRA Ccapliancs

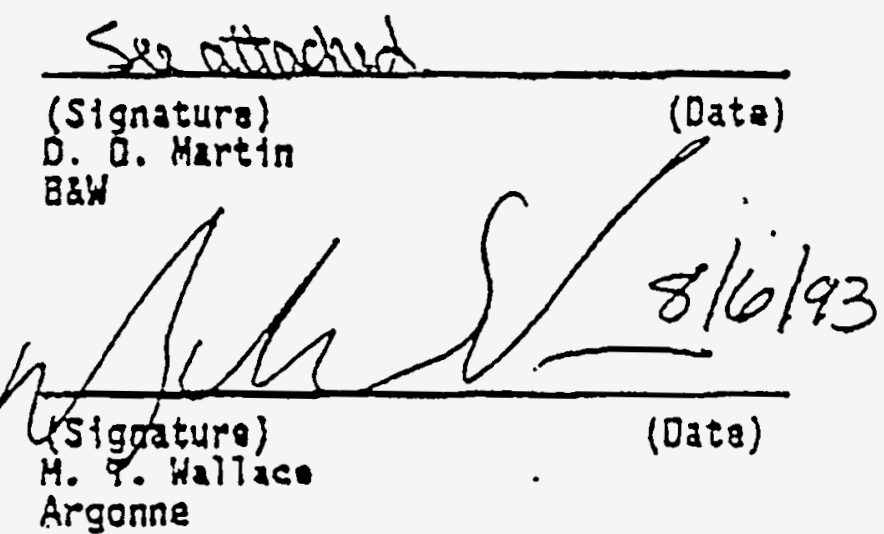

Argonne

D.A. 2ines 2-76-23

(Signature)

(Dats)

\$. A. Birrer

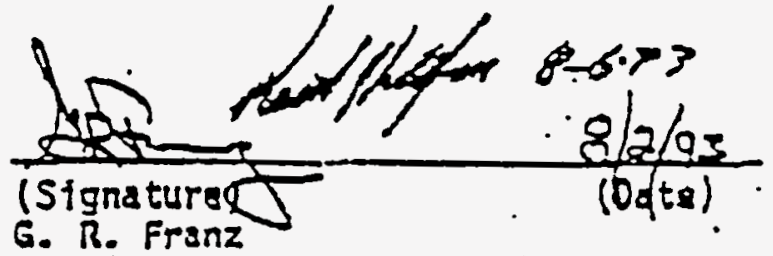

HINCO RCRA COmpltanca Manager

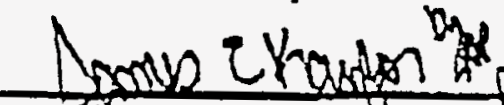

(n)

(storiteura)

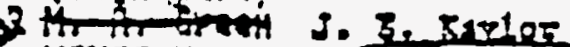

(Date)

WINCO Enytronmental Permttting and

Regulations Manager

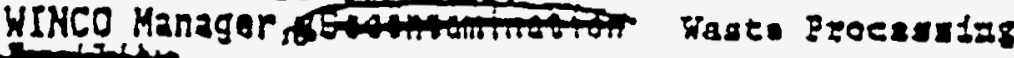

arastitisy

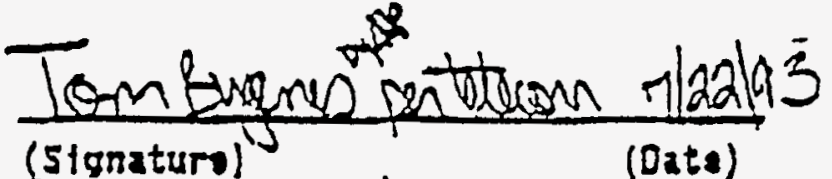

f. R. Byrnas

HINCO FAST ODERations

(Iszastisis)

H. J. Sohsion, Executiva V1ac Presidene 
INEL REPORT FOR THE RENEWAL OF THE HAZARDOUS

DEBRIS CASE-BY-CASE CAPACITY VARIANCE EXTENSION

By signing this form, I indicate that I have reviewed all the information in this document and all attachments (Appendix of Facility Inventories, Memos of Conversations) and it is, to the best of my knowledge and belief, true, accurate, and complete in those areas in which I have responsibility or expertise.

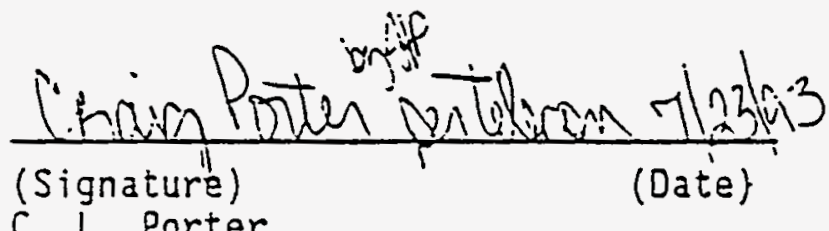

C. L. Porter

WINCO Project Engineering

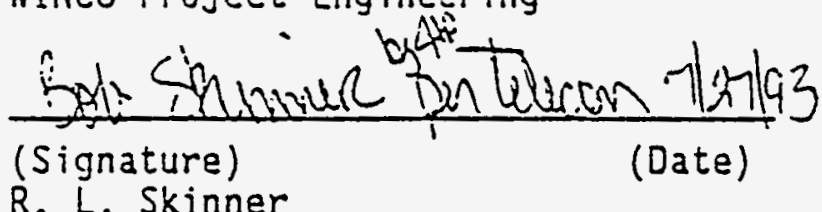

R. L. Skinner

WINCO Shipping and Materials

Management Manager

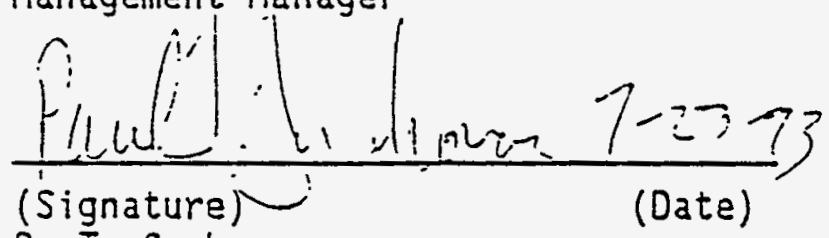

P. T. Grahovac

Law Department, WINCO

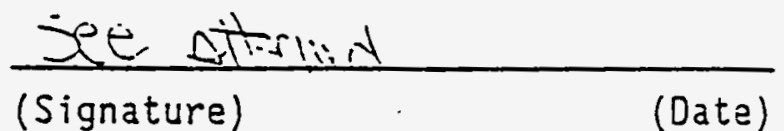

D. L. Eaton

EG\&G RCRA Compliance

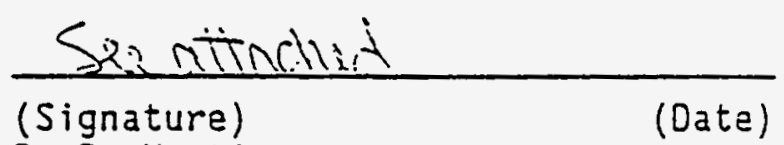
D. D. Martin $B \& W$

(Signature) (Date)

M. T. Wallace

Argonne

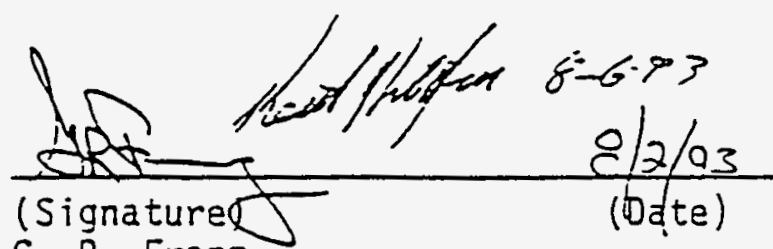

G. R. Franz

WINCO Environmental Permitting and Regulations Manager

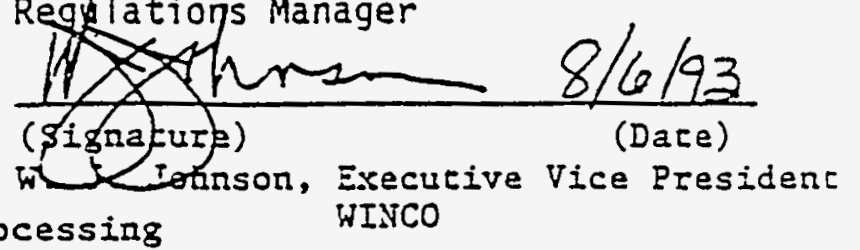
WINO

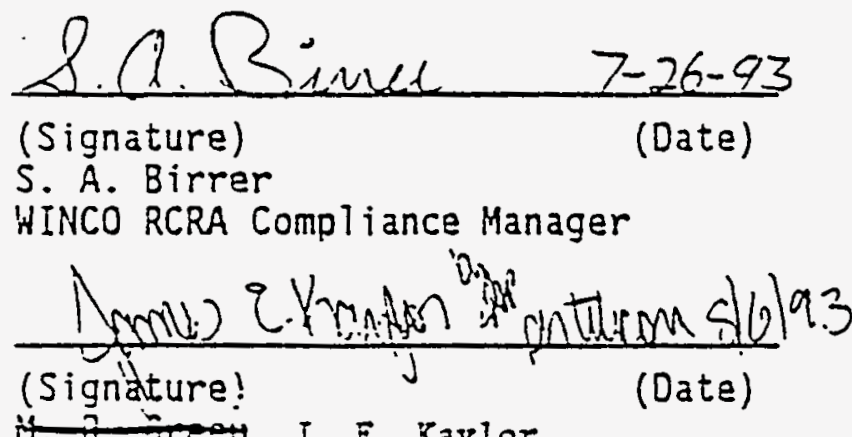

Waste Processing

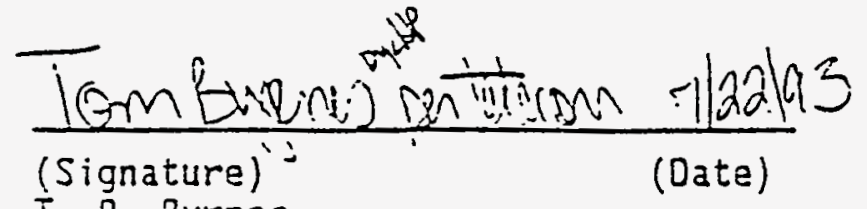

T. R. Byres

WINCO FAST Operations 
year extension of the LDR effective date. EPA indicated in this notice that persons desiring a renewal of the variance (bcyond May 8, 1993) would be required to submit an individual case-by-case variance application (i.e., for their respective sites). EPA further stated that individuals interested in receiving a renewal must have their application submitted before November 8, 1992.

Independent of the generic, case-by-case variance, in a final rule published on August 18, 1992 (57 FR 37194), EPA promulgated revised treatment standards for debris contaminated with listed hazardous waste or debris that exhibited certain hazardous waste characteristics. Under the revised standards, hazardous debris can be treated using specified treatment technologies, dependent on the type of debris and type of contaminant(s) present. The August 1992 rule identifies a number of Best Demonstrated Available Technologies (BDAT) for treating hazardous debris and allows the generator and/or treater managing the waste the flexibility of choosing the technology. Altematively, generators and/or treaters have the option to meet the existing waste-specific treatment standards for the prohibited listed or characteristic waste contaminating the debris. For a further discussion see the "Other Related Requirements" section of this bulletin.

Despite the promulgation of the revised treatment standards, by November 8, 1992. EPA had received almost 200 case-by-case variance applications requesting a renewal of the extension. Applicants stated that treatment capacity in compliance with the August 18,1992 , debns rule was still lacking and that the period of time necessary to permit, construct, and start-up treatment and storage units would prevent them from providing the necessary treatment capacity. Also, a recent EPA capacity analysis indicates that a general lack of treatment capacity for hazardous debris exists. Furthermore, uncertainty as- sociated with the physical and chemical properties of debris generated during remediation projects, as well as the type(s) of equipment needed/available to manage these debris wastes are difficult to determine.

Therefore, based on the large number of case-by-case variance applications, and the additional factors discussed above, EPA published a final rule on May 14, 1993 (58 FR 28506), granting a renewal of the case-bycase capacity variance for certain hazardous debris. ${ }^{2}$ This rule became effective on May 8 , 1993, and extends the LDR effective date for covered hazardous debris until May 8, 1994.

Information submitted by the Hazardous Waste Treatment Council to EPA indicates that some treatment capacity is available for certain categories of debris. As a result, the requirements associated with this extension include a notable difference from the preceding generic, case-by-case variance. To be eligible for this variance, EPA requires persons claiming the variance to submit a report that satisfies certain information requirements and includes a demonstration that a good-faith effort to locate appropriate trealment capacity has been undertaken (see the requirements associated with the extension described below).

\section{Conditions of the Variance}

As with the initial case-by-case capacity variance, this extension applies to debns (1) contaminated with wastes listed in 40 CFR 268.10, 268.11, and 268.12 (First, Second. and Third Third scheduled wastes); (2) contaminated with characteristic hazardous wastes for which LDR treatment standards have been established (i.e.. corrosive. reactive. ignitable, and former EP toxic ivastes): and (3) contaminated with these hazardous wastes that are also radioacuve mixed wastes. Debris contaminated with solvent wastes ad-

2 See Olfice of Environmental Guidance memorandum. "Renewal of Hazardous Debris Case-By-Case Capacity Varıance." June 21. 1993. 
dressed in 40 CFR 268.30, dioxin-containing wastes addressed in 40 CFR 268.31 , or nonliquid Califomia list wastes that are addressed in 40 CFR 268.32 or RCRA 3004(d) are not covered by this extension.

Of integral importance when identifying material that is eligible for this variance is EPA's application of the term debris. EPA affords generators some latitude when identifying material that is eligible for the renewal by allowing debris to be defined as either

\section{(1) debris as defined in 40 CFR 268.2(g);}

(2) nonfriable inorganic solids incapable of passing through a $9.5 \mathrm{~mm}$ standard sieve that require size reduction prior to stabilization, limited to the following inorganic or metal materials:

- metal slags (either dross or scoria);

- glassified slags;

- glass;

- concrete (excluding cementitious or pozzolanic stabilized hazardous wastes);

- masonry or refractory bricks;

- metals cans, containers, drums, or tanks;

- metal nuts, bolts, pipes, pumps, valves, appliances, or industrial equipment; and

- scrap metal [bits and pieces of metal parts (e.g., turnings, rods, and wire) and metal pieces that are combined using bolts or solder (e.g., radiators. railroad cars)]; or
(3) organic debris, inorganic debris, geologic materials that are not indigenous to the natural environment at or near the site, or indigenous rocks exceeding a $9.5 \mathrm{~mm}$ sieve size that are greater than 10 percent by weight, or that are at a total level that, based on engineering judgment, will affect the treatment technologies performance (see $55 F R 22650)^{3}$.

The current definition for debris under 40 CFR 268.2(g) was promulgated in the August 18, 1992, final rule (57FR 37270). This definition includes "...solid material exceeding a $60 \mathrm{~mm}$ [2.5 inch] particle size that is intended for disposal and that is: A manufactured object; or plant or animal matter; or natural geologic material...."

The particle size criterion may be implemented based on visual observation (i.e., screening is not required). EPA defines solid material in a literal sense to mean a material that retains its volume at room temperature without the need for support by a container (57 FR 37222). Although debris must be a solid material, in many cases, it may contain or be mixed with liquids or sludiges. EPA prescribes "[a] mixture of debris... is subject to regulation as debris if the mixture is comprised primarily of debris, by volume, based on visual inspection." EPA further clarifies that if debris contains free liquid that oozes from the debris, the remaining volume of entrapped liquid need not be considered when visually determining whether the mixrure is primarily debris. However, if nondebris materials (e.g., oozing liquids. clumps of soil, etc.) separate from the debris prior to treatment by a specified technology. the separated materials are no longer classified as debris.

If the materials constiute a listed hazardous waste or exhibit a prohibited charac-

\footnotetext{
3 Conversations with EPA personnel (Capacity Programs Branch and Office of General Counsel) indicate that the intent of this renewal is 10 include all hazardous debris that was covered by the previous generic. hazardous debris case-by-case capacity vartance. Eligibility for the first generic variance relied on the narrative description of debris provided in the preamble to the Third Third final rule. EPA personnel have indicated that they plan to publish a technical correction notice to clarify the appropriateness of using the June 1. 1990. description.
} 
tcristic, they must be managed as hazardous waste-or soil contaminated with a hazardous waste-subject to the applicable wastespecific treatment standards. Clumps of agglomerated clay or soil do not qualify as debris and are subject to the waste-specific treatment standards for the waste contaminating the soil. (see 57 FR 37223 and 37224)

In addition to identifying materials that qualify as debris, in the August 18, 1992, (Phase I) final rule, EPA specifically excluded several materials from meeting the codified definition of debris [40 CFR $268.2(\mathrm{~g})]$. Materials not meeting the definition of debris include the following:

- Materials with specified treatment standards identified in 40 CFR Part 268, Subpart D (e.g., D006 - cadmium containing batteries and D008 - radioactive lead solids subcategory). These wastes are subject to more specific treatment standards, which take precedence over the general debris standards.

- Process residuals such as smelter slag and residues from the treatment of waste, wastewater, sludges, or air emission residues (emphasis added).

Jonempty, intact containers of hazardous waste that are not ruptured and that retain at least $75 \%$ of their original volume.

Although process residuals were excluded from the revised definition of debris under the Phase I rule, in the preamble to the variance renewal EPA notes, “...excluded process residuals will... be included within the scope of today's renewal." Process residuals may be covered by the renewal provided the residuals meet the previously applicable definution of debns described in the June 1, 1990. Third Third final rule (see footnote 3), and are not excluded from the extension.
EPA (in the preamble to the Phase I final rule) clarifies the applicability of the definition of debris to discarded industrial equipment (e.g., filters and pumps) and associated treatment residues involved in the treatment of wastes or wastewaters. EPA states that "A discarded pump or filter used to treat a waste is debris.... Although some filtered or pumped waste will contaminate the pump or filter,... the contaminated pump or filter will virtually always be comprised primarily of debris rather than waste and so would be classified as debris." (57FR 37225)

Under 40 CFR 268.5, seven demonstrations are specified that must be made and evaluated by EPA in determining the applicability of a case-by-case variance. Normally, these demonstrations must be included as part of the case-by-case application that is submitted individually to EPA for review. However, EPA has conducted an evaluation of the demonstration requirements and determined that a renewal of the one-year variance from LDR treatment standards is warranted for eligible hazardous debris. As mentioned above, this renewal will remain in effect from May 8 , 1993, to May 8, 1994 [40 CFR 268.35(e)]. No further variance or extension can be granted for hazardous debris beyond May 8 , 1994, pursuant to RCRA statutory provisions.

To be eligible for the one-year extension. by August 12, 1993, or within 90 days after the hazardous debris is generated (whichever is (ater), ${ }^{4}$ each generator or facility owner/operator must submit a report to EP.4 containing the following information:

(1) The name, mailing address. location. and EPA identification number of the site where hazardous debris will be generated.

(2) A description of the hazardous debris waste stream, including waste code(s).

(3) Waste generation rates $\left(\mathrm{m}^{3} / \mathrm{y}\right)$, and estimated inventories $\left(m^{\prime}\right)$. 
(4) A demonstration that the generator or owner/operator has made a good-faith effort to locate and contract with treatment or recovery facilities that offer technologies suitable for managing their waste(s). To successfully make this demonstration, generators must include, at a minimum, a summary of:

- activities that demonstrates that the generators have contacted a substantial number ${ }^{5}$ of treatment or recovery facilities, but each facility rejected the debris due to its composition or because the facility lacked the necessary treatment capacity,

- the letters sent to these facilities describing the debris waste and requesting treatment, recovery or disposal (protective) for the waste, and

- the responses received from these facilities rejecting the debris waste (if the correspondence does not explain the reasons for rejection, generators must provide an explanation).

(5) Certification by an authorized representative as required under $40 \mathrm{CFR}$ 268.5(b).

Two copies of the report containing the information identified above should be sent to following address:

Chief of Training \& Technical Assistance Branch U.S. Environmental Protection Agency Office of Waste Programs Enforcement (OS-520) 401 M Street, S.W.

Washington. D.C. 20460

Attn: Debris Case-8y-Case Progress Report

This report must be submitted to EPA by August 12, 1993, for hazardous debris generated prior to May 14, 1993. For hazardous debris generated after May 14, 1993, the report must be submitted within 90 days after generation of the hazardous debris. EPA has indicated that a one-time submittal of such reports will satisfy the requirements for this extension (i.e., progress reports during the period of the extension will not be necessary). ${ }^{6}$ EPA also has indicated that in cases where a specific type of hazardous debris is generated (during the period of the extension), and this type of debris has already been identified in a previously submitted report by that generator, it is unnecessary to submit an additional report for the newly generated debris wastes. Generators must continue to locate capacity during the period of this variance, and if located, must use it to the fullest extent possible.

\section{Other Related Requirements}

Although EPA has taken this regulatory action to renew the hazardous debris case-bycase capacity variance, as with the initial oneyear extension, certain LDR requirements still remain applicable. Restricted hazardous debris subject to this variance remains subject to the LDR notification requirements [ 40 CFR 268.7(a) (3)]. Specifically, if a generator's debris is not excluded from the definition of hazardous waste under $261.3(\mathrm{f})$ and is subject to this case-by-case extension, with each shipment of waste, a notice stating that the waste is not prohibited from land disposal must be submitted to the facility receiving that waste. The notice must include the following information:

๑ EPA Hazardous Waste Number;

a the corresponding treatment standards. either included or referenced by including the appropriate subcategory, the treatability group of the waste (e.g., wastewater or nonwastewater). the CFR sections and paragraphs where the ap-

5EPA considers contact with 10 or more facilities to constitute a "substantial number."

6 Based on telephone conversations of July 14. 1993. with responsible EPA personnel withın the Capacity Programs Branch and Olfice of General Counsel. 
plicable treatment standards appear, and, where applicable (i.e., for treatment standards expressed as specified technologies), the corresponding fiveletter treatment code (e.g.. CHOXD, MACRO);

\section{the manifest number;}

waste analysis data, where available;

- the hazardous debris contaminants that are subject to treatment and a statement that the debris is subject to the alternative treatment standards; and

D the date the waste is subject to the prohibitions (e.g., May 8, 1994).

Also, waste generators who also treat, store, and dispose on-site must put the same information in their operating record (except for the manifest number).

EPA has stated repeatedly that the California list regulatory and statutory prohibitions are superseded by more specific prohibitions and treatment standards. (see $52 F R 25773$, 53 FR 31188 , and 55 FR 22674) However, during the period of a capacity variance related to more specific standards (e.g., during a case-by-case extension), the California list prohibitions continue to apply. For hazardous debris that is eligible for this additional oneyear extension, but exceeds a California list threshold, a generator's notification (i.e., during the one-year extension) must contain both the information listed above for the waste code(s) subject to the extension, as well as the appropriate treatment standard(s) applicable to the Califomia list constituent(s). Before this type of waste can be land disposed, the waste must be treated below the California list prohibition level or treated by the specified technology. Once the variance expires. generator's will resume lisung only the more specific waste code on the notification.

In the August 1992 final rule. EPA ident1fies three general categones of treatment tech- nologies appropriate for hazardous debrisextraction, destruction, and immobilization. The 17 technologies identified within these categories are considered BDAT and were based on, among other things, the properties of debris (e.g., brittleness, moisture content, and size) that may directly affect treatment efficiency. EPA also established performance and/or design and operating standards for these 17 specified technologies (40 CFR 268.45, Table 1 - Alternative Treatment Standards For Hazardous Debris).

Under the hazardous debris regulations, the selection of an appropriate BDAT for the hazardous debris is left up to the generators and treaters managing the waste. Upon treatment by one of the specified extraction or destruction technologies identified in Table 1 of 40 CFR 268.45, hazardous debris is no longer subject to regulation under Subtitle $C$, provided the debris does not exhibit a hazardous waste characteristic identified in Subpart C of 40 CFR Part 261 (i.e., ignitability, corrosivity, reactivity, or toxicity).

Generators and treaters also retain the option of treating waste to meet waste-specific treatment standards for the waste contaminating the debris. However, debris treated to waste-specific treatment standards remains subject to Subtitle $C$ regulation unless, based on a site-specific determination. an EPA Regional Administrator determines the debns no longer "contains" significant levels of hazardous waste [40 CFR 261.3(f)(2)]. Reduction of the waste levels can be achieved using any permissible form of treatment, and need not result from the application of treatment technologies specified for hazardous debris under 40 CFR 268.45.

In addition to promulgating treatment technologies, EPA amended the documentation requirements for generators and treaters of hazardous debris in the August 1992 final rule. Specifically, in addition to beanng the burden of proof that hazardous debris meet all of the 
$n$ Subtitle $C$ requirements, the rdkeeping requirements apply:

ons under $268.7(a)(1)$ must ie hazardous debris contamiject to treatment, and include nt that the debris is subject to e treatment standards identi) CFR 268.45 [268.7(a)(1)(iv)].

irs that treat their hazardous deeet applicable treatment standinks, containers, or containits using an alternative treatndard provided in $40 \mathrm{CFR}$ tre not subject to written waste plan requirements เ)(4)].

Jus debris that is either treated $x$ traction or destruction technolvided in Table 1 of 40 CFR or determined to no longer conazardous waste, are not subject .DR certification requirements :FR 268.7(a)(2) for generators, jotification/certification requireof 40 CFR 268.7 (b)(4) \& (5) for 5. Rather, such generators and $s$, who first claim their hazardous is excluded from the definition ardous waste, must submit a onetotification to the EPA or authortate, accompanied by a certificaf compliance [40 CFR 268.7(d)].

ous debris that is subject to the zergy Act because it contains radionponents (i.e., it qualifies as radioac1 waste), remains subject to the iment standards for the hazardous nponent. On October 6. 1992, the acility Compliance Act, which svereıgn immunity for RCRA rets, was signed into law. This Act special provisions for radioactive aste that delay the effectuve date ars from enactment) for Federal rolations of RCRA 3004(j) (the LDR Jrohibition), provided the mixed waste is managed in compliance with all other applicable RCRA requirements.

Although certain radioactive mixed wastes meet the definition of debris and could qualify for the generic, hazardous debris case-bycase variance, claiming the variance may not be necessary. Specifically, generators of mixed debris waste that will only undergo storage during the period of May 8, 1993 through May 8, 1994, will not require the benefits of the variance (i.e., their mixed waste will not be land disposed without meeting the treatment standards). Conversely, generators that identify disposal capacity for their mixed debris waste, but do not possess the treatment technologies necessary to achieve compliance with the LDR treatment standards, must comply with the conditions of this variance to ensure their debris may be land disposed (in compliance with the LDR program) without meeting applicable treatment standards. Any landfill or surface impoundment that receives hazardous debris (including mixed debris waste) covered by the variance must meet minimum technology requirements [40 CFR 268.5(h)(2)].

Finally, a hazardous debris that is also a polychlorinated biphenyl (PCB) waste under 40 CFR Part 761 must comply with both the applicable debris treatment standards under RCRA and $P C B$ requirements under the Toxic Substances Control Act (TSCA) [40 CFR 268.45(a)(5)]. Debris that is treated using a prescribed extraction or destruction technology remains subject to only TSCA rules. whereas debris treated by an immobilization technology remains subject to regulations promulgated under both statutes.

Please direct any questions about this RCRA notice regarding the Renewal of the Hazardous Debris Case-By-Case Capacity Variance to Bill Fortune, DOE Office of Environmental Guidance, RCRA/CERCLA Division, EH-23I, 1000 Independence Ave., S.W., Washington, D.C., 20585, at (202) 5867302. -ns

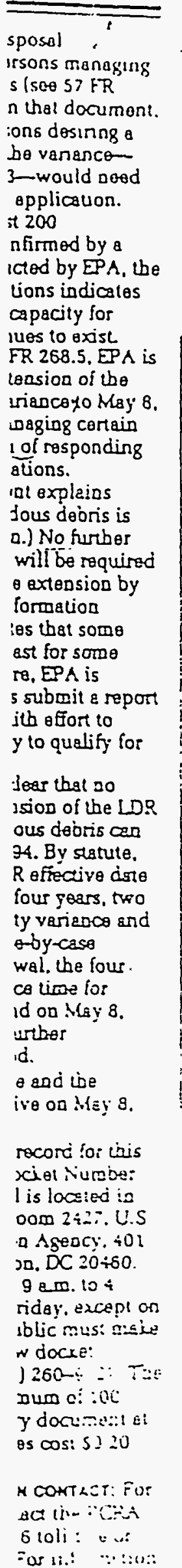


SUPPLEKENTARY INFORUATON:

Background

On Jenuary 29. 1992. propasod rulos rogarding designatod bicycle roulos whthen the Golden Gate Nauonal Rocreation Ares were publisbed in the Federal Register (57 FR 3392). After consideration of public comments. the final regulation was publisbed in the Foderal Register on Decomber 11. 1992 (57 FR 58711). In both the proposed and finel rulemaking documents. tho location description of the Alta Avenue trail. designated es open to bicycie use in the "Supplementary loformation" section of the rule, wes incorrect. This notice corrects the location description of this trail, found on page 58712. middle column, of the Decomber 11. 1992 issue of the Federal Register, from "Alta Avenue betwoen Wolf Back Ridgo Raad and Mann City". 10 " Nila Avenue between Bobcat Trail and Marin City."

This correction neither chenges the total of 46.9 miles of trail currently designated as opened 10 bicycle use, and publisbed on page 58712 of the preamble to the final regulation, nor changes the location of designated trails as merixed on the maps in the Trail Use Dosignation Plan on Ele in tbo offics of the Superintendent in addition. this correction does not effect the final regulatory text, and neither lncreases nor diminishes the superintendent's authority to desiznate routes on which bicycle use is permilted. pursuent 1036 GFR 7.97. Dasignauon of this open trail by the superintendeat sinell be eccomplisined pursuent to $36 \mathrm{CR}$ 7.97 (c) of the tonal regulation es published at 57 FR 5E716.

Dated: Apnl 30. 1993.

Jobo HL Deme.

Associate Director. Operouons.

[FR Doc 83-i1s22 Filed S-13-93.8 15 em]

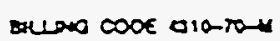

NATONAL ARCHIVES AND RECORDS NOMINISTRATION

\section{CFR Part 1232}

RIN 3085 -MA 18

\section{Audlovisual Records Mansgement}

AGEHCY: Nationsl f.r...... - - D.ards Admuistruon

ACtron: Fidal rule

sumbury: Thus final rule cortron to

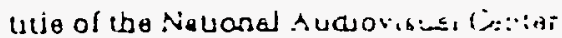
in 36 CR $1232610: 2$ s.tul.:-1.1.2 end Publicalsons Disinbutue $5: \because \div, \because:$ : rantact a morgenzulion $\because \because n$..... changos arg nade $\cdot$.
EFFECTIVE DATE: ThIS rulo is offuctuvo on MoY 14. 1993.

FOR FURTHER HFORUITON COATACT. Mary Ann Palmos ar Nancy Allard on 202-501-5110.

SUPPLEMENT NAY WAFORMUTOK: This rule is boing promulgated as a foal rile without a prior notice of proposed ruleraking as allowed by section $553(\mathrm{~b})(\mathrm{A})$ of the Administrative Procoduros thet for rules peraining solely to agancy organization.

This rule is not a major rule for the purposes of Executive Order 12291 of February 17. 1981. As required by the Reguletory Flexibility $A$ ct, it is heroby cortifed that this proposed rale will not bave e significant impact on small entilies.

\section{List of Subjects in 38 CFR Part 1232}

Archives and records.

For the reason sot forth in the pramble. NARA is amending 36 CFR part 1232 to read as follows:

\section{PART 1232-AUDIOVISUAL RECOROS MANAGEMENT}

1. The euthority citation for part 1232 continues to read as follows:

Autharity 11 U.S.C 2904 aod 3101.

\section{6 [Amordod]}

2. In $\$ 1232.6$, in the first sentence. remove "(NAC)" and, wherever else they spear in the section, remore the tilles "National Audiovisual Conter". "NAC", and "Conter's" and add, in their place, the tille "Multimedia and Publications Distribution Divisian", the tiule "the Mulumedia and Publications Distribution Division", and "Division's" respecuvaly.

Dated: May 10. 1993.

Trudy Husicemp Poreron.

Acung Arctinst of the Unred Stotes.

[FR Doc 93-11510 Filod 5-13-83: 8:45 em] aruma coos rsicos?

\section{IENVIRONMENTAL PROTECTION AGENCY}

\section{CFR Part 268}

[FRL-1655-1]

Hazardous Weste Hanagomont System: Leno Disporal Restrctlons: Renews! il !tic $r$ : zardous Dobris Caso-By-Case Cupaclty Varlance ano Renewal of Varisnce

AGENCY: Environ:- :ntal Proikz:on

ABanCY (EDA.)

NTTON: Fisai rul

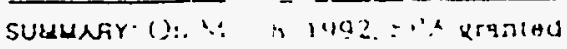
$\because \because 10^{2}$ variancy of the Land Disposal . Rostrations (LDR) to persons raneging cortain hezardous debins (soe S7 FR 20766. May 15. 1992). In that document. EPA indicatod that persons desinng a subsequent renewal of the vanancothat is. pest May 8. 1993-would noed to submit an individual epplicauon. EP $\Lambda$ bes recoived almost 200 applications to date. Confirmed by a capecity analysis conducted by EPA, the large number of applications indicates that a lack of treatment capacity for bozendous debris continues to exist. * Therefore under 40 CFR 268.5. EPA is bereby renewing the extension of the case-by-case capecity varianco yo May 8 , 1994, for all persons managing certaun hazardous debris in lieu of respondung to the individual applications.

(Elsowhere this docurent explains more fully which bazardous debris is covered by the extension.) No further individual applications will be required from persons grented the extension by this action. However, information provided to $E P \wedge$ indicates that some capecity may oxist, at leest for 50 ono forms of debris. Therefore, EP $\Lambda$ is requiring that generators submit a repor demonsurating a $800 d$ faith efiort to locate trotment copacity to qualify for the extension.

IFP $\Lambda$ wishes to make clear that no further varience ar extension of the LDP effoctive date for hazardous debas can be given after May 8, 1994 . By siatute. EPA mey extend the LDR effective date for a weste for a total of four yeers, two years by national capacity varianco and up to two years for a caso-by-case variance. With this ranewal, the four years of statutory varianca ume for hazardous deons will end on May 8 . 1994. and therolore oo furber extensians can bo granted.

EFFECTVE DATE: This rula and bie extension become ef̂ecive on l.tä 8. 1993.

MDORESSES: The oftuclal record foi this nouce is idenufied as Dociel Nurede: F-93-DCVN-FFtFF, end is locesed in the EPA RCRA Docket, room $2: 2:$. U.S Envinnmental Protecuon Agency. 401

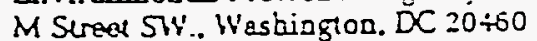
The doclet is open tom 9 a.n. 104 p.m.. Monday hrouexh Friday. except on

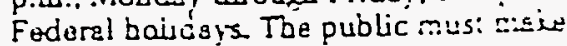
an eppowtment to review docxe"

metenals by callung (202) 260.. - ..: public ray copy a meximum o: : pages trom an rogulatory doces: $2: \cdots 1$ a: no cost Adducunal copias cos: S: $=0$ per pegio.

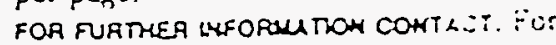

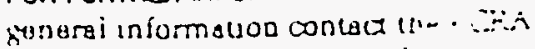

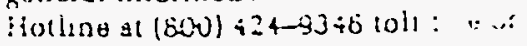
\{:031 $112-9810$ loceily. For 1i.: …42: 
TRANSPORT AND DISPOSAL OF

\section{COOEL1}

REVIEW VENDOR CAPACITY

REVIEN COE CONTAACT

AEVIEW INEL MLLW \& VENDOR WAC

REVIEW MLLW PACKAGING FOR TRANSPORTABILITY

PREPARE EC

PAEPARE CX

FORMULATE WASTE DISPOSAL PLAN

DOE CX APPROVAL

REVIEW OF DISPOSAL PLAN BY EGEG AND DOE

19 SECURE FACILITY TO TAKE SAMPLES \& REPACKAGE

17 PREPARE SAMPLE ANALYSIS PLAN

CONTAACT FOR LABORATORY

21 PREPARE PAPERS \& SHIP TO SAMPLING FACILITY

20 PREPARE SNR TO TAKE SAMPLES \& REPACKAGE

22 TAKE SAMPLES

26 SEND SAMPLES TO DATA CHEM \& ENVIROCARE

23 PREPARE WASTE FOR SHIPPING (PACKAGING \& LABELS)

24 LABORATORY ANALYSIS AND RETURN RESULTS

9 DOE APPAOVAL

27 FILL OUT ENVIROCARE FORMS

25 SEND LAB ANALYSIS, FORMS, TO ENVIROCARE

DIPOSAL FACILITY SENDS NOTICE OF TAANSPORT

28

PREPARE DOE/COE CONTRACT DELIVEAY OADER

31 NOTIFY DIPOSAL FACILITY OF SHIPPING DATE

32 DISPOSAL FACILITY APPAOVES SHIPPING DATE

29 PREPARE MANIFEST AND FAX TO DISPOSAL FACILITY

14 TAANSPORT WASTE TO MLLH FACILITY

15 SUBCONTAACT SUPPOAT

16 DISPOSAL COMPLETE 
TAANSPORT AND DISPOSAL OF IN

COOEI COOE2

2 REVIEK VENDOA CAPACITY

4 REVIEW COE CONTHACT

1 REVIEW INEL MLLW \& VENDOR HAC

3 REVIEH MLLW PACKAGING FOR TRANSPORTABILITY

5 PREPARE EC

5a PREPARE CX

7 FORMULATE WASTE DISPOSAL PLAN

6 DOE CX APPROVAL

- REVIEH OF DISPOSAL PLAN BY EGEG AND DOE

19 SECURE FACILITY TO TAKE SAMPLES \& REPACKAGE

17 PAEPARE SAMPLE ANALYSIS PLAN

18 CONTAACT FOR LABORATOAY

21 PREPARE PAPERS \& SHIP TO SAMPLING FACILITY

20 PREPARE SHA tO TAKE SAMPLES \& REPACKAGE

22 TAKE SAMPLES

26 SEND SAMPLES TO DATA CHEM \& ENVIROCARE

23 PAEPARE WASTE FOR SHIPPING (PACKAGING \& LABELS)

24 LABORATORY ANALYSIS AND RETURN RESULTS

9 DOE APPROVAL

27 FILL OUT ENVIROCARE FORMS

25 SEND LAB ANALYSIS, FORMS, TO ENVIROCARE

30 DIPOSAL FACILITY SENDS NOTICE OF TRANSPOAT

28 PREPARE DOE/COE CONTAACT DELIVERY ORDER

31 NOTIFY DIPOSAL FACILITY OF SHIPPING DATE

32 DISPOSAL FACILITY APPROVES SHIPPING DATE

29 PREPARE MANIFEST AND FAX TO DISPOSAL FACILITY

14 TRANSPORT HASTE TO MLLW FACILITY

15 SUBCONTAACT SUPPOAT

16 DISPOSAL COMPLETE
$201 \quad$ VJB

151 VJB

251 SMM

151 VJB

61 WTS

$\begin{array}{lll}10 & 1 & \text { WTS }\end{array}$

101 VJG

$\begin{array}{lll}10 & 1 & \text { VJB }\end{array}$

$51 \quad V J B$

2 SSS

102 VED

$102 A D C$

52 SRP

32 RAL

42 VED

22 GLS

$52 \mathrm{SRP}$

132 ADC

52 VNB

52 TBS

$\begin{array}{lll}2 & 2 & T S B\end{array}$

22 GJA

22 VUB

$22 \quad V J B$

22 니

33 UJ

233 VงB

$\begin{array}{lll}0 & 3 \\ \text { VJB }\end{array}$
12 LJ 


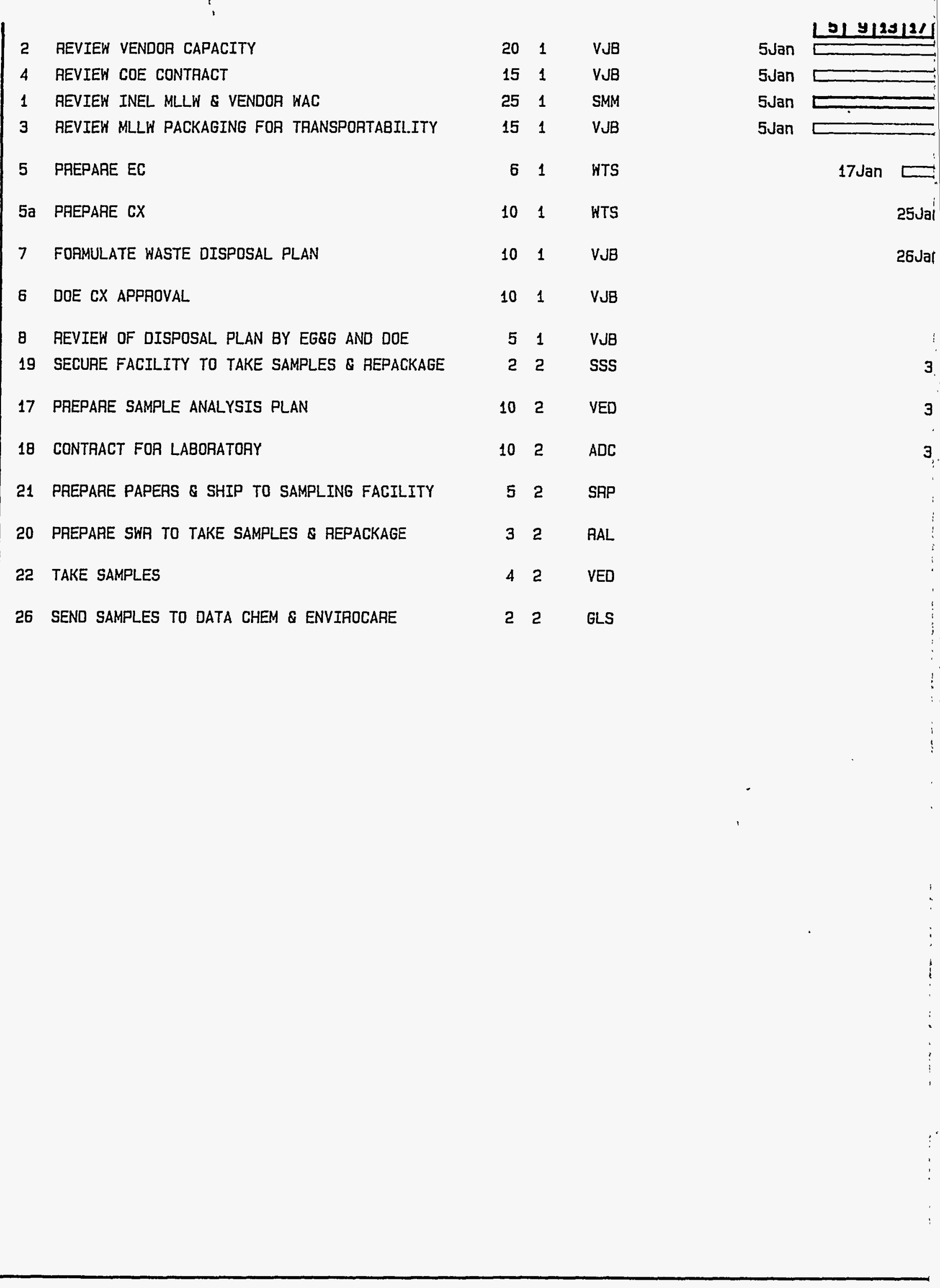




\section{ل}

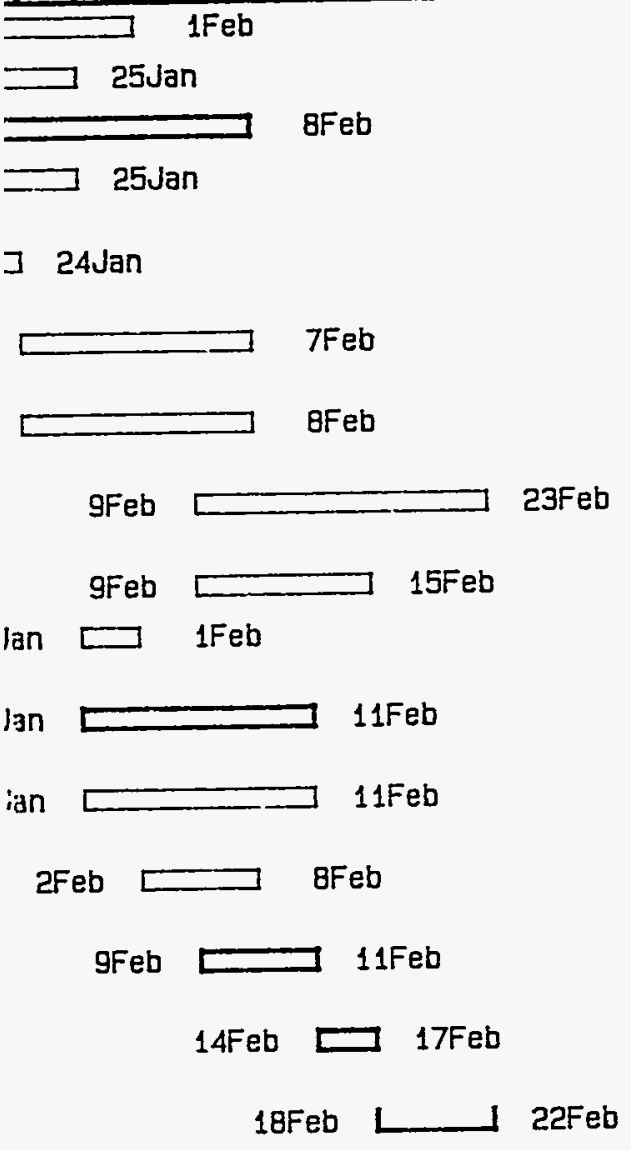


COOEI CONER

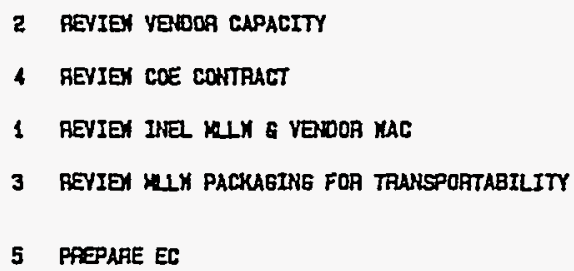

201 V 10

$15 \div$ VN

251 Sex

151 Y 10

61 VTE

101 XTS =

$101 \quad \mathrm{Vu}$

$101 \quad$ V.8

$51 \quad 4 \sqrt{B}$

22 sss

102 VER:

$525 P$

32 RAL

42 Vש

22 ตร

$52 \operatorname{SPP}$

132 ADC

52 TRS

52 V

22 TSO

22 GLA

22 Va

12 UN

22 VE

22 แง

3 山 ل 3

233 Vม

0378
102 ADC

TAANSPORT AND DISPOS

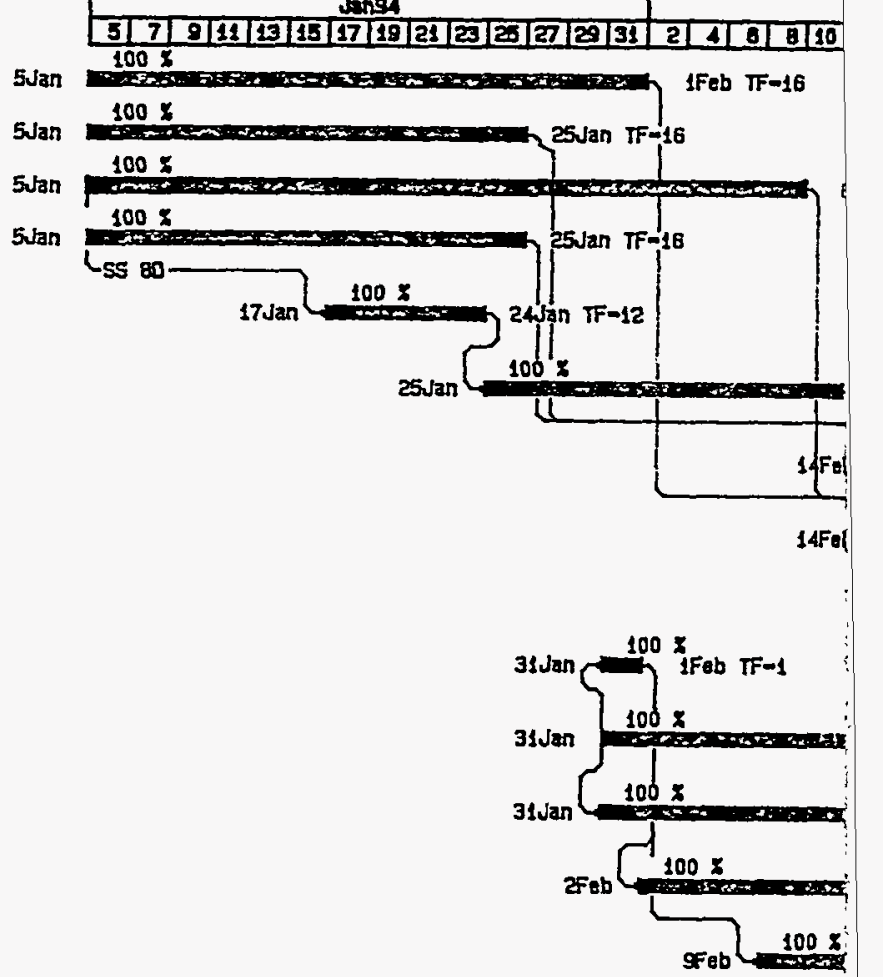

145 at 
COOE1 COOE2

IHANSHUHI ANU UISHUSAL UF INEL MLLH

\begin{tabular}{|l|l|l|l|}
\hline \multicolumn{3}{|c|}{ Jang4 } & \multicolumn{2}{c}{ Feb94 } \\
\hline 5 & 8 &
\end{tabular}

5Jan

1.

i 


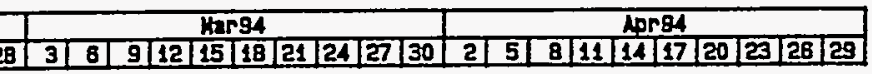

\begin{tabular}{|l|l|l|}
\hline Project: VIIN & HLW & Date: 02/16/94 \\
\hline
\end{tabular}

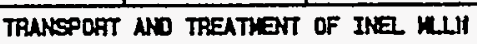

\begin{tabular}{l|l}
\hline Page: 1 & Draxn by Bh CARLSON 6-8159 \\
\hline
\end{tabular} 


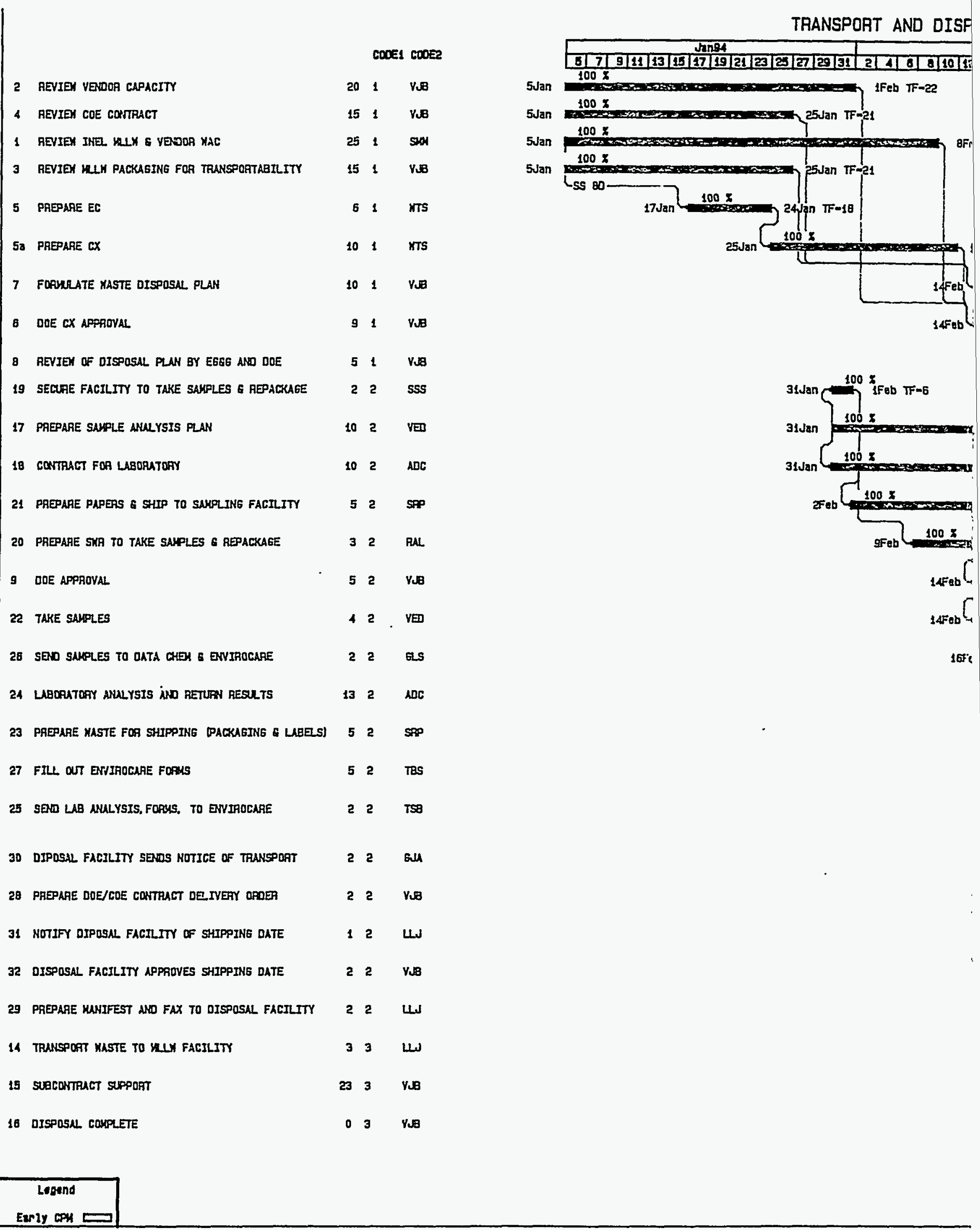


IL OF INEL MLLW

294 Kargh

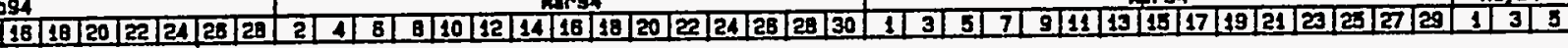

$=0$

$\pi-14$

0

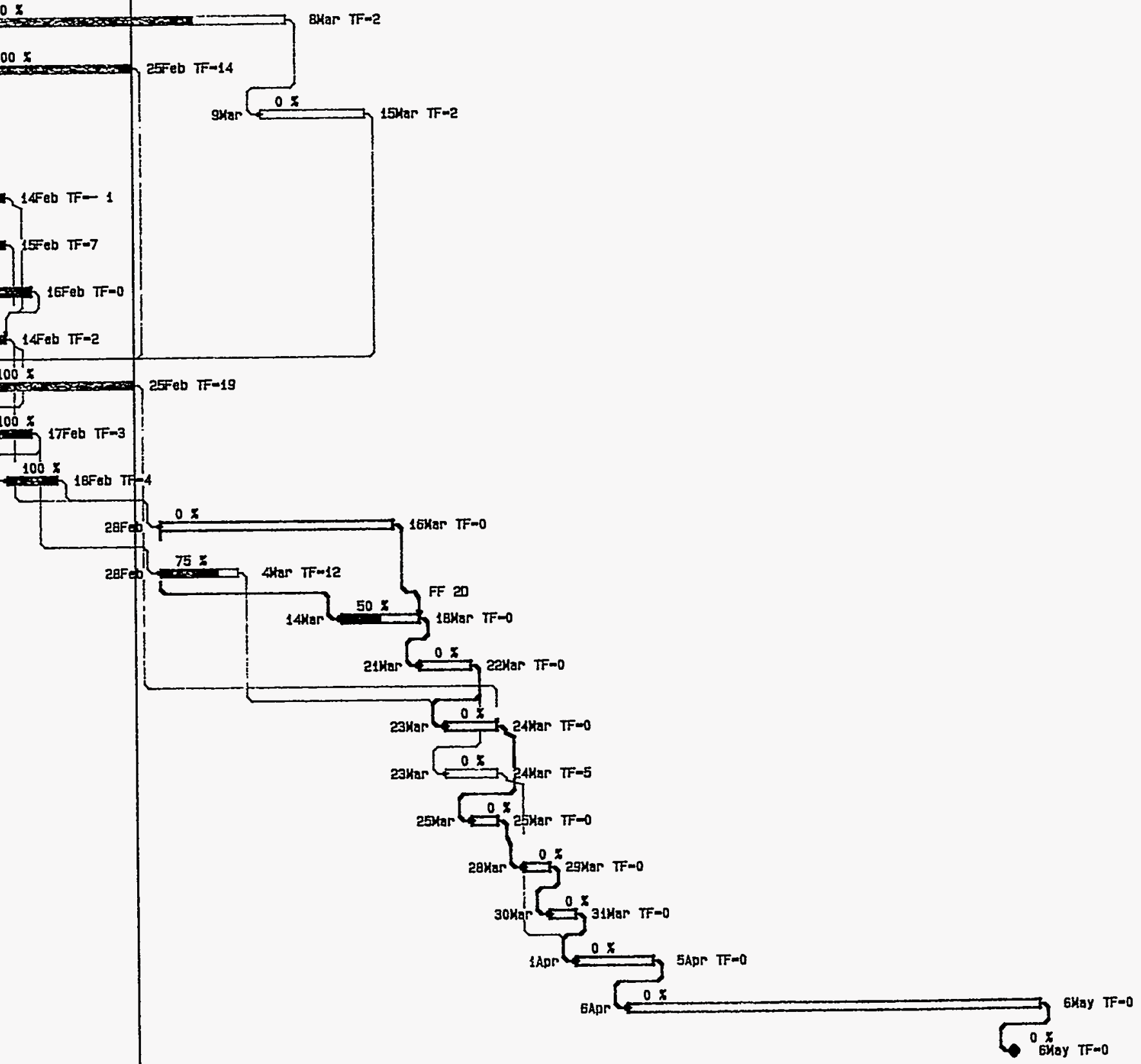

Data Date

arew 


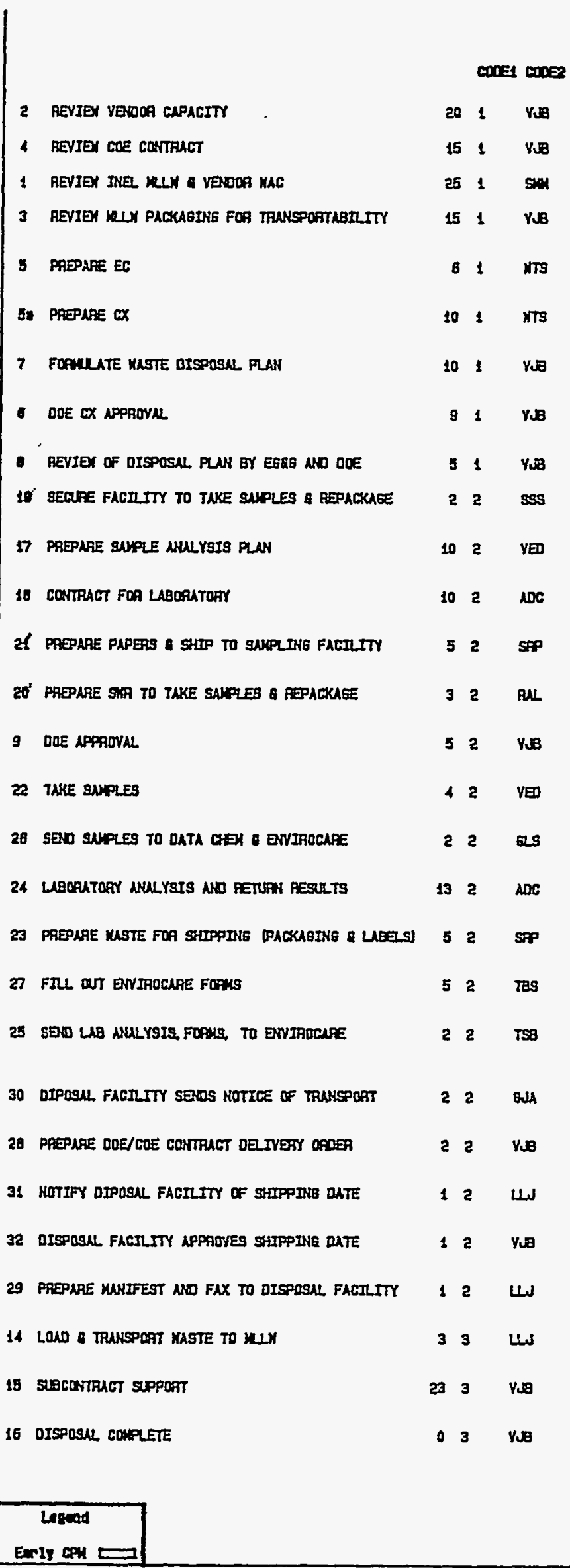

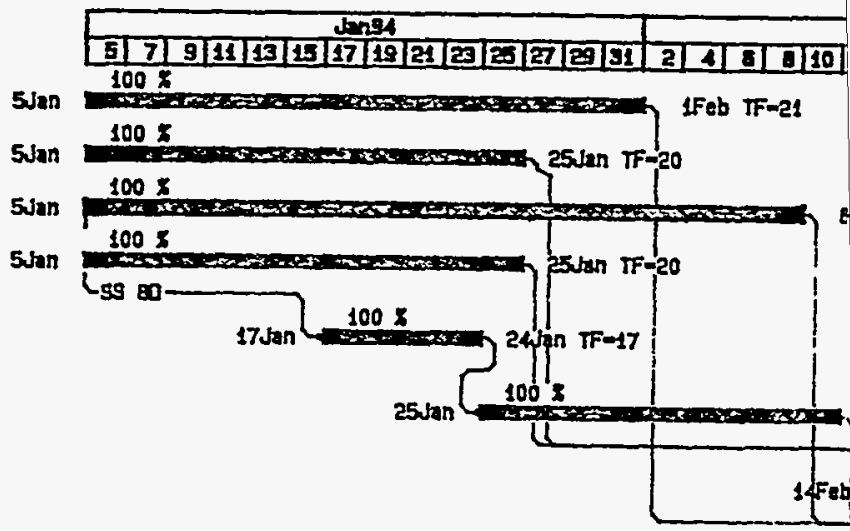

$14 \mathrm{Feb}$

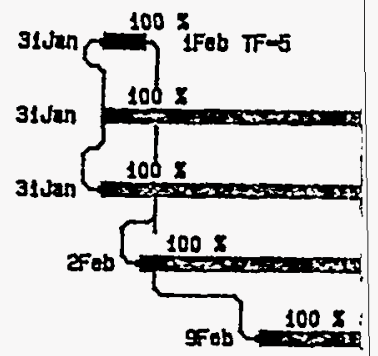

14Fab

$145 \mathrm{Bb}$

16. 
- OF INEL MLLH ba - Ther

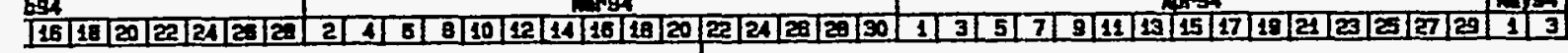

$F \rightarrow$

Ib $T=13$

$100 \mathrm{X}$

$100 \times$

$100 \Omega$

T148b $\pi-1$

LFab $15-6$

(1)

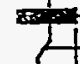

$14 \pi \times b \pi-1$

$100^{\circ} \frac{1}{2}$

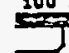

$100:$

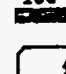

(TFB TF-

100 I $18 F \mathrm{~F}$ TF-3

$100 x$

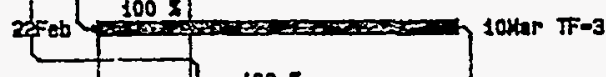

$28 F=100 \mathrm{x}$

Star 100 . FF 20

15Nar $17 t-2$

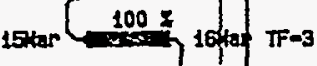

$\longrightarrow$

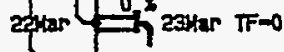

catar o ${ }^{x}$ eaktar TF-3

24matron

25istar $\pi=0$

28) 0 ar 0

29Mar 0

inor

3ay $T F=0$

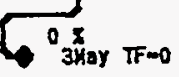

Data Date

zinur

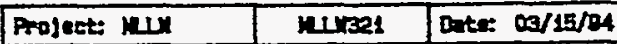

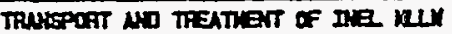

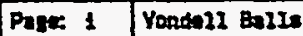




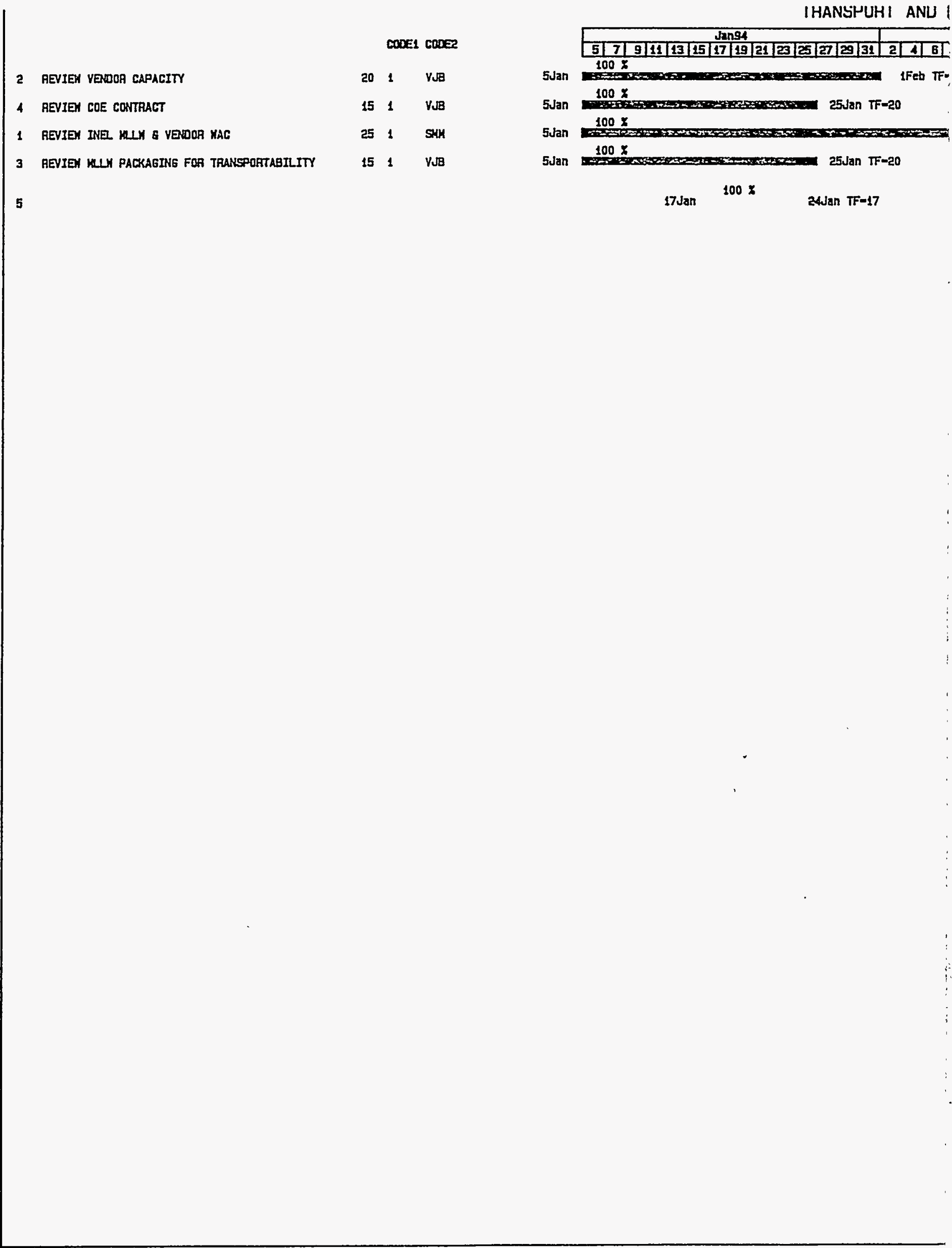


SHUSAL UF INEL MLLH

Febgh

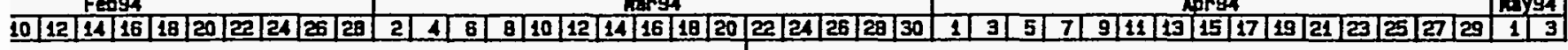

QFeb TF-0

Data Date

21kar 


\section{Appendix B}

\section{Project Management Plan}

B-1 
B-2 


\section{INTEROFFICE CORRESPONDENCE}

Date: January 11, 1994

To: Distribution

From: V. J. Bal1s, MS 2414 Ralls

Subject: TRANSPORTATION AND DISPOSAL OF IDAHO NATIONAL ENGINEERING LABORATORY MIXED LOW-LEVEL WASTE WORK PACKAGE - VJB-02-94

Attached is the work package for the subject project. This includes the identification of tasks, work scope for each task, estimated hours to complete, and associated schedule to ensure transportation and disposal to the Corps of Engineers vendor. This work package cost and schedule is based on the use of the existing Army Corps of Engineers contract \#DACW41-93-0-9001 with Envirocare of Utah, Inc.

Should you have any questions concerning the attached work package, please give me call at 526-0067.

amp

Attachment:

As Stated

Distribution

G. J. Andrews, MS 8102

B. G. Berry, MS 4133

N. J. Fix, MS 3550

J. D. Hops, MS 3591

S. M. Medina, MS 3509

J. D. Mousseau, MS 2414

T. B. Shea, MS 8102

P. J. Smith, MS 3552

N. E. Stanley, MS 3906

T. J. Thiesen, MS 8102

M. R. Wilcox, MS 3625

cc: Project File \#24.0, MS 2414

V. J. Balls Ltr. File 


\section{TASK \#263215}

for

\section{WORK PACKACE \#2632 MLLW COMMERCIAL DISPOSAL}

DATE :

PROJECT FILE NO.

DESIGN CHARGE NO.

ESTIMATED COST
24.0 $318942500-$ SCHEDULED COMPLETE

$\$ 52.502$
SCHEDULED START DATE QUALTTY LEVEL
January 5,1994

June 23, 1994

TASK $\square$ Concepual $\square$ Title I $\square$ Title II $\square$ Study/Analysis $\quad$ Other

\section{APPRQVALS}

Project Manager :

Responsible Unit Manager :
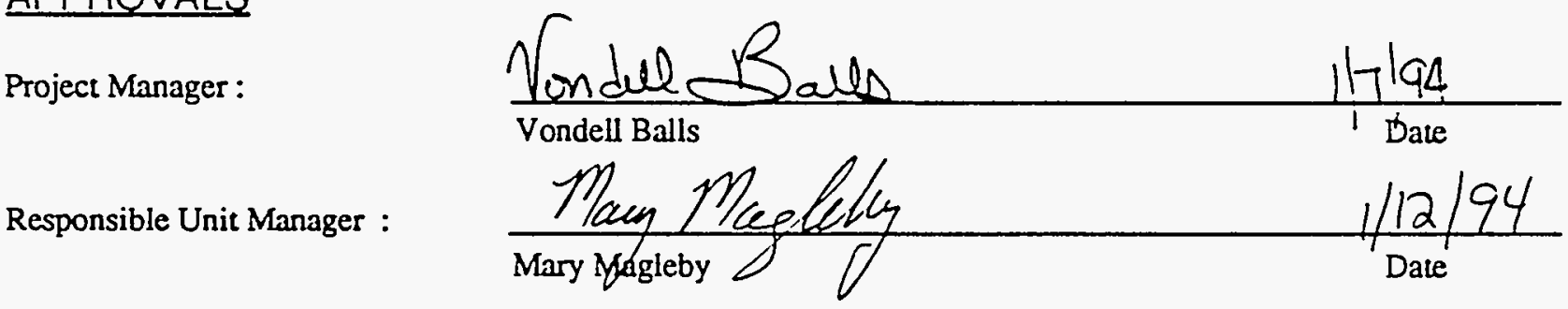

Technical Coordinator :

N/A

Name - Org.

Date

REVISION HISTORY

Date

Cost Without

Contingency

Contingency

Total Cost

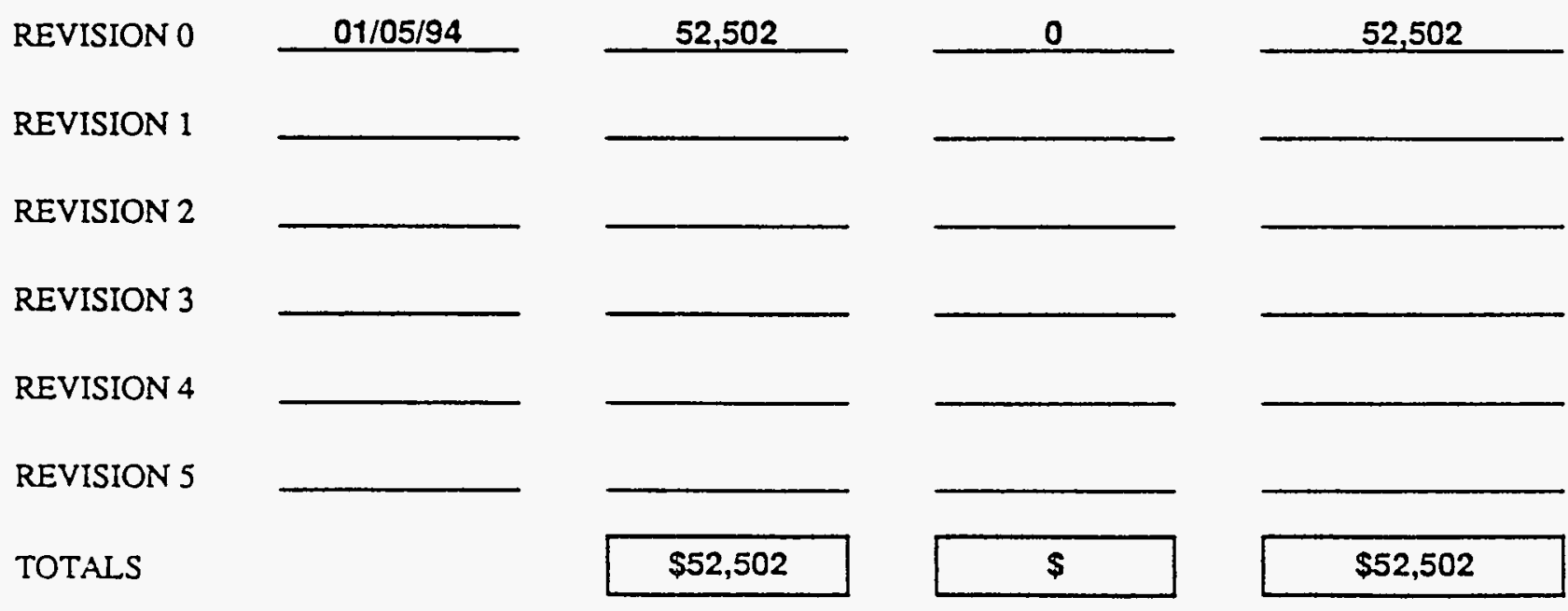




\section{MLLW COMMERCIAL DISPOSAL}

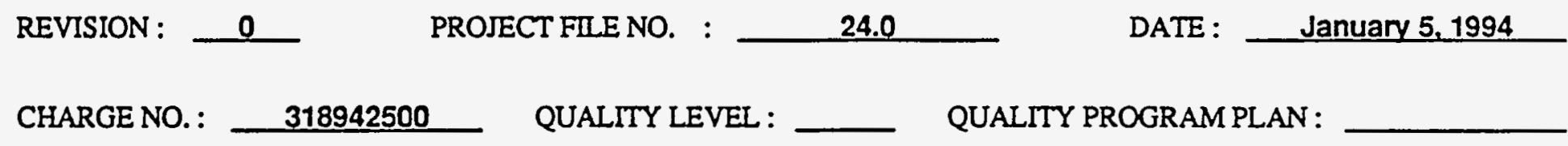

DESCRIPTION OF WORK SCOPE/REQUIREMENTS :

The Overall work scope for this project is to prepare all necessary documentation, reviews, labor assignments, contracts and funding to transport and dispose of approximately 29 Barrels of Mixed Low Level Waste Debris.

The attached schedule identifles all necessary major activities to accomplish the above work scope. If any tasks need to be added this work package will be revised.

The work identlifled in each task will also be to identify all applicable all Federal, State and local procedures codes and standards that will angly to this project.

The personnel Identifled as "lead" shall send in a brief paragraph that will status the progress, problems or Issues, hours used to date and estimate to complete. This status shall be sent to Vondell Balls at PROFS ID. VOJ by noon Frlday of each week during the duration of that activity.

The tasks with 0 hours indlcated are funded from other sources.

On all correspondence and EDFs ce Project File \# 24.0 or EDF \# as designated in task description. 


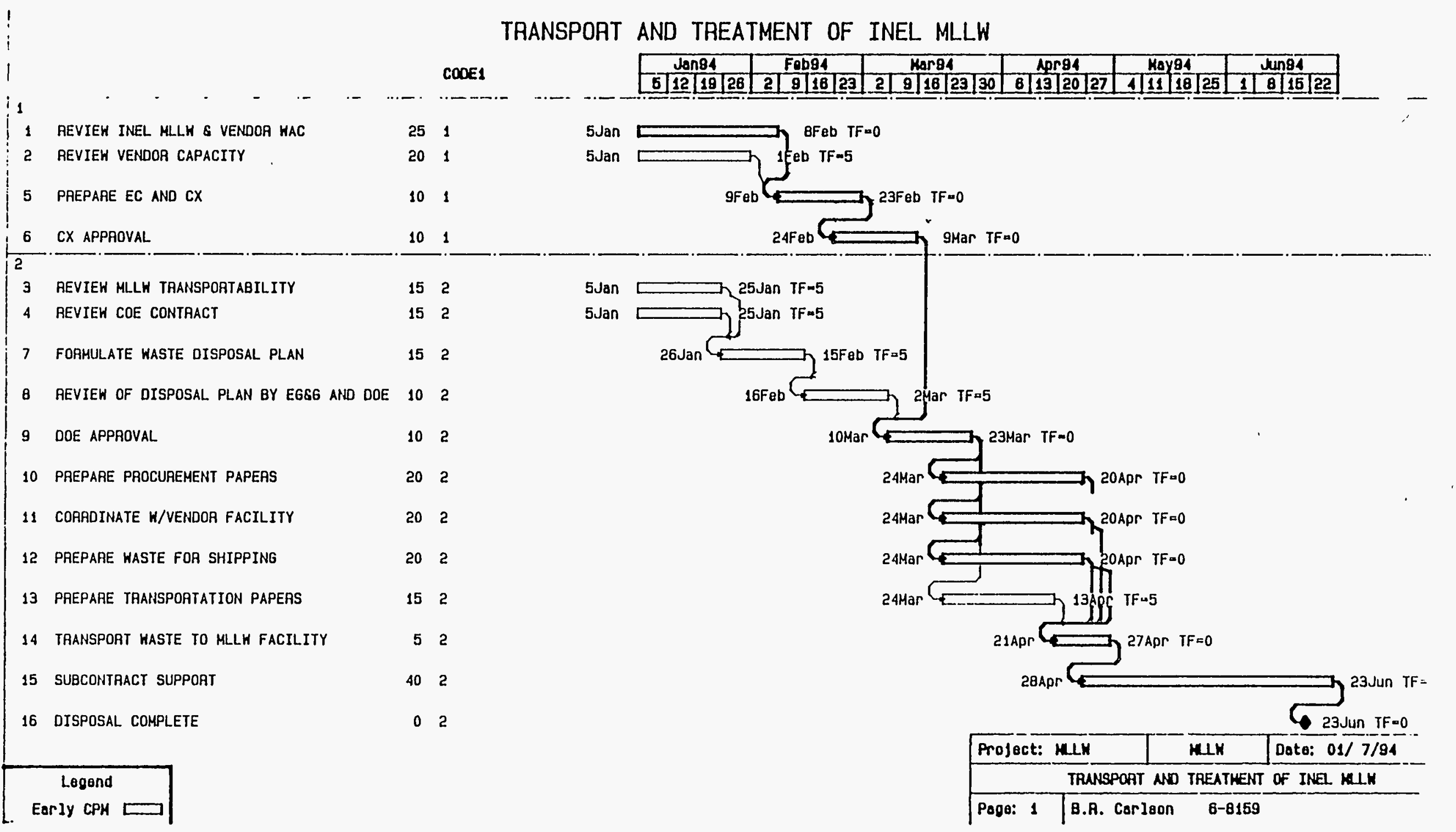


1.1 TASK \# 1: Review INEL Mixed Low Level Waste \& Vendor WAC Estimated hours $=104$

Assigned Personnel: -Sylvia Medina (Lead)

Background :

-Mike wilcox

-B. Wilcox has prepared an EDF Titled: Determination of ILMW Candidates for disposal at ENVIROCARE of UTAH, INC.

Work Scope: that will form the basis for this task.

- Compare and validate radiation profile and contents of wastes to the best available data. List methods and personnel used to verify that all waste profile data available has been evaluated. This is critical to this project since "unidentified" material in the waste shipment will cause delay and added expenses.

-Verify that all of the waste identified in the above referenced EDF will meet ENVIROCARE of UTAH, INC. Waste Acceptance Criteria.

- Prepare and itemized sheet for each waste stream and associated recommendation for off site disposal.

-Conclusions/Results and methods shall be documented in

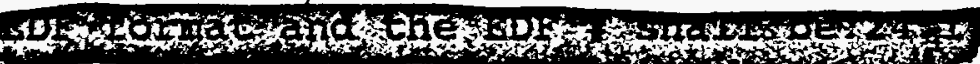

1.2 TASK \# 2: Review Vendor Capacity

Estimated hours $=112$

Personnel Assigned:

-Vondell Balls (Lead)

-Jeff Mousseau

Background:

Ann Fix has performed an ESH\&Q Liability Assessment Report of ENVIROCARE OF UTAH, INC. it is in draft form at this time.

Work Scope:

-Review vendors qualifications and procedures and prepare statement of capabilities/limitations.

- Coordinate this task with \#1 above.

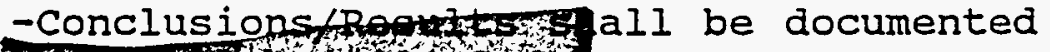

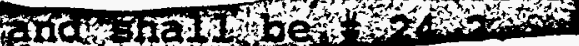


1.3 TASK \# 3: REVIEW MLLW Transportability

Estimated hours $=42$

Personnel Assigned:

-Vondell Balls (Lead)

-Sylvia Medina

-Bob Berry

Background :

Location of MLLW at the INEL that is identified in TASK \# 1 above, is not known to the project team at this time.

Work Scope: Contact is Todd Thiesen.

- Locate and inspect all waste containers identified in TASK $\# I$ and identify all work necessary to prepare for transportation and selection of transporter. -Identify transporter and associated schedule.

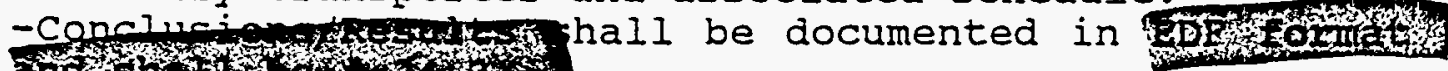


1.4 TASK \# 4: Review of Corps of Engineers Contract. Estimated hours $=66$

Personnel Assigned:

-Vondell Balls

-Ann Fix

-Jean Hops

Background :

A meeting was held December 10, 1993 with:

DOE-ID personnel:

Jan Benavidez (PSPI Project Manager)

Kevin O'Neill (Construction Projects)

EG\&G personnel:

Mike Barrett (Contracting officer)

Mary Magleby (PSPI)

Jeff Mousseau (PSPI)

Vondell Balls (PSPI)

The use of this contract to dispose of INEL Mixed Low Level Debris Waste was discussed. The COE has been working on this contract since late 1991 and it is expected to be inplace by mid Jan., 1994. Some of the preliminary issues were discussed. It was decided to use this contract based on the assumption that any problems could be negotiated. This contract will be a DOE-ID prime contract.

Work Scope:

-Review the Army Corps of Engineers Contract \#DACW41-93$\mathrm{D}-9001$ to identify any new issues and resolve the following:

- What are the EG\&G Idaho liabilities.

- What are the DOE-ID liabilities.

- What modifications to this contract are required (if any) in order to dispose of the waste identified in TASK \# 10: Review of INEL Debris MLLW.

- Prepare a flow chart for use of this contract.

-Fully identify the agreement between DOE and the COE.

-NEPA statement.

-Obtain written authorization as required by Grumbly letter dated 12 oct. 1993.

-Identify definition of NORM waste and how it applies to this project.

-Monitor progress of contract. As of this date this contract is still not in place.

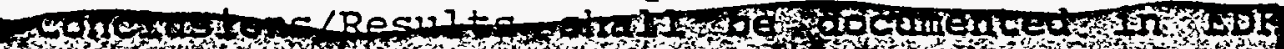

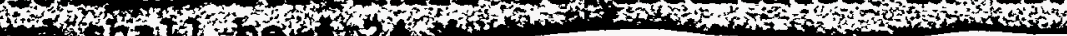

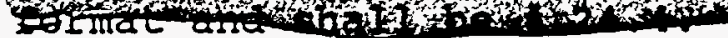


1.5 TASK \#5: Prepare Environmental Checklist (EC) and Categorical Exclusion (CX).

Estimated hours $=84$

Personnel Assigned: -Norm Stanley (lead)

- Paul Smith

Background:

-NEPA direction not yet defined. Several alternatives are available.

Work Scope:

- Coordinate/use information from task $\# 4$ as a basis for the completion of this task.

- Define NEPA strategy

-Deliverables will be a completed EC and all documentation required for $\mathrm{a} \mathrm{cx}$, with a cover letter to project file $\# 24.0$.

1.6 TASK \# 6: CX Approval

Estimated hours $=0$

Personnel Assigned:

-Vondell Balls

Background:

-None

Work Scope:

-Monitor progress and ensure schedule compliance. 
1.7 TASK \# 7: Formulate Waste Disposal Plan

Estimated hours $=79$

Personnel Assigned:

-Vondell Balls

- Jeff Mousseau

(lead)

-Sylvia Medina

-Bob Berry

- Greg Andrews

-Tom Shea

Background:

-None

Work Scope:

-Prepare written Waste Disposal Plan that will:

-Identify the results and conclusions of Tasks 1 through 6 that will provide for a complete description of the methods, assumptions, risks, schedule and costs to complete this project.

-Be presented to EG\&G and DOE for review and comment.

- Prepare cost and Schedule manpower. -This will involve the following items. - Cost and labor to prepare waste packaging for transportation.

-Cost and labor to transport to ENVIROCARE OF UTAH.

-ENVIROCARE OF UTAH disposal costs.

-Written cost and schedule report.

-Cover letter to file \#24.0.

1.8 TASK \# 8: Review of Disposal Plan by EG\&G and DOE

Estimated hours $=21$

Personnel Assigned:

-Vondell Balls (lead)

-Jeff Mousseau

Background:

-None

Work Scope:

-Present Waste Disposal Plan and resolve all comments.

Deliverable:

-Verified Waste Disposal Plan

-Resolve and document all comments and make revisions as necessary.

-Letter to file \# 24.0, of all comments and resolutions. 
1.9 TASK \# 9: DOE Approval

Estimated hours $=10$

Personnel Assigned:

-Vondell Balls (lead)

-Jeff Mousseau

Background:

-None

Work Scope:

- Prepare letter to document DOE-ID concurrence with all activities to date.

Deliverables:

-Letter to file \#24.0.

1.10 TASK \# 10: Prepare Procurement Papers

Estimated hours $=21$

Personnel Assigned:

-Vondell Balls (lead for disposal)

-Bob Berry (lead for transporter)

Background:

- Mike Barrett (DOE Procurement)

work Scope:

- Coordinate with Mike Barrett (DOE-ID contracting Officer) and ensure that all procurement papers are in order for use of the COE contract.

- Prepare procurement contract with transportation vendor. -Deliverables:

- Transportation contract.

- COE contract in place and ready to go.

- Letter to file $\frac{\|}{\pi} 24.0$, that task has been comleted. 
1.11 TASK \# 11: Coordinate W/Vendor Facility

Estimated hours $=116$

Personnel Assigned:

-Vondell Balls (lead)

- Mike Barrett (DOE-ID)

-Sylvia Medina

-Jeff Mousseau

Background:

-None

Work Scope:

-Ensure that Envirocare of Utah will be ready and all coordination of transportation receipt inspection and disposal has been done.

-Attend Envirocare Workshop. This will provide a basis for this interface.

-Prepare a flow chart that identifies the necessary steps required to transport and transfer waste to Envirocare for Disposal.

Deliverables:

- Conclusions/Results shall be documented in EDF format and shall be \#24.5.

1.12 TASK \# 12: Prepare Waste for shipping

Personnel Assigned:

-Todd Thiesen (lead)

- Greg Andrews

- Tom Shea

-Bob Berry

Background:

-None

Work scope:

-Initiate and complete all identified packaging and ready waste for shipping.

Deliverables:

- Letter to file \# 24.0, that all waste meets DOT and contract shipping requirements.

1.13 TASK \# 13: Prepare Transportation Papers

Estimated hours $=0$

Personnel Assigned:

-Bob Berry

Background:

-None

Work Scope:

-Prepare all required shipping papers and secure transporter to transport waste from INEL to Envirocare of Utah.

Deliverables:

-All shipping papers and associated transportation contract with cover letter to file \# 24.0 . 
1.14 TASK \# 14: Transport Waste to MLLW Facility

Estimated hours $=0$

Personnel Assigned: -Bob Berry

Background:

-None

Work Scope:

-Monitor and verify transportation of waste from INEL to Envirocare of Utah.

Deliverables:

-Letter to file \#24.0, of waste acceptance.

1.15 TASK \# 15 \& 16: Subcontract Support \& Disposal Complete

Estimated hours $=100$

Personnel Assigned:

-Vondell Balls

-Jeff Mousseau

Background:

-None

Work Scope:

-Provide contract assistance on an as needed basis. Deliverables:

-Letter to file \#24.0, of Project completion. 


\section{Appendix C}

\section{ESH\&Q Liability Assessment Report}


C-2 


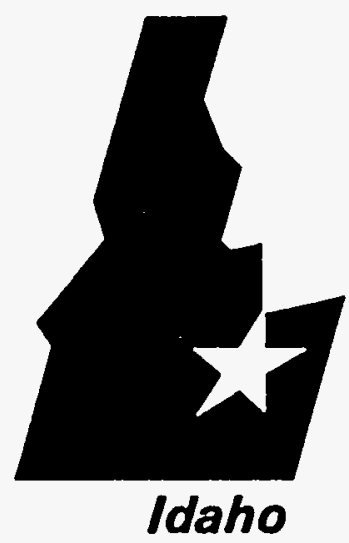

National

Engineering

Laboratory

Managed

by the U.S.

Department

of Energy

EGG-ESQ-10749

January 1994

ESH\&Q LIABILITY ASSESSMENT REPORT

OF

ENVIROCARE OF UTAH, INC.

CLIVE, UTAH

W. J. Becker
N. J. Fix
D. F. Harmon

CyEGrE Idano

Work performed under
DOE Contract

No. DE-ACO7-761D01570 


\section{ERRATA}

p. 95. Figure 29. should be Figure 27.

p. 170, para 1. Envirocare of Utah. Inc. requests that the following statement be added for clarification:

Envirocare's radioactive post closure plans cover the entire site for 100 years. Since the mixed waste cell contains both radioactive and RCRA material components it is subject to the radioactive post closure plan. In addition and beyond what the radioactive post closure plan covers. Envirocare has a RCRA post closure monitoring fund in place that will support the mixed waste RCRA requirement for 30 years. Therefore. the dual, mutual post closure requirements cover the mixed waste cell for 100 years with 30 years of double coverage.

Also, please note that [sic] DRC has not informed Envirocare of any requirement for updating the post closure plans to date.

p. 173, para 2. Envirocare of Utah, Inc. requests that the following statement be added for clarification:

The amount of 76,000 in the mixed waste trust fund is incorrect. The closure and post closure fund requirements is over one million dollars with over $\$ 496.957$ currently on deposit. The fund is based on installments over several years.

p. 173, para 3. Envirocare of Utah. Inc. requests that the following statement be added for clarification:

Envirocare's mixed waste trust fund is established to add to the existing site-wide radioactive trust fund to meet the RCRA requirement. The "additional" nature of this fund is important to consider. This fund is not replacing another or receiving cross subsidization from the sitewide radioactive trust fund. The confusion over this issue may stem from the coexistence of the two funds. 


\title{
ESH\&Q LIABILITY ASSESSMENT REPORT \\ OF \\ ENVIROCARE OF UTAH, INC. \\ CLIVE, UTAH
}

W. J. Becker, EG\&G Idaho, Inc.

N. J. Fix, EG\&G Idaho, Inc.

D. F. Harmon, EG\&G Idaho, Inc.

Published January 1994

EG\&G Idaho, Inc.

Idaho Falls, ID 83415

\author{
Prepared for the \\ U. S. Department of Energy \\ Idaho Operations office \\ Under DOE Contract No. DE-AC07-76ID01570
}


EGG-ESQ-10749

January 1994

This page intentionally left blank. 
EGG-ESQ-10749

January 1994

\section{EXECUTIVE SUMMARY}

An environment, safety, health, and quality (ESH\&Q) and financial liability assessment was conducted of Envirocare of Utah (Envirocare), located in Salt Lake City and Clive, Utah. The assessment was requested by the United States Department of Energy, Idaho Field Office (DOE-ID) as part of the evaluation of treatment and/or disposal options for RCRA hazardous/radioactive mixed waste (MW).

Envirocare operates disposal cells for Naturally Occurring Radioactive Material (NORM), Low Level Waste (LLW) which is called Low Activity Radioactive Waste (LARW), and MW. The company also operates as a large quantity generator according to the State of Utah hazardous waste regulations. The company is capable of disposing of radioactively contaminated debris in its lined disposal cells. The company is planning to build a stabilization facility to treat MW to meet the land disposal restrictions (LDR). This facility was not operational at the time of the assessment. Envirocare is allowed to dispose of hazardous wastes, which it generates as part of its processes, such as laboratory residuals and leachate, in its own cells once the wastes meet the LDR. No site generated NORM, low level, or mixed wastes leave the facility.

The INEL Assessment Team which evaluated the facility, found no current Federal or State hazardous and/or radioactive waste generation, treatment, storage, or disposal issues; or personnel safety and health issues which would place EG\&G Idaho or the United States Department of Energy (DOE) at risk while doing business with Envirocare. The major outstanding issue was the financial liability. Envirocare is privately owned and very closely held with a single shareholder. The company declined to provide financial statements to the INEL Assessment Team or to the Dun and Bradstreet financial service. Therefore, it was not possible to perform a thorough financial analysis of the company. An additional issue concerned the post closure care and monitoring of the disposal units within the facility. The State of Utah and the Nuclear Regulatory Commission were also cognizant of the ambiguities of the post closure documents and were attempting to clarify the issues. Absent resolution, this could be a significant concern; however, information contained within the documents reviewed by the INEL Assessment Team regarding this issue suggest that the concerns will be resolved satisfactorily in the near future and should not pose an unreasonable risk to the DOE.

Personnel at the Envirocare facility displayed a concern for compliance with the requirements for occupational safety, and hazardous and radioactive waste disposal and reporting. It is the opinion of the INEL Assessment Team that the company presently meets the intent of the regulations and will not provide an unreasonable risk to the DOE if the INEL contractors choose to utilize this facility for the disposal of mixed waste debris. 
EGG-ESQ-10749

January 1994

This page intentionally left blank. . 


\section{CONTENTS}

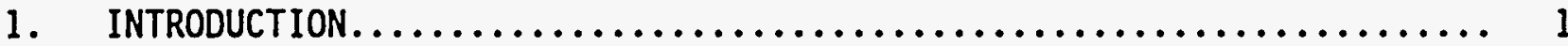

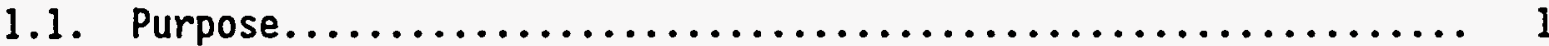

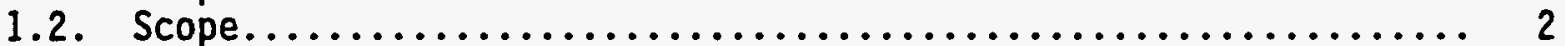

1.3. Content........................................... 4

1.4. Disclaimer.................................... 4

2. FACILITY/HAZARDOUS WASTE OPERATION IDENTIFICATION.............. 5

2.1. Facility Name and Location........................... 5

2.2. Name and Address of the Facility Owner................... 6

2.3. Facility Identification Number.......................... 6

2.4. Facility Type.................................... 9

3. BACKGROUND AND HISTORY $\ldots \ldots \ldots \ldots \ldots \ldots \ldots \ldots \ldots \ldots \ldots \ldots \ldots \ldots \ldots \ldots \ldots \ldots, 11$

3.1. Site History and Ownership $\ldots \ldots \ldots \ldots \ldots \ldots \ldots \ldots \ldots \ldots \ldots \ldots, 11$

3.2. Current and Past Use by the Generator..................... 12

3.3. Current and Historical Methods for Residue Disposal.......... 12

4. DESCRIPTION OF THE ASSESSMENT $\ldots \ldots \ldots \ldots \ldots \ldots \ldots \ldots \ldots \ldots \ldots \ldots \ldots \ldots \ldots \ldots \ldots \ldots$

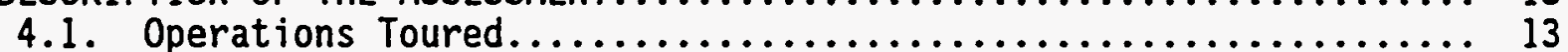

4.1.1. Treatment Facilities............................. 13

4.1.2. Storage Facilities.............................. 13

4.1.3. Disposal Facilities............................. 14

4.1.4. Laboratory Facilities........................... 14

4.1.5. Transportation Facilities........................ 14

4.2. Facility Personnel Contacted........................... 15

4.3. Regulatory Agencies Contacted......................... 16

4.3.1. U. S. EPA, Region VIII....................... 16

4.3.2. Nuclear Regulatory Commission..................... 18

4.3.3. State of Utah............................... 19

4.3.4. Tooe ie County.............................. 22

4.4.5. Other Agencies............................... 23

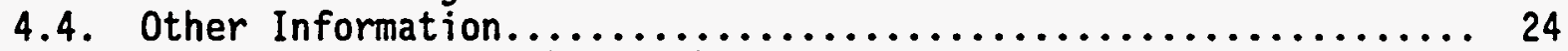

4.4.1. Environmental Checkiists............................... 24

4.4.2. Document Review................................. 24

4.4.3. Permits....................................... 26

4.4.4. Site Inspection................................ 32

5. FACILITY SETTING..................................... 33

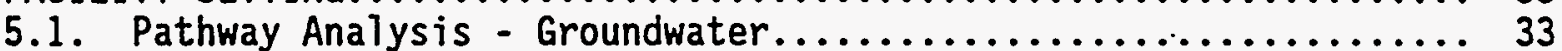

5.1.1. Background..................................... 33

5.1.2. Facility Location and Analysis.................... 39

5.2. Pathway Analysis - Surface Water....................... 40

5.2.1. Background............................... 40

5.2.2. Facility Location and Analysis.................... 41

5.3. Pathway Anatysis - Air................................ 43

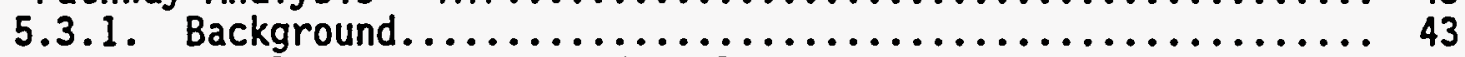

5.3.2. Facility Location and Analysis.................. 43

5.4. Receptor Analysis - Populations and Environments at Risk..... 44

5.4.1. Background............................. 44

5.4.2. Facility Location and Analysis................. 47 
6. TECHNICAL DATA AND ANALYSIS $\ldots \ldots \ldots \ldots \ldots \ldots \ldots \ldots \ldots \ldots \ldots \ldots \ldots \ldots \ldots \ldots \ldots, 49$

6.1. Site Description............................... 49

6.1.1. General Operations........................... 49

6.1.2. Treatment Facilities.......................... 50

6.1 .3 . Storage Facilities............................... 53

6.1.4. Disposal Facilities............................. 62

6.1.5. Laboratory Facilities......................... 83

6.1.6. Security.................................. 85

6.1.7. Transportation.............................. 91

6.1.8. Waste Analysis and Tracking System................ 101

6.2. Waste Description.................................. 102

6.2.1. Process Description.......................... 102

6.2.2. INEL Assessment Team Observations/Impressions......... 102

6.3. Waste Management................................... 103

6.3.1. Less Than 90 Day Storage....................... 103

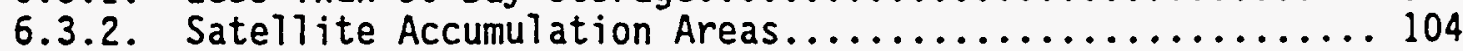

6.4. Regulatory Compliance/Violations History............... 107

6.4.1. Violations History.............................. 107

6.4.2. RCRA Remediation/Corrective Actions............... 108

6.4.3. CERCLA Remediation/Corrective Actions............. 109

6.6.4. Pending Litigation............................. 109

6.6.5. Involvement in "Superfund" Sites................. 109

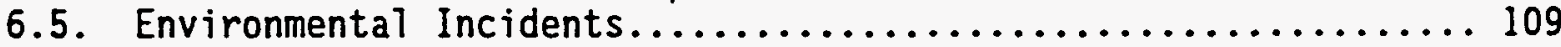

6.5.1. Summary of Incidents......................... 109

6.5.2. INEL Assessment Team Observations/Impressions......... 110

6.6. Facility Management Attitudes......................... 110

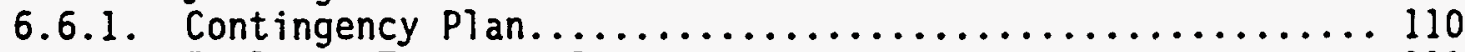

6.6.2. Employee Training Program............................. 111

6.6.3. Inspections................................. 113

6.6.4. Occupationa 7 Safety............................. 114

6.6.5. Preparedness and Prevention........................ 116

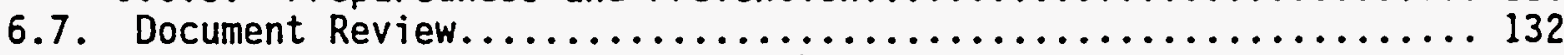

6.7.1. RCRA Part A/B Permit Application.................. 133

6.7.2. RCRA Part B Permit.......................... 139

6.7.3. Annual Hazardous Waste/Biennial Report................ 141

6.7.4. Closure/Post-Closure P1an...................... 142

6.7.5. Emergency Response/Contingency Plan................ 143

6.7.6. Facility Construction Plan....................... 144

6.7.7. Hazardous Waste Manifests....................... 144

6.7.8. Operations Record........................... 145

6.7.9. SARA Reports................................ 145

6.7.10. Sample Analysis Plan.......................... 148

6.7.11. Spi11 Prevention Control and Countermeasures Plan...... 149

6.7 .12 . Waste Analysis Plan.......................... 149

6.7 .13 . Waste Minimization Plan........................... 151

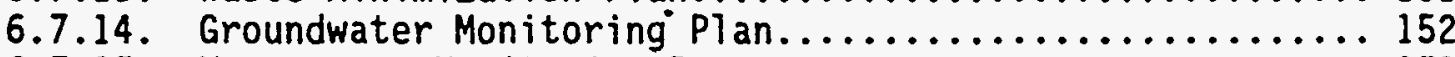

6.7.15. Wastewater Monitoring Reports................... 153

6.7.16. TSCA Storage/Disposal Approval.................... 153

6.7.17. CERCLA Off-Site Policy Approval.................... 153

6.7.18. Radioactive Materials License................... 154

6.7.19. Application for Radioactive Materials License.......... 156

6.7.20. Application for 1le. (2) Radioactive Materials License.. 157

6.7.21. Air Permit................................. 157

6.7.22. 1le.(2) Radioactive Materials License............... 158 
6.8. Environmental Monitoring Programs...................... 159

6.8.1. Air Monitoring............................... 159

6.8.2. Groundwater Monitoring........................ 160

7. FINANCIAL STRENGTH..................................... 165

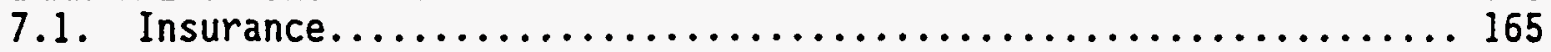

7.2. Closure and Post-ciosure Care................................ 166

7.3. Financial Assurance.................................... 172

7.4. History and Experience of Owners.......................... 174

7.5. Capital and Capacity of the Company..................... 174

7.6. Current Financial Condition........................... 175

8. RISK ASSESSMENT AND SUMMARY OF PERTINENT INFORMATION.............. 177

8.1. Public Health Risks.................................. 177

8.2. Environmental Risks............................... 177

8.2.1. Air Quality.................................. 177

8.2.2. Surface Water.................................. 178

8.2.3. Groundwater................................. 178

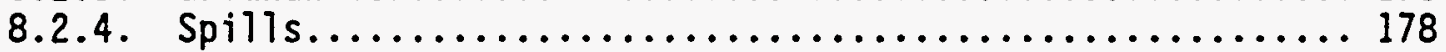

8.3. Financial Risks......................................... 179

8.4. Summary of Other Risk-Related Information.................. 180

8.4.1. Violations History........................... 180

8.4 .2 . Pending Litigation.............................. 180

8.4.3. Environmental Incidents....................... 180

8.4.4. Management Attitudes......................... 180

8.5. Rating of Facility, Based on Risks and Comparison to Other

Similar Operations................................. 181

9. SUMMARY AND CONCLUSIONS $\ldots \ldots \ldots \ldots \ldots \ldots \ldots \ldots \ldots \ldots \ldots \ldots \ldots \ldots \ldots \ldots \ldots$

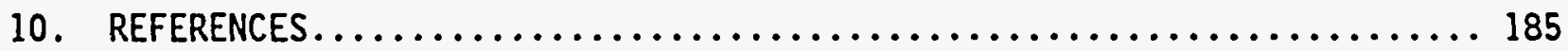

\section{FIGURES}

1. Location of the Envirocare of Utah facility................... 7

2. West Desert Hazardous Industry Area with associated facilities....... 35

3. Envirocare facility site plan.............................. 37

$4 a$. Envirocare $\mathrm{Cl}$ ive, UT wind roses.......................... 45

4b. Newfoundland Site, UT annual wind rose....................... 46

5. NORM wastes being stored on an asphalt pad..................... 51

6. LLW being stored on an asphalt pad. Wastes are segregated by

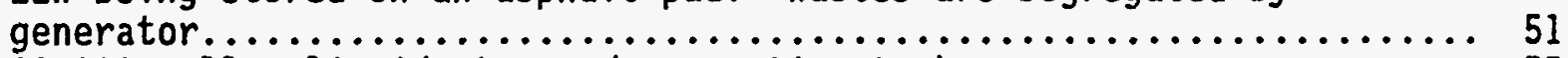

7. 20,000 galion liquid storage/evaporation tanks................ 55

8. Level indicators and associated alarm located on the evaporation

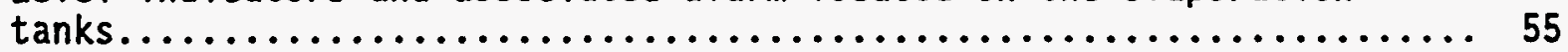

9. Geonet layer (black webbing) separating the evaporation tanks from the secondary containment.............................. 59

10. Unloading ramp and back hoe used to unload railroad gondola cars..... 63

11. Mixed waste storage pad and facility as seen from the Vitro Tailings

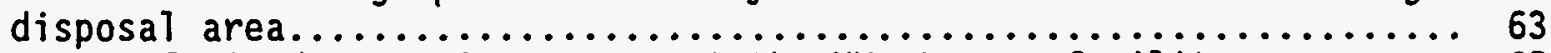

12. Boxes of mixed waste in storage at the MW storage facility......... 65

13. Storage boxes staged on the asphalt pad adjacent to the MW storage facility. 
14. Cross section of the construction of the MW landfill cell liner

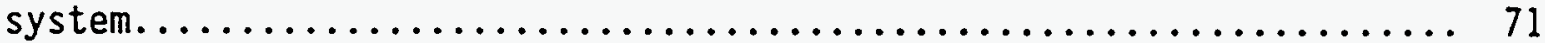

15. MW disposal cell at the Envirocare facility in March $1993 \ldots \ldots . . . . .73$

16. Close-up view of the liner of the MW disposal cell in March 1993.... 73

17. MW Disposal cell in November 1993. Surface of cell is at ground

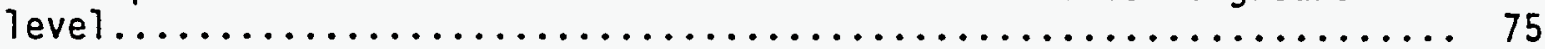

18. MW disposal cell in November 1993. Dark brown color reflects most recent disposal activities............................. 75

19. LLW disposal in cell. Wastes are segregated by generator. Flag denotes the grid position separating two generator's wastes........ 79

20. Routine maintenance of the radon barrier on the LLW disposal cell....

21. Disposal of debris in the Envirocare $L L W$ cell...................

22. Emplacement of the radon barrier on the $L L W$ disposal cell...........

23. Security diagram of the MW storage facility...................

24. Warning signs posted on the MW storage facility doorway........... 91

25. Warning signs posted on the MW disposal area security fence......... 91

26. Envirocare truck wash station in March $1993 \ldots \ldots \ldots \ldots \ldots \ldots \ldots \ldots \ldots . \ldots 9$

27. Envirocare truck wash station in November $1993 \ldots \ldots \ldots \ldots \ldots \ldots \ldots \ldots . \ldots 9$

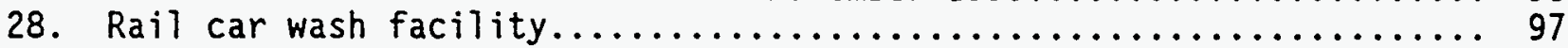

29. Rail car roll over equipment. Rail car wash facility is to the right 97

30. Close up of the rail car roll over equipment and pit. Black liner on

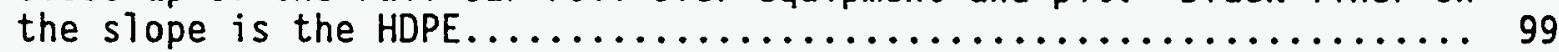

31. Inspecting an incoming load at the Envirocare facility............ 99

32. Run-on control pond at the Envirocare facility................. 105

33. Sprinkler heads (black objects in the water) in the run-on control

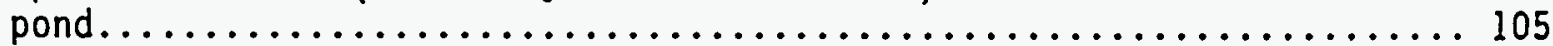

34. Warning sing and special safety equipment requirement posted outside the entrance to the active portion of the MW storage facility.......117

35. Warning signs posted outside the loading dock entrance to the MW

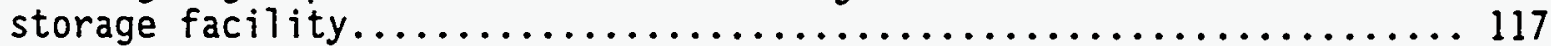

36. Safety shower and eye wash station located within the active area of the MW storage facility. Locker room is in the background.......119

37. Portable emergency eye wash station.......................119

38. Hazard communication Tabels used in the facility laboratory.......... 121

39. Hazard communication labels used in the facility laboratory......... 121

40. Alarm and visual warning light located at the MW storage facility.... 127

41. Waste storage in the MW storage facility..................... 129

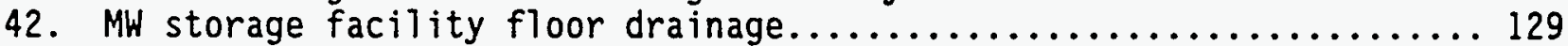

43. Air monitoring station located at the rail car roll over facility.... 161

44. Air monitoring station located east of the administration building... 161

45. Groundwater monitoring well (orange cylinder) located adjacent to the

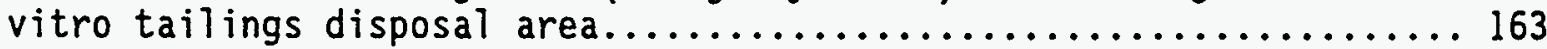

46. Groundwater monitoring wells located adjacent to facility access road 163

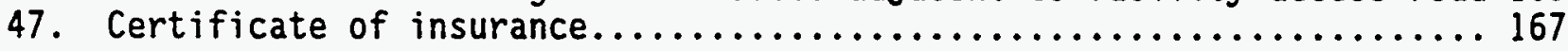

\section{TABLES}

1. INEL Liability Assessment participants at Envirocare............. 3

2. Envirocare personnel interviewed by the INEL Team............... 15

3. Documents and information reviewed concerning the Envirocare facility. 25

4. Envirocare training program out ine....................... 112

5. Comparison of RCRA Part B Permit Application with regulatory

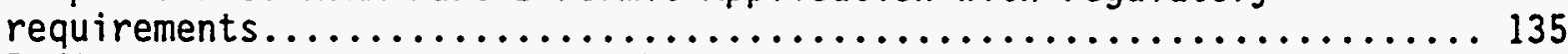

6. Radioactive isotopes accepted by Envirocare.................. 155 


\section{APPENDICES}

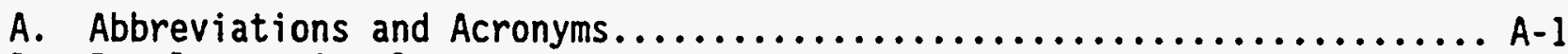

B. Regulatory Compliance Summary............................... 
EGG-ESQ-10749

January 1994

This page intentionally left blank. 


\section{ESH\&O LIABILITY ASSESSMENT REPORT OF ENVIROCARE OF UTAH, INC. CLIVE, UTAH}

\section{INTRODUCTION}

\subsection{PURPOSE}

The Comprehensive Environmental Response and Liability Act (CERCLA) and the Superfund Amendments and Reauthorization Act (SARA) assign joint liability to all responsible parties for releases of hazardous substances into the environment. Responsible parties can include treatment, storage, and disposal facility (TSDF) owners and operators, past owners and operators, transporters, and persons contracting or arranging for disposal. Therefore, Idaho National Engineering Laboratory (INEL) management and operations (M\&O) contractors which generate and contract for the disposal of hazardous waste could be liable for all or part of the cost of remedial clean up if the offsite TSDF lacks the capacity to pay for clean up. In order to reduce the potential liability inherent in dealing with an offsite contractor, which is not under the direct control of an INEL contractor, EG\&G Idaho has set up an environmental, safety, health, and quality (ESH\&Q) liability assessment program with the purpose of evaluating potential and current offsite contractors with respect to environmental compliance. It is believed that this evaluation process will provide a clearer picture of the risks associated with a contractor which will aid the INEL in making the best decisions with regard to selection of an offsite contractor.

This report describes the results of the 1993 ESH\&Q liability assessment of the Envirocare of Utah, Inc. (Envirocare) Clive facility. The Envirocare facility is a permitted Resource Conservation and Recovery Act (RCRA) and Hazardous and Solid Waste Amendment (HSWA) TSDF located near Clive, Utah. The facility is also permitted to dispose of radioactively contaminated RCRA hazardous wastes (hereafter called mixed wastes (MW)), Naturally Occurring Radioactive Material (NORM), and Low Level Waste (LLW). 
The Envirocare facility has not, as yet, been used by the INEL for the disposal of NORM, LLW, or MW. EG\&G Idaho, Inc. examined the facility in order to determine whether or not to pursue a Request for Proposal (RFP) to subcontract for MW, LLW, or NORM wastes disposal.

\subsection{SCOPE}

A complete ESH\&Q Tiability assessment was conducted of the Envirocare of Utah facility. The liability assessment consisted of pre-assessment, on-site inspection, post-assessment, financial evaluations, a risk assessment of the facilities, and this report. Emphasis for this assessment was placed on MW permit conditions, procedures, and operations at the facility, rather than the NORM and LLW operations, because MW disposal was the primary interest of the INEL operations.

The ESH\&Q liability assessment. examined compliance with regulations currently promulgated under the Atomic Energy Act (AEA), Clean Air Act (CAA), Clean Water Act (CWA), Comprehensive Environmental Response, Compensation, and Liability Act (CERCLA), Hazardous Materials Transportation Act (HMTA), Occupational Safety and Health Act (OSHA), Resource Conservation and Recovery Act (RCRA), Safe Drinking Water Act (SDWA), Superfund Amendment and Reauthorization Act (SARA), Toxic Substances Control Act (TSCA), and applicable regulations promulgated by the State of Utah and local legislation.

The complete ESH\&Q liability assessment included the following:

- On-site review of the RCRA/MW and NORM/LLW TSD facilities operations,

- Examination of facility plans and construction,

- Examination of all applicable permits,

- Examination of facility records, 
- Review of final disposal sites and methods for wastes handling and disposal,

- United States Environmental Protection Agency (EPA), State of Utah, and local (Tooele County) regulatory observations of the facilities,

- Opinions of other businesses that use the facilities,

- Review of other parties that take title of the waste or materials,

- Review of transporters,

- Review of certificates of destruction or disposal,

- Opinion of the communities near which the facilities are located, and

- Financial condition of the facilities/parent and ability to pay for potential cleanup or lawsuits.

The ESH\&Q 1iability assessment was conducted as part of the environmental oversight function of the EG\&G Idaho Environmental Support Group (ESG) to support the DOE-ID. The initial on-site portion of the assessment was conducted on March 10 and 11, 1993. The INEL Assessment Team revisited the company and site on November 8 and 9,1993 in order to update the status of several outstanding issues identified during the initial assessment. On-site evaluation assistance was also provided by the National Low Level Waste Program at the INEL. Table 1 lists the participants and their affiliations. Funding support was provided by the U. S. DOE contract DE-ACO7-76ID01570.

Table 1. INEL Liability Assessment participants at Envirocare

\begin{tabular}{|l|l|}
\hline Name of Participant & Company Affiliation \\
\hline W. J. Becker & EG\&G Idaho, Inc. \\
\hline N. J. Fix (Lead) & EG\&G Idaho, Inc. \\
\hline D. F. Harmon & EG\&G Idaho, Inc. \\
\hline
\end{tabular}




\subsection{CONTENT}

Section 1 contains the introduction and a description of the scope of this report. Section 2 identifies the facilities. Section 3 contains the background and history of the site operations. Section 4 describes the scope of the assessment. Section 5 presents pathway analyses of potential air and water contamination. Section 6 provides detailed analyses of data obtained for the assessment. Section 7 contains a financial analysis of Envirocare, including information about insurance coverage and closure care estimates. Section 8 summarizes the risks associated with Envirocare. Section 9 contains the summary and conclusions of the report. Section 10 contains a list of references used in this report. Appendix $A$ contains a list of abbreviations and acronyms used in this report. Appendix $B$ contains a summary of regulatory violations. Written comments received in January 1994 from Envirocare regarding the content of the report have been incorporated.

\subsection{Disclaimer}

The conclusions and recommendations contained in this report are based on facility background information, evaluations of information and documents from regulatory authority files and Envirocare, interviews with regulatory agencies and facility personnel, and inspections of the facility which occurred in March and November of 1993. The report represents a snap shot in time of the operations of the Envirocare facitity. The purpose of this report was to identify potential ESH\&Q or financial risks associated with the prospect of the INEL using the Envirocare facility for the disposal of MW, LLW, and/or NORM. However, the primary emphasis was placed on the MW operations because, in the opinion of the INEL Assessment Team, these operations present the greatest risk of liability for EG\&G Idaho, the other INEL M\&O contractors, and the DOE. 


\section{FACILITY/HAZARDOUS WASTE OPERATION IDENTIFICATION}

\subsection{Facility Name and location}

The Envirocare of Utah, Inc. facility consists of Low Level and mixed waste treatment and disposal units. The site is located within the West Desert Hazardous Industry Area (WDHIA) which has been selected by the Tooele County Board of County Commissioners as the designated area for locating commercial hazardous waste treatment, storage, and disposal facilities. The Envirocare facility is located about 80 miles west of Salt Lake City, Utah (Figure 1). The exact location is three ( 3 ) miles south of I-80, Exit 49 (Clive Exit).

The West Desert Hazardous Industry Area, al so known as the Tooele County Hazardous Industries Area was designated by the Tooele County Commission. The Commission's intention in establishing this area was to isolate industries that could pose a risk to human health or the environment in an area separated by distance from residential communities.

The Envirocare facility encompasses approximately 540 acres located at Latitude 40.41'000" North and Longitude 113.06'030" West in Township 1 South, Range 11 West, Section 32. The facility is bordered by public lands which are administered by the United States Department of the Interior, Bureau of Land Management (BLM).

The name and mailing address of the facility is:

Envirocare of Utah, Inc.

46 West Broadway, Suite 240

Salt Lake City, UT 84101

(801) $532-1330$

The physical address of the facility is:

Envirocare of Utah, Inc.

3 Miles South of the Clive I-80 Interchange

Clive, Utah 
or

Envirocare of Utah, Inc.

1 Mile South of the Clive Siding

Clive, Utah

The legal description of the Envirocare Clive facility is:

Section 32. Township 1 South, Range 11 West. Tooele County, Utah, except for the legal

description of their impoundnent of the Vitro site:

\section{PROPERTY OESCRIPTION FOR VITRO EMBANKMENT}

Beginning at a point located 1120.32 feet $N 89^{\circ} 56^{\circ} \mathrm{W}$. along the section 1 ine, and 329.49 feet South from the Northeast corner of Section 32. Township 1 South, Range 11 West, Salt Lake Base and Meridian and running thence: $N 89^{\circ} 56^{\circ} 32^{\circ} \mathrm{W} 1503.72$ feet. thence $S 0^{\circ} 03^{\circ}$ $28^{\prime \prime} W 2880.50$ feet, thence $S 89^{\circ} 56^{\circ} 32^{\prime \prime}$ E 1503.72 feet. N $0^{\circ} 03^{\prime} 28^{\prime \prime} E 2880.50$ feet to the point of the beginning.

\subsection{Name and Location of Facility OWNer}

The Envirocare Facility is owned by Envirocare of Utah, Inc. which has its corporate headquarters located at:

Envirocare of Utah, Inc.

46 West Broadway, Suite 240

Salt Lake City, UT 84101

(801) $532-1330$

\subsection{FACILITY IDENTIfICATION NUMBER}

The Envirocare Facility has the following identification and permit numbers:

EPA Identification Number:

UTD982598898

Part A Permit:

UTD982598898

Part B Permit:

UTD982598898

Ground Hater Quality Discharge Permit

UGW450005

NPDES Permit:

Publicly Owned Treatment Horks:

$n / a$

Utah Bureau of Air Quality Approval:

$n / a$

CERCLA off-site waste approva?

BAQE-747-90

Radioactive Materials License

$\mathrm{n} / \mathrm{a}$

Conditional Use Permit

UT2300249

2700-87 
EGG-ESQ-10749

January 1994

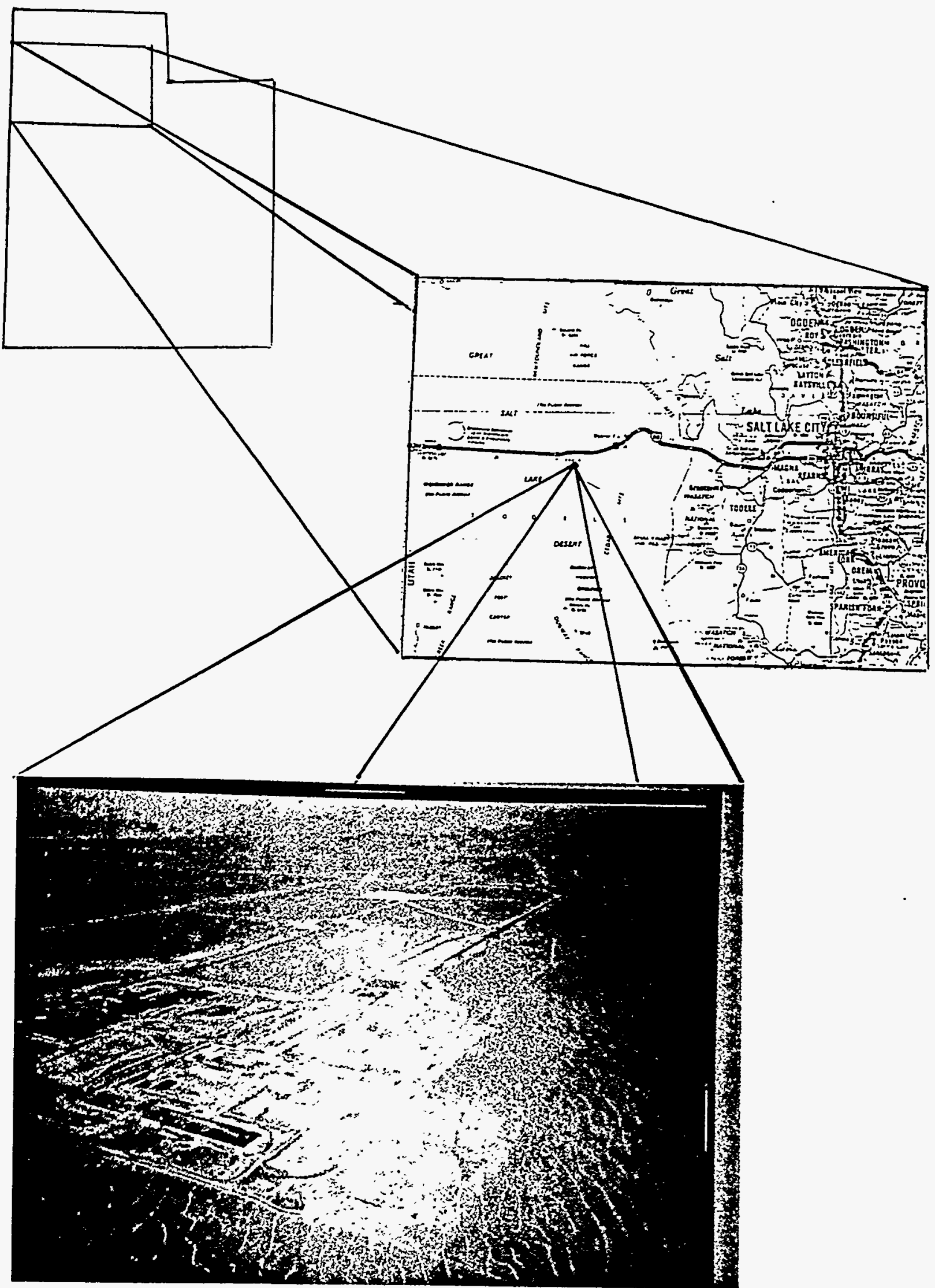

Figure 1. Location of the Envirocare of Utah facility. 
, 


\subsection{FACILITY TYPE.}

Envirocare of Utah, Inc. operates a landfill facility near Clive, Utah for the purpose of disposing of NORM, LLW, and radioactively contaminated RCRA hazardous wastes known as mixed wastes (MW).

A portion of the Envirocare of Utah Clive facility is a permitted RCRA/HSWA treatment, storage, and disposal facility. The RCRA TSDF includes a mixed waste landfill, storage facilities, and an evaporation unit. The facility is supported by an on-site laboratory. The Envirocare has RCRA and HSWA permits which allow the receipt of characteristic and listed radioactively contaminated wastes. Solids in bulk rail cars and gondolas are also accepted. The Envirocare permits do not allow for the receipt of, and disposal of, wastes containing DOT forbidden Class, Class $A$, and Class $B$ explosives; shock sensitive wastes and materials; compressed gas cylinders unless they meet the definition of an empty container; radioactive wastes that exceed the mixed waste permit conditions; EPA waste codes F020, F021, F022, F023, F026, and F027; Utah waste codes $F 999$ and P9g9 (demilitarized wastes, e.g., nerve gas); free liquids, or polychlorinated biphenyls (PCB's). 
EGG-ESQ- 10749

January 1994

This Page Intentionally Left Blank 


\section{BACKGROUND AND HISTORY}

\subsection{Site History and OWNERShIP}

The Envirocare Clive facility occupies portions of Township 1 South, Range 11 West, Section 32 surrounding the Vitro Tailings Remediation Project. At the time the Vitro Tailings Environmental Impact Statement was being researched and written (eariy 1980's), the lands around the Clive facility were investigated. The South Clive site, and all of Section 32, was owned by the State of Utah (School Lands). This land had been obtained from the United States Department of the Interior, Bureau of Land Management (BLM) through a 1 and swap between the State and the BLM. The State then transferred the ownership and administration to Tooele County. In the State of Utah, the ownership and administration of School Lands is given by the State to the County in which the lands are located. Most of the rest of the lands within a 10 mile radius of the present facility were public domain and administered by the BLM.

One hundred acres of Section 32 were used for a permanent disposal of uranium mill tailings from the remedial action taken at the former Vitro Chemical Company site located in Salt Lake County, Utah. The disposal of the tailings was part of a cooperative effort between the DOE and the State of Utah, Department of Health to remediate the Salt Lake County site. According to the 11e. (2) Draft Environmental Impact Statement (DEIS) title to the property used for the placement of the tailings will be ceded to the DOE, by the State of Utah, upon completion of the remedial action.

The approximately 540 acres surrounding the Vitro Tailings disposal cell were sold by the Tooele County to Envirocare in the 1985 or 1986 . In the State of Utah, the County has the authority to dispose of School Lands as it sees fit. This land has not changed ownership since that time.

In addition, Envirocare has obtained 140 acres of land, composed of five parcels, located north of the facility, and original 540 acres, along the railroad spur. Envirocare obtained the 140 acres from the BLM in a land swap. 
The purpose of these five parcels is to provide a right-of-way along the rail spur from Clive, UT to the facility.

\subsection{Current and Past Use by the Generator}

Envirocare began operations at the Clive facility in 1988. The first landfill cells to be permitted by the State of Utah, then constructed and opened, were the NORM cells. Envirocare then applied for, and received, a modification to their Radioactive Materials License from the State which allowed them to accept and dispose of low level radioactive wastes. Separate landfill cells were constructed for this purpose. At the same time, the company submitted RCRA Part A and Part B permit applications to the State of Utah and EPA, Region VIII, for the storage and disposal of mixed waste. The facility received both the RCRA Part $B$ and HSWA permits and has been allowed to dispose of mixed waste since the completion of the mixed waste disposal cell in April 1992.

\subsection{Current and Historical Methods for Residue Disposal}

A11 residues generated by the Envirocare Clive facility are treated, or stored, and disposed of on site. The facility is allowed to treat selected waste streams by evaporation only. The company has submitted, and received, a permit modification which will allow it to treat wastes by stabilization. A new stabilization facility is schedule to be built in calendar year 1994. Residues from tank evaporation are currently being stored in the mixed waste container storage area pending solidification and final disposal. No hazardous or radioactive waste residues leave the site for disposal. Domestic and/or municipal wastes, such as paper and trash, are removed by a private contractor for disposal at a municipal landfill. 


\section{DESCRIPTION OF THE AUDIT}

\subsection{Operations TOUREd}

The INEL Assessment Team toured the entire Envirocare Clive facility and inspected the mixed waste operations and storage facilities as part of this assessment. The tour and inspection took place on March 10 and 11, 1993 and again on November 8 and 9, 1993. The weather at the time of the March 1993 assessment on site portion of the inspection was heavily overcast, with heavy pockets of fog. Temperatures were in the high $30^{\prime} \mathrm{s}$ to $10 \mathrm{w} 40^{\prime} \mathrm{s}$. The disposal operations were not active at the time of the inspection due to the heavy snow cover and water saturated soils at the site. Envirocare received about 18 inches of snow during the 1992-93 winter (November through February) season. Normal total precipitation for this area is about 1.19 inches as recorded by the Wendover Civil Aeronautic Administration Airport (CAA AP).

Members of the Assessment Team returned to the site on November 9, 1993 in order to observed waste receipt and disposal operations. The weather at the time of the revisit was generally clear with some pockets of ground fog during the morning hours. Temperatures were in the $30^{\prime} \mathrm{s}$. The disposal operations were active and the site was dry.

\subsubsection{Treatment Facilities}

Envirocare operates two evaporation tanks which are permitted as treatment facilities. The purpose of these tanks is to reduce the volume of liquid wastes generated at the facility in order to facilitate disposal on site. Liquid wastes generated include leachate, truck and railcar wash waste water, laboratory standards, and site run on. The evaporation tanks and their associated processes were discussed and inspected as part of this assessment.

\subsubsection{Storage Facilities}

Envirocare operates several types of regulated storage facilities on site. The facility stores incoming low level and NORM wastes on asphalt pads while 
awaiting disposal in the appropriate landfi17-cells. Mixed wastes are stored at a RCRA/HSWA permitted facility. Containers are stored inside the building and bulk materials on an asphalt pad outside the building. The company also operates satellite accumulations areas (SAAs) in the laboratory for storage of wastes generated by the laboratory processes. Tanks designated as less than 90 day storage areas ( $<90$ day areas) are used to store truck wash and rail car wash waste water. These $<90$ day areas are tanks. All wastes are completely treated and disposed of on site. The various storage facilities were discussed.and inspected as part of this assessment.

\subsubsection{Disposal Facilities}

Envirocare operates NORM, low level radioactive, and mixed waste disposal landfill cells at the Clive facility. As previously stated, at the time of the March 1993 assessment, waste disposal operations were inactive. Routine winter maintenance of the NORM and low level waste cells was ongoing. The mixed waste cell was heavily snow covered and no operations were planned until the snow melted and the cell dried out. All of the landfill cells were discussed and toured as part of this assessment.

When the INEL Assessment Team re-visited the facility in November 1993 the NORM/LARW cells were active. The MW cell was inactive because there were no MH wastes awaiting disposal at that time.

\subsubsection{Laboratory Facilities}

Envirocare operates a laboratory on site which analyzes samples from incoming shipments for verification of the profiles. The laboratory, its procedures, processes, and waste management were discussed and inspected as part of this assessment.

\subsubsection{Transportation Facilities}

Envirocare does not operate a transportation company. Generators must make arrangements with common carriers, who maintain the appropriate permits, for the transportation of materials to the Clive facility. Envirocare does 
operate a railroad spur with associated shunting engines. The company and state regulators prefer that LARW shipments arrive at the facility by rail, however truck shipments are commonly received. Envirocare representatives stated that they preferred that MW shipments arrive by truck and discouraged the use of rail for this stream. The railroad spur, rail car roll off, rail car wash, and truck wash facilities were discussed and inspected in March 1993 as part of this assessment.

\subsection{Facility Personnel Contacted}

The following Envirocare personnel were contacted during the onsite inspection of the facility:

Table 2. Envirocare personnel interviewed by the INEL Assessment Team

\begin{tabular}{||l|l||}
\hline Name & Position \\
\hline V. Andrews & $\begin{array}{l}\text { Corporate Radiation } \\
\text { Safety Officer }\end{array}$ \\
\hline G. Copeland & $\begin{array}{l}\text { Quality Assurance } \\
\text { Officer }\end{array}$ \\
\hline B. Howard & $\begin{array}{l}\text { NORM Laboratory } \\
\text { Supervisor }\end{array}$ \\
\hline J. Low & Laboratory Manager \\
\hline D. Owen & Site Manager \\
\hline S. Peterson & Site Engineer \\
\hline A. Rafati & $\begin{array}{l}\text { Director, Business } \\
\text { Development }\end{array}$ \\
\hline S. Rice & Marketing Representative \\
\hline V. Romero & Financial/Accounting \\
\hline K. Semnani & President \\
\hline J. Vance & Environmental Engineer \\
\hline D. Young & Radiation Monitor \\
\hline
\end{tabular}




\subsection{Regulatory agencies Contacted}

The U. S. EPA, Region VIII, Utah State Department of Environmental Quality (DEQ), Division of Solid and Hazardous Waste (DSHW), and Tooele County, Utah, are the authorities governing the generation, treatment, and disposal of hazardous wastes at the facility, within the State of Utah. The DSHW has primacy with regard to RCRA permitting and compliance. EPA, Region VIII, is the governing authority with regard to newly listed wastes regulated by HSWA.

\subsubsection{U. S. EPA, Region VIII}

The State of Utah is authorized by the U.S. EPA to administer the Clean Air Act program and the Clean Water Act programs, as well as the RCRA provisions. Discussions with EPA, Region VIII, contacts clearly indicated that EPA's role in facility oversight in Utah is minimal. EPA's primary role is to receive and review Utah's reports concerning the state's performance of the regulatory functions.

\subsubsection{Air and Toxics Division.}

4.3.1.1.1. Air Quality Branch -- The State of Utah has full, primary responsibility for the Clean Air Act. The EPA's role is to receive and review reports from the State on its inspection, enforcement, and other regulatory activities. The EPA, Region VIII, Air Quality Branch was contacted. The Branch indicated that the state of Utah has a commitment to inspect on an annual basis. They noted only one Notice of Violation (NOV), dated October, 1988, on the books and it concerned the control of fugitive dust, with no penalty assessed. The issues were minor, involving the requirement to control fugitive dust on unpaved roads and areas, the required record-keeping for water used for dust control, and installing water spray equipment required. The Branch indicated the issues were resolved satisfactorily by the 1989 inspection.

4.3.1.1.2. Pesticides/Toxics Branch -- The Envirocare facility does not accept wastes regulated by the TSCA or Federal Insecticide, Fungicide, 
Rodenticide Act (FIFRA). Therefore, the Toxics/Pesticides Branch was not contacted as part of this assessment.

4.3.1.1.3. Radiation Control Branch. The Radiation Control Branch was contacted. According to the Branch it has no involvement in the oversight of. the Envirocare facility. This function is performed by the State of Utah Bureau of Radiation Control because Utah is a Nuclear Regulatory Commission (NRC) Agreement State.

\subsubsection{Environmental Services Division.}

4.3.1.2.1. Emergency Planning and Response Branch -- The Emergency Planning and Response Branch was not contacted as part of this assessment because of the relative lack of EPA involvement in compliance and oversight for the Envirocare facility noted in discussions with EPA regulators. The state has primacy for enforcing the emergency planning regulations under SARA and was contacted instead.

\subsection{Environmental Monitoring/Compliance Branch -- This} Branch was not contacted for this report because of the relative lack of EPA involvement in compliance and oversight for the Envirocare facility noted in discussions with EPA regulators.

\subsubsection{Hazardous Waste Management Division.}

4.3.1.3.1. Program Support Branch -- The Program Support Branch was not contacted for this report, due to the indicated lack of EPA direct oversight.

4.3.1.3.2. RCRA Branch -- The EPA, Region VIII, RCRA Branch, is responsible for administering the HSWA portion of RCRA, with the remainder of RCRA being administered by the State of Utah. EPA's last inspection of the facility occurred just before the facility's RCRA/HSWA Part B Permit was issued. This permit was issued on February 14, 1991. The EPA RCRA branch was contacted as part of this assessment. The RCRA Branch contact is also the CERCLA Off-Site Policy Coordinator. The information received from the 
regulators has been incorporated into subsequent sections of this report, as appropriate.

\subsection{Superfund Enforcement Branch -- The Superfund} Enforcement Branch was contacted as part of this assessment. The Superfund staff member who was contacted stated that the Envirocare facility was not on the National Priorities List (NPL), and to his knowledge, there was no Superfund activity at the site. He indicated that this did not preclude that such activity was occurring at the facility, but only that with Utah as part of his territory, he was not aware of any relevant Superfund activity.

\subsubsection{Water Management Division. The EPA, Region VIII, Water} Division, specifically the Groundwater Branch, was contacted as part of this assessment. The EPA contact stated that the State of Utah has complete primacy for water quality, and that the EPA has adopted a "hands-off" policy for water. The EPA role is limited to receipt of the required reports from the State of Utah concerning enforcement, inspections and other components of the state program. Also, the Envirocare facility is not required to have or obtain a wastewater discharge permit, so the Water Compliance Branch was not contacted as part of this assessment. As a result, further contacts with the EPA Water Management Branch regarding Envirocare were not made.

\subsubsection{Nuclear Regulatory Commission}

The Nuclear Regulatory Commission (NRC), Low Level Waste Office was contacted concerning a pending application from Envirocare to permit the facility to accept 1le.(2) materials for disposal. According to the NRC the application is still pending, and it is anticipated that the permit should be approved by November, 1993. The NRC noted the 1le.(2) Draft Environmental Impact Statement (DEIS) findings that there were identified no environmental risks or impacts resulting from the issuance of the permit and the 1le.(2) operations, and the DEIS's recommendation that the permit be issued.

The lle.(2) materials license was subsequentily approved on November 19, 1993. Envirocare provided the INEL Assessment Team with a copy of the license in January 1994. 


\subsubsection{State of Utah}

State of Utah regulations require that hazardous waste treatment facilities be inspected at least once a year; these inspections may be unannounced. The minimum number of inspections for facilities which receive waste from a Superfund site is two per year.

Eight State inspectors are permanently assigned to Tooele County with the responsibility for inspecting the various hazardous waste generating and handling industries located there. In some instances Tooele County may perform inspections in conjunction with or at the request of the State. However, the State has primacy for RCRA.

In discussions with the State regulators the positive relationship which Envirocare has with the regulators was apparent. Problems noted in inspections were typically resolved to the satisfaction of the regulators, without undue delay or confrontation.

4.3.3.1. Emergency Response Commission. The Utah Emergency Response Commission was contacted as part of this assessment. They indicated that the agency's involvement with Envirocare was minimal, with most of the documentation being provided to the RCRA branch. Envirocare's SARA reporting to the agency is in compliance. Spill reports have been minimal, with none in the past four months.

\subsubsection{Department of Environmental Quality.}

4.3.3.2.1. Division of Air Quality -- The State of Utah has primacy for enforcing the air quality requirements within the State. The Utah Department of Health, Division of Air Quality was contacted for this report. The Division confirmed that Utah has primacy for the air programs, and that Envirocare has an air quality permit. The permit is for construction and operations of the low level radioactive material disposal site. The Division also stated that there are no outstanding or current enforcement actions between the Division of Air Quality and Envirocare. Further information was not available because the State of Utah is in litigation over Envirocare. The 
issue of the suite was not specifically identified, however, it appeared to be about, rather than with, Envirocare.

\subsection{Environmental Health Division -- The Environmental} Health Division was not contacted as part of this assessment.

4.3.3.2.3. Division of Radiation Control -- The State of Utah is an NRC Agreement State, and exercises authority for licensing and control of radioactive materials. The Utah Division of Radiation Control (DRC) implements this program. Because the Envirocare facility disposes of lowlevel wastes and NORM, the DRC regulates the radioactive portion of Envirocare's operations. The Division of Radiation Control was contacted.

The Division stated that the Envirocare facility does have an active permit to accept Naturally Occurring Radioactive Materials (NORM), and an active permit to receive certain levels of Special Nuclear Material (SNM). It was noted that Envirocare had a pending application before the state to expand the type and number of isotopes which may be accepted, but that the application had not been acted upon. In addition, the Division noted that Envirocare had a pending application before the NRC, which also had not been acted upon. The DRC noted that while the facility had received a number of NOVs, the NOVs were low-to-mid level in severity, and expected for the size and complexity of the facility. The Division indicated that, in all, it was satisfied with the compliance and operation of the Envirocare facility.

The Division of Radiation Control was contacted again in November 1993 regarding the ownership and post closure care of the Envirocare facility. The Division indicated that they were aware of concerns and issues surrounding the assumptions of post closure care and maintenance of the various units at the facility. Envirocare and the DEQ have entered into a restrictive covenants agreement which addresses some of the concerns raised regarding actual ownership of the site. Envirocare will always own the land. The trust funds established for post closure maintenance are designed to provide the necessary funding for the State of Utah, if, or when, it is required to assume the closure and/or post closure care. 
The Division was aware that the Envirocare post closure plans required for NRC licensing do not, at this time, specifically address the various units, i.e., NORM, LARW, and MW cells, at the site. This issue was a concern especially because of the RCRA/NRC overlap between the closure and post closure care of the MW cell. There is still some confusion regarding the NRC post closure care of the MH cell after the RCRA 30-year post closure care expires.

The Division plans to propose to the 1994 Utah Legislature a bill to permit the State to require a perpetual care fund be established for the Envirocare facility. The State controlled fund would provide the State the necessary financing to react to a catastrophic event at the site.

The Division recently completed its annual inspection of the Envirocare facility and stated that they were quite pleased with the operations. The recent introduction of the quality assurance officer at the site has resulted in significant improvements in both the operations and the documentation. The INEL Assessment Team made a similar observation.

4.3.3.2.4. Division of Solid and Hazardous Waste -- The State of Utah exercises primary authority for the non-HSWA portion of RCRA. The Utah Division of Solid and Hazardous Waste was contacted. The Division stated that Utah is an authorized state for RCRA, including for mixed waste. The Division maintained constant oversight during construction, including daily inspections. They stated that they feel very confident with the mixed waste cells operated by Envirocare. Envirocare received its RCRA Part B Permit on November 30, 1990. They noted that there had been two NOVs, both of which had been satisfactorily resolved. Very little public comment on Envirocare had been received during a recent RCRA Permit modification.

\subsection{Water Pollution Control -- The Envirocare facility is} not required to have or to obtain a wastewater discharge permit. The facility does, however, have a groundwater discharge permit, and the Water Pollution Control Unit was contacted for this report. The groundwater discharge permit, No. UGW450005, was issued on March 19, 1992. 
4.3.3.3. Industrial Commission. The State of Utah Industrial Commission is responsible for enforcement of the Occupational Safety and Health Act (OSHA). The Utah Industrial Commission, Occupational Safety and Health Division, Compliance Review Section was contacted. The agency apparentiy is limited to conducting planned inspections of facilities biennially. The Utah OSHA records indicated that the facility has been inspected only once, on December 22, 1992. The Utah OSHA does not exercise authority for Federal lands/facilities, these remain under federal jurisdiction.

\subsubsection{Tooele County}

"On January 12, 1988, The Tooele County Commission established the West Desert Hazardous Industry Area (WDHIA). The USPCI [United States Pollution Control, Inc.] sites are located within this area. Rather than being a formal zone designated for hazardous waste disposal activities, the area retains its multiple use designation. However, the WDHIA is the only area in the county where site-specific zoning changes for hazardous industries will be considered.

"Tooele County amended the uniform zoning ordinance by adding the 'Hazardous Industrial District' zoning classification (MG-H), and this is the classification to which hazardous industry sites within the WDHIA are rezoned. The purpose of the new zoning classification is to provide for appropriate locations where hazardous industrial processes necessary to the economy may be conducted, and prohibiting such activities in all other zoning classifications of Tooele County. The regulations of this classification are designed to protect the environmental quality of the site and Tooele County. All activities relating to commercial storage, treatment, and disposal of wastes classified as hazardous wastes under Section 26-14-2(6) of the Utah Solid and Hazardous Waste Act or otherwise regulated as a "waste" under TSCA, CERCLA, or other Federal or State laws and regulations are covered under this zoning ordinance.

"Tooele County established performance standards for the storage, treatment, and disposal of hazardous wastes which may be authorized in the Hazardous Industrial District Zoning District (MG-H). These performance standards are 
intended to be used as a mechanism to review and assess the potential social, health, and environmental impacts and risks that may be associated with any proposed hazardous industrial activity or proposed MG-H Zoning District. In the case of a conflict between the county's siting standards and those promulgated by the State of Utah Solid and Hazardous Waste Committee, the stricter of the two would apply.

"The Planning and Zoning Commission is responsible for reviewing each application on a case-by-case basis. All zoning changes and conditional use permits for development(s) located in this area must then be reviewed and approved by the Tooele County Commission prior to taking effect" (C)ive EIS pp. 3-37, 3-38).

The Tooele County Planning and Zoning Board was contacted for this assessment. The Planner stated that as a part of the conditional use permit Envirocare must meet certain requirements, primarily the submission of copies of state submittal documents to the Planning and Zoning Commission. Additionally, the $\mathrm{Pl}$ anning and Zoning Commission conducts inspections of the facility on an intermittent basis. The Commission stated that the Envirocare facility is in compliance with their conditional use permit and is a good facility operator.

\subsubsection{Other Agencies}

\subsubsection{Salt Lake City Better Business Bureau. The Salt Lake City} Better Business Bureau (BBB) was contacted because there is no BBB for the Tooele/Clive area. Also, Envirocare maintains its corporate headquarters in Salt Lake City. The Salt Lake City BBB had not record of any comments, negative or positive, being submitted regarding Envirocare.

4.3.5.2. Tooele Chamber of Commerce. The Tooele, Utah Chamber of Commerce was contacted. There is no Chamber of Commerce for Clive, Utah. The Tooele Chamber of Commerce also had no records of comments, negative or positive, being submitted concerning the Envirocare facility or the company.

4.3.5.3. Tooele County Fire Department. The Fire Department is not listed separately, but is dispatched through the Tooele County Sheriff's 
Office. The Tooele County Sheriff's Office was contacted. Because the appropriate personnel were not available, the county's Emergency Management Department was contacted. According to the Emergency Management Department (EMD), the responsibilities for emergency management were transferred from the EMD to the Sheriff's Office. The EMD does feel confident in Envirocare's planning and preparation. While these responsibilities were in the EMD, Envirocare had met the requirements satisfactorily, and the EMD understands that Envirocare continues to meet their requirements.

\subsection{OTHER INFORMATION}

\subsubsection{Environmental Checklists}

Environmental audit checklists were used for part of the facility appraisal. These checklists tested compliance with regulations promulgated by the $U$. $S$. EPA. The checklists used were generated by the Audit Master environmental audit checklist, which is a commercially available computer software program that generates facility specific audit checklists. (See Section 10 for references.) The Audit Master ${ }^{\mathrm{N}}$ checklists concerning solid and hazardous waste (RCRA), water quality (CWA, SDWA), air quality (CAA), and communityright-to-know/chemical risk (SARA reporting), toxic substances (TSCA), underground storage tank programs (USTs), and spill prevention were generated on site during the interviews with facility representatives. These checklists are kept as part of the assessment record.

\subsubsection{Document Review}

The following documents and information were reviewed before and/or during the site inspection and at the Envirocare facility: 
Table 3. Documents and Information Reviewed Concerning the Envirocare Facility

\begin{tabular}{|c|c|}
\hline $\begin{array}{l}\text { DOCUMENT/INFORMATION REVIEHED (R). DISCUSSED (D) OR NOT APPLICABLE } \\
\text { (N/A) }\end{array}$ & \\
\hline Air Monitoring Data & R. D \\
\hline Air Permits & R. $D$ \\
\hline Annual Hazardous Haste/Biennial Report & $R, D$ \\
\hline Bills of Lading & N/A \\
\hline CERCLA Off-Site Policy Approval & 0 \\
\hline Certificates of Insurance for Sudden and Non-Sudden Incidents & $R, D$ \\
\hline Cha in-of-Custody Procedures & R. $D$ \\
\hline Closure/Post Closure Plan & $R, D$ \\
\hline $\begin{array}{l}\text { Emergency Response/Contingency Plan, including Spill Response and } \\
\text { Clean up Procedures }\end{array}$ & R. $D$ \\
\hline Facility Construction Plans & R. $D$ \\
\hline Final Environmental Impact Statement & $R, D$ \\
\hline Groundwater Monitoring Data & R. $D$ \\
\hline Groundwater Monitoring Plan & R. $D$ \\
\hline Hazardous Haste Manifests & $R, D$ \\
\hline Information concerning OSHA compliance & R. $D$ \\
\hline $\begin{array}{l}\text { Information on assignees to which waste is transferred and final } \\
\text { disposition of the waste }\end{array}$ & N/A \\
\hline Inspection Records & $R, D$ \\
\hline Medical Surveillance Program & 0 \\
\hline Notices of Violation and Consent Orders & R. $D$ \\
\hline Hot ification of Hazardous Waste Act ivities & $R, D$ \\
\hline Operations Record & R. $D$ \\
\hline Part A Permit Application & R. D \\
\hline Part B Permit Application & R. $D$ \\
\hline Part B Permit & R. $D$ \\
\hline Pending Environmental Litigation & R. D \\
\hline Personnel Training Records & R. D \\
\hline $\begin{array}{l}\text { Provisions for transport of recyclable materia is/hazardous waste to } \\
\text { and from this facility }\end{array}$ & $D$ \\
\hline Quality Assurance Plan & $R, D$ \\
\hline Safety Program Plan & D \\
\hline Sample Analys is Plans & R. D \\
\hline SARA Reports & $D$ \\
\hline
\end{tabular}




\begin{tabular}{||l|l|}
\hline $\begin{array}{l}\text { DOCUMENT/INFORMATIOH REVIEWED (R). DISCUSSED (D) OR NOT APPLICABLE } \\
(N / A)\end{array}$ & \\
\hline Sewage Permit & N/A \\
\hline Solid Haste Disposal Permit & N/A \\
\hline Spill Prevention Control and Countermeasures Plan & D \\
\hline TSCA Storage/Disposal Permit & N/A \\
\hline Visitor's Log & R \\
\hline Waste Analysis Plan & R. D \\
\hline Water Oischarge Data & H/A \\
\hline Wastewater Permit & R. D \\
\hline
\end{tabular}

\subsubsection{Permits}

\subsubsection{RCRA Part A/B Permit.}

4.4.3.1.1. RCRA Part A Permit Application -- Envirocare filed the EPA 8700-12 form (Notification of Hazardous Waste Activity) on March 3, 1989 with the State of Utah. The State responded on March 6, 1989 with an assignment of EPA Identification Number: UTD982598898 to the Envirocare facility.

Envirocare submitted its RCRA Part A Application for treatment, storage, and disposal of hazardous/radioactive (mixed) wastes to the State of Utah on Apri1 2, 1990. The Part A Application was submitted in conjunction with the RCRA Part B Permit Application according to the requirements delineated in 40 CFR $\S 270.10$. Envirocare did not qualify for interim status as defined by 40 CFR 265 and, as such, was not able to operate solely under a Part A Permit Application as defined by 40 CFR $\S 270.10$.

The Envirocare RCRA Part A Permit Application was reviewed in detail. The purpose of the review was to identify the waste streams and processes described for the facility and compare the actual operations with the permit information. The details of this review can be found in Section 6.7.1. of this document. 
4.4.3.1.2. RCRA Part B Permit -- Envirocare submitted its RCRA Part B Application for treatment, storage, and disposal of hazardous/radioactive (mixed) wastes to the State of Utah on April 2, 1990. As previously stated the Part A and Part B Permit Applications were submitted together according to the requirements delineated in 40 CFR $\S 270.10$.

Envirocare did not qualify for interim status as defined by 40 CFR $\S 265$ and, as such, was not able to operate solely under a Part A Permit Application as defined by 40 CFR $\S 270.10$, nor was it able to construct the facility at Clive, UT without the Part B Permit.

Envirocare requested a permit modification which would enable it to conduct stabilization treatment to meet Land Disposal Restrictions for certain wastes. It was granted in September 1993. The permit modification documentation was not available for review. Envirocare was contacted for a description of the process. Essentially, they will place the wastes in a mixer, add water, stabilization agents and materials, solidify the mass, and wait for results to assure that the process is successful before placing the treated wastes in their landfill cells. These stabilization treatments are targeted for the D018 through D043 waste codes. These codes were part of the RCRA/HSWA Part B permit, but had not been added to the State RCRA Part B Permit.

The Envirocare RCRA Part B Permit was reviewed in detail. The purpose of the review was to identify the operating requirements for the facility and compare the actual operations with the permit conditions. The details of this review can be found in Section 6.7.2. of this document.

\subsection{RCRA/HSWA Part B Permit -- Envirocare received a RCRA} Part B Permit from EPA Region VIII on February 12, 1991. This permit is also known as the HSWA Permit and allows Envirocare to treat and/or dispose of RCRA hazardous and/or mixed wastes for which the State of Utah does not have primacy. The permit is in effect from February 14, 1991 until February 14, 1996, uniess revoked by EPA, Region VIII. It was issued based on the premise that the information submitted in the Part B Permit Application dated April 21, 1989, as modified by subsequent revisions dated August 14, 1989; October 9, 1989; November 2, 1989; November 30, 1989; 
March 30, 1990; Apri1 4, 1990; Ju1y 17, 1990; August 17, 1990;

October 5, 1990; October 12, 1990; October 19, 1990; and the responses submitted in response to HSWA requirements is accurate and that the facility would be constructed and operated as described in the application, except as modified by the conditions in the HSWA Permit.

Subsequent to the on site portion of the assessment, the U.S. EPA issued a HSWA permit modification on May 5, 1993, which added ten (10) waste codes to the list of wastes which could be accepted/stored/disposed of at the facility under its RCRA Part B Permit. The permit modification was issued in response to a request submitted by Envirocare on October 23, 1992. The additional wastes codes are:

$\begin{array}{llllllllll}\text { F024 } & \text { P105 } & \text { U003 } & \text { U122 } & \text { U123 } & \text { U133 } & \text { U134 } & \text { U219 } & \text { U328 } & \text { U359 }\end{array}$

Envirocare is allowed to treat by evaporation, store in tanks and containers, and dispose in landfill cells, specified hazardous waste(s) in accordance with the conditions of the permit. [Hazardous wastes included as specified hazardous wastes are those hazardous wastes listed in the State RCRA Envirocare Permit and the following hazardous waste codes: D018 through D043 and F039.] Envirocare is also permitted to manage radioactive/hazardous waste according to all applicable rules and permit conditions for hazardous wastes as described in both the HSWA and RCRA permits from the EPA and from the State of Utah, as long as the waste also meets the rules, criteria and regulations for radioactive waste described in licenses [as amended] from the State of Utah and the NRC.

The Envirocare HSWA Part B Permit was reviewed in detail. The purpose of the review was to identify the operating requirements for the facility and compare the actual operations with the permit conditions. The details of this review can be found in Section 6.7.2. of this document.

4.4.3.2. TSCA Storage/Disposal Permit. Envirocare has not been required to obtain TSCA storage/disposal permit because it does not accept PCBs at the facility. Therefore, this section is not applicable. 
4.4.3.3. Conditional Use Permit. Envirocare received a Conditional Use Permit (\#2700-87) from Tooele County in 1987. The permit was issued for the low level waste repository. In order to locate and operate a hazardous industry within the WDHIA, the impact mitigation agreement which was originally negotiated with the DOE for the Vitro Chemical Site remedial actions, i.e., Vitro Tailings, was imposed upon the Clive facility in the conditional use permit. The Envirocare facility completely surrounds the Vitro Tailings disposal cell. This agreement between S. K. Hart, d.b.a. Envirocare of Utah, and Tooele County was designed to ensure that there are adequate emergency response capabilities within Tooele County. The permit did not discuss specifically NORM wastes or mixed wastes.

4.4.3.4. BLM Right-of-Way Grant. Envirocare states in its RCRA Part B Permit Application that it has a BLM Right-of-Way Grant, which is also known as the Temporary Use Permit. The facility was unable to locate a copy for the INEL Assessment Team to review during the assessment period. A copy was located in January 1994 and sent to the INEL Assessment Team as part of the written comments.

Envirocare obtained a Right-of-Way Grant/Temporary Use Permit from the BLM to construct, operate, maintain, and terminate a water pipe line, access road, and well area use on public lands described as follows:

6.50 acres on the following described lands:

Township 1 South, Range 11 West, Salt Lake Principal Meridian Section 17: S/2 NH/4, NE/4 SW/4, SW/4 NE/4, NW/4 SE/4

Section 18: $\mathrm{S} / 2 \mathrm{NE} / 4, \mathrm{~N} / 2 \mathrm{SE} / 4$
1. Pipe line right-of-way
$5,280^{\prime} \times 10^{\prime}$
2. Road access
3. Well area
$4,000^{\prime} \times 10^{\prime}$
$100^{\prime} \times 100^{\prime}$

The permit is in effect until october 1, 2000, a 10 year term, unless relinquished, abandoned, terminated, or modified pursuant to the terms and conditions of the instrument or any applicable Federal law or regulation.

4.4.3.5. Air Permit. Envirocare has an air quality approval order for the low level radioactive materials disposal site which was granted by the 
State of Utah, Department of Health, Division of Environmental Health, Bureau of Air Quality (UBAQ), now known as the Division of Air Quality. The approval, dated December 21, 1990, authorizes Envirocare to construct the low level radioactive material disposal site in Tooele County, Utah.

The approval is based upon information Envirocare submitted in a notice of intent, dated August 25, 1987, additional information dated October 5, 1987, February 13, 1987, and a meeting held on November 2, 1990. The UBAQ granted approvals; dated January 28, 1988, March 16, 1989, and November 30, 1990; to Envirocare based on the supplied information. The U.S. EPA indicated that there was also a permit issued December 1990 which replaced of the prior permits. All of these approvals were voided by the present approval. The contents and conditions of the permit are reviewed in Section 6.7.21. of this report.

4.4.3.6. Groundwater Monitoring Permit. Envirocare received a ground water quality discharge permit from the State of Utah, Division of Water Quality, Utah Water Quality Board (Permit No.: UGW450005) on March 19, 1992. This permit modification is in effect from March 20, 1992 until midnight March 20, 1997. The permit was granted for ground water discharge for the Low Activity Radioactive Waste (LARW) Disposal Facility. LARW is also called LLW. The facility, as described by the permit, consists of three separate operable units: an existing LARW cell and two future LARW disposal cells, which are located at approximately Latitude $40^{\circ} 41^{\prime} 18^{\prime \prime}$ North, Longitude $113^{\circ} 06^{\prime} 54^{\prime \prime}$ West.

Detailed review of the permit conditions and associated plans are located in Section 6.7.14. of this report.

4.4.3.7. Hastewater Permit. Envirocare has not been required to obtain an Wastewaster Permit from any regulatory agency. Therefore, this section is not applicable.

4.4.3.8. CERCLA off-Site Policy Approval. The CERCLA Off-Site Policy was discussed with Envirocare representatives. The company was unable to produce documentation substantiating approval to accept CERCLA wastes under the Off-Site Policy. However, the Clive facility has received and disposed of 
CERCLA remediation wastes. This was supported by the U.S. EPA, Region VIII, Off-Site Policy Coordinator, who stated that the facility was, as of May 1993, approved to accept CERCLA wastes under the Off-Site Policy. Company representatives asked for, and received from EG\&G Idaho, copies of the Office of Solid Waste and Emergency Response (OSWER) directives and Federal Register notice describing the Off-Site Policy.

Subsequent to the initial site assessment, EPA promulgated the Off-Site Policy at 40 CFR $\S 300.440$. The Envirocare Environmental Manager indicated that he would review these new regulations in order to ensure that Envirocare would retain its approval.

4.4.3.9. Radioactive Materials License. The Utah Division of Environmental Quality, Division of Radiation Control has primacy with respect to the rules for the control of ionizing radiation in the State of Utah. Envirocare received its radioactive materials license from this agengy. The license in effect at the time of the assessment was UT 2300249 amendment 11 . This amendment was issued March 16, 1992 and the license is effective until February 28, 1996. Subsequent to the initial assessment Envirocare received Amendment 14 of the 7 icense. This amendment will remain in effect until February 28, 1996 unless modified, re-issued, or revoked. This amendment permits Envirocare to accept 13 additional radioisotopes. The contents and conditions of the current license are discussed in Section 6.7.18. of this report.

4.4.3.10. 11e.(2) Radioactive Materials License. Envirocare has submitted an application for an lle.(2) (By-product Materials) license to the NRC. The permit had not yet been granted at the time of the assessment. The NRC contact confirmed the State contact's understanding that this permit should be issued by approximately November 1993. The permit has been recommended in the Draft EIS and Final EIS, and is in the final stages of review. The license had not been granted as of the date of the November 1993 re-assessment.

Subsequent to the November 1993 re-assessment, the NRC issued the Byproduct Material License N. SMC-1559 to Envirocare. This license authorizes the 
company to receive, store, and dispose of $11 \mathrm{e}$. (2) byproduct material (as defined in section 1le.(2) of the Atomic Energy Act of 1954, as amended) at the Clive, UT site. The issuance was published in the Federal Register on November 29, 1993 (58 FR 62690). The INEL Assessment Team received a copy of the lle.(2) license in January 1994 as part of Envirocare's written comments regarding the content of this report. The contents and conditions of the license are discussed in Section 6.7.22. of this report.

4.4.3.11. Solid Waste Disposal Permit. According to the RCRA Part A Permit Application and Part B Permit Application, Envirocare holds a solid waste disposal permit from the Utah State Department of Health, Bureau of Solid and Hazardous Waste. Envirocare was unable to locate a copy of this report during the assessment period. Therefore, the permit was not reviewed as part of this assessment.

\subsubsection{Site Inspection}

The INEL Assessment Team conducted a site inspection of the Envirocare Facilities. The purpose of the inspection was to observe and compare the operations of the facilities with their documentation and permit conditions. The site inspection consisted of documentation reviews, process flows, and operational observations. Photographs were taken of various facilities and operations. Copies of relevant photographs are included in this report. All of the photographs are kept as part of the assessment record. 


\section{FACILITY SETTING}

The Envirocare facility is located in the Great Salt Lake Desert approximately 80 miles west of Salt Lake City, Utah in Tooele County (See Figure 1). The location is within a 100 square mile area set aside by the Tooele County Commission for hazardous waste activities (Figure 2). Envirocare owns 680 square acres of this area; of which approximately 400 square acres are utilized for active waste management by the Clive facility (Figure 3 ).

The following sections contain pathway analyses of potential groundwater, surface water, and air contamination, and a receptor analysis of potential populations and environments that could be at risk from activities conducted at the Envirocare facility. The purpose of a pathway analysis is to determine potential paths that pollutants could take which would significantly degrade the quality of a natural resource. The receptor analysis uses information from the pathway analysis and determines the potential risk to neighboring populations from a release of pollutants at the facility in question. The information in this section is derived from the Clive EIS, Vitro Tailings EIS, 11e.(2) DEIS, Climates of the United States, and Roadside Geology of Utah (See Section 10.5 for references). The Clive area has been well studied, in comparison to similar facilities because of the requirement for National Environmental Policy Act (NEPA) documentation (See the various EIS's for facilities and activities in the area) for any activities which might disturb the Federal lands.

\subsection{Pathway Analysis - Groundwater}

\subsubsection{Background}

The Envirocare Clive facility is located in the eastern portion of the semiarid Great Salt Lake Desert. This area is characteristic of the Basin and Range Physiographic Region, being a sediment filled basin, or graben, located between block faulted (horst) mountain ranges. 
The Envirocare facility is underlain by Recent, Quaternary, and Pleistocene sediments of the ancient Lake Bonneville bed. The sediments consist of a silty clay deposit which is estimated to be 500 feet thick and is underlain by an estimated 3,000 feet of valley fill. The shallow aquifer of the lake bed does not contain any potable water. The total dissolved solids contained in the groundwater range from $55,000 \mathrm{mg} / 1$ to more than $100,000 \mathrm{mg} / 1$. The soil underlying the site exhibits high sodium and chloride concentrations and has a natural permeability ranging from $1 \times 10^{-3} \mathrm{~cm} / \mathrm{sec}$. to $1 \times 10^{-8} \mathrm{~cm} / \mathrm{sec}$. The moderate permeability and a very low gradient result in a slow rate of westnorthwest movement of the groundwater. The seepage velocity averages less than 10 feet per year and ranges from a few inches per year to approximately 30 feet per year.

Two major groundwater systems occur in this area of the Great Salt Desert: valley fill and the alluvial fans bordering the desert. Recharge to the alluvial fans occurs in the mountains bordering the desert, for the $\mathrm{Cl}$ ive area this recharge would probably occur in the Cedar Mountains. The alluvial fans may recharge to valley fill. Direct infiltration of incident precipitation is not considered significant with respect to the total ground water regime in the Clive area.

As previousiy stated, the local groundwater recharge from meteoric sources in the area of the facility and the Great Salt Desert, in general, is limited. The recorded annual pan evaporation is more than 60 inches per year, which is considerably higher than the average annual rainfall which is five (5) inches per year. According to the 11e.(2) DEIS it is likely that recharge occurs largely in the areas adjoining the mountains because of the higher precipitation rates and more favorable lithologies. The subsurface flow probably moves towards the center of the basin. This interpretation is supported by the high salinity and isotopic composition of the area ground water, which are indicative of long flow paths and/or residence times.

"There is evidence that the site is located in a regional groundwater discharge setting, with largely upward flow and flow gradients. This is 


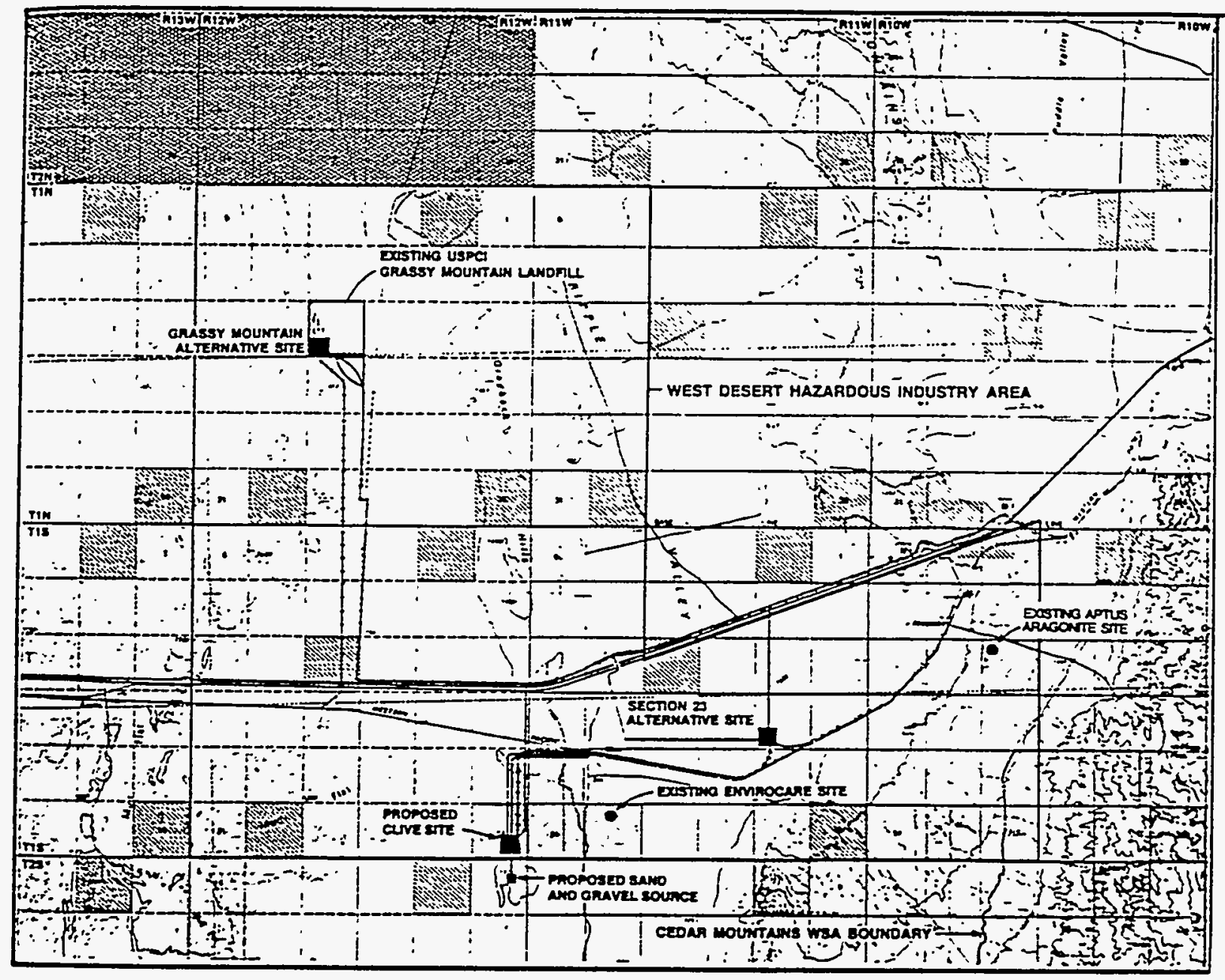

LEGENO

PRESENT LAND OWNERSHIP

\begin{tabular}{|c|c|}
\hline & PUELC LANDS (BLW) \\
\hline Haw & STATE LND \\
\hline & PAIVATE LAND \\
\hline POSE & D FACILTIES \\
\hline & $\begin{array}{l}\text { RAll SPUR } \\
\text { NEW ACCESS MOND } \\
\text { POWER LNE }\end{array}$ \\
\hline & 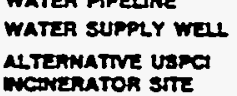 \\
\hline
\end{tabular}

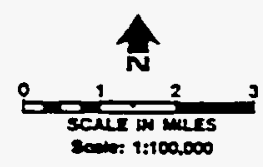

Figure 2. West Desert Hazardous Industry Area with associated facilities. 
EGG-ESQ-10749

January 1994

This Page Intentionally Left $\mathrm{Blank}$ 


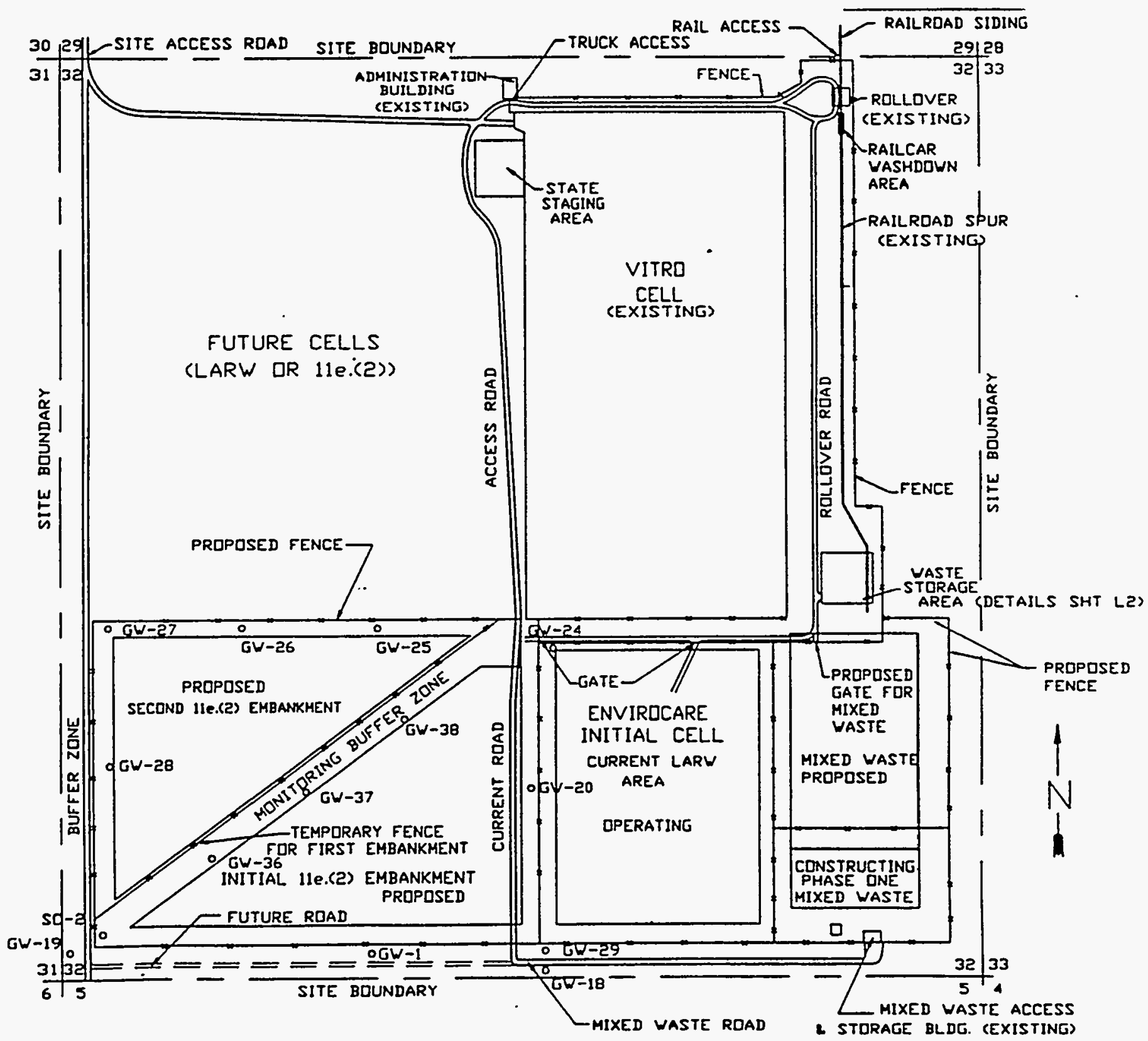

Figure 3. Envirocare facility site plan. 
EGG-ESQ-10749

January 1994

This page intentionally left blank. 
because: (1) water level and density measurements in several wells completed to different depth in the site area indicate a consistent increase of the potentiometric head with depth; (2) the salinity and isotopic composition of the subsurface water are indicative of long flow paths, long residence times, or both; and (3) the site is located in a regionaliy low physiographic and topographic setting, which is characteristic of regional ground-water flow discharge zones" (1le.(2) DEIS, p. 4.26).

\subsubsection{Facility Location and Analysis}

Groundwater quality data are fairly well documented for the Clive area. Previous investigations, including data collected for the Vitro Tailings remediation, Clive incinerator, and the APTUS incinerator, as well as, groundwater monitoring activities conducted by Envirocare at its facility, provide a fairly substantial database. Although some inconsistencies exist in the various data collections, the data conclusively indicate that the groundwater in the area of the Envirocare Clive facility is a poor quality and unsuitable for most uses. The State of Utah considers the groundwater a hazardous waste and requires that the groundwater samples be managed as such.

Groundwater at the Envirocare facility is routinely monitored by analyzing samples collected from both upgradient and downgradient wells. All monitoring wells have been approved by the regulatory agencies. The water quality analytical results are available for review at the facility. No contamination of the groundwater by activities at the facility has been identified.

Sodium and chloride are the most prevalent ions present in groundwater under the facility. The high levels of total dissolved solids and sodium and chloride concentrations in the groundwater are indicative of long flow paths, residence time, or both. According to the 11e.(2) DEIS the sodium and chloride concentration decrease with increasing depth, which provides additional evidence that there is minimal or no downward vertical movement from the unconfined to confined aquifers.

Envirocare conducted radionuclide analyses, including gross alpha, gross beta, Radium ${ }^{225}$, Radium ${ }^{228}$, Radon ${ }^{222}$, Lead ${ }^{220}$, Poionium ${ }^{210}$, Cesium ${ }^{137}$, Thorium ${ }^{230}$, and 
tatal Uranium on samples pulled from seven lle.(2) on site wells. According to the 11e. (2) DEIS plots of the concentrations of the selected radionuclides indicated that above normal concentrations for some radionuclides, e.g., Radium ${ }^{26}$ and total Uranium in Monitoring Well GW-3. The above norma? concentrations could not be confirmed in repeat analyses.

Envirocare analyzed stable/non-stable ratios for selected isotopes in order to characterize groundwater recharge sources, geochemistry, and flow. "The following isotopes were analyzed: Hydrogen $\left(\mathrm{H}^{1} / \mathrm{H}^{2}\right)$, Oxygen $\left(0^{18} / 0^{16}\right)$, Carbon $\left(\mathrm{C}^{13} / \mathrm{C}^{12}\right)$, and Sulfur $\left(\mathrm{S}^{34} / \mathrm{S}^{32}\right)$. Tritium $\left(\mathrm{H}^{3}\right)$ and Carbon $14\left(\mathrm{C}^{14}\right)$ were al so determined for selected wells to evaluate the age of the water. The results show that there are low Tritium concentrations (1.8 - $4.9 \mathrm{TU})$ in the ground water, which suggests a pre-1953 recharge and subsequently long subsurface flow paths, long residence time, or both. Radiocarbon dating of the water was inconclusive.

The ground-water quality index by Envirocare also involved determining the saturation index (SI) for selected minerals, which is a measure of the water's tendency to precipitate (positive SI) or dissolve (negative SI) a mineral. Envirocare concluded that ground water in the site area has a tendency to precipitate such minerals as aragonite, calcite, dolomite, fluorite, and magnesite, and a tendency to dissolve such minerals as halite, gypsum, anhydrite, and Mirabilite, but that the dissolution/precipitation tendencies of some minerals are complex. The dissolution and precipitation of minerals in the ground water in the site area is controlled generally by complex mineralogical and geochemical factors that cannot be thoroughly analyzed from the available data" (11e.(2) DEIS, p. 4.32).

\subsection{Pathway Analysis - Surface Water}

\subsubsection{Background}

The arid to semi-arid climate that prevails profoundly affects the surface water regime. No surface water bodies are present at $\mathrm{Clive.} \mathrm{The} \mathrm{nearest}$ stream channel ends about two miles east of the Envirocare site. Stream flows from higher elevations usually evaporate and infiltrate into the ground before 
reaching lower, flatter 1 and. The stream channels are well defined in their upper reaches, such as through the Cedar Mountains, but as they approach the bas in the size of the channels decreases until there is no discernible evidence of the channel being present in the basin.

Precipitation patterns are such that spring is the wettest time of the year. This slight maximum is due to the fact that Pacific storms are strong enough to get past the Cascade and Sierra Nevada mountain ranges at this time of year. Precipitation at other times of the year is due to moisture from the Gulfs of California and Mexico. The annual average precipitation amounts range from about five inches (5") at Wendover, NV and seven inches (7") at Dugway, UT to 16 inches at Tooele, UT. The Tooele precipitation amount is due to the proximity and effect of the Great Salt Lake. The precipitation rate at USPCI's Grassy Mountain facility varies from zero to six inches (6") per year. In addition, the Clive facility is located in an area with a net solar evaporation of approximately 42 inches per year. The normal lake evaporation rate is 48 inches per year. Relative humidity averages nine percent (9\%).

\subsubsection{Facility Location and Analysis}

The Envirocare site lies to the west of the Cedar Mountains in a relatively flat basin. The streams within the Cedar Mountain watershed do not normally reach the site. The channels end about two miles east of the site which indicates that the flow normally infiltrate the ground water regime or evaporate before reaching the basin. There is no outlet for the water shed and any water that flows by the Envirocare facility would pond in a playa located several miles to the west.

No historical data on floods are available for the Envirocare site. No floods have been recorded at the site since its inception.

There are no other streams or rivers within 40 miles of the Envirocare facility. The nearest naturally occurring body of water is the Great Salt Lake, the western shore 1 ine of which is 30 miles to the east of the facility. An evaporative ponding system has been constructed about nine (9) miles to the north west of the facility. These ponds were constructed by the Magnesium 
Corporation of America (Magcorp) to concentrate brines pumped from the Great Salt Lake as part of their solar mining of magnesium chloride.

The Envirocare facility is also affected by the West Desert Pumping Project. The project involved pumping water from the Great Salt Lake into ponds in the Great Salt Lake Desert to control the elevation of the lake. Although the project has been completed, the ponds still exist. The ponds could increase surface moisture in the area by increasing precipitation and decreasing evaporation. No studies have been conducted.to determine climatic changes due to the project. Quantifying the magnitudes of these changes with available data and methods of analysis is not possible because moisture fluctuations are highly variable from year to hear. However, because of the shallowness of the ponds, the effect on precipitation levels is not expected to be great. The most likely areas to receive increased precipitation are areas such as the west side of the Grassy Mountains or Cedar Mountains. The ponds could decrease evaporation by increasing fog, cloud cover, and humidity (Clive EIS, p. 3-8).

According to the 11e.(2) DEIS there are two possible ways for temporary surface waters to be contaminated by operations at the Envirocare site: 1) rain water could come into contact with the waste material, and 2) water accumulating during decontamination of vehicles and equipment. Envirocare has obtained a Ground Water Discharge Permit from the State of Utah, which requires the company to put in place significant controls to limit the contamination of any surface waters. All precipitation that comes into contact with waste materials must be controlled and either placed in the evaporative tanks or used for engineering purposes during embankment construction, i.e., waste disposal activities.

Decontamination water, which is obtained from a well located northwest of the facility and owned by Envirocare, is collected, after use, on a concrete pads and in sumps. The water is then pumped into a tanks which are pumped into the evaporation tanks for treatment. 


\subsection{Pathway Analysis - Air}

\subsubsection{Background}

The existing climate at the site is arid and characterized by large annual and diurnal variations in temperature and limited precipitation. The Clive Incinerator EIS contains tables of representative temperature and precipitation data from locations surrounding the site, as well as from the USPCI Grassy Mountain facility, which is located about nine miles north northwest of the Envirocare facility. These data indicate that the temperatures ranged from an average low of $19^{\circ}$ to $27^{\circ} \mathrm{F}$ in January to an average high of $75^{\circ}$ to $80^{\circ} \mathrm{F}$ in July. The data from the Grassy Mountain facility were limited to one year (July 1988 through June 1989). Temperature extremes for this area can range from $-22^{\circ}$ to $105^{\circ} \mathrm{F}$.

The Clive Incinerator EIS states that the prevailing wind flow is parallel to the major terrain feature, such as the Grassy Mountains. The local topography suggests that the expected winds would be along a north-south trajectory. This wind direction is reflected in data from the Newfoundland site which is located about 10 miles to the north-northwest of the Grassy Mountain facility. The Newfoundland site is part of the Great Salt Lake Pumping Project and is operated by the Utah State Climatology Office. Data from this site shows that the most predominant winds are from the south through southwest and north through northeast. There is also a secondary maximum associated with strong northwest winds that accompany the passage of winter storm systems. The USPCI audit information report states that prevailing winds are generally from the northwest (Figures $4 a$ and $4 b$ ).

\subsubsection{Facility Location and Analysis}

The 11e. (2) DEIS examined the potential of degraded air quality as a result of Envirocare's activities and determined the effects to be minimal. The major source of potential air pollutants is dust from the activities. Envirocare obtained an air permit from the State of Utah which requires that the company take measures to mitigate the potential for pollution. Envirocare employs dust suppression techniques to reduce windblown particulates. The 
construction equipment and railroad switching engines are equipped with exhaust emission controls. Because the facility disposes of radioactive wastes, the release of radionuclides is of concern. Release of radionuclides under normal conditions during operations at the facility are usually limited to the following mechanisms:

- exhalation of radon gas from embankment areas that have not been covered with the compacted clay barrier, and

- windblown materials from the disposal cells and unloading areas.

Envirocare had the release mechanisms modeled to estimate the maximum exposure dose at the property boundary, and to the surrounding population. This evaluation is described in the 1le.(2) DEIS. The general consensus is that due to the isolated location, low human and animal populations, and desert environment, the impact is minimal.

\subsection{Receptor Analysis - Populations and Environments at Risk}

\subsubsection{Background}

The Envirocare facility is situated in the Desert Alkali range site, which th: $B L M$ rates as being poor for grazing or forage production. However, the vegetation provides an important ground cover and deterrent to soil erosion, and habitat for wildlife species. Animal species identified in the area include black-tailed jackrabbits, deer mice, grasshopper mice, horned lark, and desert horned lizard. Aquatic ecosystems do not occur on or near the Clive area.

The vegetation of the Clive area is a homogeneous, semi-desert low shrubland, composed primarily of shadscale. The shrubland is part of the Northern Desert Shrub Biome of the Cold Desert Formation, and has been described as a saltbush-greasewood shrub complex. Vegetation patterns in this area are correlated with soil salinity and corresponding shifts in the presence or abundance of species. 

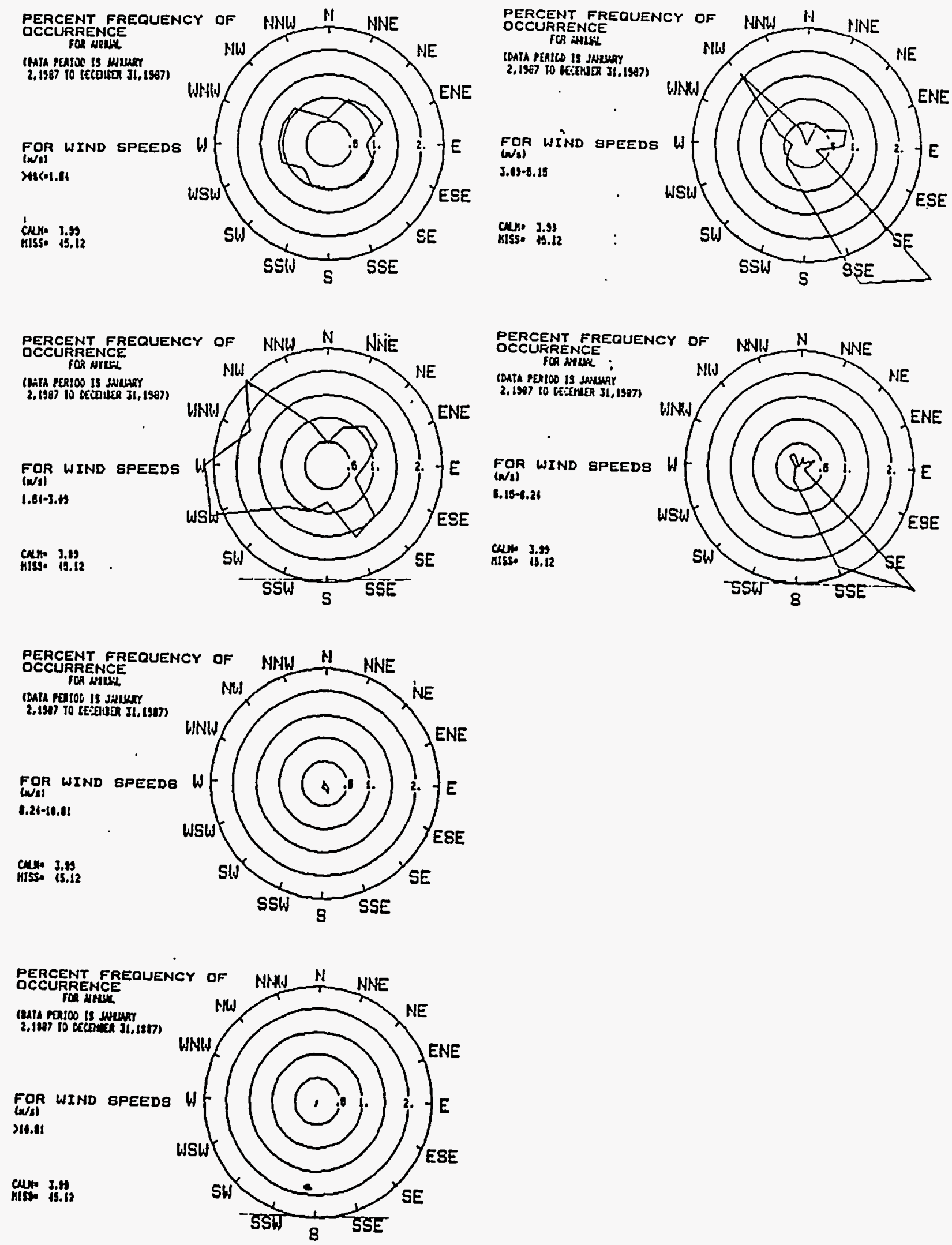

Figure 4a. Envirocare Clive, UT annual wind roses 


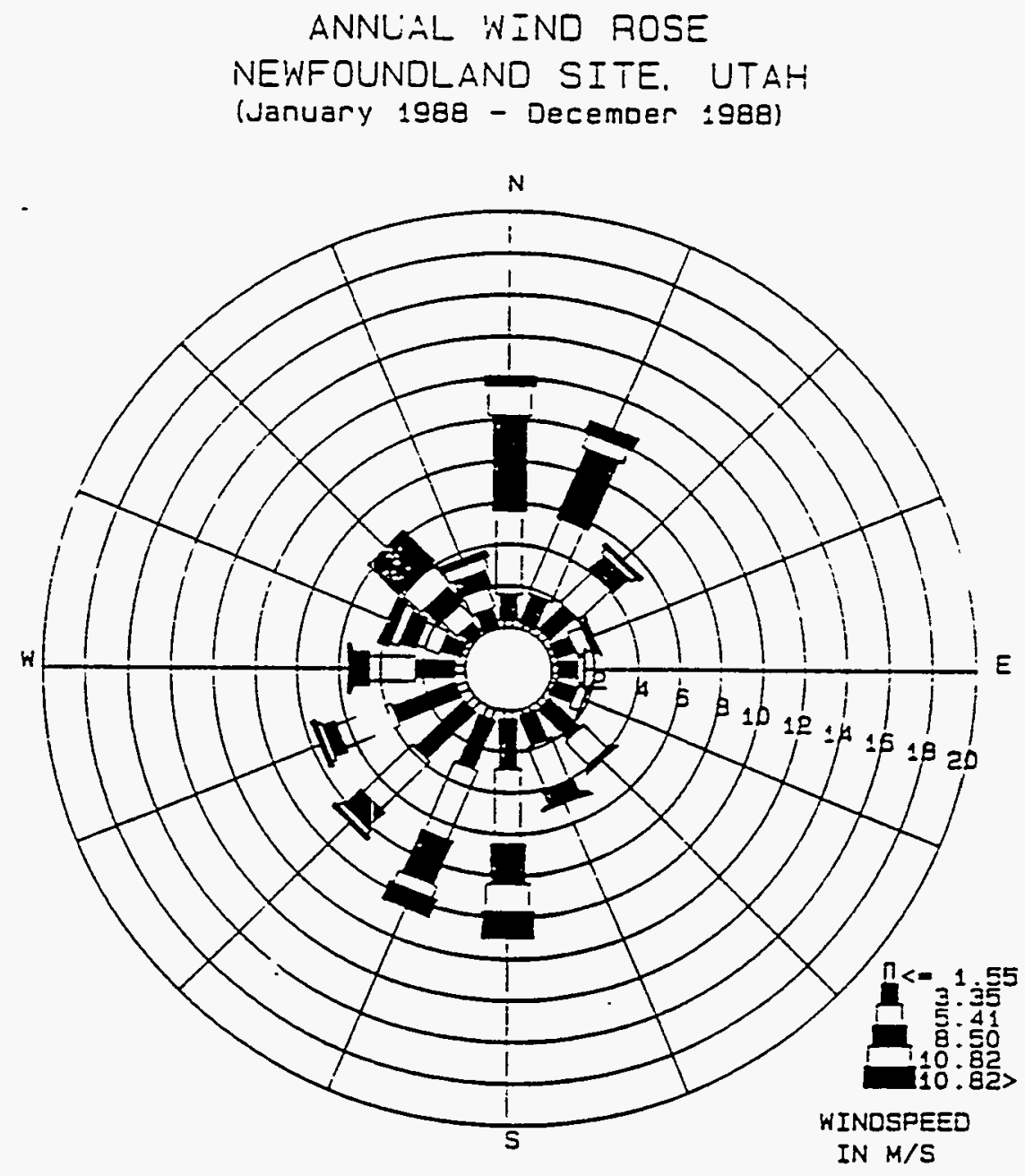

Figure 4b. Newfoundland Site, UT annual wind rose 


\subsubsection{Facility Location and Analysis}

No threatened or endangered plant species or known important habitats are known to occur in the Clive area. No threatened or endangered animal species are known to occur in the Clive area as well. However, the area is used by Bald Eagles for winter foraging.

The Vitro Tailings EIS states that the Clive area has been used for grazing since the early settlers. No events of historical significance are known to have occurred on the site. No sites of archaeologic, historic, or cultural significance are known to exist at the site. The Donner Trail probabiy passed north of the site, but the trail's exact location is unknown.

The historical sites closest to the Envirocare facility are the Ground to Air Pilotless Aircraft Launch Site and Blockhouse, which is listed in the National Register of Historic Places. This site is located approximately 10 miles west of the Envirocare facility at Knolls, UT. The other historical site is the Iosepa Settlement Cemetery, located approximately 23 air miles southeast of the facility. Neither would be affected by activities at the Envirocare facility.

The nearest residential neighbor is located approximately 40 miles west of the Envirocare facility in Wendover, UT. The land within a 30 -mile radius of the site is used as a bombing range by the U. S. Air Force and for desert warfare training by the U. S. Army. Ninety-five percent (95\%) of the land in this surrounding 30 miles is owned by the Bureau of Land Management. Magnesium Corporation of America, formerly AMAX, (Magcorp) owns an evaporation pond located approximately seven (7) miles north-northwest of the facility. The APTUS incinerator is located at Aragonite, UT about seven (7) miles northeast of the Envirocare facility. The Union Pacific Clive railroad siding is located about one and a quarter $(1-1 / 4)$ miles north of the facility. The USPCI Clive incinerator facility is located about one (1) mile west of the Envirocare facility. 
EGG-ESQ- 10749

January 1994

This Page Intentionally Left $B 1$ ank. 


\section{TECHNICAL DATA AND ANALYSIS}

This section describes the facilities inspected and documents reviewed in detail. The facility processes and documents were evaluated against regulatory requirements and RCRA Part $B$ permit conditions. For this inspection the Federal regulations, particularly 40 CFR $\S \S 262,264$ and 265, were used in lieu of the State of Utah Solid and Hazardous Waste regulations. The State of Utah regulations are very nearly the same as the Federal regulations, except that the State is more stringent with respect to manifests and manifest discrepancy reporting, American Petroleum Institute (API) separator process vents, and $F 999$ and P9g9 hazardous wastes, i.e., demilitarized wastes such as nerve gas. The State regulators stated that using the Federal regulations was a valid comparison.

\subsection{SITE DEscription}

\subsubsection{General Operations}

As previously stated, the on site portion of the assessment was conducted in early March and November 1993. Operations at the Envirocare facility had been curtailed in March due to excessive rainfall and snowfall having been received during the winter season. Routine maintenance of the NORM and LLW cells was ongoing. No activity was present at the MW disposal cell because of the snow cover. Shipments of NORM and LLW were being staged on asphalt pads awaiting better disposal conditions (Figures 5 and 6 ). MW shipments were being stored and managed in the MW storage building or on the adjacent asphait pad.

The majority of the following sections will discuss the processes used by Envirocare for waste storage and management. INEL observations/impressions will, by necessity, focus on the management procedures and documentation in place for the operations. The INEL Assessment Team discussed the operations with the facility representatives and management. It was mutually agreed, in March, that the INEL Assessment Team should revisit the site once waste disposal activities are restarted in order to obtain an accurate picture of the actual operations at the Envirocare facility. 
The INEL Assessment Team subsequently revisited the site in November 1993 in order to observe acceptance and disposal operations. Comments regarding changes to the operations have been incorporated into this section. The technical data should reflect tivo sets of observations and impressions which the INEL Assessment Team believes presents a more accurate representation of the company and site operations.

\subsubsection{Treatment Facilities}

Treatment, as defined by RCRA means any method, technique, or process, including neutralization, designed to change the physical, chemical, or biological character or composition of any hazardous waste so as to neutralize such waste, or so as to recover energy or material resources from the waste, or so as to render such waste non-hazardous, or less hazardous; safer to transport, store, or dispose of; or amenable for recovery, amenable for storage, or reduced in volume (40 CFR $\S 260.10)$.

Although the Envirocare facility does not conduct waste treatment other than evaporation, at present, the DSHW indicated that Envirocare has a pending RCRA Permit modification before the agency which seeks permission to build a treatment facility and to conduct a variety of treatments on wastes to meet the Land Disposal Restrictions (LDRs). The permit modification was subsequentiy approved and construction of the treatment facility was scheduled to begin in 1994 .

6.1.2.1. Stabilization. Envirocare does not operate, at this time, any stabilization facilities at the $\mathrm{Cl}$ ive facility. The company has submitted a modification to its RCRA Part B Permit Application which describes the construction and operations of a stabilization facility. The purpose of the stabilization facility is to allow the company to treat selected mixed waste streams in order to meet the LDR before the wastes are landfilled. The company had received approval from the State for the modification, however, siting and construction of the facility had not begun at the time of the November 1993 inspection. Therefore, process descriptions and INEL observations and impressions are not applicable at this time. 
EGG-ESQ-10749

January 1994

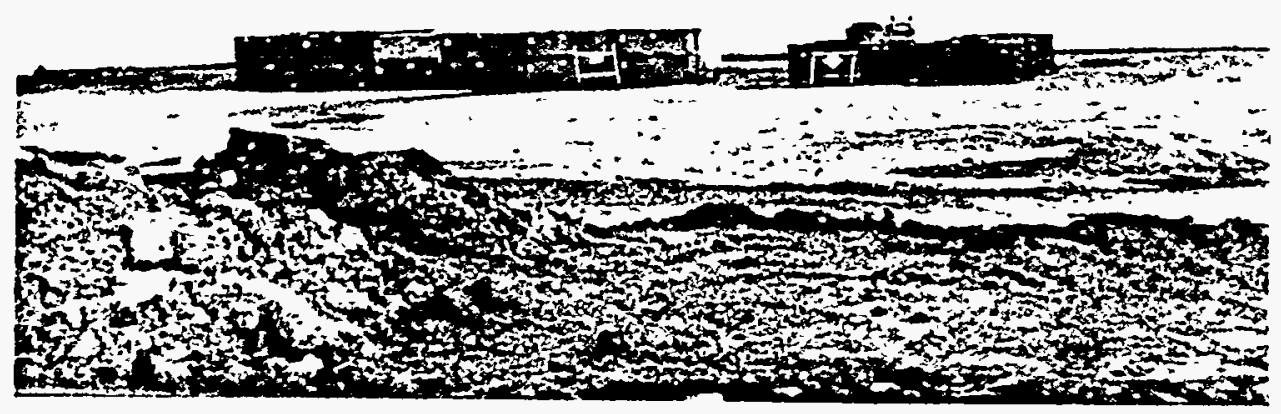

Figure 5. NORM wastes being stored on an asphalt pad.

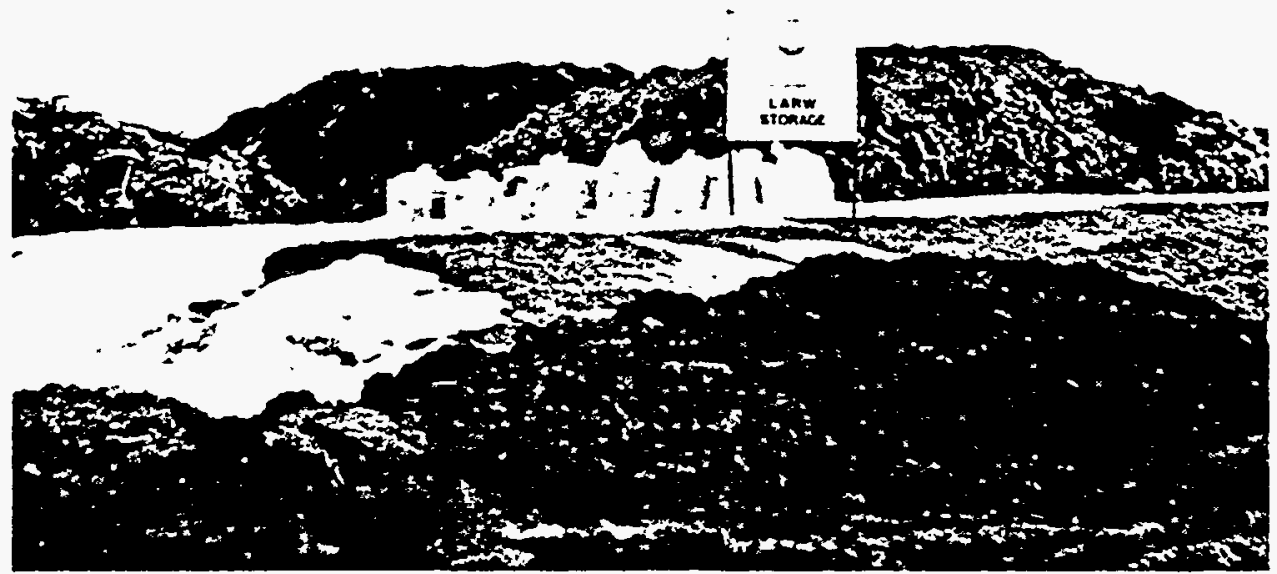

Figure 6. LLW being stored on an asphalt pad. Wastes are segregated by generator. 
$=$ 
6.1.2.2. Neutralization System. Envirocare does not operate any neutralization facilities at the Clive facility. Therefore, this section is not applicable.

6.1.2.3. Land Treatment Units. 40 CFR $\S \S 264$, Subpart $M$ and 265, Subpart $M$ state that an owner or operator who wishes to treat or dispose of hazardous waste in a land treatment unit must establish a land treatment program that is designed to ensure that the hazardous constituents placed in or on the treatment zone are degraded, transformed, or immobilized within the treatment zone.

Envirocare does not operate any land treatment units at the Clive, Utah facility. Therefore, this section is not applicable.

\subsubsection{Evaporation.}

6.1.2.4.1. Process Description -- Two Tiquid storage/evaporation tanks are used by Envirocare to store and/or treat wastes and residues from leachate collection in the landfill cell. The tanks also receive wastewater from the truck and rail car wash down operations, from mixed waste wash bay located within the container storage building, and from liquid wastes generated in the site laboratory. The treatment process used in the tanks is evaporation.

\subsection{INEL Assessment Team Observations/Impressions -- The} evaporation tanks were observed during the inspection of the MW storage facility. The evaporation process was not observable. The contents of the tanks were not observable from ground level. The discussion of the tanks, and associated secondary containment, are presented in Section 6.1.3.1.2. of this report.

\subsubsection{Storage Facilities}

6.1.3.1. Tanks. Requirements for the construction, use, and maintenance of tanks and tank systems used for the storage and treatment of hazardous wastes are specified in 40 CFR $\S \S 264$, Subpart $J$ and 265 , Subpart J. Specific 
requirements for operation of hazardous waste tank storage are delineated in the RCRA Part B Permit Application, Section D, HSWA Part B Permit, Module IV, and RCRA Part B Permit, Module IV.

6.1.3.1.1. Process Description -- Two RCRA permitted 20,000 gallon liquid storage/evaporation tanks are used by Envirocare to store and/or treat wastes and residues from leachate collection in the landfill cell (Figure 7). The facility is permitted to store and/or treat a total volume of 30,000 gallons of hazardous wastes at any time in these two tanks. The tanks are constructed of carbon steel. The interiors are coated with a polyurethane protective coating and the exteriors are painted to protect them from corrosion. The tanks are also open to the atmosphere. The facility may use air sparging to aid evaporation. The tanks are contained in an epoxy coated concrete vault which has a minimum capacity of more than 20,000 gallons.

The facility must maintain at least two (2) feet of freeboard in each tank during normal operations. Each tank is equipped with a level indicator which activates a visual alarm (flashing red light) when the level of the liquid is within three (3) feet of the top of the tank (Figure 8). An audio alarm sounds if the indicator detects liquid within 2.25 feet of the top of the tank.

The facility is required to empty accumulated sludge from the tanks when the sludge reaches a depth of eight ( 8 ) inches. The facility must measure the height of the sludge on a monthly basis and retain this measurement in the operating record. The sludge, assumed to be mixed waste, must be stabilized and pass the paint filter liquids test before it can be placed in the mixed waste landfill. (See Section 6.2. of this report for discussion of the sludge.)

Wastes stored and/or treated in the evaporation tanks, in addition to leachate, include precipitation, waste water from tanks in the vehicle and rail car decontamination areas. The rail car and vehicle decontamination storage tanks are considered $<90$ day storage areas and are discussed in Section 6.3. of this report. Laboratory wastes, managed as hazardous waste from a satellite accumulation area, are also sent to the evaporation tanks. 
- sत्रuef

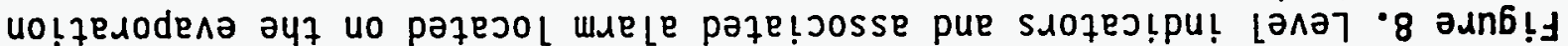

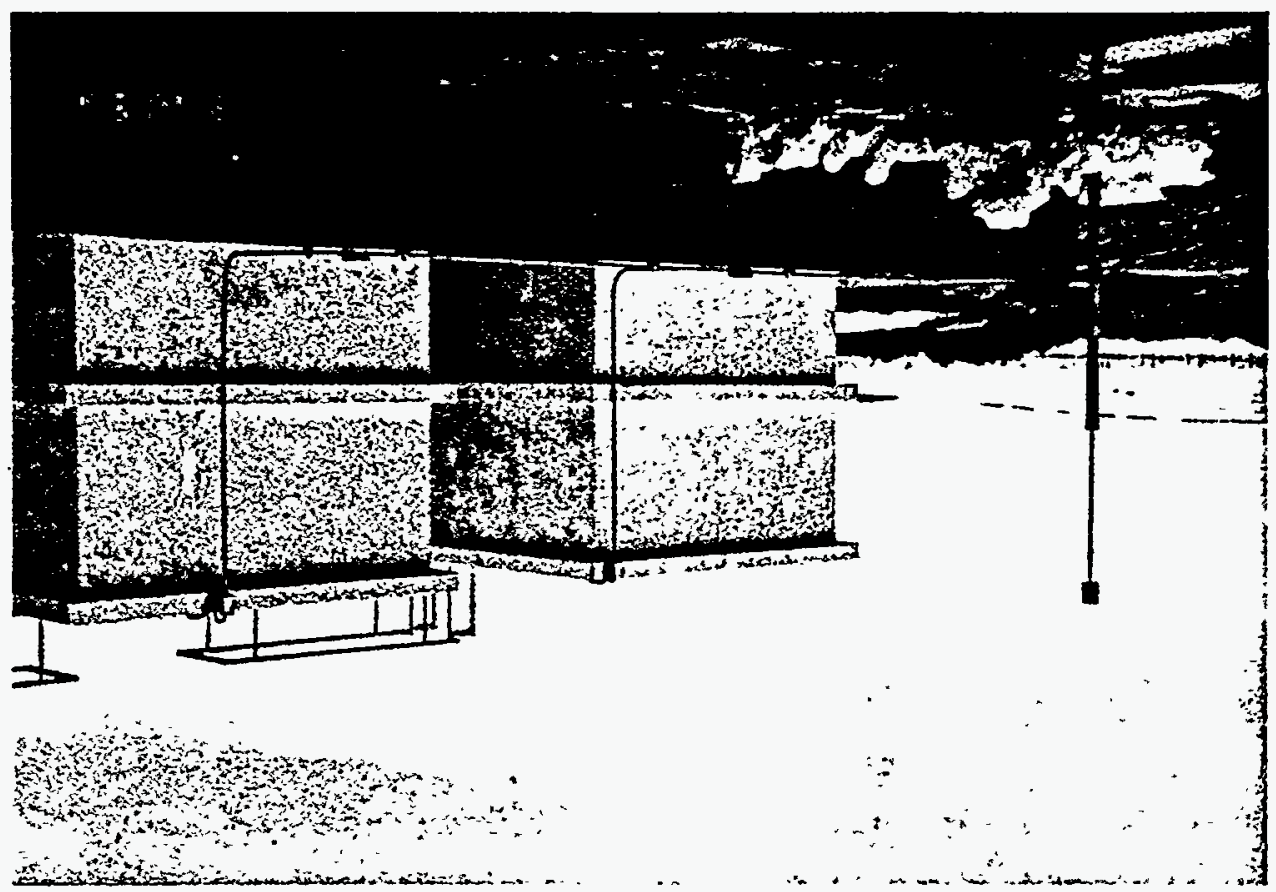

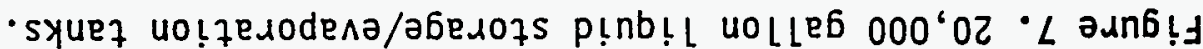

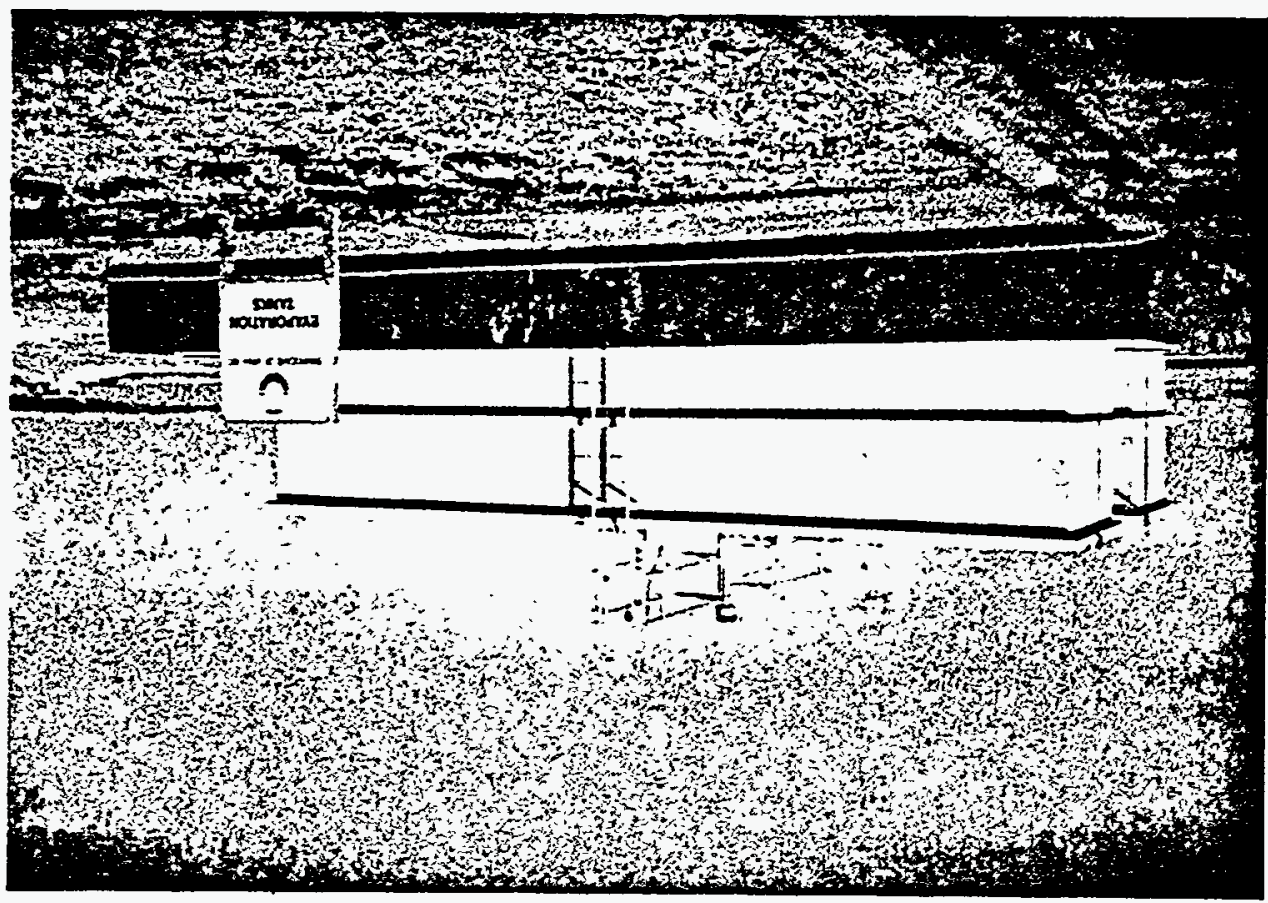


6.1.3.1.2. INEL Assessment Team Observations/Impressions -- The two evaporation tanks were observed during the March 1993 onsite inspection of the mixed waste storage facility. A detailed inspection of the tanks and associated secondary containment was not possible due to the amount of snow present at the time. The tanks and associated vault appeared to be well maintained and in good condition. The inspection records were reviewed and appeared to be accurate. Therefore, the two permitted evaporation tanks appeared to meet all of the requirements of the RCRA Part B permit. The permit allowed leachate and sludge from leachate collection to be stored in containers in the permitted container storage area.

The evaporation tanks were inspected again in November 1993. The secondary containment was good. The floor sloped to a blind sump which was designed to collect any overflow. No cracks were evident in the walls or floors. One outside corner of the containment appeared to have been struck by a water truck or other heavy equipment and a piece of concrete was broken off. The INEL Assessment Team suggested to the facility representatives that they might consider placing concrete pillars or some other barrier around the corners of the containment to protect it from damage.

The tanks, themselves sat on six inch platforms, with a layer of geonet separating the two, above the floor of the containment (Figure 9). The purpose of the geonet was to provide a means to determine if the tanks were leaking and to provide circulation between the tanks and the platforms.

The evaporation tanks were not identified with hazardous waste labels. Although not strictly required by the regulations for permitted tanks, a suggestion was made to the facility representatives that labeling the tanks would be a good management procedure from a hazard communication point of view. It was suggested that the facility stencil the words "hazardous waste" on all sides so that, in case of a catastrophic site emergency, the words could be read from a distance. In addition, it was suggested that hazard communication labels be placed on the tanks which would identify the potential hazards associated with the contents. Both of these suggested related to prevention and mitigation of hazards under the RCRA, SARA, and OSHA regulations. 
The INEL Assessment Team did not perform detailed physical inspections of the $<90$ day storage tanks. The required weekly inspections on the tanks in the $<90$ day areas were being done but were not documented in the Inspection Log. A recommendation was made during the March 1993 inspection for Envirocare to revisit the regulations in 40 CFR $\S \S 262.34$ and 265 , Subpart $J$ to ensure compliance with those requirements.

The November 1993 re-assessment showed that the inspections were now being documented in the Inspection Log.

6.1.3.2. Containers. The use and management of containers is reguiated by 40 §§ CFR 264, Subpart I and 265, Subpart I. Specific requirements for operation of hazardous waste container storage areas are delineated in the RCRA Part B Permit Application, Section D, HSWA Part B Permit, Module I, and RCRA Part B Permit, Module III. This section will describe the use and management of containers as part of the treatment, storage, and disposal of hazardous wastes received in containers at the Envirocare facility. Use and management of containers of hazardous waste generated by the Envirocare facility operations, such as less than 90 day accumulation areas, is discussed in Section 6.3 of this document.

6.1.3.2.1. Process Description -- Envirocare's Part B permit allows the following types of containers:

1) Containers up to 110 gallons,

2) Boxes up to 100 cubic feet,

3) Polyethylene Bags up to 120 cubic feet,

4) Dump trucks up to ten cubic yards,

5) Seavans up to 20 cubic yards, and

6) Railroad Gondola cars up to sixty cubic yards.

The Container Management Plan described two general categories of waste management. The two categories were bulk waste (gondola cars) and containerized waste. Bulk materials are either taken to the landfill cell to be emptied and emplaced or will be containerized and stored for later placement in the randfill cell. 


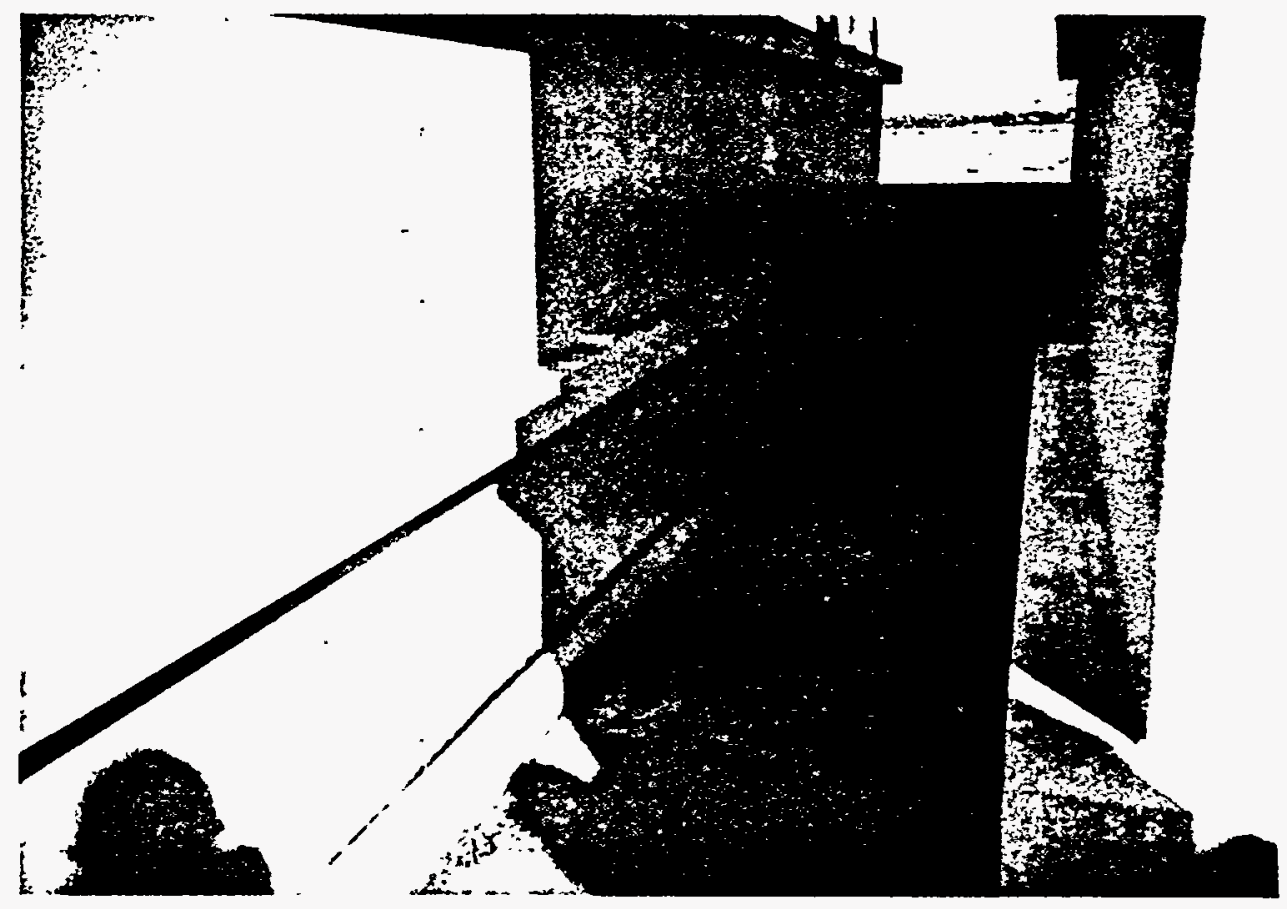

Figure 9. Geonet layer (black webbing) separating the evaporation tanks from the secondary containment. 
. 
A rail spur, including several sidings, allow the storage of 250 rail cars on Envirocare property at any given time. However, Table III-l of the RCRA Part B Permit limits the number of rail car gondolas on site to a maximum of 165 . An unloading ramp is used for the unloading of bulk material by means of a backhoe (Figure 10). While on the siding, the rail cars are inspected, sampled, analyzed, and either accepted or rejected according the Waste Analysis Pran.

Envirocare accepts mixed wastes as solids only.

6.1.3.2.2. INEL Assessment Team Observations/Impressions -- The container storage area consisted of a building and storage pad with capacity of approximately 100,000 cubic yards (Figure 11). The containers were all properly labeled and required inspections were being performed. The aisle space met the requirements of the Part $B$ permit for access to all containers with emergency equipment (Figures 12 and 13). All containers observed were kept closed as required by the Part $B$ permit.

There were no changes to the condition of the container storage building and pad observed during the follow up inspection, except that the volume of waste was significantly reduced. The facility representatives stated that the only wastes remaining in permitted storage were site generated sludges which were awaiting stabilization before landfilling.

The INEL Assessment Team noticed that a single container managed in the laboratory satellite accumulation area (SAA) was improperly labeled. A recommendation was made to Envirocare to revisit the requirements of 40 CFR $\S$ 262.34 to ensure compliance with those requirements.

The laboratory SAA's were inspected during the follow up inspection and were found to be properly labeled and managed. It is noteworthy that the container collecting outflow from the atomic absorption equipment was properly labeled with a hazardous waste label. 
6.1.3.3. Surface Impoundment. Requirements for the construction, use, and maintenance of surface impoundments used for the storage and treatment of hazardous wastes are specified in $40 \S \S$ CFR 264, Subpart K and 265, Subpart K.

Envirocare does not operate any RCRA regulated surface impoundments at the Clive facility. Therefore, this section is not applicable.

The facility does operate a run on control pond at the site. This pond is not regulated as a surface impoundment under 40 CFR $\S \S 264$, Subpart $K$ because it is not used for the treatment of hazardous wastes. The pond was $l$ ined with HDPE and contained a leachate collection system. A sprinkler system was installed in the pond to assist the evaporation process. The facility representatives indicated that they were having some difficulty preventing waterfowl from landing on the pond. The cannon apparently did not frighten the birds any more. It was suggested to them that commercial flags, such as those used a automotive dealers, might work. The INEL Assessment Team had observed them in use at several commercial hazardous waste TSDF which were operating surface impoundments. The flags apparently were successful at those facilities.

\subsubsection{Disposal Facilities}

6.1.4.1. RCRA Landfill Cells. Requirements for the construction, use, and maintenance of landfill cells used for the disposal of hazardous wastes are specified in 40 CFR $\S \S 264$, Subpart $N$ and 265 , Subpart $N$. Specific requirements for construction, maintenance, operation, and closure of a hazardous waste landfill are delineated in the RCRA Part B Permit Application, Section D, and the RCRA Part B Permit, Module V.

Requirements for the construction, use, and maintenance of landfill cells used for the disposal of radioactive wastes are specified in 10 CFR 61. Specific requirements for construction, maintenance, operation, and closure of a radioactive waste landfill are delineated in the Application for Radioactive Materials License, Section 4 and the HSWA Part B Permit, Module III, which references the specific requirements of the RCRA Part B Permit, Module V. 
EGG-ESQ-10749

January 1994

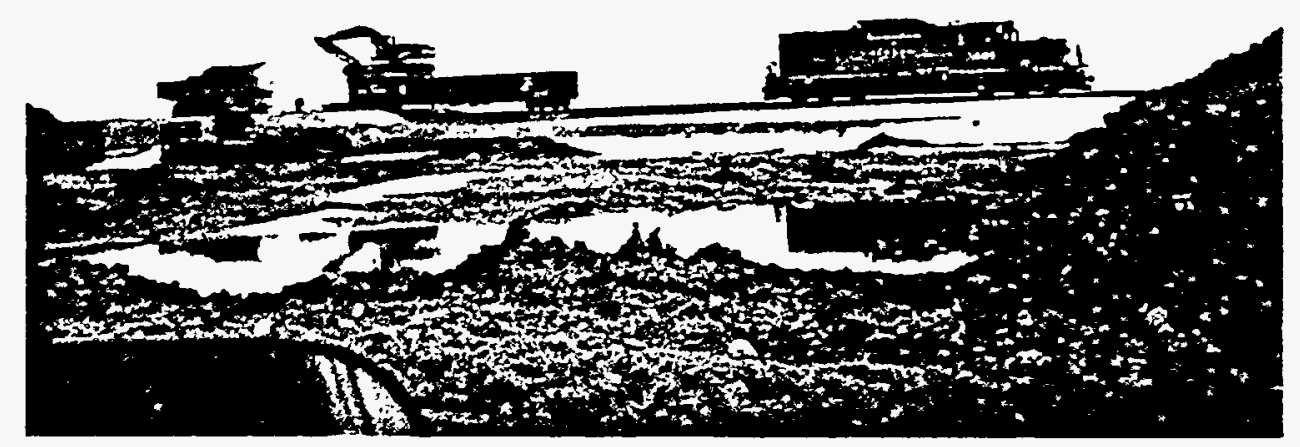

Figure 10. Unloading ramp and backhoe used to unload railroad gondola cars.

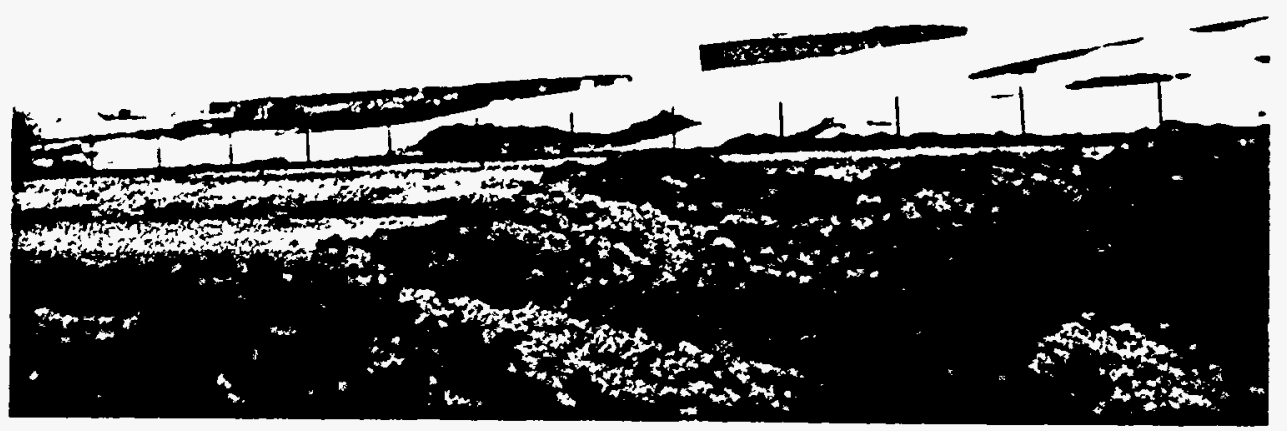

Figure 11. Mixed waste storage pad and facility as seen from the Vitro Tailings disposal area. 
, 


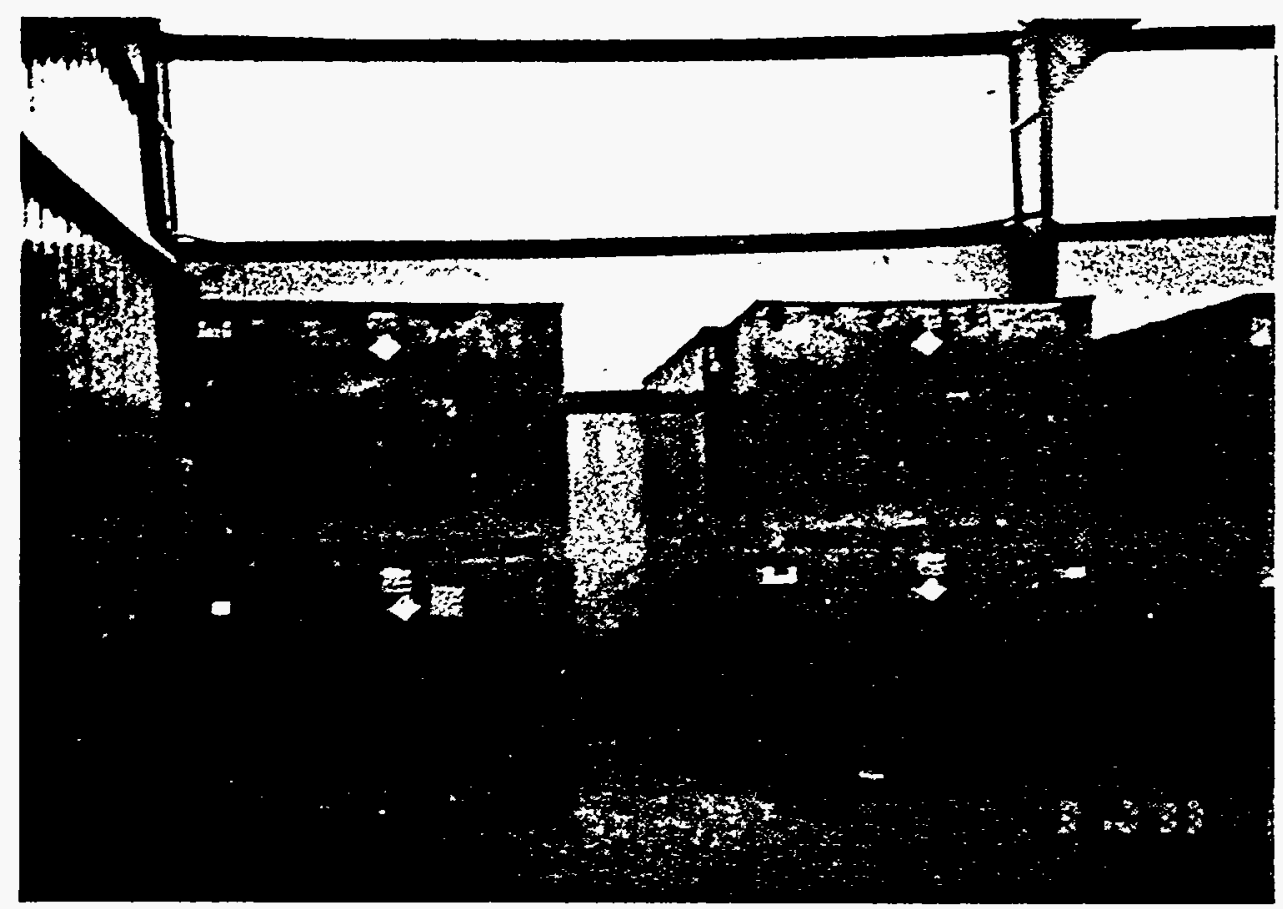

Figure 12. Boxes of mixed waste in storage at the MW storage facility.
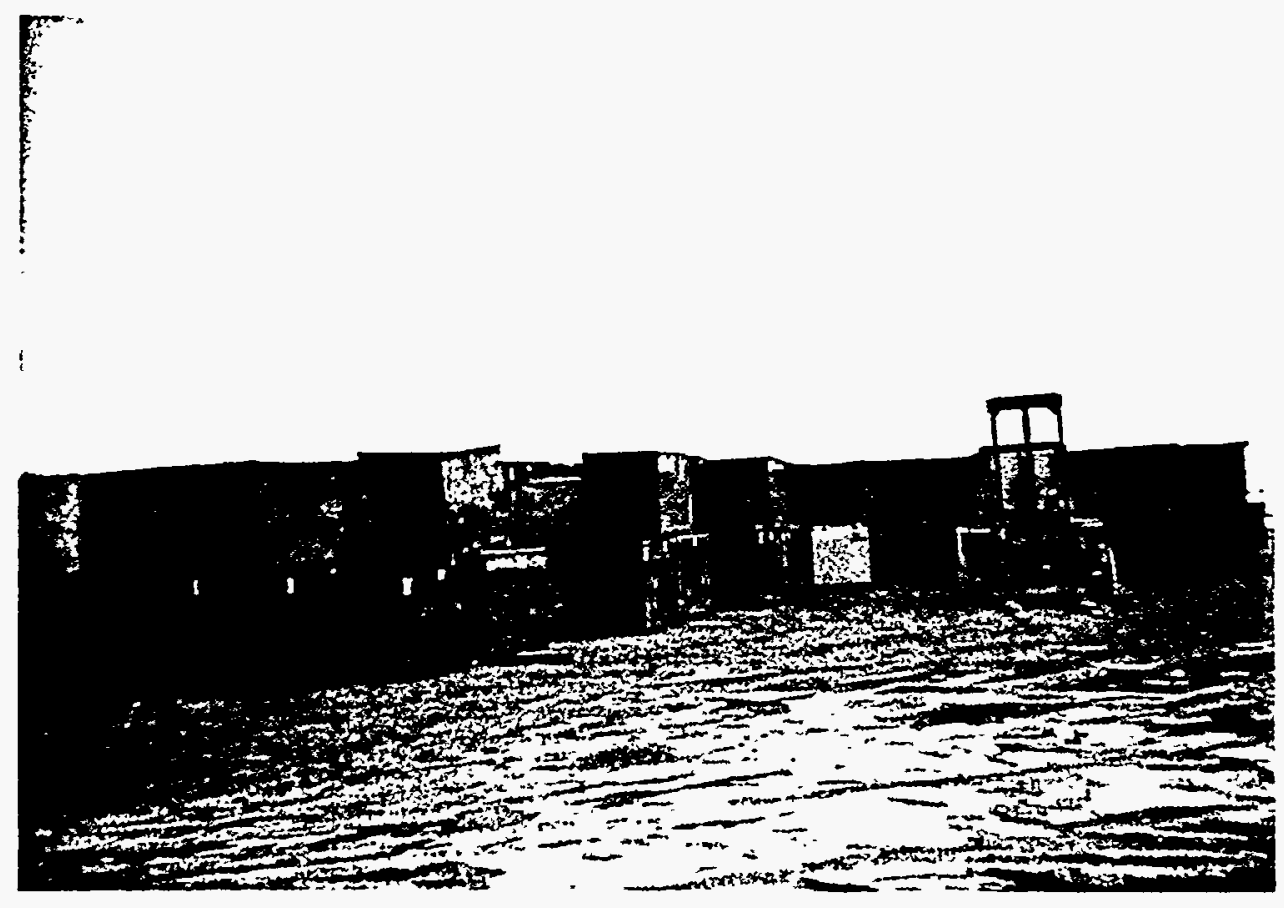

Figure 13. Storage boxes staged on the asphalt pad adjacent to the MW storage facility. 

6.1.4.1.1. Process Description -- The following paragraphs contain descriptions of the operations and construction of the MW landfill cell. This subsection is followed by the INEL observations and impressions of the landfill operations.

\subsection{Cell Construction -- The initial MW landfill cell has two phases. The first cell is the Phase 1 Cell and the second is Phase 2 Cel1. The capacity of the Phase 1 Cell is approximately 225,000 cubic yards. The second cel1 will be approximately 675,000 cubic yards.}

The cells are designed as RCRA-type waste embankments that also incorporate the design and construction features for radioactive waste disposal. The designed features for the management of radioactive wastes are those which were used for the Vitro cell and the NORM disposal cell.

The RCRA Part B Permit Application supplies the following description of the mixed waste landfill liner system:

"The mixed waste embankment will be under la in by a quadruple liner system. ... In general, the complete liner system is described as follows. (top to botton):

1. A structural layer of granular material which protects the underlying liners from the weight of the embankment and equipment. This layer will be at least 2 feet thick.

2. A synthetic filter fabric - A non-woven geotextile fabric fibretex 400 or approved equiva lent.

3. A tertiary drainage net. Tensar $\mathrm{OH}-1$ (or approved equivalent) material.

4. A $80 \mathrm{mil}$ high-density polyethylene (HDPE) liner.

5. A structural layer of granular material which protects the underlying liners from the weight of the embankment and equipment. This layer will be at least 2 feet thick.

6. A synthetic filter fabric - A non-woven geotextile fabric fibretex 400 or approved equivalent.

7. A tertiary drainage net. Tensar ON-1 (or approved equivalent) material.

8. A $60 \mathrm{mil}$ HDPE liner.

9. A primary drainage net. Tensar $\mathrm{ON}-3$ or approved equivalent material.

10. A second $60 \mathrm{mil}$ HDPE liner.

11. A 3-foot clay liner with a permeability of no more than $1 \times 10^{-7} \mathrm{~cm} / \mathrm{sec}$.

12. The entire system will be constructed on the in situ clay material which will be scarified and recompacted" (Part 8 Permit Application, Pp. 0-23 \& 0-24). 
6.1.4.1.1.2. Cell operations -- Envirocare is not allowed to. place any hazardous wastes restricted under 40 CFR 268, Subpart $C$ in the permitted landfills unless the wastes are treated to meet the standards in 40 CFR 268, Subpart $D$ or subject to an appropriate national variance, an approved petition under 40 CFR $\S 268.6$, an extension under 40 CFR $\S 268.5$, or a treatment standard variance under 40 CFR $\S 268.44$.

Envirocare is permitted to land dispose wastes which contain the following waste codes, provided that treatment standards of 40 CFR 268 are met for all waste codes that comprises such wastes:

\begin{tabular}{|c|c|c|c|c|c|c|c|c|c|c|c|c|}
\hline $\begin{array}{l}0001 \\
0014\end{array}$ & $\begin{array}{l}0002 \\
0015\end{array}$ & $\begin{array}{l}0003 \\
0016\end{array}$ & $\begin{array}{l}0004 \\
0017\end{array}$ & 0005 & 0006 & 0007 & 0008 & 0009 & D010 & 0011 & 0012 & 0013 \\
\hline $\begin{array}{l}\text { F001 } \\
\text { F028 }\end{array}$ & $\begin{array}{l}\text { F002 } \\
\text { F039 }\end{array}$ & $F 003$ & F004 & F005 & F006 & $F 007$ & F008 & F009 & F010 & F011 & $F 012$ & F019 \\
\hline K011 & $K 013$ & K050 & K051 & K052 & K061 & K069 & & & & & & \\
\hline $\begin{array}{l}P 002 \\
P 022 \\
P 051 \\
P 098 \\
P 120\end{array}$ & $\begin{array}{l}P 003 \\
P 024 \\
P 056 \\
P 099 \\
P 121\end{array}$ & $\begin{array}{l}\text { P004 } \\
\text { P027 } \\
\text { P059 } \\
\text { P101 } \\
\text { P122 }\end{array}$ & $\begin{array}{l}P 005 \\
P 028 \\
P 060 \\
P 102 \\
P 123\end{array}$ & $\begin{array}{l}\text { P010 } \\
\text { P029 } \\
\text { P071 } \\
\text { P104 }\end{array}$ & $\begin{array}{l}\text { P011 } \\
\text { P030 } \\
\text { P074 } \\
\text { P106 }\end{array}$ & $\begin{array}{l}P 012 \\
P 034 \\
P 075 \\
P 107\end{array}$ & $\begin{array}{l}\text { P013 } \\
P 037 \\
P 077 \\
P 108\end{array}$ & $\begin{array}{l}\text { P014 } \\
\text { P039 } \\
\text { P082 } \\
\text { P111 }\end{array}$ & $\begin{array}{l}P 015 \\
P 046 \\
P 085 \\
P 113\end{array}$ & $\begin{array}{l}\text { P017 } \\
\text { P047 } \\
\text { P089 } \\
\text { P114 }\end{array}$ & $\begin{array}{l}\text { P020 } \\
\text { P048 } \\
\text { P094 } \\
\text { P115 }\end{array}$ & $\begin{array}{l}\text { P021 } \\
\text { P050 } \\
\text { P097 } \\
\text { P119 }\end{array}$ \\
\hline U002 & U004 & U005 & U007 & v009 & U012 & vols & 4019 & U021 & U022 & v027 & U028 & v029 \\
\hline U030 & U031 & U032 & U036 & U037 & U038 & U039 & v041 & U042 & U043 & vo44 & U045 & U047 \\
\hline UO48 & U050 & U052 & U056 & 4057 & U060 & U061 & U062 & U063 & U064 & v066 & U067 & U068 \\
\hline U069 & U070 & U071 & U072 & U073 & U074 & U075 & v076 & v077 & U078 & U079 & U080 & U081 \\
\hline U082 & U083 & U084 & U085 & U088 & U089 & U091 & U093 & vo94 & U095 & U101 & U102 & U105 \\
\hline U106 & U107 & U108 & U109 & U112 & U115 & U117 & 4118 & U119 & U120 & U121 & U127 & U128 \\
\hline U129 & U130 & U131 & U132 & U135 & U137 & U138 & U140 & U141 & U142 & U144 & U145 & U146 \\
\hline U147 & U149 & U151 & U152 & U1 54 & U155 & U157 & U158 & U159 & U161 & U162 & U165 & U166 \\
\hline U167 & U168 & U169 & U170 & U171 & $\mathrm{U} 172$ & U174 & U179 & U180 & U181 & 4182 & U183 & U184 \\
\hline U185 & U187 & U188 & U190 & U191 & U192 & U194 & U196 & U197 & U201 & U203 & U204 & U205 \\
\hline U207 & U208 & U209 & U210 & U211 & U212 & U214 & U215 & U216 & U217 & U220 & U221 & U223 \\
\hline U225 & U226 & U227 & U228 & U230 & U231 & U232 & U233 & U234 & U235 & U237 & U238 & U239 \\
\hline U240 & U242 & U243 & U247 & & & & & & & & & \\
\hline
\end{tabular}

Envirocare is also permitted to land dispose wastes which contain the following waste codes provided that treatment standards do not exist for such wastes or that such wastes meet the treatment standards when they become effective:

$\begin{array}{lllllllllllll}0018 & D 019 & 0020 & D 021 & 0022 & 0023 & 0024 & 0025 & 0026 & 0027 & 0028 & 0029 & 0030 \\ 0031 & 0032 & 0033 & 0034 & 0035 & 0036 & 0037 & 0038 & 0039 & D 040 & 0041 & 0042 & 0043\end{array}$

Subsequent to the on site portion of the assessment, Envirocare received a RCRA Permit modification on May 5, 1993, pursuant to the Company's request 
which allows the facility to land dispose of the following additional waste codes:

$\begin{array}{llllllllll}F 024 & P 105 & U 003 & U 122 & 0123 & \text { U133 } & \text { U134 } & \text { U219 } & \text { U328 } & \text { U359 }\end{array}$

A11 wastes must contain radioactive components in addition to the RCRA hazardous components in order to be considered for disposal in the MW cell. All wastes must be devoid of free liquids as determined by the Paint Filter Liquids Test (SH-846, Method 9095). Wastes will be removed from containers before disposal in the landfill cell. The wastes will be placed in 12 inch lifts at $90 \%$ compaction. The wastes will be segregated by generator and mapped on a three dimensional grid system.

Envirocare is required to cease operations at the landfill cells when wind speeds are in excess of $40 \mathrm{mph}$.

\subsection{INEL Assessment Team Observations/Impressions -- Site} construction drawings were reviewed with the site construction engineer. The mixed waste storage cell was designed to specifications of the Part B permit, except that it contains a tertiary. liner system as opposed to a quaternary system, assuming that the HDPE is considered the actual liner. Envirocare calls the system a quaternary because it contains three synthetic liners and a recompacted clay liner. The mixed waste cell has a three foot $10^{\mathrm{E}-7} \mathrm{clay}$ layer on the bottom protected by three layers of, HDPE. Drainage net is interspaced to allow leachate to be collected (Figure 14). Phase $I$ is allowed a maximum capacity of 225,000 cubic yards. As built engineering plans and specifications have been submitted.

The mixed waste cell is managed by a Landfill Management Plan (Attachment V-4 of the RCRA Part B permit).

The mixed waste disposal cell was completely buried in snow at the time of the March 1993 on site portion of the assessment (Figures 15 and 16). Operations had been suspended for the winter due to the large accumulation of snow. Facility representatives stated that it would not be possible to meet the moisture and compaction requirements because of the snow. The only small 
portions of the wall and leachate collection pipes were visible. No impressions were recorded.

The mixed waste disposal cell was observed during the re-assessment in November 1993. At that time, the cell had received waste and the working 1 ift was at about ground level (Figures 17 and 18). No wastes were being emplaced during the assessment because none were available. Therefore, no operational impressions were recorded. The cover on the lift appeared to be adequate.

\subsection{Industrial Waste Landfill Cells. Requirements for the} construction, use, and maintenance of industrial waste landfill cells are specified in 40 CFR 257.

Envirocare does not operate an industrial waste landfill cell at the Clive, Utah facility. Therefore, this section is not applicable.

6.1.4.2.3. Low Level Radioactive Waste Landfill Cells. Requirements for the construction, use, and maintenance of landfill cells used for the disposal of radioactive wastes are specified in 10 CFR 61 . Specific requirements for construction, maintenance, operation, and closure of a radioactive waste landfill are delineated in the Application for Radioactive Materials License, Section 4 and the active Radioactive Materials License issued by the State of Utah.

\subsection{Process Description -- The following paragraphs} contain descriptions of the operations and construction of the LLW landfill cell. This subsection is followed by the INEL impressions of the landfill operations.

A11 wastes must contain radioactive components in concentrations not to exceed those specified in the Radioactive Materials License in order to be considered for disposal in the LLW cell. All wastes must be devoid of free liquids as determined by the Paint Filter Liquids Test (SW-846, Method 9095). Wastes 


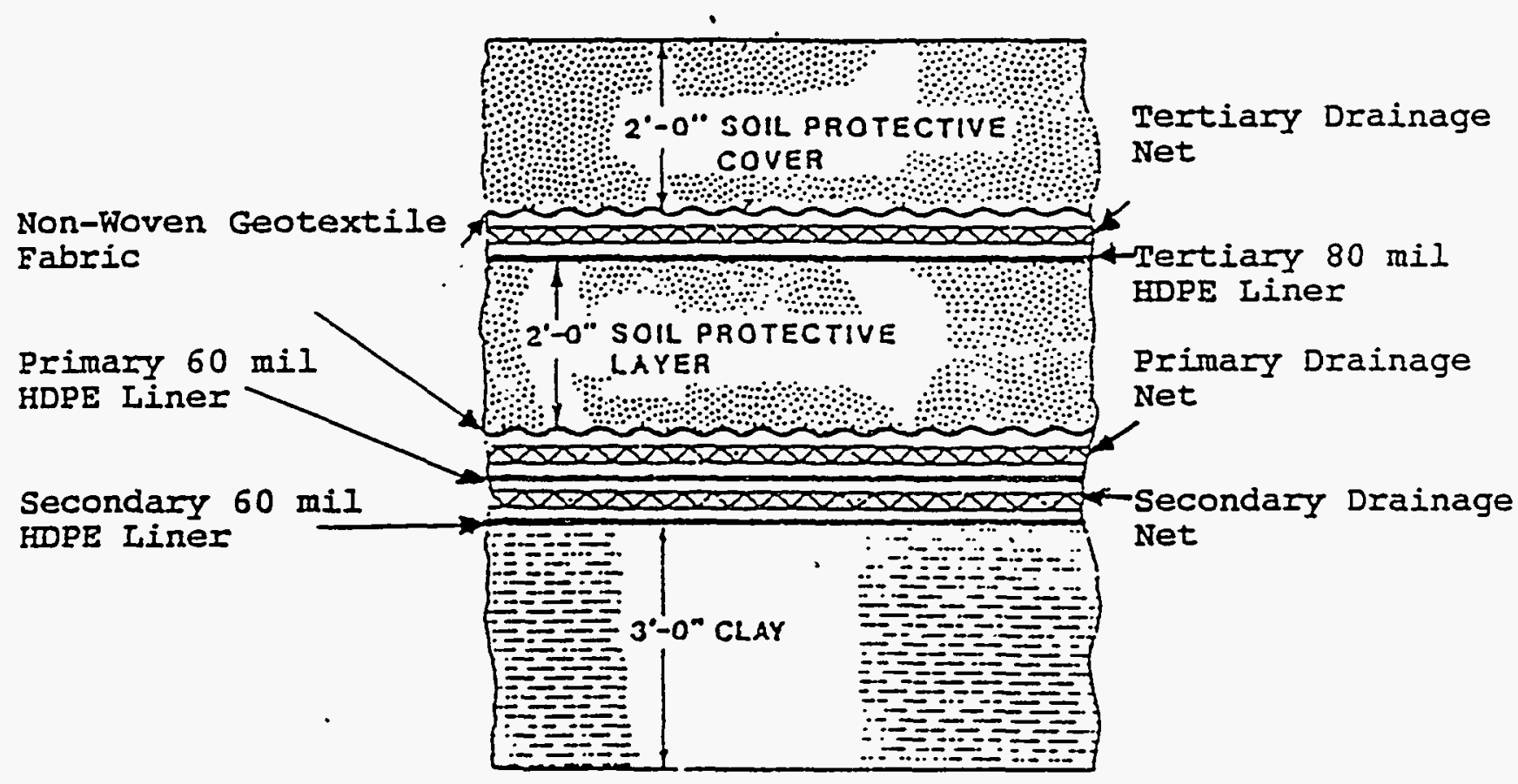

Figure 14. Cross section of the construction of the MW Iandfill cell liner system. 
EGG-ESQ-10749

January 1994

This page intentionally left blank. 
EGG-ESQ- 10749

January 1994

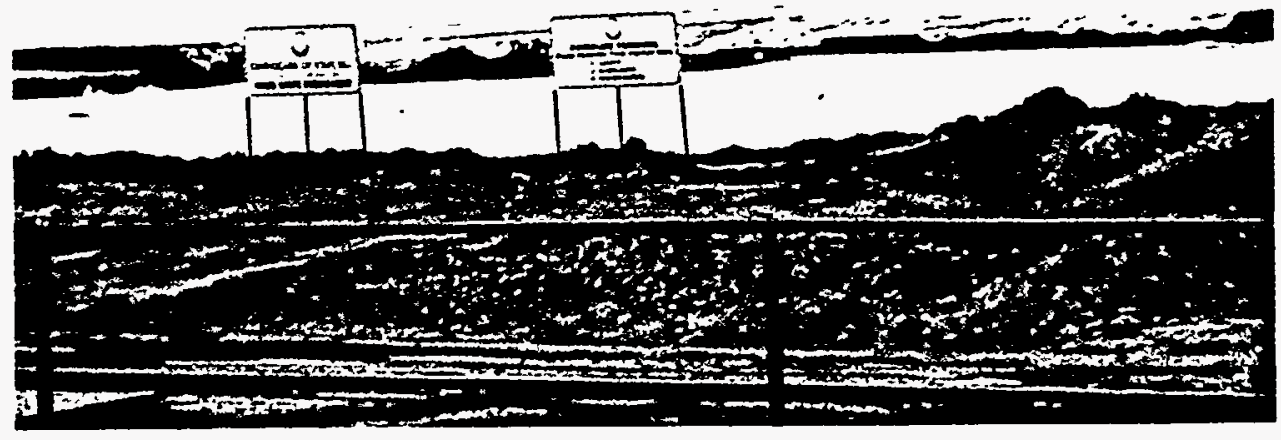

Figure 15. MW disposal cell at the Envirocare facility in March 1993.

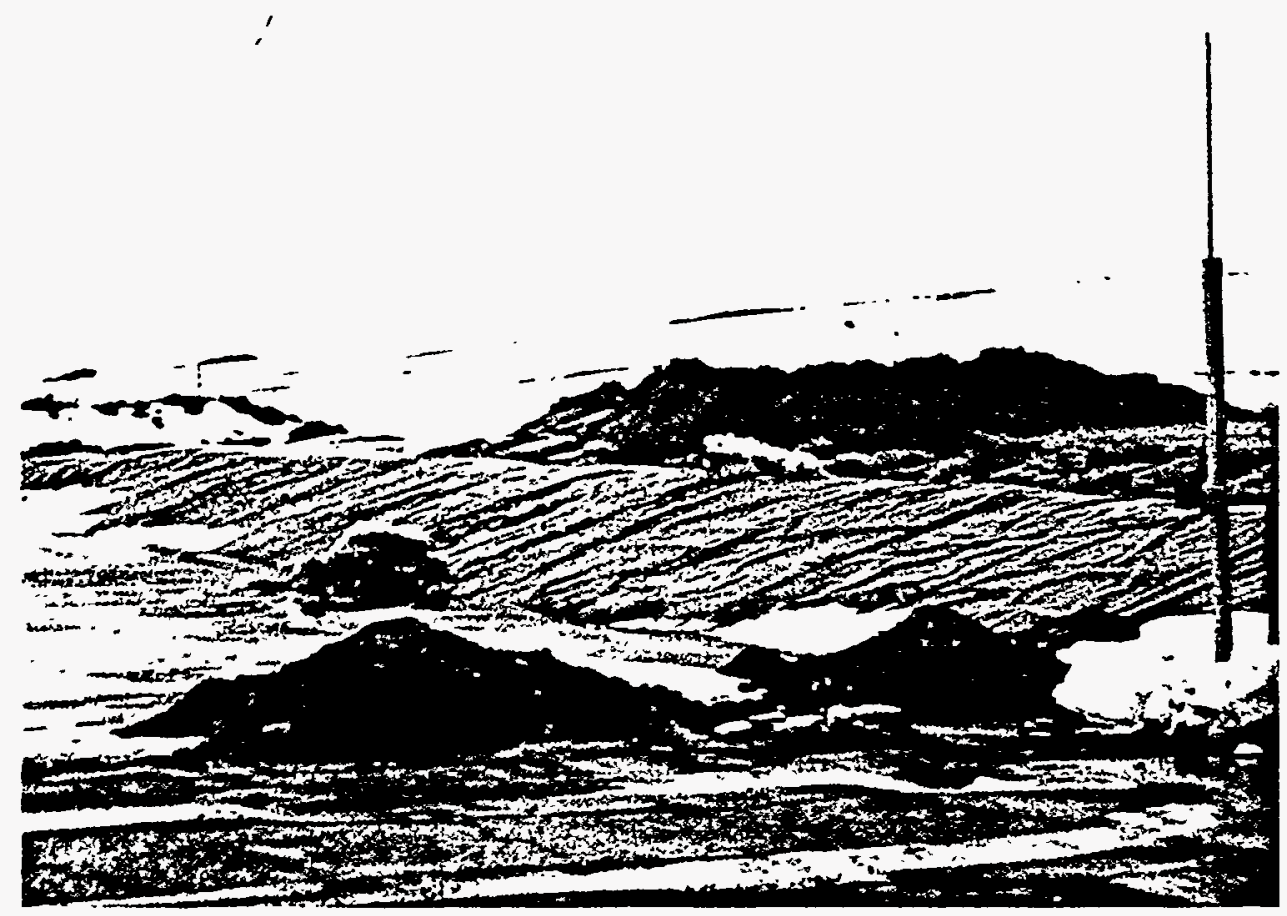

Figure 16. Close-up view of the liner of the MW disposal cell in March 1993. 



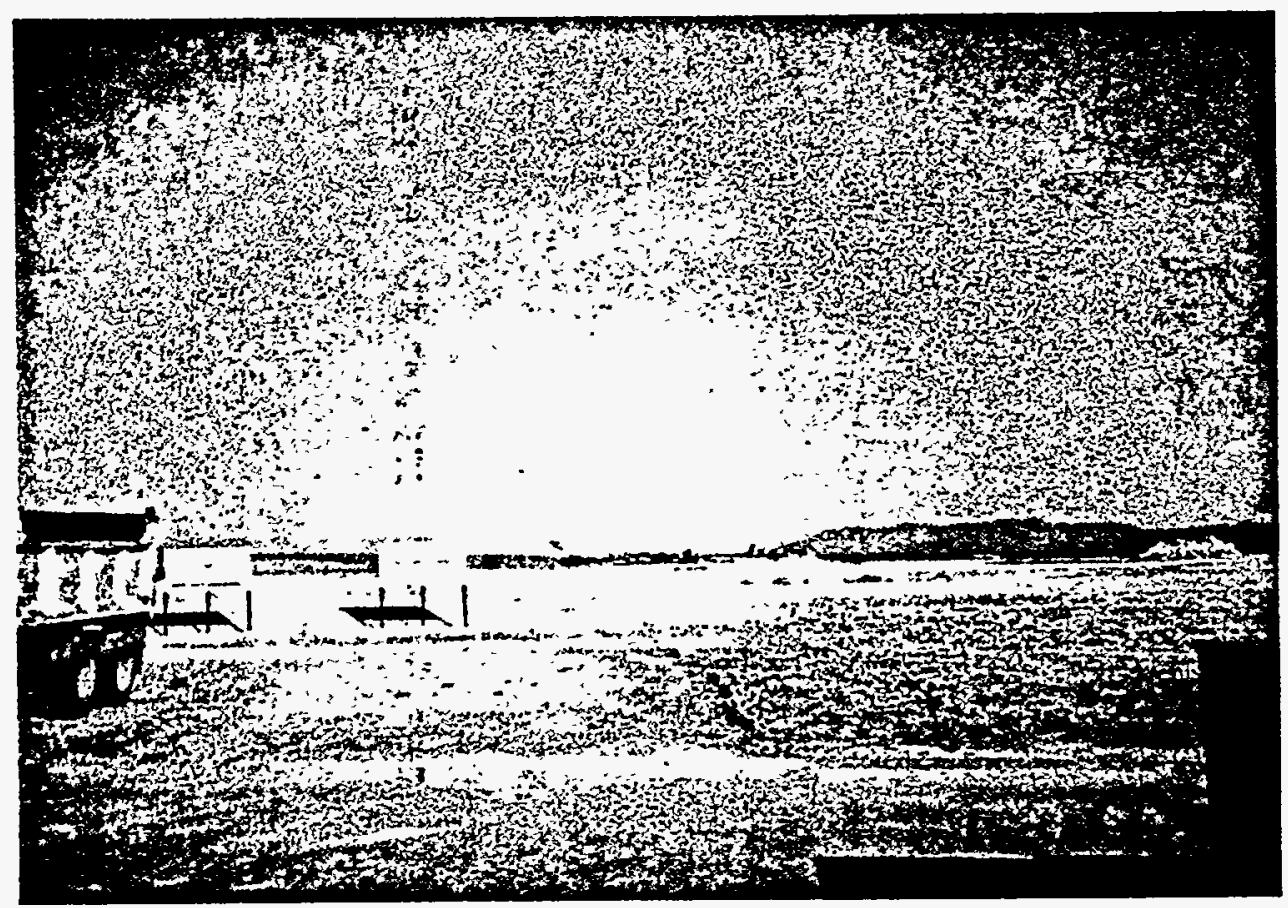

Figure 17. MW disposal cell in November 1993. Surface of cell is at ground levet.

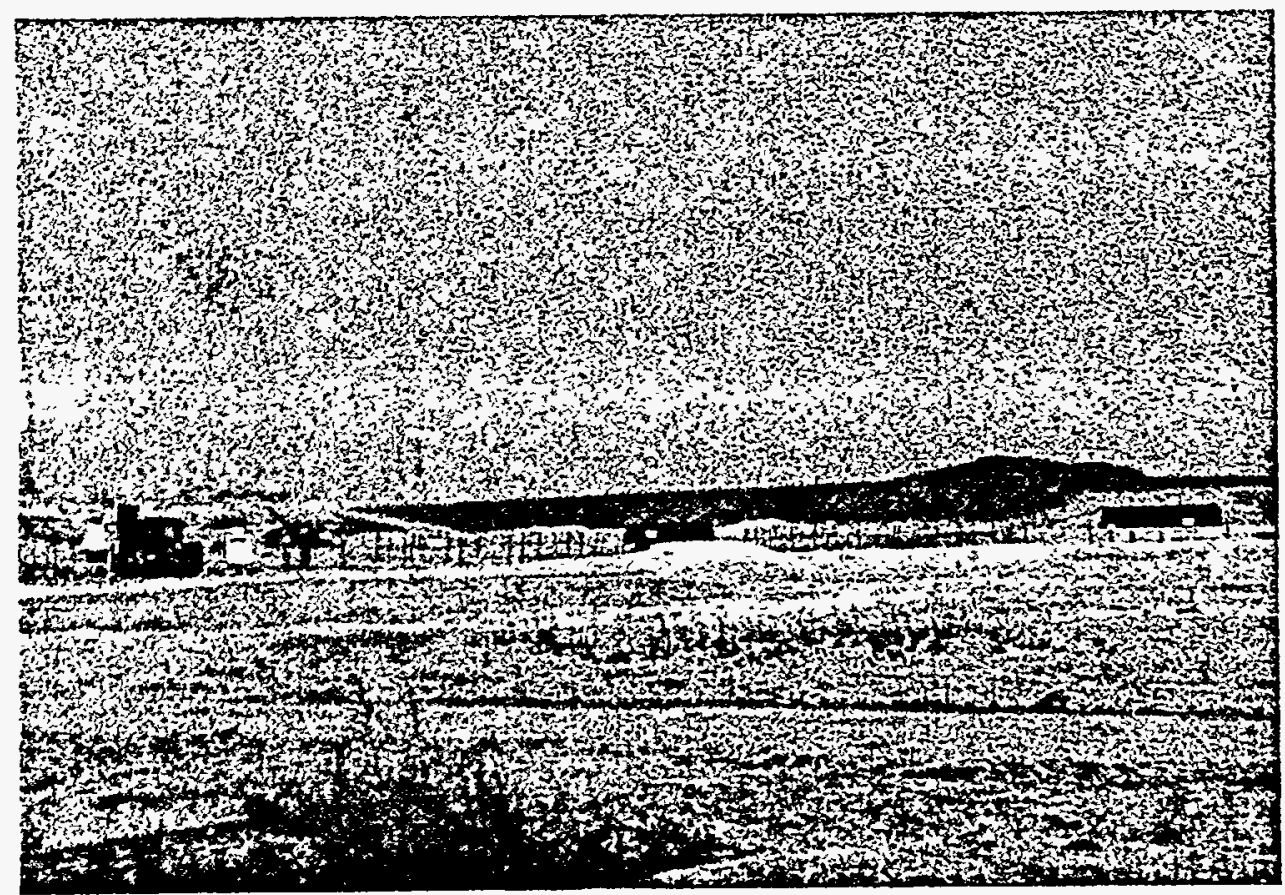

Figure 18. MW disposal cell in November 1993. Dark brown color reflects most recent disposal activities. 
will be removed from containers before disposal in the landfill cell. The wastes will be placed in 12 inch lifts at 90\% compaction. The wastes will be segregated by generator and mapped on a three dimensional grid system.

Envirocare is required to cease operations at the landfill cells when wind speeds are in excess of $40 \mathrm{mph}$.

\subsection{INEL Assessment Team Observations/Impressions -- LLW} landfill disposal activities were not active at the time of the onsite portion of the assessment. Routine maintenance of the cells was observed (Figures 19 and 20). The facility continuously monitors and maintains the radon barrier over the completed portions of the cell until it is covered with the erosion barrier.

LLW landfill construction plans were discussed with facility representatives during the on site portion of the assessment.

The operations at the $L L W$ disposal cells were active during the November 1993 re-assessment. The INEL Assessment Team observed the emplacement of a load of LLW debris, the compaction quality assurance/quality control (QA/QC) sampling, and the emplacement of the radon cover along the active face of the cell.

The LLW debris (Figure 21) arrived in bags which were being opened to spread the debris across the 1ift. A Caterpillarm D6 track-type tractor equipped with a scoop shovel was being used to move the material. No manual handling was observed. Envirocare utilizes a subcontractor, Broken Arrow Construction, for all disposal cell construction, operation, and maintenance.

The compaction $Q A / Q C$ process was described by the facility representative as the INEL Assessment Team observed the operations. Envirocare provided the following description of the soil testing technique:

The thickness of the $1 \mathrm{ift}$ is determined by physically digging through the loose lift (prior to compaction) at a location determined by a random number generator. Neither the contractor nor the $Q C$ inspector knows beforehand where the lift thickness will be measured. 
If the thickness and debris concentration are approved the lift is compacted.

Once the lift is compacted, the QC inspector again generates two random numbers (one for the north-south coordinates and one for the east-west coordinates) for the location of moisture/density testing. This testing is performed by use of a "Troxler" nuclear density gage. If the 1 ift density is greater than $90 \%$ of the maximum compaction for the $1 \mathrm{ift}$ material and the moisture content is less than 5\% greater than optimum, the lift compaction and moisture content is provisionally approved. Frequently, the QC inspector is skilled enough in visual determination of the lift compaction to direct further compaction efforts, if needed, but will always perform the testing required before lift approval is granted.

A moisture sample of the lift material is obtained at the same location as the Troxler test was performed and dried overnight in an oven dry test to validate the moisture tests performed with the Troxler. Five percent of the density tests are calibrated/validated by performing sand cone tests.

Final approval of the lift is obtained when the oven dry test ensures the moisture content is within specification.

The INEL Assessment Team also observed the emplacement of the radon cover along the active face of the LLH cell (Figure 22). The clay used for this cover is excavated locally and stockpiled for use. The permeability of this clay is less than $1 \times 10^{-7} \mathrm{~cm} / \mathrm{sec}$. Much of the material underlies the cells.

\subsection{NORM Waste Landfill Cells. Requirements for the} construction, use, and maintenance of landfill cells used for the disposal of radioactive wastes are specified in 10 CFR 61 . Specific requirements for construction, maintenance, operation, and closure of a radioactive waste landfill are delineated in the Application for Radioactive Materials License, Section 4 and the active Radioactive Materials License issued by the State of Utah.

NORM landfill construction plans were discussed with facility representatives during the on site portion of the assessment. 


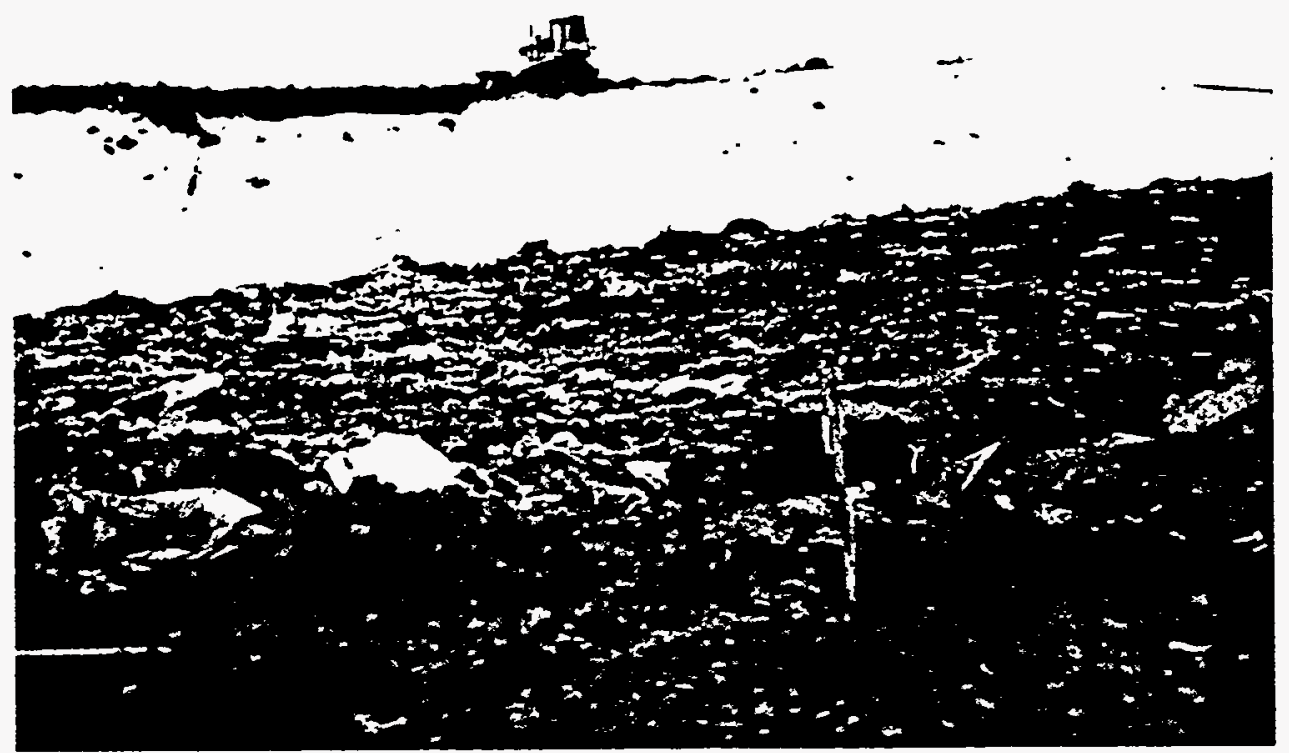

Figure 19. LLW disposal in cell. Wastes are segregated by generator. Flag denotes the grid position separating two generator's wastes.

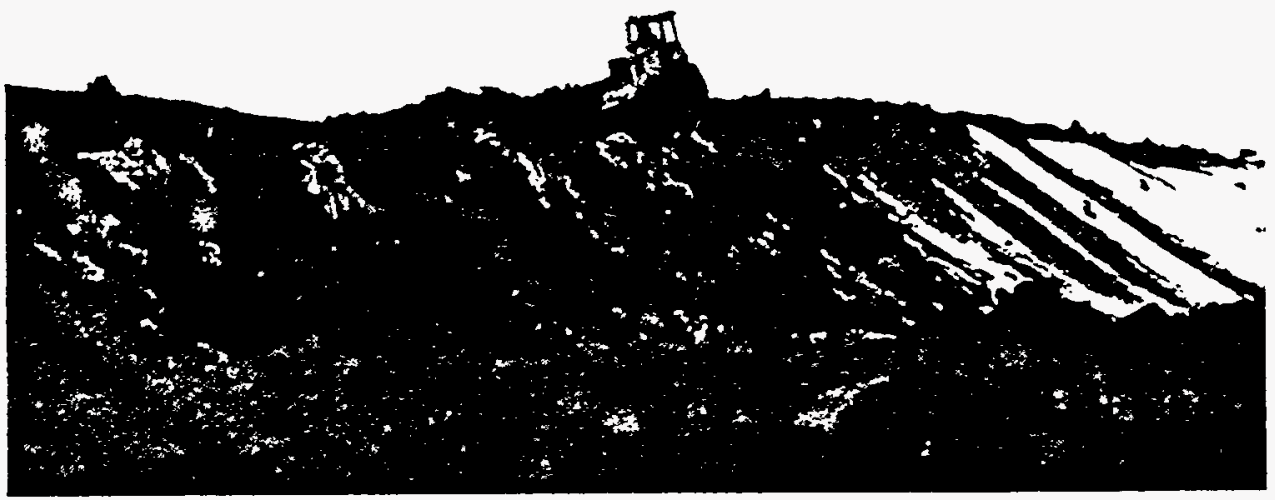

Figure 20. Routine maintenance of the radon barrier on the $L L H$ cell. 


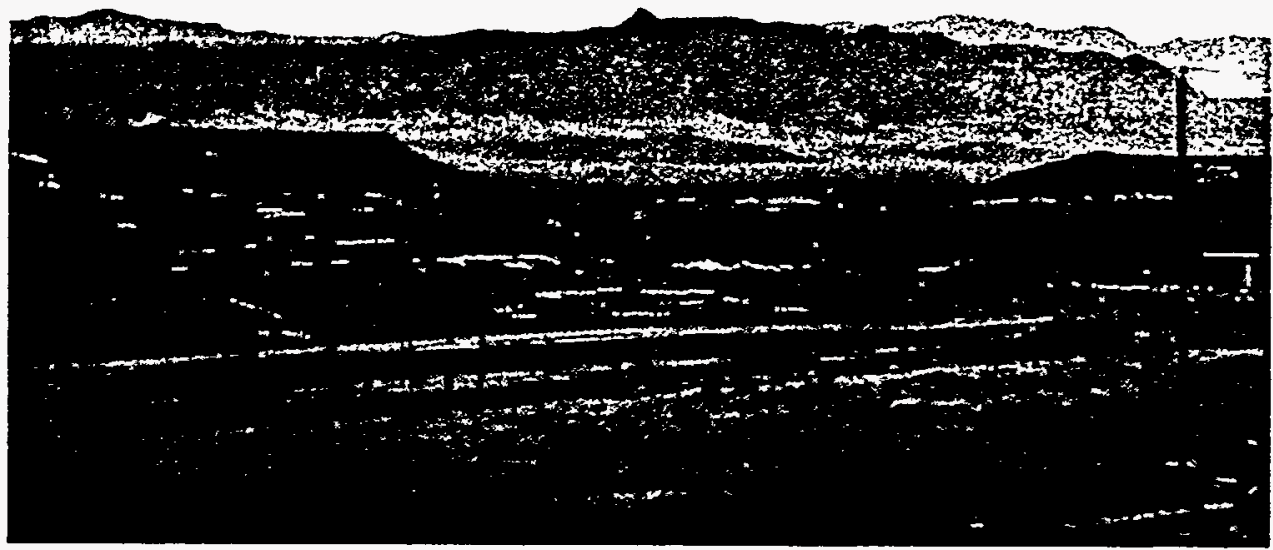

Figure 21. Disposal of debris in the Envirocare LLW cell.

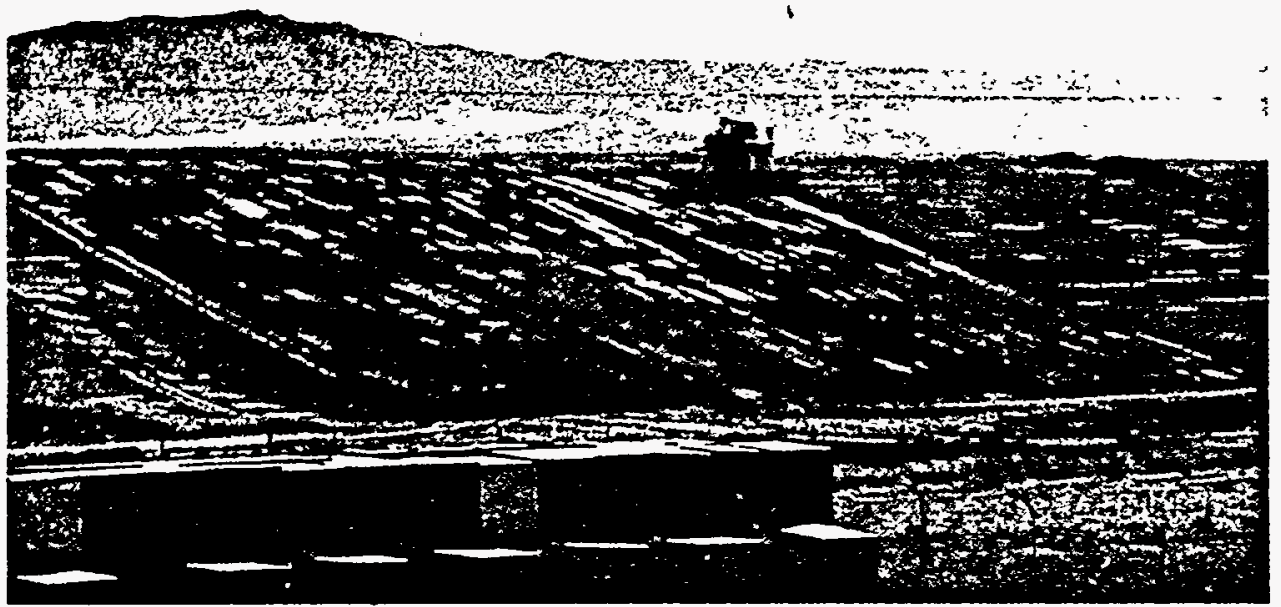

Figure 22. Emplacement of the radon barrier on the LLW disposal cell. 
6.1.4.2.4.1. Process Description -- The following paragraphs contain descriptions of the operations and construction of the NORM landfill ce11. This subsection is followed by the INEL Assessment Team impressions of the landfill operations.

A11 wastes must contain NORM components in concentrations not to exceed those specified in the Radioactive Materials License in order to be considered for disposal in the NORM cell. All wastes must be devoid of free liquids as determined by the Paint Filter Liquids Test (SW-846, Method 9095). Wastes will be removed from containers before disposal in the landfill cell. The wastes will be placed in 12 inch lifts at 90\% compaction. The wastes will be segregated by generator and mapped on a three dimensional grid system. Envirocare is required to cease operations at the landfill cells when wind speeds are in excess of $40 \mathrm{mph}$.

\subsection{INEL Assessment Team Observations/Impressions -- NORM} waste landfill disposal activities were not active at the time of the onsite portion of the assessment. Routine maintenance of the cells was evident. The facility continuously monitors and maintains the radon barrier over the completed portions of the cell until covered with the erosion barrier.

NORM waste landfill disposal activities were not active during the November 1993 re-assessment. No impressions were recorded.

\subsubsection{Laboratory Operations}

6.1.5.1. Process Description. Envirocare operates a laboratory on site at the Clive facility which is used to perform "fingerprint" analyses of incoming waste shipments. The purpose of the fingerprint analyses is to verify that the shipments received match the acceptance criteria for the facility and match the generator's waste profile and pre-acceptance samples.

Envirocare also uses off site laboratories for analytical services. Analyses required by Envirocare's HSWA Part B Permit, must be performed by a Utahcertified laboratory or a laboratory which has been approved through the EPA Contract Laboratory Program (CLP). 
6.1.5.1.1. Chain-of-Custody -- Chain-of-Custody (COC) procedures are applied to samples from incoming waste shipments. The procedures are also required for groundwater monitoring sample collection, analysis, and reporting. Procedures were available for review.

6.1.5.1.2. Quality Assurance/Quality Control -- A Quality Assurance Project Plan is in effect for incoming shipment sampling and analysis. The laboratory also has a quality assurance/quality control (QA/QC) program in place as required by the facility's RCRA Part B Permit.

\subsection{Testing Methods/Procedures -- Envirocare uses the EPA} approved SW-846 Test methods for the conduct of onsite tests. The laboratory performs the following fingerprint tests: solid/soil $\mathrm{pH}$, paint filter liquids, oxidizer/reducer, cyanide/sulfide, photoionizer "sniffer", pyrophoricity, shock sensitivity, air reactive, and water reactive.

\subsubsection{INEL Assessment Team Observations/Impressions. Laboratory} operations and documentation were reviewed by the INEL Assessment Team during the on site portion of the assessment. Members of the team were also allowed to accompany the laboratory manager on a groundwater sampling task.

The company provided the INEL Assessment Team with a copy of a list of Utahcertified laboratories. Only one of the laboratories on the list could provide mixed waste analyses at the time of the assessment.

6.1.5.2.1. Chain-of-Custody -- Adequate COC procedures appeared to be in place. Members of the INEL team observed the sampling of one of the onsite ground water monitoring wells. Proper $C O C$ procedures were being used.

6.1.5.2.2. Quality Assurance/Quality Control -- A QA/QC program is in place as required by the RCRA Part $B$ Permit. Conditions of the Part $B$ Permit requiring the $Q A / Q C$ program appeared adequate.

Subsequent to the March 1993 assessment, Oak Ridge National Laboratories (ORNL) DOE Operations Office conducted an audit of Envirocare as part of its RFP for the disposal of MW. At the time of this audit Envirocare was in the 
process of writing a new Quality Assurance Manual incorporating the NQA-1 [Nuclear Quality Assurance] Standards. This major change was still in process at the time of the INEL re-assessment in November 1993. The company has stated that the QA manual will be further revised in the Spring/Summer 1994 to reflect the standards and format of the new American Society for Quality Control (ASQC) E-4 manual. The company had made significant changes to many of its policies and procedures for both laboratory and general operations. The company had also added a QA officer to its staff in order to ensure that the requirements were properly implemented and followed.

6.1.5.2.3. Testing Methods/Procedures -- Test Methods were done according to SW-846. Capabilities for doing fingerprint samples on all incoming waste are maintained at the facility.

\subsubsection{Security}

RCRA security requirements found at 40 CFR $\S \S 264.14$ and 265.14 state that "The owner or operator must prevent the unknowing entry, and minimize the possibility for the unauthorized entry, of persons, or livestock onto the active portion of his facility...." The facility must have a 24-hour surveillance system which continuously monitors and controls entry onto the active portion or the facility; or an artificial or natural barrier, which completely surrounds the active portion of the facility. The facility must have a means to control entry, at all times, through gates or other entrances to the facility. It must also have a sign with the legend, "Danger -Unauthorized Personnel Keep Out" which must be posted at each entrance to the active portion of the facility, and at other locations, in sufficient numbers to be seen from any approach to this active portion. The legend must be written in English and in any other language prominent in the area surrounding the facility.

6.1.6.1. Process Description. Security at the Envirocare Clive facility is described in the Site Security PIan (Attachment II-2 of the RCRA Part B Permit). The company has identified the following measures which it believes satisfy the requirements. The State has accepted the plan and specified several additional requirements. 
"The hazardous waste management areas at the site will be enclosed by artificial barriers. Where fences are used, the fence must be a standard sixfoot, chain-link ... fence, ... top mounted with a three-strand barbed wire fence, ... with gates or locking devices" (Security Plan, p. 1).

Part of this barrier consists of the mixed waste storage facility building, the doors of which are locked (Figure 23). If the gates or doors are unlocked, an attendant must be within 100 feet of the gate or door.

"The facility will be equipped with warning signs which read: 'Danger -Unauthorized Personnel Keep Out'. These signs will be posted at all security gates and at 100-foot intervals on the permanent fencing or access control barrier surrounding the active area. The signs will be visible and legible from a minimum distance of 25 feet. The warning signs will be placed at the doors at the entrance to the storage building and at 100-foot intervals along the portions of the structures that serve as access control" (Security Plan, p. 1).

The portions of the facility which are covered by the Security Plan are:

"The hazardous waste landfill cell;

The hazardous waste container storage building and area;

The hazardous waste evaporative tanks; and

The hazardous waste unloading area for rail cars" (Security Plan, p. 1).

Under special situations, when the fence, gates, doors, or buildings do not enclose the areas mentioned, Envirocare is required to provide for on-site surveillance of the facility.

6.1.6.2. INEL Assessment Team Observations/Impressions. The Security $\mathrm{Pl}$ an discusses hazardous waste management facilities, as opposed to mixed waste management facility. The team assumes that the term, hazardous waste, is meant to reflect the mixed waste facilities. 


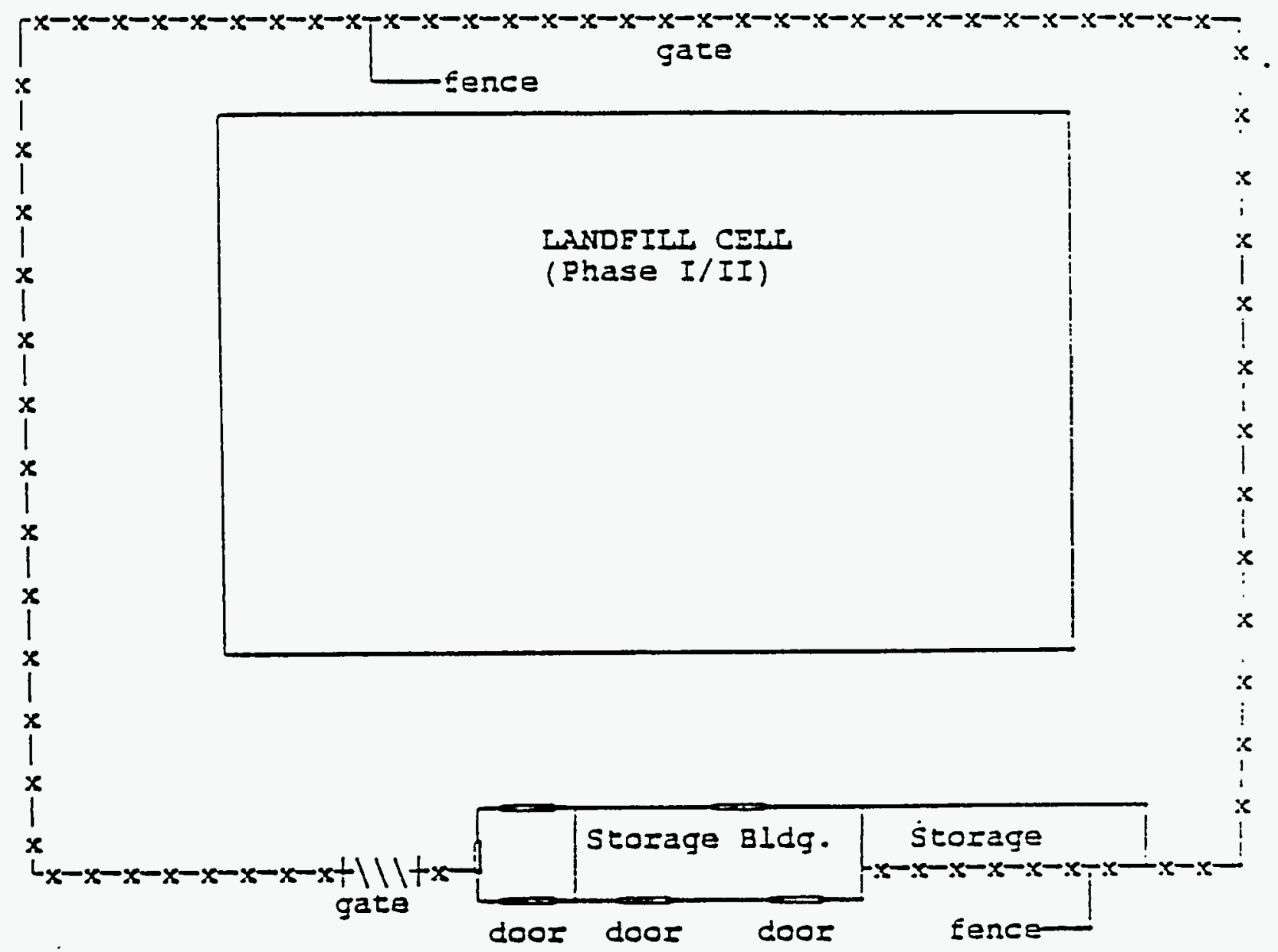

Figure 23. Security diagram of the MW storage facility. 
EGG-ESQ-10749

January 1994

This page intentionally left blank. 
The INEL Assessment Team inspected the security systems as part of the assessment. Security fences were in good repair. The warning signs were displayed in accordance with the Security Plan. The signs were legible at 25 feet and worded in English only (Figure 24 and 25). This portion of Utah does not have a large population present which would require a second language be used.

The INEL Assessment Team did identify a concern associated with site security. The RCRA Part B Permit, Module II, Section II.E.4. states that "The facility shall have a guard stationed at each open access point, or shall have all access to the site controlled through a locked gate." This statement is also repeated in the Envirocare Site Security Plan (Attachment II-2 of the RCRA Part B Permit). The INEL Assessment Team noted that the main access to the site did not have a gate, nor were any guards visible during the site inspection. These points were discussed with the facility representatives during the on site portion of the assessment who stated that a guard was present at the rail entrance to the facility and actual access to the mixed waste storage facility, in particular, was controlled by the locked storage facility door. The INEL Assessment Team had a concern about the potential for sabotage and/or illegal dumping of materials at the facility, especially during off hours. The issue was also discussed at the close out meeting with Envirocare management. The company management stated that they are investigating better methods of surveillance of activities and controlling access to the facility.

During the November 1993 re-assessment security was discussed. The surveillance system was still being assessed by the company. The INEL Assessment Team noticed cattle in the vicinity of the active portion of the facility. The facility representatives stated that cattle, ranging on the BLM land, did occasionally get through the barbed wire fences thereby gaining access to the Envirocare property. The INEL Assessment Team suggested that the facility investigate better perimeter fencing for their property. It was the opinion of the INEL Assessment Team that the potential for the cattle to be struck by Envirocare equipment should be a liability concern for the company. It should be noted that although it was possible to access the perimeter property of the facility, it was not possible to access the areas 
where hazardous waste activities were.occurring because of the chain link fencing.

\subsubsection{Transportation}

6.1.7.1. Process Description. Envirocare does not operate transportation services for customers. The facility accepts shipments by - common carriers, both truck and rail cars. The company does operate a railroad spur which allows them to receive rail cars on site for inspection and off loading. Envirocare operates two railroad shunting engines which move the cars from the Clive siding to the facility siding.

6.1.7.1.1. Driver's Training/Certification -- Envirocare does not operate interstate or intrastate transportation services for customers. Therefore, this section is not applicable.

6.1.7.1.2. Inspections -- Vehicle inspections were not addressed in any of the RCRA documents reviewed during the assessment.

\subsection{Load Verification and Placarding -- Load verification} and placarding were not addressed in any of the RCRA documents reviewed during the assessment.

6.1.7.1.4. Manifest System and Recordkeeping -- The manifest system and recordkeeping requirements were discussed with the facility representatives as part of the Audit Master" session. As a permitted TSDF, the facility accepts shipments from off-site generators as long as the shipment is accompanied by an approved manifest or shipping paper. The shipments may arrive either by truck or rail transport. The facility has a written procedure in place to confirm that all shipments of mixed waste received at the site are consistent with the manifest or shipping paper. Manifest discrepancies are resolved between Envirocare and the generator's before the shipment is accepted at the facility. A copy of the shipping paper from rail shipments is also sent to the Union Pacific Railroad, the owner of the rail line, and the approved transporter. 


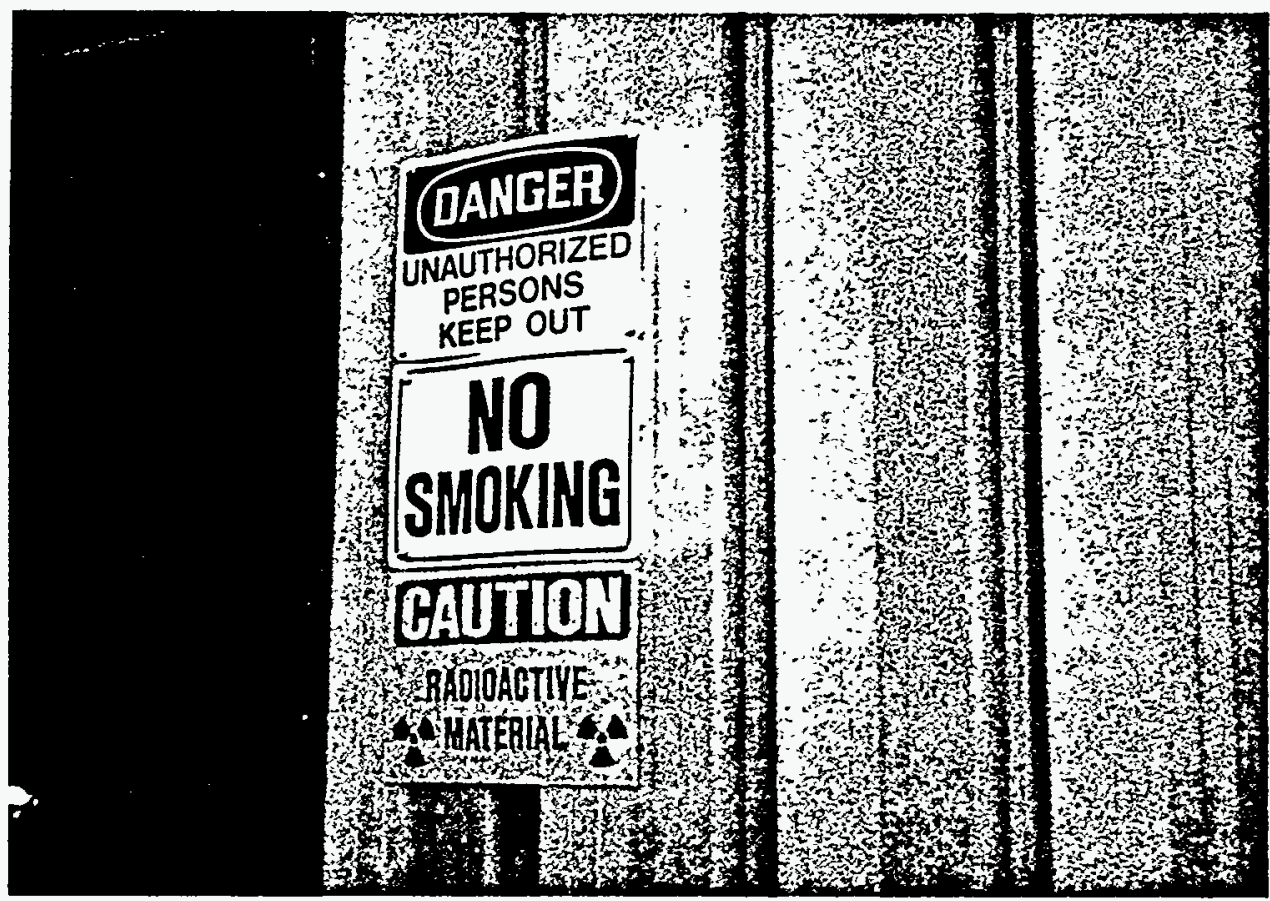

Figure 24. Warning signs posted on the MW storage facility door way.

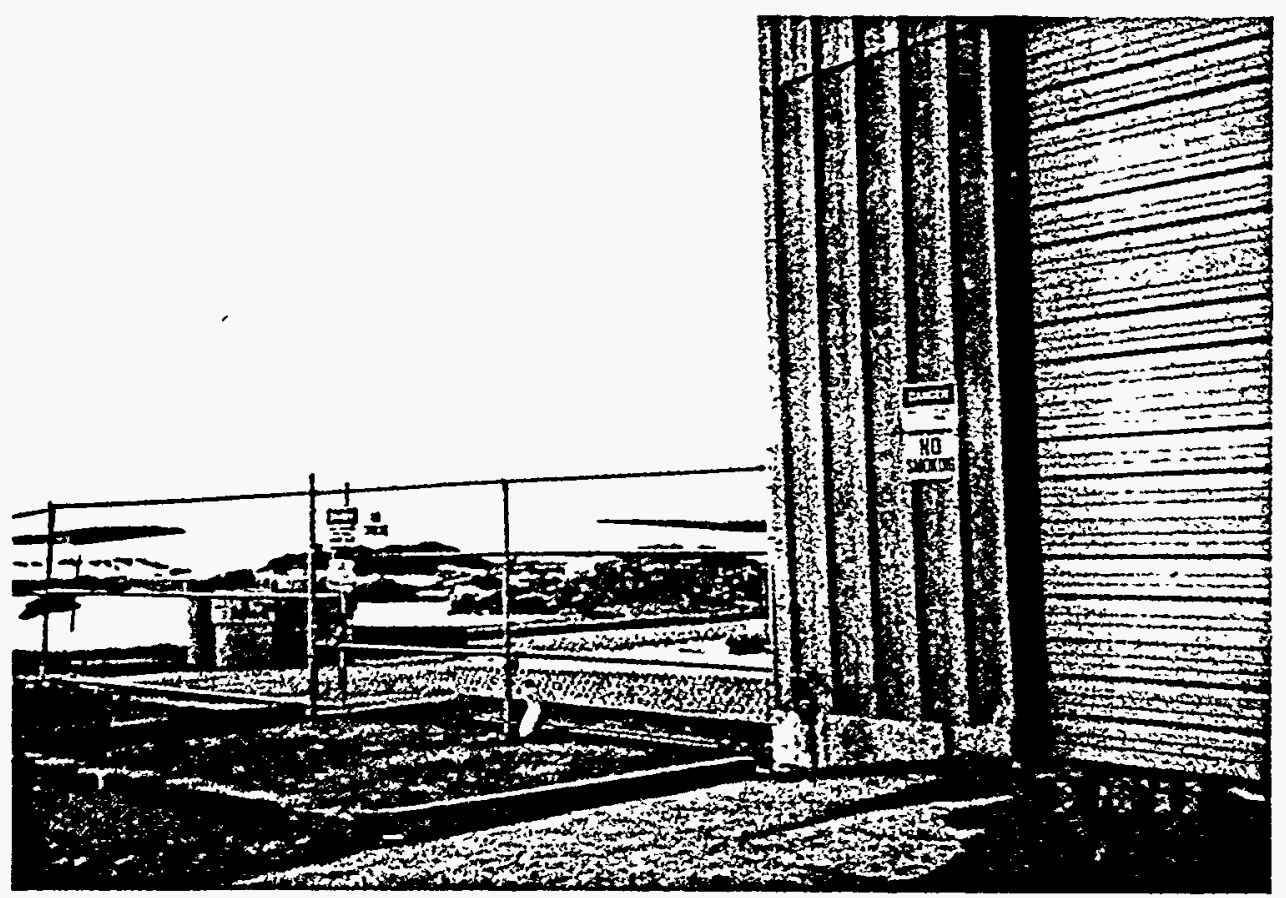

Figure 25. Harning signs posted on the MW disposal area security fence. 
Copies of the manifests, and all associated documentation, are kept at the facility as part of the operating record.

6.1.7.1.5. Permits -- Envirocare does not operate interstate or intrastate transportation services for customers. Therefore, this section is not applicable.

\subsection{Spill Prevention and Cleanup Procedures -- Spill}

prevention and cleanup procedures were not specifically addressed with respect to transportation services in any of the RCRA documentation reviewed during the assessment.

6.1.7.1.7. Truck Hash -- Envirocare operates a truck wash platform at the entrance to the active portion of the facility, adjacent to the Administration Building (Figures 26 and 27). The truck wash consists of a pad with drains to an underground tank. The tank is managed as a <90 day accumulation area. All vehicles are washed before exiting the active portion of the facility.

\subsection{Rail Car Wash -- Envirocare operates a rail car wash} facility adjacent to the rail car rollover equipment. The facility consists of a covered tunnel through which the gondola rail cars are pulled (Figure 28). The wash water from this operation is collected in an underground tank which is managed as a $<90$ day accumulation area. All rail cars are washed before exiting the active portion of the facility.

6.1.7.1.9. Rail Car Roll Over -- A rail car rollover structure is used to empty debris out of gondola rail cars at the facility (Figure 29). Rail cars are rolled into the rollover apparatus. The equipment turns the cars completely over which dumps the debris and waste into a pit beneath the structure. The pit is constructed of a ten inch thick concrete pad. The walls above the pit are lined with HDPE and clay (Figure 30). Front end loaders pick up the debris from the pit and load it into facility dump trucks which carry. the loads to the appropriate disposal cell. 


\subsubsection{INEL Assessment Team Observations/Impressions.}

6.1.7.2.1. Driver's Training/Certification -- Envirocare does not operate interstate or intrastate transportation services for customers. Therefore, this section is not applicable.

\subsection{Inspections -- Inspections of incoming loads was} discussed with Envirocare facility representatives during the Audit Master ${ }^{\text {N }}$ sessions conducted during the onsite portion of the liability assessment.

The INEL Assessment Team did not accompany company representatives to observe an incoming or exiting vehicle inspection procedure during the March 1993 assessment.

Inspection of an incoming load was observed during the November 1993 reassessment (Figure 31). The site Radiation Monitor walked around the vehicles checking the radiation levels and comparing these levels to those identified on the shipping papers. This inspection took place before the vehicle was allowed into the controlled area. If the radiation levels matched, then the vehicle proceeded into the controlled area to be sampled. The truck was vehicle was held in this are until the sample results were complete and matched the shipping papers and acceptance criteria. At that point, the vehicle was allowed to proceed to the disposal area.

\subsection{Load Verification and Placarding -- Load verification} and placarding of incoming loads and exiting from the facility were discussed with Envirocare facility representatives during the Audit Master ${ }^{\text {m }}$ sessions conducted during the onsite portion of the liability assessment.

The INEL Assessment Team did not accompany company representatives to observe a load verification procedure. However, the procedure was discussed with the company representatives and laboratory personnel. 
EGG-ESQ-10749

January 1994

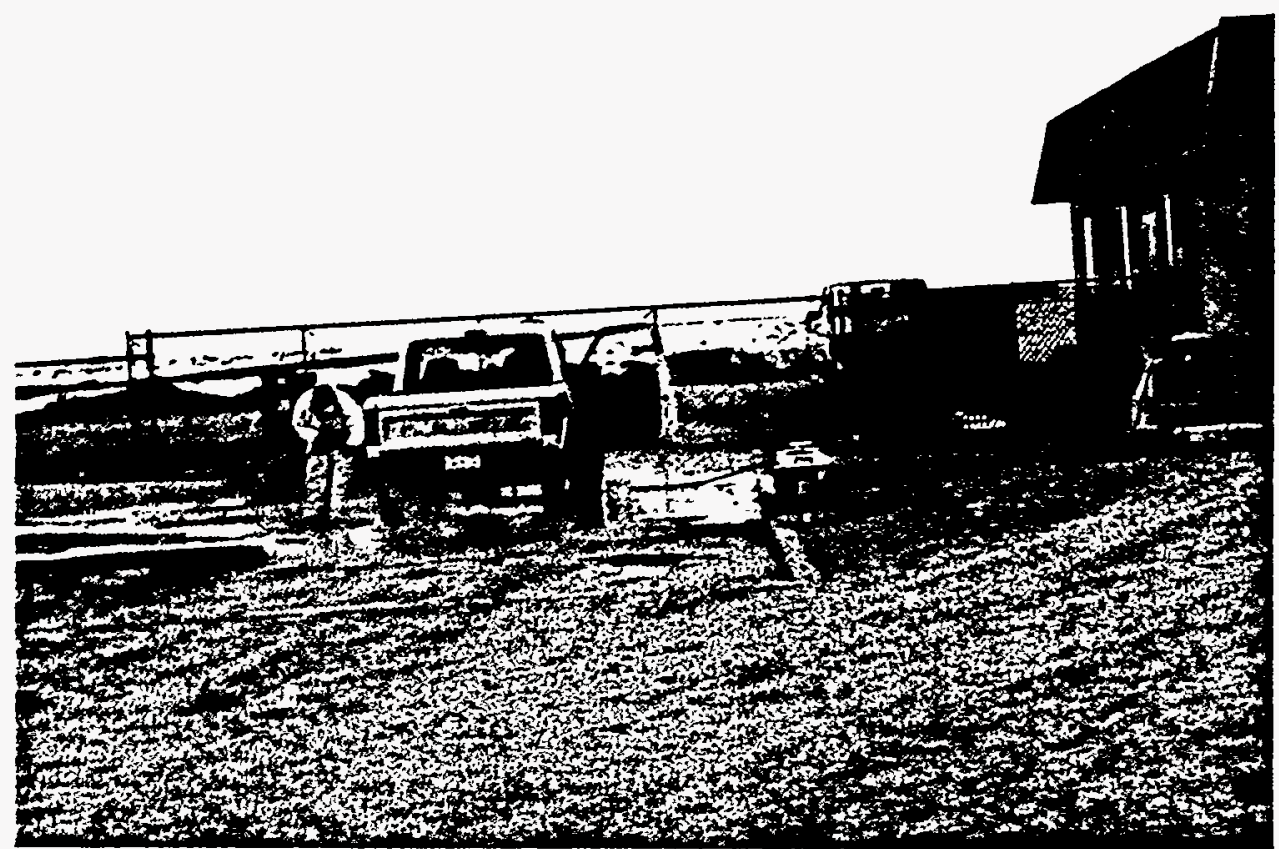

Figure 26. Envirocare truck wash station in March 1993.

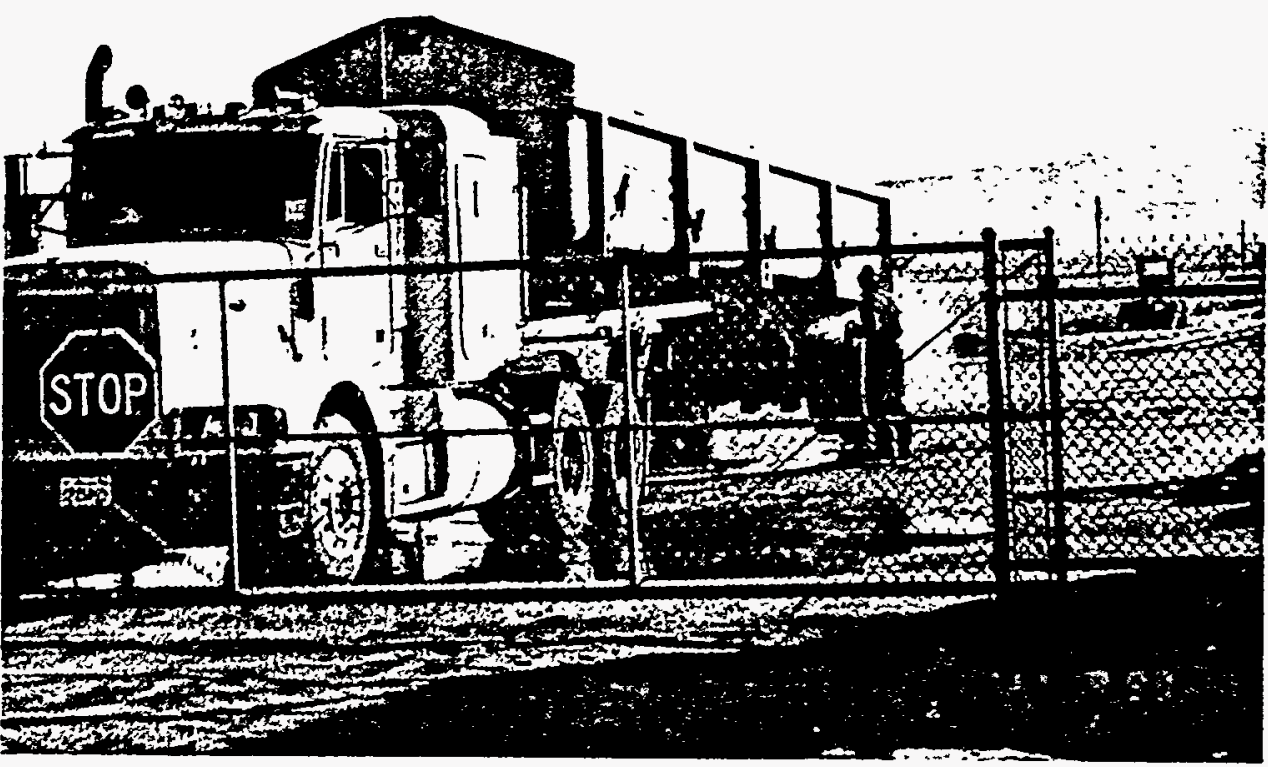

Figure 29. Envirocare truck wash station in November 1993. 


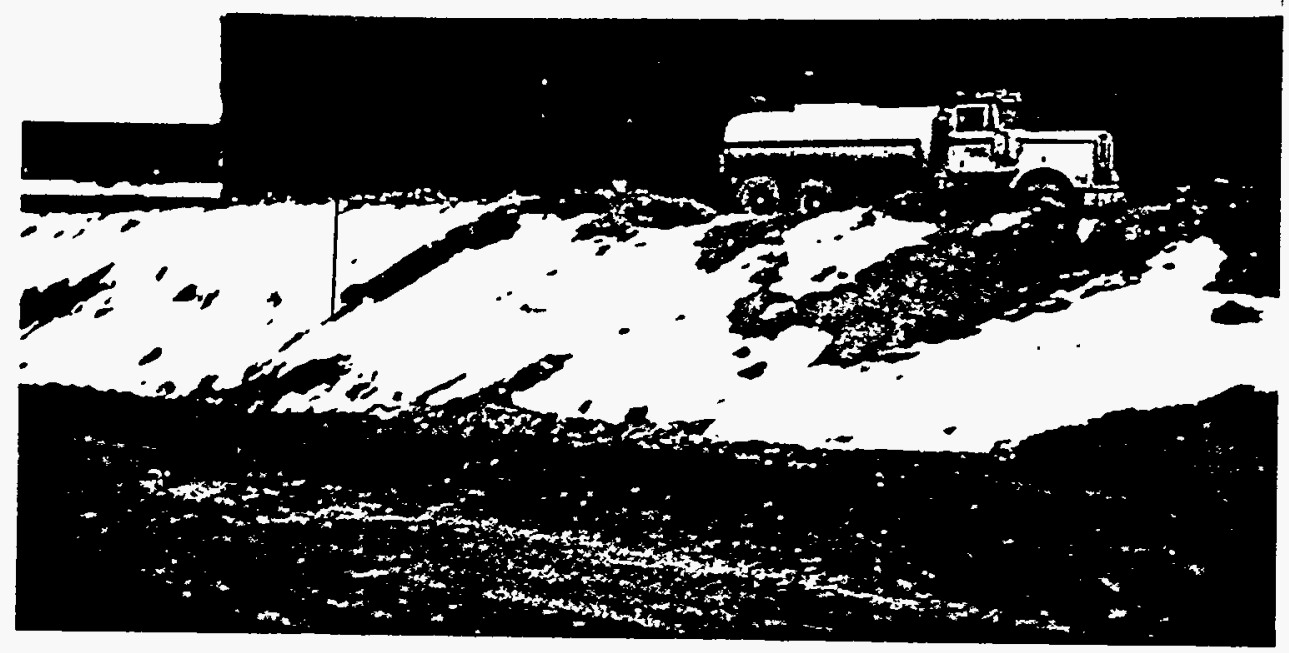

Figure 28. Envirocare rail car wash facility.

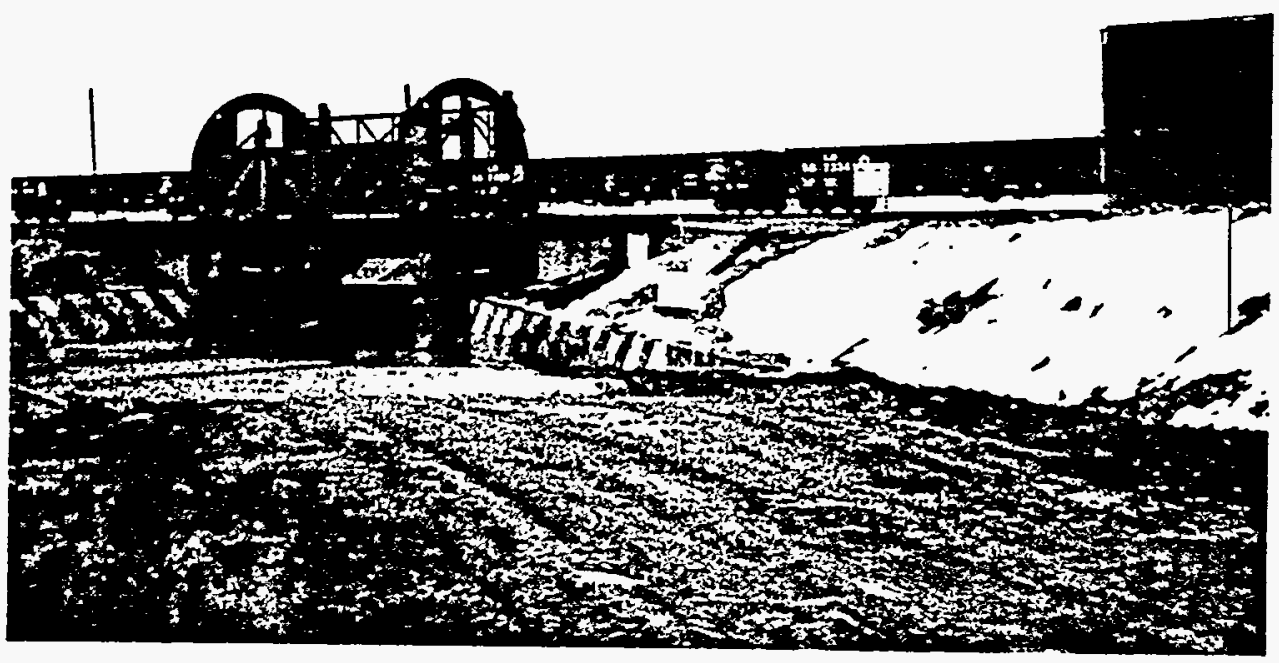

Figure 29. Rail car roll over equipment. Rail car wash facility is to the right. 
EGG-ESQ-10749

January 1994

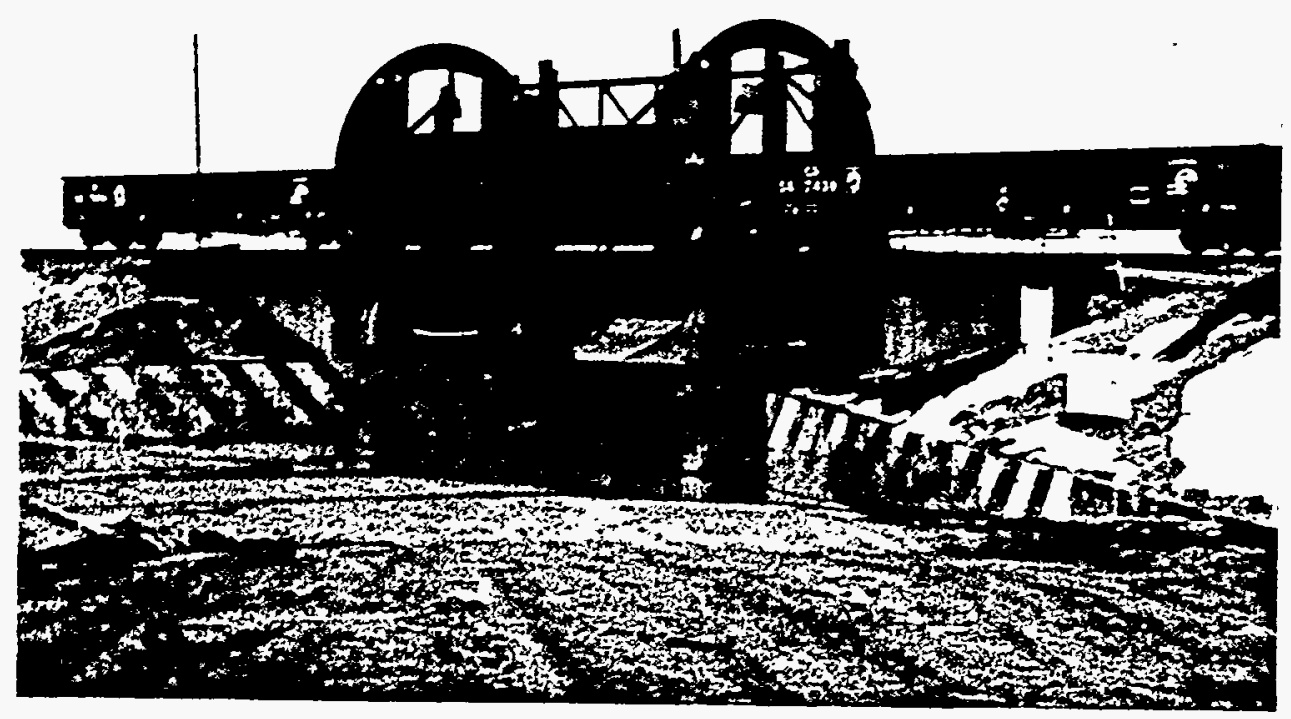

Figure 30. Closeup of the rail car roll over equipment and pit. Black liner on the slope is the HDPE.

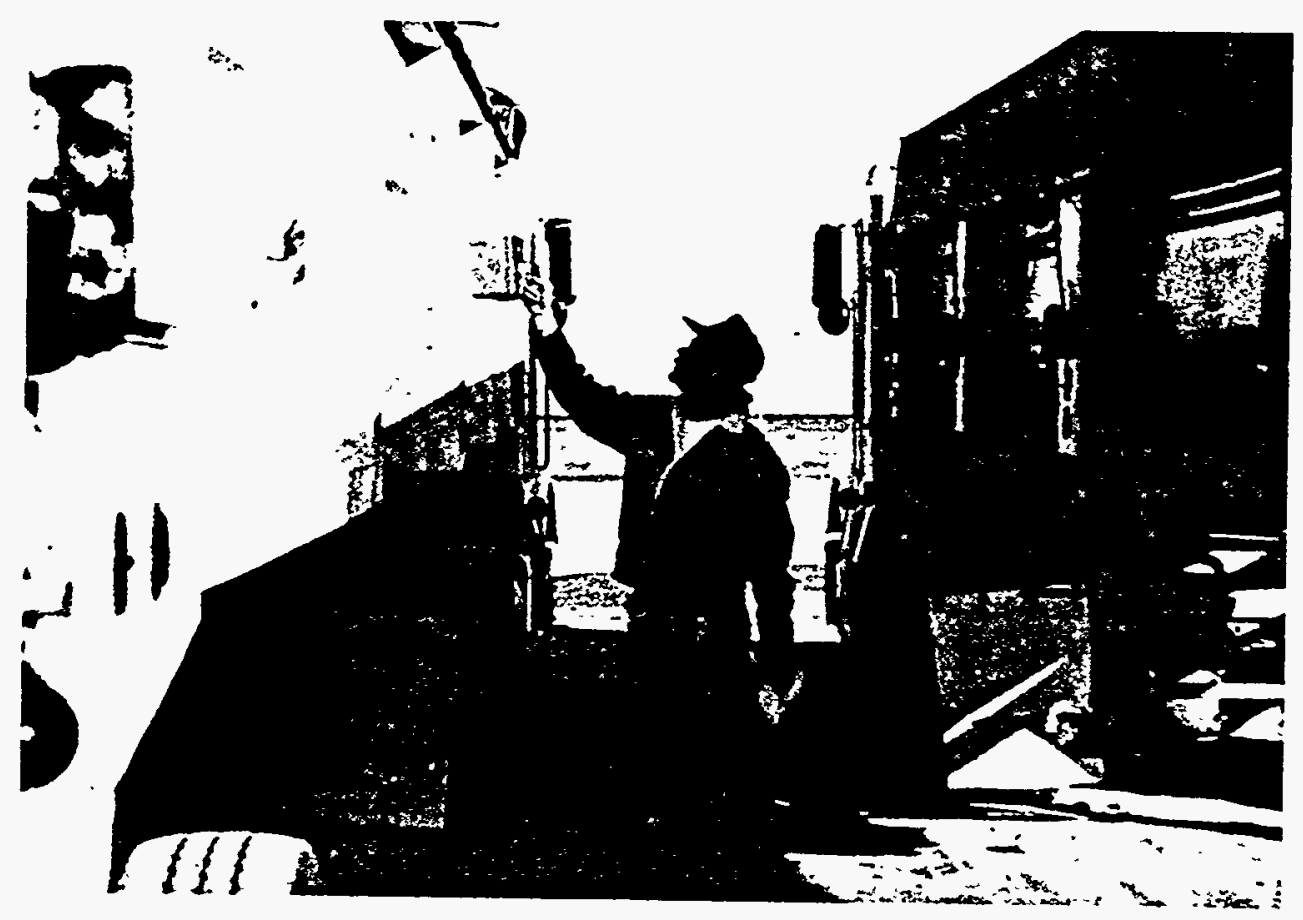

Figure 31. Inspecting an incoming load at the Envirocare facility. 


\subsection{Manifest System and Recordkeeping -- The manifest} system and recordkeeping procedures used during the transportation phase of a shipment, were discussed with Envirocare facility representatives during the Audit Master ${ }^{\text {M }}$ sessions conducted during the onsite portion of the liability assessment. The review of manifests and recordkeeping are described in Section 6.7.7. of this report.

6.1.7.2.5. Permits -- Envirocare does not operate interstate or intrastate transportation services for customers. Therefore, this section is not applicable.

\subsection{Spill Prevention and Cleanup Procedures -- Spill}

prevention and cleanup procedures, with respect to the transportation phase of a shipment, were discussed with Envirocare facility representatives during the Audit Master ${ }^{\mathrm{N}}$ sessions conducted during the onsite portion of the liability assessment

6.1.7.2.7. Truck Wash -- The INEL Assessment Team observed vehicles being washed at the truck wash facility during the March and November 1993 on site portion of the assessment (See Figures 26 and 27). A hose with a high pressure nozzle was used to dislodge mud and debris from the vehicles. The facility personnel were attired in appropriate personnel protective equipment (PPE), i.e., tyvex and respirators.

6.1.7.2.8. Rail Car Wash -- Operation of the rail car wash facility was not observed by the INEL Assessment Team during the March or November 1993 on site portions of the assessment.

\subsection{Rail Car Roll Over -- Operation of the rail car roll}

over was not observed by the INEL Assessment Team during the March or November 1993 on site portions of the assessment.

\subsubsection{Waste Analysis and Tracking System}

6.1.8.1. Process Description. Daily information regarding placement in the mixed waste landfill cell is recorded on an Envirocare internal form "ECO900." The ECO900 form documents placement of wastes coming from off-site 
or on-site sources. At the end of the day the EC0900 form is filed. Information from the ECO900 form may be transferred into a computer file as part of the permanent operating record. The title of that document is "The Storage Facility Location and Tracking Record (EC-0950)." Detailed information on the waste tracking system can be found in the Waste Identification and Tracking Plan.

Containerized Waste is labelled with a tracking number and placed into storage in the container storage area.

6.1.8.2. INEL Assessment Team Observations/Impressions. The separation of wastes according to generator and the tracking systems used for those wastes are one of the main selling points of Envirocare. The company stated that no mixing of wastes between generators occurs. Envirocare was able to demonstrate satisfactorily their capability in this area.

\subsection{WASTE DEScRIPTION}

\subsubsection{Process Description}

Envirocare generates multi-source leachate, contaminated wash water, sludge, and laboratory wastes as a result of its operations at the clive facility. The multi-source leachate is collected from the landfill cell system. The contaminated wash waters are the result of the truck and rail car wash operations. The sludge results from the treatment of rinse waters in the evaporation tanks or the collection of wash waters. The laboratory wastes include spent standards, sample analysis residuals, and rinse waters.

The facility also collects run-on and run-off waters in a lined pond. This water results primarily from precipitation. The pond is not a RCRA regulated surface impoundment. No RCRA/HSWA hazardous wastes are treated in it.

\subsubsection{INEL Assessment Team Observations/Impressions}

The INEL Assessment Team observed the RCRA regulated sludges in storage in the mixed waste storage facility. The sludges were awaiting treatment to meet the 
LDR. This treatment will not occur until the stabilization unit comes on line in 1994. Envirocare can store this material for up to one year. Nothing in storage was nearing the storage prohibition.

The laboratory wastes were collected in properly labeled SAA containers, including the outflow from the atomic absorption equipment. Characterization of this latter waste stream is often overlooked at facilities.

The run-off control pond was also observed. The pond was lined with a double layer of HDPE (Figure 32). The company has installed sprinkler heads in the pond to assist evaporation of the water (Figure 33 ). The facility representatives stated that they did have some problems with water fowl landing on the pond and had installed a cannon to scare the birds away. The birds now ignore the sound of the cannon. The INEL Assessment Team suggested that the company install decorative flags such as those automotive dealers use on their lots. The moving $f l a g s$ and shiny surfaces have proved successful in deterring birds from landing on surface impoundments at other commercial facilities. The facility representatives said that they would try that method along with several other options.

\subsection{Waste Management}

\subsubsection{Less Than 90 Day Storage}

A generator may accumulate hazardous wastes on site for 90 day or less without a permit or having interim status provided he meets the regulatory requirements specified by 40 CFR $\S 262.34(b, c)$.

6.3.1.1. Process Description. Envirocare operates four tanks which are managed as $<90$ day storage facilities. These tanks are described as follows:

$\begin{array}{lll}\text { General Classification } & \begin{array}{l}\text { Tank Capacity } \\ \text { Mominal/Horking(in } \\ \text { gallons) } \\ 5.000 / 4,400\end{array} & \begin{array}{l}\text { Material Stored } \\ \text { Mixed waste landfill cell } \\ \text { leachate }\end{array} \\ \text { Leak Detection } & 5.000 / 4,400 & \text { Leachate }\end{array}$




$\begin{array}{lll}\text { Truck Hash Down } & 2,000 / 1.700 & \text { Wash water } \\ \text { Rail Car Wash Down } & 2,000 / 1.700 & \text { Wash water }\end{array}$

The RCRA Part B permit requires that the tanks be emptied into the evaporation tanks at least every 90 days and only if the tank contains liquid waste. If the tanks are empty no action is required. In addition, the facility is required to manage these tanks in accordance with the Tank Management Plan which is contained in Section D of the Part $B$ Permit Application and as Attachment IV-1 of the RCRA Part B Permit.

6.3.1.2. INEL Assessment Team Observations/Impressions. The INEL Assessment Team observed the tanks which are designated as $<90$ day areas. In general, the tanks appeared to be well maintained and in good condition. However, it did not appear to the team that all of the regulatory requirements were being met. Inspections on the tanks in the $<90$ day storage area were performed but were not documented in the Inspection Log. The INEL Assessment Team recommended to the Envirocare management that they revisit the regulations in 40 CFR $\S \S 262.34$ and 265 Subpart $J$ to ensure compliance with those requirements.

During the November 1993 re-assessment, the Inspection Log showed required inspections of the $<90$ day storage tanks.

\subsubsection{Satellite Accumulation Areas}

A generator may accumulate as much as 55 gallons of hazardous wastes or one quart of acutely hazardous wastes as listed in 40 CFR $\S 261.33$ (e) in containers at or near the point of generation where the wastes initially accumulate, which is under the control of the operator of the process generating the waste, without a permit or having interim status provided he meets the regulatory requirements specified by 40 CFR $\S 262.34(c)$.

6.3.2.1. Process Description. Envirocare manages wastes generated as part of the laboratory processes in Satellite Accumulation Areas (SAA's). 
EGG-ESQ-10749

January 1994

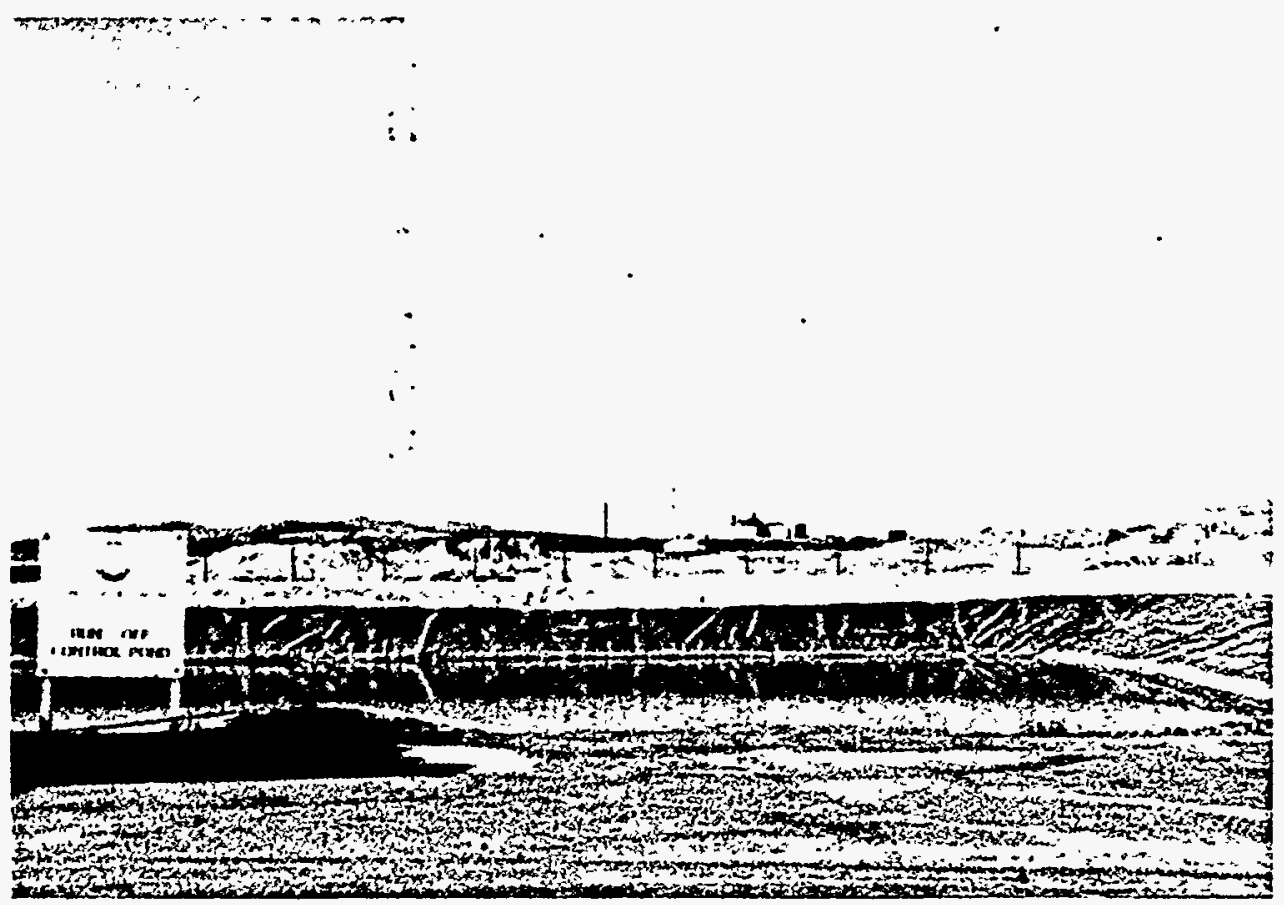

Figure 32. Run-off control pond at the Envirocare facility.

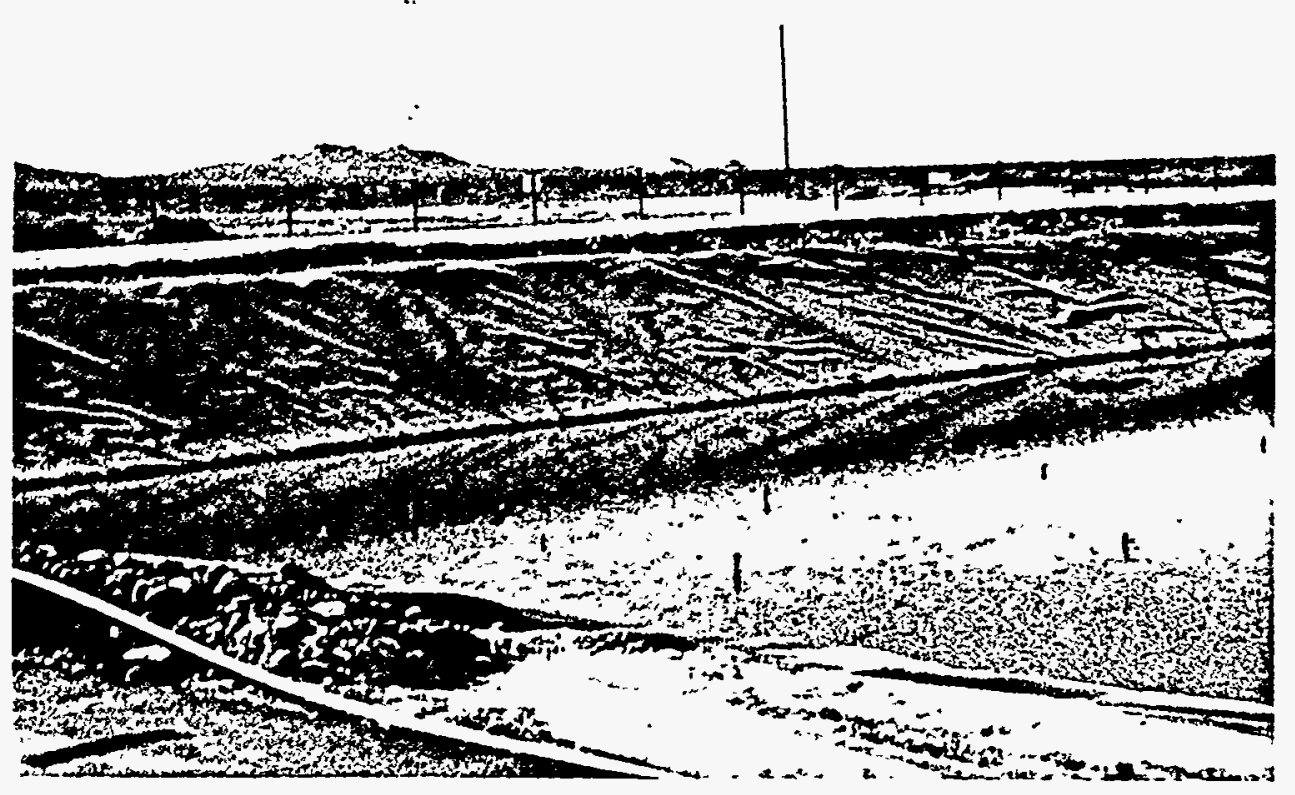

Figure 33. Sprinkler heads (black objects in the water) in the run-on control pond. 
6.3.2.2. INEL Assessment Team Observations/Impressions. The INEL Assessment Team noticed that a single container managed in the laboratory SAA was improperly labeled. A recommendation was made to Envirocare to revisit the requirements of 40 CFR 262.34 to ensure compliance with those requirements.

During the November 1993 re-assessment, all containers in SAA's were properly labeled.

\subsection{Regulatory COMpliance/Violations History}

\subsubsection{Violations History}

\subsubsection{Surmary of Violations.}

6.4.1.1.1. RCRA Violations -- Envirocare received two Notices of Violations (NOVs) from the State of Utah for RCRA issues since it received its Part B permit. These NOVs were issued September 20, 1991 and November 3, 1992. Both NOVs focused entirely upon observed multiple deficiencies in the groundwater monitoring program procedures and implementation. These deficiencies, and the NOVs based upon these were resolved, and no penalties were assessed by the State (See Appendix B, Table B-1).

Additionally, the State issued three Warning Letters. The first was issued on May 23, 1991 for "improper certification on permit submissions". The second was issued July 11, 1991 for "[e]xceeding limitations for initial gross excavation of landfill cell", and "[f]ailure to stop work and notify Executive Secretary upon encountering unexpected material during initial excavation". The third Warning Letter was issued January 5, 1993 for equipment within the container storage pad, inadequate sampling of incoming loads, and "failure to construct a permitted concrete waterway along the north side of the outdoor container storage pad". All warning letter issues are resolved to the State's satisfaction. Additionally, the issues raised in the NOVs and Warning Letters are not repeat issues. The groundwater issues which were the subjects of the NOVs did not recur, and are not subjects of the Warning Letters. 
6.4.1.1.2 Radiation Control -- Between 1988 and 1991 Envirocare received 43 NOVs from the Utah Division of Radiation Control. All but one was Class III or lower in severity, with the one exception being a Class II. Of the 43 NOVs, 14 were dismissed or reclassified as observations. Of the remaining 29, 16 were classified as "Other Violations", the lowest level of violation. No penalty assessments are noted, and the compliance history indicates that all issues were satisfactorily resolved by Envirocare.

\subsection{Air Quality Violations -- Envirocare received one NOV} for air quality violations in October, 1988 from the State of Utah. The violations were for fugitive dust control on unpaved roads and areas, record-keeping for water used for dust control, and installing water spray equipment. These were promptly resolved by Envirocare, and no penalty was assessed.

6.4.1.2. INEL Assessment Team Observations/Impressions. At the time of the March 1993 INEL assessment, operations were suspended because of the excessively wet weather. No observations were recorded with respect to air quality issues.

During the November 1993 re-assessment, fugitive dust appeared to be controlled. The roadways were sprayed with water on a regular basis. No fugitive dust was apparent on any of the disposal cells.

\subsubsection{RCRA Remediation/Corrective Actions}

No RCRA remediation/corrective actions have been identified for the $\mathrm{Clive}$, UT facility. Envirocare facility representatives stated that the company is not involved in any RCRA remediation/corrective actions at any other facility in the country. Therefore, this section is not applicable.

However, the State of Utah Bureau of Solid and Hazardous Waste did identify the following solid waste management units (SWMUs) at the Envirocare facility as part of the RCRA Part B Permit: NORM landfill cell, NORM operation staging area, rail car roll-over, outdoor vehicle wash down area, rail car/backhoe unloading ramp, indoor vehicle wash down area, rail car wash down area tank 
sump, and the Utah Bureau of Radiation Control open burn container. The State has not provided a corrective action compliance schedule for these SWMUs. No action is required at this time.

\subsubsection{CERCLA Remediation/Corrective Actions}

No CERCLA remediation/corrective actions have been identified for the Clive, UT facility. Envirocare facility representatives stated that the company is not involved in any CERCLA remediation/corrective actions at any other facility in the country. This is supported by statements of EPA, Region VIII, contacts who indicated that they were unaware of any CERCLA activities at the Envirocare Clive, UT site. Therefore, this section is not applicable.

\subsubsection{Pending Litigation}

A LEXIS/NEXIS database query and discussions with regulatory agencies were used to identify any pending litigation which might impact Envirocare's ability to perform under the proposed subcontract. There was no pending litigation involving either Envirocare of Utah, Inc. or the Envirocare Clive, UT TSDF, as a party identified at the time of the assessment. Therefore, this section is not applicable.

\subsubsection{Involvement at "Superfund" Sites}

Envirocare facility representatives stated that the company is not involved as a potentially responsible party (PRP) in any "Superfund" cleanup actions at its own or any other facility in the country. This statement was verified through discussions with the regulatory agencies. Therefore, this section is not applicable.

\subsection{ENVIRONMENTAL InCIDENTS}

\subsubsection{Summary of Incidents}

No environmental incidents have been recorded for the Envirocare facility and none were observed by the INEL Assessment Team at the time of the inspection. 


\subsubsection{INEL Assessment Team Observations/Impressions}

The Envirocare facility appeared to be run in an environmentally responsible manner. One might be concerned about the large amounts of material accumulated on the LLW and NORM storage pads during winter or inclement weather and were awaiting better weather for disposal into the appropriate cells. The storage before disposal issue should be re-visited by the team when the facility is operating.

During the November 1993 re-assessment, no waste was observed on the storage pads. The facility appeared to be operating smoothly and efficiently.

\subsection{Facility Management Attitudes}

\subsubsection{Contingency Plan}

RCRA 40 CFR $\S \S 264$, Subpart $D$ and 265 , Subpart $D$ require that the owners and operators of all hazardous waste facilities must prepare and implement a contingency plan for the facility. This plan is designed to minimize hazards to human health or the environment from fires, explosions, or any unplanned sudden or non-sudden release of hazardous waste or hazardous waste constituents to the air, soil, or surface water.

6.6.1.1. Process Description. Envirocare maintains a contingency plan for the Clive, UT facility. The contingency $p l a n$ also constitutes module II- 6 of the State of Utah issued RCRA Part B Permit.

6.6.1.2. INEL Assessment Team Observations/Impressions. The contingency plan was reviewed and generally met the conditions of the Part B permit. The equipment and associated locations were listed. However, the list of capabilities of emergency equipment was not present. A recommendation was made to Envirocare to revisit the requirements of 40 CFR $\S 264.52$.

Subsequent to the March 1993 assessment (November 3, 1993), Envirocare held a mock emergency drill which activated the contingency plan. The company then critiqued the drill and made recommendations for improvements. The INEL 
Assessment Team received a copy of the critique. It appeared to be a very honest assessment of the drill. Deficiencies in training was the most important issue identified.

\subsubsection{Employee Training Program}

RCRA 40 CFR $\S \S 264.16(a)$ and 265.16(a) state that "Facility personnel must complete a program of classroom instruction or on-the-job training that teaches them to perform their duties in a way that ensures the facility's compliance with the requirements of this part [40 CFR 264]..."

6.6.2.1. Description of Process. Envirocare has developed and implemented a personnel training plan which is required by 40 CFR $\S \S 264.16$ and 270.14(b)(12). The training $\mathrm{plan}$ addresses introductory orientation training, on-the-job training, classroom instruction and training, and the annual review training. The $\mathrm{plan}$ discusses which level of personnel must take each type of training. It describes the content of each level of training. The plan contains forms which. must be signed by the both the employee and supervisor documenting the completion of the various levels of training. These documents are kept as part of the operating record.

The introductory orientation training includes basic personnel safety guidelines, preparedness and prevention, use and maintenance of safety - equipment, and specific Contingency $P l$ an training. The on-the-job training program requires the individual to complete the introductory orientation training, and then continues with additional details in each of the subject areas. The annual refresher addresses the basic personnel safety guidelines of the introductory training and adds a an unannounced contingency $p l a n$ implementation drill to the session. 
Table 4. Envirocare training program outline

\begin{tabular}{|c|c|c|}
\hline \multirow{3}{*}{ VISITOR } & ESCORTED & A \\
\hline & & \\
\hline & NON-ESCORTED & A $B$ \\
\hline \multirow{3}{*}{$\begin{array}{c}\text { HOH-WASTE HANAGEMENT } \\
\text { WORKER }\end{array}$} & 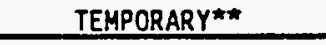 & A C \\
\hline & & \\
\hline & PERMANENT & A B H \\
\hline \multirow{3}{*}{$\begin{array}{l}\text { WASTE MANAGEMEHT } \\
\text { WORKER }\end{array}$} & TEMPORARY/SUPERVISED & $B E F(45$ days $) G H(M W:+D)$ \\
\hline & PERMANENT/SUPERVISED & $B E F(6$ months $) G H(M H:+D)$ \\
\hline & UNSUPERVISED & $B E F G H \perp J K(M W:+D)$ \\
\hline
\end{tabular}

A. Factlity Entrance Training*

B. 40-hour training and 3-day supervised field experience

C. 24 hours of Safety Training and 1 day supervised field experience

D. Hixed Waste Horker must also receive Hazardous Haste Physical = $(M W:+0)$

E. 2 hours Mixed Waste Introductory Orientation Training

F. 10 hours of Mixed Waste Classroom Training and documentation of Mixed Waste On-the-Job Training within 6 months of hire date or 45 days for temporary worker (may be part of $40-h r$ Safety Training)

G. 3 hours Radiation Safety Training (may be part of 40 -hr Safety Training)

H. Bioassay Annually

I. 4 hours of Mixed Waste Refresher Training Annually

J. 4 hours of Safety Refresher Training Annually

K. 1 hour of Radiation Refresher Training Semiannually (may be part of 4-hour Safety Refresher Training

- Includes Entrance Training for Safety. Radiation Safety. Mixed Waste, Low-Activity Waste and Hazard Communication

** Temporary Employees are personnel not directly employed by Envirocare or its prime contractor. Limited to: 7-day Authorization. Twice Renewable.

In March 1993 respirator training was not conducted in house. Industrial Health, Inc., a Salt Lake City firm, conducted the respirator qualification and annual respirator fit tests. Subsequently Envirocare established an in house respirator training and fit testing program, which was in place during the November 1993 re-assessment. 
Radioactive/hazardous waste operations workers are fit in half-face and fullface respirators. Emergency Responders are fit in half-face and full-face respirators, and self contained breathing apparatus (SCBA's).

\subsubsection{INEL Assessment Team Observations/Impressions. The INEL} Assessment Team evaluated the implementation of the training program and employee records documentation. The training $p l a n$ and program appeared to address all of the 40 CFR $\S \S 264.16$ and 270.14 (b)(12) regulatory requirements, we well as, the OSHA safety requirements. The employee records were undergoing a revision at the time of the inspection. The INEL Assessment Team identified several sets of records that appeared not to be complete. The facility representatives were made aware of this and stated that they would review the records for completeness.

The records were reviewed again during the November 1993 re-assessment. The QA officer had recently re-vamped much of the training record keeping in accordance with NQA-1. The training $p 7$ an was being re-written and would be submitted as part of a major RCRA Part B Permit modification. This plan was being revised to meet the NQA-1 requirements. The training program appeared to be more vigorous than previously observed. The training records were much easier to follow and appeared to be more accurate. A suggestion was made by the INEL Assessment Team to place the appropriate job description in each employee's training file. This would make the RCRA required training records complete in one rocation.

\subsubsection{Inspections}

RCRA 40 CFR §§ 264.15(a) and 265.15(a) states that "The owner or operator must inspect his facility for malfunctions and deterioration, operator errors, and discharges which may be causing -- or may lead to -- (1) releases of hazardous waste constituents to the environment or (2) a threat to human health."

6.6.3.1. Process Description. Daily and weekly inspections are required as conditions of the Part B permit. Envirocare has prepared a Site Inspection Plan as part of its Part B Permit Application. This plan was incorporated into the Part B permit as Module II-3 by the State of Utah. 
6.6.3.2. INEL Assessment Team Observations/Impressions. A review of inspections performed by Envirocare indicated that the conditions of the Part $B$ Permit were being met. The inspection reports were kept as part of the site operating record, except for the $<90$ day tank storage. This deficiency was discussed with the facility representatives.

The only noted deficiency for the $<90$ day tank storage inspections was corrected when the facility was re-assessed in November 1993.

\subsubsection{Occupational Safety}

OSHA 29 CFR 1910.120(p) requires that employers conducting operations at a TSDF are required to have a safety program and a medical surveillance program. This program is commonly referred to as the Hazardous Waste Operations and Emergency Response (HAZWOPER) training, 40- or 24-hour OSHA training, and 8hour OSHA refresher.

6.6.4.1. Safety Program. Requirements for the OSHA safety program are specified in 29 CFR $\S \S 1910.120(b)$ and $1910.120(p)(1)$. Requirements for the hazard communication program are specified at 29 CFR 1200.

6.6.4.1.1. Process Description -- Envirocare has rolled the OSHA safety program and hazard communication requirements into the personnel training $\mathrm{plan}$ which is required by 40 CFR $\S \S 264.16$ and 270.14 (b)(12). The training $\mathrm{plan}$ is maintained as Module II-4 of the RCRA Part B Permit.

\subsection{INEL Assessment Team Observations/Impressions -- The} personnel safety requirements were reviewed with respect to implementation of the training program and employee records documentation. The training plan and program appeared to address the OSHA safety requirements. The employee records were undergoing a revision at the time of the March 1993 inspection and were not complete. The facility representatives were made aware of this and stated that they would review the records for completeness. 
The INEL team made the following observations regarding the implementation of the OSHA safety and hazard communication requirements during the inspection of the facility operations:

- Facility personnel were observed to be wearing appropriate personnel protective equipment (PPE) during routine operations (See Figures 26 and 27).

- Warning signs and special facility safety requirements were posted on the entrances to active portions of the facility (Figures 34 and $35)$.

- Safety equipment, such as eye wash stations and safety showers were well located, maintained, and free of obstructions (Figures 36 and 37). Evaluation of the inspection records indicated that the inspections of the equipment was current. Eye wash stations had the protective eye cups in place.

- Hazard communication labels were prominently displayed where required (Figures 38 and 39 ). It was suggested to the facility representatives that hazard communication labels be placed on the $<90$ day tanks for an additional measure of safety.

6.6.4.2. Medical Surveillance. Requirements for the medical surveillance program are specified in 29 CFR 1910.120(f) and 29 CFR $1910.120(p)(3)$.

6.6.4.2.1. Process Description -- Envirocare has a medical surveillance program in place for facility personnel. The program consists of annual physical examinations for all employees and annual bioassays for radioactive/hazardous waste operations workers. The physical examinations and bioassays are performed by medical facilities in Salt Lake City. Envirocare does not have a medical surveillance program on site.

6.6.4.2.2. INEL Assessment Team Observations/Impressions -- The medical surveillance program was discussed with facility personnel. The INEL 
Assessment Team did not review any medical records as part of the March 1993 assessment. However, it did appear that the program was in place and was effective.

During the November 1993 re-assessment medical surveillance records were reviewed. All records reviewed appeared to be accurate.

\subsubsection{Preparedness and Prevention}

The RCRA regulations promulgated by 40 CFR $\S \S 264$, Subpart $C$ and 265 , Subpart $C$ specify requirements for the design and operation of the facility, required equipment, testing and maintenance of equipment, access to communications or alarm system, required aisle space, and arrangements with local authorities for owners and operators of all hazardous waste facilities, unless they meet the exemptions specified in 40 CFR $\S \S 264.1$ or 265.1 . The requirements are stated and INEL observations of the facility and its operations are discussed as follows:

6.6.5.1. Design and Operation of Facility. 40 CFR $\S \S 264.31$ and 265.31 state that "Facilities must be designed, constructed, maintained and operated to minimize the possibility of a fire, explosion, or any unplanned sudden or non-sudden release of hazardous waste or hazardous waste constituents to air, soil, or surface water which could threaten human health or the environment."

6.6.5.1.1. Process Description -- The procedures to prevent hazards in the design and operation of the facility are described in the RCRA Part $B$ Permit Application, Section F and the RCRA Part B Permit Attachment II-5. Addition plans which address specifics such as security and inspections are maintained as separate appendices.

\subsection{INEL Assessment Team Observations/Impressions -- The} Envirocare facility has a distinct advantage over many TSDFs in that it is a new facility and was constructed to meet the RCRA requirements, rather than being retrofit to meet the requirements. Observations of the operations suggest that the facility is designed and operated safely. 


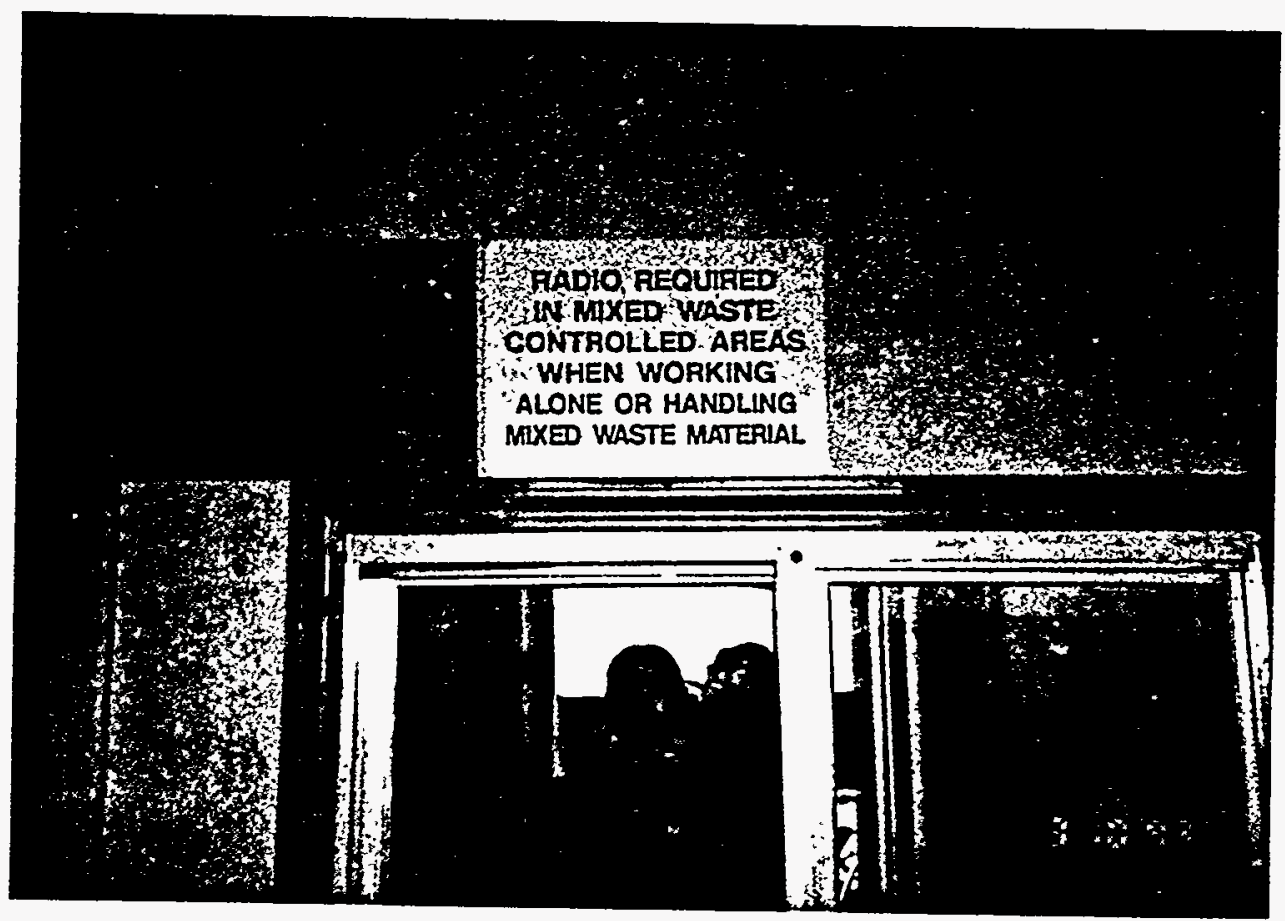

Figure 34. Warning sign and special safety equipment requirement posted outside entrance to the active portion of the MW storage facility.

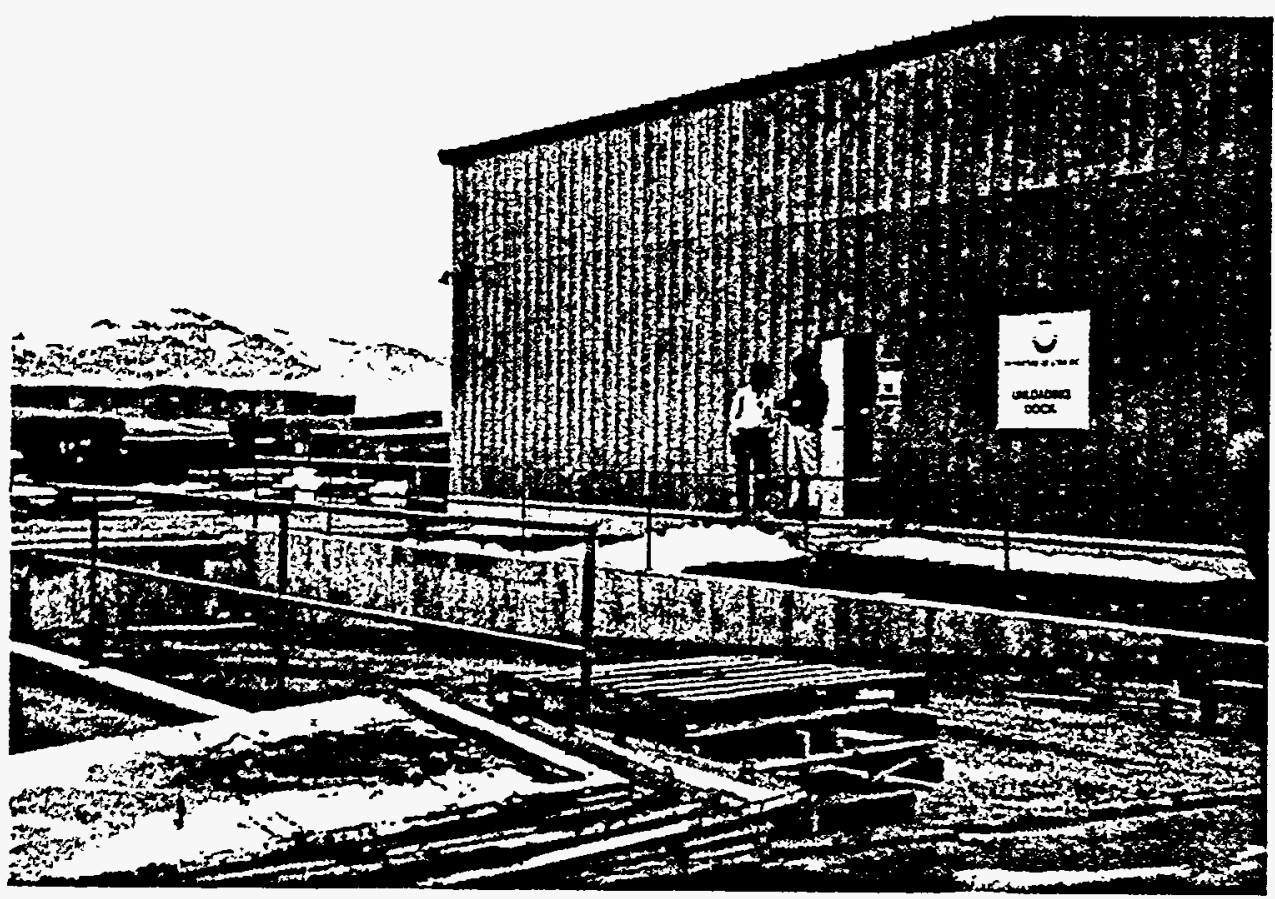

Figure 35. Warning signs posted outside the loading dock entrance to the MW storage facility. 


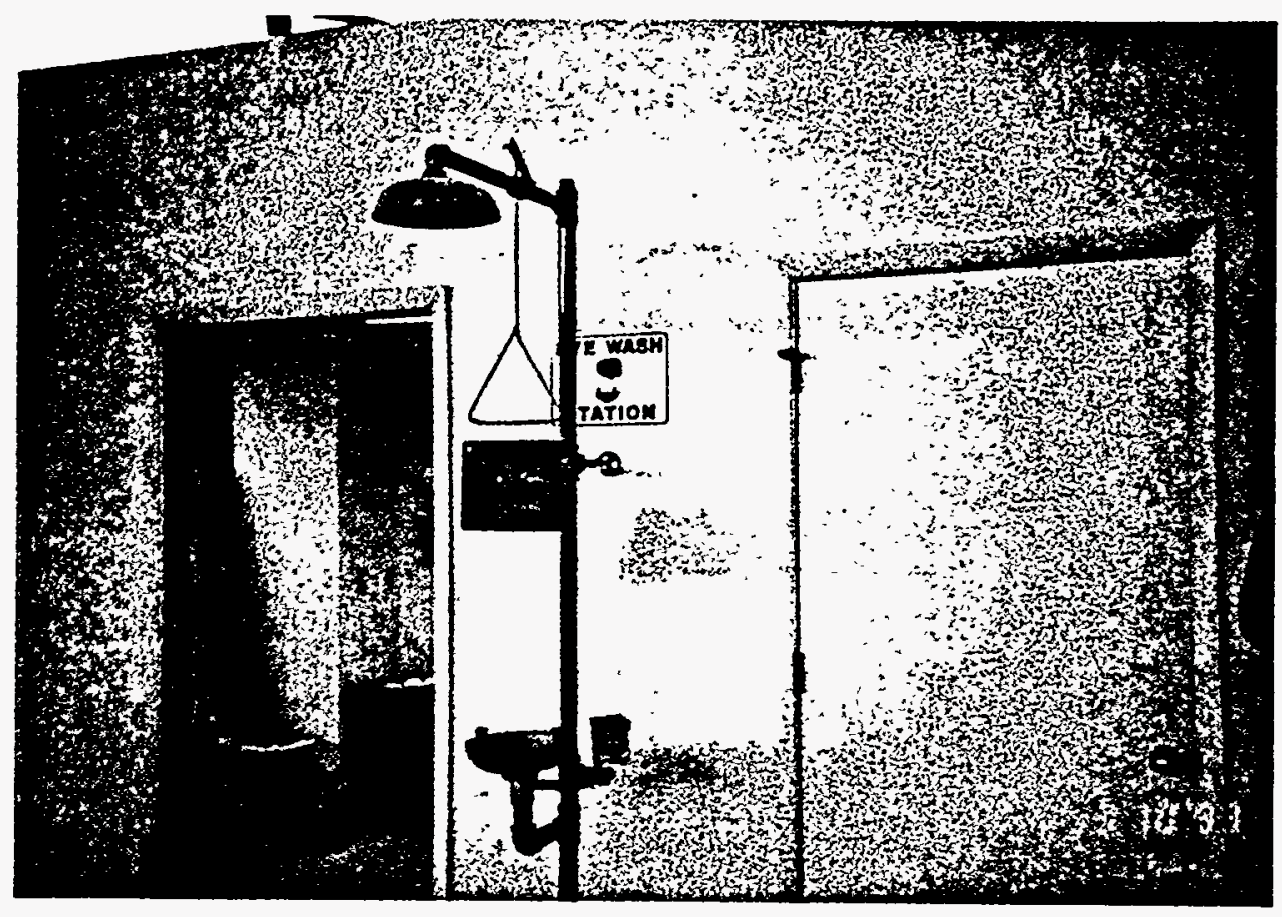

Figure 36. Safety shower and eye wash station located within the active area of the MW storage facility. Locker room is in the background.

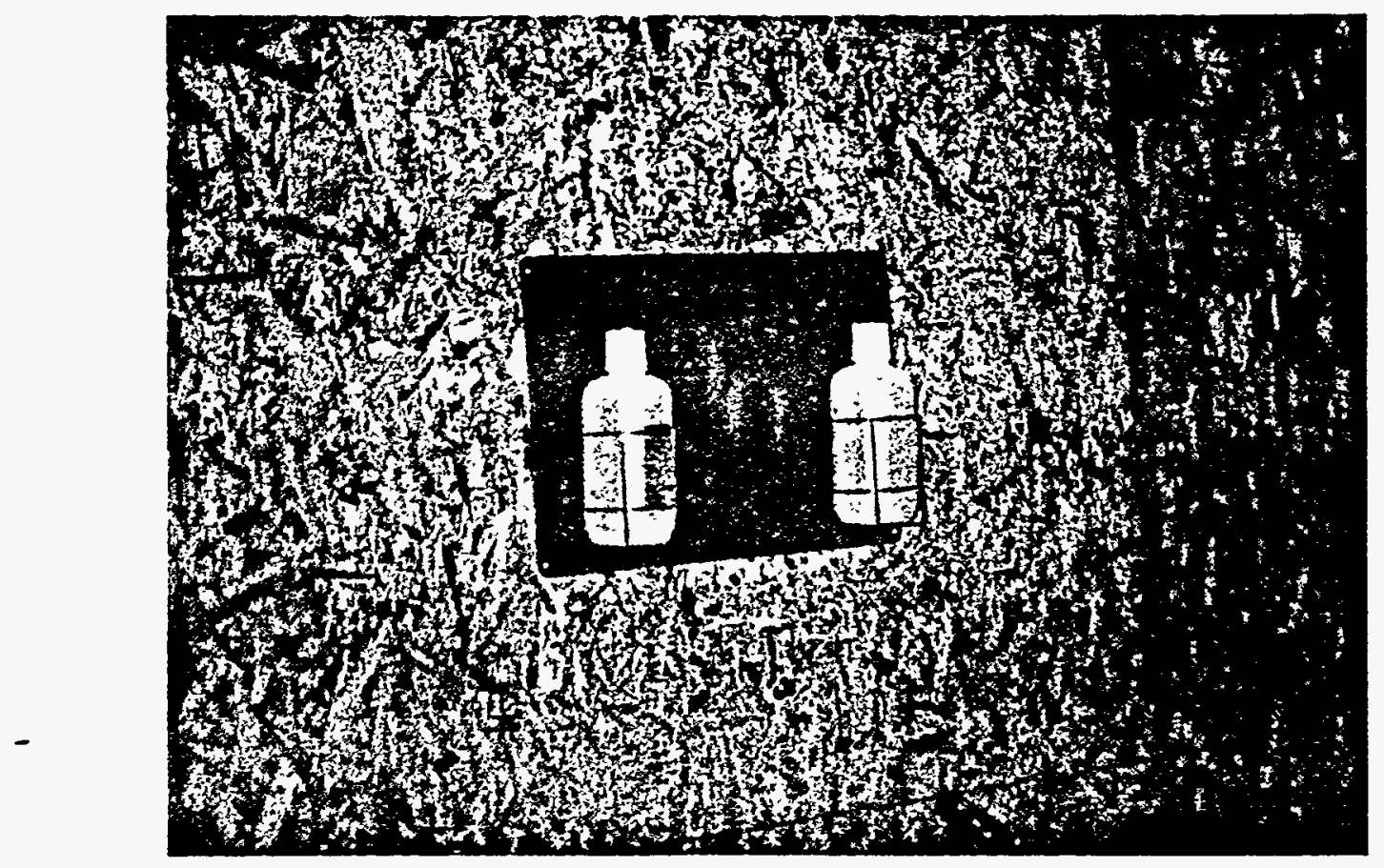

Figure 37. Portable emergency eye wash station. 


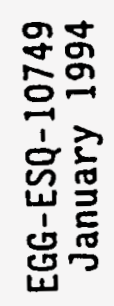
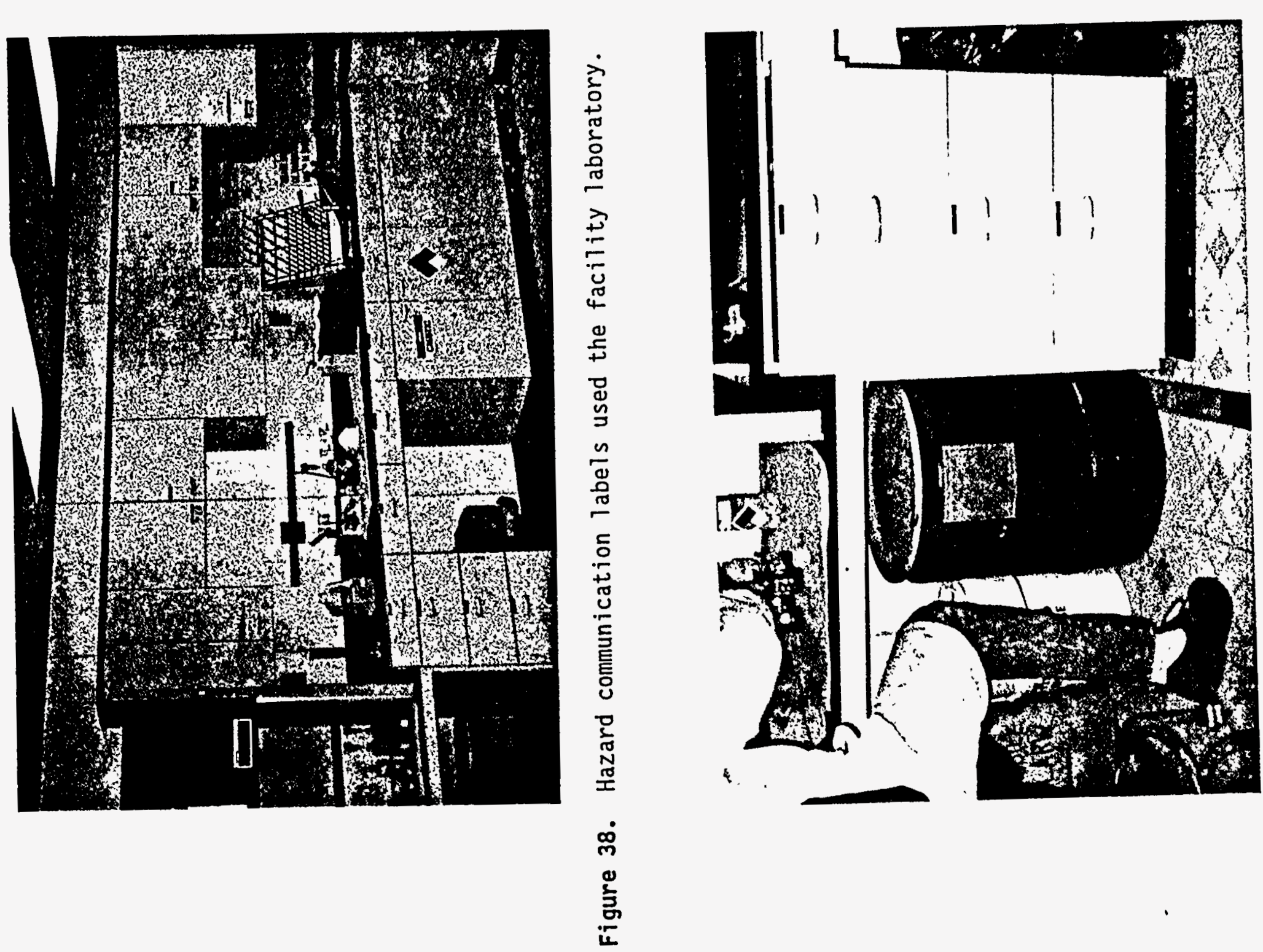

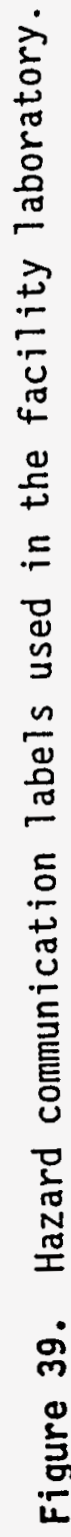


6.6.5.2. Required Equipment. 40 CFR $\S \S 264.32$ and 265.32 state that the facilities must be equipped with the following equipment: internal communications or alarm system, telephone or two-way radio, portable fire extinguishers, and water at adequate volume and pressure.

\subsection{Process Description -- Envirocare has internal and} external communications, alarm systems, telephones and two-way radios, emergency lighting in the MW container storage facility, portable fire extinguishers, and access to water at the Clive facility.

\subsection{Communications -- Two-way radios are used primarily} for on-site communications. The radios have enough range to reach each area of the site at any time. At a minimum the site manager and one of the facility supervisors have access to the radios to contact the base station. The base station is located so that the operator can immediately activate an audible alarm in the case of an emergency. The base station is also equipped with a telephone for external communication. The system is inspected monthly.

Envirocare has a functional microwave telephone system at the site. This telephone system has a Salt Lake City base and number. The system allows site personnel to establish immediate communication and notification of local police departments, fire departments, or State and Local Emergency Response Teams. Emergency numbers are posted near all phones.

6.6.5.2.1.2. Fire Control -- At the present time Envirocare has access to water from a well located just north of I-80. Envirocare has stated in the Part B Permit Application that it will keep a minimum of 5,000 gallons of water in a retention basin for emergency fire protection purposes. The facility has a gasoline-powered pressure washer and hose rig that can pump the water to extinguish fires.

The facility has portable $A B C$ fire extinguishers placed in strategic locations around the site.

6.6.5.2.2. INEL Assessment Team Observations/Impressions -Emergency response equipment was discussed with the facility representatives 
as part of the solid and hazardous waste Audit Master session. The equipment was also observed in place during the facility inspections.

6.6.5.3. Testing and Maintenance of Equipment. 40 CFR $\S \S 264.33$ and 265.33 state that "All facility communications or alarm systems, fire protection equipment, spill control equipment, and decontamination equipment, where required, must be tested and maintained as necessary to assure its proper operation in time of emergency."

6.6.5.3.1. Process Description -- Conditions of the Part B permit require weekly inspections of external alarms systems, fire protection equipment, etc.

\subsection{INEL Assessment Team Observations/Impressions -- A} review of the weekly inspection $\mathrm{log}$ indicated the conditions of the Part $B$ Permit were being met for testing and maintenance of equipment. Observations of fire extinguishers during the facility inspection revealed that inspections were current.

The INEL Team had a concern about spill control equipment. During the facility inspection, especially within the MW container storage building, the INEL Assessment Team looked for the spill control kit. This equipment is generally kept under control in a labeled cabinet or area. The Team did not see any thing identified as such. The facility representatives were queried about the situation and they stated that the equipment was kept with materials in a cage in the corner. The INEL Assessment Team suggested to the facility management and representatives that they might want to re-consider this decision as there did not appear to be good controls on what constituted a spill control kit and its contents. The contents of the spill kit is generally checked by regulatory inspection teams and frequently constitutes a finding when an item is missing from the kit.

As previously discussed in Section 6.6.1.2. the capabilities of the emergency equipment were missing from the Contingency Plan. The INEL Assessment Team suggested to the facility management that they should review the spill kits with respect to the Contingency Plan as well. 
During the November 1993 re-assessment, the spill kits were noted. The company had purchased pre-fabricated spill kits for the mixed waste storage facility.

\subsubsection{Access to Communications or Alarm Systems. 40 CFR $§ \S 264.34$} and 265.34 state that whenever hazardous waste is being poured, mixed, spread, or otherwise handled, all personnel involved in the operation must have immediate access to an internal alarm or emergency communication device,.... In addition if there is ever just one employee on the premises while the facility is operating, he must have immediate access to a device, such as a telephone,....

\subsection{Process Description -- Instructions to evacuate the site} can be provided in one or more of the following ways as deemed necessary by the Emergency Action Director (EAD). The signal for evacuation is a continuous sounding of the alarm. The alarm is an audio signal operated by a switch in the MW container storage building. The alarm is audible in the MW landfill cell, MW container storage and evaporative tank area. The alarm also provides a visual warning light for the landfill cell area when the landfill cell is active (Figure 40). The EAD may initiate or accomplish site evacuation by verbal command to site personnel to evacuate. The EAD may give evacuation instructions over the two-way radio or other available internal communication system.

Envirocare requires all personnel to work in teams of at least two individuals. This is to ensure that if an emergency were to occur, one or the other of the team members could notify the EAD. Each team is equipped with a two-way radio and is instructed in its proper use.

\subsection{INEL Assessment Team Observations/Impressions -- The} emergency alarms systems were observed during the site inspection. Facility personnel were also observed to be working in teams with at least one radio between them. This "buddy system" is a company requirement.

6.6.5.5. Required Aisle Space. 40 CFR $\S \S 264.35$ and 265.35 state that "The owner or operator must maintain aisle space to allow the unobstructed 
movement of personnel, fire protection equipment, spill control equipment, and decontamination equipment to any area of facility operation in an emergency, unless it can be demonstrated to the Regional Administrator that aisle space is not needed for any of these purposes."

6.6.5.5.1. Process Description -- The RCRA Part B Permit Condition II.J.4. requires 2.5 feet of aisle space between the rows of containers. All containers are stored up off the ground on pallets or runners. The RCRA Part B Permit Application prepared by Envirocare states that containers are required to be stored with at least two feet of aisle spacing between drums on pallets in neighboring rows.

6.6.5.5.2. INEL Assessment Team Observations/Impressions -- The MW container storage area was neat and well kept (Figure 41). The containers meet the required aisle spacing requirements of the Permit. The operating records and inspections records were reviewed and no deficiencies found. The INEL Team did observe water running through the container storage facility. The room in which the containers are stored is adjacent to a truck wash and water from the truck wash was flowing under the door and into the room. The floor in the container storage room is sloped to a floor drain (Figure 42). The drain empties into a sump which is then pumped to the evaporation tanks. The water flow was discussed with the facility representatives who stated that they would have the facility supervisor check the door seals.

The door seals had been modified by the time of the November 1993 reassessment. All customer wastes which were in storage during the March 1993 assessment, had been disposed of before the re-assessment. The only wastes still in storage were sludges generated by Envirocare. These wastes were awaiting treatment to meet the LDR's. The containers holding the sludge were labeled and appeared well managed.

6.6.5.6. Arrangements with Local Authorities. 40 CFR $\S \S 264.37$ and 265.37 state that the owner or operator must make arrangements with local emergency authorities and State emergency response teams to familiarize them with the layout of the TSDF, the hazardous waste handled there, and the 


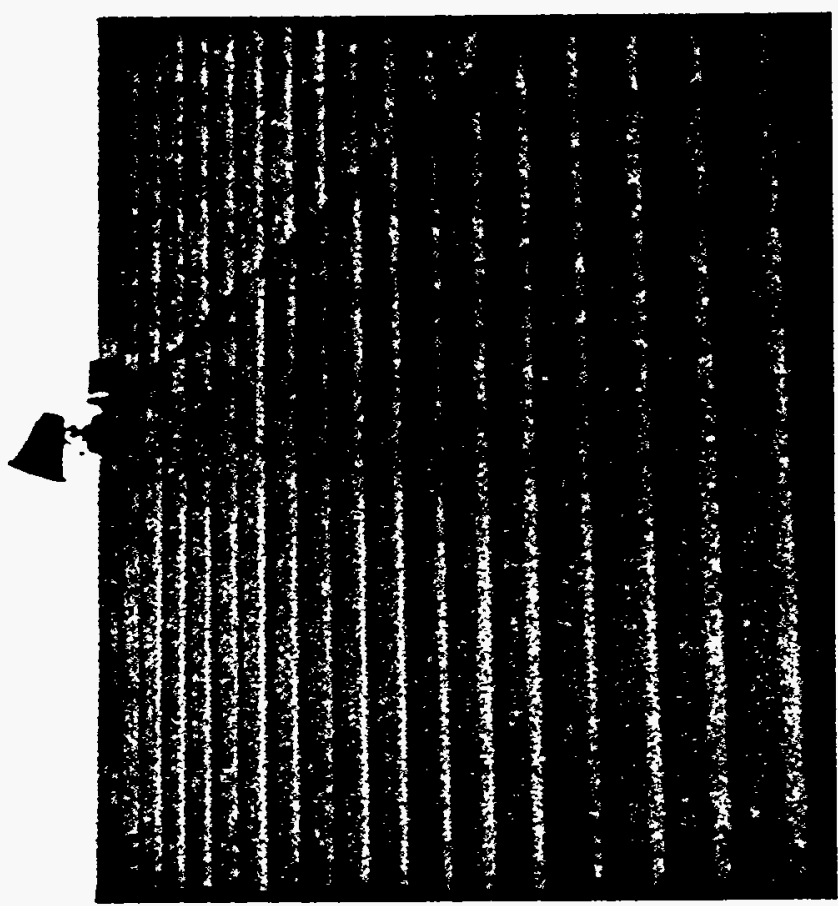

Figure 40. Alarm and visual warning light located at the MW storage facility. 


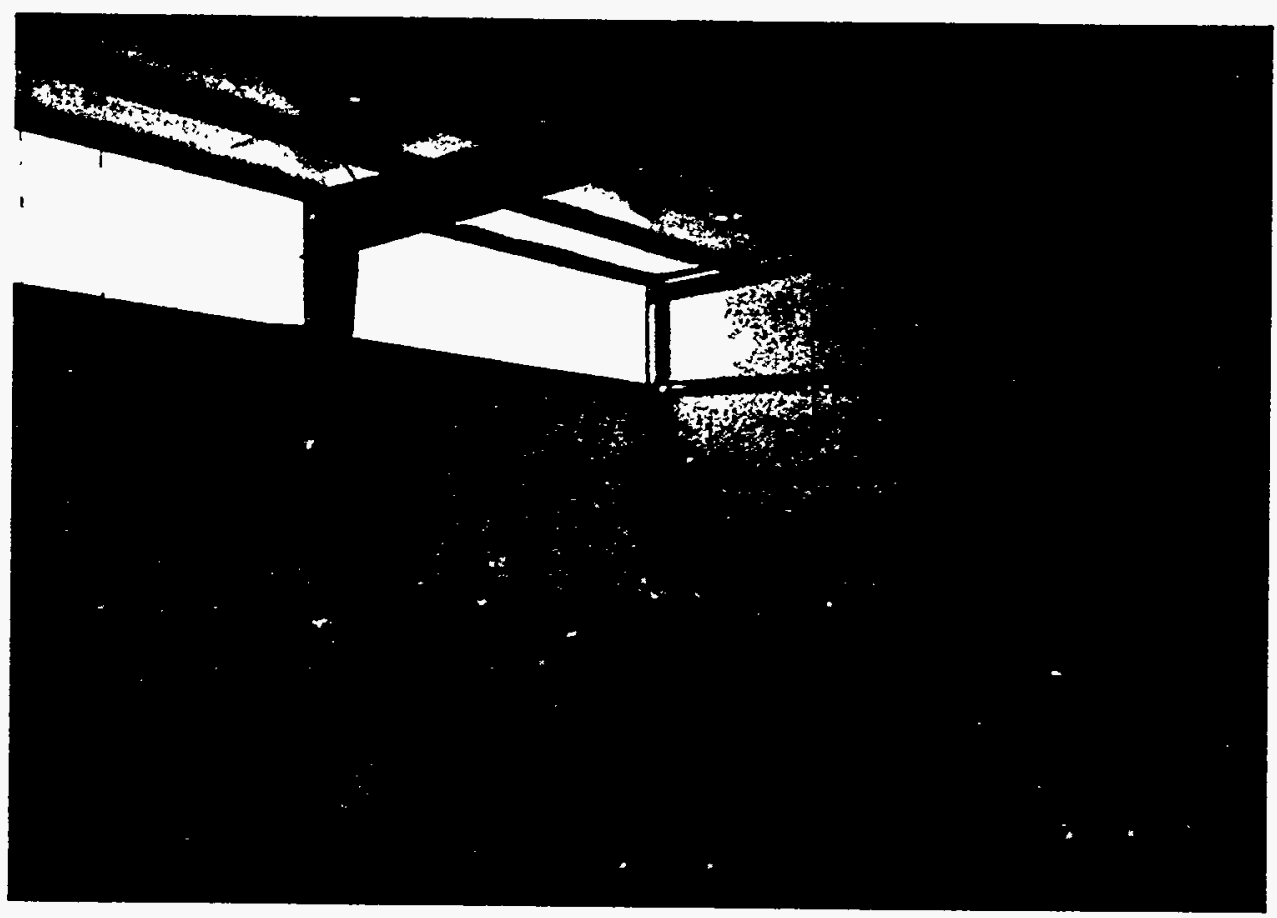

Figure 41. Waste storage in the MW storage facility.

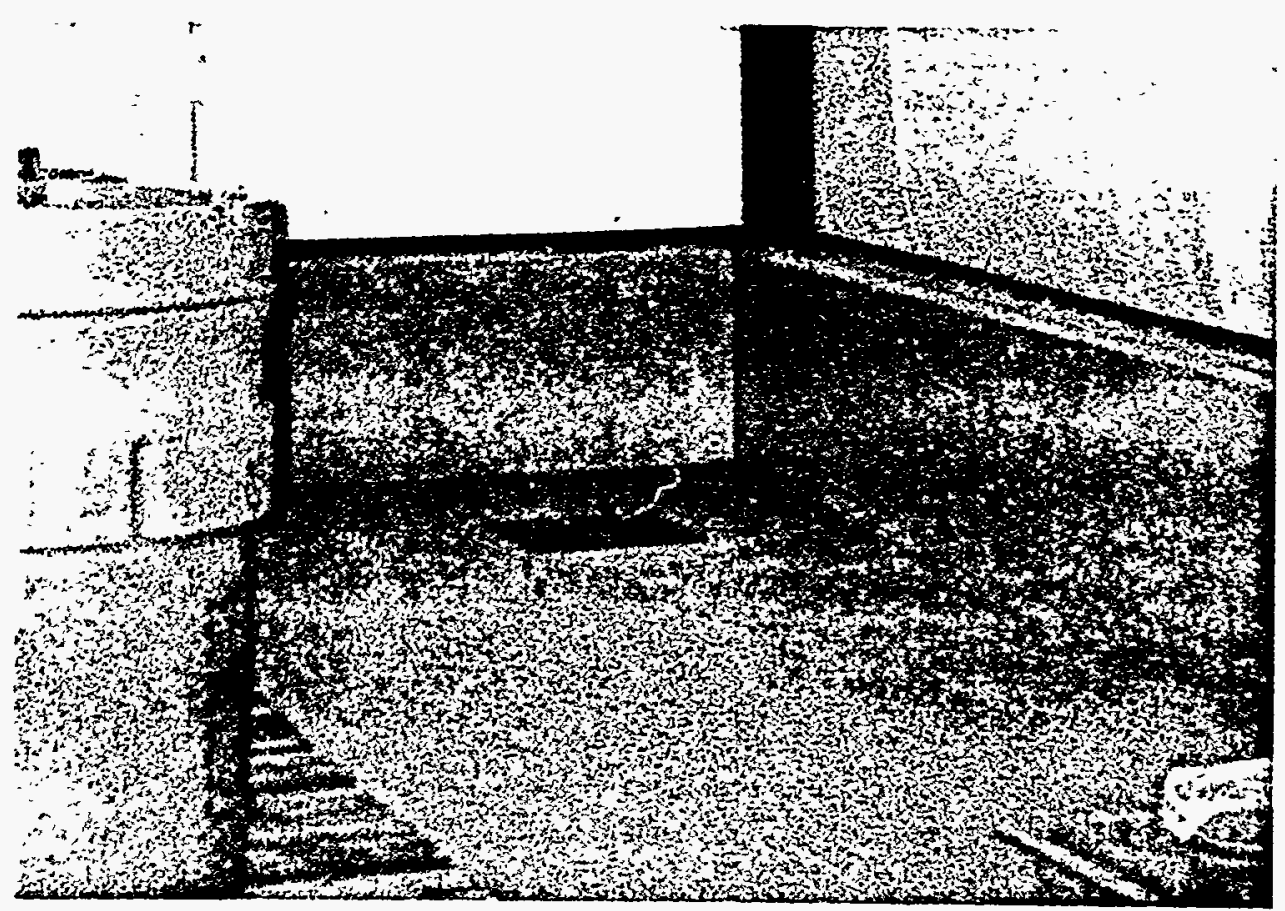

Figure 42. MW storage facility floor drainage. 
emergency plans. In addition the owner or operator must document the arrangements or the refusal of such arrangements. The documentation must be part of the operating record.

\subsection{Process Description -- Envirocare has identified the} Tooele Valley Medical Center, University of Utah Health Science Center, Tooele County Sheriff, Utah Highway Patrol, and Wendover Police Department as the applicable local and state emergency authorities.

The requirement for arrangements with the local authorities was discussed with

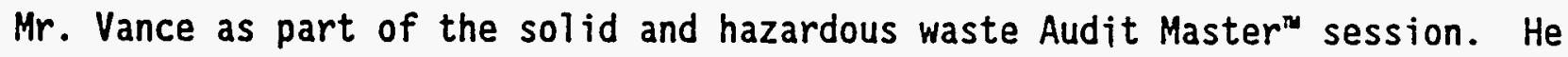
stated that the facility did not receive much interest from the authorities whenever they were invited to the site. He was asked if the facility conducted any emergency drills with the local authorities in order to confirm response times. They had not. The facility holds an annual open house and invites each of the local authorities with jurisdiction. The turnout for the open house has not been very good according to the representatives.

\subsection{INEL Assessment Team Obseryations/Impressions --} Attempts to make arrangements with local emergency authorities and State emergency response teams were very well documented at the Envirocare facility. Mr. Jay Vance, the environmental manager, referenced the appropriate State solid and hazardous waste regulations, as well as, the section of the Part $B$ Permit in each letter relating to this requirement. Mr. Vance supplied detailed correspondence to the BSHW describing the attempts made with the local authorities (See letter from J. Vance to D. R. Downs, dated January 7,1991$)$. The documents are maintained as part of the operating record.

The INEL Assessment Team suggested to the Envirocare facility representatives that they might consider working out an emergency response agreement with USPCI and APTUS. These two facilities have emergency responders and are located much closer (one mile and seven miles, respectively) to the Envirocare facility than any of the governmental agencies. This type of arrangement has been used very successfulty by Rollins Environmental Services (TX), Inc, and 
the surrounding chemical plants, in Deer Park, Texas. The facility representatives said that they would consider the suggestion.

Although no reflection on Envirocare's efforts, it should be noted that the contact with the Tooele County Sheriff's Department proved to less than comforting. The call to the Sheriff's Office for information was passed through two individuals to the dispatch officer all of whom appeared to know nothing about hazardous materials response with respect to the Envirocare or WDHIA sites. The dispatch officer also did not have emergency contact information. He then suggested that the county engineer's office be called, for which he gave a phone number which had been changed over a year ago. The county engineer's office secretary was at least able to direct the call to the county's Emergency Management Department (EMD). The contact at the EMD was very capable and familiar with the requirements, but the responsibilities had been transferred about one-to-two years ago to the Sheriff's Department. She indicated that the dispatch person had been trained in the area, and could not account for the response. It appears that the WDHIA facilities will need to engage in some substantial outreach/education processes to adequately acquaint the response organizations with the hazards, notwithstanding the documented lack of interest in the response authority community.

As previously stated, Envirocare held an emergency drill at the Clive facility. The local authorities were notified in order to ensure that they could be reached in the event of an actual site emergency. The facility was successful in reaching the necessary authorities.

\subsection{DOCUMENT REVIEW}

This section contains a brief discussion of documents which were reviewed as part of this assessment. The purpose of the document review is to ensure that permit and plan requirements are being met by the facility operators. The information contained in the documents is referenced during the on site inspection portion of the assessment. Any errors, or inaccuracies, identified by the INEL Assessment Team during either the review or inspection are reported to the facility representatives. 


\subsubsection{RCRA Part A/B Permit Application}

6.7.1.1. Part A Permit Application. Envirocare submitted a RCRA Part A Permit Application to the Utah Department of Health, Bureau of Solid and Hazardous Waste on April 2, 1990. The Application stated that Envirocare of Utah would be accepting (hazardous/radioactive) mixed waste for permanent disposal in a lined cell. It also stated that Envirocare would manage a container storage facility and evaporation tanks for wastes generated on site. Other permits referenced by this application were the air quality permit, NORM radioactive disposal license, and the solid waste disposal permit.

The permit application requested container storage and landfill disposal permission for the following waste codes:

\begin{tabular}{|c|c|c|c|c|c|c|c|c|c|c|c|c|}
\hline $\begin{array}{l}0001 \\
0014\end{array}$ & $\begin{array}{l}D 002 \\
D 015\end{array}$ & $\begin{array}{l}0003 \\
0016\end{array}$ & $\begin{array}{l}D 004 \\
0017\end{array}$ & 0005 & 0006 & 0007 & 0008 & 0009 & 0010 & 0011 & D012 & 0013 \\
\hline $\begin{array}{l}\text { F001 } \\
\text { F028 }\end{array}$ & $\begin{array}{l}\text { F002 } \\
\text { F039 }\end{array}$ & $F 003$ & F004 & F005 & F006 & F007 & F008 & F009 & F010 & F011 & F012 & F019 \\
\hline KO11 & $\mathrm{K} 013$ & K050 & K051 & K052 & K061 & K069 & & & & & & \\
\hline $\begin{array}{l}P 002 \\
P 022 \\
P 051 \\
P 098 \\
P 120\end{array}$ & $\begin{array}{l}\text { P003 } \\
\text { P024 } \\
\text { P056 } \\
\text { P099 } \\
\text { P121 }\end{array}$ & $\begin{array}{l}P 004 \\
P 027 \\
P 059 \\
P 101 \\
P 122\end{array}$ & $\begin{array}{l}\text { P005 } \\
\text { P028 } \\
\text { P060 } \\
\text { P102 } \\
\text { P123 }\end{array}$ & $\begin{array}{l}\text { P010 } \\
\text { P029 } \\
\text { P071 } \\
\text { P104 }\end{array}$ & $\begin{array}{l}\text { P011 } \\
\text { P030 } \\
\text { P074 } \\
\text { P106 }\end{array}$ & $\begin{array}{l}\text { P012 } \\
\text { P034 } \\
\text { P075 } \\
\text { P107 }\end{array}$ & $\begin{array}{l}\text { P013 } \\
\text { P037 } \\
\text { P077 } \\
\text { P108 }\end{array}$ & $\begin{array}{l}\text { P014 } \\
\text { P039 } \\
\text { P082 } \\
\text { P111 }\end{array}$ & $\begin{array}{l}\text { P015 } \\
\text { P046 } \\
\text { P085 } \\
\text { P113 }\end{array}$ & $\begin{array}{l}P 017 \\
P 047 \\
P 089 \\
P 114\end{array}$ & $\begin{array}{l}\text { P020 } \\
\text { P048 } \\
\text { P094 } \\
\text { P115 }\end{array}$ & $\begin{array}{l}\text { P021 } \\
\text { P050 } \\
\text { P097 } \\
\text { P119 }\end{array}$ \\
\hline U002 & 004 & UOO & 1007 & 4009 & U012 & v018 & U019 & U021 & Y022 & U027 & U028 & v029 \\
\hline U030 & U031 & U032 & U036 & U037 & U038 & U039 & U041 & U042 & U043 & UO & U045 & 0047 \\
\hline U048 & U050 & U052 & U056 & U057 & U060 & 0061 & U062 & U063 & v064 & U086 & U067 & v068 \\
\hline U06S & U070 & U071 & U072 & U073 & U074 & U075 & U076 & U077 & U078 & Uo & U080 & U081 \\
\hline UOB2 & U083 & U084 & U085 & U088 & U089 & U091 & U093 & U094 & U095 & U101 & U102 & U105 \\
\hline U10 & U107 & U108 & U109 & U112 & U115 & U117 & U118 & U119 & U120 & U121 & U127 & U128 \\
\hline U129 & U130 & U131 & U132 & U135 & U137 & U138 & U140 & U141 & U142 & U144 & U145 & U146 \\
\hline U147 & U149 & U15 & U152 & U154 & U155 & U157 & U158 & U159 & U161 & U162 & UI65 & U166 \\
\hline U167 & U168 & U169 & U170 & U171 & U172 & U174 & U179 & U1 80 & U181 & U182 & U183 & U184 \\
\hline U185 & U187 & U18 & U190 & U191 & U192 & U194 & U196 & U197 & U201 & U203 & U204 & U205 \\
\hline U207 & U208 & U209 & U210 & U211 & U212 & U214 & U215 & U216 & U217 & U220 & U221 & U223 \\
\hline U225 & U226 & U227 & U228 & U230 & U231 & U232 & U233 & U234 & U235 & U237 & U238 & U239 \\
\hline U240 & U242 & U243 & U247 & & & & & & & & & \\
\hline
\end{tabular}

The U.S. EPA issued a HSWA permit modification on May 5, 1993, which added ten (10) waste codes to the 1ist of wastes which could be accepted/stored/disposed of at the facility under its RCRA Part B permit. The permit modification was issued in response to a request submitted by Envirocare on October 23, 1992. The additional waste codes are:

$\begin{array}{llllllllll}F 024 & P 105 & \text { U003 } & \text { U122 } & \text { U123 } & \text { U133 } & \text { U134 } & \text { U219 } & \text { U328 } & \text { U359. }\end{array}$ 
The application also requested tank storage, container storage, and landfill disposal for leachate sludge and tank storage and landfill disposal for leachate.

6.7.1.2. Part B Permit Application. The Envirocare facility Part B Permit Application was reviewed with respect to the regulatory requirements specified in 40 CFR $\S \S 270$ and 264.

\author{
6.7.1.2.1. Standard Conditions -- Section A of the Permit \\ Application contains the standard conditions for operations allowed under the \\ permit. The section describes the duties of the facility operators and the \\ regulatory agents. This section also contained a copy of the RCRA Part $A$ \\ Permit Application.
}

\title{
6.7.1.2.2. General Requirements -- 40 CFR $\S 270.14$ specifies the
} general information requirements for a Part $B$ Permit. This information is required for all hazardous waste management (HWM) facilities, unless 40 CFR $\S$ 264.1 specifies otherwise. The following information is required:

(1) A general description of the facility.

(2) Chemical and physical analysis of the hazardous wastes to be handled at the facility.

(3) A copy of the waste analys is plan required by 40 CFR $\$ 264.13$.

(4) A description of the security procedures and equipment required by 40 CFR $\S 264.14$.

(5) A copy of the general inspection schedule required by 40 CFR $\$ 264.15$ (b)

(6) A justification of any request for a waiver(s) of the preparedness and prevention requirements of 40 CFR 264 Subpart $C$.

(7) A copy of the contingency plan required by 40 CFR 264 Subpart $D$.

(8) A description of the procedures, structures, or equipment used at the facility to prevent hazards.

(9) A description of prevent accidental ignition or reaction of ignitable, reactive, or incompatible wastes (40 CFR $\S 264.17$ ).

(10) Traffic patterns, estimated volumes, and controls.

(11) Facility location information, including:

- Political jurisdiction

- Compliance with the seismic standard (40 CFR 264, Appendix VI)

- Identification as to whether or not the facility is located within the 100-year flood pla in

(12) An outline of both the introductory and continuing training programs.

(13) A copy of the closure plan.

(14) For hazardous waste disposal units that have been closed, documentation that notices required under 40 CFR $\$ 264.119$ have been filed.

(15) The most recent closure cost estimate for the facility prepared in accordance with 40 CFR $\S$ 264.142 and a copy of documentation required to demonstrate financial assurance under 40 CFR $\$$ 264.143 .

(16) Where applicable, the most recent post-closure cost est imate for the facility prepared in accordance with 40 CFR $\$ 264.144$ plus a copy of documentation required to demonstrate financial assurance under 40 CFR $\$ 264.145$.

(17) Where applicable, a copy of the insurance policy or other documentation which comprises compliance with 40 CFR \& 264.147.

(18) Where appropriate, proof of coverage by a State financial mechanism in compliance with 40 CFR $\S \S 264.149$ or 264.150 .

(19) A topographic map meeting the informational requirements of 40 CFR $\$ 270.14(\mathrm{~b})(19)$, including: 


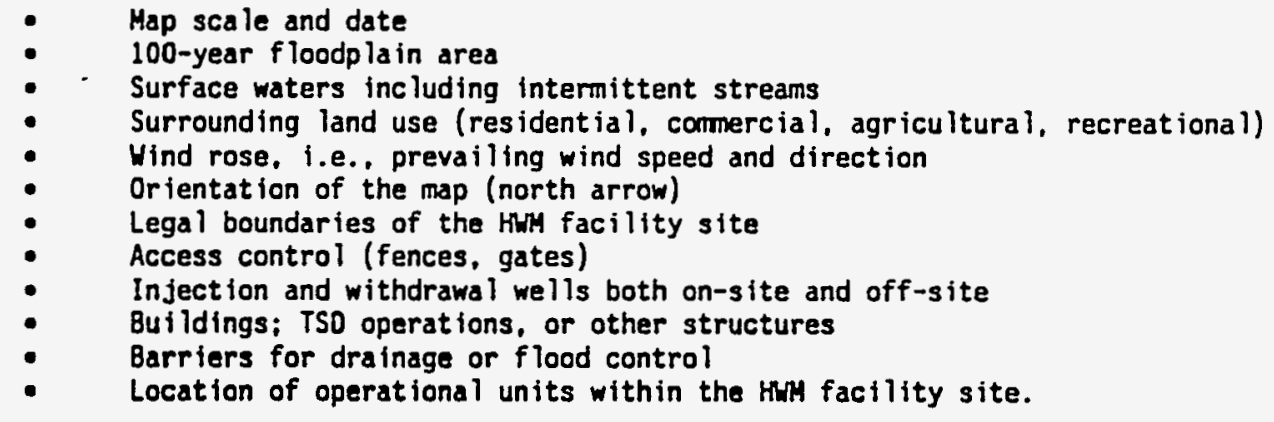

The Envirocare RCRA Part B Permit Application was reviewed with respect to the above specified requirements. The following table identifies the sections of the permit application which address each of the applicable requirements.

Table 5. Comparison of the RCRA Part B Permit Application with regulatory requirements

\begin{tabular}{|l|l|l|l|}
\hline $\begin{array}{l}\text { Regulatory } \\
\text { Reguirement }\end{array}$ & $\begin{array}{l}\text { Permit Application } \\
\text { Section }\end{array}$ & $\begin{array}{l}\text { Regulatory } \\
\text { Reguirement }\end{array}$ & $\begin{array}{l}\text { Permit App 1icat ion } \\
\text { Section }\end{array}$ \\
\hline 40 CFR 270.14(b)(1) & 8 & 40 CFR 270.14(b)(11) & B \\
\hline 40 CFR 270.14(b)(2) & C & 40 CFR 270.14(b)(12) & $H$ \\
\hline 40 CFR 270.14(b)(3) & C & 40 CFR 270.14(b)(13) & I \\
\hline 40 CFR 270.14(b)(4) & F & 40 CFR 270.14(b)(14) & N/A \\
\hline 40 CFR 270.14(b)(5) & F & 40 CFR 270.14(b)(15) & \\
\hline 40 CFR 270.14(b)(6) & N/A & 40 CFR 270.14(b)(16) & \\
\hline 40 CFR 270.14(b)(7) & G & 40 CFR 270.14(b)(17) & \\
\hline 40 CFR 270.14(b)(8) & F & 40 CFR 270.14(b)(18) & \\
\hline 40 CFR 270.14(b)(9) & F & 40 CFR 270.14(b)(19) & 8 \\
\hline 40 CFR 270.14(b)(10) & B & & \\
\hline
\end{tabular}

\subsection{Groundwater Monitoring -- 40 CFR $\S 264.14$ (c) contains} additional informational requirements regarding the protection of groundwater if the facility requesting the permit contains a regulated unit, unless that unit meets the requirements of 40 CFR $\S 264.90(b)$.

Section $E$ of the Envirocare Part B Permit Application address the additional informational requirements regarding groundwater protection. This section includes the groundwater monitoring $\mathrm{plan}$, the detection monitoring $\mathrm{plan}, \mathrm{a}$ description of the site's natural groundwater features, and the identification of required monitoring parameters. 
6.7.1.2.4. Solid Waste Management Units -- 40 CFR § 264.14(d) describes information requirements regarding solid waste management units (SWMUs) at a facility seeking a permit.

No SWMUs were identified in the Envirocare Part B Permit Application because the company did not own and/or operate any SWMUs at the time the Application was being prepared. As previously stated, Envirocare did not qualify for interim status under the regulations because it did not construct or operate the facility before November 19, 1980, or have been in operation when a new regulation was issued that first made the facility subject to RCRA regulation.

\subsection{Storage in Containers -- 40 CFR $\S 270.15$ specifies} information that owners and operators of facilities that store containers of hazardous waste must supply in the Part B Permit Application except as otherwise provided in 40 CFR $\S 264.170$.

Section $D$ of the Envirocare Part B Permit Application addresses the informational requirements required for container storage at a permitted facility. The information in this section was consulted by the INEL Team while making comparisons of the facility's management of containers with regulatory requirements.

6.7.1.2.6. Treatment and Storage in Tanks -- 40 CFR $\S 270.16$ specifies information that owners and operators of facilities that use tanks to store or treat hazardous waste must supply in the Part B Permit Application except as otherwise provided in 40 CFR $\S 264.190$.

Section D of the Envirocare Part B Permit Application addresses the informational requirements required for tank storage at a permitted facility. The information in this section was consulted by the INEL Team while making comparisons of the facility's management of storage tanks with regulatory requirements.

6.7.1.2.7. Surface Impoundment -- 40 CFR $\S 270.17$ specifies information that owners and operators of facilities that store, treat, or 
dispose of hazardous waste in surface impoundments must supply in the Part B Permit Application except as otherwise provided in 40 CFR $\S 264.1$.

Envirocare does not operate any RCRA regulated surface impoundments at the Clive facility. The run off control catchment basin is not considered a surface impoundment at this time by the State regulators. Therefore, this section is not applicable.

6.7.1.2.8. Waste Piles -- 40 CFR $\S 270.18$ specifies information that owners and operators of facilities that store or treat hazardous waste in waste piles must-supply in the Part B Permit Application except as otherwise provided in 40 CFR $\S 264.1$.

Envirocare does not operate any RCRA regulated waste piles at the Utah facility. Therefore, this section is not applicable.

\subsection{Incineration -- 40 CFR $§ 270.19$ specifies information} that owners and aperators of facilities that incinerate hazardous waste must supply in the Part B Permit Application except as otherwise provided in 40 CFR $\S 264.340$.

Envirocare does not operate any RCRA regulated incinerators at the Utah facility. Therefore, this section is not applicable.

\subsection{Land Treatment Units -- 40 CFR $\S 270.20$ specifies} information that owners and operators of facilities that dispose of hazardous waste in land treatment units must supply in the Part B Permit Application except as otherwise provided in 40 CFR $\S 264.1$.

Envirocare does not operate any RCRA regulated 1 and treatment units at the Utah facility. Therefore, this section is not applicable.

6.7.1.2.11. Landfil1s -- 40 CFR $\S 270.21$ specifies information that owners and operators of facilities that dispose of hazardous waste in landfills must supply in the Part B Permit Application except as otherwise provided in 40 CFR $\S 264.1$. 
Section $D$ of the Envirocare Part B Permit Application addresses the informational requirements required for landfill operations at a permitted facility. The information in this section was consulted by the INEL Team while making comparisons of the facility's construction and operation of the mixed waste landfill cell with regulatory requirements.

\subsection{Drip Pads -- 40 CFR $\S 270.22$ specifies information} that owners and operators of facllities that collect, store, or treat hazardous waste on drip pads must supply in the Part B Permit Application except as otherwise provided in 40 CFR $\S 264.1$.

Envirocare does not operate any RCRA regulated drip pads at the Utah facility. Therefore, this section is not applicable.

\subsection{Miscellaneous Units -- 40 CFR $\S 270.23$ specifies} information that owners and operators of facilities that treat, store, or dispose of hazardous waste in miscellaneous units must supply in the Part $B$ Permit Application except as otherwise provided in 40 CFR $\S 264.600$.

Envirocare does not operate any RCRA regulated miscellaneous units at the Utah facility. Therefore, this section is not applicable.

6.7.1.2.14. Process Vents -- 40 CFR $\S 270.24$ specifies information that owners and operators of facilities that have process vents to which 40 CFR, Subpart AA applies must supply in the Part B Permit Application except as otherwise provided in 40 CFR $\S 264.1$.

These regulations were not promulgated at the time Envirocare submitted its RCRA Part B Permit Application. Therefore, this section is not applicable until such time as the State of Utah calls for a new application or the present RCRA Part B Permit expires and a renewal application is submitted.

\subsection{Equipment Leaks -- 40 CFR $\S 270.25$ specifies} information that owners and operators of facilities that have equipment to which 40 CFR 264 Subpart BB applies must supply in the Part B Permit Application except as otherwise provided in 40 CFR $\S 264.1$. 
These regulations were not promulgated at the time Envirocare submitted its RCRA Part B Permit Application. Therefore, this section is not applicable until such time as the State of Utah calls for a new application or the present RCRA Part B Permit expires and a renewal application is submitted.

\subsubsection{RCRA Part B Permit}

As previously stated in Section 4.3. of this document, Envirocare operates according to two RCRA Part B Permits. The State of Utah has been awarded primacy by EPA, Region VIII, for all of RCRA except for the 1984 HSWA amendments and mixed waste. Primacy for these last two sets of regulations has remained with EPA, Region VIII. Therefore, Envirocare was required to obtain the two Part B Permits in order to operate a mixed waste disposal facility. Both Permits were reviewed during this assessment.

6.7.2.1. RCRA Part B Permit (Utah Primacy). The RCRA Part B Permit was issued to Envirocare by the State of Utah, Department of Health, Bureau of Solid and Hazardous Waste on November 30, 1990. The permit will remain in effect, unless revoked, until November 30, 2000.

A note in the permit states that "The Envirocare Site is 1 icensed by the Utah Bureau of Radiation Control for disposal of radioactive waste. The site is al so licensed by the Utah Bureau of Radiation Control and permitted by the Utah Bureau of Solid and Hazardous Haste for the disposal of "mixed" (hazardous/radioactive) waste."

The Envirocare RCRA Part B Permit was reviewed in detai1. The purpose of the review was to identify the operating requirements for the facility and compare the actual operations with the permit conditions. The permit is composed of seven modules. Module I contains the standard conditions, such as the effect of the permit, duties and responsibilities, required submissions, etc. Module II consists of the general facility conditions: design and operation of the facility, record keeping and reporting, and financial assurance/cost estimates for corrective measures. This module also contains the following plans: waste analysis, security, site inspection, personnel training, contingency, site evacuation, closure, and post-closure. These plans were excerpted from 
Envirocare's permit application. Module III addresses the storage in containers. Module IV addresses storage in tanks. Module $V$ controls disposal in landfills: waste codes approved for disposal, design of the cells, and segregation of wastes. Module VI contains groundwater monitoring requirements: groundwater monitoring plan, groundwater sampling and analys is plan, statistical analysis, etc. Module VII addresses the corrective action program regarding SWMUs. The State has identified the following SWMUs at the Envirocare facility: NORM landfill cell, NORM operation staging area, rail car roll-over, outdoor vehicle wash down area, rail car/backhoe unloading ramp, indoor vehicle wash down area, rail car wash down area tank sump, and the Utah Bureau of Radiation Control open burn container.

\subsubsection{RCRA/HSWA Part B Permit (EPA, Region VIII, Primacy). The} RCRA/HSWA Part B Permit was issues to Envirocare by EPA, Region VIII, on February 14, 1991. The permit will remain in effect, unless revoked, until February 14, 1996.

The permit allows Envirocare to treat, by evaporation, and store in tanks and containers, and dispose in landfill cells, specified hazardous waste(s) in accordance with the conditions of the permit. [Hazardous wastes included as specified hazardous wastes are those hazardous wastes listed in the State RCRA Envirocare Permit and the following hazardous waste codes: D018-D043 and F039.] Envirocare is also allowed to manage radioactive/hazardous waste according to all applicable rules and permit conditions for hazardous wastes as described in both the HSWA and RCRA permits from the EPA and from the State of Utah, as long as the waste also meets the rules, criteria and regulations for radioactive waste described in licenses [as amended] from the State of Utah and the U. S. Nuclear Regulatory Commission.

The Envirocare HSWA Part B Permit was reviewed in detail. The purpose of the review was to identify the operating requirements for the facility and compare the actual operations with the permit conditions. The permit is composed of six modules. Module I contains the standard conditions, such as the effect of the permit, duties and responsibilities, required submissions, etc. Module II consists of the general facility conditions: design and operation of the facility, record keeping and reporting, and financial assurance/cost estimates 
for corrective measures. Module III addresses the landfill cells: waste codes approved for disposal, design of the cells, and segregation of wastes. Module IV specifically address land disposal restriction issues: waste analysis, general prohibitions on land disposal, F-solvent wastes, California list wastes, three thirds scheduled wastes, new toxicity characteristic wastes, and other new listed wastes. Module V was reserved. Module VI addressed requirements for the identification of solid waste management units. (Envirocare did not identify any SWMUs in its Part B Permit Application.) The HSWA Waste Analysis Plan is included as Attachment.A to the Permit.

\subsubsection{Annual Hazardous Waste/Biennial Report}

The RCRA Sections 3002, 3004, and 3007, as promulgated by 40 CFR $\S \S 264.75$ and 265.75, require owners or operators of a TSDF to prepare and submit a single copy of a biennial report to the Regional Administrator (the State of Utah in this case) by March 1 of each even numbered year. Regulations promulgated at 40 CFR § 262.41 require the same of hazardous waste generators. The purpose of the report is to provide the EPA with information that will be used to facility waste capacity studies, waste tracking, and assessment of waste minimization activities, and to support State hazardous waste programs (EPA, p. 1). The Biennial Report was also an Envirocare RCRA Part B Permit Condition (I.F.20).

The 1991 Envirocare Biennial Report was obtained from the facility during the assessment. It was the most recent report available at this time. The report was submitted to the State of Utah on March 30, 1992. The report was reviewed with respect to the requirements specified in 40 CFR $\S \S 262.41,264.75,265.75$ and the EPA 1991 Hazardous Waste Report Instructions and Forms.

The company listed itself as a conditionally exempt small quantity generator for its 1991 generator status. The Envirocare Biennial Report was composed of the following forms:

IC Identification and Certification

GM Waste Generation and Management

WR Waste Received from offsite 
PS Waste Treatment, Disposal, or Recycling Process Systems

oI Off-Site Identification

A11 of the forms appeared to be complete and accurate.

Hazardous wastes which were generated and reported by the Envirocare operations were spent Safety Kleen solvents and laboratory wastes. The spent solvents were shipped off-site to Safety Kleen (UTD 980957 088) for reclamation. The laboratory wastes were treated and disposed of on site.

Envirocare reported the first shipments of mixed wastes in 1991. The materials were listed as land disposed.

\subsection{4.' Closure/Post-Closure Plan}

40 CFR $\S \S 264$ Subpart G, Section 112 and 265 Subpart G, Section 112 require that the owner or operator of a hazardous waste management facility must have a written closure plan. The approved closure plan must become a condition of any RCRA permit. In addition 10 CFR $\S 61.12$ requires license applicants to provide a description of the disposal site closure plan as part of the specific technical information required for licensing of a radioactive waste land disposal facility.

Envirocare had to meet both sets of regulations. The RCRA closure plan was included in Section I of the Part B Permit Application. The NRC closure plan was included as Section 5 of the Radioactive Materials License Application. It is also addressed in the 1le.(2) Radioactive Materials License Application. Only the RCRA Closure/Post-Closure Plan was reviewed during the March 1993 assessment.

The Closure $\mathrm{Pl}$ an addressed partial, as well as, full closure of the mixed waste facilities, i.e., storage and landfill. This plan deviated slightly from standard RCRA landfill closure plans because of the requirement to protect the pub7ic from radiation. Closure cost estimates and financial surety were also described. 
The Post Closure $\mathrm{Pl}$ an addressed inspection, monitoring, and maintenance requirements for the mixed waste facility. It also contains instructions for the post-closure perimeter and general facility inspection schedule and checklist.

Both of these $\mathrm{plans}$ were incorporated, verbatim, into the RCRA Part B Permit by the State of Utan.

\subsubsection{Emergency Response/Contingency Plan}

40 CFR $\S \S 264$ Subpart $D$ and 265 Subpart $D$ require the owners and operators of all hazardous waste facilities to have a contingency plan for the facility. The contingency plan must be designed to minimize hazards to human health or the environment from fires, explosions, or any unplanned sudden or non-sudden release of hazardous waste or hazardous waste to air, soil, or surface water.

A review of Envirocare's Contingency $P$ lan showed indicated that it was written to the requirements for the RCRA Part $B$ permit. The only deficiency identified was the omission of the capabilities of the emergency equipment was not found. A recommendation was made to Envirocare to revisit the requirements of 40 CFR $\S 264.52$.

The modification to the Contingency Plan was in progress at the time of the November 1993 re-assessment.

Envirocare also had a specific Groundwater Discharge Contingency $\mathrm{Pl}$ an which was a condition of its groundwater monitoring permit. This contingency plan was required of the facility to ensure that it would maintain compliance with the protection levels in Part I C of the Groundwater Discharge Permit in the event that concentration limits were exceeded in the down-gradient compliance monitoring wells. 


\subsubsection{Facility Construction Plans}

Facility Construction Plans for the mixed waste RCRA cell were reviewed. The As Built drawings have been submitted to the State of Utah and are included in the Part B Permit Application.

\subsubsection{Hazardous Haste Manifests}

40 CFR $\S \S 264$, Subpart $E$ and 265, Subpart $E$ specifies the requirements for the manifest system, as well as, general record keeping and reporting. The INEL Assessment Team reviewed several manifests with respect to the requirements of 40 CFR $\S \S 264.71,264.72,265.71$ and 265.72 .

During the March 1993 assessment it was noted that the facility did not have very many hazardous waste manifests on file. Most of the manifests appeared to correctly completed. The LDR certifications were attached as we17. The manifests are kept as part of the operating record.

One manifest reviewed did not appear to be completely correct to the team. This manifest indicated that the generator who shipped the waste to Envirocare did not properly characterize the waste before shipping. The facility representatives stated that they had attempted to work with the generator to fix the problem while the load was sitting at the Clive Railroad Siding. The problem was resolved. The INEL Assessment Team cautioned the facility representative to be very careful about working with the generator, no matter who it is, government agency or private company, to ensure that Envirocare receives and accepts properly completed manifests, discrepancy reports, and the like. The INEL Assessment Team was concerned that with changes in the way in which regulatory agencies interpret their own regulations, that one manifest, in particular might trigger a violation.

During the November 1993 re-assessment, no discrepancies were noted in any of the manifests reviewed. 


\subsubsection{Operations Record}

The RCRA regulations promulgated by 40 CFR $\S \S 264.73$ and 265.73 state that the owner or operator must keep a written operating record at his facility. The information specified by this section must be kept as part of the operating record until closure of the facility. The only exception to the "lifetime retention" requirement is that inspection records must only be kept three years.

The operations record is also specifically required by the HSWA Part B Permit, Module I, Section I.

The operations record at the Envirocare facility was kept in a series of lockable file cabinets. The files were kept locked at all times, except when the file custodian was pulling requested information. Site workers were not allowed to access the files without the file custodian's assistance and permission.

The file system tied the actual records to the applicable section of the RCRA Part $B$ permit. For example, personnel training files, as required by the RCRA Part B permit section II.G. were kept in file section II.G. of the operations record. The training $\mathrm{plan}$ was located in file II.G.1. and the training records were located in file II.G.2. The Envirocare file custodian was able to pull information requested by the INEL Assessment Team immediately based on the applicable RCRA Part B Permit sections.

\subsubsection{SARA Reports}

The primary purpose of SARA Title III is to inform the public of the presence of toxic chemicals in their communities. The following sections describe the basic SARA reporting requirements. In every case, even though a facility may not appear to be subject to the requirements based on the qualifying criteria, the State Emergency Response Commission (SERC) may require the facility to file. 
- Envirocare does not operate within SIC code range of 20-39 (Envirocare reported 9511 on its Biennial Report and 4953 to the Dun and Bradstreet service), but does have ten or more full time employees (20 on site), and uses toxic chemicals in excess of the applicable threshold quantities (some laboratory chemicals), therefore it is not subject to all of the SARA reporting requirements. Compliance with the various SARA regulatory requirements was discussed in some detail with the facility representatives while developing the Audit Master ${ }^{\mathrm{m}}$ checklists.

6.7.9.1. SARA Section 370 (NSDS Reporting). Under 40 CFR Part 370, a11 employers are required to inform state and local emergency response groups, and local fire departments of their inventories of hazardous chemicals. Two major reporting requirements are imposed: material safety data sheets (MSDSs) or equivalent lists must be submitted for hazardous chemicals present above certain threshold levels, and an inventory report must be submitted for these chemicals on an annual basis.

Facilities that are subject to the MSDS requirements of OSHA's Hazard Communication Standard (HCS) must submit copies of their MSDSs, or equivalent list, to the appropriate local emergency planning commission (LEPC), SERC, and local fire department. This material must be submitted by October 17, 1990, or three months after a facility is required to have an MSDS under the OSHA regulations, whichever is later.

Envirocare has reviewed the Emergency $\mathrm{Planning}$ and Notification requirements and has determined that it is subject to them. The company notified the SERC within the allowable 60 day window and the LEPC within the allowable 30 day window after it first became subject to the requirements. A facility emergency coordinator was appointed. Envirocare keeps the LEPC and associated fire department appraised of any changes which occur at the facility and which are relevant to emergency planning.

Envirocare has obtained and maintains material safety data sheets (MSDS's) for all chemicals used on site. The MSDS's are kept in 3-ring binders at the facility. The company has not been required to submit the MSDS's or a list of hazardous chemicals to the SERC, LEPC, or fire department with jurisdiction 
over the facility because it does not maintain hazardous chemicals at the facility in excess of their threshold planning quantities (TPQ).

6.7.9.2. SARA Section 311 Tier I and/or Section 312 Tier II Report. The hazardous chemical inventory requirements of SARA Title III Sections 311 and 312 cut across two federal programs: the HCS administered by OSHA and the Title III program administered by EPA.

Facilities that are required to submit MSDSs are also required to submit an annual inventory form containing:

- an estimate of the maximum amount of each hazardous chemical present at the facility at any one time during the previous calendar year,

- an estimate of the average daily amount of each hazardous chemical at the facility, and

- the location of these chemicals at the facility.

These inventories may be submitted on either the Tier I or Tier II Forms. The annual inventory must be submitted by March 1 for chemicals at the facility for the preceding year.

Envirocare does not operate within SIC codes 20 to 39 . Therefore, even though it has more than 20 employees and uses hazardous chemicals above the threshold reporting quantities, it is not required to file SARA 311 or 312 reports. The SERC has not called for either report from the company.

6.7.9.3. SARA 313 Form R Report. Section 313 of SARA Title III requires EPA to create an annual inventory of toxic chemical emissions that occur as a result of normal business operations.

Four basic criteria are used to determine if a facility is subject to the reporting requirements: 
- The facility must manufacture, import, process, or otherwise use one or more of the approximately 330 chemicals listed in 40 CFR $\S$ 372.65 ;

- The facility must have more than 10 full-time employees;

- The facility must have a primary SIC code between 20 and 39 ; and

- The quantity of chemical used, manufactured, imported or processed must exceed certain threshold levels that range from 10,000 pounds per year to 25,000 pounds per year.

Envirocare is not subject to the Toxic Chemical Release Reporting (Form R) requirements because it does not fall within SIC codes 20-39. However, it did file a Form $R$ in 1993.

\subsubsection{Sample Analysis Plan}

Each waste from each incoming shipment is sampled by Envirocare. Sampling is performed according to procedures in the Quality Assurance Project Plan. Each sample is analyzed at Envirocare's onsite laboratory for the following parameters: Solid/Soil pH, Paint Filter Liquids, Oxidizer/Reducer Test, Cyanide/Sulfides Test, Photoionizer "sniffer" Test, Pyrophoricity Test, Shock Sensitivity Test, Air Reactivity Test, and Water Reactivity Test. These analytical procedures are designed to be used as a final fingerprint screen. The results of the analyses for incoming wastes are compared to results of the analyses of pre-shipment samples. Waste is accepted based upon results of the onsite analyses for incoming shipments.

Samples are collected from random locations in bulk shipments or from randomly selected containers as determined by a random number generator and a grid. Procedures written of sample selection include: 1) Sample Site Selection Procedure, 2) Sampling Frequency Determination Procedure, 3) Random Numbers Selection Procedure, and 4) Waste Stream Subset Procedure. 


\subsubsection{Spil1 Prevention Control and Countermeasures P1an}

40 CFR § 112 requires owners or operators of non-transportation-related onshore and offshore facilities engaged in drilling, producing, gathering, storing, processing, refining, transferring, distributing, or consuming oil and oil products, and which, due to their location, could reasonably be expected to discharge oil in harmful quantities, as defined in 40 CFR $\S 110$, into or upon the navigable waters of the United States or adjoining shorelines to prepare and maintain a Spil1 Prevention Control and Countermeasures (SPCC) Plan.

Al though Envirocare uses and stores petroleum products on site, it has not developed a specific SPCC PIan to address discharges of oil. Spills of any hazardous materials are controlled through activation of the Contingency Plan. Discussion of the use of the Contingency Plan can be found in Section 6.6.1. of this report.

The RCRA Part A Application states that Envirocare does not discharge to "waters of the United States". Therefore, an SPCC PIan should not be required for this facility, unless specifically requested by a State or Federal regulatory agency. The company verified this position with the regulatory agencies.

\subsubsection{Waste Analysis plan}

40 CFR $\S \S 264.13(4)(b)$ and $265.13(4)(b)$ require the owner/operator of a TSDF to develop and follow a written waste analysis $\mathrm{plan}$ which describes the procedures which he will carry out to comply with in order to obtain a detailed chemical and physical analysis of a representative sample of a waste for treatment, storage, or disposal. This $p l$ an must also be kept at the facility. The regulation then proceeds with a description of the requirements for the plan.

In addition, 40 CFR $\S 268.7$ (a)(4) requires a generator who is managing a land disposal prohibited waste in tanks, containers, or containment buildings regulated under 40 CFR $\S 262.34$, and who is treating such waste in such tanks, 
containers, or containment buildings to meet applicable treatment standards under 40 CFR 268, Subpart D. The generator must also develop and follow a written waste analysis plan which describes the procedures the generator will carry out to comply with the treatment standards. This plan must be kept on site in the generator's records.

Envirocare's Waste Analysis P7an (WAP) was contained in Attachment II-1 of the Part B Permit. The sections of the plan included: 1) Background, 2) Overview, 3) Pre-Shipment Evaluation Procedures, 4) Analysis of the PreShipment Acceptance Sample and Establishment of Incoming-Shipment Tolerances, 5) Incoming-Shipment Procedures, 6) Sampling Procedures, 7) continuing Waste Stream Evaluation Procedures, 8) Analytical Methods and Rationale, and 9) Quality Assurance Project Plan.

The Environmental Protection Agency issued Envirocare a RCRA/HSWA Part B Permit on February 14, 1991. The permit required that all relevant provisions be met relating to generation, storage, treatment, and disposal of wastes authorized for Envirocare's facility operations and subject to 1 and disposal restrictions.

The HSWA permit requires a waste analysis of generated hazardous waste subject to land disposal restrictions. The waste must be tested using the test method applicable to the specific waste in accordance with 40 CFR 268, Subpart C or by using knowledge of the waste to determine if the waste is restricted from land disposal.

Envirocare developed a HSWA Waste Analysis $P 1$ an which addressed the analysis and other requirements for wastes subject to the LDR prohibitions. This HAP is maintained as Attachment A of the HSWA Part B permit. The plan addressed the following issues:

- general provisions including: interim storage provisions for wastes being sampled and analyzed; alternative sampling methods and waivers of analyses for wastes which do not lend themselves to analyses, e.g., lead bricks and tree stumps; timely sample collection and waste removal or disposal; segregation of wastes subject to 
treatment standards; decontamination of equipment moving from one segregated waste to another; waste disposal tracking and recordkeeping;

- waste analysis data and the operating record;

- waste analysis requirements, testing frequency, and parameters;

- on-site generated wastes, waste analysis and frequency;

- off-site waste shipments without certification;

- procedures following receipt of analytical results for off-site waste shipments;

- sampling procedures, quality assurance, and documentation; and

- Envirocare's guarantee to comply with all applicable regulations with respect to land disposal of F-solvent and F-dioxin wastes, first-, second- and third-third wastes, and newly listed wastes.

\subsubsection{Waste Minimization Certification/P1an}

40 CFR $\S 264.73(b)(9)$ requires the owner/operator of a TSDF to certify on at least an annual basis that they have a program in place to reduce the volume and toxicity of hazardous waste that he generates to the degree determined by the permittee to be economically practicable; and the proposed method of treatments, storage, or disposal that is the practicable method currently available to the permittee which minimizes the present and future threat to human health and the environment.

Envirocare has developed a waste minimization $\mathrm{plan}$ which is designed to reduce the volume and toxicity of hazardous wastes generated at its Clive, Utah facility. The plan was signed in January 1993. The goal of the plan was to establish a treatment system for the following wastes from on and off site by August 1993: 
15,000 gallons of liquid and solid decontamination wastes

30 gallons of liquid and solid laboratory wastes

250 gallons of liquid groundwater monitoring wastes

500 gallons of disposal cell leachate

The facility also generated liquids and solids as a result of treating waste water in its evaporation tanks. The facility also generated liquids and solids as a result of treating waste water in its evaporation tanks. These wastes were not included as part of this $p l a n$ because the facility representatives consider the wastes to be second generation which they state are not applicable as a part of the plan.

Envirocare plans to reduce the volume of the wastes generated by conserving the use of decontamination water, sample analyzed and purge water. The company also plans to begin using stabilization in order reduce the toxicity of wastes generated, once stabilization is approved as part of a permit modification. The company also stated that it would review and update this waste minimization plan in March of every year.

The INEL Assessment Team inquired as to the status of the waste minimization goals during the November 1993 re-assessment. The company stated that it had not yet met the goal set for August 1993 because the stabilization unit had not yet been constructed. The regulatory agencies had only recently approved the permit modification allowing this treatment method. However, the company was still committed to reaching its waste minimization goals.

\subsubsection{Groundwater Monitoring Plan}

40 CFR $\S \S 264$, Subpart $F$ and 265 , Subpart $F$ require that owners and operators of solid waste management units, surface impoundments, landfills, and 1 and treatment units must comply with the monitoring requirements of the subpart. 40 CFR §§ 264.97 and 265.97 specifies the general groundwater monitoring requirements.

Envirocare's Ground Water Monitoring Plan addresses the groundwater requirements found in $40 \mathrm{CFR} 264$, Subpart F. The plan describes the 
"statistical comparison procedure that will be used to indicate whether any established background detection limit value (BDLV) has been exceeded. The results of analyses of conventional indicator parameters in Envirocare's location of brackish groundwater have shown to be unreliable indicators for determining and identifying statistically significant increases of contamination from regulated units."

"The results of the following methods have been selected by Envirocare as the indicator parameters for the detection monitoring program at the Envirocare facility: Method 8240 and 8270 . Test Methods for Evaluating Sol id Waste: Physical/Chemical Methods SH-846, Third Edition, or most current."

\subsubsection{Wastewater Monitoring Reports}

Envirocare does not discharge any wastewaters from the Clive facility. The facility has not been required by any agency to monitor wastewaters treated in the evaporation tanks. Therefore, this section is not applicable.

\subsubsection{TSCA Storage/Disposal Approval}

Envirocare doe not accept TSCA regulated PCB's for storage or disposal at the Clive, Utah facility. Therefore, this section is not applicable.

\subsubsection{CERCLA Off-Site Policy Approval}

Envirocare did not provide evidence of the CERCLA Off-Site Policy Approval during this assessment. The CERCLA Off-Site Policy Approval was also discussed during the re-assessment in November 1993. At that time the Environmental Manager stated that he had contacted EPA, Region VIII, regarding the approval and was told verbally that the facility was qualified. EPA, Region VIII, declined to provide a written approval. 


\subsubsection{Radioactive Materials License}

Envirocare received its 14 th amendment to its Radioactive Materials License on September 10, 1993. This amendment, and the entire 1icense, will remain in effect until February 28, 1996. The license permits Envirocare to transfer, receive, possess, and use specified radioactive materials for the purposes outlined in the conditions of the license. Envirocare is licensed to receive volumetric bulky materials or structural debris containing the isotopes and activities listed in Table 6.

Envirocare is not permitted to accept low-level radioactive waste generated outside the region comprised of the party states to the Northwest Interstate Compact on Low-Level Radioactive Waste Management (Alaska, Hawaii, Idaho, Montana, Oregon, Utah, and Washington) unless certain provision of the Compact are met. In addition to accepting the above listed isotopes for disposal, Envirocare is subject to an addition 55 conditions regarding the management and disposal of the materials. The most important conditions, from a customer standpoint, are those concerning debris disposal, as follows:

- For the purposes of this license, debris is defined as any radioactive waste for disposal other than soils. Compactible debris is defined as: (A) having a gradation that will pass through a four inch (4") grizzly and: (B) as having a density greater than seventy pounds per cubic foot dry weight in accordance with ASTM 0-698. Contaminated materials, other than soil, not meeting either of these criteria are defined as noncompactible debris.

- The licensee shall place bulk radioactive materials in lifts with an uncompacted thickness not exceeding twe lve inches (12").

- In-place bulk radioactive waste shall be compacted at a moisture content up to three percent (3\%) above opt imum as determined by the Standard Proctor Method ASTM D-698.

- The licensee shall compact each lift to not less than ninety percent (90\%) of opt imum density as determined by Standard Proctor Method ASTM D-698. Sampling points for compaction testing shall include locations immediately adjacent to debris when debris is included in the lift.

- All debris shall be less than ten inches (10") in at least one (1) dimension, and no longer than eight feet $\left(8^{\circ}\right)$ in any direction.

These conditions impose restrictions, of which the customer should be aware, upon the composition, form, and size of the materials destined for disposal in the cells. 
Table 6. Radioactive isotopes accepted by Envirocare

\begin{tabular}{|c|c|c|c|}
\hline $\begin{array}{l}\text { Radioactive Mater- } \\
\text { ial (E lement and } \\
\text { Mass Number) }\end{array}$ & $\begin{array}{l}\text { Maximum Concentra- } \\
\text { ion in Waste for } \\
\text { Disposal ( } \mathrm{pC} i / g)\end{array}$ & $\begin{array}{l}\text { Radioactive Mater- } \\
\text { ial (Element and } \\
\text { Mass Number) }\end{array}$ & $\begin{array}{l}\text { Maximum Concentra- } \\
\text { ion in Waste for } \\
\text { Disposal }(p \mathrm{Ci} / g)\end{array}$ \\
\hline Americ fum-241 & $2.3 E^{+02}$ & Nickel-63 & $2.0 E^{+06}$ \\
\hline Americium-243 & $1.7 E^{+03}$ & Hiobium-94 & $1.6 \mathrm{E}^{+02}$ \\
\hline Ant imony-124 & $7.9 E^{+02}$ & Pluton ium-238 & $1.0 E^{+04}$ \\
\hline Ant imony-125 & $5.3 E^{+03}$ & Pluton fum-238* & $8.2 E^{+03}$ \\
\hline Beryllium-7 & $3.8 E^{+04}$ & Pluton ium-239 & $9.9 E^{+03}$ \\
\hline Calctum- 45 & $4.0 E^{+08}$ & Pluton fum-240 & $1.0 E^{+04}$ \\
\hline Cadnium-109 & $4.6 \mathrm{E}^{+04}$ & Pluton ium-241 & $3.5 E^{+05}$ \\
\hline Carbon-14 & $4.0 E^{+05}$ & Pluton ium-241* & $1.1 E^{+03}$ \\
\hline Ces ium-134 & $1.2 E^{+03}$ & Pluton ium-242 & $1.0 E^{+04}$ \\
\hline Cesium-137 & $5.6 E^{+02}$ & Polonium-210 & $2.0 E^{+04}$ \\
\hline Chromium-51 & $6.8 E^{+04}$ & Potassium-40 & $1.0 \mathrm{E}^{+04}$ \\
\hline Cobalt -56 & $3.6 \mathrm{E}^{+02}$ & Radium-226 & 2. $.0 E^{+03}$ \\
\hline Cobalt-57 & $1.9 E^{+04}$ & Radium-228 & $1.8 E^{+03}$ \\
\hline Cobalt-58 & $1.6 E^{+03}$ & Radium-228 (1 year) & $1.2 E^{+03}$ \\
\hline Coba it -60 & $3.6 E^{+02}$ & $\begin{array}{l}\text { Radium-228 (5 } \\
\text { years) }\end{array}$ & $6.7 E^{+02}$ \\
\hline Curium-242 & $1.4 E^{+06}$ & $\begin{array}{l}\text { Radium-228 (10 } \\
\text { years). }\end{array}$ & $5.6 E^{+02}$ \\
\hline Curtum-242 & $8.1 E^{+03}$ & Ruthen ium-106 & $1.9 E^{+04}$ \\
\hline Curium-243 & $1.5 E^{+03}$ & Silver-110m & $5.6 E^{+02}$ \\
\hline Curfum-243* & $1.3 E^{+03}$ & Sodium-22 & $7.8 E^{+02}$ \\
\hline Curium-244 & $1.0 E^{+04}$ & Strontium-90 & $2.0 E^{+04}$ \\
\hline Curium-244* & $7.4 E^{+03}$ & Technet ium-99 & $1.0 E^{+05}$ \\
\hline Europium-152 & $1.7 \mathrm{E}^{+03}$ & Thor ium-230 & $1.5 E^{+04}$ \\
\hline Europium-154 & $1.4 \mathrm{E}^{+03}$ & Thor ium-232 & $6.8 \mathrm{E}^{+02}$ \\
\hline Hydrogen-3 & $2.0 E^{+07}$ & Tin-113 & $7.3 E^{+05}$ \\
\hline Iodine-129 & $3.1 E^{+03}$ & Uranium-234 & $3.7 E^{+04}$ \\
\hline Irtdtum-192 & $2.5 E^{+03}$ & Uran ium-235 & $7.7 \mathrm{E}^{+02}$ \\
\hline Iron-55 & $1.8 \mathrm{E}^{+06}$ & Uran ium-236 & $3.6 \mathrm{E}^{+04}$ \\
\hline Lead-210 & $2.3 \mathrm{E}^{+05}$ & Uran ium-238 & $2.8 \mathrm{E}^{+04}$ \\
\hline Manganese-54 & $5.6 \mathrm{E}^{+03}$ & Uranium-Natural & $1.8 \mathrm{E}^{+04}$ \\
\hline Mercury-203 & $1.0 E^{+04}$ & Uran ium-dep leted & $1.1 \mathrm{E}^{+05}$ \\
\hline Meptun fum-237 & $2.0 \mathrm{E}^{+03}$ & Zinc- 65 & $1.1 E^{+04}$ \\
\hline Nicke 1-59 & $7.0 E^{+02}$ & & \\
\hline
\end{tabular}




\subsubsection{Application for Radioactive Materials License}

Envirocare of Utah, Inc. Application for Radioactive Materials License, UT2300249 was submitted to the Utah Division of Environmental Health, Bureau of Radiation Control and was approved by the agency on March 21, 1991. The permit application resembles a RCRA Part B Permit Application as follows: Section 1. General Information; Section 2. Site Characteristics; Section 3. Design and Construction; Section 4. Facility Operations; Section 5. Site Closure and Institutional Controls; Section 6. Safety Assessment; Section 7. Occupational Radiation Protection; Section 8. Conduct of Operations; Section 9. Quality Assurance Program; and Section 10. Trust agreement. Regulations concerning the content of the license application are promulgated at 10 CFR §§ 61.11 through 61.16, and Subpart A of 10 CFR 51. The Ticense application was not reviewed in detail as part of this assessment.

\subsubsection{Application for 1le.(2) Radioactive Materials License}

Envirocare prepared an Application for 1le.(2) Radioactive Materials License as well. This application was prepared in the same format as the Radioactive Materials License Application. Regulations concerning the content of this license application are the same as those for the radioactive materials license and are promulgated at 10 CFR $\S \S 61.11$ through 61.16, and Subpart $A$ of 10 CFR 51. This license application was not reviewed in detail as part of this assessment.

\subsubsection{Air Permit}

Envirocare has an air quality approval order for the low level radioactive materials disposal site which was granted by the State of Utah, Department of Health, Division of Environmental Health, Bureau of Air Quality (UBAQ). The approval, dated December 21, 1990, authorizes Envirocare to construct the low level radioactive material disposal site in Tooele County, Utah.

As previously state the approval is based upon information Envirocare submitted in an initial notice of intent, dated August 25, 1987, with 


\section{additional information submitted until 1990. The present approval contains the following conditions:}

"3. The approved installations shall consist of the following equipment located at the site:

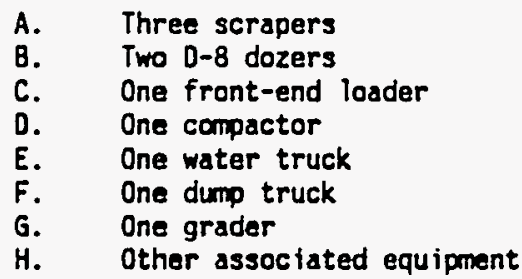

"4. Visible emissions from any point or fugitive emissions source associated with the installation or control facilities shall not exceed $20 x$ opacity....

"5. All unpaved roads and other unpaved operational areas in use shall be water sprayed and/or chemically treated to reduce fugitive dust. The application rate of water shall be a minimum of 0.5 gallons per square yard. Application shall be made at least once every two hours during all times the installation is in use unless daily rainfall exceeds .10 of an inch. If chemical treatment is to be used. the plan must be approved by the Executive Secretary of the Utah Air Conservation Comittee. Records of water treatment shall be kept for all periods when the plant is in operation. The records shall include the following items:
A. Date
B. Number of treatments made
C. Rainfall received
D. Time of day treatments were made

Records of treatment shall be made avallable to the Executive Secretary upon request and shall include a period of two years ending with the date of the request.

"6. The sulfur content of any fuel oil burned shall not exceed 0.85 pounds of sulfur per million British Thermal Units (BTU) heat input as determined by ASTM Method D-4329-83. The sulfur content shall be tested only if directed by the Executive Secretary.

"7. All installations and facilities authorized by this approval order shall be adequately and properly maintained.

"8. The Executive Secretary shall be notified upon start-up of the installation, as an initial compllance inspection is required.

"9. Eighteen months from the date of this approval order the Executive Secretary shall be notified of the status of construction of this project. unless construction has been completed.

"10. A spray bar shall be installed on the mainline of the track. The spray bar shall operate whenever the moisture content of the material is below $7 \%$. The moisture content test shall be determined according to ASTM Method 0-2216 on the -40 mesh portion of the sample. Moisture content testing shall be performed on at least every 5 rail cars that come to the site and at least one test shall be run every day that cars are unloaded at the site. The spur located south of the mainiine shall be used to store the cars that require spraying. Records of moisture content tests shall be kept for all periods when the plant is in operation, and shall be made available to the Executive Secretary upon request and shall include a period of two years ending with the date of this request.

"11. The amount of material disposed at the site shall not exceed 500.000 tons per year without prior approval in accordance with Section 3.1. UACR. Records of material disposed shall be kept for all periods when the plant is in operation. Records of material disposal shall be made available to the Executive Secretary upon request, and shall include a period for two years ending with the date of this request. Material disposal shall be determined by weigh sca les and record keeping.

"12. The disposal material shall have a moisture content of no less than $2 \%$ by weight during handling operations. 
"13. The disturbed area shall not exceed 63 acres at any given time.

"Al 'owable emissions' as defined in Section 1.12, UACR, for this source (the entire plant) are currently calculated at 155.27 TPY Particulates, 68.46 TPY PM 10.37 .98 TPY $\mathrm{SO}_{2}, 17.25$ TPY NO $\mathrm{X}, 0.985$ TPY $\mathrm{CO}$ and 0.813 TPY methane. These calculations are for the purposes of determining the applicability of PSO and nonattainment area major source requirements of the UACR. They are not to be used of the purposes of determining compliance."

\subsubsection{1le.(2) Radioactive Materials License}

Envirocare received its $11 \mathrm{e}$. (2) Radioactive Materials License from the NRC on November 19, 1993. This Ticense is effective from November 30, 1993 until November 30, 2003. The license permits Envirocare to acquire, transfer, receive, and possess byproduct, source, and special nuclear material for the purposes outlined in the conditions of the license. The company is permitted to accept up to 3.3 million cubic yards of packaged or bulk radioactive waste containing 1le.(2) byproduct material. The license is deemed to contain and is subject to the conditions specified in the NRC regulations set forth in 10 CFR Chapter 2, Parts $19 ; 20 ; 21 ; 40$, including Appendix $A ; 51 ; 61.80$; and 61.82 and is subject to the rules, regulations, and order of the NRC now or hereafter in effect; and is subject to an additional 36 conditions specified or incorporated in the license. The most important conditions, from a customer standpoint, are those concerning debris disposal, as follows:

- The licensee shall assume full responsibility for cleaning up the groundwater of all hazardous constituents detected at the point of compliance (POC) in concentrations that exceed the limits specified in the license. It shall be assumed that the 11e. (2) disposal facility is the source of all of the hazardous constituents detected in the POC wells, unless it can be demonstrated to the NRC's sat isfaction, based on field and laboratory data, that the lle.(2) facility is not the source of particular constituents. NRC shall have the final decision concerning any claim by the licensee that the $1 \mathrm{e}(2)$ is not the source of a particular constituent that is detected at the POC.

- The licensee shall use the Environmental Protection Agency Paint Filter Liquid Test (SW-846, Method 9095) on radioactive waste shipments prior to acceptance on site to insure that the [sic] no waste is accepted for storage or disposal with free standing liquid.

- The licensee shall. upon arrival of waste, ensure that wastes will be segregated into two categories of specific activities: lower activity and higher activity. The licensee shall not accept higher activity waste (those with average concentrations at or greater than $1.000 \mathrm{pCi} / \mathrm{g}$ for any radionuclide), unless it can be disposed of within 10 days of acceptance.

- The licensee shall operate the facility in compliance with the following spec if ications:

a) The maximum bulk mass of ${ }_{5}$ waste disposed of annually will not exceed $4.536 \times$ $10^{5}$ tonnes [sic] $\left(5 \times 10^{5}\right.$ tons $)$.

b) The maxiqum annual disposal area will not exceed $229 \mathrm{~m} \times 168 \mathrm{~m}$ (equivalent to $\left.38.472 \mathrm{~m}^{2}\right)$. 
c) The 11e.(2) waste will be disposed of in no more than two-thirds of the annual disposal area at any one time.

d) The total embankment capacity will not exceed $2.52 \times 10^{6} \mathrm{~m}^{3}\left(3.3 \times 10^{6} \mathrm{yd}^{3}\right)$.

e) The maximum volume of waşte that may be sţored on site prior to disposal will not exceed $2.743 \times 10^{4} \mathrm{~m}^{3}\left(9.687 \times 10^{5} \mathrm{ft}^{3}\right)$ at any one time.

f) Waste with an average concentration above $2.000 \mathrm{pCi} / \mathrm{g}$ for any radionuclide in the uranium serles or above $6.000 \mathrm{pCl} / \mathrm{g}$ for any radionuclide in the thorium series in any truck load or raflcar will not be accepted.

g) The annual bulk concentration of higher activity material at the site will be restricted to an average of $1.000 \mathrm{pCl} / \mathrm{g}$ for any radionuclide and to $10 \mathrm{X}$ of the bulk waste.

h) The yearly average concentrations of any radionuclide will be restricted to $500 \mathrm{pCi} / \mathrm{g}$.

- The licensee shall immediately report: 1) any failure of the 1le. (2) byproduct materfal disposal cell that results in a release to waste into unrestricted areas: or 2) any unusual conditions that if not corrected could indicate the potential or lead to the failure of the system and result in a release of waste into an unrestricted area; to NRC Region IV and the Chief of the Uranium Recovery Branch. Division of Low Level Waste Management and Decomissioning. Office of Nuclear Materials Safety and Safeguards.

\subsubsection{Environmental Monitoring Programs}

\subsubsection{Air Monitoring}

6.8.1.1. Process Description. Envirocare received a State Air Quality Permit on December 21, 1990. The permit conditions stated that visible emissions from any point or fugitive emissions source associated with the installation or control facilities may not exceed $20 \%$ opacity. Opacity observations of emissions from stationary sources must be conducted according to 40 CFR 60, Appendix A, Method 9.

6.8.1.2. INEL Assessment Team Observations/Impressions. At the time of the March 1993 site inspection, the entire area was extremely wet from an above average snow fall. No visible emissions were present from fugitive dust. The INEL Assessment Team did observe the air monitoring stations (Figures 43 and 44). All stations appeared to be well maintained and in good working order.

During the November 1993 re-assessment, the INEL Assessment Team noted that Envirocare was managing fugitive dust. The roadways were being watered on a 
regular basis. No fugitive dust emissions were noted from either the road surfaces or from cover operations at the landfill cells.

\subsubsection{Groundwater Monitoring}

6.8.2.1. Process Description. The Ground Water Monitoring Program, as written in the Part B Permit, requires several sub-programs. The Ground Water Monitoring Program requires a Detection Monitoring Program. The Detection Monitoring Program is outlined in Section VI.F of the Ground Water Monitoring Plan. Whenever a hazardous constituent is detected, a Compliance Monitoring Program is instituted as defined in Section VI.I.

Whenever hazardous constituents exceed concentration limits as per the Part $B$ permit, a Compliance Monitoring and or Corrective Action Program is implemented.

6.8.2.2. INEL Assessment Team Observations/Impressions. The Ground Water Monitoring Program appeared to be very thorough and well thought out. The sampling of a monitoring well was observed and proper sampling and chainof-custody procedures were being followed. The conditions of the Part $B$ Permit appeared to be satisfied.

The groundwater monitoring wells appeared to be well maintained and labeled (Figures 45 and 46). The INEL Assessment Team did suggest to the Envirocare management, however, that stanchions be place around the wellheads in order to protect them from being damaged by heavy equipment traffic in the area. This risk of damage was especially noticeable for the well heads located less than about five (5) feet from the facility access roads (See Figure 45).

During the subsequent inspection in November 1993, the INEL Assessment Team was told that concrete highway dividers were now in place around several of the monitoring well heads. The Assessment Team did not observe the wells, because of the high volume of truck traffic in the area. 
EGG-ESQ-10749

January 1994

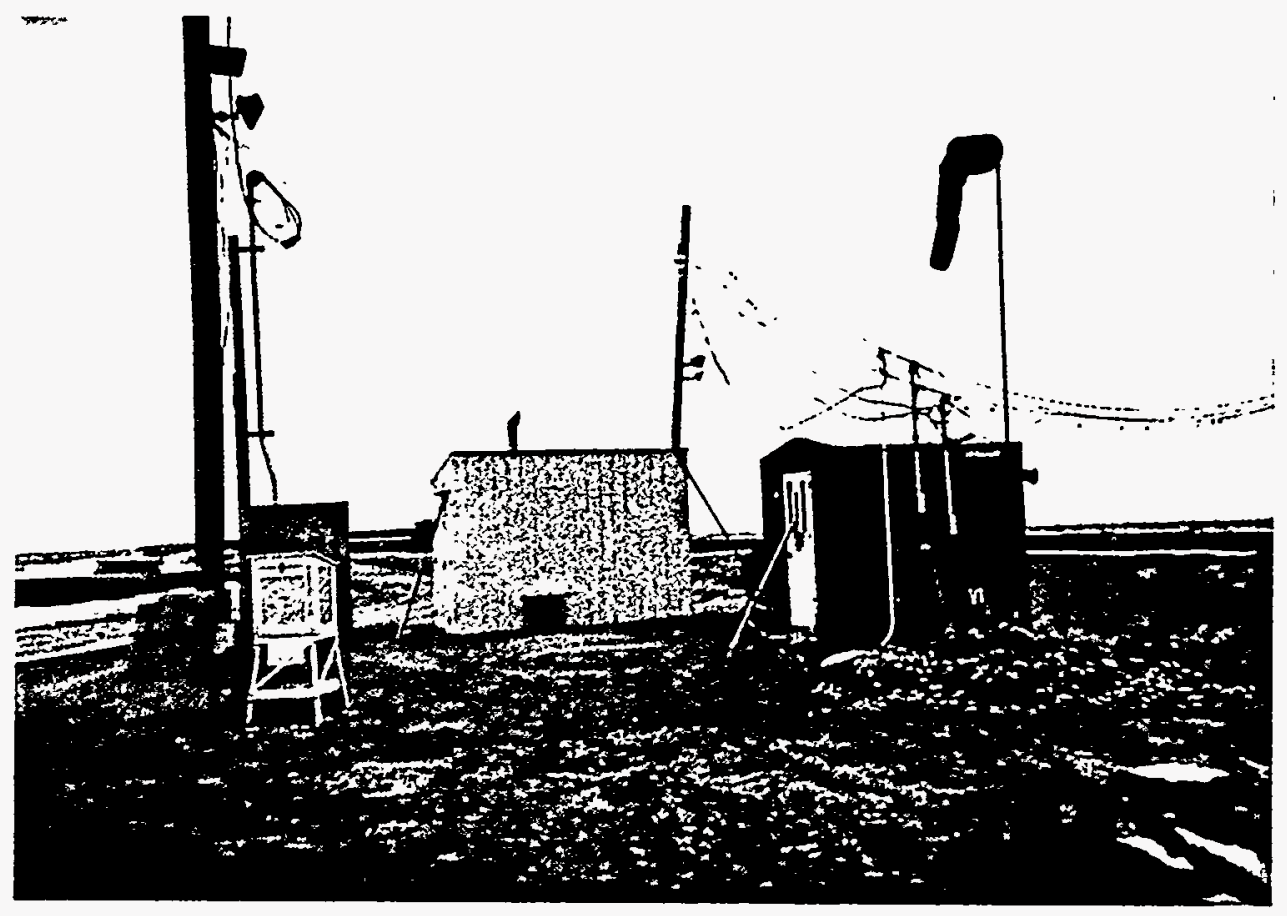

Figure 43. Air monitoring station located at the rail car rollover facility.

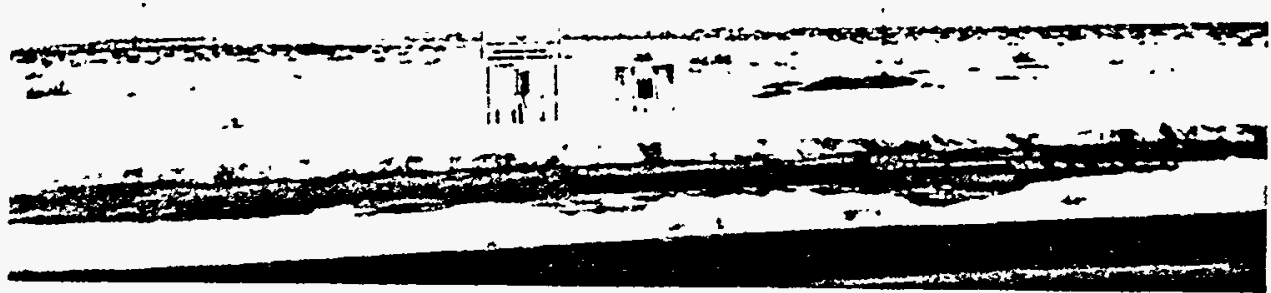

Figure 46. Air monitoring station located east of the Envirocare administration building. 


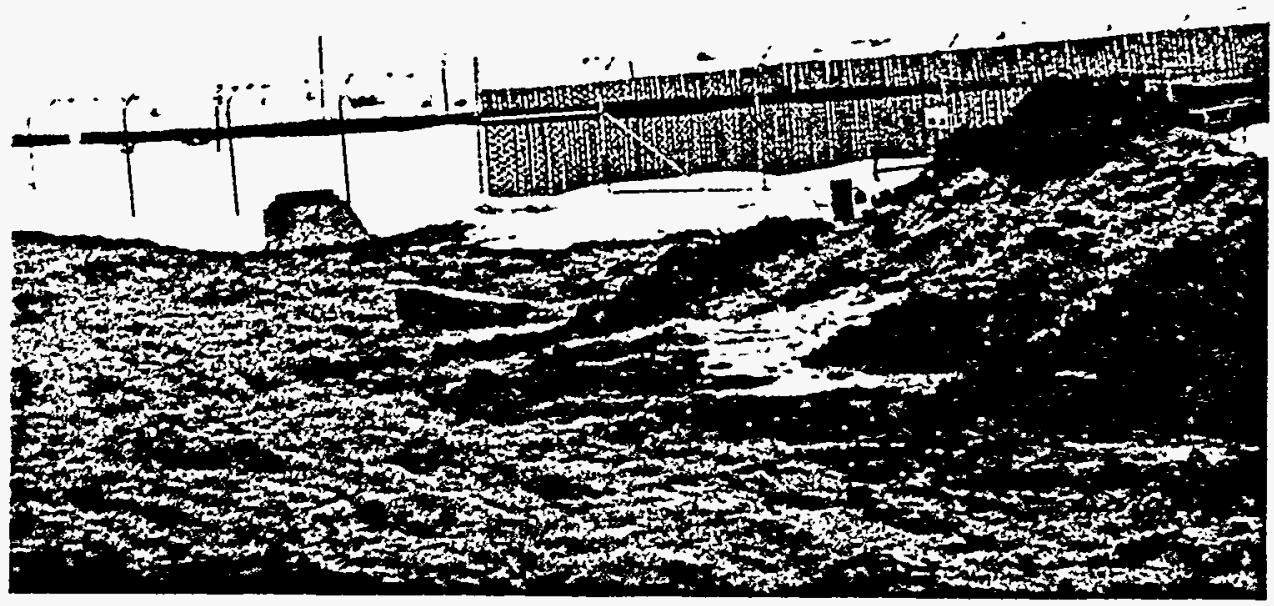

Figure 45. Groundwater monitoring well (orange cylinder) located adjacent to the Vitro Tailings disposal cell.

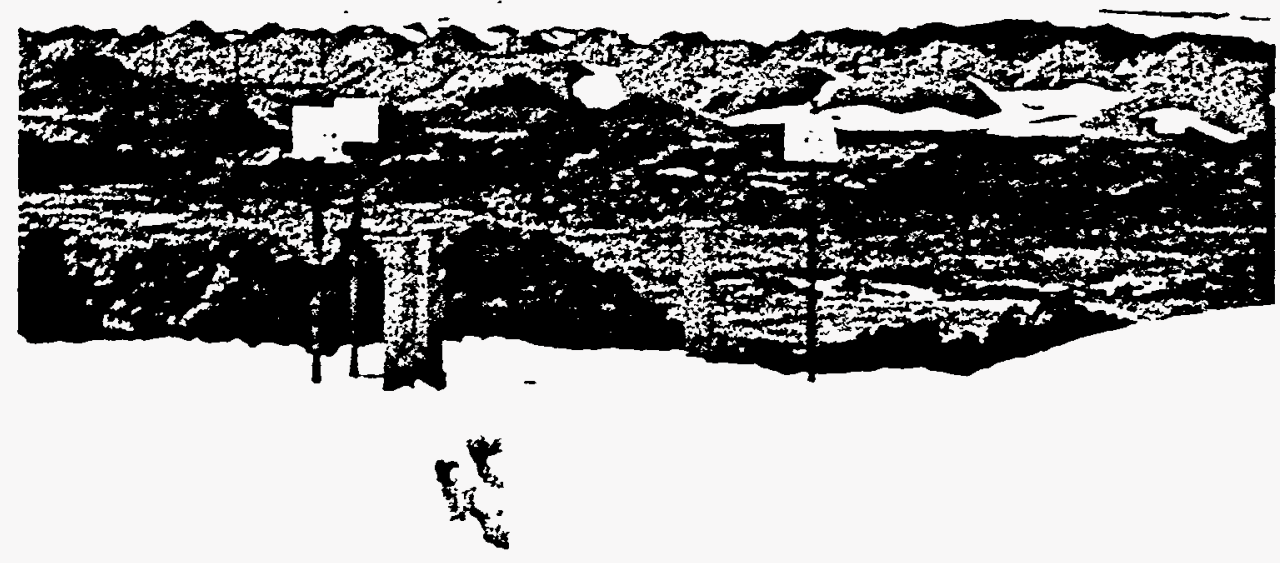

Figure 46. Groundwater monitoring well located adjacent to an Envirocare facility access road. 


\section{FINANCIAL STRENGTH}

The purpose of this section is to provide documentation verifying Envirocare's abilities to respond quickly to environmental, safety, and health incidents, to provide adequate financial assurances for facility closure costs, and to maintain financial assurances for any potential litigation.

\subsection{InSURANCE}

40 CFR §§ 264.147 and 265.147 require an owner or operator of a hazardous waste treatment, storage, or disposal facility, or a group of such facilities, to maintain liability insurance. In particular, 40 CFR $\S \S 264.147(a)$ and 265.147 (a) require the owner or operator to maintain coverage for sudden accidental occurrences arising from operations of the facility or group of facilities. (A sudden accidental occurrence is defined as "an occurrence which is not continuous or repeated in nature" (40 CFR $\S 264.140(\mathrm{~g})$ ).) The owner or operator must have and maintain liability coverage for sudden accidental occurrences in the amount of at least $\$ 1$ million per occurrence with an annual aggregate of at least $\$ 2$ million, exclusive of legal defenses. The regulations specify the methods which the owner or operator may use in order to demonstrate the liability coverage.

40 CFR §§ 264.1747 (b) and 265.147 (b) require the owner or operator of a surface impoundment, landfill, or land treatment facility which is used to manage hazardous waste, or a group of such facilities, to maintain coverage for nonsudden accidental occurrences arising from operations of the facility or group of facilities. (A nonsudden accidental occurrence is defined as "an occurrence which takes $p l a c e$ over time and involves continuous or repeated

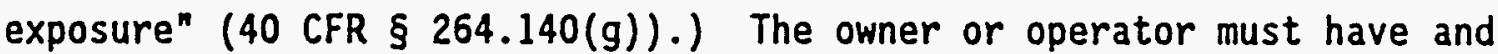
maintain liability coverage for nonsudden accidental occurrences in the amount of at least $\$ 3$ million per occurrence with an annual aggregate of at least $\$ 6$ million, exclusive of legal defenses. The owner or operator who must meet the requirements of this section may combine the sudden and nonsudden accidental coverages into a single per-occurrence level and combine the required annual aggregate coverage levels for sudden and nonsudden accidental coverages into a 
single annual level. Owners or operators who combine coverage levels must maintain liability coverage in at least $\$ 4$ million per occurrence and at least $\$ 8$ million annual aggregate. The regulations specify the methods which the owner or operator may use in order to demonstrate the liability coverage.

Envirocare maintains general liability, automobile liability, and pollution legal liability insurance (Figure 47). The pollution legal liability insurance, purchased from National Union Fire Insurance Company, is maintained in accordance with 40 CFR $\S 264.1747$ (b) for owners and operators of a landfill. Envirocare has chosen to combine coverage levels for sudden and nonsudden accidental coverages into a single annual level of $\$ 4,000,000$ for each loss and $\$ 8,000,000$ for total losses.

\subsection{Closure and Post-Closure Care}

40 CFR $\S \S 264.142$ and 265.142 require an owner or operator to have a detailed written estimate, in current dollars, for the cost of closing the facility in accordance with the requirements in $\S \S 264.111$ through 264.115 and/or 265.111 through 265.115 and applicable closure requirements in $\S \S 264.178$ and/or 265.178 (containers), 264.197 and/or 265.197 (tanks), 264.228 and/or 265.228 (surface impoundments), 264.258 and/or 265.258 (waste piles), 264.280 and/or 265.280 ( 1 and treatment units), 264.310 and/or 265.310 ( 1 andfills), 264.351 and/or 265.351 (incinerators), and 264.601 through 264.603 and/or 265.601 through 265.603 (miscellaneous units).

In addition the regulations (40 CFR $\S \S 264.142(b)$ and 265.142(b)) specify that during the active life of the facility the owner or operator must adjust the closure cost estimate for inflation within 60 day prior to the anniversary date of the establishment of the financial instrument(s) used to comply with 40 CFR §§ 264.143 and 265.143.

Envirocare operates a RCRA permitted landfill which is subject to the closure requirements of $40 \mathrm{CFR} \S 264.310$ and the closure cost estimate requirements specified in 40 CFR $\S 264.142(b)$. 


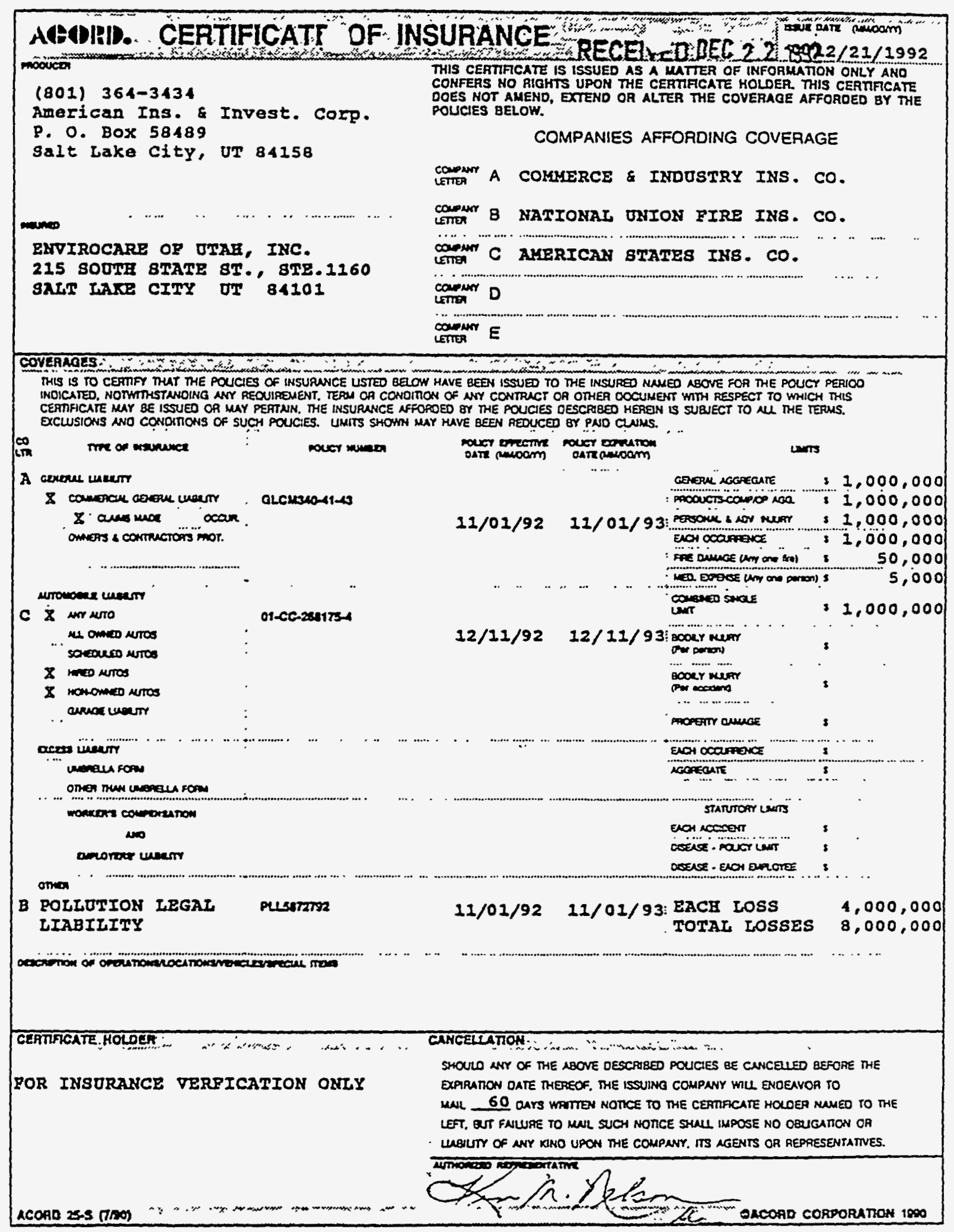

Figure 47. Envirocare Certificate of Insurance. 
EGG-ESQ-10749

January 1994

This page intentionally left blank. 
Because the Envirocare facility disposes of radioactive wastes (LLW), the facility must be 1 icensed under the NRC regulations of 10 CFR Part 61 . The regulations require that, beyond the financial assurance requirements of the RCRA/HSWA permit(s), the facility must meet additional financial assurance requirements. The regulations also specify requirements for institutional controls on the land, with concomitant requirements for financial assurances sufficient to provide the mandated institutional controls for the specified period. Under 10 CFR $\S 61.61$ the facility owner/applicant must show that it has sufficient assets or assurance of sufficient assets to operate the facility. In 10 CFR $\S 61.62$, the applicant is required to demonstrate that it is financially capable of conducting all required operations during the life of the facility. Under 10 CFR $\S 61.63$ the applicant must provide the financial assurances that all institutional controls can be maintained for the required (presumably 100 years) period.

The INEL Assessment Team identified concerns regarding the facility's, assurances and controls under the NRC and EPA regulations. These concerns were also identified by the Office of the Legislative Auditor General for the State of Utah. The concern for the INEL relates to what happens to the site if Envirocare were to default or cease to exist before the end of active waste management and/or the post closure care period. The questions raised were:

- Who would be responsible for the closure and post closure care of the site?

- Who would pay for the closure and post closure care of the site?

- Who would own the site?

EG\&G Idaho believes that it has a responsibility to protect itself; its parent, EG\&G, Inc.; and its customer, the DOE, from entering into any subcontracts with the knowledge that the risk of becoming a PRP is significant. Therefore, clarification of Envirocare's closure and post closure assurances and controls under the NRC and EPA regulations was important to the INEL Assessment Team. 
The NRC regulations require that institutional controls on the land be established for up to one hundred (100) years following transfer of site control to the land owner ( 10 CFR $\S 61.59$ ), with the concomitant financial assurances to maintain and monitor the site during the institutional control period (10 CFR § 61.63). The Envirocare MW Closure Care Plan only provides for such post-closure care out to thirty years. The documentation reviewed did not indicate that the NRC or State had signed off on a thirty year period to satisfy the 10 CFR $\S 61.59$ and 61.63 requirements. This point was discussed with the facility representatives who stated that at the end of the 30 year period, the NRC post closure $p l$ an would cover the additional 70 year requirements. The INEL Assessment Team noted that the NRC post closure plans did not specifically address the various units, e.g., NORM, LLW, and MW, at the facility. The Assessment Team was concerned about the ability to enforce the use of the NRC plans for units not specifically identified. The company did not consider this to be an issue, however, the DRC was aware of the plans. As previously stated in Section 4.3.3.2.3. of this report, the DRC was proposing that a perpetual care fund be established in order to ensure that the State would not be required to fund the post closure care of the site if Envirocare should cease to exist. The DRC was also considering requiring Envirocare to update its post closure plans to address the units in question. However, no action had been taken by the DRC as of the date of this report.

A concern was also raised about the land ownership of the Clive facility. The NRC requires nuclear waste facilities to be owned by either the State or Federal Governments under 10 CFR $\S 61.59(a)$. Because Envirocare, a private company, owns the land, a concern exists over the long-term responsibilities for the site, and the implications for generators disposing of materials at the site.

This concern was also raised during the performance audit of the DEQ by the Utah Office of the Legislative Auditor General. The State auditors noted that the primary areas of concern were in site ownership and the effect of ownership on state liability and overall state liability for the site should the site operator become insolvent. Site ownership was a concern because there is no consensus as to whether private or public ownership was more beneficial to government. On this issue the NRC and EPA take completely 
different stances. The company stated that if Envirocare left the state, or ceased to exist, the State would own the Envirocare property. However, in a memorandum from S. J. Chilk, NRC to J. M. Taylor, NRC, dated June 28, 1993, a concern regarding this ownership was raised. It was noted that the Utah Legislature had not, to date, authorized the State to take title to the site nor to take responsibility for the site. Therefore, the NRC has required the State to place specific restrictions on the future use of the land in the restrictive covenants in order to provide for the control of the waste disposal area for the period of time contemplated in 10 CFR 61 .

The auditors made the following statements regarding site ownership as an issue:

\footnotetext{
Site ownership is an issue because it revolves around the question of site responsibility after the colls have been sealed and operations have ceased. While the question of ownership addresses legal responsibility, should all other sources fail. state responsibility. has never been questioned. Should problems occur and the legal owner be unable to fund corrective action, public funds may have to be used to protect public health and the enviroment. Given the long life of the toxicity of radioactive and hazardous wastes, fallure and lack of private funds are possibilities.
}

\begin{abstract}
8oth the EPA and the MRC believe that post-closure ownership of waste disposal site is important but their views as to who should own the property diverge. The EPA requires any disposal site with RCRA wastes to be privately owned and maintained. The reasoning is that the waste site operator retains all responsibility for site liability. If the operator is unable to handle the financial responsibility. EPA doctrine requires the waste generators with wastes at that site to be financially responsibie.
\end{abstract}

\begin{abstract}
MRC rules are exactly the opposite as they question whether or not the operator or generators will exist as viable entities 20 , 50, or 100 years in the future. The NRC requires what it calls institutional ownership of sites in post-closure. The logic here is that private companies do not exist for the long periods of time necessary for radioactive materials to breakdown. Government ownership allows immediate access to the site and governmental responsibility should anything happen. In the long run, either governmental or private ownership may be inconsequential to governmental liability because the time involved is so long it is difficult to expect the businesses involved will continue to exist or that technologies will remain the same.
\end{abstract}

Post-closure ownership has been debated heavily in Utah since the radioactive waste site opened. The NRC believes in institutional control of the site after it is closed. with the state or federal government obtaining title to the property. Utah's DRC, however, decided that the EPA approach of maintaining private ownership and thus private liability was preferable. Because of this preference, the ORC exempted the Envirocare site from its rules requiring institutional ownership. Such an exemption is allowed within the ORC's rules. This was considered a moot point because NRC thinking. like that of the EPA, is that properly designed waste containment cells will not allow contamination, making liability low. Both NRC and EPA treatment of sites in the post-closure period make the assumption that nothing will go wrong during or even after the monitoring period (Performance Audit: 1993:56-57).

The legislative audit stated further that liability for possible problems in the future was a far more important question than who owned the site. The report stated the EPA's superfund site experience showed that years after a 
site was closed, government ultimately accepted some of the liability. Utah's program mirrored the federal thinking that a worst-case scenario, e.g., a ruptured or breached containment cell, would not happen; therefore Utah required only enough funding for post-closure monitoring by a third party. other states have taken a different approach and assess fees to protect themselves. Utah does not, at this time.

The report noted that state liability was reduced significantly during site operation and closure because the state's licenses and permits required some financial surety as a license stipulation. Financial surety accounts were established for the closure and post-closure monitoring of disposal facilities in Utah. The accounts are dedicated strictly for this purpose; funds cannot be withdrawn from the account without approval from the DEQ.

In spite of the funds and accounts available, the State auditors recommended that the Legislature consider statutory inclusion of waste disposal fees for possible funding of site surety and liability accounts. These fees would help to protect the state, and the generators, from high clean-up costs that could result from unforeseen problems occurring after closure. The same types of fees are presently imposed by South Carolina and Washington for their radioactive waste disposal sites. To date, the fee structure has not been authorized by the Utah Legislature.

\subsection{Financial Assurance}

There are six different methods allowed by the RCRA rules to guarantee closure costs (40 CFR §§ 264.146 and/or 265.146):

- Closure Trust Fund [40 CFR §§ 264.143(a) and/or 265.143(a)]

- Surety Bond for payment into a Trust Fund [40 CFR $\S \S 264.143$ (b) and/or $265.143(\mathrm{~b})$ ]

- Performance Surety Bond [40 CFR $\S \S 264.143$ (c) and/or 265.143(c)]

- Closure Letter of Credit [40 CFR $\S \S 264.143$ (d) and/or 265.143(d)] 
- Closure Insurance [40 CFR §§ 264.143(e) and/or 265.143(e)]

- Financia] Test and/or Corporate Guarantee [40 CFR §§ 264.143(f) and/or $265.143(f)]$

Envirocare has entered into two Trust Agreements with Key Trust Company in order to ensure closure costs for the Clive facility. Key Trust Company is a Utah corporation with offices in Salt Lake City, Utah. The Trusts al so ensure that Envirocare shall have the funds necessary to close, and subsequently provide post-closure care for, the radioactive waste disposal and hazardous waste management facilities under its ownership. The beneficiary of the Trusts is the Utah State Department of Environmental Quality. The trust agreement for the radioactive disposal facilities was signed by K. B. Semnani for Envirocare and J. D. Sparks for Key Trust Company on July 9, 1992. The trust agreement for the hazardous waste management facility was signed by $K$. B. Semnani for Envirocare and J. D. Sparks for Key Trust Company on January 10, 1991 .

The hazardous waste management facility trust agreement met the requirements of 40 CFR $\$ 264.143$ (a). The schedule A listed the amount of liability coverage as $\$ 76,000.00$ Thousand U. S. dollars with K. B. Semnani identified as the signatory for the grantor. The Schedule $B$ stated that the funding of this standby agreement consists of cash. A letter dated January 12, 1993 from Envirocare to the DEQ updated the closure cost estimate for the RCRA regulated facility.

An interesting note was that the State RCRA Permit specifically states: "The Permittee shall not be allowed to use existing agreements for the company NORM operations to provide financial assurance for mixed waste management." (Permit Condition II.P.2.) Notwithstanding this prohibition, the Closure Cost Estimate (Appendix I1-7-1, Envirocare RCRA Permit Application, as adopted by incorporation by the state permit, at page 2) specifies that the general inspection costs for post-closure "are already covered by the trust funds set up for the NORM facility." On the surface this would seem to contravene the stated prohibition of the state permit. Whether the prohibition can be read to require duplicative sets of assurances for all components is not clear. 


\subsection{History and EXPERIENCE OF OWNERS}

Envirocare is a waste disposal and environmental engineering firm. The business was started by its corporate officers in 1988. The Dun and Bradstreet (D\&B) report states that the "For Profit" corporation was incorporated on December 4, 1987 in Utah.

This company is related to $S K$ Hart Engineering through common ownership and/or financial interest. S K Hart Engineering was started in 1982 and operates as a land development firm.

Envirocare of Utah, Inc. (formerly known and licensed as Hart Engineering or S. K. Hart).

Envirocare is owned by Mr. Khosrow Semnani, who also owns $100 \%$ of the capital stock in the company. Mr. Semnani was instrumental in the formation, permitting, and construction of the hazardous waste treatment/disposal facility (Grassy Mountain) currently operated by USPCI in the WDHIA of Tooele County, Utah. In early $1988 \mathrm{Mr}$. Semnani obtained the proper permits and began construction of Envirocare's NORM disposal facility, which occupies contiguous property with the present operations.

\subsection{Capacity and Capital of the Company}

The most recent D\&B report could not provide a current balance sheet and income statement data. D\&B analysts were contacted by the EG\&G Idaho financial analysts in order to determine if enough detail could be obtained from the balance sheets submitted by Envirocare to D\&B to calculate the necessary ratios. The D\&B analysts told the EG\&G analysts that they were unable to obtain any detail from Envirocare and were unable to calculate the ratios. Attempts to obtain more timely, and complete, financial data from Envirocare were unsuccessful. 
The information presented in this section was extracted from the most current D\&B report available, dated February 12, 1993.

Decenber 31. Fiscal

Current Assets

Current Liabilities

Current Ratio

Working Capital

Other Assets

Worth

Sales

Long Term Liability
December 31, 1990
4.543 .034
689.495
6.58

13.0

2.873 .501

711.033

$3,584,534$

$6,168,501$
Decenber 31. 1990

December 31, 1991

Monthly rent $\$ 4,600$. Lease expires Mar 1993.

Submitted by Victor Romero, controller. Extent of audit, if any, not indicated.

\section{STATEMENT ITEMS EXPLANATIONS}

The complete balance sheet was reviewed in its entirety and the above highlights were extracted for publication.

CURREHT ASSETS: Consist of cash and receivables.

CURREHT LIABILITIES: Consist of accounts payable, taxes and accrued expenses.

CONTINGENCIES: HONe.

LONG-TERM LIABILITIES: Consist of notes.

WORTH: There were no intangibles listed in the financial statement therefore the worth

figure contains no deductions.

LIQUIDITY: Liquid assets provide full coverage of current liabilities.

DEFERRED CREOITS: There were no deferred credits listed in the financial statement.

NOH-CURRENT Assets: Consist of fixed assets.

On DEC 031992 Victor Romero, controller, referred to the above figures as still representative.

He submitted the following partial estimates date SEP 03 1992: Sales for 1991 were $\$ 16,000,000$.

The EG\&G Idaho financial analysts would not commit to making a determination as to the financial strength and stability of the company based on these data.

\subsection{Current Financial Condition}

As previously stated, attempts to obtain timely, and complete, financial data from Envirocare were unsuccessful. The D\&B report stated that with respect to banking, as of March 1992 Envirocare's accounts averaged moderated seven figures. The account was open over three years. It was a non borrowing account. Overall relations were satisfactory. 
Overall, based on the information available, O\&B rated Envirocare $4 A 1$. The history was listed as clear and the financial condition as strong. 


\section{RISK ASSESSMENT AND SUMMARY OF PERTINENT INFORMATION}

All off-site commercial treatment, storage, and disposal facilities will present some level of risk to a waste generator. The handling and treatment of hazardous and toxic wastes is by nature fraught with environmental, human health, and regulatory related risks. The purpose of an ESH\&Q liability assessment is to facilitate the proper management of those risks.

\subsection{Public Health Risks}

The remote location and security present at the Envirocare facility make it highly unlikely that the general public could come into contact with anything that could be considered a public health risk. The regulations specifying that wastes $p l a c e d$ in the active landfill cells be covered each day also reduce this risk. The prevailing winds in the area would disperse any debris away from public access to the facilities.

The most reasonable potential risk to public health would be to the workers at the facilities. The training programs in place at the facilities are designed to reduce this risk by instructing employees in the proper operations of the facilities, as well as, the risks associated with these operations.

Risk to the public, in general, can be hypothesized by a scenario depicting an accident involving a transport vehicle, truck or rail car, loaded with MW, LLW, or NORM waste. The Clive Incinerator EIS, Vitro Tailings EIS, and 11e. (2) DEIS discuss the probability of the occurrence and severity of a transport scenario and consider it to be a very limited risk.

\subsection{ENVIRONMENTAL RISKS}

\subsubsection{Air Quality}

There are no air quality risks to the general public or environment associated with daily operations of the railroad siding or landfill facilities. 


\subsubsection{Surface Water}

The facility contains no surface water. No perennial, intermittent, or ephemeral streams occur in the area of the facility. The site is not located on a 100 year flood plain.

The Great Salt Lake is located approximately 31 miles east of the facility with the Cedar Mountains separating the two. Any spills near the facility would not affect the Great Salt Lake. The potential is minimal of a spill occurring along the 19 mile stretch of $[-80$ that lies within 0.5 miles of the Great Salt Lake. However, a spill into any surface water could be significant.

\subsubsection{Groundwater}

There has been no groundwater contamination identified through the groundwater monitoring program at the Envirocare facility to date.

It is unlikely that there will be a high risk of groundwater contamination at the Envirocare facility from activities at the landfill cells due to the triple redundant liner requirements for the landfill cells, the fact that the landfill cells are located above grade, and the extreme aridity of the climate. The only scenario that could produce such contamination would be a "massive" spill to the surface with no immediate cleanup response. This scenario is unlikely.

\subsubsection{Spills}

"The significance of a potential spill would depend on two primary factors: the type of waste spilled and the location of the spill. It is possible that a highly toxic material could be spilled in a remote desert area along an Interstate highway and could be cleaned up without significant effects on humans, wildlife, or water resources. Conversely, a less toxic material could be spilled in a sensitive area, e.g., town, wetland, shallow groundwater basin, with significant effects on the sensitive resource" (CTive EIS, p. 451). 


\subsection{Financial Risks}

The INEL Assessment Team and financial representatives were unable to obtain financial data concerning Envirocare of Utah. Without these data it is not possible to determine whether or not a financial risk exists with respect to bal ance sheets and current financial conditions. The pollution liability insurance policy suggests that the company is able to cover most potential spills or corrective actions which might occur before customers are drawn in for support.

However, the most uncomfortable financial risk is that associated with the closure and post-closure maintenance of the facility. As previously noted, the NRC's DEIS and FEIS stated that the State of Utah does not intend to assume the long-term custodial role for the lle.(2) site. The DEIS and FEIS also stated that the DOE would take title to the lle.(2) disposal site upon termination of the Envirocare license. Documentation substantiating such an agreement between the NRC, DOE, State of Utah, and/or Envirocare has not been identified.

From a MW perspective, the closure and post closure maintenance issues are clearer. Financial ownership has not been conclusively determined and adequate funding for the 30 - 70 year post closure period has not been fully identified. In addition, the DRC, DEQ, and NRC are aware of the site ownership and maintenance issues should Envirocare cease to exist before the completion of the post-closure care periods. The regulatory agencies are addressing the issues and requiring additional financial assurances in order to ensure that the State can adequately close and monitor the site should Envirocare be incapable. The proposal by the DRC that the Legislature require a perpetual care fund from Envirocare, if passed, should alleviate much of the concern for the DOE. Therefore, from a DOE and M\&O Contractor standpoint post-closure care of the MW facility should Envirocare be unavailable, should be less of an issue and potential risk than previously thought. 


\subsection{SUMMARY OF OTHER RISK-RELATED INFORMATION}

\subsubsection{Violations History}

The NOVs noted by the regulatory contacts were few in number, were resolved, and generally did not present issues with a potential for releases to the environment which would put generators at legal or financial risk.

\subsubsection{Pending Litigation}

There was no pending litigation identified involving Envirocare as a party. Therefore this section is not applicable.

\subsubsection{Environmental Incidents}

No environmental incidents were identified for operations at the Envirocare facility. No environmental incidents were observed during the onsite inspections.

\subsubsection{Management Attitudes}

Management attitudes at the Envirocare facility were excellent. Envirocare of Utah has put a lot of effort into ensuring that all of the paperwork is in place to meet the intent of the EPA and NRC regulations. Management support for the implementation of the requirements was also excellent. It was apparent that personnel at the facility were well trained and given much leeway to perform their assigned tasks within the regulatory framework. Management appeared to support improvements in processes and procedures.

During the November 1993 re-assessment the INEL Assessment Team found that the majority of the comments made regarding operations in March 1993 had been addressed. These included regulatory interpretations and best management practices. In addition, the company had instituted the NQA-1 requirements at the request of ORNL. They indicated that this had been a very good move for them. This indicated that the company was very conscious of its position 
within the industry and was genuinely interested in improving both its compliance status and its appearance to its customers.

\subsection{Rating of Facility, Based on Risks and Comparison to Other Similar Operations}

The Envirocare of Utah disposal facility is the only site in the U. S. at this time which is permitted to accept any type of mixed waste for disposal. For the purposes of this section, the operations of the Envirocare facilities were compared with those of several commercial hazardous waste disposal facilities which have been assessed by members of the INEL Assessment Team. It is the opinion of the Assessment Team that Envirocare compares very favorably with the commercial hazardous waste disposal facilities. The operational records and documentation appeared to meet the intent of the regulations in effect at the time of the assessment. The conditions of the treatment and storage facilities appeared excellent. The condition of the cover and open faces of the landfill cells appeared acceptable. 
EGG-ESQ-10749

January 1994

This page intentionally left blank. 


\section{SUMMARY AND CONCLUSIONS}

An ESH\&Q and financial liability assessment was conducted of Envirocare. The assessment was requested by the DOE-ID as part of the evaluation of treatment and/or disposal options for RCRA hazardous/radioactive mixed waste.

Envirocare operates disposal cells for NORM, LLW which is called LARW in facility permits and documentation, and MW. The company also operates as a large quantity generator according to the State of Utah hazardous waste regulations. The company is capable of disposing of radioactively contaminated debris in its lined disposal cells. The company is planning to build a stabilization facility to treat MW to meet the LDR. This facility was not operational at the time of the assessment. Envirocare is allowed to dispose of hazardous wastes, which it generates as part of its processes, such as laboratory residuals and leachate, in its own cells once the waste meet the LDR. No site generated NORM, low level, or mixed wastes leave the facility.

The INEL Assessment Team which evaluated the facility, found no current Federal or State hazardous and/or radioactive waste generation, treatment, storage, or disposal issues; or personnel safety and health issues which would place the EG\&G operated DOE facilities at risk while doing business with Envirocare. The only outstanding issue was the financial liability. Envirocare is privately owned and very closely held with a single shareholder. The company declined to provide financial statements to the INEL Assessment Team or to the Dun and Bradstreet financial service. Therefore, it was not possible to perform a thorough financial analysis of the company. An additional issue concerned the post closure care and monitoring of the disposal units within the facility. The State of Utah and the NRC were cognizant of the ambiguities of the post closure documents and were attempting to clarify the issues. Information contained within the documents reviewed by the INEL Assessment Team regarding this issue suggest that the concerns will be resolved satisfactorily in the near future and should not pose an unreasonable risk to the DOE.

Personnel at the Envirocare facility displayed a concern for compliance with the requirements for occupational safety, and hazardous and radioactive waste 
disposal and reporting. It is the opinion of the INEL Assessment Team that the company presently meets the intent of the regulations and from an operational perspective will not provide an unreasonable risk to the DOE if the INEL M\&O Contractors choose to utilize this facility for the disposal of mixed waste debris. 


\section{REFERENCES}

\subsection{Federal Statutes}

Atomic Energy Act (as amended) 42 U. S. C. 2011-2259.

Clean Air Act (as amended) 42 U.S.C. 7401 et seq.

Clean Water Act (Federal Water Pollution Control Act) (as amended) U.S.C. § 1251 et seq.

Comprehensive Environmental Response, Compensation, and Liability Act (as Amended) Title I - Hazardous Substances Releases, Liability, Compensation, 42 USC § 9601 et seq.

Comprehensive Environmental Response, Compensation, and LiabiTity Act (as Amended) Title III - Miscellaneous Provisions, 42 USC $\S 9651$ et seq.

Comprehensive Environmental Response, Compensation, and Liability Act (as Amended) Title 1 - Hazardous Substances Releases, Liability, Compensation, 42 USC § 9601 et seq.

Energy Reorganization Act of 1974 PL 93-438

Hazardous and Solid Waste Amendments of 1984, Subtitle C, "Hazardous Waste Management,"

Hazardous Materials Safety Act of 1974, (P. L. 93-633).

Hazardous Materials Transportation Act of 1974, (49 USC 1801 et seq). Nuclear Waste Policy Act of 1982 (as amended) 42 U.S.C. 10101 et seq. Safe Drinking Water Act (as Amended) 42 USC $\S 300$ et seq.

Toxic Substances Control Act, as Amended, 42 USC 2601 et seq.

Uranium Mill Tailings Radiation Control Act of 197842 USC $\S \S 7901-7942$

Water Quality Act of 1987 (P. L. 100-4).

\subsection{Federal Regulations}

Code of Federal Regulations, 10 CFR 20, "Standards for Protection Against Radiation," Environmental Guidance Program Reference Book: Atomic Energy Act and Related Legislation, ORNL/M1900, Oak Ridge National Laboratory, Revision 6, September 1992.

Code of Federal Regulations, 10 CFR 30, "Rules of General Applicability to Domestic Licensing of Byproduct Material," Environmental Guidance Program Reference Book: Atomic Energy Act and Related Legislation, ORNL/M1900, Oak Ridge National Laboratory, Revision 6, September 1992. 
Code of Federal Regulations, 10 CFR 40, "Domestic Licensing of Source Material," Environmental Guidance Program Reference Book: Atomic Energy Act and Related Legislation, ORNL/M1900, Oak Ridge National Laboratory, Revision 6, September 1992.

Code of Federal Regulations, 10 CFR 51, "Environmental Protection Regulations for Domestic Licensing and Related Regulatory Functions," Environmental Guidance Program Reference Book: Atomic Energy Act and Related Legislation, ORNL/M1900, Oak Ridge National Laboratory, Revision 6, September 1992.

Code of Federal Regulations, 10 CFR 61, "Licensing Requirements for Land Disposal of Radioactive Waste," Environmental Guidance Program Reference Book: Atomic Energy Act and Related Legislation, ORNL/M1900, Oak Ridge National Laboratory, Revision 6, September 1992.

Code of Federal Regulations, 10 CFR 71, "Packaging and Transportation of Radioactive Material," Environmental Guidance Program Reference Book: Atomic Energy Act and Related Legislation, ORNL/M1900, Oak Ridge National Laboratory, Revision 6, September 1992.

Code of Federal Regulations, 10 CFR 192, "Health and Environmental Protection Standards for Uranium and Thorium Mill Tailings," Environmental Guidance Program Reference Book: Atomic Energy Act and Related Legislation, ORNL/M1900, Oak Ridge National Laboratory, Revision 6, September 1992.

Code of Federal Regulations, 10 CFR 960, "General Guidelines for the Recommendation of Site for Nuclear Waste Repositories, "Environmental Guidance Program Reference Book: Atomic Energy Act and Related Legislation, ORNL/M1900, Oak Ridge National Laboratory, Revision 6, September 1992.

Code of Federal Regulations, 10 CFR 962, "Byproduct Material," Environmental Guidance Program Reference Book: Atomic Energy Act and Related Legislation, ORNL/M1900, Oak Ridge National Laboratory, Revision 6, September 1992.

Code of Federal Regulations, 29 CFR 1910.120, "Hazardous Waste Operations and Emergency Response," Office of the Federal Register, July 1992.

Code of Federal Regulations, 29 CFR 1910.1200, "Hazard Communication," Office of the Federal Register, July 1992.

Code of Federal Regulations, 40 CFR 50, "National Primary and Secondary Ambient Air Quality Standards," Environmental Guidance Program Reference Book: Clean Air Act, ORNL/M498, Oak Ridge National Laboratory, Revision 3, November 1987.

Code of Federal Regulations, 40 CFR 60, "Standards of Performance for New Stationary Sources," Environmental Guidance Program Reference Book: Clean Air Act, ORNL/M498, Oak Ridge National Laboratory, Revision 3, November 1987.

Code of Federal Regulations, 40 CFR 61, "National Emissions Standards for Hazardous Air Pollutants (NESHAPs)," Environmental Guidance Program Reference Book: Clean Air Act, ORNL/M498, Oak Ridge National Laboratory, Revision 3, November 1987. 
Code of Federal Regulations, 40 CFR 110, "Discharge of 0i1, "Environmental Guidance Program Reference Book: Clean Air Act, ORNL/M-1278, Oak Ridge National Laboratory, Revision 5, October 1990.

Code of Federal Regulations, 40 CFR 112, "0il Pollution Prevention," Environmental Guidance Program Reference Book: Clean Air Act, ORNL/M-1278, Oak Ridge National Laboratory, Revision 5, October 1990.

Code of Federal Regulations, 40 CFR 116, "Designation of Hazardous Substances," Environmental Guidance Program Reference Book: Clean Air Act, ORNL/M-1278, Oak Ridge National Laboratory, Revision 5, October 1990.

Code of Federal Regulations, 40 CFR 117, "Determination of Reportable Quantities for Hazardous Substances, "Environmental Guidance Program Reference Book: Clean Air Act, ORNL/M-1278, Oak Ridge National Laboratory, Revision 5, October 1990.

Code of Federal Regulations, 40 CFR 122, "EPA Administered Permit Programs: The National Pollutant Discharge El imination System, "Environmental Guidance Program Reference Book: Clean Air Act, ORNL/M-1278, 0ak Ridge National Laboratory, Revision 5, October 1990.

Code of Federal Regulations, 40 CFR 125, "Criteria and Standards for the National Pollutant Discharge El imination System, "Environmental Guidance Program Reference Book: Clean Air Act, ORNL/M-1278, Oak Ridge National Laboratory, Revision 5, October 1990.

Code of Federal Regulations, 40 CFR 136, "Guidelines Establishing Test Procedures for the Analysis of Pollutants, "Environmental Guidance Program Reference Book: Clean Air Act, ORNL/M-1278, Oak Ridge National Laboratory, Revision 5, October 1990.

Code of Federal Regulations, 40 CFR 141, "National Primary Drinking Water Regulations," Environmental Guidance Program Reference Book: Safe Drinking Water Act, ORNL/M-1899, Oak Ridge National Laboratory, Revision 6, September 1992.

Code of Federal Regulations, 40 CFR 142, "National Primary Drinking Water Regulations Implementation," Environmental Guidance Program Reference Book: Safe Drinking Water Act, ORNL/M-1899, Oak Ridge National Laboratory, Revision 6, September 1992.

Code of Federal Regulations, 40 CFR 143;, "National Secondary Drinking Water Regulations," Environmental Guidance Program Reference Book: Safe Drinking Water Act, ORNL/M-1899, Oak Ridge National Laboratory, Revision 6, September 1992.

Code of Federal Regulations, 40 CFR 144, "Underground Injection Control Program," Environmental Guidance Program Reference Book: Safe Drinking Water Act, ORNL/M-1899, Oak Ridge National Laboratory, Revision 6, September 1992.

Code of Federal Regulations, 40 CFR 146, "Underground Injection Control Program: Criteria and Standards," Environmental Guidance Program Reference 
Book: Safe Drinking Water Act, ORNL/M-1899, Oak Ridge National Laboratory, Revision 6, September 1992.

Code of Federal Regulations, 40 CFR 148, "Hazardous Waste Injection Restrictions," Environmental Guidance Program Reference Book: Safe Drinking Water Act, ORNL/M-1899, Oak Ridge National Laboratory, Revision 6, September 1992.

Code of Federal Regulations, 40 CFR 401, "General Provisions," Environmental Guidance Program Reference Book: Clean Air Act, ORNL/M-1278, Oak Ridge National Laboratory, Revision 5, October 1990.

Code of Federal Regulations, 40 CFR 403, "General Pretreatment Regulations for Existing and New Sources of Pollution, "Environmental Guidance Program

Reference Book: Clean Air Act, ORNL/M-1278, Oak Ridge National Laboratory, Revision 5, October 1990.

Code of Federal Regulations, 40 CFR 148, "Restrictions on the Underground Injection of Hazardous Hastes," Environmental Guidance Program Reference Book: Resource Conservation and Recovery Act, ORNL/M-1897, Oak Ridge National Laboratory, Revision 11, March 1992.

Code of Federal Regulations, 40 CFR 257, "Criteria for Classification of Solid Waste Disposal Facilities and Practices," Environmental Guidance Program Reference Book: Resource Conservation and Recovery Act, ORNL/M-1897, Oak Ridge National Laboratory, Revision 11, March 1992.

Code of Federal Regulations, 40 CFR 260, "Hazardous Waste Management System General," RCRA Regulations and Keyword Index, 1992 Edition, Lakewood, Colorado: McCoy and Associates, Inc., 1992.

Code of Federal Regulations, 40 CFR 261, "Identification and Listing of Hazardous Waste," RCRA Regulations and Keyword Index, 1992 Edition, Lakewood, Colorado: McCoy and Associates, Inc., 1992.

Code of Federal Regulations, 40 CFR 262, "Standards Applicable to Generators of Hazardous Waste," RCRA Regulations and Keyword Index, 1992 Edition, Lakewood, Colorado: McCoy and Associates, Inc., 1992.

Code of Federal Regulations, 40 CFR 263, "Standards Applicable to Transporters of Hazardous Waste," RCRA Regulations and Keyword Index, 1992 Edition, Lakewood, Colorado: McCoy and Associates, Inc., 1992.

Code of Federal Regulations, 40 CFR 264, "Standards for Owners and Operators of Hazardous Waste Treatment, Storage, and Disposal Facilities, " RCRA Regulations and Keyword Index, 1992 Edition, Lakewood, Colorado: McCoy and Associates, Inc., 1992.

Code of Federal Regulations, 40 CFR 266, "Standards for Management of Specific Hazardous Wastes and Specific Types of Hazardous Waste Management Facilities," RCRA Regulations and Keyword Index, 1992 Edition, Lakewood, Colorado: McCoy and Associates, Inc., 1992. 
Code of Federal Regulations, 40 CFR 268, "Land Disposal Restrictions, " RCRA Regulations and Keyword Index, 1992 Edition, Lakewood, Colorado: McCoy and Associates, Inc., 1992.

Code of Federal Regulations, 40 CFR 270, "EPA Administered Permit Programs: The Hazardous Waste Permit Program," RCRA Regulations and Keyword Index, 1992 Edition, Lakewood, Colorado: McCoy and Associates, Inc., 1992.

Code of Federal Regulations, 40 CFR 271, "Requirements for Authorization of State Hazardous Waste Management Programs," RCRA Regulations and Keyword Index, 1992 Edition, Lakewood, Colorado: McCoy and Associates, Inc., 1992.

Code of Federal Regulations, 40 CFR 272, "Approved State Hazardous Waste Management Programs," RCRA Regulations and Keyword Index, 1992 Edition, Lakewood, Colorado: McCoy and Associates, Inc., 1992.

Code of Federal Regulations, 40 CFR 280, "Underground Storage Tanks," RCRA Regulations and Keyword Index, 1992 Edition, Lakewood, Colorado: McCoy and Associates, Inc., 1992.

Code of Federal Regulations, 40 CFR 281, "State Programs for Administering the Underground Storage Tank Programs," RCRA Regulations and Keyword Index, 1992 Edition, Lakewood, Colorado: McCoy and Associates, Inc., 1992.

Code of Federal Regulations, 40 CFR 761, "Polychlorinated Biphenyls (PCBs) Manufacturing, Processing, Distribution in Commerce, and Use Prohibition," Environmental Guidance Program Reference Book: Toxic Substances Control Act, ORNL/M-1126, Oak Ridge National Laboratory, Revision 5, May 1990.

Code of Federal Regulations, 40 CFR 300, "National $0 i 1$ and Hazardous Substances Pollution Contingency Plan, "Environmental Guidance Program Reference Book: Comprehensive Environmental Response, Compensation and Liability Act, ORNL/M-1177, Oak Ridge National Laboratory, Revision 11, October 1991 .

Code of Federal Regulations, 40 CFR 302, "Designation, Reportable Quantities, and Notification," Environmental Guidance Program Reference Book:

Comprehensive Environmental Response, Compensation and Liability Act, ORNL/M1177, Oak Ridge National Laboratory, Revision 11, October 1991.

Code of Federal Regulations, 40 CFR 355, "Emergency P1anning and Notification, "Environmental Guidance Program Reference Book: Comprehensive Environmental Response, Compensation and Liability Act, ORNL/M-1177, Oak Ridge National Laboratory, Revision 11, October 1991.

Code of Federal Regulations, 40 CFR 370, "Hazardous Chemical Reporting: Community Right-To-Know," Environmental Guidance Program Reference Book: Comprehensive Environmental Response, Compensation and Liability Act, ORNL/M1177, Oak Ridge National Laboratory, Revision 11, October 1991.

Code of Federal Regulations, 40 CFR 372, "Toxic Chemical Release Reporting: Community Right-To-Know," Environmental Guidance Program Reference Book: Comprehensive Environmental Response, Compensation and Liability Act, ORNL/M1177, Oak Ridge National Laboratory, Revision 11, October 1991. 
Code of Federal Regulations, 49 CFR 171, "General Information, Regulations, and Definitions," Environmental Guidance Program Reference Book: Hazardous Materials Transportation Act, ORNL/M-1023, Oak Ridge National Laboratory, Revision 5, October 1991.

Code of Federal Regulations, 49 CFR 172, "Hazardous Materials Table, Special Provisions, Hazardous Materials Communications Requirements and Emergency Response Information, " Environmental Guidance Program Reference Book: Hazardous Materials Transportation Act, ORNL/M-1023, Oak Ridge National Laboratory, Revision 5, October 1991.

Code of Federal Regulations, 49 CFR 173, "Shippers - General Requirements for Shipments and Packagings," Environmental Guidance Program Reference Book: Hazardous Materials Transportation Act, ORNL/M-1023, Oak Ridge National Laboratory, Revision 5, October 1991.

Code of Federal Regulations, 49 CFR 177, "Carriage by Public Highway," Environmental Guidance Program Reference Book: Hazardous Materials Transportation Act, ORNL/M-1023, Oak Ridge National Laboratory, Revision 5, October 1991.

Code of Federal Regulations, 49 CFR 178, "Specifications for Packagings," Environmental Guidance Program Reference Book: Hazardous Materials Transportation Act, ORNL/M-1023, Oak Ridge National Laboratory, Revision 5, October 1991.

Code of Federal Regulations, 49 CFR 180, "Continuing Qualification and Maintenance of Packagings," Environmental Guidance Program Reference Book: Hazardous Materials Transportation Act, ORNL/M-1023, Oak Ridge National Laboratory, Revision 5, October 1991.

OSWER/OER/HSCD, "CERCLA Off-site Policy: Providing Notice to Facilities," 9330.2-05.

OSWER/OER/HSCD, "CERCLA Off-site Policy -- Eligibility of Facilities in Assessment Monitoring," 9330.2-06.

50 FR 214, "Procedure for Planning and Implementing Off-Site Response Actions," U. S. Environmental Protection Agency, 45933-45937, November 5, 1985.

\subsection{CORRESPONDENCE}

Letter from C. Kammerer, NRC, to K. Alkema, DEQ, Subject: "Routine Review of Utah Radiation Control Program," September 2, 1992.

Letter from C. Kammerer, NRC, to K. Alkema, DEQ, Subject: "Additional Concerns regarding State's Rationale for Exemption of Envirocare from Site Ownership Requirement," December 24, 1992.

Letter from D. R. Nielson, DEQ to C. Kammerer, NRC, Subject: "Partial Response to December 24, 1992 Letter, "February 12, 1993. 
Letter from D. R. Nielson, DEQ to C. Kammerer, NRC, Subject: "Response to September 2, 1992 Letter," March 13, 1993.

\subsection{Computer SOfTWARE}

Air Quality, Federal Version, Audit Master, Version 4.8, Pittsford, New York: Utilicom, 1993.

EPCRA, Federal Version, Audit Master, Version 4.8, Pittsford, New York: Utilicom, 1993.

Hazardous Materials Transportation, Federal Version, Audit Master, Version 4.8, Pittsford, New York: Utilicom, 1993.

Industrial Hygiene, Federal Version, Audit Master, Version 4.8, Pittsford, New York: Utilicom, 1993.

Materials and Equipment Safety, Federal Version, Audit Master, Version 4.8, Pittsford, New York: Utilicom, 1993.

Occupational Medicine, Federal Version, Audit Master, Version 4.8, Pittsford, New York: Utilicom, 1993.

PCB Management, Federal Version, Audit Master, Version 4.8, Pittsford, New York: Utilicom, 1993.

Personnel Safety, Federal Version, Audit Master, Version 4.8, Pittsford, New York: Utilicom, 1993.

Solid and Hazardous Waste, Federal Version, Audit Master, Version 4.8, Pittsford, New York: Utilicom, 1993.

Spill Prevention, Federal Version, Audit Master, Version 4.8, Pittsford, New York: Utilicom, 1993.

Storage Tanks, Federal Version, Audit Master, Version 4.8, Pittsford, New York: Utilicom, 1993.

Water Quality, Federal Version, Audit Master, Version 4.8, Pittsford, New York: Utilicom, 1993.

\subsection{Publications}

Cahill, Lawrence B. and Raymond W. Kane, Environmental Audits, 6th Edition, Rockville, Maryland: Government Institutes, Inc., 1989.

Chronic, Halka, Roadside Geology of Utah, Missoula, Montana: Mountain Press Publishing Company, 1990.

Office of Legislative Auditor General, A Performance Audit of the Utah Department of Environmental Quality, Report to the Utah State Legislature, Report Number 92-08, December 1992. 
U. S. Department of Energy, Final Environmental Impact Statement: Remedial Actions at the Former Vitro Chemical Company Site, South Salt Lake City, Salt Lake County, Utah, DOE/EIS-0099-F, JuTy 1984.

U. S. Department of the Interior, Bureau of Land Management, Final Environmental Impact Statement: USPCI Clive Incineration Facility, Tooele County, Utah, June 1990.

U. S. Environmental Protection Agency, Multi-Media Investigation Manual, Rockville, Maryland: Government Institutes, Inc., 1992.

U. S. Nuclear Regulatory Agency, Draft Environmental Impact Statement to Construct and Operate a Facility to Receive, Store, and Dispose of 11e. (2) Byproduct Material Near Clive, Utah, NUREG-1476, February 1993.

U. S. Nuclear Regulatory Agency, Final Environmental Impact Statement to Construct and Operate a Facility to Receive, Store, and Dispose of 11e. (2) Byproduct Material Near Clive, Utah, NUREG-1476, August 1993. 


\title{
APPENDIX A. ABBREVIATIONS AND ACRONYMS
}

\author{
AEA Atomic Energy Act \\ a.k.a. also known as \\ API American Petroleum Institute \\ ASQC American Society for Quality Control \\ ASTM American Society of Test Metallurgists \\ BBB Better Business Bureau \\ BDLV Background Detection Limit Value \\ BLM United States Department of the Interior, Bureau of Land Management \\ BSHW Utah State, Division of Health, Bureau of Sol id and Hazardous Waste \\ BTU British Thermal Unit \\ CAA Clean Air Act \\ CAA AP Civilian Aeronautic Administration Airport \\ CERCLA Comprehensive Environmental Response and Liability Act \\ CFR \\ CLP \\ $\mathrm{cm} / \mathrm{sec}$ \\ $\mathrm{CO}$ \\ Code of Federal Regulations \\ Carbon Monoxide \\ COC Chain-of-Custody \\ CRTK Community Right-to-know \\ CWA Clean Water Act \\ D Discussed \\ D\&B Dun and Bradstreet \\ d.b.a. doing business as \\ DEIS Draft Environmental Impact Statement \\ DEQ Department of Environmental Quality \\ DOE United States Department of Energy \\ DOE-ID United States Department of Energy, Idaho Field Office \\ DOT \\ DRC \\ United States Department of Transportation \\ DSHW Division of Solid and Hazardous Waste \\ EA Environmental Assessment \\ EAD Emergency Action Director \\ EG\&G Idaho EG\&G Idaho, Inc. \\ EIS Environmental Impact Statement \\ EMD Emergency Management Department \\ EPA United States Environmental Protection Agency \\ EPCRA Emergency Planning and Community Right-to-Know Act \\ ES\&H Environment, Safety, and Health \\ ESG Environmental Support Group \\ ESH\&Q Environment, Safety, Health, and Quality \\ F Fahrenheit \\ FEIS Final Environmental Impact Statement \\ FIFRA Federal Insecticide, Fungicide, and Rodenticide Act \\ FOIA Freedom of Information Act \\ FR Federal Register
}


GM Waste Generation and Management

HAZHOPER Hazardous Waste Operations and Emergency Response

HCS Hazards Communication Standard

HDPE High Density Polyethylene

HMTA Hazardous Materials Transportation Act

HSWA Hazardous and Sol id Waste Act

HWM Hazardous Waste Management

IC Identification and Certification

INEL Idaho National Engineering Laboratory

$\begin{array}{ll}\text { K } & \text { thousand } \\ \text { LARW } & \text { Low Activity Radioactive Waste } \\ \text { LDR } & \text { Land Disposal Restrictions } \\ \text { LEPC } & \text { Local Emergency Planning Commission } \\ \text { LLW } & \text { Low Level Waste } \\ \text { LQG } & \text { Large Quantity Generator } \\ \text { LTU } & \text { Land Treatment Unit } \\ & \\ \text { Magcorp } & \text { Magnesium Corporation of America } \\ \text { M\&O } & \text { Management and Operations } \\ \text { mg/1 } & \text { milligrams per liter } \\ \text { MSDS } & \text { Material Safety Data Sheet } \\ \text { MW } & \text { Mixed Waste } \\ \text { N/A } & \text { Not Applicable } \\ \text { NEPA } & \text { National Environmental Policy Act } \\ \text { NESHAPS } & \text { National Emissions Standards for Hazardous Air Pollutants } \\ \text { NORM } & \text { Naturally Occurring Radioactive Material } \\ \text { NOV } & \text { Notice of Violation } \\ \text { NOV/CO } & \text { Notice of Violation and Order for Compliance } \\ \text { NO } & \text { Nitrogen Oxide compounds } \\ \text { NPDES } & \text { National Pollution Discharge El imination System } \\ \text { NPL } & \text { National Priorities List } \\ \text { NQA } & \text { Nuclear Quality Assurance } \\ \text { NRC } & \text { United States Nuclear Regulatory Commission } \\ \text { NUREG } & \text { Nuclear Regulations } \\ & \\ \text { OER } & \text { Office of Emergency Response } \\ \text { OI } & \text { Off-Site Identification } \\ \text { ORNL } & \text { Oak Ridge National Laboratory } \\ \text { OSHA } & \text { Occupational Safety and Health Act } \\ \text { OSWER } & \text { Office of Solid Waste and Emergency Response } \\ & \end{array}$




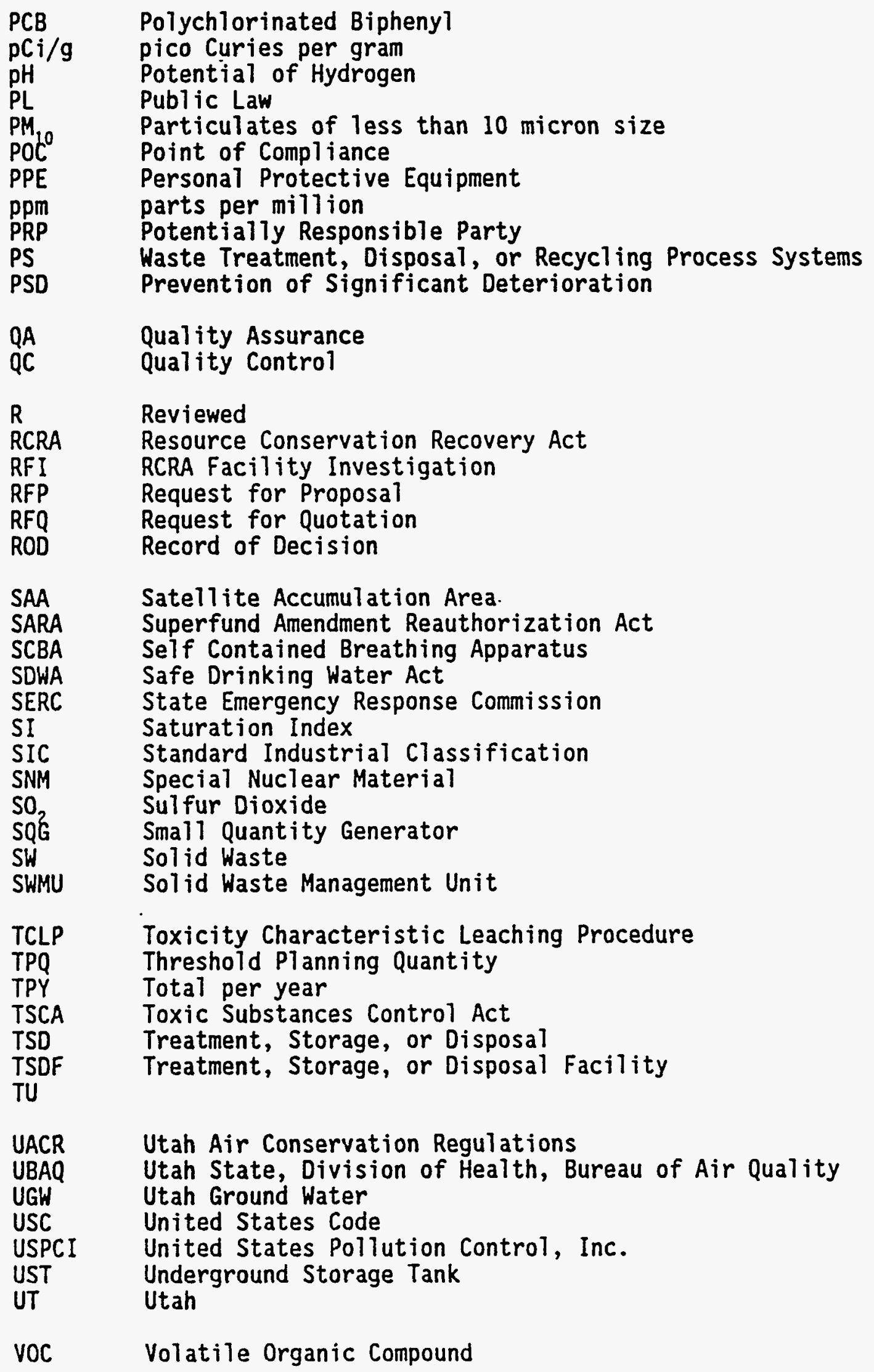


EGG-ESQ- 10749

January 1994

$\begin{array}{ll}\text { WAC } & \text { Waste Acceptance Criteria } \\ \text { WAP } & \text { Waste Analysis Plan } \\ \text { WDHIA } & \text { West Desert Hazardous Industry Area } \\ \text { WR } & \text { Waste Received from Off Site } \\ \text { Y } & \text { Year }\end{array}$




\section{APPENDIX B. HISTORY OF REGULATORY VIOLATIONS}

Table B1. Utah Division of Solid and Hazardous Waste Actions.

\begin{tabular}{|c|c|c|c|}
\hline DATE & ISSUES & ACTION & RESOLUTION \\
\hline Hay 23, 1991 & $\begin{array}{l}\text { Improper certification statement on } \\
\text { permit submissions. }\end{array}$ & $\begin{array}{l}\text { Uarning } \\
\text { Letter }\end{array}$ & "Not Applicable" \\
\hline JuTy 11. 1991 & $\begin{array}{l}\text { Exceeding limitations for initial gross } \\
\text { excavation of landfill cell. } \\
\text { Failure to stop work and notify } \\
\text { Executive Secretary upon encountering } \\
\text { unexpected material during initial } \\
\text { excavation. }\end{array}$ & $\begin{array}{l}\text { Warning } \\
\text { Letter }\end{array}$ & "Hot Applicable" \\
\hline September 20, 1991 & 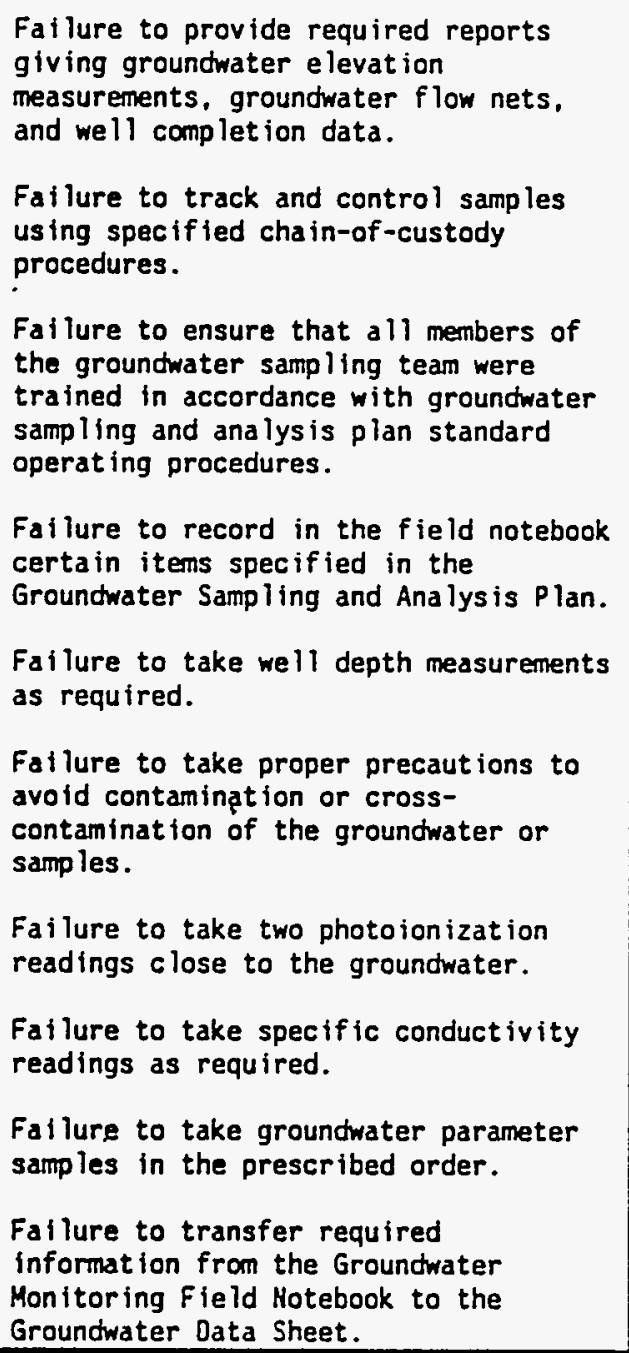 & NOV & $\begin{array}{l}\text { "Through formal correspondence } \\
\text { and several meetings with } \\
\text { Envirocare officials, each of } \\
\text { the issues identifies in the } \\
\text { September } 20 \text {, 1991 compliance } \\
\text { action was satisfactorily } \\
\text { resolved. No penalty was } \\
\text { assessed in connection with } \\
\text { this action." }\end{array}$ \\
\hline
\end{tabular}




\begin{tabular}{|c|c|c|c|}
\hline DATE & ISSUES & ACTION & RESOLUTION \\
\hline November 3, 1993 & $\begin{array}{l}\text { Failure of the groundwater sampling } \\
\text { tean to take water level readings as } \\
\text { required. } \\
\text { Failure of the groundwater sampling } \\
\text { team to use proper precautions to } \\
\text { ensure that contamination or cross- } \\
\text { contaminat lon of samples was avoided. } \\
\text { Failure of the groundwater sampling } \\
\text { tean to use bottles with the minimum } \\
\text { required volume. } \\
\text { Failure of the groundwater sampling } \\
\text { team to take successive equivalent } \\
\text { water level readings as required. } \\
\text { Failure of the groundwater sampling } \\
\text { team to take pH and temperature } \\
\text { readings as required. } \\
\text { Failure to track and control } \\
\text { groundwater samples using required } \\
\text { chain-of-custody procedures. }\end{array}$ & MOV & $\begin{array}{l}\text { "Through formal correspondence } \\
\text { and a subsequent permit } \\
\text { modification, each of the } \\
\text { issues identif ied in the } \\
\text { November 3. } 1992 \text { compliance } \\
\text { action was sat isfactorily } \\
\text { resolved. Ho penalty was } \\
\text { assessed in connection with } \\
\text { this action." }\end{array}$ \\
\hline January 5. 1993 & $\begin{array}{l}\text { Inadequate sampling procedures used to } \\
\text { obtain incoming load samples. } \\
\text { Heavy equipment allowed on the outdoor } \\
\text { container storage pad. } \\
\text { Fallure to construct a permitted } \\
\text { concrete waterway a long the north side } \\
\text { of the outdoor container storage pad. }\end{array}$ & $\begin{array}{l}\text { Warning } \\
\text { Letter }\end{array}$ & $\begin{array}{l}\text { Resolved (per June } 17,1993 \\
\text { phone conversation with DSHW } \\
\text { contact). }\end{array}$ \\
\hline $\begin{array}{l}\text { June, } 1993 \text { (per } \\
\text { June } 17.1993 \\
\text { phone conversation } \\
\text { with BSHW } \\
\text { contact). }\end{array}$ & Ho issues identified. & None. & Not applicable. \\
\hline
\end{tabular}




\section{Appendix D}

\section{Project Meeting Minutes}

D-1 


\section{MEEIIING MINUIES}

Date \& Time: 1/27/94 8:00am to 10:00am

Location: TSB Conf. Room C

Project: Mixed Low Level Waste Commercial Disposal

Purpose: Discuss results of Envirocare seminar and new schedule and associated impacts.

Desired Results: Consensus on schecule and sampling

requirements/procedures.

Facilitator: V. J. Balls (PSPI)

Persomel Attending:

-G. J. Andrews: WROC

T. J. Thiesen: WROC

J. D. Mousseau: PSPI

-T. B. Shea: WROC

-W. T. Savkranz: ER\&WM OS

-S. M. Medina: Environmental Technology

-D. L. Eaton: Enviromental Support Group

\section{Agenda/Items Discussed:}

\# 1. Review the revised schedule. (V. J. Balls)

\# 2. General overview of Envirocare WAC and Sample requirements. (S. M. Medina)

\# 3. What are the resources (Iabor, Materials, Equipment and Facilities) needed to prepare the waste for shipping and acceptance by Envirocare. \# 4. What are the impacts and can we get this work done to meet the revised schedule.

\# 5. What are the transportation/shipping issues.

\#6. Recommendations/resolution to concerns.

\#7. Other

-Action Items

-Todd Thiesen

-Call and establish priority with Group Manager that prepares the safety analysis plan. Due COB 1/27/94.

- Call and identify Facility to take samples these were

-Dave Eaton identified as WERF or TAN Warm/Hot shop. Due OOB 1/27/94.

-Send copy of 1994 Variance for MUTW to Project File \# 24.0, also cc Copy to Sylvia Medina. Due COB $1 / 28 / 94$.

-Vondell Balls

-Call SMO unit and get personnel assigned to prepare the Sample Analysis Plan and verify duration. Due COB $1 / 28 / 94$. -Call Procurement and identify any existing private Utah certified labs on contract and what is their turn around time, for both procurement and analysis. Due COB 1/28/94. -Call Shawn Parkinson at the MLIW facility and see if he can support our efforts.

-Teleconference with Jeff Mousseau, Vondell Balls, and Todd Thiesen 1/31/94 at 10:00am and determine if project is $G 0$ or NO GO!

-Schedule and plot revised schedule with new activities and 
send out for comment. Due COB $1 / 27 / 94$ send out $1 / 28 / 94$

camments due back $C O B 1 / 28 / 94$. Fax to Vondell Balls at Fax \# 2714.

-Schedule meeting with DOE, WINCO and EG\&G to discuss the procedures in using the COE contract. Some of the issues are Envirocare's definition of "generator"? Is this to mean EG\&G, WINCO or INEI this needs to be coordinated and agreed upon at this end to eliminate confusion at the $C E$ and Envirocare. Also how and what curation is required to activate the COE contract? Iead times ect..

-Call Wendy Savkranz 1/31/94 at 12:30 with final information for EC and CX.

-Sylvia Medina

-Iook at existing SAP's done by her group and get copies assembled. Duse COB 1/28/94.

- Have draft of EDF ready for review. Due COB 2/3/94.

-Wendy Savkranz

-Finish EC and CX. Monday at 12:30 Vondell Balls will call with final information on sampling location and finalize this effort. Duse to Paul Smith 2/1/94. 
Date \& Time: 1/27/94 8:00am to 10:00am

Iocation: TSB Conf. Room C

Project: Mixed Low Level Waste Commercial Disposal

Purpose: Discuss results of Envirocare seminar and new schectule and associated impacts.

Desired Results: Consensus on schedule and sampling

requirements/procecures.

Facilitator: V. J. Balls (PSPI)

Required Persomel: (Mandatory for meeting to be successful)

-G. J. Andrews: WROC

-T. J. Thiesen: WROC

J. D. Mousseau: PSPI

-L. L. Jones: Transportation

-T. B. Shea: WROC

-W. T. Savkranz: ER\&WM OS

-S. M. Medina: Environmental Technology

Participating Personnel: (Information for future tasks and meeting input.)

-D. I. Eaton: Enviromental Support Group

-N. J. Fix: Enviromental Support Group

-M. T. Magleby: PSPI

Agenda/Items To Be Discussed:

\# 1. Review the revised schedule. (V. J. Balls)

\# 2. General overview of Envirocare WAC and Sample requirements. (S. M. Medina)

\# 3. What are the resources (Iabor, Materials, Equipment and Facilities)

needed to prepare the waste for shipping and acceptance by Envirocare.

\# 4. What are the costs and can we get this work done to meet the revised scheciule.

\# 5. What are the transportation/shipping issues.

\# 6. Recommendations/resolution to concerns.

\# 7. Other

-Action Items 


\section{MEEIING MINUTES}

Date \& Time: $2 / 2 / 94$ 3:30pm to $4: 30 \mathrm{pm}$

Iocation: TSB Conf. Room C

Project: Mixed Low Level Waste Commercial Disposal

Pumpose: Discuss Sampling activities and new schedule

Desired Results: Schedule commitment, identify and assign

responsibilities and determine if there are any no go issues.

Facilitator: V. J. Balls (PSPI)

Required Persomel: (Mandatory for meeting to be successfull)

GAl *G. J. Andrews: WROC

位 $*$ G. L. Schwendiman: WROC

il1. | *J. D. Mousseau: PSPI

$-1 ; *$ L. L. Jones: Transportation

$\because, r$ *T. B. Shea: WROC

A. $\because *$ W. T. Savkranz: ER\&WM OS

- jri*S. M. Medina: Enviromental Technology

itis + *A. D. Chapman: TS\&PM

S.l. Enitibil-B. N. Rinehart: E\&RT

$=$ । *S. R. Parkinson: WROC

-A. E. Millhouse: WERF

Y.D -V. E. Daniels: E\&ES

$S$ AT $^{-} *$ S. S. Sato: WERF

K. $\therefore *$ R. A. Lopez: WERF

:ris. B. French: ER\&WM OS

Participating Persomel: (Information for future tasks and meeting input.)

I. : : -D. L. Eaton: Enviromental Support Group

1 i:"i-M. T. Magleby: PSPI

*=Those personnel present at the meeting

Agenda/Items To Be Discussed:

\#1. Brief overview and current status (V. J. Balls)

The Group went over the proposed schedule in detail and all activities and durations were discussed: The schedule is very tight and critical items require commitment and support from the entire group. Each activity was assigned a lead person accountable for all aspects of that task (Iabor, Facility, Task definition, ect.). S. Sato requested management support. M. Magleby spoke to McAnally and he will provide any assistance we need. V. Balls will have M. Magleby talk to I. Parsons and other unit managers on this issue.

\#2. Review the revised schedule and associated tasks. (V. J. Balls)

\# 3. Assion Task responisibilities and commitments activities:

The following personnel were assigned as Lead on the associated
Activity \# Lead
S. Sato
V. Daniels
A. Chapman
S. Parkinson
R. Lopez 


$\begin{array}{ll}22 & \text { V. Daniels } \\ 26 & \text { V. Daniels, L. Schwendiman } \\ 23 & \text { S. Parkinson } \\ 24 & \text { A. Chapman, L. Schwendiman } \\ 27 & \text { T. Shea } \\ 25 & \text { T. Shea } \\ 30 & \text { G. Andrews } \\ 28 & \text { V. Balls } \\ 31 & \text { I. Jones } \\ 29 & \text { L. Jones } \\ \text { to schedule for activity descriptions. }\end{array}$

\section{\#3. Action Items}

$-V$. Balls. Schedule meeting for sampling process for $2 / 3 / 94$.

-S. Sato. WERF issue with WERF SAR, cue at $2 / 2 / 94$ meeting.

-L. Schwendiman. Variance requirement on treatment issue, due $2 / 4 / 94$.

$-V$. Daniels. Place WERF on review cycle for SAP.

$-V$. Balls. Revise schedule to back up sampling from the holiday, cue $2 / 3 / 94$.

-A. Chapman. Concur with lab on schedule and testing also investigate contract incentives, due $2 / 3 / 94$.

$-V$. Balls. Check with Envirocare on durations and sample shipping, due $2 / 3 / 94$.

$-V$. Balls. Have my unit manager talk to all other unit managers represented.

-All Iead persormel shall send a 1 or 2 paragraph statement on their interpretation of their assigned task, send to profs id. var, due C. O. B. $2 / 3 / 94$.

With positive conclusion of all of these action items it was determined by this project team that we will meet the scheculed dates. On 2/4/94 by CB V. Balls will send a note to all members with the results of the meeting today and results of all the above action items. This will determine final commitments required for this project. 
MEEIING MINUTHES

Date \& Time: $2 / 3 / 94$ at $12: 45 \mathrm{pm}$ to $2: 15 \mathrm{pm}$

Iocation: CFA Cafeteria

Project: Mixed Low Ievel Waste Commercial Disposal

Purpose: Discuss Laboratory/sampling process and procedures

Desired Results: Schedule and sampling requirements/procedures.

Facilitator: V. J. Balls (PSPI)

Required Persomel: (Mandatory for meeting to be successful)

-G. J. Andrews: WROC

-I. L. Jones: Transportation

-T. B. Shea: WROC

-S. M. Medina: Enviromental Technology

-S. S. Sato: WERF (Did not attend)

-R. A. Lopez: WERF (Did not attend)

-G. L. Schwendiman: WROC

-V. E. Daniels: E\&ES

-A. D. Chapman: TS\&PM

-B. L. BToWn: GMR\&E

-R. Wells: TStPM

\section{Agenda/Items Discussed:}

General: Project meetings start promptly at the time indicated in the Meting Notification. If you camot make the meeting get sameone to represent you and be on time.

\# 1. Review the revised schedule. V. J. Balls handed out a fax copy of the revised schedule. A large size with all lead personnel assigned to each task will be mailed out monday to all personnel associated with this project.

\# 2. General overview of Envirocare WAC and Sample requirements. S. M. Medina and V. J. Balls gave an over view of Envirocares Material Acceptance criteria for those new to the project. \# 3. What are the resources (Iabor, Materials, Equipment and Facilities) and procedures needed to: prepare the waste for sampling, take the sarmles, ship the samples and prepare the waste for shipping. The group discussed this and a schedule for just the sampling was generated and agreed to. It is as follows:

-Feb. 3 to Feb. 9, Prepare SAP (Vience Daniels Lead)

-Feb. 10 at 8:00am to 11:30am at PBF 601A. The SAP will be presented, reviewed and approved contingent on all comments resolved and incorporated.

-Feb. Il COB the SAP will be finalized and issued. Also on this day all SWR and other required paper work will be completed to allow sampling to begin on monday morning.

-Feb. 14 to Feb. 17, Sampling will be started and completed. \# 4. What are the costs and can we get this work done to meet the revised schedule. The group estimated the following:

$-\infty \mathrm{E} /$ Envirocare costs based on approx. $30 \mathrm{cy}$ a $1000 \mathrm{~s} / \mathrm{cy}=30 \mathrm{k}$ $-\infty \mathrm{E}$ contract costs $=5 \mathrm{k}$ 


\begin{abstract}
Transportation costs
- Lab Analysis

$=2 \mathrm{k}$

$=40-80 \mathrm{k}$

The group agreed on 11 waste streams and defined:

\#1. laboratory sample as: 2 packages one for the rad and one for the Haz tests this was the minimum amount per waste stream. The maximm could be 2 or 3 times this amount, no way of telling this until the barrels are opened. -\#2. fingerprint sample is defined as: The required amount of pieces of debris to establish the "range", placed in zip lock bags tagged and placed in 5 gallon buckets, with the "sniffer" test material placed in glass containers (V. Balls confirmed this with Envirocare on 2/4/94).
\end{abstract}

\# 5. What are the transportation/shipping issues. L. Jones didn't indicate any major issues. We will ship the laboratory samples to the Analysis $\mathrm{lab}$ and the fingerprint samples to Envirocare as they are taken. L. Jones will coordinate these shipments also.

\# 6. Can the Laboratory perform the required tests in the time given? Adrian confirmed that the lab can perform the tests in the time period given for approx. 3k per test.

\# 6. Reconmendations/resolution to concerns. As noted above.

\# 7. Other

-Action Items

-V. Balls schedule room for SAP presentation on Feb. 10. This meeting will be in PER 601A from 8:00am to 11:30am. -S. Sato to make arrangements for necessary $\mathrm{HP}, \mathrm{IH}$ and other personnel required for the sampling effort for the week of FEB 14th. Due 2/10/93 at SAP review meeting.

-G. Andrews to call NRF on chromium waste. Due $2 / 7 / 93$

$-T$. Shea one page summary on waste profile files. Due 2/7/93

-V. Balls to call Envirocare on fingerprint samples and see if taking 5 gallon buckets with pieces contained in zip lock bags would be ok inlieu of 5-2\# samples. V. Balls called $\mathrm{K}$. Higgins and he said this would be ok. We still need to put the volatile test samples in glass. -PER 613 is where V. Daniel will send all materials to stock pile for week of Feb. 14.

-L. Swctwendiman will set up charge \# for the physical work. V. Balls will send profs on what PSPI will fund. Due $2 / 7 / 94$. $-V$. Daniel will get someone to assist him on the ordering of materials. Due 2/4/94.

$-V$. Balls to include R. Horne for Feb 10 meeting.

$-V$. Balls to get list of people to review SAP. Due $2 / 7 / 94$.

-S. Medina to finish EDF by COB $2 / 7 / 94$ (since this is her last day).

-L. Swctwendiman to review all existing treatment capabilities for the subject waste as a prerequisite for disposal under this extension. Due $2 / 7 / 94$. 


\section{MEEITING NOTIFICATION}

Date \& Time: $2 / 3 / 94$ at $12: 45 \mathrm{pm}$ to $2: 15 \mathrm{pm}$ (town personnel to return on $2: 30$ bus if required)

Location: CFA Cafeteria

Project: Mixed Low Ievel Waste Commercial Disposal

Purpose: Discuss Laboratory/sampling process and procedures

Desired Results: Schedule and sampling requirements/procedures.

Facilitator: V. J. Balls (PSPI)

Required Persomel: (Mandatory for meeting to be successful)

Biti. G. J. Andrews: WROC

I. -I. L. Jones: Transportation

泬 T. B. Shea: WROC

:yil! -S. M. Medina: Enviromental Technology

iri -S. S. Sato: WERF

T.L -R. A. Lopez: WERF

H... -G. L. Schwendiman: WROC

$\because \check{Z i}-V$. E. Daniels: E\&ES

Aitict -A. D. Chapman: TS\&FM

BC:B -B. L. Brown: GMR\&E

-Notice to town personnel. I could not get a vehicle. I am riding the bus out and back. Vondell.

Agenda/Items To Be Discussed:

\# 1. Review the revised schedule. (V. J. Balls)

\# 2. General overview of Envirocare WAC and Sample requirements. (S. M. Medina)

\# 3. What are the resources (Iabor, Materials, Equipment and Facilities)

and procedures needed to: prepare the waste for sampling, take the samples, ship the samples and prepare the waste for shipping.

\# 4. What are the costs and can we get this work done to meet the revised schedule.

\# 5. What are the transportation/shipping issues.

\# 6. Can the Laboratory perform the required tests in the time given.

\#6. Recommendations/resolution to concerns.

\# 7. Other

-Action Items 


\section{Appendix E}

\section{Engineering Design Files}

E-1 
E-2 
EG\&G Idaho, Inc.

FORM EGG-2631\%

(Rev. 01-92)

Project File Number

EDF Serial Number

Functional File Number
WROC-PROJ-008

WROC-EDF-223

\title{
ENGINEERING DESIGN FILE
}

\author{
Project/Task Debris Oisposal at \\ Envirocare, Utah. \\ Subtask \\ Debris Treatment at INEL \\ EDF Page 1 of 2
}

\section{TITLE:}

\section{SUMMARY}

The sumary briefly defines the problem or activity to be addressed in the EDF, gives a summary of the activities performed in addressing the problem and states the conclusions. recomendations, or results arrived at from this task.

Low-level Mixed Waste debris was identified that could be sent to Envirocare, Utah for disposal. The waste was being shipped without treatment based on a variance to the May 14, 1993 ruling for debris treatment and disposal. The variance was extended through May 8, 1994. However, to comply with the variance the generator (being DOE) must ensure that additional capacity for treatment of the debris is not avai lable prior to May 8. 1994. The regulation states." if capacity is found to be available during the extension period, the owner or operator must use treatment capacity for as large a portion of its waste as possible (58 FR 28506, page 9)". The only facility with potential capacity to treat mixed waste debris is ICPP.

The purpose of this Engineering Design File (EDF) is to demonstrate, through contact with people involved in treatment facility operations and TSOF permitting. that NO capacity was available. on site at the INEL. to treat mixed waste debris which has been stored at the Mixed Waste Storage Facility.

Distribution (complete package):

V. J. Balls, G. L. Schwendiman, J. S. Irving, H. T. Savkranz, WROC-PROJ-008.

Oistribution (sumary page on ly): T.J. Thiesen. K. McNeel, A. D. Rodgers.

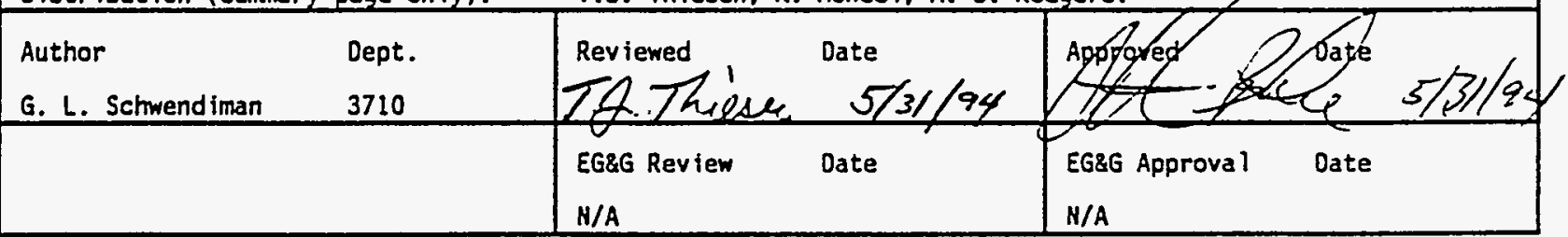


EG\&G Idaho, Inc.

FORM EGG-2631*

(Rev. 01-92)

\subsection{Introduction}

Low-level Mixed Waste debris was identified that could be sent to Envirocare, Utah for disposal. The waste was being shipped without treatment based on a variance to the May 14, 1993 ruling for debris treatment and disposal. The variance was extended through May 8, 1994. However, to comply with the variance the generator (being $D O E$ ) must ensure that additional capacity for treatment of the debris is not available prior to May 8,1994 . The regulation states. "If capacity is found to be available during the extension period, the owner or operator must use treatment capacity for as large a portion of its waste as possible". (58 FR 28506. page 9)

To dispose of low-level mixed waste at the Envirocare. Utah mixed waste Treatment Storage and Disposal Facility (TSDF), an evaluation was conducted of INEL site low-level mixed waste debris treatment capacity. This Engineering Design File (EDF) outlines the steps taken to insure that the mixed waste identified in the EDF (WROC-EDF-220) "Evaluation of Mixed Waste Debris for Disposal at Envirocare". for disposal could not be treated at the INEL prior to disposal at Envirocare. Utah.

\subsection{Debris Treatment Evaluation}

2.1 Rod Sidwell with WINCO at the Idaho Chemical Processing Plant (ICPP) was contacted February 7. 1994 to determine if WINCO had the capability (permits, etc.) and/or capacity to treat mixed waste debris from the Mixed Waste Storage Facility (MWSF). Rod indicated they had applied for a permit to treat debris, however they had not received it and did not expect to before the May 8. 1994 variance deadline. ICPP only treats mixed waste debris in their 90 day storage areas. As of May 8. 1994, WINCO had not obtained approval from the State of Idaho to treat mixed waste debris from the MUSF.

Ann Boehmer with EG\&G Idaho. Inc. was contacted February 8, 1994 to confirm that WINCO, or other facilities at the INEL, were not permitted to treat mixed waste debris. She indicated that no facilities were currently permitted for debris treatment. WINCO and the WEDF had permits at various stages of review.

Robert Montgomery with EG\&G Idaho. Inc.'s Environmental Policy and Guidance Unit was contacted February 11. 1994 to confirm whether mixed waste debris could be treated at the INEL. He spoke with WINCO and determined they could not accept mixed waste from a TSO facility (MWSF) for treatment.

See Attachent A. for PROFS correspondence.

2.2 The Waste Experimental Reduction Facility (WERF) was also an option for treatment and disposal capacity of the low-level mixed waste debris stored at the MWSF. However, the WERF incinerator was not operational for mixed waste incineration at anytime through the May 8. 1994 variance deadline. Also, the incinerator was not scheduled to come on iine until January. 1996.

3.0 Conclusion

The only two facilities that potentially could have treated mixed waste debris at the INEL were the Waste Engineering Development Facility (WEDF) and WINCO ICPP. The WEDF facility was only in the early stages of permitting and WINCO ICPP has applied for a permit, but was only treating debris in 90 day storage areas. Neither of these facilities were permitted to treat mixed waste debris stored at the Mixed Waste Storage Facility. Therefore, prior to May 8, 1994 variance deadline, there was NO capacity to treat the low-level mixed waste debris currently stored in the MWSF at the INEL. 
EG\&G Idaho, Inc.

FORM EGG-2631)

(Rev. 01-92)

ATTACHWENT A 


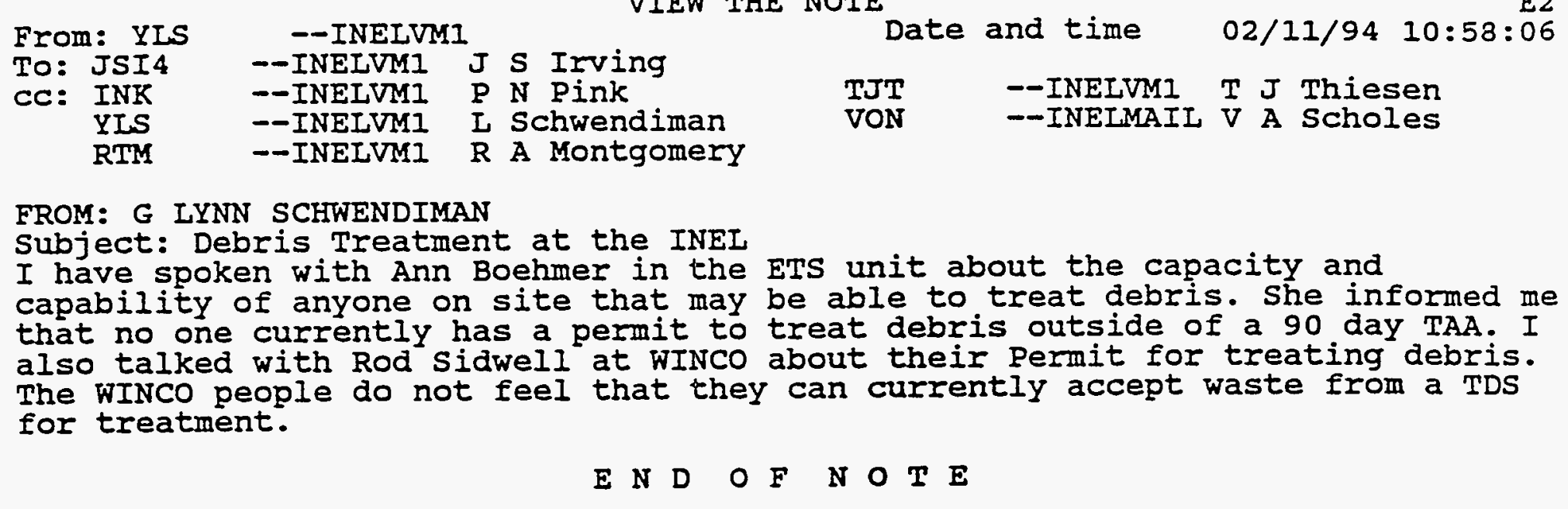
that no one currently has a permit to treat debris outside of a 90 day TAA. I also talked with Rod sidwell at WINCO about their Permit for treating debris. The WINCO people do not feel that they can currently accept waste from a TDS for treatment.

$$
\begin{array}{lllllllll}
E & N & D & O & F & N & O & T & E
\end{array}
$$

\begin{abstract}
PFI Alternate PFs PF2 Copy to PF6 Reply PF7 Resend PF8 Print
\end{abstract} $4 \mathrm{BÜ}$
PF3 Reep PF4 Erase PF5 Forward Note PF9 Help PFI0 Next PFI1 Previous PF12 Return B7--SESSION1 R 23 C 33 o-OPI $18: 17 \quad 2 / 09 / 94$ 


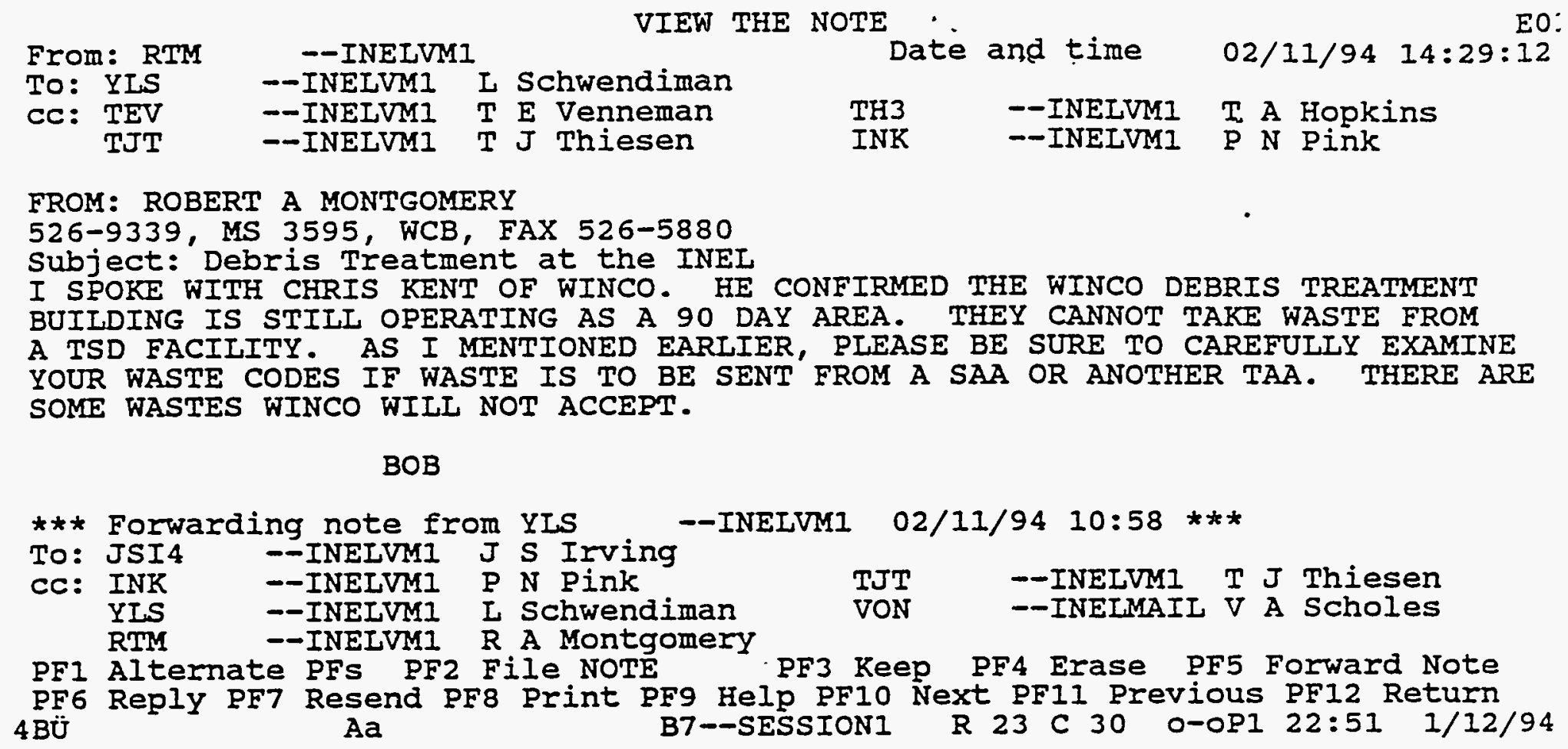


EG\&G Idaho, Inc.

FORM EGG-2631\#

(Rev, 01-92)

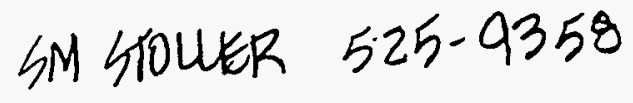

Project File Number

WROC-PROS- 008

EDF Serial Number

Functional File Number

\section{ENGINEERING DESIGN FILE}

Project/Task

Transport and Disposal of INEL Mixed Low-Level Waste

Subtask

RCRA Evaluation

EDF Page 1 of 6

\section{TITLE: Evaluation of Mixed Waste Debris for Disposal at Envirocare}

\section{SUMMARY}

\section{Summary}

Disposal of radioactive mixed debris waste is subject to the Land Disposal Restrictions (LDRs) promulgated by the Resource Conservation \& Recovery ACt (RCRA). The LDRs dictate the treatment standard that must be met prior to land disposing of the waste. The treatment standard either requires the use of one or more specified treatment technologies or they require that wastes be treated to meet certain concentration limits for the hazardous constituent. Where concentration limits are used, EPA assumes that a waste is treated with best demonstrated technology (BDAT), although not required.

In the Federal Register (57 FR 20766, May 15, 1992) the EPA made available to generators a one year extension for generic case-by-case variances for hazardous debris contaminated with radionuclides. The effective termination date being May 8 , 1993. An application was submitted by EG\&G (JCO-347-92, November 5,1992$)$ for the 1-year extension. The wastes included in the extension covers only those mixed waste streams covered by the LDR third-third listing. These typically include characteristic type wastes, and some listed wastes (see 40 CFR 268.12).

In the Federal Register dated May 14, 1993, the EPA granted an additional reprieve from the previous extension date. extending the variance through May 8,1994 . This was postponed because of the lack of significant treatment capacities for the mixed debris waste. Currently EG\&G Idaho, Inc. has stored in the Mixed Waste Storage Facility (MWSF) approximately 29 containers of wastes that are included in this variance. Because of this, EG\&G is proposing to ship these items to Envirocare a receiving Treatment, Storage, and/or Disposal (TSD) Facility located in Utah. Envirocare is currently licensed to land dispose of specific Low Level mixed waste items. This Engineering Design File (EDF) contains an evaluation of each candidate waste stream as it compares to the Envirocare Waste Acceptance Criteria (WAC), RCRA permit, and subject LDR variance requirements.

Distribution (complete package):

Distribution (summary page only):

\begin{tabular}{|c|c|c|c|c|c|}
\hline $\begin{array}{l}\text { Author } \\
\text { Sylvia M. Medina } \\
\text { Tom Shea } \\
\text { Greg Andrews }\end{array}$ & $\begin{array}{l}\text { Dept. } \\
\text { EELS } \\
\text { WROC TPS } \\
\text { WROC TPS }\end{array}$ & $\begin{array}{l}\text { Reviewed } \\
\text { Vondell Balls }\end{array}$ & Date & Approved & Date \\
\hline & & $\begin{array}{l}\text { EG\&G Review } \\
\text { Jeff Mousseau }\end{array}$ & Date & $\begin{array}{l}\text { EG\&G Approval } \\
\text { Todd Thiesen }\end{array}$ & Date \\
\hline
\end{tabular}




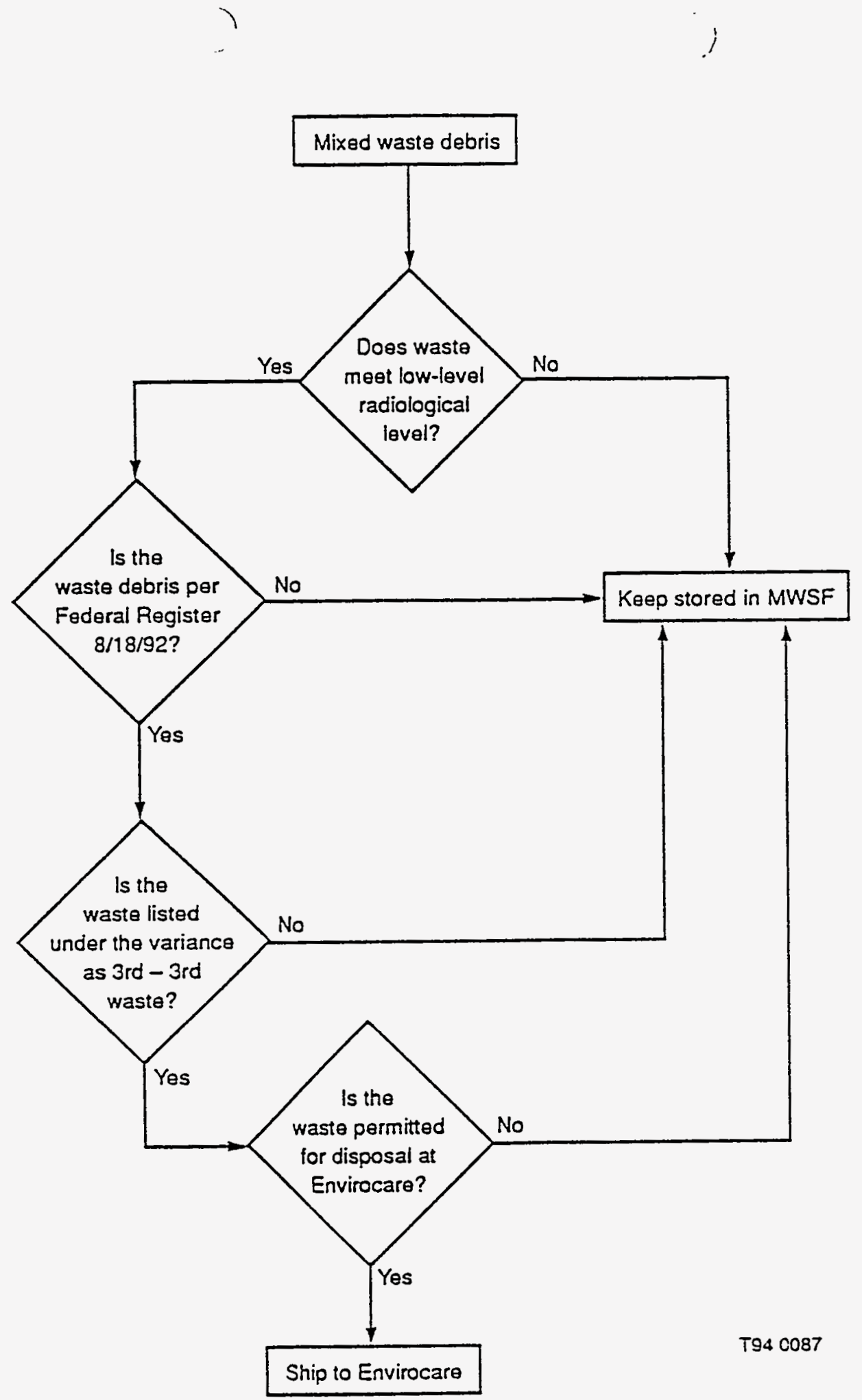


EG\&G Idaho, Inc.

FORM EGG-2631\#

(Rev. 01-92)

\subsection{Introduction}

The Waste Acceptance Requirements (WAC), RCRA permit, and the NRC license define the hazardous and radiological isolopes and associated levels that can be accepted for land disposal at Envirocare. In order to dispose of waste at this TSD facility, the waste must meet all of the criteria identified in the documents. Envirocare is currently permitted to receive very low quantities of low-level radiological contaminants. Information presented in two EDFs (WROC-PROJ-008/241) evaluates the radiological component of the mixed waste stored at the MWSF, and identifies those specific waste items that meet the minimal radiological parameters specified by Envirocare's NRC license. The evaluation provided a basis for short-listing the mixed waste stored in the MWSF. This short-list is provided in Table 1 of this EDF.

LDR restricted waste must be treated to specified concentration levels or by a specific treatment methodology established by the EPA. If the waste is not treated to the specified LDR concentration levels or treatment technologies it cannot be land disposed of. However, as mentloned in the summary, specific variances have been granted by the EPA for disposing of LDR waste to a RCRA permitted landfill without treatment until May 8, 1994.

This final list of mixed waste will be evaluated to determine if it meets the requirements imposed by the RCRA permit and the requirements identified for the extension to the variance. In addition, a reevaluation of the radiological contaminants was performed. All of the waste identified for shipment to Envirocare meets the radiological criteria established by Envirocare's NRC license. Other information shall be presented in Attachment 1 of this EDF.

\subsection{RCRA Evaluation}

2.1 Regulatory Synopsis. A general flowchart defining the eligibility of the waste for receipt to Envirocare is depicted in Flowchart. This section will summarize the requirements and their applicability as specified in the flowchart.

2.1.1 Debris. The final ruling of the LDRs for debris and newly listed wastes were published in the August 18, 1992 Federal Register. In order for the mixed waste to meet the variance requirements established by the EPA, the waste must meet the definition of "debris." This definition has changed from the original LOR definition. The definition now reclassified as "debris" and "hazardous debris," being:

"Debris means solid material exceeding a $60 \mathrm{~mm}$ (approximately 2.5 inches) particle size that is intended for disposal and that is: (1) a manufactured object; or (2) plant or animal matter; or (3) natural geologic material. However, the following materials are not debris: (1) any material for which a specific treatment standard is provided in Subpart D, Part 268: (2) process residuals such as smelter slag and residues from the treatment of waste, wastewater, sludges, or air emission residues; and (3) intact containers of hazardous waste that are not ruptured and that retain at least $75 \%$ of their original volume. A mixture of debris that has not been treated to the standards provided by 40 CFR 268.45 and other material is subject to regulation as debris if the mixture is comprised primarily of debris, by volume, based on visual inspection (40 CFR 268.2(g)).

"Hazardous debris means debris that contains a hazardous waste listed in Subpart D of part 261, or that exhibits a characteristic of hazardous waste identified in subpart C of part 261 (40 CFR 268.2(h))."

The definition of debris also excludes material for which a treatment standard is provided in Subpart D of Part 268 including D008 radioactive lead solids subcategory (refers to elemental forms of lead). This is because the treatment standard established by the EPA for this metal takes precedence over the general debris treatment standards.

In addition the final definition of debris specifies that "mixtures of debris and other materials, such as soil or sludge, are regulated as debris if the mixture is comprised primarily of debris (by volume) based on visual inspection. This will eliminate the need to separate debris and nondebris materials prior to treatment.

2.1.2 Case-by-Case Variance Requirements. Originally the EPA announced a one year extension to the generic case-by-case (CBC) variance for hazardous debris contaminated with radionuclides. The effective termination date for this variance was May 8, 1993 (57 FR 20766, May 15, 1992). But, because of the lack of available treatment capacity for much of the mixed third-third debris waste the EPA granted a one-year extension (May 8, 1994). To qualify for this extension the generator must demonstrate to the EPA that they have made a good faith effort to identify available treatment capacities for their waste (May 15, 1992, 54 FR 20768-20769). Documentation providing proof of this effort was transmitted through DOE to the EPA.

The original variance approved by the EPA applies to specific third-third debris wastes. This variance aliows land disposal of the debris waste, except for waste containing the following contaminants (the ones listed here are applicable only to the candidate waste streams to be shipped to Envirocare):

radioactive wastes mixed with newly listed or identified wastes for which treatment standards were proposed in the September 14, 1993 rule, being:

D012-D017 that fall the TCLP but pass the EP toxicity test, D018-D043, K141-K145. $\mathrm{K} 147-\mathrm{K} 148$, and K149-K151.

Debris waste contaminated with spent solvents (F-listed), dioxin wastes, and nonliquid, California-list halogenated organic compounds. 
EG\&G idaho, inc.

FORM EGG-2631\#

(Rev. 01-92)

An additional generic variance was extended through May 8, 1994 if the generator fulfilled certain obligations as specified in the May 14, 1993 ruling. The application submitted to the EPA for extension to this generic variance was granted by the EPA. Because of this, the specific LDR third-third wastes listed in Table 1 meet the variance requirements established by the EPA.

However in order to maintain the extension to the variance, the generator (being DOE) must ensure that additional capacity for treatment of the waste does not become available. In other words, "if capacity is found to be available during the extension period, the owner or operator must use the treatment capacity for as large a portion of its waste as possible (58 FR 28506, pg 9). One treatment facility which may fall in this category is the treatment identified by WINCO. Prior to shipping the mixed waste debris to Envirocare, EG\&G must review WINCO treatment capabilities and confirm that they currently do not have the capacity to treat any of the candidate mixed waste streams, defined in this EDF, between the present time and May 8, 1994.

2.1.3 RCRA Evaluation. The decision process for mixed waste debris acceptance to Envirocare followed the course defined in the flowchart (and described in this section). The first item that was evaluated, dealt with the specific isotopes and radiological contamination present in the waste stored in the MWSF. From this evaluation, if the waste met the requirements established by the NRC license for Envirocare then the waste was considered as a potential mixed waste debris candidate.

The next decision process was based on the waste meeting the definition of debris. In comparing the physical description of the waste provided in the Form EG\&G 669s, it was determined that all of the waste met the definition. However, there is a question regarding the applicability of the variance to the 1472 waste code. The EG\&G 669 form specifies that the waste contains soil with lead particles. According to the LDRs, the variance for debris waste is not inclusive of soils containing a hazardous waste (being lead). But, if by visual inspection the debris mixture is comprised primarily of debris (by volume) the entire waste container is regulated as debris (FR August 18, 1992). NOTE: From the February 3rd meeting as presented in Section 3.0, Lynn Schwendiman provided a description of this waste. He confirmed that the waste was composed primarily of pebbly sized particles. Therefore, this waste does not meet the definition of debris. In addition, some of the waste streams physical characteristics are yet unknown, thus these waste containers will be opened to ensure the waste composed primarily of debris.

The next item deals with the issue of whether the waste meets the 3rdrad listing. All of the wastes identified in this table are considered to be third-third wastes as specified in 40 CFR 268.12 and the January 1, 1990 FR (pg 22644).

The final decision process is based on whether Envirocare is permitted as a RCRA TSD facility to receive and dispose of the RCRA waste codes for each waste stream. According to the Envirocare RCRA Part B permit granted by the EPA, all of the wastes in the Table can be land disposed of at this TSD. Note that a question mark is one of the headers listed in the last column, this is because questions still remain regarding the wastes acceptability at Envirocare (see Section 3.0).

2.2 Sampling Requirements. In order to meet Envirocare approval, specific additional analytical procedures must be performed on waste samples. According to the WAC, Envirocare is requirng that five 2-pound diverse, representative pare-shipment samples (i.e. fingerprint) per waste stream be sent to the faclity. A qualitative analyses will be performed by Envirocare to ensure verification of the waste characteristics prior to accepting the waste. In addition, the laboratory analysis for the candidate mixed waste must be performed by a Utah Certified Laboratory (these samples will be referred to as laboratory samples).

At this point, the analytical information provided by the INEL waste generators to the MWSF per the EG\&G 669 forms, are based primarily on process knowledge, and very little true laboratory analysis. In order, to obtain representative samples, EG\&G will be required to sample all of the waste debris and obtain samples representative of the waste streams as described above. Personnel at the Envirocare faclity, suggested that a sample from each piece of debris per waste stream be obtained and submitted for the qualitative analyses (i.e., being a part of the 5 samples).

To lessen the laboratory costs for the analyses, it may benefit EG\&G to consolidate some of the waste streams into one waste stream, thereby requiring fewer samples. One candidate waste stream was nominated for this consolidation, being 1818,2100, 3959, and 3960 (cadmium contaminated clathing/equipment). In repackaging this waste, the curre content will have to be recalculated to ensure the distribution meets the requirements identified by DOT and the Envirocare WAC and NRC license.

\subsection{Meeting Summary}

At a meeting held on February 3, 1994, an evaluation of the proposed waste stream was performed by a committee. The following items were evaluated during this meeting (from both a radiologıcal and RCRA perspective) and changes made to the list of wastes considered for shipment to the facility:

1. The committee decided to eliminate the fuel racks containing cadmium strips from the candidate waste streams(barcode 3410 ). This is because, the radiological analysis is questionable and it is believed that the curle contents will exceed the allowable limits specified in Envirocare's license.

2. The items identified as $536,537,538$, and 539 are waste debris originating from NRF. These items were at one time repackaged in B-25 bin boxes (i.e., $2^{\prime \prime} \times 2 \times 2$ cardboard boxes). It was decided that before eliminating this waste stream, that a visual inspection should be made of the waste. Based upon the inspection if the waste is indeed debris, the waste can be shipped to Envirocare.

NOTE: The container lids of of these waste items will be removed and visual confirmation made of the waste contents. 
EG\&G Idaho, Inc.

FORM EGG-2631\#

(Rev. 01-92)

3. The waste listed under barcodes 623,625 , and 629 are also questionable because of the presence of an absorbent material known as spill-x. Because of the physical characteristics of the absorbent it may not meet the definition of a debris.

NOTE: The container lids of these waste items will be removed and visual confirmation made of the waste contents.

4. Waste item identified as barked 535 should be removed (per conversation with Sytvia Medina and Tom Sheah on February 7 th) because the curie content for Cs-137 exceeds the radiological limitations as specified by the Envirocare license.

5. Finally, waste item listed under barked 674, is no longer stored at the MWSF and the waste stream description is not wholly described in the EG\&G 669 forms, therefore a visual inspection of the waste would be required to ensure it meets the definition of debris. It is not recommended that this waste be shipped to Envirocare in this shipment.

\subsection{Conclusion}

Based on this preliminary evaluation all of the waste listed in the Table other than 535, and 674 meets the LDR requirements (variance), the RCRA permit, and the Envirocare NRC license. Waste streams listed as 536, 537, 538, 539, 623, 625, and 629 should be opened up to visually inspect the waste contents. If the waste meets the debris definition it can also be shipped to Envirocare. 


\begin{tabular}{|c|c|c|c|c|c|c|c|c|c|c|c|c|c|}
\hline \multirow[t]{2}{*}{$\begin{array}{l}\text { Waste } \\
\text { Burcode } \\
\text { Nember }\end{array}$} & \multirow[t]{2}{*}{ 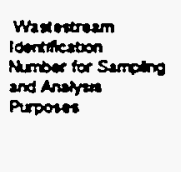 } & \multirow[t]{2}{*}{ 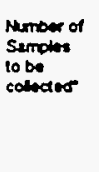 } & \multirow[t]{2}{*}{ 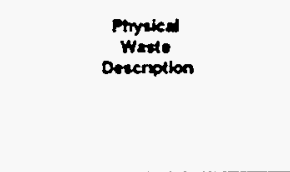 } & \multicolumn{2}{|c|}{ la werete debrte } & \multirow[t]{2}{*}{$\begin{array}{l}\operatorname{nckn} \\
\operatorname{cose}\end{array}$} & \multicolumn{2}{|c|}{ 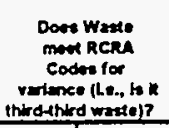 } & \multicolumn{2}{|c|}{$\begin{array}{l}\text { he Enwroeser } \\
\text { permeted } \\
\text { for RCRA } \\
\text { wmate? }\end{array}$} & \multicolumn{3}{|c|}{ 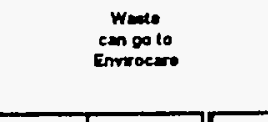 } \\
\hline & & & & $m$ & no & & $m$ & mo & rem & no & yom & no & ? \\
\hline $\begin{array}{l}1299 \\
1394 \\
\end{array}$ & ous & in & 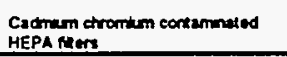 & $x$ & & $\begin{array}{l}D 006 \\
0007 \\
\end{array}$ & $x$ & & $x$ & & & $x$ & \\
\hline 1472 & 1D-EQSO-142 & sa & 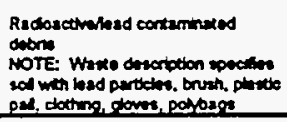 & $\mathbf{r}^{*}$ & & 0006 & $x$ & & $x$ & & & & $x$ \\
\hline $\begin{array}{l}12118 \\
2100 \\
\end{array}$ & 10.-111 & 52 & 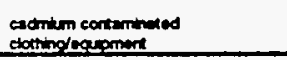 & $x$ & & $\infty 006$ & $x$ & & $x$ & & $x$ & & \\
\hline 3387 & $\infty 00$ & $s n$ & Cadrmem enouts & $x$ & & 0006 & $x$ & & $x$ & & $x$ & & \\
\hline 2410 & $m$ & $\mu$ & sel ince weth eacrem grps & $x$ & & 0006 & $x$ & & $x$ & & & $x$ & \\
\hline $\begin{array}{l}3857 \\
3950 \\
\end{array}$ & ous & $m$ & 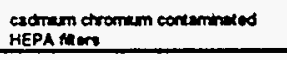 & $x$ & & $\begin{array}{l}0006 \\
0007 \\
\end{array}$ & $x$ & & $x$ & & $x$ & & \\
\hline $\begin{array}{l}3959 \\
3960 \\
\end{array}$ & 10.6ne-119 & m & 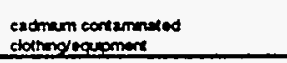 & $x$ & & 0006 & $x$ & & $x$ & & $x$ & & \\
\hline 8028 & sol & $5 / 2$ & 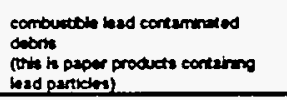 & $x$ & & 0000 & $x$ & & $x$ & & $x$ & & \\
\hline $\begin{array}{l}4747 \\
4748 \\
4749 \\
4750 \\
4751 \\
4752 \\
4753 \\
4754 \\
4755 \\
4755 \\
\end{array}$ & 502 & $5 / 2$ & 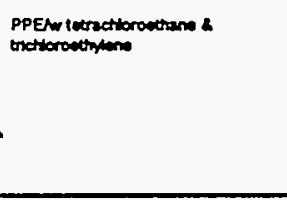 & $x^{2}$ & & $\begin{array}{l}0000 \\
0010\end{array}$ & $x$ & & $x$ & & $\times$ & & \\
\hline 4724 & S3S & $s / 2$ & ISU HEPA FIMU & $x$ & & $\begin{array}{l}D 004 \\
\text { Doos } \\
0008\end{array}$ & $x$ & & $x$ & & $x$ & & \\
\hline $\begin{array}{l}5295 \\
5298 \\
\end{array}$ & S23 & $5 / 2$ & Lasd cortarmenod doom & $x$ & & 0008 & $x$ & & $x$ & & $x$ & & \\
\hline $\begin{array}{l}689 \\
384\end{array}$ & NR-NRF-113 & $5 / 2$ & NAF crronem contementexes rage & $x$ & & $\infty 007$ & $x$ & & $x$ & & $x$ & & \\
\hline 535 & NR-ARF.113 & ma & NRF mereury & $x$ & & 0008 & $x$ & & $x$ & & &. & \\
\hline 536 & NR-NRF-113 & $5: 2$ & MRF posusum erromite & $x$ & & 0007 & $x$ & & $x$ & & & & $\therefore$ \\
\hline $\begin{array}{l}537 \\
530\end{array}$ & MRARRF-IIJ & $s / 2$ & NAF dromem & $x$ & & 0007 & $x$ & & $x$ & & & & $x$ \\
\hline 538 & NR-NRF-113 & $5: 2$ & 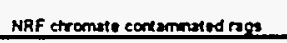 & $x$ & & Do07 & $x$ & & $x$ & & & & $\therefore$ \\
\hline $\begin{array}{l}623 \\
625 \\
628 \\
\end{array}$ & TANL120 & $s / 2$ & TAN mareary contemmedod serpop & $x$ & & $\begin{array}{l}D 009 \\
0009 \\
0009\end{array}$ & $x$ & & $x$ & & & & $x$ \\
\hline 674 & m & m & 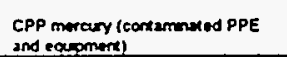 & $x$ & & 0000 & $x$ & & $x$ & & & . & \\
\hline
\end{tabular}

In order for this waste to meet the definntion of debrns, if by usual inspection. the majorty of the wasto sis a mixture of debns then this material mill meet the definition. Therefore a visual inspection must be made to contirm this.

Bocause the RCRA codes are DO39 and D040. these contaminants aro considered to be nemly.tdentufiod wastes and are therefore, currently not subject to the LDR requirements. It should be noted that treatment standards have boon proposed and have yot to bo finalized andlor implemented.

5 of the samples are fingerprnt samples and 2 are laboratory samples.

NOTE. This ovaluation is based on exaseng information dervod from flios obtainod from the MWSF 


\section{DRAFT}

Project File Number

EDF Serial Number

Functional File Number
WROC-PROJ-008

IROC-EDF-221

(Enown

ENGINEERING DESIGN FILE

\begin{tabular}{llll} 
Project/Task & MLLH Commercial Disposal \\
Subtask & EDF Page 1,5 \\
\hline
\end{tabular}

\section{TITLE: \\ Calculation of Acceptability of MLLW for Commercial Disposal}

\section{SUMMARY:}

This EDE pregents a summary of calculations performed on waste streams currently stored at the Mixed Waste Storage Facility (MWSF). These wastes, classified as debris, may be acceptable for transfer to Envirocare of Utah, Inc., a commercial disposal fadility, if radionuclide concentrations are found to be within the Iimits stipulated in the license granted by the state of Utah. Disposal of the MWSE debris must occur before May 8, 1994.

A total of 43 waste containers $(16,425$ lb) representing 18 different waste streams were found to be acceptable for disposal at Envirocare.

A total of 16 other waste containers (9306 ib) representing at least 7 waste streams may be acceptable for disposal at Envirocare, but additional information is required. Six containers (516 lb) may be acceptable for disposal if Envirocare is successful in amending its license to include Ba133 and $\mathrm{Ag}-108 \mathrm{~m}$. Five containers $(1490 \mathrm{lb})$ may be acceptable if it can be determined that the waste contains $C r-51$ and not Co-60. Five other containers (7300 1b) may be acceptable if additional information on waste form and radionuclide levels can be obtained.

Distribution (complete package):

Vondell Balls

Sylvia Medina

Distribution (summary page only):

\begin{tabular}{|ll|l|l|}
\hline Author & Dept. & $\begin{array}{l}\text { B820 } \\
\text { Review }\end{array}$ & Date \\
Blaine w. Brown & B820 & & \\
& & & \\
\hline
\end{tabular}




\section{DRAFT}

\section{PURPOSE}

The purpose of this work was to determine whether certain waste streams stored at the Mixed Waste Storage Facility (MWSF) were suitable for disposal at the facility operated by Envirocare of Utah, Inc. near Clive, Utah. These waste streams are classified as debris, and as such have no identified treatment options. Land disposal is possible at Envirocare if the wastes meet the radiological limits stipulated in the license Envirocare has with the state of Utah. Further, the debris must be interred before May 8, 1994 in order to meet the exemption granted by

This work was an extension of and EDF "Determination of LLMW Candidates for Disposal at Envirocare of Utah. Inc." authored by Mike wilcox dated March 29, 1993 (WROC Project File WROC-PROJ-008, no EDF number available).

\section{HASTE STREAMS CONSIDERED}

The following waste streams were considered:

$\begin{array}{ll}\text { ANL-111 } & \text { WIN-111 } \\ \text { EGG-108 } & \text { WIN-131 } \\ \text { EGG-117 } & \text { WIN-305 } \\ \text { EGG-142 } & \text { ANL-178 } \\ \text { EGG-161 } & \text { EGG-126 } \\ \text { EGG-212 } & \text { EGG-128 } \\ \text { EGG-213 } & \text { EGG-262 } \\ \text { EGG-253 } & \text { EGG-266 } \\ \text { EGG-261 } & \text { NRF-113 } \\ \text { EGG-263 } & \text { NRF-131 } \\ \text { EGG-267 } & \end{array}$

\section{MEYIBOD}

Data were obtained for the waste streams using the Idaho Mixed Waste Information (IMWI) database. The data obtained were compared to the data used by Wilcox. Data were also compared to the original manifests. Waste containers that contained mixed fission products (MFP) were not included in the calculations, as it was not possible to determine which isotopes were present.

The data were loaded into a spreadsheet file (Lotug 1-2-3) to perform the calculations. Acceptance criteria for the radionuclides from the Envirocare ilcense (Attachment 1) were also input to the spreadsheet.

Calculations were performed by comparing the concentration of the radionuclides for each waste container (identified by bar codes) to the maximum allowable. When this ratio was less than 1.0 , the waste was deemed acceptable. When more than one radionuclide was present, the sum of all of the ratios must be less than 1.0 in order for the waste to be acceptable. Attachment 2 contains a printout of the calculations.

\section{ADDITIONAT INFORMATION}

Vern Andrews of Envirocare (801-532-1330) was contacted January 31,1994 todetermine the radiologic limitg for $Y-90$ and $B a-137 \mathrm{~m}$. He said that these were daughter products of $\mathrm{Sr}-90$ and $\mathrm{Cs}-137$, respectively. The Iimits of the parent isotopes could be used. 


\section{DRAFT}

\section{SAMPIE CAICUTATION}

A sample calculation is presented for one waste container, barcode INEL1393. This waste is described as Cadmium and Chromium contaminated HEPA filters. It is contained in a single 55 gal drum and weighs 144 lb.

\begin{tabular}{|l|l|l|l|l|l|}
\hline $\begin{array}{l}\text { Radio- } \\
\text { nuclide }\end{array}$ & $\begin{array}{l}\text { Amount } \\
\text { (Ci) }\end{array}$ & $\begin{array}{l}\text { Concentration } \\
\text { (pCi/g) }\end{array}$ & $\begin{array}{l}\text { Envirocare } \\
\text { WAC (PCi/g) }\end{array}$ & $\begin{array}{l}\text { Ratio } \\
\text { (Concentration } \\
\text { /WAC) }\end{array}$ & $\begin{array}{l}\text { Sum of } \\
\text { Ratios }\end{array}$ \\
\hline Sb-125 & $1.2 E-7$ & 1.84 & 5300 & 0.00035 & 0.00035 \\
\hline$C g-137$ & $6.1 E-8$ & 0.93 & 560 & 0.00167 & 0.0020 \\
\hline
\end{tabular}

The concentration is calculated by multiplying the number of Curies by $10^{\prime 2}$ to get picocuries (pCi) and dividing by the weight (144 ib $x 453.6 \mathrm{~g} / 1 \mathrm{~b})$. This concentration is compared to the limit ( 5300 for Sb-125 and 560 for Cs-137). Each of these ratios is much less than 1.0 and the sum of the ratios is also much less than 1.0. This waste should be acceptable for disposal at Envirocare. 


\section{DRAFT}

\section{RESULTS}

The following waste containers (barcode numberg) representing 18 different waste gtreams were found to be acceptable for disposal at Envirocare. According to the Envirocare waste acceptance procedures, independent laboratory data must be obtained for any waste to be interred at its facility. These barcodes, therefore, represent wastes that can be considered for acceptance at Envirocare.

Table 1. Wastes Considered Acceptable for Disposal at Envirocare

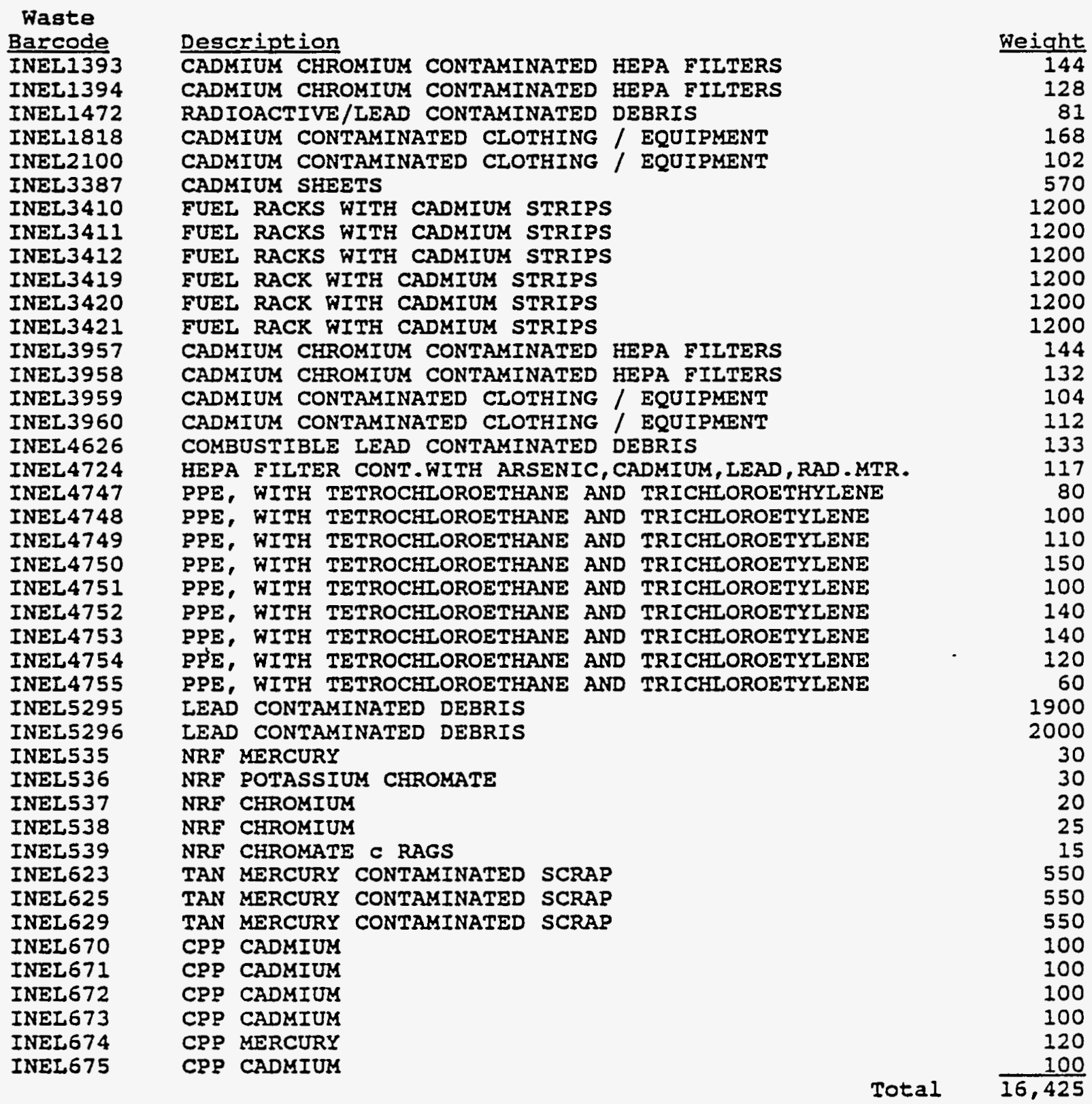




\section{Appendix F}

Categorical Exclusion and

DOE 5820.2A Exemption Requirements 


\section{Department of Energy \\ Idaho Operations Office 785 DOE Place \\ Idaho Falls, Idaho 83401-1562 \\ February 17, 1994}

Mr. S. M. Halupa, Vice President and Manager

Operations Department

Westinghouse Idaho Nuclear Company, Inc.

P.O. Box 4000, MS 5233

Idaho Falls, ID 83403

Mr. Dick Jansen, Manager

Environmental Regulatory Unit

EG\&G Idaho, Inc.

P.O. Box 1625, MS 3906

Idaho Falls, ID 83415

SUBJECT: Categorical Exclusion (CX) Approval (OPE-SN-94036)

Dear Messrs. Halupa and Jansen:

The CX for the following INEL action has been approved by J. M. Wilcynski, Acting Manager, DOE-ID. Verbal notification of approval was provided earlier. This transmittal provides documentation for the project files.

1. Off-Site Disposal of Mixed Waste Project (ID-CPP-94002)

You are authorized to proceed with this project.

Sincerely,

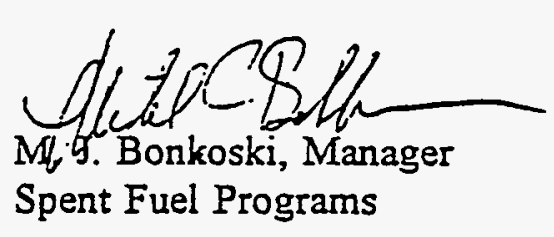

Attachments

cc: $\quad$ R. S. Scott, DOE-HQ, EM-20, 6B-138/FORS

D. E. Henninger, DOE-HQ, EM-331, 376/TREV

L. K. Wade, DOE-HQ, EM-30, A-333/GTN

P. A. Hiller, WINCO

A. M. Umek, WINCO

WINCO ERC, MS/3412

EG\&G NEPA Files, MS-3552 
CATEGORICAL EXCLUSION DETERMINATION

DOE IDAHO OPERATIONS OFFICE

PROPOSED ACTION: Off-Site Disposal of Mixed Waste

PROPOSED BY: WINCO

HQ PROGRAM SPONSOR: EM

LOCATION: INEL, Idaho Chemical Processing Plant (ICPP)

DESCRIPTION OF THE PROPOSED ACTION: The proposed project would

ship mixed waste from DOE-ID facilities to an off-site, licensed and

permitted disposal facility.

CX(S) TO BE APPLIED (from Appendix B to Subpart $D$ of the DOE NEPA Regulations, 10 CFR 1021:

(B6.1) Removal Actions under CERCLA/RCRA; (B6.1) Routine Maintenance;

(B2.5) Safety \& Environmental Improvements

The proposed action would not: 1) threaten a violation of applicable statutory, regulatory, or permit requirements for environmental, safety, and health, including requirements of DOE Orders; 2) require siting and construction or major expansion of waste storage, disposal, recovery, or treatment facilities; 3 ) disturb hazardous substances, pollutants, contaminants, or CERCLA-excluded petroleum and natural gas products that preexist in the environment such that there would be uncontrolled or unpermitted releases; 4) adversely affect environmentally sensitive resources. In addition, no extraordinary circumstances related to the proposal exist which would affect the significance of the action, "and the action is not "connected" or "related" (40 CFR 1508.25(a)(1) and (2) respectively) to other actions with potentially or cumulatively significant impacts.

DETERMINATION: I have determined that the proposed action as described meets the requirements for the $C X(s)$ referenced above. Therefore, I have determined the proposed action is categoricaliy excluded from further NEPA review and documentation.

Approval

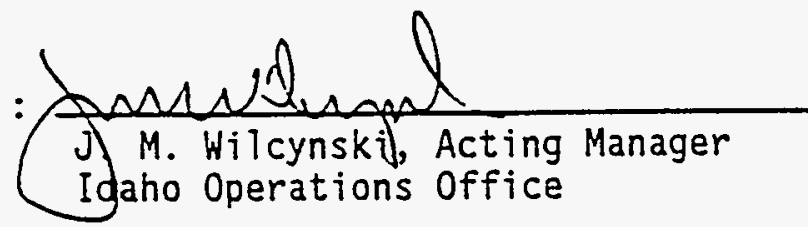

Date:

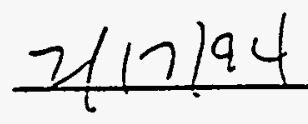
Igaho Operations Office

Attachment 


\author{
Attachment to the Environmental Checklișt \\ for the \\ Off-Site Disposal of Mixed Waste Project
}

\title{
SECTION B: PROJECT DESCRIPTION
}

The proposed project would be located at facilities operated by the Idaho Field Office of the Department of Energy (DOE-ID).

The purpose of this one-time limited proposed project is to ship (prior to May 8, 1994) mixed waste debris and soil from DOE-ID facilities to an offsite, licensed and permitted disposal facility. The INEL is storing debris contaminated with radioactive and hazardous constituents. The debris primarily consists of personal protective equipment, cleanup materials, and asbestos debris. The mixed waste was primari7y generated from the management of existing listed waste from activities involving on-going production, routine maintenance, upgrade, decontamination and decommissioning, site remediation, construction, and safety and environmental improvement activities.

Under the "debris variance" EPA will allow the land disposal of RCRA regulated debris in approved subtitle C landfill until May 8, 1994. Because of the derived from and mixture rules, the mixed debris carries a large number of waste codes. Due to our limited storage capacity and the lack of treatment for mixed debris, it is not possible to meet the treatment standards for all of the waste codes. DOE-EM has authorized operations offices to use commercial facilities for disposal of small quantities of mixed waste, and provided an exemption to DOE for the relevant requirements of 5480.2A. (Memo: Grumbly to Operations Office Managers, October 12, 1993)

The total shipments would not exceed $1,000 \mathrm{~m}^{3}$. The waste would meet all disposal facility and Department of Energy (DOE) requirements. Necessary documentation would be in place prior to off-site shipment. The hazardous waste transporter(s) would possess all necessary Department of Transportation (DOT) permits required to transport the waste.

The disposal facility would have sufficient capacity to accept this waste, a Nuclear Regulatory Commission (NRC) radioactive material license, a Resource Conservation and Recovery Act (RCRA) Part B permit, and any necessary state permits needed to receive and dispose of mixed waste. Transportation would be performed in accordance with DOT and Environmental Protection Agency (EPA) requirements. No environmentally sensitive areas would be affected. 


\section{Attachment to the Environmental Checklist \\ for the \\ Off-Site Disposal of Mixed Waste Project}

\section{SECTION C. SOURCES OF IMPACTS}

\section{Mixed Waste:}

No more than $1,000 \mathrm{~m}^{3}$ of mixed waste would be removed from temporary storage locations at DOE-ID facilities and shipped for permanent disposal. The containerized waste would meet all transportation and disposal criteria and would be disposed at a licensed and permitted disposal facility.

\section{SECTION C. SOURCES OF IMPACTS}

\section{Asbestos:}

The asbestos available for off-site disposal has been included in the Notifications of Asbestos Removal submitted annually to DOE. A7l asbestos waste has been handled and packaged in compliance with State and Federal regulations and DOE orders as implemented by approved contractor procedures. Off-site disposal at this facility would also be in compliance.

\section{SECTION D. CATEGORY EYALUATION CRITERIA}

2. The proposed action would take place at existing INEL facilities, and disposal would occur off-site.

\section{SECTION E. CONTRACTOR ENVIRONMENTAL ORGANIZATION REVIEW}

A Categorical Exclusion (CX) is recommended for the described activity. A CX should be granted on the basis that the proposed activity is included in one or more of the following CXs: CERCLA Removals/Similar Actions Under RCRA or other Authorities, Meeting CERCLA Cost/Time Limits or Exemptions [including removal of bulk containers (for example, drums, barrels) that contain or may contain hazardous substances, pollutants, contaminants, CERCLA-excluded petroleum or natural gas products, or hazardous wastes (designated in 40 CFR part 261)] (B6.1); Routine Maintenance/Custodial Services for Buildings, Structures, Infrastructures, Equipment (BI.3); Safety and Environmental Improvements of a Facility, Replacement/Upgrade of Facility Components (B2.5). These CXs are from the list of categorical exclusions in 10 CFR 1021, Appendix $B$ to Subpart D. 


\section{memorandum}

OCT I: 2993

Dare

$\operatorname{mans}$

atmon:

streer:

To:
Managers, DOE Operations offices
Acting Hanager, Fernald Field Office
Acting Hanager, Rocky Flats Office

This memorandum authorizes the Department of Energy (DOE) Operations

offices, Field offices, and sites, to use cowercial facilities for the disposal of small quantities of mixed waste on a case-by-case basis. This memorandum is an approved exemption to the relévant requirements of DOE Order $5820.2 A$ and is based upon gy review and consultation with the Office of Environaent, Safety and Health (EH).

\section{The folloring conditions appiy to this exeeptioney}

(11.). The exemption is limited to sonil volumes of mixed waste as deternined to be needed or appropriate on a case-by-case basis.

42. Appropriate environmental documentation under the National Environmental Policy Act shall be prepared.

43. - If applicable, appropriate documentation under the Resource Conservation and Recovery Act, the Toxic Substances Control Act, or the Comprehensive Eavironmental Response, Compensation, and Liability Act shall also be prepared.

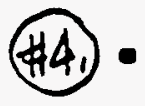

Appropriate procurement or contracting documents shall be prepared for waste disposal services. The Oak Ridge Operations Office is procuring 2 large volume contract for land disposal of mixed waste; this contract may be used by other DOE Operations offices if-it meets the maste disposal requirements of other facilities.

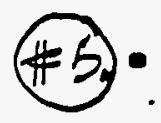

Prior to execurtion of a contract, the permits, 1 icenses, approvals, and regulatory record of ahy proposed disposal facility shail be reviewed to establish the types of waste that may he accepted and to assess the operational perforwance of the facility iflony treatment necessary to meet applicabie land Disposal Restrictions shall be identified. If +47 applicable, this review shall estahi ish that the appropriate lor-level - waste compact or State has no objection to the acceptance of DOE waste at the disposal facility.

This blanket exemption is not intended to authorize or encourage the land disposal of untreated hazardous or toxic wastes. A17 wastes which are Land Disposai Restricted shal1 meet Best Demonstrated AvaiTabTe Technalogy (i.e,, LRR treatment) standards or concentration standards prior to being land disposed. 
(49) Prior to the beginning of each shipment campaign, EM-33 shall be notified of the raste type, total volume, and destination of the waste. This information will be factored into equity discussions under the Federal Facility Compliance Act.

(10) Prior to shipment of waste, the regulatory status of the facility shall be confirmed.

(411) Periodic revteus/audits of the commercial facility or facilities will be conducted by your staff. If there is a continuing use of any particular commercial facility, these reyieus/audits should be conducted annualiy. Alternatively, reference to a similar effort by another DOE entity may be provided.

In addition to this authorization, I would also like to advise you of my position in regard to plamning and negatiations for the treatment, storage, and disposal of mixed waste from DOE sites. In my vier, after consultation with EH-1, planning for the treatment, storage, and disposal of DOE mixed waste should not be constrained by the existing DOE Order 5820.2A restriction limiting disposal at DOE sites. Discussions with the State, the Envirarmental Protectian Agency, and the public should be open and straightforward in this regard. Decisions on the disposal of DOE uixed waste on site, off site at another DOE facility, or at a commercial treatment/disposal facility will be addressed in the programatic environmental impact statement for DOE wastes now ongoing and DOE policy will be revised accordingly.

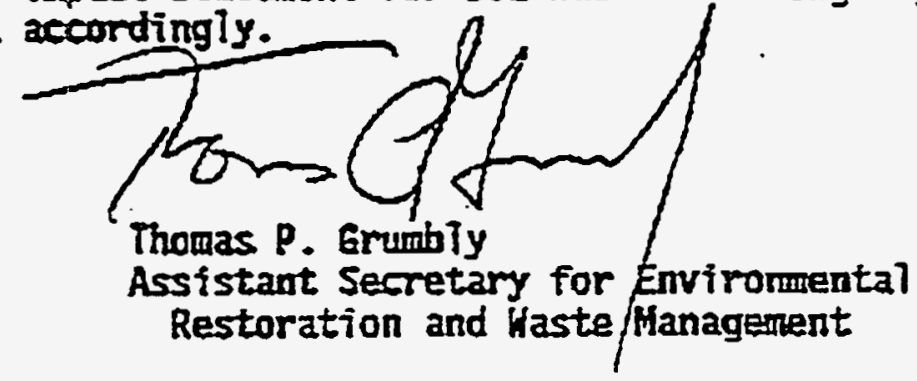

CE:

R. P. Witfield, El-40

J. Lytle, EH-30

R. Berube, EH-20 
DATE

RERTY TO

ATIN OF:

DCT 12 TYS

EH-421 (K. A. MF7liams, 903-8143)

\begin{tabular}{|c|c|}
\hline \multirow{2}{*}{$\begin{array}{l}\text { Fost-ft" brand fax transmitt } \\
\text { Ta Sue Rice. }\end{array}$} & 2mo $76 \pi$ tof poges +13 \\
\hline & Erais Parter. \\
\hline co Envivocare & co wisco \\
\hline Dept & ${ }^{\text {prom }}(30 !) 601-1426$ \\
\hline $5 \times 1801) 537^{\circ}$ & $(201) 601-1480$ \\
\hline
\end{tabular}

surect: Commercial Disposal of Department of Energy Radioactive (By-Product and Low-Levei) and Mixed Hastes

To: Assistant Secretary for Enviromenta]

Restoration and Waste Management, EM-I

This neerorandium is to request your approval of the use of coumercial radioactive and mixed waste disposal facilities for several types of Department of Energy (BOE) wastes.

Backoround:

DOE Order 5820.2A requires the disposal of al1 DOE radioactive and mixed wastes at DOE facilities. However, many DOE sites are expected to generate mixed or radioactive wastes for wich there is no an-site disposal capacity. In sone cases, no disposal capacity exists within the DOE system, and the use of comercial disposal would permit the disposal of waste that would othernise be indefinitely stored. In Novenber 1991, former Assistant Secretary for Environmental Restoration and Waste Hanagement, Leo P. Duffy, approved the Iturited use of comercial disposal facilities and disapproved an effort to modify DOE Order 5820.2A to permit generai use of conmercial disposal facilities.

On April 8, 1992, former Assistant Secretary for Environment, Safety and Heal th, Paul L. Liemer, expressed several concerns regarding the use of coumercial disposal facilities. These included:

- Colmercial disposal by DOE could affect State efforts to site conmercial disposal sites because comercial sites are not planning for the volume of waste that might be generated by DOE;

- The conmercial waste disposal proposal contradicts DOE's position regarding relief from Land Disposal Restrictions; and

- The proposal nay require review under the National Enviranmental Policy Act.

JiTl Lytle and I have discussed these concerns with Ray Berube, Deputy Assistant Secretary for Environment, and we have reached consensus that exemptions from the DOE facility disposal requirement in DOE 5820.2A shouid be approved (1) for radjoactive wastes from "off-site" environental restoration activities specified below and (2) for small volumes of mixed waste from DOE sites on a case by case basis. These approvals should be conditioned on the completion of appropriate environmental documentation under the Mational Eavironmental Pol icy Act and; if applicable, appropriate documentation under the Resource Conservation and Recovery Act, the Toxic Substances Control Act, or the 
Comprehensive Environmental Response, Conpensation, and Liability Act. Further, in regard to disposal of mixed waste from DOE facilities, we have discussed the importance of not artificially restricting planning options for the disposal of DOE waste based on past prescriptions for waste disposal in DOE 5820.2A. Planning for treatarent, storage, and disposal of these wastes should consider the full range of options, including DOE and commercial treatment, storage, and dispusai facilities. Decisions on these options will be the subject of the planned programeratic environmental impact statement.

Commercial Disposal of Radinactive Yastis:

Conmercial disposal of radioactive waste is recommended for a wide range of environwental restoration activities conducted at "off-site" iocations or facilities, i.e., those not located at wajor DOOE installations. These sites, programs, or projects are as follows:

- Formeriy Utilized Sites Remedial Action Program (FUSRAP)

- Uraniur Hill Tailings Remedial Action Project (URTRAP)

- Grand Junction Renedia] Action Project (GJRAP)

- Konticello Remedial Action Praject (HRAP)

- Battelle Col umbus Laboratory (BCL)

- Site A/PI ot 1 (Pajos Park)

- Laboratory for Energy-Re] ated Health Research (LEHR)

- Santa Susana Field Laboratory

- RHI Titanivor Company (Ashtabuia)

- Ceneral Electric Vajlecitos Nuclear Center

- General htomics facility (San Diego)

In each of these off-site remedial action projects, we reconmend that the appropriate headquarters and field personnel consider commercial disposal as a viable alternative for disposing of radioaetive waste. The approval of these exemptions to DOE Order 5820.2A for commercial disposal of these "off-site" wastes shoutd be issued, with the clear understanding that this alternative can be implemented without further approval under DOE Order 5820.2A, wenever it represents the best programatic alternative. for managing waste from any particular site. When appropriate, as part of the enviromental documentation process, each of the projects will consider an range of waste disposal al ternatives, inciuding (at a minimm) a DOE disposal site, an in-State site, and availabie comercial facilities.

In the case of IMTRAP, GJRAP, and HRAP, the recommended exemptions are further limited to onily apply to suall ad hoc remedial activities. In these projects, contaminated soil is typicaliy left beneath roads and structures because there is Tittle risk and a high cost of excavating the soil and replacing the road or structure. However, when the soil is excavated for. imprayements or utility pipe installation, small quantities of contaminated soil are generated. The small amount of contamination resulting from these ad hoc remedial actions can be disposed in comercial 
facilities at a very small cost compared with the cost of uncovering and using a closed on-site DOE disposal cell.

\section{Commercial Disposal of Hixed Haste:}

Approval of commercial disposal of uixed wasto is recoumended for small volumes of mixed waste from DOE sites on a case-by-case basis as deterwined by the Operations office Manager. The approval increases the alternatives availabie for the disposa?/management of the mixed waste; it promotes enviromental cormiliance by permitting coumercial disposal of limited amounts of mixed waste without additional approval under DOE. order 5820.2A. This action aiso decreases the perception that any particular DOE or comercial facitity is the "dumping ground" for alT DOE mixed waste nationwide.

\section{Reconmendations:}

I recommend that you approve the exemptions to DOE Order 5820.2A to permit the use of commercial waste disposal facilities subject to the conditions and adyisory included in the attached memoranda to the operations Office Managers.

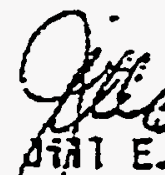

A Til E. Lythe

Députy Assistant Secretary for lasto Management

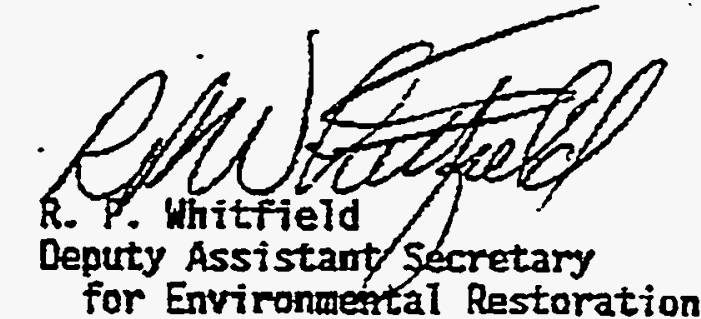

Attachurents

cr:

R. Berube, EH-20

R. Scott, ER-20

Pursuant to DOE Order 5820:2A, the required consultation with the Assistant Secretary for Enviroment, Safety and Health has been accoupl ished for these exemptions.

Erevious signature valid per

R. Eelletier 10/7793

Peter N. Brush

Acting Assistant Secretary

Approved:

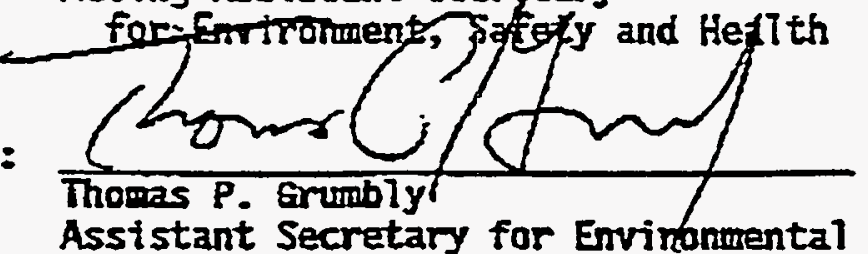

Restoration and Haste Hanagent
Date:

Date: 
"Providing research and development services to the government"

\section{INTEROFFICE CORRESPONDENCE}

Date: February 11, 1994

To: $\quad$ V. J. Balls, MS 2414

From: J. S. Irving, MS 3552 亿

Subject: MWSF - MLLW (DEBRIS) DISPOSAL (OFF-94-008) - JSI-07-94

Environmental Support Group (ESG) has reviewed the proposed actions' Environmental Checklist (EC). ESG recommends the National Environmental Policy Act (NEPA) level of documentation is a categorical exclusion (CX). The applicable CX is in the U.S. Department of Energy (DOE) NEPA Rules and Regulations, 10 CFR 1021 at Appendix B to Subpart D, Subsection 6.1.

This determination is based on information provided in the EC and other project documentation. Please review the attached EC and CX determination to ensure that the information is current and technically accurate. If any of the information is incorrect or if the project description or scope changes, please notify ESG.

The DOE requires written approval and concurrence of the EC and CX determination before proceeding with the proposed action. To obtain this review and concurrence, send the attached EC and CX determination to your DOE-ID counterpart line organization for routing and approval. After DOE-ID written approval of the EC/CX and a 14-day review period for DOE-HQ concurrence, you may proceed with the action. Please return a copy of the approved $\mathrm{EC} / \mathrm{CX}$ to this office so that we may maintain a complete file.

ESG conducted this review according to Section 8.5, "Preparation and Approval of NEPA Documentation," of the EG\&G Idaho Company Procedures Manual. For further transmittals regarding this EC, reference the ESG-generated project / activity number (OFF-94-008). If you have any questions or comments, please contact me at 526-8745.

JSI

Attachments:

As Stated

cc: J. R. Mitchell, MS $3552 \mathrm{gem}$

T. J. Thiesen, MS 8102

L. C. Tuott, MS 3552 A

W. T. Savkranz, MS 3906

G. L. Schwendiman, MS 8102
NEPA File OFF-94-008

WERF-PJ-322A (Sharon Hathaway, MS 8108)

WROC-PROJ-008 (Donna Frisbie, MS 8102)

J. S. Irving File 


\section{IDAHO .... TIONAL ENGINEERING LABOK... ORY \\ CATEGORICAL EXCLUSION DETERMINATION \\ DOE IDAHO OPERATIONS OFFICE}

PROPOSED ACTIONS: Mixed Waste Storage Facility - Mixed Low-Level Waste (Debris) Disposal

PROPOSED BY: Private Sector Participation Initiative, Org. No. 3920, EG\&G, Idaho, Inc.

\section{HO PROGRAM SPONSOR: EM}

LOCATION: Mixed Waste Storage Facility at the Power Burst Facility on the Idaho National Engineering Laboratory and Envirocare of Utah, Inc. located 50 mi. west of Salt Lake City, Utah.

DESCRIPTION OF THE PROPOSED ACTIONS: The purpose of the proposed action is to dispose of about 3055 -gal drums and five B25 bins of mixed low-level debris generated at the INEL to a RCRA permitted facility. Disposal at a RCRA permitted facility would reduce the likelihood of spillage, leakage, fire, explosion, or exposure to humans, animals, or the food chain. In addition, disposal of this waste would take advantage of the Environmental Protection Agency's (EPA) Hazardous Debris National Case-by-Case Capacity Extension. However, May 8, 1994 is the deadline to dispose waste under this extension. The INEL has explored treatment options and none currently exist. Project scope includes waste identification, verification, packaging, and transporting. The INEL would transport the waste, about two truck loads, from the Mixed Waste Storage Facility to Envirocare of Utah, Inc., a private disposal company.

CX TO BE APPLIED: (from Appendix B to Subpart D of the DOE NEPA Regulations, 10 CFR 1021):

- B6.1, CERCLA removals/similar actions under RCRA or other authorities, meetings CERCLA cost/time limits or exemptions.

The proposed actions would not: 1) threaten a violation of applicable statutory, regulatory, or permit requirements for environmental, safety, and health, including requirements of DOE orders; 2) require siting and construction or major expansion of waste storage, disposal, recovery, or treatment facilities; 3) disturb hazardous substances, pollutants, contaminants, or CERCLA-excluded petroleum and natural gas products that preexist in the environment such that there would be uncontrolled or unpermitted releases; 4) adversely affect environmentally sensitive resources. In addition, no extraordinary circumstances related to the proposal exist which would affect the significance of the action, and the action is not "connected" nor "related" (40 CFR 1508.25(a)(1) and (2), respectively) to other actions with potentially or cumulatively significant impacts.

DETERMINATION: I have determined that the proposed action as described meets the requirements for the $\mathrm{CX}$ referenced above. Therefore, I have determined the proposed action is categorically excluded from further NEPA review and documentation.

Approval:

J. M. Wilcynski, Acting Manager

Date:

Idaho Operations Office

Attachment 
DOE-HQ PROGRAM: EM

DIRECTIONS: Sections $A$ through $C$ to be completed by Program/Project Manager. Remainder, including the NEPA document ID number, is to be completed by the Contractor Environmental Organization or DOE-ID program NEPA Point of Contact. Provide responses to Section B, and explanations for any "YES" answers in Sections C and $D$, on an attachment.

SECTION A. PROJECT TTTLE: PROJECT NUMBER:

MWSF - Mixed LoW-Level Waste (Debris) Disposel

PERFORMING OROANIZATION:

Privale Sector Participation Initiative, 3920

DOE PROJECT TECHNICAL MANAGER:

J. C. Benavidez

PERFORMING ORGANIZATION CONTACT:

V. J. Balls

SECTION B. PROJECT DESCRIPTION: Attach a brief description of the Project/Action, localion, purpose and need, project or construction start and end time projections, approximate cost and type of action; e.g. new construction, process modification, maintenance, new activity, research and development, work for others, etc.

SECTION C. SOURCES OF IMPACTS: WOULD THE ACTION INVOLVE, GENERATE, OR RESULT IN CHANGES TO ANY OF THE FOLLOWING?

YES NO

\section{AIR EMISSIONS}

4. LIQUID EFFLUENT

7. SOLID WASTE

10. RADIOACTTVE WASTE

13. HAZARDOUS WASTE

16. MLXED WASTE

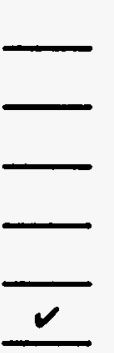

DATE:

February 7. 1994

TELEPHONE NUMBER:

$\$ 26-5968$

TELEPHONE NUMBER:

$526-0067$

YES NO

YES NO

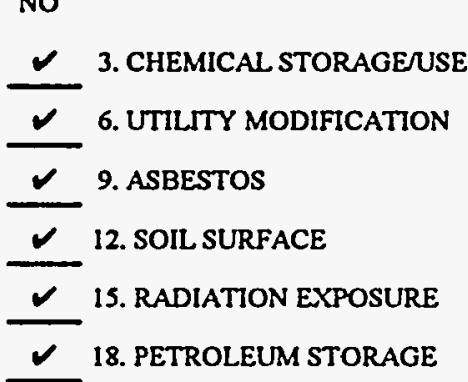

17. PESTICIDE USE

2. WATER USERIVERSION

5. WATER TREATMENT

8. WATER COURSE MODIFICATION

11. WORKFORCE ADJUSTMENT

14. EXCESS NOISE LEVELS
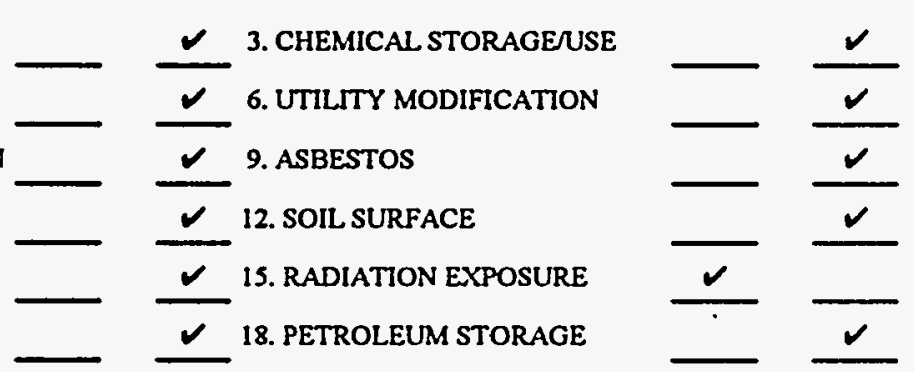

SECTION D. CATEGORY EVALUATION CRITERIA: WOULD THE ACTION:

1. Be related to a proposed action with potentially significant impacts?

2. Take place in an area of previous or on-going disturbance?

3. Create uncertain, unique, or unknown risks?

4. Require any federal, state or local permits, approvals, etc.?

5. Create hazardous, radioactive or mixed waste for which no disposal is available?

6. Impact a RCRA-regulated unit or facility?

7. Threaten or violate any statute, regulation, or DOE order?

8. Disturb hazardous substances, pollutants or contaminants that preexist in the environment?

9. Require siting, construction, or expansion of a waste TSD facility?

10. Adversely affect any environmentally sensitive resources such as: objects or structures of archaeologic, historic or architectural significance, threatened or endangered species or their habitat, floodplains or wetlands, wildemess areas, national parks, national natural landmarks, wild \& scenic rivers, wildlife refuges, marine sanctuaries, prime agricultural lands, vital waler sources, tundra coral reefs, or rain forests, etc.?

SECTION E. NEPA LEVEL OF DOCUMENTATION RECOMMENDATION:

10 CFR 1021 SUBPART "D": $\quad C X \_$EA___ EIS ___ NOT COVERED IN SUBPART "D": RECOMMENDATION

REFERENCES: 10 CFR 1021 Appendix B to Subpart D. Subsection B6.1, "CERCLA removals/similar actions under RCRA or other authorities, meeting CERCLA cost / time limits or excmptions." Sampling efforts are covered under routine operations. See also Section E for further discussion.

NAME: John S. Irving

SIGNATUIRE:

.

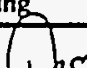




\section{ENVIRONMENTAL CHECKLIST \\ U.S. DEPARTMENT OF ENERGY, IDAHO \\ OPERATIONS OFFICE}

\section{ENVIRONMENTAL CHECKLIST ATTACHMENT}

NEPA LOG NO. OFF-94-008

SECTION B (con't): PROJECT DESCRIPTION: The purpose of the proposed action is to dispose of about 30 55-gal drums and five B25 bins of mixed low-level debris generated at the INEL to a Resource Conservation and Recovery Act (RCRA) permitted facility. Disposal at a RCRA permitted facility would reduce the likelihood of spillage, leakage, fire, explosion, or exposure to humans, animals, or the food chain. In addition, disposal of this waste would take advantage of the Environmental Protection Agency's (EPA) Hazardous Debris National Caseby-Case Capacity Extension. However, May 8, 1994 is the deadline to dispose of waste under this extension. ${ }^{1}$ The INEL has explored treatment options and none currently exist (see attached Office Vision note from L. Schwendiman).

Project scope includes waste identification, verification, packaging, and transporting. The INEL would transport the waste, about two truck loads, from the Mixed Waste Storage Facility (MWSF) to Envirocare of Utah, Inc. (Envirocare), a private disposal company. The program must prepare a waste disposal plan before shipping wastes. Inspection of containers showed that three percent of the containers may need repackaging for shipment. Sampling of waste is required prior to shipping and would occur at the Waste Experimental Reduction Facility. A sampling plan is required.

An engineering design file ${ }^{2}$ provides data to compare and validate all waste with the radiation profile and contents of wastes. This and subsequent laboratory analysis will ensure that Envirocare's waste acceptance criteria are met. The waste transporter would be selected based on waste packaging information and experience with this kind of waste. The cost of this proposed action is an estimated $\$ 50,000$. Envirocare requires that all waste be at their facility by March 31 , 1994, to meet the May 8, 1994, deadline.

1 EPA, under 40 CFR 268.5, renewed the original extension of the case-by-case capacity variance to May 8, 1994. No further variance or extension of the Land Disposal Regulations effective date for hazardous debris can be given after May 8, 1994.

2 Engineering Design File No. WROC-EDF-220. 
SECTION C (con't): SOURCES OF IMPACTS: WOULD THE ACTION INVOLVE, GENERATE, OR RESULT IN ANY OF THE FOLLOWING?

15. Radiation Exposure - No radiation exposure is anticipated. However, should it occur, worker exposure to radioactivity would be managed in accordance with standards imposed by DOE Order 5484.1, "Environmental Protection, Safety and Health Protection Information Reporting Requirements." In addition to establishing dose limits, DOE orders also establish a policy of maintaining occupational exposures as low as reasonable achievable using time, distance, and shielding.

16 Mixed Waste - The project would ship INEL-generated mixed waste off-site for disposal. However, the process would not produce new mixed waste.

\section{SECTION D (con't): CATEGORY EVALUATION CRITERIA: WOULD THE ACTION:}

2. Take place in an area of previous or on-going disturbance? The MWSF is an existing facility within a previously disturbed and developed area at the INEL. Envirocare is located $50 \mathrm{mi}$. west of Salt Lake City, Utah. The facility meets all the requirements of 40 CFR 192 and Utah Radiation Control Rules, which conform to 10 CFR 61. Envirocare holds a RCRA Part B Permit from the Utah Divison of Solid and Hazardous Waste and is prepared to handle mixed waste.

6. Impact a RCRA-regulated unit or facility? The MWSF is a RCRA-regulated treatment, storage, and disposal facility on the INEL with a Part B application filed with the State. The . facility is currently in interim status. The proposed action is in compliance with this interim permit status.

\section{SECTION E (con't): CONDITIONS:}

CONTRACTOR COMMENTS - Currently, there is no available capacity or capability on the INEL site to treat this mixed waste debris (see attached Office Vision note from L.

Schwendiman). The only potential facilities are Waste Engineering Development Facility and Westinghouse Idaho Nuclear Company's Debris Decontamination Facility. These facilities will not be available for the debris case-by-case extenstion cutoff date of May 8, 1994. A good faith effort indicated that other treatment or disposal options are not available (see attached letter to 
ID F-5440.1A\#

Ref. DOE 5440.10

(Rev. 10-92)

Pg. 4

\section{ENVIRONMENTAL CHECKLIST \\ U.S. DEPARTMENT OF ENERGY, IDAHO \\ OPERATIONS OFFICE}

the EPA). This action will remove bulk containers (i.e., drums, bins) that contain hazardous substances, thus reducing the likelihood of spillage, léakage, fire, explosion, or exposure to humans, animals, or the food chain. Such actions are covered under 10 CFR 1021, Appendix B to Subpart D, Subsection B6.1 (b), p. 15156). 


\section{Appendix G}

\section{Sample Analysis Plan}

G-1 
G-2 
WROC-SAP-6.1

Rev. 0

February 1994

Sampling and Analysis Plan for

Disposal of Mixed Waste Debris at Envirocare

\author{
Prepared by \\ Sylvia Medina \\ Isabel Anderson \\ Vince Daniel
}

)

February 14, 1994 
WROC-SAP-6.1

Rev. 0

February 1994

Sampling and Analysis Plan for Sampling of Mixed Waste Debris for Disposal at Envirocare

Prepared by:
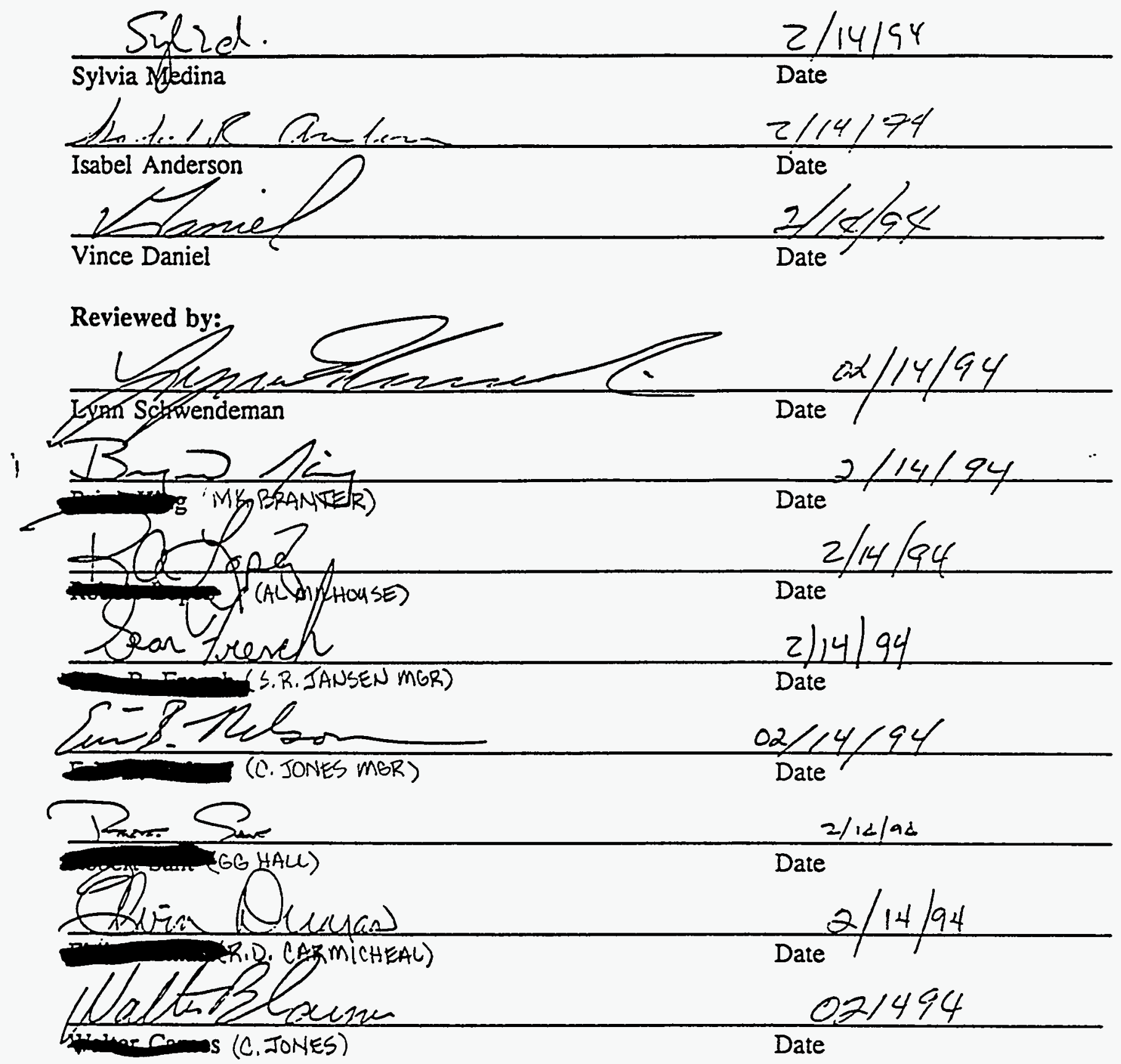

i RELEASED

$\frac{\text { Alum Niblathewry } 2 / 16 / 94}{\text { Wigt/Dato }}$

2 
WROC - SAP - 6. I

Rev. 0

February 1994

Approyed By:

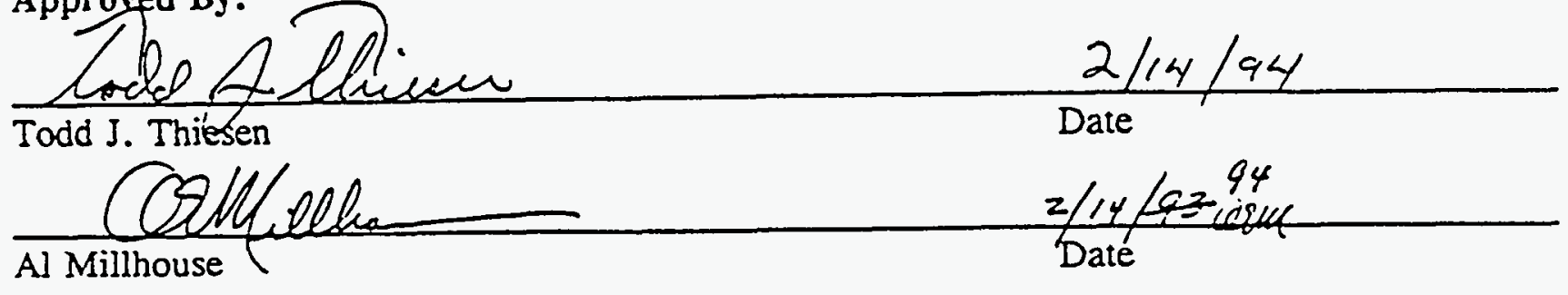


Table of Contents

Table of Contents $\ldots \ldots \ldots \ldots \ldots \ldots \ldots \ldots \ldots \ldots \ldots \ldots \ldots$

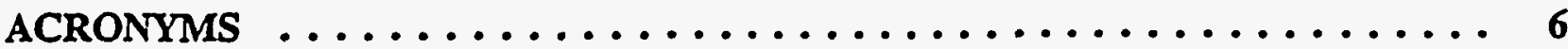

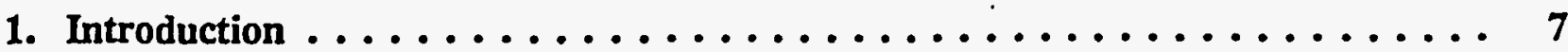

2.0 Project Organization and Responsibilities $\ldots \ldots \ldots \ldots \ldots \ldots \ldots \ldots$

3. Quality Assurance Objectives and Sampling Strategy ... . . . . . . 10

3.1 Objective ......................... 10

3.2 Envirocare WAC Requirements . . . . . . . . . . 10

3.3 PARCC Parameters . . . . . . . . . . . . . . . . 15

3.4 Analytical Levels $\ldots \ldots \ldots \ldots \ldots \ldots \ldots \ldots \ldots \ldots \ldots \ldots$

4.0 Training Requirements $\ldots \ldots \ldots \ldots \ldots \ldots \ldots \ldots \ldots \ldots$

5.0 Sampling Procedures $\ldots \ldots \ldots \ldots \ldots \ldots \ldots \ldots \ldots \ldots \ldots \ldots$

5.1 Sampling Preparation Procedures $\ldots \ldots \ldots \ldots \ldots \ldots \ldots \ldots \ldots$

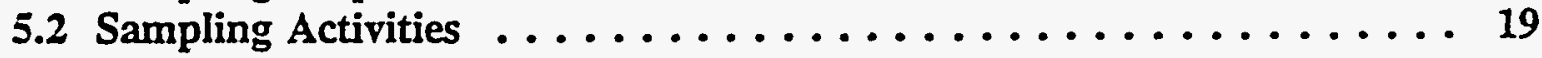

6. Document Management and Sample Handling .............. 22

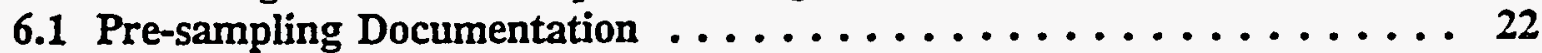

6.2 Sampling Documentation. . . . . . . . . . . . . . 22

6.2.1 Sample Labels ..................... 22

6.2 .2 Sample Identification Number ............... 23

6.2 .3 Custody Seals ..................... 23

6.2 .4 Logbooks . . . . . . . . . . . . . . . . 23

6.3 Chain of Custody ...................... 24

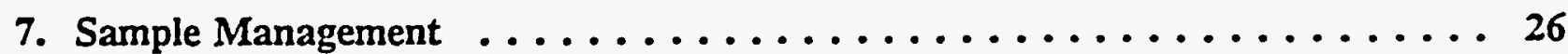

7.1 Sample Tracking ....................... 26

7.2 Sample Containers ..................... 26

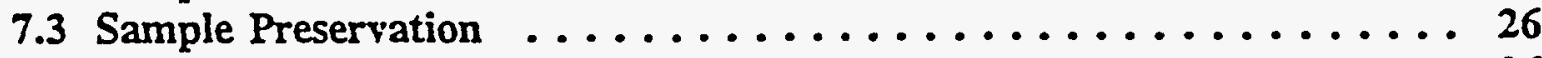

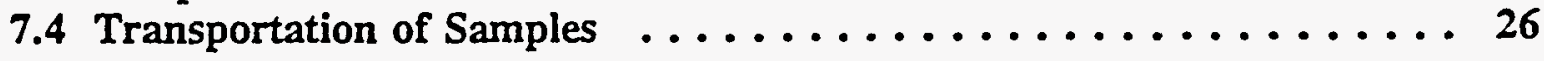

8. Health and Safety Requirements $\ldots \ldots \ldots \ldots \ldots \ldots \ldots \ldots \ldots \ldots$ 
WROC-SAP-6.1

Rev. 0

February 1994

9. Waste Management .......................... 29

9.1 Mixed Low-Level Wastes . . . . . . . . . . . . . . . . . . 29

9.2 LOW-LEVEL WASTE

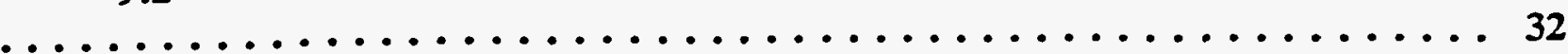

9.3 INDUSTRIAL WASTE $\ldots \ldots \ldots \ldots \ldots \ldots \ldots \ldots \ldots$

10. Corrective Action . . . . . . . . . . . . . . . . 35

10.1 Field Corrective Action . . . . . . . . . . . . . 35

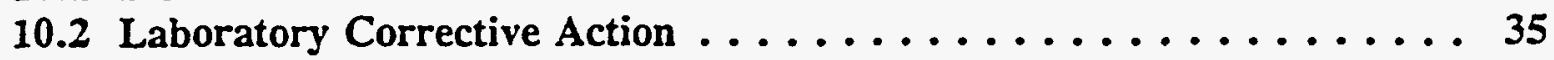

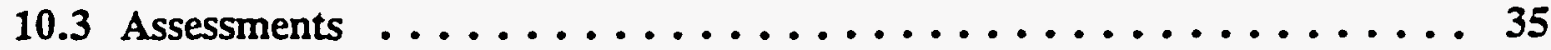

11.0 Record Keeping $\ldots \ldots \ldots \ldots \ldots \ldots \ldots \ldots \ldots \ldots \ldots \ldots \ldots \ldots \ldots \ldots$

12.0 References $\ldots \ldots \ldots \ldots \ldots \ldots \ldots \ldots \ldots \ldots \ldots \ldots \ldots \ldots \ldots$

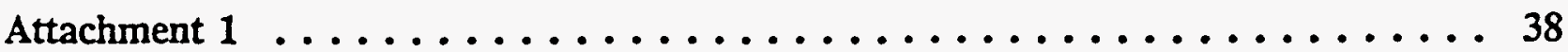

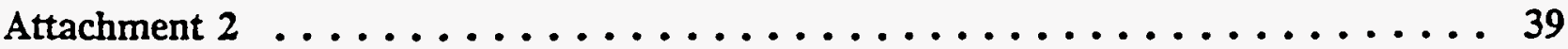

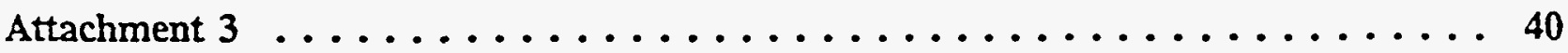

Attachment $4 \ldots \ldots \ldots \ldots \ldots \ldots \ldots \ldots \ldots \ldots \ldots \ldots \ldots \ldots \ldots$ 
WROC-SAP-6.I

Rev. 0

February 1994

\section{ACRONYMS}

$\begin{array}{ll}\text { CFR } & \text { Code of Federal Regulations } \\ \text { CLP } & \text { Contract Laboratory Program } \\ \text { DOT } & \text { Department of Transportation } \\ \text { ER } & \text { Environmental Restoration } \\ \text { FO } & \text { Facility Operator } \\ \text { FTL } & \text { Field Team Leader } \\ \text { IH } & \text { Industrial Hygienist } \\ \text { MW } & \text { Mixed Waste } \\ \text { MWSF } & \text { Mixed Waste Storage Facility } \\ \text { NRC } & \text { Nuclear Regulatory Commission } \\ \text { QA } & \text { Quality Assurance } \\ \text { QC } & \text { Quality Control } \\ \text { PARCC } & \text { Precision, Accuracy, Representativeness, Comparability, and } \\ & \text { Completeness } \\ \text { PO } & \text { Purchase Order } \\ \text { PPE } & \text { Personal Protective Equipment } \\ \text { PM } & \text { Project Manager } \\ \text { RCT } & \text { Radiological Controls Technician } \\ \text { RCRA } & \text { Resource Conservation \& Recovery Act } \\ \text { SAP } & \text { Sampling \& Analysis Plan } \\ \text { SMO } & \text { Sample Management Office } \\ \text { SOW } & \text { Statement of Work } \\ \text { STs } & \text { Sampling Technicians } \\ \text { SWR } & \text { Site Work Release } \\ \text { TAA } & \text { Temporary Accumulation Area } \\ \text { TOS } & \text { Task Order Statement } \\ \text { TPS } & \text { Technical Programs } \\ \text { TSD } & \text { Treatment, Storage, and/or Disposal Facility } \\ \text { WAC } & \text { Waste Acceptance Criteria } \\ \text { WERF } & \text { Waste Experimental Reductions Facility } \\ \text { WM } & \text { Waste Management } \\ \text { WROC } & \text { Waste Reductions Operations Complex } \\ & \end{array}$


WROC-SAP-6.1

Rev. 0

February 1994

\section{Introduction}

The purpose of this project is to collect sufficient sample volume to provide sampling and analytical data of documented quality for the characterization of mixed waste debris stored at the Mixed Waste Storage Facility (MWSF) which will ultimately be disposed of at Envirocare, a Treatment, Storage, and Disposal (TSD) facility in Utah. The waste shall be moved from the MWSF to a Temporary Accumulation Area (TAA) located in WERF (PER 609) where it will be sampled (see Figure 1). The waste to be sampled is containerized in a variety of waste packages which include TX-4 boxes, drums, and 2' $\times 2^{\prime} \times 2^{\prime}$ cardboard boxes (stored in B-25 bin boxes). All of the waste has been previously characterized as mixed waste.

The sample data obtained from this characterization effort will be used to ensure compliance requirements as specified by the Envirocare Waste Acceptance Criteria (WAC), RCRA permit, and NRC license. 
WROC-SAP-6.1

Rev. 0

February 1994

Figure 1 - WERF TAA

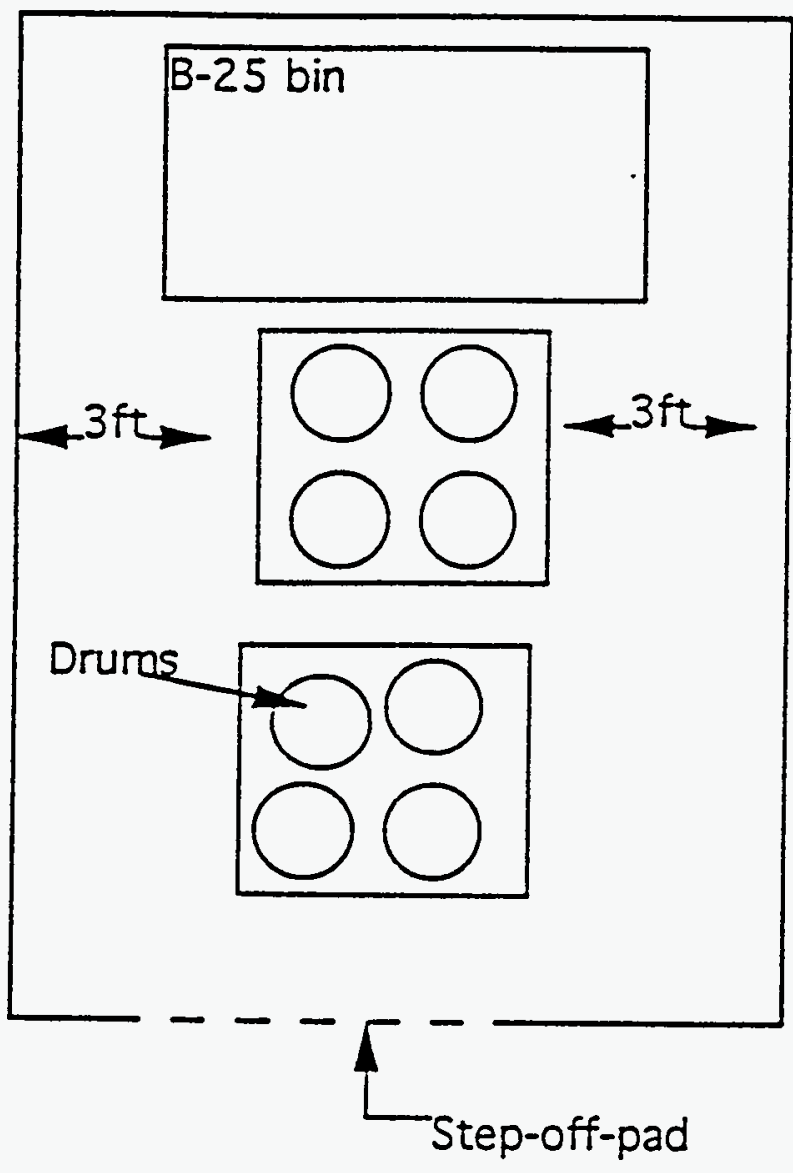

Example of Typical Layout in TAA 
WROC-SAP-6.1

Rev. 0

February 1994

\subsection{Project Organization and Responsibilities}

The following is a list of key project personnel and their corresponding responsibilities:

T. J. Thiesen

Lynn Schwendiman

Vondell Balls

V. E. Daniel

I. R. Anderson

R. Sayer

R. Mockli

L. Shelley

S. Amaro

Adrian Chapman

S. B. French

Eric B. Nelson

Walter Carnes

Brian King

Robert Lopez
Project Manager (PM), Waste Reductions Operations Complex (WROC) Technical Programs

Project Manager, WROC

Task Project Manager

Field Team Leader (FTL)

Field Team Leader

Sampling Team

Sample Management Office laboratory interface

WERF Environmental Coordinator

Industrial Hygienist

Industrial Safety

WERF Radiological Control

Facility Operator 
WhOC-SAF- - . 1

Rev. 0

February 1094

\section{Quality Assurance Objectives and Sampling Strategy'}

\subsection{Objective}

The quality assurance objective is to definitively characterize mixed u'aste debris destined for disposal at Envirocare (see Table 3-1). These candidate waste streams are currently stored at the MWSF in a variery of containers as specified in the table. In order to guarantee acceptance of this waste to Envirocare. the waste must be characterized as specified by the Envirocare WAC. Information from the sampling and analysis effort u'ill provide the basis required for obtaining acceptance of the waste to this TSD and assure compliance with the disposal standards specified in 40 CFR 268. Quality Procedures outlined in the S.AP comply with the Quality Assurance Project Plan (QAPjP) except when noted (WROC-PROJ-001241).

\subsection{Envirocare WAC Requirements}

The data quality objectives (Table 3.2) for this sampling and analy'sis effort are specified to gain acceptance of the mixed waste debris to Envirocare. In order to meet these requirements it is imperative that the samples collected are representative of each waste stream. A specific number of samples must be collected for analysis at a Utah-certified anzivtical laboratory. Also, a set of representative samples will be sent to Envirocare for "fingerprinting". If the w'aste meets the Envirocare NRC. WAC and the RCRA permitting requirements, the waste can be shipped to Envirocare. The following analyses are required:

Analytical samples required by a Utah-certified laboratory

- $\quad$ reactive hy'drogen cyanide/hydrogen sulfide

- full TCLP (8 metals. 32 organics)

- TOX (Total Organic Halides)

- Gamma Spectroscopy

- Uranium isotopes

- Thorium isotopes

Envirocare fingerprint samples required

- $\quad 1-\delta$ gallon representative sample from each w'aste stream (See Page II.3 of the Material Acceptance Process Manual for Envirocare, 12/02/93).

Each sample will include all types of debris items found in an individual waste stream and the range of contaminants present in the debris. For example, biased samples should be 
WROC-SAP-6.1

Rev. 0

February 1994

collected where it is evident that the residue of a contaminant is visually present. If there is no visual indication, samples should be collected from portions that would most likely be contaminated (e.g., butt, knees, and elbows of PPE coveralls). 
WROC-SAP- 6.1

Rev. 0

February 1994

\begin{tabular}{|c|c|c|c|c|c|c|c|c|c|c|c|c|c|c|}
\hline \multirow[t]{2}{*}{$\begin{array}{l}\text { Waste } \\
\text { Darcode } \\
\text { Number }\end{array}$} & \multirow[t]{2}{*}{$\begin{array}{l}\text { Warle sueam } \\
\text { Identificstion } \\
\text { Number for }\end{array}$} & \multirow[t]{2}{*}{$\begin{array}{l}\text { Number of } \\
\text { Samples } \\
\text { lo be collected }\end{array}$} & \multirow[t]{2}{*}{ Type of Containers } & $\begin{array}{l}\text { Thystear } \\
\text { Wescriplinis }\end{array}$ & \multicolumn{2}{|c|}{ Is waste debrts } & \multirow[t]{2}{*}{$\begin{array}{l}\text { RCR } \\
\text { Code }\end{array}$} & \multicolumn{2}{|c|}{$\begin{array}{l}\text { Does Warte } \\
\text { meet RCRA } \\
\text { Codes for } \\
\text { nartance (f.e., } \\
\text { b K thitrd. } \\
\text { itted waste)? }\end{array}$} & \multicolumn{2}{|c|}{$\begin{array}{l}\text { Is Eartrocare } \\
\text { permilted } \\
\text { for RCRA } \\
\text { waste? }\end{array}$} & \multicolumn{3}{|c|}{$\begin{array}{c}\text { Weste } \\
\text { Can so to } \\
\text { Eartrocere }\end{array}$} \\
\hline & & & & & jes & $\infty$ & & je & no & yes & Do & jes & no & $?$ \\
\hline $\begin{array}{l}1393 \\
1394 \\
\end{array}$ & 646 & NA & $\begin{array}{l}\text { 55. zallon drum } \\
\text { SS.gallon drum }\end{array}$ & $\begin{array}{l}\text { Cadminem chuomium } \\
\text { contemminuled lit:PA fillers }\end{array}$ & $x$ & & $\begin{array}{l}\text { D006 } \\
\text { DOS7 }\end{array}$ & $x$ & & 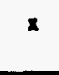 & & $x$ & & \\
\hline 1472 & ID.EG\&G.142 & NA & IS gallim drum & 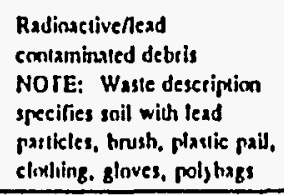 & $x$ & & DOOB & $x$ & & 2 & & & & $x$ \\
\hline $\begin{array}{l}1818 \\
2100\end{array}$ & ID-WIN-III & $s / 2$ & $\begin{array}{l}\text { S5-galliom drum } \\
\text { SS gallim drum }\end{array}$ & $\begin{array}{l}\text { cadminn contamiruled } \\
\text { clnthing/equipment }\end{array}$ & $x$ & & D006 & $x$ & & $x$ & & $x$ & & \\
\hline 3387 & 609 & $5 / 2$ & 30 gallm drum & cadmium sheets & $\approx$ & & D006 & $x$ & & $x$ & & $x$ & & \\
\hline $\begin{array}{l}3957 \\
3958\end{array}$ & 646 & NA & $\begin{array}{l}\text { 55.gallon drum } \\
\text { S5 gallon drum }\end{array}$ & $\begin{array}{l}\text { cadmium chromium } \\
\text { contaminaled HI:PA filless }\end{array}$ & $x$ & & $\begin{array}{l}\text { D006 } \\
\text { D007 }\end{array}$ & $x$ & & $x$ & & $x$ & & \\
\hline $\begin{array}{l}3959 \\
3960\end{array}$ & ID.WIN-III & NA & $\begin{array}{l}\text { S5. gallon drum } \\
\text { S5 gallon drum }\end{array}$ & $\begin{array}{l}\text { cadiningm contaminaled } \\
\text { clouling/equipment }\end{array}$ & $x$ & & D006 & $x$ & & $x$ & & $x$ & & \\
\hline 4626 & sol & $5 / 2$ & 30 gallon drum & $\begin{array}{l}\text { conntustihle lead } \\
\text { contaninated debtis } \\
\text { (Uis is paper procticls } \\
\text { coutraining lead particles) }\end{array}$ & $x$ & & D008 & $x$ & & $x$ & & $x$ & & \\
\hline
\end{tabular}


WROC-SAP-6.1

Rev. 0

February 1994

TAIIIE 3-1 Waste StrenIII Descriptions

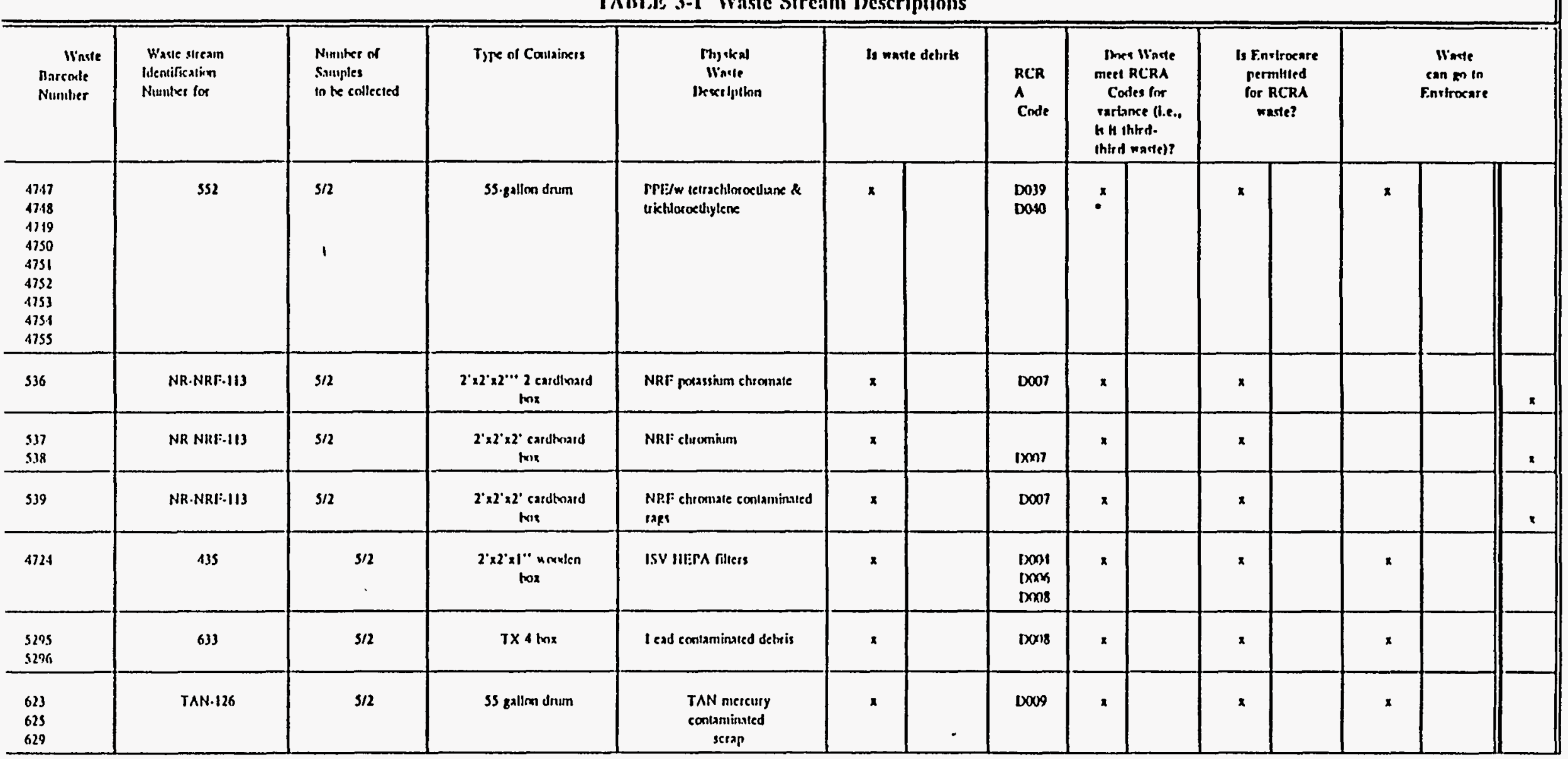


WROC-SAP-6.1

Rev. 0

February 1994

TAMLE, 3-1 Waste Stream Descriptions

\begin{tabular}{|c|c|c|c|c|c|c|c|c|c|}
\hline $\begin{array}{l}\text { W'ast: } \\
\text { Narcoste } \\
\text { Number }\end{array}$ & $\begin{array}{l}\text { Waste stream } \\
\text { lderrification } \\
\text { Number for }\end{array}$ & $\begin{array}{l}\text { Number of } \\
\text { Samples } \\
\text { to be collected }\end{array}$ & Thpe of Conteiners & $\begin{array}{l}\text { ThyskenI } \\
\text { Whate } \\
\text { Desctipition }\end{array}$ & Is waste debrts & $\begin{array}{l}\text { RCR } \\
\hat{A}_{\text {Code }}\end{array}$ & 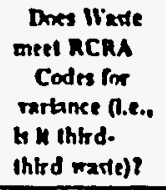 & $\begin{array}{l}\text { Lo Fintroeare } \\
\text { permiled } \\
\text { lor RCRA } \\
\text { meste? }\end{array}$ & $\begin{array}{l}\text { Werte } \\
\text { cen goo 10 } \\
\text { Envitocese }\end{array}$ \\
\hline $\begin{array}{l}\text { 683 } \\
681\end{array}$ & NR.NRF. 113 & $9 / 2$ & 35. zallon drum & $\begin{array}{l}\text { NRF Chrnmian } \\
\text { Comlamtrated iags }\end{array}$ & $x$ & 0001 & - & 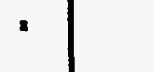 & \\
\hline
\end{tabular}

Talle 3.2 Dala Quality Objectives

\begin{tabular}{|c|c|c|c|c|c|c|}
\hline Measureinent & Method(s) & Deteclion Limit & Analytical Level & Volume & Container & \\
\hline Ganinia Isotopes & Lab SOP & $10 \mathrm{pCi} / 1$ & Level V & $16 \mathrm{oz}$. & plastic wide mouth & \\
\hline Uraniun Isolopes & Lab SOP & S Pcill & Level V & 1602. & plastic wide mouth & \\
\hline Tllorium Isotopes & Lab SOP & $5 \mathrm{pCill}$ & Level V & $16 \mathrm{oz}$. & plastic wide mouth & \\
\hline ICLP Metals, Volatile, Semi-volatile & SIV.846 6010, 8240, 8270, 7470/7471 & melliod-specific & Level III & $500 \mathrm{~mL}$ & slass wide mouth & \\
\hline Tulal Organic Ilalides (TOX) & SW.846 9020/9022 & method-speciric & Level III & $250 \mathrm{~mL}$ & glass wide mouth & \\
\hline Jazardous Waste Reactivity & Cyanide/Sulfide & melhod-specific & Level III & $500 \mathrm{~mL}$ & glass wide mouth & \\
\hline Einvirocare fingerprint & WAC-specilied & WAC-specilic & Level I & 8 gallon & Dor $17 \mathrm{C}$ & \\
\hline Prujecl screening (IInU, rad, screening) & RCT/III-specified & melloos-specific & Level I & none & none & \\
\hline
\end{tabular}

14. 
WROC-SAP-6.1

Rev. 0

February 1994

\subsection{PARCC Parameters}

PARCC parameters (data precision, accuracy, representativeness, comparability, and completeness) will be applied primarily in a qualitative sense to the sampling described by this SAP since the sampling procedures entail no extensive requirements for precision and accuracy. Samples must be withdraw'n in precise amounts (know'n to with in 25 milliliters) while of $\pm 10 \%$ of the sample volumes given in Table 3.2. Representativeness will be accomplished by using sampling techniques and tools that allow' representative sampling to be performed. For example, PPE may be collected utilizing scissors and sampler discretion, which will be used to obtain a sample in the visible range of contamination. Likewise, appropriate methods will be used for metallic or wood w'astes, such as the use of a hack saw'. All wastes will be sampled using techniques that will permit representativeness while minimizing the spread of airborne particulates. A spoon will be used to collect congealed materials. No liquid sample will be collected.

All drums in each waste stream under consideration will be sampled. Finally, sampling data shall be recorded in such a way as to allow for ready comparison with project objectives and other existing data.

PARCC parameters for sample analyses given in Table 3.2 will be consistent with the EPA analytical level assigned to each testing methodology, keeping in mind that the sampling and analysis described in this document are done to support waste characterization to meet the WAC established by Envirocare.

\subsection{Analytical Levels}

EPA defines five levels of analytical strategies with Level I the least costly and complex. Level I are often not compound-specific and not quantitative, but results are available in real-time. For the project, data needed to answer questions on radiation fields and airborne chemical vapors and radionuclides in the vicinity of the process equipment can be partially supplied by simple field monitors.

Level III analy'ses are performed in an analytical laboratory. Analytical methods must be approved by the EPA (or equivalent). Uncertainties in analytical results are quantified on a sample-set basis by the use of duplicates and matrix spikes. Documentation and validation procedures for individual samples are followed as specified in the analytical laboratory statement of work ( $\mathrm{SOW}^{\prime}$ ). Analytical Level III data are needed for characterization of RCRA Appendix IX wastes and RCRA characteristic wastes.

Level $\mathrm{V}$ analyses are performed at a laboratory using non-standard analytical 
WROC-SAP-6.1

Rev. 0

February 1994

techniques. This analytical level is used for analytes for which no procedure has been approved by the EPA. CLP data package documentation and validation are required for analyses directly related to disposal. Any radionuclide measurements necessary for disposal will be Level $V$ analyses, since the EPA has not approved any radioanalytical procedures. No independent validation shall be performed on the data. 
WROC-SAP-6.1

Rev. 0

February 1094

\subsection{Training Requirements}

Indoctrination and training shall be provided to personnel performing activities affecting quality as necessary to assure that suitable proficiency is achieved and maintained. The minimum training requirements for personnel involved in the sampling activities are listed in Table 4.1.

Table 4.1 Training Requirements

Requirement FTL Samplers Observers Safety Personnel

\begin{tabular}{|c|c|c|c|c|}
\hline 24-hr OSHA ${ }^{2}$ & $\mathrm{X}$ & $x$ & $\mathrm{X}$ & $x$ \\
\hline Respirator & $\mathrm{X}$ & $x$ & & $\mathrm{X}^{*}$ \\
\hline Rad Worker II & $\mathrm{x}$ & $\mathrm{x}$ & & $\mathrm{X}$ \\
\hline WERF TSD & $\mathrm{x}$ & $\mathrm{x}$ & $\mathrm{X}$ & $\mathrm{X}$ \\
\hline Medic $1 s t^{b}$ & $\mathrm{X}$ & $\mathrm{x}$ & & $\mathrm{X}$ \\
\hline OSHA Supervisor & $x$ & & & \\
\hline Special Rad worker & & & $\mathrm{X}$ & \\
\hline$W^{\prime} E R F$ site-specific ${ }^{d}$ & $\mathrm{X}$ & $\mathrm{x}$ & $\mathrm{X}$ & $\mathrm{x}$ \\
\hline
\end{tabular}

a. Personnel without this training may not enter contamination zone, but may be in sampling area with an approved escor.

b. Required for a least 2 personnel, only.

c. Per EG\&G Company Procedure 10.19 , personnel operating radiation measurement instruments shall receive training on the use of these instrument by a RCT Level III or higher. The training is only applicable on a job-by-job basis.

d. Personnel not receiving this training must be escorted by an approved escort.

* Only required upon entering the contamination area. 
WROC-SAP-6.1

Rev. 0

February 1994

\subsection{Sampling Procedures}

The following section describes the sampling procedures that must be followed in order to meet the DQOs defined in this sampling and analysis plan.

\subsection{Sampling Preparation Procedures}

Prior to use, all equipment will be cleaned using ETSOP-47 (Attachment 1) at a location other than the sampling site. The following sample preparation activities will be performed prior to initiation of actual sample collection (PM = Project Manager, FTL = Field Team Leader, FO = Facility Operators, STs=Sampling Technicians):

(PM) 1. Notify and coordinate with all appropriate parties (area landlord, area RCTs, area IH, etc.) prior to arrival at the sampling site. A Radiological Work Permit (RWP) and Site Work Release (SWR) are required prior to initiation of sampling activities.

(FTL) 2. Request the ER\&WM Sample Management Office (SMO) to create a data base and subsequent field support materials (sample table, labels, tags, sampling guidance forms, etc.) that contain the list of samples, identified by sample identification number, sample type (example, quality control (QC) duplicates or regulars), sampling location, sample collection method, sample matrix and analyses to be performed.

(PM) 3. Request analytical services to be coordinated through SMO and work with the SMO to ensure contract laboratory services are procured and the laboratory is ready to receive samples. Obtain purchase order (PO) numbers, Statement of Work (SOW), or Task Order Statement (TOS) from the SMO (Attachment 2).

(FTL) 4. Assign sampling support personnel, as required.

(FTL) 5. Assemble field support materials (tools, equipment, parts, and supplies) which include:

* aluminum pan or other appropriate catchment basin

* plastic trash bags ( 30 gallon)

* absorbent paper wipes

* coolers with vermiculite or other packing material

* 500-ml widemouth glass jars 
* 250-ml widemouth glass jars

* $\quad 16 \mathrm{oz}$. plastic squat jars

* $\quad$ plastic sheeting

* $\quad$ scissors and other sampling equipment (e.g., hacksaw, etc.)

* 8-gallon containers to ship fingerprint samples to Envirocare

* deionized water

* latex gloves

* safety glasses

* parafilm

* $\quad 2^{n}$ clear tape

* strapping tape

* plastic scrub brush

* aluminum foil

* black permanent pens

* black marking pens

* $\quad$ spray bottles

* $\quad$ 1-gallon plastic freezer bags

* duct tape

* $\quad$ shipping forms and labels

* sampling logbook

(FTL) 6. Ensure accurate identification of each container to be sampled. The documentation must clearly indicate which INEL Waste Code corresponds to each drum.

(FO) 7. Prepare the area for sampling and move the containers into the sampling area per the SWR and the container movement plan.

(ST) 8. Stage needed sample collection materials in sampling area. Note: Do not take in more than will be needed, as all supplies and equipment may be discarded as low-level waste.

\subsection{Sampling Activities}

Note: The FTL will be responsible for recording all pertinent information in the sample logbook, starting at the beginning of each shif, including notes on the pre-job briefing. The logbook will be passed from one shift to the other with the outgoing FTL recording the turnover of the logbook to the incoming FTL.

(AIL) 1. Participate in and document a pre-job briefing prior to start of each shift. Pre- 
WROC-SAP-6.1

Rev. 0

February 1994

job briefing shall include the following:

a. Specific types of radiological, hazardous, and industrial hazards potentially affiliated with each waste stream to be sampled on that shift.

b. Types of debris expected to be encountered in each waste stream to be sampled on that shift.

c. Sampling equipment needed to collect representative samples from the waste streams to be sampled on that shift.

d. Applicable sections of the SWR.

e. Discussion of any questions or concerns.

(ST) 2. Dress out and enter the contamination arrea in accordance with IH and RCT directions.

(ST) 3. Open and sample one drum at a time, beginning with the drums furthest from the entrance to the contamination area.

(ST) 4. Upon opening a drum, obtain a smear of the inside lid and interior of the (RCT- waste container, as directed by the RCT, to assume unexpected

Holding) radiological contaminants are not released into the breathing zone.

(ST) 5. Also, upon opening each drum, measure the headspace of the drum, as directed by the $\mathrm{IH}$, to assure unexpected volatile organic vapors are not continuous in the breathing zone.

(FTL) 6. Record all measurement values in the sampling logbook.

(ST) 7. Visually inspect the contents of the drum. If the contents are not primarily debris (>60 mm dia.), do not collect samples. Inventory all contents and replace the lid. (Note: A sample of the material may be collected, based on recorded field measurements of the waste and at the discretion of the FTL, IH, and $\mathrm{RCT}$ ).

(FTL) 8. Record full inventories of each drum in the sampling logbook.

(ST) 9. Collect volumes of debris equal to the ratio found in the waste container. For example, if the drums consists of $90 \%$ PPE, $5 \%$ absorbent wipes, and $5 \%$ 
WROC-SAP-6.1

Rev. 0

February 1994

wood chips, the sample will contain material in the same ratio. Collect samples from least contaminated (visual inspection) to most contaminated. Utilize standard methodologies and those discussed with the receiving waste facility and laboratory. The choice of sampling methods and equipment are left to the discretion of the sampling team, provided task objectives are being followed. It may be necessary to strew the contents of the drum onto the plastic sheeting to obtain representative samples.

(ST) 4. To prevent cross-contamination between waste streams, sampling equipment will be rinsed with water and wiped clean or replaced between waste streams, where the use of disposable equipment is preferred over decontamination. 
WROC-SAP-É. I

Rev. 0

February 1994

\section{Document Management and Sample Handling}

The follow'ing sections summarize document management and sample control. Documentation includes all documents used to record field data, sampling procedures, and chain of custody. All documentation and records will be provided to the project manager for filing, record storage, etc., at the conclusion of the sampling and analy'sis activities.

\subsection{Pre-sampling Documentation}

The FTL will ensure that signatures are obtained in the sample logbook to document that all field team members have completed and fully understand the required reading. Additionally, the RW'P and SWP must be read, understood, and initialed by all sampling team members.

Before acrual sampling, a pre-job meeting will be held with attendance required of all team members. This will done before every shift. At this time, all aspects of the sampling effort will be thoroughly explained and reviewed. Specific duties will be assigned to each team member by the FTL. Attendance and topics discussed at this meeting will be documented in the logbook.

The project requestor or designee, and the appropriate WERF personnel will be notified of the intended activity before it commences.

\subsection{Sampling Documentation}

- The FTL is responsible for ensuring that all information peraining to the sampling project is recorded accurately and completely. The following documentation requirements a:e to ensure quality and control of chain of custody.

\subsubsection{Sample Labels}

Pre-printed sample labels will be supplied. Labels will include information on the sample identification number, the drum barcode, the waste stream identification number, and the analy'sis type. Sample information collected in the field will be w'ritten on the label with indelible ink. Information to be added includes date, time, samplers initials, and contents listing. Note that radiation levels will be measured, recorded and placed onto the sample container by the RCT.

The same information (other than analysis rype) will be written on the fingerprint sample labels for samples destined for Envirocare. 
WROC-SAF-6. I

Rev. 0

February' 1094

\subsubsection{Sample Identification Number}

A unique sample identification number will be assigned to each sample container. The first three characters of the number are an acronym for the sampling activity, MWD = mixed waste disposal. The next three numbers are serialized numbers indicating where the sample is located on the sample plan table (see Attachment 3 ). The two characters following the serial number are an indication of the sample type. For this project all samples are designated as regular samples and these numbers should be 01 . The final two characters indicate the sample analysis, $T 1=T O X, T R=T C L P$ Metals/Semi-volatiles, $T V=T C L P$ volatiles, UT = gamma spec/U-isotopes/Th-Isotopes, $\lambda \hat{3}$ = cyanide/sulfide.

The fingerprint samples are not identified by a coded number, but by the waste stream identification and the drum barcodes associated with each waste stream.

\subsubsection{Custody Seals}

Field staff will be responsible for the proper handling and storage of the samples until the samples are delivered to the laboratory'. To store samples at the WERF facility, the Environmental Coordinator should be contacted for location of a specific area. Custody seals will be used to detect unauthorized tampering of samples following sample collection until analysis. The seal will be anached to each coole: used to store multiple sample containers in such a way that the seal must be broken to gain access to the sample. The seal will contain the following information:

- The signature of the person collecting the sample or other sampling team personnel participating in the sample collection, and

- $\quad$ The date of the seal emplacement.

\subsubsection{Logbooks}

A bound field logbook with consecutively numbered pages will be maintained by field personnel. The FTL is responsible for retaining and ensuring the correct use of the logbook. Field loghooks will be used to record sample collection activities and field observations. All logbook entries will be made in permanent indelible black ink, dated, and signed by the individual making the entry (each page). At the beginning of each shift a new page will be used to begin documenting the sampling activities.

Because of radiological controls, the logbook will not be taken into the immediate sampling area. It will be kept by the field team member who will be located outside of the radiation zone during the sampling operation. 
WROC-SAP-6.1

Rev. 0

February 1094

If an error is made on any document, corrections will be made by drawing a single line through the error and entering the correct information. All corrections will be initialed and dated by the individual making the corrections. Pages will not be removed from the logbook and correction fluid will not be used for any reason.

Information logged on a daily basis will include:

- pre-job briefing information

- date and time of sampling activity

- $\quad$ RWP/SWT numbers

- $\quad$ personnel present during sampling (including visitors)

- description of the waste. This should include a direct inventory (and if possible \% of each type of material present in the drum). This information will later be labeled on the drum (with indelible ink).

- quantity and type of samples (grab or composite)

- names, signamres, initials, and specific discipline of the sampling team members,

- the specific type of sampling device used

- description of sample location (i.e., bias, etc., describe how the hazardous/radiological range was determined and obtained)

- waste identification number and barcode number

- $\quad$ sample collection information; any notable problems or concerns

- field observations

- all instrument readings and field measurements

- collector's name

\subsection{Chain of Custody}

The chain-of-custody record will establish the documentation necessary to trace the sample possession from the time of collection to analysis. Each change of possession will be documented thus establishing a chain for tracking the handling of samples.

A minimal number of persons will handle the samples. The appropriate sample identification documents will be completed prior to or immediately following sample collection. If. at any time, the chain of custody is broken, the last person on the COC record will be contacted to explain the problem.

The COC record will contain the following information: 
WROC-SAP-6.1

Rev. 0

February 1994

- $\quad$ sample number

- $\quad$ signature of sampler

- $\quad$ requested analysis

- date of sample collection

- any remarks, descriptions, or concerns about the sample

Refer to ERSOP 11.3 (Attachment 4 ) for details on maintaining sample custody, sample handling and packaging. 
WROC-SAP-6.1

Rev. 0

February 1994

\section{Sample Management}

To maintain sample traceability and quality control the following section must be adhered to.

\subsection{Sample Tracking}

Incoming laboratory samples will carry identification numbers. Laboratory and fingerprint samples shall be labelled according to the identification numbers provided by the SMO. In addition, the appropriate waste identification number shall be written on the sample container, this will ensure traceability of the sample to the appropriate waste stream. Each sample will also be marked with the assigned laboratory number. The numbers will be recorded in the laboratory sample logbook or computer database. The information on the COC record, sample tag, and label will be cross-checked at the analytical laboratory.

\subsection{Sample Containers}

All laboratory sample containers used for the analytical analyses shall be precleaned by an EPA approved supplier. The containers used for the fingerprint samples must be unused. Extra containers will be available in the event of breakage, contamination, etc.

\subsection{Sample Preservation}

Coolers will be used to store the samples destined for the analytical laboratories during sampling.

\subsection{Transportation of Samples}

All samples will be shipped "priority one/overnight" via Federal Express through the Federal Express Office in accordance with the regulations issued by the DOT; 49 CFR 171 through 179; EPA sample handling, packaging, and shipping method; and 40 CFR 261. C3C3. In addition, sample shipping will meet the requirements defined in the EG\&G Hazardous Materials Transportation Manual.

All samples will be packaged and transported in a manner that protects the integrity of the sample and prevents sample leakage. Laboratory samples will be placed in an ice chest with adequate vermiculite to insulate the samples from shifting during transportation. 
The fingcrprimt samples shall he shipped in 8 gallon containers. One waste stream shall he shipped per container. This will ensure the waste streams are not mixed upon receipt at Envirocare.

After sample collection and packaging in the field, the samples must reach the laboratory intact and in a timely manner, as specified in the statement of work (SOW). Samples will be packaged and labeled according to DOT shipping requirements. Samples for this project will be both radioactive and hazardous. The samples will be packaged in appropriate shipping containers according to DOE regulations and in accordance with the Hazardous Materials Transportation Manual. Personnel from WM Traffic will review' the shipping documentation, container requirements. elc. to ensure the samples are shipped in accordance with the regulations. 


\section{Health and Safety Requirements}

The health \& safety requirements for sampling of the mixed waste debris will be determined by the facility cognizant safety professionals. These individuals will review the appropriate waste profile summary sheets to determine the type of contaminants that are to be expected from each waste stream. This will assist the cognizant safety professionals in determining the types of Personal Protective Equipment (PPE) that will be required. The information from this evaluation w'ill be transferred onto the Radiolngical Work Permit (RWP), Site Work Release, and the information relayed to the sampling team during the prejob hriefings.

At a minimum, the sampling team shall don modesty clothing, u'ear steel-toed boots, gloves. and safety' glasses (are not required due to no potential of mechanical hazards to the eye). The safety personnel may require additional protection depending upon the characteristics of the waste streams. 
BinOC-SAP-G.:

Rev: 0

February logs

\section{Waste Management}

Management of wastes generated by this activity will be performed in accordance with the WROC Waste Minimization Plan. The Waste Treatment Plan described in this section identifies the type, quantity, and disposition of wastes expected to be generated by this project. Waste types expected to be produced are: Industrial Waste. Low'Level Waste. and Mixed Low-Level Waste. Wherever feasible, waste minimization efforts will be used to limit the amount of waste produced. Some specific waste minimization recommendations are included in the plan where appropriate.

\subsection{Mixed Low-Level Wastes}

Mixed low-level wastes will be created from a number of tasks in the sampling project. Likely mixed waste streams are: Samples returned from the laboratory or duplicate samples held for follow-up; Residues resulting from the procedures used to obtain the analytical information; Personal Protective Equipment which may become contaminated with or mixed with the waste being sampled; contamination control materials such as plastic sheeting, blotter paper etc., which may become contaminated with or mixed with the waste being sampled. In some cases, the sampling equipment itself may become contaminated or mixed with the waste. Additionally, since some of the characterization data currently available for these wastes is quite old, some unexpected items may be encountered.

\subsubsection{SAMPIES}

Samples that have not been chemically altered will be renurned to the INEL from the subcontract laboratory. These samples will have the identical characterization as the the waste from which the sample was obtained and therefore will retain the original waste stream number. If possible, these samples will be managed as part of the original waste stream with the parent waste stream. If this is not possible, the waste samples will be returned to storage at the MW'SF pending final disposition. Except in the case that an unexpected waste analysis result is obtained, the samples will have been fully characterized for treatment or storage. The case of the unexpected waste analysis result is discussed further below.

Unaltered samples will be shipped by the subcontract laboratory to the WiERF. The quantity of waste sample expected to be returned is about $80 \%$ of the amount shipped for sampling. Prior to shipping, the subcontract laboratory shall contact Ly'n Schwindeman of WROC Technical Support. He shall coordinate between the contract laboratory, WERF, WROC Technical Support and WROC Operations for a suitable shipping date and identify appropriate shipping requirements. WROC shall make every effort to have these samples 
WROC-SAP-6.1

Rev. 0

February 1994

dispositioned for storage or treatment within sixty days of receipt, and in any' case at least within ninety day's of receipt. This includes completion of all documentation, such as $669^{\circ} s$, $669 a^{\circ} s$ and shipping papers.

A large number of treatment standards are expected to apply to the samples, how'ever, a list will not be included here for brevity. In some cases, treatment standards have not yet been established. Additionally, for some of the wastes, an extension of the applicable date of the storage prohibition has been granted.

The anticipated treatment for these wastes w'ill be direct disposal at an off-site treatment facility in a subsequent shipment. In some cases, the samples will require treatment prior to disposal, since it is likely the storage prohibition extension will have expired. If treatment is required, macroencapsulation of the remaining sample per the alternative treatment standards for debris is recommended. WROC Technical Support will ensure these wastes are properly characterized and dispositioned as appropriate.

\subsubsection{ANALYTICAL RESIDUES}

Analytical Residues resulting from the processes used to digest or leach the waste for analysis will also be generated. The residues may be managed and disposed of by the Laburatory doing the analysis per their established procedures. Or, the residues may be returned to the Idaho National Engineering Laboratory. Such residues have been previously' returned and have been placed into storage pending treatment.

It is recommended that all of the residues resulting from this analysis be mixed and combined into a single waste stream, provided they are compatible. This may not minimize the amount of waste, but it will minimize the amount of documentation required for further shipping, storage and treatment of these residues.

These residues will be shipped by the subcontract laboratory to the WERF. Prior to shipping, the subcontract laboratory shall contact Lynn Schwendiman of W'ROC Technical Support. He shall coordinate between the contract lajoratory, W'ERF, W'ROC Technical Suppor and $W^{\prime} R O C$ Operations for a suitable shipping date and identify appropriate shipping requirements. W'ROC shall make every effor to have these residues dispositioned for siorage or treatment within sixty days of receipt, and in any case at least within ninety day's of receipt. This includes completion of all documentation, such as $669^{\circ} \mathrm{s}, 669 \mathrm{a}$ 's and snipping papers.

It is recommended these uastes be evaluated to determine if the characterization matches that of a previous waste stream, and if so, the residues should be managed (stored, 
WROC - SAP-6.1

Rev. 0

February 1994

treated and disposed,) in accordance with that waste stream. If a match is not possible, generator treatment of the residues by stabilization, neutralization, or ion exchange and carbon absorption most likely will be applicable to the waste. Finally, filtration, carbon absorption, and ion exchange at the Portable Water Treatment Unit is a likely alternative option. Waste Reduction Operations Complex Waste Technical Support will ensure these wastes are properly characterized and dispositioned as appropriate.

\subsubsection{PERSONAL PROTECTION EQUIPMENT}

Personal protection equipment may become contaminated with hazardous constituents from the waste. Equipment such as respirators, gloves, and coveralls will be exposed to the contaminated materials. If contaminated, these items themselves become "contaminated debris." One alternative treatment standard for such materials is to wash or clean with a suitable cleaning agent so that no visible stain or contamination remains. Therefore, it is recommended this standard be utilized to characterize parts of this equipment. If visible contamination or stains are present, the portion of the waste which contains the stain is likely to be a mixed waste. To minimize the amount of this waste generated, stained portions of the equipment should be separated from the clean portions. This may be accomplished by disassembling, or cutting the waste. These portions should be sampled and included with the wastes being sampled, since they are also debris. The portions that are not contaminated should be managed as industrial or low level waste.

CAUTION: Samples sent to envirocare and the analytical laboratory for analysis must be representative of the waste matrix. Therefore, if mixed waste is added to the waste streams as a result of sampling, the added waste must also be included in the samples in a representative amount.

\subsubsection{CONTAMINATION CONTROL EQUIPMENT AND SAMPLING EQUIPMENT}

Plastic sheeting, blotting paper and sampling tools should be managed in the manner described in 9.1.3.

However, maslin cloths, swipe papers, and other materials used to decontaminate or measure the waste material, should be considered to be contaminated. These materials are also debris, and should be sampled and included with the waste being evaluated.

Characterization forms for the waste may need to be modified to include these materials if included in and managed with the waste stream.

CAUTION: Samples sent to envirocare and the analytical laboratory for analysis must be representative of the waste matrix. Therefore, if mixed waste is added 
WROE-SAP-ó. 1

Rev. 0

February 1994

to the waste streams as a result of sampling, the added waste must also be included in the samples in a representative amount.

\subsubsection{UNEXPECTED MIXED WASTES}

It is possible that a waste article may be encountered that is not adequately described in the waste profile sheets. Additionally, some of the descriptions in the profile sheets are quite broad, and in some cases may' include w'aste not acceptable for disposal at Envirocare. If either of these siruations is encounterd, the WERF EC should be notified immediately.

These wastes will be segregated from the main waste stream. If the waste does not meet the original waste description, it is recommended that the uaste be sampled as originally intended, with notations made into the Sample Logbook. WROC Technical Support should be contacted as soon as possible. If the WERF EC and WROC Technical Support aggree the item is likely to be acceptable for disposal at Envirocare, it may be renumed to the original waste stream once the waste stream description has been properly modified.

If the unexpected item can not be included with the original waste stream, other waste streams being sampled should be evaluated to determin if the item may be included. If so, the item should be bagsed or contained as directed by Rad. Con and kept in the TAA until it can be combined with an appropriate waste stream.

If it does not appear to be acceptable for shipment, it should be containerized as a new waste stream. Any new waste streams will be stored in the WERF TAA per Company Procedure 8.3. The W'ERF EC will ensure the proper lables are attached, and that the waste is properly entered into the WERF TAA Logbook. WERF will conduct weekly inspections of the waste in accordance with EG\&G Company Procedure 8.6 while the waste is stored in the WERF TAA. WROC Technical Suppor will be responsible for obtaining characterization data as required, will arrange for treatment and/or storage, and will be responsible for preparing all necessary documentation for such actions.

\subsection{LOW-LEVEL WASTE}

Low-level waste will be generated during the sampling project. Low level uaste is usually characterized as incinerable, compactible, and washable. Low level waste shall be managed in accordance to the WROC Waste Minimization Plan and applicable WERF operating procedures.

One exception to the WERF procedures is hereby noted. WERF requires that the 
WROC-SAP-6.1

Rev. 0

February 1994

WCR or Form 669 be provided prior to acceptance of a waste for treatment or storage. WROC will prepare all necessary documentation for this waste stream by March 30, 1994. W'ERF personnel will provide a letter to file indicating that a waste has been accepted into the facility pending such documentation.

\subsubsection{Incinerable Low-Level Waste}

Incinerable waste should be collected at WERF. The source of the waste and estimates of amounts produced should be noted in the Sample Logbook. Radiological measurements of the waste should be recorded in the WERF Health Physics Log per standard procedures. WERF personnel will manage and store this waste. The waste may either be stored and treated at WERF prior to disposal, or may be directly disposed at the RWMC. WROC Technical Support shall be responsible for preparing all documentation necessary to characterize, treat, and dispose of the waste, such as a Form 669, Waste Characterization Report, shipping papers, or Waste Certification Program Plan.

\subsubsection{Compactible Low-Level Waste}

Compactible waste should be collected at WERF. The source of the waste and estimates of amounts produced should be noted in the Sample Logbook. Radiological measurements of the waste should be recorded in the WERF Health Physics Log per standard procedures. WERF personnel will manage and store this waste. The waste may either be stored and treated at WERF prior to disposal, or may be directly disposed at the RWMC. WROC Technical Support shall be responsible for preparing all documentation necessary to characterize, treat, and dispose of the waste, such as a Form 669, Waste Characterization Report, shipping papers, or Waste Certification Program Plan.

\subsubsection{Washable Low-Level Waste}

Washable waste will be collected at WERF. WERF personnel will manage and store the waste until it can be cleaned. While a W'CR or Form 669 is not required for this waste, WROC Technical Support will provide characterization data as required to ensure the waste is acceptable by the laundry facility. This may include identifying the isotopes and estimating their activity.

\subsection{INDUSTRIAL WASTE}

Only small quantities of industrial waste are expected to be produced. Industrial waste must be shown to be neither hazardous or radioactive per the INEL Landfill Waste Acceptance Criteria. WERF personnel will manage all industrial waste in accordance with their operating procedures. These procedures include screening to ensure no radioactively or 
WROC-SAP-6.1

Rev. 0

February 1994

hazardous contaminated materials are included. 
WROC-SAP-6.1

Rev. 0

February 1994

\section{Corrective Action}

\subsection{Field Corrective Action}

The initial responsibility for monitoring the quality of field measurements lies with the sampling personnel. The FTL is responsible for verifying that all quality assurance (QA) procedures are followed. This requires that the FTL assess the correctness of field methods and their ability to meet QA objectives, and make a subjective assessment of the impact that a procedure has on sampling objectives and subsequent data quality.

If a problem occurs that might jeopardize the integrity of the project, cause a QA objective not to be met, or impact data quality', the FTL will immediately notify the project manager. The FTL will document the situation, the field objectives affected, the corrective action taken, and the results of that action. Copies of the documentation will be provided to the project manager.

Corrective action will be implemented when the project objectives are not met or when conditions adverse to quality have been identified. Conditions adverse to qualify shall be promptly identified and corrected as soon as possible. The identification, cause, and corrective actions to prevent recurrence shall be determined and documented for significant conditions adverse to quality.

\subsection{Laboratory Corrective Action}

The laboratory corrective action plan will be detailed in the laboratory quality program plan. The need for corrective action may come from several sources: equipment malfunctions, failure of internal QC checks, method blank contamination, failure of performance or sy'stem assessments, or noncompliance with QA requirements. The laboratory corrective action plan has been reviewed and approved by EG\&G SMO prior to contract au'ard and will not be discussed in any further detail in this S.AP.

\subsection{Assessments}

Normally, at least one performance assessment will be conducted by' an EG\&GCertified Quality Engineer. This assessment should be scheduled to provide assessment during sampling operations. 
h'ROL-SÁ-E. I

Rev. 6

Februāry :09á

\subsection{Record Keeping}

Original records from the sampling activities will be maintained with W'ERF Document Control. WROC Document Control will be responsible for distributing the originals. however, copies of the records will be maintained by W'ROC Document Control. Those records that must be maintained include the following:

* completed logbook

* SAP

* compieted SW'R

* completed RW'P

* analytical results

All completed documents must be appropriately signed off and dated. 
WROC-SAP- 6.1

Rev. 0

February 1994

\subsection{References}

1. EG\&G Idaho, Inc., Equipment Deçontamination, ETSOP 47, September 1990.

2. EG\&G Idaho, Inc., Chain-of-Custody, Sample Handling, and Packaging, SOP 11.3, October 20, 1993.

3. EG\&G Idaho, Inc., Quality Assurance Project Plan for the Treatment of Nonincinerable Land Disposal Restricted Mixed Waste Project, WROC-PROJ-001241, Rev. 1, 7/93.

4. EG\&G, Hazardous Materials Transportation Manual

5. Envirocare, Waste Acceptance Process, December 12, 1993. 


\section{Appendix H}

\section{Laboratory Analysis Contracts}


H-2 
EG\&G IDAHO, INC.

ENVIRONMENTAL RESTORATION AND WASTE MANAGEMENT DEPARTMENT

SAMPLE MANAGEMENT OFFICE

\section{TASK ORDER STATEMENT OF WORK}

ORGANIC AND INORGANIC ANALYSIS OF MIXED LOW LEVEL WASTE DEBRIS SAMPLES

COLLECTED FROM THE WASTE EXPERIMENTAL

REDUCTION FACILITY

AT THE IDAHO NATIONAL ENGINEERING LABORATORY (INEL)

\section{ER-TOS-145}

Prepared by:

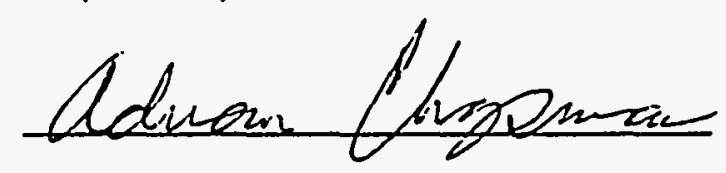

A. D. Chapman, Assoc. Scientist, ER\&WM Department SMO

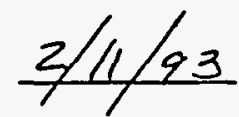

Date

Reviewed by:

V. W. Watson, Quality Engineer, ER Quality Assurance

Date

Reviewed / Approved by:

Voudels Palla

$2-11-94$

Vondell Balls, Project Manager, EG\&G MLLWCD

Date

Approved by:

C. S. Watkins, Technical Leader, ER\&WM Department SMO

Date 


\title{
TASK ORDER STATEMENT OF WORK
}

\author{
ORGANIC AND INORGANIC ANALYSIS OF MIXED LOW LEVEL WASTE DEBRIS SAMPLES \\ COLLECTED FROM THE WASTE EXPERIMENTAL \\ REDUCTION FACILITY \\ AT THE IDAHO NATIONAL ENGINEERING LABORATORY (INEL)
}

\section{PURPOSE}

This Task Order Statement of Work (TOS) identifies EG\&G Idaho, Inc. Environmental Restoration/Waste Management approved subcontractor support for the organic and inorganic analysis of samples collected from the INEL Waste Experimental Reduction Facility. The samples to be analyzed will consist of materials known to contain radiological contamination. Samples may therefore contain radionuclides with activities above normal background. The sampling and analyses will provide EG\&G Idaho, Private Sector Initiative Unit, characterization data necessary to ship the waste to Envirocare of Utah for commercial disposal.

\section{SCOPE}

The number of samples being sent to the laboratory shall be; Seventy-five (75) solid debris samples. This number of samples is an estimated maximum.

The samples and a tentative shipping schedule are listed in Table 1. The laboratory shall receive all samples via prepaid air freight. EG\&G shall notify the laboratory of any changes in the schedule presented in Table 1. EG\&G shall also notify the laboratory before shipping samples. 
Doament ARTOS-145

Revision: 1

SAP \#: NA

Dato: February 11, 1994

Page 2 of 9

Table 1. Sampling and Shipping Schedule.

\section{WASTE TYPE}

Solid Debris
Number of

Samples by Matrix

(32) Solid Waste

(32) Solid Waste

(32) Solid Waste
Anticipated *

Dates of

Collection

$02 / 14-17 / 94$

$02 / 14-17 / 94$

$02 / 14-17 / 94$

\section{Maximum Number of Samples}

(96) Solid Waste

o. This is the estimated maximum number of samples to be collected from the Mixad Waste Storage Facility.

b. The following is the key for the numbers used in the anslysis column of this table:

1. TCLP Motals, Volatilo, and Semi-Volatilo (SW-846 1311 followed by 6010, 8240, 8270, 7470/7471 or any additional metals enalysis required to meet the detection limit requirements of ERD-SOW-107)

2- Total Organic Halides (SW-846 9020/9022 or any methods necessary to meet the requirements of ERD-SOW-145).

3. Hazardous Wasto Reactivity - Cyenide/Sulfide 12.1.3 or 8.3 or any methods necessary to meet the requirements of ERD-SOW59).

- This is a tontative sampling schedule. The actual dates may vary.

NOTE: The methods listed above are the base mothods for the required analyses. Any additional quality control, reporting requirements otc. specified in ER-TOS-145 shell be used in addition to the minimum requirements specified in the methods. 
Doamont H: RRTOS-145

Revision: 1

SAP \#: NA

Date: Fobruary 11, 1994

Page 3 of 9

\section{Task Specific Requirements}

The following requirements must be met to perform the work required by ER-TOS-145.

\subsection{Sample Custody}

3.1.1 When accepting possession of a sample shipment, the laboratory shall observe the condition of the sample containers and any identification documents (e.g., labels and/or tags) accompanying the samples. Record in writing any discrepancies in the information given on the identification documents or unusual conditions of the sample or container (e.g., cracked, leaking) in the "Remarks/Descriptions" section of the COC form. The laboratory shall maintain an internal COC record tracking samples, extracts, and/or digestates resulting from sample preparation. A laboratory sample custodian (LSC) shall sign, enter the date and time on the COC form in the "Received By" section of the form. The LSC shall then detach and return the yellow copy of the COC (Form EG\&G-114) and the Shipping Document (Form EG\&G-361) immediately upon receipt of the samples at the laboratory. The laboratory shall return the original EG\&G Idaho COC form, along with the laboratory's internal COC documentation, when submitting the last data package produced for samples represented on the EG\&G Idaho COC form.

\subsection{Utah State Certification}

3.2.1 The analytical laboratory must be "Utah State Certified" for the following before the analyses can be performed:

- Soil pH SW-846 Method 9045

- Paint Filter Liquids Test SW-846 Method 9095

- Reactive Cyanide and Sulfide 2.1 .3 or 8.3

- Total and Amenable Cyanide SW-846 Method 9010 or 9012

- TCLP Metals (Appendix IX listed Metals less Cobalt and Tin) by SW-846 Methods

- TCLP Volatile Organics SW-846 Method 8240

- TCLP Semi-Volatile Organics SW-846 Method 8270

- Total Organic Halides (TOX) SW-846 Method 9020 or 9022

- Organochlorine Pesticides and PCBs SW-846 Method 8080

- Ignitability SW-846 Method 1010 or 1020

3.2.2 The analytical laboratory must include a copy of their "Utah State Certification" with the analytical results 
Doamert H: ERTOS-145

Revision: 1

SAP \#: NA

Date: February 11, 1994

Pago 4 of 9

\subsection{Disposal}

3.3.1 The analytical laboratory must archive the unused sample volume for 60 days after the last SDG in the project has been submitted to EG\&G Idaho. Unused sample volume must be left in the original EG\&G sample container with the legible original label still attached, packaged, and returned to EG\&G Idaho. A request for disposal must be sent to EG\& $G$ Idaho project personnel before returning the unused sample volumes or residual sample wastes generated during analysis. The request for disposal must include the exact characterized materials that will be shipped to EG\&G Idaho and whether these materials have been altered in the analysis process. EG\&G Idaho will not accept any glassware, clothing or other laboratory wastes, only residual sample materials may be shipped. Contact Lynn Schwediman at (208) 526-8732 to obtain the sample return address and schedule.

\subsection{Analytical and Reporting Requirements}

3.4.1 At least one analysis for each of the TCLP extracts must be run at a concentration that allows evaluation of the extract relative to the TCLP regulatory limits. The details for Required Detection Limits for metals analyses of TCLP extracts are found in ERD-SOW-107. For organic analyses on TCLP extracts that contain none of the regulated compounds, the extracts must not be analyzed at a dilution that raises the quantitation limit to greater than one half the regulatory limit for any compound. When one or more of the TCLP regulated compounds is present in the extract, and a large dilution is required to quantitate that compound within the calibration range of the instrument, then a higher dilution is allowed.

3.4.2 The forms and format used to report the results must summarize the same types of information required by a CLP deliverable (e.g., calibration data, blank data, spike recoveries etc.). The requirement for reporting the results of analyses is that enough information consisting of raw data, copies of notebook entries, etc., be included such that the data can be validated and qualified to the method requirements by EG\&G Idaho. All header information on the forms must be completed and consistent between forms. Type or legibly write all entries on the data forms. Sample ID numbers must be reported as written on the labels.

3.4.3 The analytical laboratory must report the results of all TCLP metals analysis on the report forms provided in ERD-SOW-107.

3.4.4 For the TOX and reactivity analyses, hard copy results will include any raw data produced and an analysis summary form. The laboratory shall provide a hard copy of the completed analysis summary forms and any charts or other computer generated graphics. One duplicate sample shall be analyzed per SDG.

3.4.5 Certified National Institute of Standards and Technology (NIST) or EPA traceable standards shall be used for all analyses where applicable.

3.4.6 All samples shall be submitted to the laboratory with a chain-of-custody form that will originate with sample collection. A laboratory sample custodian shall be required to sign all chain-of-custody forms accompanying sample shipments (see Section 3.1). The complete 
Doament \#: ERTOS-145

Revision: 1

SAP \#: NA

Dato: February 11, 1994

Page 5 of 9

EG\&G Idaho, Inc. sample number, the lab sample numbers, analytical batch number, and lab file IDs, used in a data package must be consistent on all data deliverables in the data package. Notify the EG\&G Idaho Project Manager [Vondell Balls (208) 526-0067] and note on the chain-of-custody forms any sign of tampering with or damage to the samples.

3.4.7 The subcontractor must prepare and submit a narrative for each data package produced for EG\&G Idaho, Inc. under ER-TOS-145. The narrative must contain a discussion of any analytical problems or method deviations that may have occurred during the analysis of the samples associated with ER-TOS-145. A table in the narrative shall be provided to relate lab sample IDs and lab file IDs to EG\&G Idaho sample numbers.

3.4.8 Each completed data package shall be sent in triplicate to EG\&G Idaho, Inc. care of:

\author{
Ms. Donna Kirchner \\ Field Data Coordinator \\ EG\&G Idaho, Inc. \\ P.O. Box 1625 \\ Idaho Falls, Idaho 83415-3904
}

Please notify Adrian Chapman at (208) 526-1586 when the data package has been sent and of any difficulties encountered during the analyses of theses samples when they happen, rather than letting us find out upon data receipt.

\title{
3.5 Missed Holding Times
}

All samples must be extracted or analyzed within the holding time specified in SW-846 (Chapter Eleven, Pages Eleven-7 and Eleven-8) for all analysis types except volatile organics. Samples for volatile organics analysis must be analyzed within fourteen days of sample collection. There will be no payment for extracting/analyzing a sample after the holding time has expired. If the laboratory identifies an instance where holding times aren't going to be met, the laboratory shall contact EG\&G Idaho Sample Management Office project personnel (Adrian Chapman [208-52615861) about the possibility for obtaining a replacement.

\subsection{Turn Around Time Requirements}

All samples shall be analyzed and reported within fourteen days of receipt of the last sample in the SDG. The first day of the fourteen day period is the day after receipt of the last sample in the SDG, the last day is the day Donna Kirchner receives it. The definition of an SDG can be found in ER-SOW-47 and ER-SOW-59. 


\section{PRICING SCHEDULE}

This estimate is based on the assumption that all work shall be performed according to EG\&G Idaho SOWs 47, 59, \& 107 and ER-TOS-145.

All costs associated with the work as specified in ER-TOS-145 have been estimated in the unit costs. The number of samples shown below is an estimate. Equipment blanks and QC samples have been included as part of the estimate. The actual number of samples may be slightly higher or lower and actual analyses may vary.

\begin{tabular}{|c|c|c|c|c|c|}
\hline MEDIA & ANALYSIS & METHOD NO. & NO. & $\begin{array}{l}\text { UNIT } \\
\text { COST }\end{array}$ & $\begin{array}{l}\text { TOTAL } \\
\text { COST }\end{array}$ \\
\hline \multirow[t]{13}{*}{ Waste } & Metals/SVOC & SW-846 1311 & 33 & $\$ 120$ & $\$ 3,960$ \\
\hline & Metals & SW-846 6010, 7470/71 & 32 & $\$ 408$ & 13,056 \\
\hline & $\begin{array}{l}\text { Metals } \\
\text { QC }\end{array}$ & SW-846 6010, 7470/71 & 4 & $\$ 408$ & $\$ 1,632$ \\
\hline & Cyanide & SW-846 9010/12 & 32 & $\$ 129$ & $\$ 4,128$ \\
\hline & $\begin{array}{l}\text { Cyanide } \\
\text { OC }\end{array}$ & SW-846 9010/12 & 2 & $\$ 129$ & $\$ 258$ \\
\hline & Sulfide & SW-846 9030 & 32 & $\$ 90$ & $\$ 2,880$ \\
\hline & $\begin{array}{l}\text { Sulfide } \\
\text { QC }\end{array}$ & SW-846 9030 & 2 & $\$ 90$ & $\$ 180$ \\
\hline & Organics & SW-846 1311 ZHE & 32 & $\$ 516$ & $\$ 16,512$ \\
\hline & VOCs & SW-846 8260 & 32 & $\$ 633$ & $\$ 20,256$ \\
\hline & $\begin{array}{l}\text { VOCs } \\
\mathrm{OC}\end{array}$ & SW-846 8260 & 4 & $\$ 633$ & $\$ 2,532$ \\
\hline & SVOCs & SW-846 8270 & 32 & $\$ 1200$ & $\$ 38,400$ \\
\hline & $\begin{array}{l}\text { SvoCs } \\
\mathrm{aC}\end{array}$ & SW-846 8270 & 4 & $\$ 1200$ & $\$ 4,800$ \\
\hline & TOX & SW-846 9020 & 32 & $\$ 225$ & $\$ 7,200$ \\
\hline
\end{tabular}


Dooument \#. ERTOS-145

Rovision: 1

SAP \#: NA

Date: Februery 11, 1994

Page 7 of 9

TOX

SW-846 9020

ac

Estimated cost

$10 \%$ Early Delivery Award

Total estimated cost
$\$ 116,244$

$\$ 11,624$

$\$ 450$

$\$ 127,868$

"The above prices assume a $50 \%$ surcharge for a two-week turn around time deliverable

Estimator's Signature and Title

Date 


\section{PRICING SCHEDULE}

This estimate is based on the assumption that all work shall be performed according to EG\&G Idaho SOWs 47, 59, \& 107 and ER-TOS-145.

All costs associated with the work as specified in ER-TOS-145 have been estimated in the unit costs. The number of samples shown below is an estimate. Equipment blanks and $\mathrm{OC}$ samples have been included as part of the estimate. The actual number of samples may be slightly higher or lower and actual analyses may vary.

\begin{tabular}{|c|c|c|c|c|c|}
\hline MEDIA & ANALYSIS & METHOD NO. & NO. & $\begin{array}{l}\text { UNIT } \\
\text { COST }\end{array}$ & $\begin{array}{l}\text { TOTAL } \\
\text { COST }\end{array}$ \\
\hline \multirow[t]{13}{*}{ Waste } & Metals/SVOC & SW-846 1311 & 33 & $\underline{\$}$ & $\$$ \\
\hline & Metals & SW-846 6010, 7470/71 & 32 & $\$$ & $\$$ \\
\hline & $\begin{array}{l}\text { Metals } \\
\text { OC }\end{array}$ & SW-846 6010, 7470/71 & 4 & $\$$ & $\$$ \\
\hline & Cyanide & SW-846 9010/12 & 32 & $\$$ & $\$$ \\
\hline & $\begin{array}{l}\text { Cyanide } \\
\text { OC }\end{array}$ & SW-846 9010/12 & 2 & $\$$ & $\underline{\$}$ \\
\hline & Sulfide & SW-846 9030 & 32 & $\$$ & $\$$ \\
\hline & $\begin{array}{l}\text { Sulfide } \\
\text { QC }\end{array}$ & SW-846 9030 & 2 & $\underline{\$}$ & $\$$ \\
\hline & Organics & SW-846 1311 ZHE & 32 & $\$$ & $\underline{\mathbf{s}}$ \\
\hline & VOCs & CLP $3 / 90$ & 32 & $\$$ & $\$$ \\
\hline & $\begin{array}{l}\text { Vocs } \\
\text { QC }\end{array}$ & CLP $3 / 90$ & 4 & $\underline{s}$ & $\underline{\mathbf{s}}$ \\
\hline & SVOCs & CLP 3/90 & 32 & $\underline{\$}$ & $\$$ \\
\hline & $\begin{array}{l}\text { SVOCs } \\
\text { OC }\end{array}$ & CLP $3 / 90$ & 4 & $\$$ & $\$$ \\
\hline & TOX & SW-8469020 & 32 & $\$$ & $\$$ \\
\hline
\end{tabular}


Dooument \#: BRTOS-145 Rovision: 1

SAP \#: NA

Dete: February 11, 1994

Page 9 of 9

TOX

SW-846 9020

ac
2

\$

Estimated cost

10\% Early Delivery Award

Total estimated cost
$\$$

s

$\$$

Estimator's Signature and Title

Date 
EG\&G IDAHO, INC.

ENVIRONMENTAL RESTORATION AND WASTE MANAGEMENT DEPARTMENT

SAMPLE MANAGEMENT OFFICE

TASK ORDER STATEMENT OF WORK

RADIOLOGICAL ANALYSIS OF SAMPLES COLLECTED IN SUPPORT OF

MIXED LOW LEVEL WASTE COMMERCIAL DISPOSAL BY THE

IDAHO NATIONAL ENGINEERING LABORATORY

ERD-TOS- 150

Prepared by:

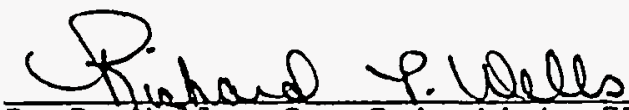

R. P. KeTTs, Sr. Scientist, ER\&WM Department SMO

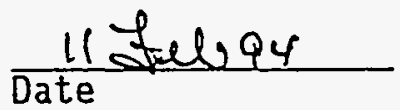

Reviewed by:

V.W. Watern

V. W. Watson, Quality Engineer, ER Compliance Assurance

$\frac{2 / 11 / 94}{\text { Date }}$

Reviewed/Approved by:

VARaula

V. J. Balls, Project Manager

$2-11-94$

Approved by:
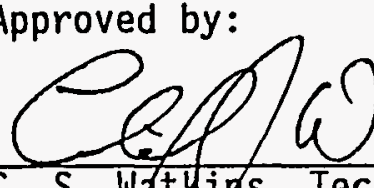

c. S. Wathipls, Technical Leader, ER\&WM Department SMO

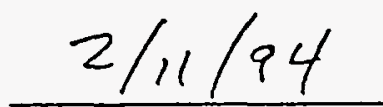

Date 
Document \#: ER-TOS-150

Revision: 0

SAP \#: N/A

Date: February 11, 1994

Page 1 of 6

TASK ORDER STATEMENT OF WORK

RADIOLOGICAL ANALYSIS OF SAMPLES COLLECTED IN SUPPORT OF

MIXED LOW LEVEL WASTE COMMERCIAL DISPOSAL BY THE

IDAHO NATIONAL ENGINEERING LABORATORY

\subsection{PURPOSE}

This Task Order Statement of Work (SOW) identifies required subcontractor support for radiological analysis of waste samples collected in support of the mixed low level waste commercial disposal effort being conducted by EG\&G Idaho, Inc. at the Idaho National Engineering Laboratory (INEL). These samples represent various mixed waste streams existing at the INEL. The waste streams are to be disposed by a commercial contractor which requires waste characterization. This SOW also addresses the task-specific requirements for the required services.

\subsection{SCOPE}

The work described by this SOW shall be conducted according to the guidelines put forth in ERP-SOW-33, EG\&G Idaho, Inc. Statement of Work for Radiological Analyses. This SOW identifies any task specific requirements which shall be used in the analysis of samples for this project. All analyses shall be performed by an off-site laboratory.

\subsection{Project Specific Information}

For the work being performed for this project-specific SOW, ER-TOS-150, the following project designations shall be used on the EG\&G Idaho reporting forms :

\section{Project titles: MIXED LOW LEVEL WASTE COMMERCIAL DISPOSAL}

\subsection{Sampling Schedule}

The sampling effort will include the collection of 32 solid waste samples to be analyzed for gamma spectroscopy, uranium isotopes $\left({ }^{234} \mathrm{U},{ }^{235} \mathrm{U}\right.$, and $\left.{ }^{238} \mathrm{U}\right)$, and thorium isotopes $\left({ }^{228} \mathrm{Th},{ }^{230} \mathrm{Th}\right.$, and $\left.{ }^{232} \mathrm{Th}\right)$. The samples shall include but not be limited to vermiculite, rags, acid pillows, filters, paper swipes, debris, and paper products. A list of the samples and tentative sampling and shipping 
Document \#: ER-TOS-150

Revision: 0

SAP \#: N/A

Date: February 11, 1994

Page 2 of 6

schedule is given in Table 1. The Environmental Restoration and Waste Management Department (ER\&HM) Sample Management Office (SMO) of EG\&G Idaho will notify the laboratory of any changes in the schedule presented in Table 1 .

\section{Table 1:}

\begin{tabular}{cccc}
\hline $\begin{array}{c}\text { Sample } \\
\text { Description }\end{array}$ & $\begin{array}{c}\text { Number } \\
\text { of Samples }\end{array}$ & $\begin{array}{c}\text { Analyses } \\
\text { Waste Samples }\end{array}$ & $\begin{array}{c}\text { Sampling and } \\
\text { Shipping Schedule* }\end{array}$ \\
& $\begin{array}{l}\text { Gama } \\
\text { Spectroscopy }\end{array}$ & \\
U Isotopes & \\
& Th Isotopes &
\end{tabular}

- This is a tentative schedule, the actual dates may vary.

\subsection{CONSTRAINTS}

The following special conditions are constraints that shall be met to perform the work required by this sow.

\subsection{Disposal}

The analytical laboratory shall hold any unused samples for thirty (30) days after data package submission. The laboratory may then dispose of the samples in accordance with all federal, state and local regulations or, in the case of radioactively-contaminated samples, return the unused sample volume to the address provided by the EG\&G Idaho project manager for disposal.

\subsection{Materials and Service}

3.2.1 The Taboratory shall have a current Utah State Certification for radiological analysis of Resource Conservation and Recovery Act (RCRA) samples. The certification shall not expire for a period of not less than 180 days from the date of acceptance of this subcontract.

3.2.2 The laboratory sample custodian shall be required to sign and date the chain-of-custody forms that accompany the samples. All samples shall be checked for damage and tampering upon receipt by the laboratory. The EG\&G Idaho project personnel in the ER\&WM SMO, Richard Wells $(208-526-4561)$, shal1 be informed at once of 
Document \#: ER-TOS-150

Revision: 0

SAP \#: N/A

Date: February 11,1994

Page 3 of 6

any problems with the received samples. The yellow copy of the chain-of-custody form shall be returned to EG\&G Idaho at the address listed for the data deliverables upon receipt of the samples, and the original shall be returned with the completed data package.

3.2.3 The laboratory shall assign the samples received to Sample Delivery Groups (SDGs). A SDG is a batch of samples from one sampling project, collected over no more than a two week period, and is not to exceed twenty (20) samples. The SDG number shall be the sample number of the lowest numbered sample, taking into consideration both alphanumeric and numeric designations. The laboratory shall use the SDG number throughout the data package.

3.2.4 For isotopic uranium and isotopic thorium analyses, the laboratory shall take the necessary steps to prepare the samples for total dissolution (e.g. size reduction by cutting, sieving, milling, etc.).

3.2.5 For isotopic uranium and isotopic thorium analyses the laboratory shall run the following quality control (QC) samples: One blank and one laboratory control sample for each SDG; one duplicate sample for each ten samples in the SDG (if the SDG contains three (3) samples or less, no duplicates are required; if the SDG contains more than three (3) but ten (10) or less samples, one (1) duplicate is required; if the SDG contains more than ten (10) samples, two (2) duplicates are required). For gamma spectrscopy, the duplicate analys is requirement shall apply with the

aforementioned frequency. A description of the different, types of QC samples is provided in ERP-SOW-33.

3.2.6 Work for this SOW requires that the Taboratory shall provide in their data package the deliverables described in ERP-SOW-33, Section 5. The data contained on the Form I(s) and Form II(s) of the data package shall be provided to EG\&G Idaho as an ASCII file on a 3.5 inch IBM compatible diskette. All analysis results shall be reported in the format of the subcontractor laboratory.

3.2.7 The completed data package shall be sent in triplicate to EG\&G Idaho's Information Systems and Laboratory Management Unit at the following address:

Ms. Donna Kirchner

EG\&G Idaho, Inc.

P.0. Box 1625

Idaho Falls, ID 83415-3904 
Document \#: ER-TOS-150

Revision: 0

SAP \#: N/A

Date: February 11, 1994

Page 4 of 6

3.2.8 The required detection limits for this project are shown below in Table 2.

Table 2. Analysis Detection Limits

$\begin{array}{lc}\text { 1. Gamma Spectroscopy } & \frac{(\mathrm{pCi} / \mathrm{g})}{1^{\circ}} \\ \text { 2. Uranium Isotopes } & 0.05 \\ \text { 3. Thorium Isotopes } & 0.05\end{array}$

Solid

Detection Limit

$\frac{(\mathrm{pCi} / \mathrm{g})}{1^{\circ}}$

$\begin{array}{ll}\text { 2. Uranium Isotopes } & 0.05 \\ \text { 3. Thorium Isotopes } & 0.05\end{array}$

(a) Based on cesium-137 $\left({ }^{137} \mathrm{Cs}\right)$, all other gamma isotopes shall have a detection limit commensurate with its photon yield and energy as related to the ${ }^{137} \mathrm{Cs}$ detection limit.

\subsection{LABORATORY QUALITY ASSURANCE/QUALITY CONTROL}

The laboratory shall comply with the quality assurance/quality control requirements for this project as described in ERP-SOW-33 and in the Laboratory Quality Assurance P1an (LQAP).

\subsection{CONDITIONS FOR PAYMENT}

The following conditions are applicable for payment under this sow.

\subsection{Out of Control Analyses}

In cases where sample results or quality control sample results are outside the control limits established by the laboratory or if the required detection limits are not met, these samples or the entire SDG shall be put through the final analytical steps again and recounted, or reanalyzed from a new sample aliquot, at the laboratory's discretion, at no extra cost to EG\&G Idaho.

In cases where matrix effects prevent the achievement of these control limits, the EG\&G Idaho project personnel shall be notified prior to reporting of the results. 
Document \#: ER-TOS-150

Revision: 0

SAP \#: N/A

Date: February 11, 1994

Page 5 of 6

\subsection{Turnaround Times}

All analyses shall be completed and a report issued within 14 calendar days from the time the laboratory takes custody of the last sample in an SDG.

\subsection{Data Deliverables}

All analytical data shall be delivered within the required turnaround time and shall be complete and compliant at the sample level. The laboratory shall resolve any deficiencies in the data package identified by the EG\&G Idaho ER\&HM SMO data validation staff prior to payment. 


\section{PRICING SCHEDULE}

ER-TOS-150

\begin{tabular}{|c|c|c|c|c|}
\hline MEDIA & ANALYSIS & NO. & UNIT COST & TOTAL COST \\
\hline \multirow{8}{*}{$\begin{array}{l}\text { Sol id } \\
\text { Waste }\end{array}$} & Uranium Isotopes & 32 & $\$ 80$ & $\$ 2,560$ \\
\hline & Thorium Isotopes & 32 & $\$ 75$ & $\$ 2,400$ \\
\hline & Gamma Spectroscopy & 32 & $\$ 175$ & $\$ 5,600$ \\
\hline & $\begin{array}{l}\text { Total Estimated } \\
\text { Analyses Cost }\end{array}$ & & & $\$ 10,560$ \\
\hline & $\begin{array}{l}\text { Sample } \\
\text { Preparation }\end{array}$ & 32 & & \\
\hline & $\begin{array}{l}\text { Surcharge for } \\
15 \text { day turn- } \\
\text { around }\end{array}$ & & & \\
\hline & $\begin{array}{l}\text { Potential } 10 \% \\
\text { Early Delivery } \\
\text { Incentive }\end{array}$ & & & \\
\hline & Total Amount & & & \\
\hline
\end{tabular}




\section{PRICING SCHEDULE}

ER-TOS- 150

$\begin{array}{cll}\text { MEDIA } & \text { ANALYSIS } & \text { NO. } \\ \text { Solid } & \text { Unanium Isotopes COST } \\ \text { Haste } & 32 & 32 \\ & \text { Thorium Isotopes } & 32 \\ \text { Gamma Spectroscopy } & \\ \text { Total Estimated } \\ \text { Analyses Cost } \\ \text { Sample } \\ \text { Preparation } \\ \text { Surcharge for } \\ \text { 15 day turn- } \\ \text { around } \\ \text { Potential 10\% } \\ \text { Early Delivery } \\ \text { Incentive } \\ \text { Total Amount }\end{array}$

TOTAL COST
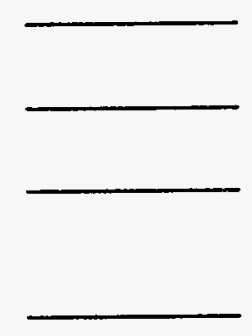

otal Estimated

Sample

Surcharge for 15 day turnaround

Early Delivery

Total Amount 


\section{Appendix I}

\section{U.S. Army Corps of Engineers Contract}




\section{Department of Energy \\ Idaho Operations Office \\ 785 DOE Place \\ Idaho Falls, Idaho 83401-1562}

TRANSMITTAL FORM

DATE: January 12, 1994

TO: Mr. Thomas F. Urbaniak

U. S. Army Corps of Engineers - Kansas City District

CEMRK-ED-TS

601 E. 12th Street

Kansas City, MO 64106-2896

PLEASE NOTE THE BLOCKS BELOW. THE SELECTIONS APPLICABLE TO THIS ACTION ARE MARKED. PLEASE FOLLOW THE INSTRLCTIONS CONTAINED IN THE MARKED BLOCKS.

\section{[] Contract [ ] Modification [X] Interagency Agreement [ ] Amendment}

Number: Contract No DE-AI7-94D13280 Modification No. A000

Enclosed is/are [ ] one (1) [ ] three (3) [X] four (4) copies of the subject award.

Please have all the copies signed by an authorized official and return

[ ] two (2) [X] three (3) [ ] four (4) fully executed copies to this office within

[X] 2 days [ ] three (3) weeks from the date of receipt of this form.

[ ] Please retain one (1) fully executed copy for your files.

[ ] Please return all fully executed copies.

[ ] Please submit a task plan and Organizational Conflict of Interest (OCI) input within ten (10) calendar days from the effective date of the modification.

Comments: $\quad$ Tom, Please review and if $O K$ have the District Engineer sign and return to me for signature. Send it to mr name at the above address and Mail Stop 1221.

If you have any questions, please call Michael $\mathrm{K}$. Barrett at (208) 526-5743.

FAL: (208) $526-5548$

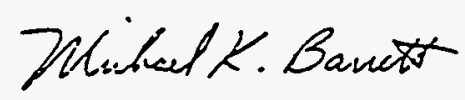


Interagency Agreement With:

U.S. Army Corp of Engineers

Kansas City District

Attn: CEMRK-ED-TS

601 E. 12th Street

Kansas City, MO 64106

This Interagency Agreement (IA) consists of the following:

IA Face Page - DOE Form 1270.1

General Information

References and Authorities

Article 1 Purpose

Article II Scope of Work

Article III Cost

Article IV Deliverables and Due Dates

Article $V$ Duration of Agreement

Article VI Program Officers

Article VII Obligation of Funds

Article VIII Payment

Article IX Applicable Documents

Article $X$ Officials Not to Benefit

Article XI Amendment and Termination

Article XII Effective Date

Attachment 1 - Standard General Provisions for IA's

Attachment 2 - NORM Standard Operating Procedures

Attachment 3 - Contract DACW41-93-D-9001 
JAN 13 '94 B9:31AM DOE ID CONTRACTS

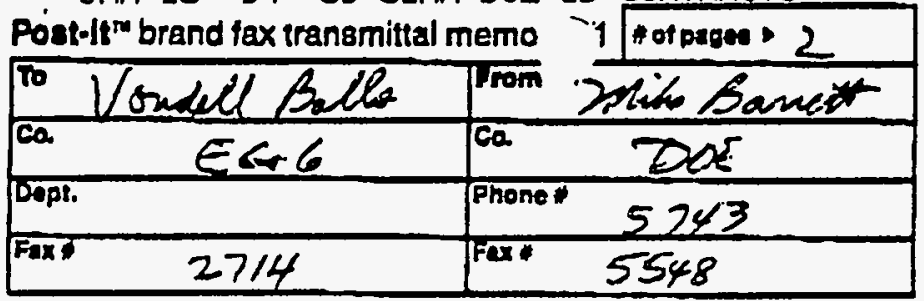

LA No. DE-A107-941D13280

DOE Idaho - Amry Corpe of Engineors KCD

\section{DEPARTMENT OF ENERGY (DOE) \\ FUNDS OUT \\ INTERAGENCY AGREEMENT (IA)}

(33 U.S.C. 8830)

\begin{tabular}{|c|c|}
\hline$t-1 t^{\text {tw }}$ brand fo & nemo 7671 \# of pages • \\
\hline$\therefore \quad \vdots$ & From $1,1,-1,1 i$ \\
\hline & Co. $\because 3 \%$ \\
\hline$\therefore$ & Phone "I, $-4, i\}$ \\
\hline 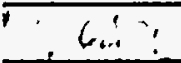 & Fax" $\div, 9711$ \\
\hline
\end{tabular}

DOE IA No. DE-AIO7-94ID13280

Interagency Agreement With:

U.S. Army Corp of Engineers

Kansas Clty District

Attn: CEMRK-ED-TS

601 E. 12th Street

Kansas City, MO 64108

I. Purpose.

a. General Information.

This agreement is between the U. S. Army Corps of Engineers, Kansas City District, and the U.S. Department of Energy (DOE), Idaho Operations Office, Idaho Falls, ID. For the purpose of technical assistance under this agreement, DOE shall be construed to include Westinghouse Idaho Nuclear Company (WINCO) and EG\&G Idaho, Inc., prime operating contractors at the Idaho National Engineering Laboratory (INEL) for DOE under Contracts No. DE-AC07-84ID12435 and DE-AC07-76ID01570, respectively.

The Kansas City District, U. S. Army Corps of Engineers, offers low cost disposal of all radioactive material meeting the requirements of Envirocare of Utah's Radioactive Material Handling License \#UT 2300249, and EPA Identification Number UTD982598898.

Envirocare is currently the only facility licensed to receive and dispose of these materials.

b. Beferences and Authorities

1. U.S. Code, Title 33, Section 8830. 
2. The Economy Act of 1932, as amended, (31 U.S.C. 1535).

3. Federal Acquisition Regulation Subpart 17.5.

4. Department of Energy Acquisition Regulation Subpart 917.5

5. Memorandum of Understanding Between the U. S. Department of Energy and the U.S. Department of the Army dated July 12 , 1990.

\section{c. Purpose.}

The purpose of this agreement is for the Army Corps of Engineers to dispose of an estimated quantity of 500 cubic yards per year of radioactive waste from the INEL.

II Scope of Work.

The Kansas City District, U. S. Army Corps of Engineers, shall provide disposal of radioactive material shipped from the INEL. For a period of two years, the Kansas City District shall perform the disposal of up to 500 cubic yards per year of mixed debris and soil from the Idaho National Engineering Laboratory (INEL) at Envirocare of Utah, Inc.

All work shall be in accordance with:

a. The requirements of Envirocare of Utah's Radioactive Material Handling License \#UT 2300249, and EPA Identification Number UTD982598898.

b. The provisions of the Memorandum of Understanding between the U. S. Department of Energy and the U. S. Department of the Army signed by both parties on July 12, 1990.

c. U. S. Army Corps of Engineers Standard Operating Procedures for Naturally Occurring Radioactive Material (NORM) and NORM/Hazardous Waste Disposal Contract dated July 1993 and December 3, 1993 (Attachment 2 to this Interagency Agreement). 
IA No. DE-A107-94ID13280

DOE Idaho - Army Corps of Engineers KCD

III Cost.

The total estimated cost for accomplishing the IA Statement of Work is $\$ 400,000$.

1. The sum of $\$ 2,000$ to Kansas City District for the administrative cost of performing this agreement.

2. Unit prices per yard for disposal of toxic or hazardous waste in accordance with the attached price schedule for an estimated volume of 500 cubic yards per year over the period of two years from the effective date of this interagency agreement. Measurement and payment shall be made in accordance with U. S. Army Corps of Engineers Contract No. DACW41-93-D-9001 Modification No. P00003 dated November 15, 1993 (Attachment 3 to this Interagency Agreement).

IV Deliverables/Reports.

Description of Deliverables Due Dates

(none)

V Duration of Agreement.

See Item 4 of Face Page.

VI Program Management.

a. DOE Management and Qversight. See Items 6 and 7 of Face Page.

b. Dispute Resolution.

The parties to this IA shall make reasonable efforts to informally resolve disputes at the project manager or immediate supervisor level. If resolution cannot be achieved informally, disputes shall be elevated, for a period of 30 days at each level to the following officials: (1) Kansas City District Engineer and the 
IA No. DE-A107-941D13280

DOE Idaho - Army Corps of Engineers KCD

DOE Idaho Operations Office Assistant Manager, Office of Institutional Development; and (2) Missouri River Division Engineer and the DOE Idaho Operations Office Deputy Manager.

VII Qbligation of Funds.

The total amount obligated by the United States Department of Energy is $\$ 400,000$.

\section{Payment.}

The request for payment shall be via Standard Form 1080 Voucher for Transfers Between Appropriations and will include a breakdown of the actual cost elements being reimbursed. The SF-1080 shall include the following citations:

A. DOE Accounting Appropriation Data, see Block 5(a) on Face Page.

B. DOE Interagency Agreement Number, see Block 1 (a) on Face Page.

C. DOE Mail Address, Block 5(e) on Face Page.

Method of Payment - Cost Reimbursement

IX Documents Attached and Part of this Agreement.

- Attachment 1 - Standard General Provisions for $\mid A^{\prime}$ 's

- Attachment 2 - NORM Standard Operating Procedures

- Attachment 3 - Contract DACW41-93-D-9001

The above referenced documents have the same force and effect as if physically included within the agreement.

$X \quad$ Officials Not to Benefit.

No member of or delegate to the Congress, or resident commissioner, shall be admitted to any share or part of this agreement, or any benefit that may arise therefrom.

XI Modification and Termination. 
IA No. DE-A107-941D13280

DOE Idaho - Army Corps of Engineers KCD

This IA may be modified by written agreement between the DOE and the Kansas City District. It may be terminated by mutual written agreement or by either party giving 30 days written notice to the other. In the event of termination, the DOE shall be responsible for the costs of closing out the ongoing projects and the costs for demobilization of Corps' personnel and facilities working on the projects. The Kansas City District shall retain the contract administration responsibilities for the projects until they have been financially closed.

XII Effective Date.

This IA shall become effective on the last day it is signed by both parties and shall remain in effect unless revised by the mutual consent of the parties to more accurately reflect changing circumstances which may affect the needs or capabilities of either party or terminated as described above. 
IA No. DE-A107-94ID13280

DOE Idaho - Army Corps of Engineers KCD

\section{STANDARD GENERAL PROVISIONS \\ FOR DOE INTERAGENCY AGREEMENTS}

1. Definitions. For purposes of this agreement, "DOE" means the United States Department of Energy or any duly authorized representative thereof, and "Agency" means the performing agency stated in the agreement or any duly authorized representative thereof.

2. Cost Chargeable to DOE Funds. Direct costs are the costs that can be directly identified with and charged to the work under the agreement and within the limitations set forth below. Examples of such costs are salaries, wages, technical services, materials, travel and transportation, communications, and any facilities and equipment expressly approved for purchase under the interagency agreement.

a. Expenditures for domestic travel expected to exceed $\$ 1,000$ per individual trip shall not be allowable hereunder without prior written approval of the DOE Contracting Officer.

b. Foreign travel costs are allowable only when the trip has received the advance approval of the DOE Contracting Officer.

c. Reimbursement for expenditures at technical meetings and seminars at which attendance is not required by DOE, shall not be allowable without prior written approval of the DOE Contracting Officer.

3. Financing. DOE will finance programs on a reimbursable basis when acceptable to the other agency. If the reimbursable basis is not acceptable, however, then DOE will finance the work by a Consolidated Working Fund Advance, preferably on a quarterly basis, or by an appropriation transfer or transfer appropriation. DOE will reimburse or will make available, in advance, the amount specified in the Interagency Agreement incorporating these general provisions. Requests for funds shall show separately the amount required for (a) operating costs, (b) capital equipment (as defined in 9 below), and (c) acquisition or condemnation of any real property or any facility or for plant or facility acquisition, construction or expansion.

a. Vouchers for payment will be submitted on an appropriate agency or contractor voucher.

b. Any funds advanced which are expected to remain beyond the original period of performance for a project which is incomplete, or for which there is an increased scope of work, will remain available to the Agency if the IA is amended by the DOE to extend the periods of performance for the research 
IA No. DE-A107-941D13280

DOE Idaho - Army Corps of Engineers KCD

project or any other work beyond the original completion date. Request for such time extensions should be made to the DOE by the Agency at least 30 . days prior to the end of the performance period.

c. Any advanced funds remaining for a continuing research project or any other work remain available for the entire performance period of the project, unless there is a date specified as a required completion date after which no further funds shall be expended.

d. Any advanced funds remaining after the completion of a research project shall be reimbursed to the DOE.

4. Notice of Cests Approaching Total Estimated Costs. Whenever the Agency has reason to believe the total cost of the work under this agreement will be substantially greater or less than the presently estimated cost of the work, the Agency shall promptly notify the DOE in writing. The Agency shall also notify the DOE, in writing, when the aggregate of costs incurred and outstanding commitments allowable under this agreement is equal to 90 percent lor such other percentage as the DOE may from time to time establish by notice to the Agency) of the presently estimated total costs under this agreement. When the costs incurred and outstanding commitments equal 100 percent of such estimated total costs, the Agency shall make no further commitments or expenditures lexcept to meet existing commitments) and shall be excused from further performance of the work unless and until the DOE shall increase the total estimated costs to be incurred with respect to this agreement.

5. Excess Funds. The Agency shall take prompt action to return to the DOE any funds determined to be excess to the work during the performance of the work and any unobligated funds after the completion of the agreement or as of September 30 each year unless the agreement has been extended and any unused balances have been carried forward in the extension. In a joint venture project where the performing Agency deposits the advance in any annual consolidated working fund, any unobligated balances shall be returned to the DOE before the cutoff date at the close of each fiscal year.

6. Financial Reperts. The Agency shall furnish the DOE, not later than 15 days after the close of each reporting period, monthly or other periodic cost or financial reports in such form and detail as may be required by the DOE. Any costs incurred for capital equipment or other assets shall be supported by a list showing the description, make, any serial number, and the cost of each item acquired. 
IA No. DE-A107-94ID 13280

DOE Idaho - Army Corps of Engineers KCD

7. Accounting Records. The Agency shall accumulate and account for obligations and costs incurred in connection with the work being performed under this-agreement in such form and detail as may be required by the DOE.

8. Termination. The DOE may terminate this agreement upon 30 days written notice of such termination addressed to the Agency. In the event of such termination the Agency shall be reimbursed, to the extent permitted, for obligations actually incurred to the effective date of termination and for commitments extending beyond the effective date of termination to a date not later than the date upon which the agreement would have expired if not terminated under this paragraph, which the Agency, in the exercise of due diligence, is unable to cancel. Payments under this agreement, including payments under this article shall not exceed the ceiling amount elsewhere specified in this agreement.

9. Capital Equipment.

a. "Capital Equipment" means each item of equipment which is expected to have an extended period of service, generally a year or more, and has sufficient monetary value, generally of $\$ 500$ or more, to justify continuing accounting records for the item.

b. Unless expressly authorized by the contracting officer in advance the Agency shall not be reimbursed or use funds made available under this agreement for the procurement or fabrication of capital equipment.

c. If capital equipment is purchased or otherwise acquired pursuant to an authorization under Paragraph (b) above, except an may be otherwise agreed by the DOE and the Agency:

(1) the title thereto shall vest in the DOE;

(2) the Agency shall be responsible for the maintenance and safeguarding thereof; and

(3) the Agency shall maintain a record in such a manner as to insure adequate control and accounting satisfactory to the DOE, of capital equipment procured or fabricated.

10. Real Property and Facilities.

a. Unless expressly authorized by the contracting officer in advance, the Agency shall not be reimbursed or use funds made available under this 
IA No. DE-A107-941D13280

DOE Idaho - Army Corps of Engineers KCD

agreement for the acquisition or condemnation of any real property or any facility or for plant or facility acquisition, construction or expansion.

b. If the Agency acquires or condemns any real property or any facility or acquires, constructs, or expands any plant or facility pursuant to an authorization under (a) above, except as may be otherwise agreed by the DOE and the Agency:

(1) the title thereto shall vest in the DOE, and property accountability and control shall become the responsibility of DOE;

(2) the Agency shall be responsible for the maintenance and safeguarding thereof; and

(3) the Agency shall maintain a record thereof in such a manner as to insure adequate control and accounting satisfactory to the DOE.

\section{Patents and Technical Data.}

a. Patents. It is understood and agreed by DOE and the Agency that the patent policy to be employed in Interagency Agreement Number DE-AlO7943ID 13280 will be as follows:

(1) The aforementioned Agencies will include the Patent clause required by 37 C.F.R. 401, suitably modified to identify the parties in any funding agreement, which might be a contract, subcontract, task order, or grant, for experimental, developmental or research work to be performed by a small business or a domestic nonprofit organization. For business entities or arrangements not classified as a small business or a domestic nonprofit organization, the Agencies shall include the Patent Rights article of 41 C.F.R. 9-9.107-5(a), or 41 C.F.R. 9-9.107-6 as appropriate, modified to identify the parties.

(2) Where a contract will normally contain a patent clause giving the Government title in inventions made, offerors and prospective contractors shall be provided with notice of and the opportunity to request, in accordance with applicable DOE regulations, an advance waiver of all or any part of the rights of the United States with respect to inventions which may be conceived or first actually reduced to practice in the course of or under the contract. The request may be made at any time prior to the execution of the contract, or within 30 days after the execution of the contract. 
IA No. DE-A107-941D13280

DOE Idaho - Army Corps of Engineers KCD

\section{Security of Restricted Data.}

a. Contracting Agency's duty to safeguard restricted data, formerly restricted data, and other classified information. The Agency shall, in accordance with DOE security regulations and requirements, be responsible for safeguarding restricted data, formerly restricted data, and other classified information and protecting against sabotage, espionage, loss and theft, the classified documents and material in the Agency's possession in connection with the performance of work under this agreement. Except as otherwise expressly provided in this agreement, the Agency shall upon completion or termination of this agreement, transmit to DOE any classified matter in the possession of the Agency or any person under the Agency's control in connection with performance of this agreement. If retention by the Agency of any classified matter is required after the completion or termination of the agreement and such retention is approved by the DOE, the Agency will complete a certificate of possession to be furnished to DOE specifying the classified matter to be retained. the certification shall identify the items and types or categories of matter retained, the conditions governing the retention of the matter and the period of retention, if known. If the retention is approved by the DOE, the security provisions of the agreement will continue to be applicable to the matter retained.

b. Regulations. The Agency agrees to conform to all security regulations and requirements of DOE.

c. Definition of Restricted Data. The term "restricted data," as used in this clause, means all data concerning: (1) design, manufacture, or utilization of atomic weapons; $(2)$ the production of special nuclear material; or (3) the use of special nuclear material in the production of energy, but shall not include data declassified or removed from the restricted data category pursuant to Section 142 of the Atomic Energy Act of 1954.

d. Definition of Formerly Restricted Data. The term "formerly restricted data," used in this clause, means all data removed from the restricted data category under Section $142 \mathrm{~d}$ of the Atomic Energy Act of 1954, as amended.

e. Security Clearance of Personnel. The Agency shall not permit any individual to have access to restricted data, formerly restricted data, or other classified information, except in accordance with the Atomic Energy Act of 1954, as amended, and the DOE's regulations or requirements applicable to the particular type or category of classified information to which access is required. 
IA No. DE-A107-941D13280

DOE Idaho - Army Corps of Engineers KCD

f. Criminal Liability. It is understood that disclosures of restricted data, formerly restricted data, or other classified relating to the work or services ordered hereunder to any person not entitled to restricted data, or any other classified matter that control in connection with work under this agreement, may subject any representatives of the Agency, its agents, employees or subcontractors to criminal liability under the laws of the United States. (See the Atomic Energy Act of 1954, as amended, 42 U.S.C. 2100 et sep.: 18 U.S.C. 793 and 794; Executive Order 11652.)

g. Centracts and Purchase Orders. Except as otherwise authorized in writing by DOE, the Agency shall insert provisions similar to the foregoing in all contracts and purchase orders under this agreement.

h. Security Requirements for Proprietary Energy Data. The Agency shall safeguard DOE limited official use information, or other proprietary or sensitive data (including material relating to patents), from unauthorized access, disclosure, modification or destruction in accordance with applicable DOE security regulations and applicable orders and directives.

i. Computer Security Requirements. In the event that this Agreement involves utilization of a DOE computer system, the Agency will establish administrative, technical physical security procedures in accordance with applicable DOE regulations, to ensure against access to DOE information to individuals not formally authorized by the DOE to possess such information.

13. Classification. In the performance of the work under this Agreement, the Agency shall assign or obtain classifications to all documents, material, and equipment originated or generated by the Agency in accordance with classification guidance furnished to the Agency by the DOE. Every subcontract and purchase order issued hereunder to involving the origination or generation of classified documents, material, or equipment, shall include a provision to the effect that in the performance of such subcontract or purchase order, the subcontractor or supplier shall assign classifications to all such documents, material and equipment in accordance with classification guidance furnished to such subcontractor or supplier by the Agency.

14. Technical Progress Reports: Publication. The Agency will make such reports to the DOE on the progress of the work under this Agreement as may be mutually agreed upon.

It is the policy of DOE to make the results of the research, development and demonstration work contemplated under interagency agreements broadly available to the scientific, technical and engineering community and others through the timely 
IA No. DE-A107-94ID13280

DOE ldaho - Army Corps of Engineers KCD

publication of reports or journal articles. All publications and engineering materials prepared under the IA will be free exchanged, made available for public sales, unless classified, and a minimum of two copies sent to Ms. Kathy Sharp, Department of Energy, Office of Scientific and Technical Information (OSTI), P.O. Box 62, Oak Ridge, TN 37813. Each IA technical report issued and each task order technical report issued pursuant to a master IA will be accompanied by a DOE Form 537 and a statement describing the technical reports delivered and will be sent to OSTI for incorporation into the Technical Information Management System (TIMS).

(This Item 14 above is not applicable to this agreement No. DE-AlO7-94ID13280)

15. Environmental Safety and Health Requirements. DOE will not assume responsibility for prescribing and/or enforcing environmental safety and health requirements for operators of other Agency facilities engaged in the performance of DOE work.

\section{Subsidiary Agreements.}

Additional working agreements regarding specific cooperative efforts, if needed, shall be effected in writing by both parties as the need arises.

17. Ihird Party Liability.

Liability of the U.S. Government for acts of its employees is governed by the Federal Tort Claims Act and other Federal statutes.

18. Amendments and Review.

This agreement may be amended at any time by the written mutual consent of the parties concerned. It may be subject to reconsideration at such other times as may be required and as agreed.to by the parties entering into this agreement.

\section{Qther Provisions.}

Nothing herein is intended to conflict with current Agency directives or applicable law. If the terms of this agreement are inconsistent with existing directives or with applicable law, then those portions of this agreement which are determined to be inconsistent shall be invalid; but the remaining terms and conditions of this agreement not affected by any inconsistency shall remain in full force and effect. At the first opportunity for review of the agreement, such changes as are deemed necessary will be accomplished by either an amendment to this agreement, or by entering into a new agreement, whichever is deemed expedient to the interest of both parties. 
IA No. DE-A107-94ID13280

DOE Idaho - Army Corps of Engineers KCD

\section{Terms of Agreement.}

This agreement will become effective upon the signatures of both approving officials of the respective parties entering into this agreement, and will remain in effect until terminated by: (1) mutual written agreement; (2) 30 days advance written notice by either party; or (3) completion of the objectives of this agreement.

In the event of termination prior to completion of the objective of this agreement, all direct and indirect phasing-out costs shall be paid by the party requesting the termination. In the event of a mutually agreed upon termination, each agency assumes their respective termination costs. Termination costs claimed shall not exceed the actual costs incurred as a result of termination of the project. 


\section{Standard Operating Procedures (SOP)}

\section{$\bar{x}$ \\ 1. \\ Naturally Occurring Radioactive Material \\ (NORM) \\ and \\ NORM/Hazardous Waste Disposal Contract}

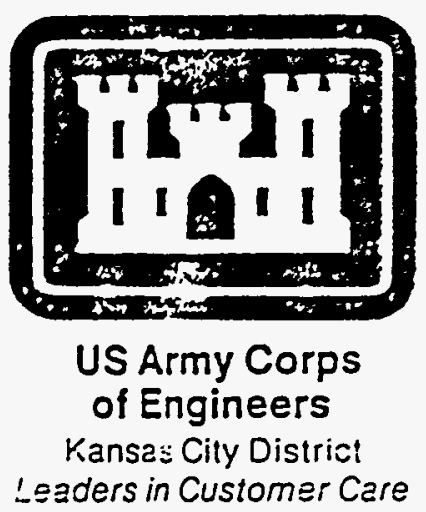

July 1993 


\section{Kansas City District, Corps of Engineers Standard Operating Procedures (SOP) for Naturally Occurring Radioactive Material (NORM) and NORM/Hazardous Waste Disposal Contract}

\section{TABLE OF CONTENTS}

Objective $\ldots \ldots \ldots \ldots \ldots \ldots \ldots \ldots \ldots \ldots \ldots \ldots \ldots \ldots \ldots \ldots \ldots \ldots \ldots \ldots \ldots$

Contract Number $\ldots \ldots \ldots \ldots \ldots \ldots \ldots \ldots \ldots \ldots \ldots \ldots \ldots \ldots \ldots \ldots \ldots \ldots$

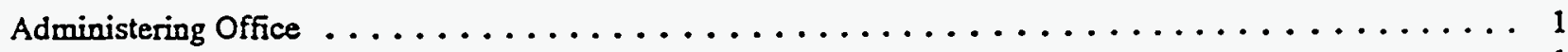

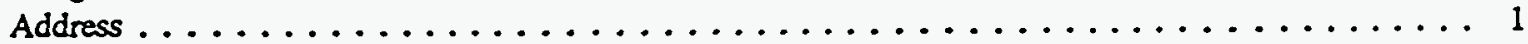

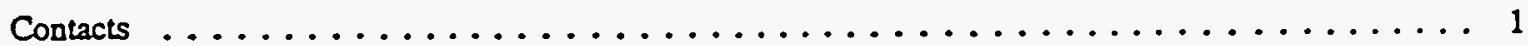

Disposal Contractor: $\ldots \ldots \ldots \ldots \ldots \ldots \ldots \ldots \ldots \ldots \ldots \ldots \ldots \ldots \ldots \ldots \ldots \ldots \ldots \ldots$

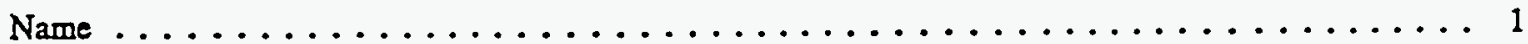

EPA Identification Number $\ldots \ldots \ldots \ldots \ldots \ldots \ldots \ldots \ldots \ldots \ldots \ldots \ldots \ldots \ldots$

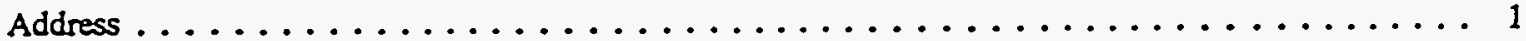

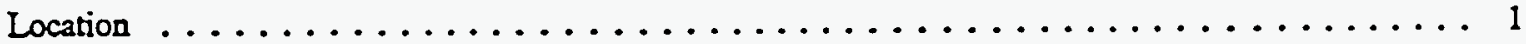

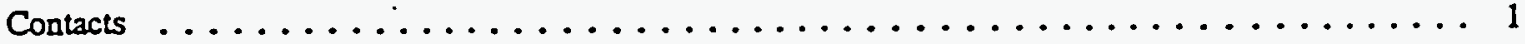

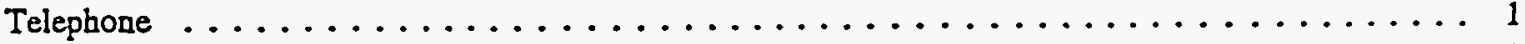

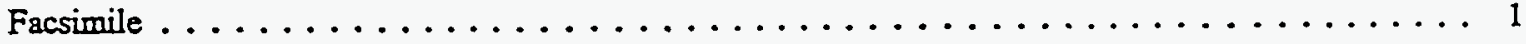

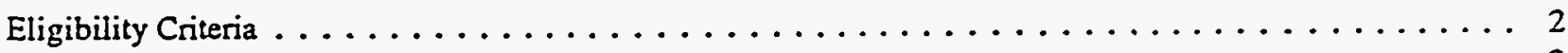

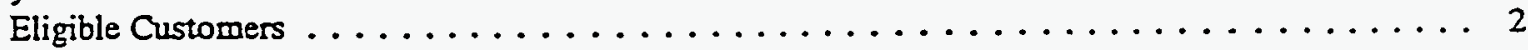

Waste Parameters . . . . . . . . . . . . . . . . . . . . . . 2

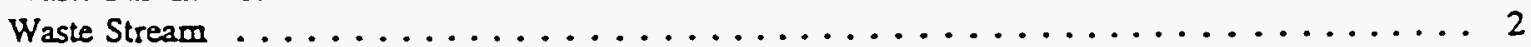

Customer Requirements $\ldots \ldots \ldots \ldots \ldots \ldots \ldots \ldots \ldots \ldots \ldots \ldots \ldots \ldots \ldots \ldots \ldots$

Pricing $\ldots \ldots \ldots \ldots \ldots \ldots \ldots \ldots \ldots \ldots \ldots \ldots \ldots \ldots \ldots \ldots \ldots \ldots \ldots \ldots$

Funding from Superfund $\ldots \ldots \ldots \ldots \ldots \ldots \ldots \ldots \ldots \ldots \ldots \ldots \ldots \ldots$

Other Funding $\ldots \ldots \ldots \ldots \ldots \ldots \ldots \ldots \ldots \ldots \ldots \ldots \ldots \ldots \ldots \ldots \ldots$

Delivery Orders $\ldots \ldots \ldots \ldots \ldots \ldots \ldots \ldots \ldots \ldots \ldots \ldots \ldots \ldots \ldots \ldots \ldots \ldots$

Manifests to Confirm Delivery $\ldots \ldots \ldots \ldots \ldots \ldots \ldots \ldots \ldots \ldots \ldots \ldots \ldots \ldots$

Customer's Responsibility for Transportation $\ldots \ldots \ldots \ldots \ldots \ldots \ldots \ldots \ldots \ldots \ldots \ldots$

General Background Information $\ldots \ldots \ldots \ldots \ldots \ldots \ldots \ldots \ldots \ldots \ldots \ldots \ldots \ldots$

Kansas City District Related Services $\ldots \ldots \ldots \ldots \ldots \ldots \ldots \ldots \ldots \ldots \ldots \ldots \ldots \ldots \ldots$

Previous Projects $\ldots \ldots \ldots \ldots \ldots \ldots \ldots \ldots \ldots \ldots \ldots \ldots \ldots \ldots \ldots \ldots \ldots$ 


\section{Kansas City District, Corps of Engineers Standard Operating Procedures (SOP) \\ for}

Naturally Occurring Radioactive Material (NORM)

and

NORM/Hazardous Waste Disposal Contract

1 Objective: This Standard Operating Procedure (SOP) will outline the methods and procedures to be used for the disposal of radioactive waste as provided in the licenses and permits obtained by Envirocare of Utah, Incorporated.

\section{Contract Number: DACW41-93-D-9001}

\section{Administering Office (CEMRK):}
a. Address:
US Army Engineer District, Kansas City,

b. Contacts:

(1) Engineering - Tom Urbaniak, CEMRK-ED-TS, (816) 426-5832, Ext. 3026; FAX (816) 426-5949

(2) Contracting - Norma Reynolds, CEMRK-CT-H, (816) $426-6484$, FAX (816) 426-5777

\section{Disposal Contractor:}

a. Name: Envirocare of Utah, Incorporated

b. EPA Identification Number: UTD 982598898

c. Address: 215 South State Street, Suite 1160

Salt Lake City, UT 84111

d. Location: 50 miles east of the Utah-Nevada border 3 miles south of Interstate 80

e. Contacts:

(1) Al Rafati, Director, Business Development

(2) Susan Rice, DOD Program Manager

(3) Steve Moynahan, Business Development

f. Telephone: (801) $532-1330$

g. Facsimile: (801) $537-7345$ 


\section{Eligibility Criteria to Use This Contract:}

a. Eligible Customers. Any Agency or Department of the US Government funded through civil or military appropriations may use this contract.

b. Waste Parameters:

(1) NORM waste:

- Radioactive in its natural state (not manufactured)

- Radioactivity less than the equivalent of 2,000 picocuries of radium-226 per gram

- Does not include Source material, Byproduct material, Special nuclear material as defined in 10 CFR 40.4 , or 10 CFR 72.3

(2) NORM/Hazardous Waste:

- Includes hazardous chemical waste identified in 40 CFR 261 (F-, K-, P- and Ulisted and characteristic waste) with radio nuclides

- The contractor's license specifies acceptable bazardous waste streams

c. Waste Stream Classification:

(1) The contractor, Envirocare of Utah, Inc., must assure the Cussomer that the waste material is within its licensed disposal capability before any action may proced under the disposal contract.

(2) Envirocare uses a standardized questionnaire to determine whether its disposal license applies to the identified waste. The waste Customer must provide the information required by Envirocare, and Envirocare must process that information to determine that the waste profile is within its disposal capability.

(3) Low-Activity Radioactive Waste and Mixed Waste as provided for in the Disposer's license.

\section{Customer Requirements:}

a. The Customer shall ship or deliver to the Disposer (Envirocare of Utah) only waste material that conforms in every material respect to the Disposer's license and other permits or autiorizations granted pursuant to applicable regulations.

b. The Customer shall not mix or otherwise combine the waste material with any otier material or products from any other party or source, or present any mixed material for receipt by the Disposer. 
c. All waste shall be within plus- or minus-5 percent of optimum moisture content by the Standard Proctor Method when it arrives at the disposal facility.

7. Pricing.

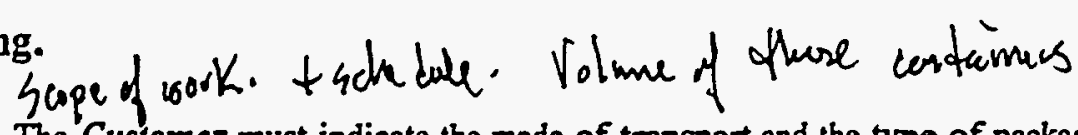
Lax 5949

a. The Customer must indicate the mode of transport and the type of packaging to be used for the waste material. This information is necessary to determine the appropriate unit price.

b. The unit price will be quoted per cubic yard of material. This contract typically makes highly costeffective unit pricing available to the customer.

c. Customers will pay the applicable unit price established by the terms of the contract plus an administration fee based on the Kansas City District cost to process contract administration actions.

\section{Funding from Superfund.}

a. USEPA shall transfer the Interagency Agreement (IAG) funds for receipt and disposal of NORM and NORM Hazardous Waste to the Missouri River Division, Corps of Engineers (CEMRD-RM-B, Marvene Seaman, (402) 221-7434). USEPA will transfer funds to CEMRD sufficient to offset the disposal cost at the then current contract rate per cubic yard.

b. Each disposal order shall also include additional funds to offset the Kansas City District's processing and administration fee.

c. CEMRD-RM-B will transfer funds to the Corps of Engineers District performing the remediation work under the Superfund Grant.

d. The Kansas City District (CEMRR-CT-H) will execute a Delivery Order on the Disposal Contract for a stated quantity of material.

e. CEMRK-CT-H will routinely process a disposal contrast modification to transfer Contracting Officer authority for the Delivery Order to an Alternate Contracting Officer identified by the District performing the remedial work to enable that District to process progress payments for the applicable Delivery Order.

f. The Kansas City District (CEMRRK) will retain Contracting Officer authority over a Delivery Order only when:

(1) USEPA is performing an emergency response action, or

(2) The Corps of Enginiers is not accomplishing the remedial work.

\section{Other Funding.}

a. The Customer will provide a fund cite for contract administrative costs to CEMRK-RM-B, for military appropriations to Mary Alers; for civil appropriations to Gloria Henshaw. Either may be reached at (816) 426-5658: 
b. The Customer will certify to CEMRK-RM-B that funds are available sufficient to pay the disposal cost at the then current contract rate per cubic yard.

c. The Kansas City District (CEMRK-CT-H) will execute a Delivery Order on the Disposal Contract for a stated quantity of material.

d. CEMRK-CT-H will process a disposal contract modification to transfer Contracting Officer authority over the Delivery Order to an Alternate Contracting Officer identified by the Customer to enable the Customer to process progress payments for the applicable delivery order.

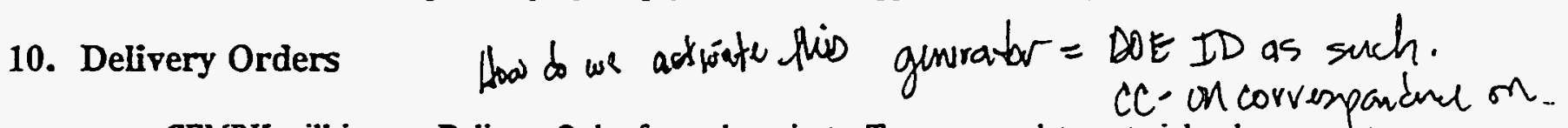
a. CEMRK will issue a Delivery Order for each project. To accommodate material volumes greater than specified in the project Delivery Order, CEMRK will issue a modification to the project Delivery Equivoca Order.

b. The mode of transport and type of packaging determine the price-per-cubic-yard for each project Delivery Order or Delivery Order Modification.

\section{Manifests to Confirm Delivery.}

2. The Customer or the Customer's agent shall complete and execute all required manifests.

b. Manifests will confirm the delivery and receipt of the material for disposal.

c. The signed copy of the original manifests will accompany the Pay Estimate submitted by the disposal contractor, Envirocare.

d. The original manifests will be sent back to the Customer once Envirocare receipts the wrste shipment.

\section{Customer's Responsibility for Transportation.}

a. Transportation of waste is not part of this Disposal Contract.

b. The Disposer (Envirocare) shall have no responsibility for arranging for transport, scheduling, or transporting waste.

c. The Customer or the Customer's agent shall transport and deliver the waste material to the disposal fasility:

d. Waste material for disposal under this contrast shall be transported and deliveret only

(1) In trucks or rail cars;

(2) In bulk or packages as required by 49 CFR 173, or as approved in uriting by the Disposer (Envirocare) prior to loading and shipment, and 
(3) In accordance with regulations for radioactive material in 49 CFR and any other applicable regulations.

e. The Generator or the Generator's agent shall be responsible for all packages and containers, shall warrant compliance with all rules, regulations, laws, and ordinances applicable to the safety, packaging, storage or transportation of such containers.

f. Any waste material not delivered packaged as described in paragraph $11 \mathrm{~d}$. may be considered nonconforming waste material at the option of the Disposer (Envirocare).

g. Upon discovering nonconformity or noncompliance of delivered material, the Disposer will give the Generator written notification. At its sole option, the Disposer may

(1) Remove or cause any nonconforming waste material to be removed and returned to the Generator, or

(2) Demand that the Generator remove or cause the waste material to be promptly removed.

h. All costs, expenses and fees for or resulting from the preparation for removal and removal of nonconforming waste material, including analysis and handling, shall be borne by the Generator.

i. The Generator shall schedule in writing each shipment of waste material with the Disposal Contractor. The Generalor shall provide the written schedule a minimum of three (3) days, but not more than five (5) days in advance of the shipment's arrival. A Generator's failure to provide a timely shipment schedule shall invalidate the contractually established turn-around time at the disposal facility, and the Disposer will not accept or be liable for any late charges or fees incurred.

j. Shipments must arrive at the Facility by 12 noon on the scheduled working day. Shipments arriving after 12 noon will be considered to have arrived the following working day.

k. Within two (2) working days after receipt of material by truck, or within four (4) working days of receipt of material by rail, the Disposer will unload shipping containers and prepare them for release.

1. Within 60 days, the Disposer shall make payment to the carrier of all demurrage and otber charges invoiced by the carrier by reason of the Disposer's failure to unload and release vehicles as agreed.

m. The Facility is required to accept a maximum of one hundred $(100)$ vehicular deliveries in any consecutive 7-day period. The Disposer shall be responsible for late charges for failure to meet the unload-and-release schedule only when:

(1) The Generator meets the required shipment notification schedule described in paragraph 11 i.

(2) The Generator delivers no more material than scheduled in a consecutive 7-day period; and

(3) The shipments meet all requirements of 49 CFR. 


\section{General Background Information.}

a. This contract assures ready access to all Government agencies of a licensed low-activity radioactive and mixed waste disposal facility.

b. A Customer may combine access to this disposal contract with its remediation and transportation contract to produce a complete remedy.

\section{Kansas City District Related Services.}

a. CEMRK has contracts with Architect-Engineer (A-E) firms qualified to design hazardous, toxic, and radiological waste remedies. We may use these contracts to support other agencies that lack adequate contracting capability. We may also support other agencies in procuring site-specific contracts with qualified remedial design A-E firms. With the assistance of an A-E firm, we can prepare remedial designs for advertisement and award a remediation contract.

b. CEMRK bas pre-placed contracts that make the services of selected remedial contractors available in a short time. Currently, three contractors with a broad scope of specialties are available to complete a mission in a time-critical manner.

\section{Previous Projects that used this NORM Disposal Facility.}

Radium Chemical Company, Woodside, Queens, New York

Montclair, West Orange, and Glen Ridge Radium Superfund Site, New Jersey

Denver Radium, Colorado

Lansdowne, Pennsylvania

Tinker Air Force Base, Oklahoma 


\section{IENDMENT OF SOLICITATIONIIII FICATION OF CONTRACT}

MENOMENTIMODIFICATIONNO.

POOJCS

1. EFFECTIVE CA: E

EDTS*-3298-0031

$\bar{\Sigma}: \vdots 0 \equiv Y$

ธะระ

$\mathrm{CT} \cdot \mathrm{H}$

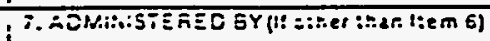

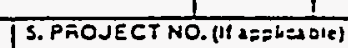

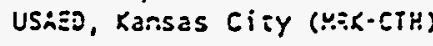

757 fecieral Building

601 E 12th Street

Kansas City, HO 64105-2596

Norna H. Reynolds

C37 (816)425-6isst

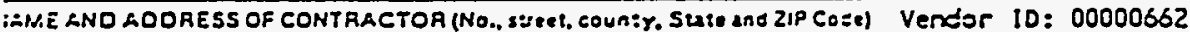

EWVIROCARE OF UTAH IHC

AT?EYT:CY: SUE R!SE

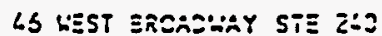

SALT LAKE CITY

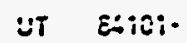

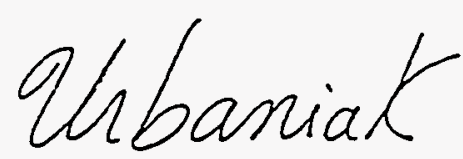

\begin{tabular}{|c|c|}
\hline$\infty$ & SA AMENDMENT OF SOLICITATION NO. \\
\hline & SB. OATEO (SEEITEM II) \\
\hline \multirow{2}{*}{$x$} & 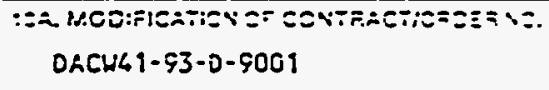 \\
\hline & $\begin{array}{l}\text { 105. DATED(SEEELEM 1J) } \\
\text { 12/31/92 }\end{array}$ \\
\hline
\end{tabular}

:DE

$0 T P 96$

TF́CILITY CODE

i. THIS TTEM ONLY AFFL:ES TO A'.:ENDMENTS OF SOUCITATIONS

ine above numbered soliciaion is ameneed as sei fonh in liem is. ine noir and caia specilied for receipt of OHers $\square$ is exiended, $\square$ is not exiencec.

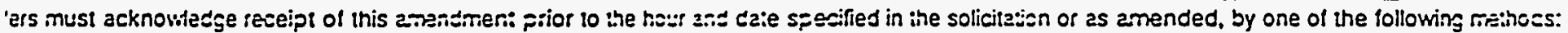

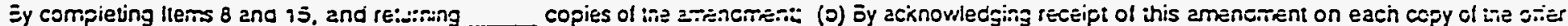
zmined; of (c) DY separate lerer or telegram which tncludes a rele:ence to the solicitation and amenctient numbers. FAILURE OF YOUR ACKUOWLEDG-

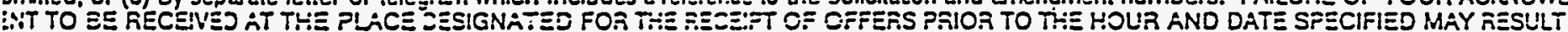

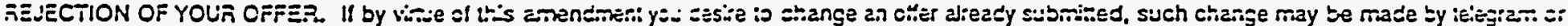

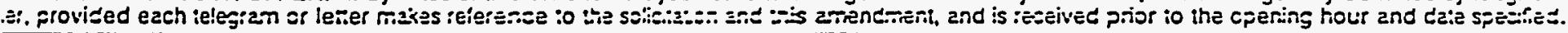

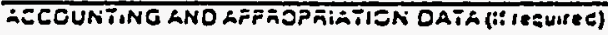

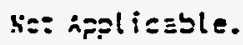

13. THIS ITEIA APPLIES ONLY TO MODIFICATIONS OF CONTRACTS/ORDERS, IT MODIFIES THE CONTRACTIORDER NO. AS DESCRIBED IN ITEM 14.

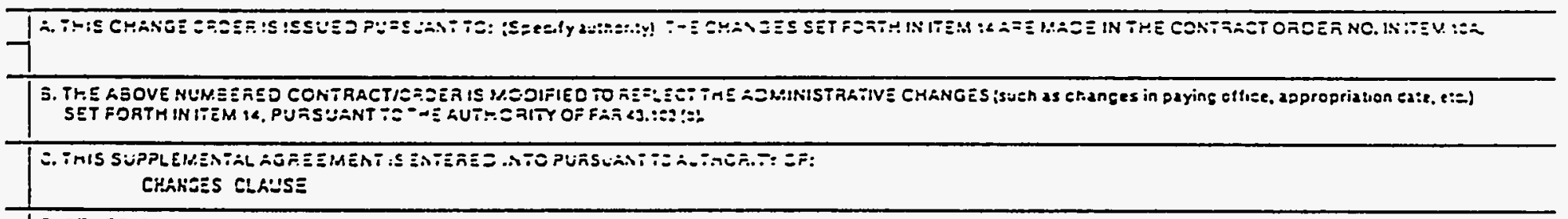

D. OTHER (Specily type of mociflesuon an: at: nori:yi

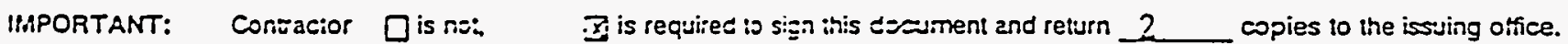

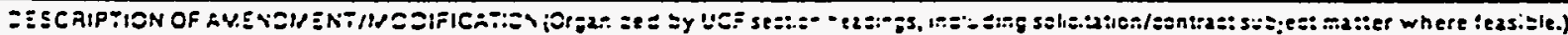

a. Hesessity for the znange. io deleie $p 25=5-2$, and sections $6 \cdot 1$

and $6-2$, and replase with a revisst page and ievised sez:ions of the

same number, dated kovember 15, 1893 for ite res:izt and sisposal of

MORM and Mixed Was:e.

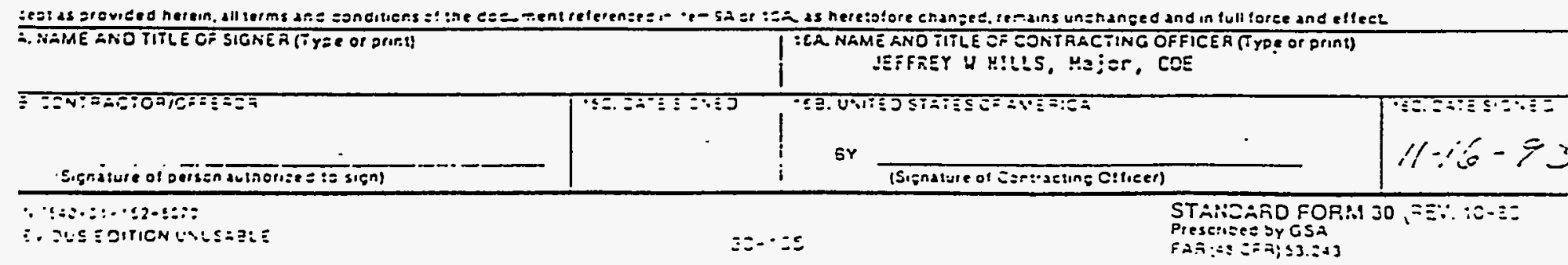


Ervirocare of liah, ine.

65 west sroadiay, Suite 200

Salt lake city, U:ah siriol

EIH: $\quad 87-0452047$

LS/KSA/S/H

Project Manager: Ton Urbaniak 8is-426-5832

Ex:. 3025

14. Description of anenciens/madisication:

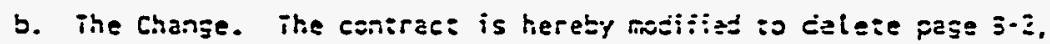
and seezions $C-1$ and $C-2$, and replace with a revis:- page and revised sections of the same numer, dated Novenjer i5, ijij. A copy of the revised page and each revised section accorpanies sis mocitication.

c. Time: Kot applicable.

d. Payment: Hot applicable.

The rosal obligated amoins of the Contract remains ithe sa=s at $57,787,533.00$. 
Radicxuclitk Dispasal Silc

RADIONUCLIDE WASIT DIDDING SQIIEDULE 2ND YIEAR

\begin{tabular}{|c|c|c|}
\hline 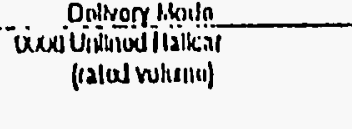 & s & 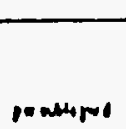 \\
\hline 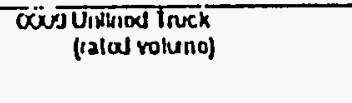 & 1 & onaterpes \\
\hline 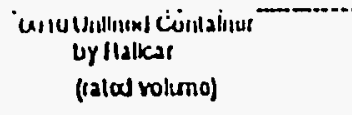 & $\$$ & onnateres \\
\hline 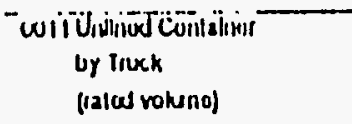 & s & ondented \\
\hline 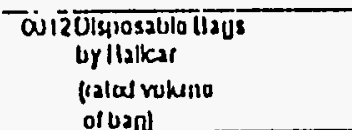 & $\$$ & pocaspost \\
\hline 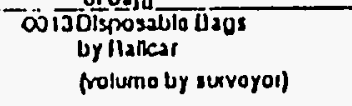 & $s$ & paternd \\
\hline 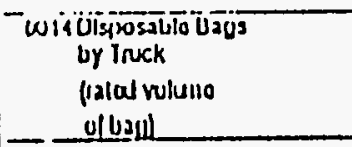 & $\$$ & penterped \\
\hline coss Dwils Dlgnocal by llabical & $\$$ & Mantopes \\
\hline QupDouils Disposal by Tiuck & $s$ & pundires \\
\hline
\end{tabular}

Riudionuclidi:Dispxasal Silc MIXED WASTE IUIDING SCHIEDULE 2ND YE:AIR

\begin{tabular}{|c|c|c|}
\hline 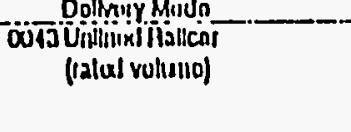 & 3 & oxachored \\
\hline 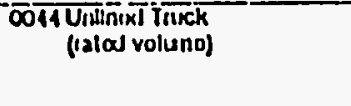 & $s$ & paserof \\
\hline 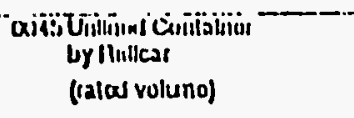 & 3 & pacestoposes \\
\hline $\begin{array}{l}\text { ôto Uidilixicunntahioi } \\
\text { ur Tiuck } \\
\text { (ralul volunos }\end{array}$ & 1 & puscaspes \\
\hline 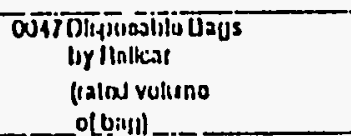 & 8 & incostent \\
\hline 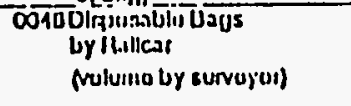 & 3 & 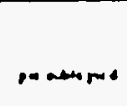 \\
\hline 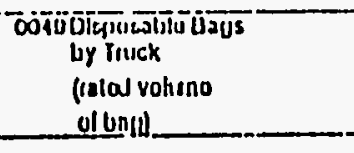 & $s$ & Matingers \\
\hline 01000 disis 1)tequosel liy flatkins & 3 & 1...040rs: \\
\hline 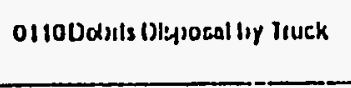 & 3 & encolowe \\
\hline
\end{tabular}


$D$ DAn $41-92-R-0026$

\section{INDEX}

SECTION $\mathrm{C}-1$

\section{SECTION}

C-1 MEZSUREMENT AND PAYMEITI

C-1-1 sid Sciedule Items 0003 $\approx 0043$ - jnlingd Railcar.

c-1-2 3id Schedule Items $0009 \& 0044$ - Unlined Truck.

C-1-3 Bid Schedule Items 0010 \& 0045 - Unlined Containers by Railcar.

C-1-4 3id Schedule Items 0011 \& 0046 - Unlined Containers by Truck.

C-1-5 3id Schedule Items $0012 \& 0047$ - Disposable Bags by Railcar.

C-1-6 3id Schedule Items 0013 \& 0048 - Disposable Bags by Railcar (Volume by Surveyor).

C-1-7 3id Scredule Items 0014 \& 0049 - Disposable Bag by Truck.

c-1-8 3id Sciedule Items $0080^{\circ} \& 0100$ - Deiris Disposal by Railcar.

C-1-9 bid Schedule Items 0090 \& 0110 - Dejris Disposal by irick.

(CH2304) 


\section{SECTIO:T $C-1$ MEASUREMENT IID PAYMENT}

C-1. GENERAI: Bid schedule items for all disposal volumes will be made at the unit prices bid, which unit prices shall include furnishing all labor, materials, equipirent, supplies and incidentals required to receive meterial and permanently dispose of same. The contracting officer will decide winich bid payment items are appropriate on sinipments from a given site.

C-1-1 Bid schedule iters 0008 \& 0043 - Unlined Railcar.

Ieasurezent for payment for the above subject items for disposal 0 i all soil and rubble material shall be the rated volume capacity of the railcar in cubic yards. Measurement will not consider material settlewent in transit. In shipments where the r.:-ierial has a readily identifiable shape, the contracting 0 ificer reserves the right to measure the volume of the pieces for paysent in lieu of the rated capacity of the railcar.

Payment for the above subject itess will be at the luit price bid EEI cubic yard wich paysent shall be full cozpensation for receipt and disposal oi the material.

C-1-2 3id schecule iters 0009 \& 0044 - Unlined Truck.

Yeasurezent for payment of the ajove subject itens for disposal OF 2 II Eaterial shall be the rated volume capacity $c$ i the truck in cubic yarcis. Yeasurement will not consider raterial settlezent in transit. In siprents finere the material has a readily identifiable shape, the contracting officer reserves the right to measure the volume of the pieces for payment in lieu of tise rated capacity of the truck.

payment for the above subject itens will be at the unit price bid per cubic yard which payment shall be full compensation for receipt and disposal of the material.

C-1-3 3id schedule items 0010 \& 0045 - Unlined Container by railcar.

Keasurement for payment of the aiove subject items for disposal cif all =aterial shall be the rated volume capacity of the unlined contairer in cubic yards. Measurenent will not consider naterial settlement in transit. In shipments were the material has a readily identifiable shape, the contracting officer reserves the right to measure the volume of the pieces for payment in lieu of

$$
C-:-1
$$

DACir41-93-D-9001 P00003

November 15,1993 
tise rated capacity of the railcar.

Payment for the above subject items will be at the unit price bid rer cubic yard which payment shall be full compensation for receipt and disposal of the naterial.

\section{C-1-4 Bid schedule items 0011 \& 0046 - Unlined Container by Truck.}

Yeasurement for payment of the above subject items for disposal ci all material shall be the rated volume capacity of the unlined container in cubic yards. Measurement will not consider material settlement in transit. In shipments where the material has a readily identifiable shape, the contracting officer reserves the rigint to measure the volume of the pieces for payment in lieu of tive rated capacity of the truck.

Eysent for the above subject itens wili be at the unit price bid Ear cubic yard which payment shall be full compensation for receipt and disposal of the raterial.

\section{C-1-5 Bid schedule items $0012 \& 0047$ - Disposable Sag by Railcar}

Yeasurement for payment of the above subject items for disposal oE naterial shall be the rated volune capacity of the disposable jag in cubic yards. Keasurezent will not consider aterial sEttlement in transit.

Eyment for the above subject itens will be at the unit price bid Eer cubic yard which payzent shall be full compensation for IEceipt and disposal of the raterial.

C-1-6 Bid schedule items 0013 \& 0041 - Disposable sag by Railcar.

Yazsurement for payment of the above subject items shall be the in situ volune of contazinated soil mezsured by a licensed surveyor at the site of origisation.

jaynent for the above subject items will be at the linit price bid ఏE cubic yard which payment shall be full compensation for zeceipt and disposal of the material.

C-1-7 3id schedule items 0014 \& 0049 - Disposable Eag by Truck

Ysasurement for payment of the above subject items for disposal $=$ E. iaterial shall be the rated volune capacity of the disposable

$$
c-1-2
$$


bag in cubic yards. Measurement will not consider material settlemert in transit.

Payment for the above subject items will be at the unit price bid per cubic yard which payment shall be full compensation for receipt and disposal of the material.

\section{C-1-3 Bid schedule items 0080 \& 0100 - Debris Disposal by Railcàr.}

Measurement for payment of the above subject items for disposal of contarinated debris shall be the rated volume of the container in cubic yards. Allowances will be made for weight linits to fill the containers. Measurement will not consicer materiai settlement in transit.

Payment for the above subject items will be at the unit price bid per cubic yard which paysent shall be full compensation for receipt and disposal of the material.

C-1-9 Bid schedule iters 0090 \& 0110 - Debris Disposal by Truck

Measurement for payment of the above subject itess for dispcsal of contaminated debris shall be the rated volune of the container in cubic yards. Allowances will be made for rieight limits to fill the containers. Measurement will not consizer =aterial settlezent in transit.

Payment for the above subject items will be at tre unit price bid per cubic yard which paynent shall be full cospensation for receipt and disposal of the material.

END OF SECTION

(Cri2302) 
DACH4 1-92-R-0026

\title{
IํำX \\ SECTEOR C-2
}

\author{
SECTION \\ C-2 CONTIMINATED SOIT \\ C-2-I scope o: ro: \\ c-2-2 2pplicable E:̈jlicaticns \\ c-2-3 Regulatory Becuizements \\ C-2-4 Contract Ovarview

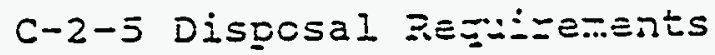 \\ C-2-6 fiaste contazinants \\ C-2-7 Products \\ c-2-3 Execution
}

(C)2304)

DAC $\because \div 1-93-D-5=01$ 


\author{
SECTION C-2 \\ CONTAMINATED SOIL DISPOSAI
}

\title{
C-2 GENERAI
}

\section{C-2-1 SCOPE OF WOPK}

The scope of work in this section addresses tise dispcsal of radioactive and mixed waste contaminated soil and deoris irom Civil $\bar{\alpha}$ Military sites within the continental united states. All radioactive material meeting the requirements of Envirocare of Utan's Radioactive Material License $\frac{5 T T}{\pi} 2300249$, and EPA Identification Number UTD982598893 shall be available For receipt and disposal under this contract at the licensed disposal facility.

This specification is for the purchase of services to permanently dispose of low activity radioactive waste from sites within the continental United States. This will be a sole source requirement contract. The initial contract shall be for a period on one (1) year with an option for four (4) additicnal years.

The disposal facility shall, as a minimua:

- Rèceive and unload contaminated zaterial.

- Test containers for renovable contamination and decontaminate as necessary prior to release from disposal facility for return to the site or origin, after unloading.

- Provide effective environfental jarriers to contain contaminated waste during unloading and placezent and prevent impacts of adverse reather occurrences ( erosion due to wind and rain).

- Notify waste generator's contractor to retrieve cecontaminated containers. Specisy wisether each container is suitable for reuse.

- Provide final decontamination of containers at conclusion of their use for shipment of material.

- Dispose of radioactive contaminated material waste according to applicable licenses and permits held by the disposer and according to all applicajle Federal, -State and local regulations.

$$
c-2-1
$$


C-2-2 PPPLICABLE PUBIICITIONS.

- Safety and Health Standard 29 CFR 1910 (GeneraI Industry), U.S. Department of Labor, Occupational Safety and Health Adrinistration (OSHA). Hereafter, referred as "29 CFR 1910".

- OSHA 29 CER 1910.120 Hazardous haste operations and Emercency Resconse, U.S. Departiment OE IaDcz, OSHA.

- OSiLA Safety and Health standard 29 CFR 1926 (Construceion Iroustry), U.S. Departient of Iabor, OSHa.

- U.S. Department of Transoortation 49 CER 171 throuch 49 CE? 179, as applicable.

- Standard Oderatino safetv Guidelines, U.S. Invironmenital Protection A.gency (EPA), Environmental Response Branci, iazarcious Response Support Division, Office of Emergency and Reredial Response.

- Occupational Safoty and jealth Guidance Manual for iizardous Waste site Activities, U.S. Department of ت̈ealth and ruran Services, Public jealtin Service, Cesiers for Disease Control, National Institute for Occupaticral safety and Eealti (HIOSii).

- Standards for Radiation Protection, 10 CFR 20, Nuclea= Regulatory Conisision (NRC).

- Guidelines for Decontamination of Facilities and equipreent Prior to Release for Unrestricted Use, NRC, 1976.

- Federal Acouisition Peoulations. (FAR) accident peevention, FAR Clause 52.236 .13 .

- Eederal Acouisition Requlations. (FAR) Indefinite Delive $=$ Contract Definition, FAR 52.216-221.

- Coros of Enoireers Safetv and iealth Peouirements Marazl, ER 385-1-1 (1987).

- Standards for grotection Aaainst Uraniun Mill Tailires, 40. CFP 192, U.S. Environaental Protection Agency (EPS). 
- Standards for owners and operators of yazarcous Haste Treatment, storage ard Disvosal Facilities, 40 CER 264 , EPA.

- Requlations for Identifyino Hazardous Fiaste, 40 CER 26I, EPA.

- Interin status standards for owners and operators of

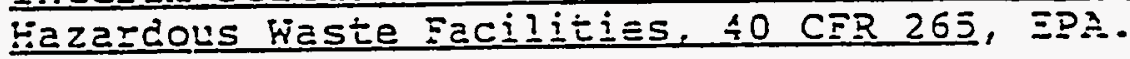

- Interim siandards for Owners and operacors of riazardolis Waste Facilities, 40 CFR 267, E?A.

- Requlations on Iand Disposal Requiremerts, s0 CFR 253, EPA.

\section{C-2-3 REGUTATORY REOUIREME:TSS}

Disposal of radioactive contanisated soil and ceoris shall conform but not necessarily be linited to the following regulations:

- occupational safety and Eealth Aoministration standarcs (OSil) Standards: 29 CFR 1910 and 1926.

- USEPX Standards for Irotection Against Uranium Mill Tailings (40 CFR 192).

- Nuclear Regulatory Comission Standarcs for Protection Against Radiation ( 10 CER 20).

- applicable Regulations oz state in whici the radiologicaliy conteninated soil is being disposed.

- USEPA Solid Faste Regulations and Stancards: 40 CFR 261; 40 CER 264; 40 CFR 255; 40 CFR $26740 \equiv 2$ 263.

- CERCIX Section $121(\dot{c})(3)$.

- Applicable Regulaticrs of the State of utan in inich the radioactive waste a:I rajioactive RCR:-iazardous haste is being disposed. 


\section{C-2-4 COYTRACT OOERVIEN}

The Governgent is awarding an indefinite quantity fixed unit price contract. The estimated volume to be generated is approximately 400,000 cubic yards of radioactive waste and approximately 4,000 cubic yards of Iadioactive RCRA-hazardous waste. Yet, the volune of material for this solicitation is unlinited.

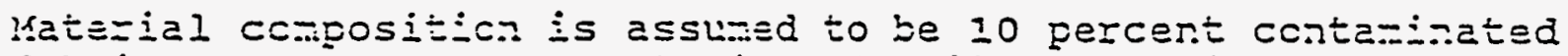
deoris and 90 percent contaminated soils. Deiris compesition is asslired to be material that is composed of building materials, rubble, and equipaent with very little soil. Soil is recessary to coyer tine ceiris in the disposal cell. wren contaminated soils are sot availajle, the disposal facility considers the use of uncontaninated soils to gain the required cover.

The tern of this contract will be from date of arard tinougin a period not to exceed five years. Ine disposal facility siali provide disposal services in complete accordance with tisis IF3 including ali ters and conditichs of this solicitatich.

It is the Govern=ent's intent to issue orders against this Iequizezents type contract on a Iixed-unit price basis lising tine estajlisind unit zices as stated in tre schedule. Tisese luit prices wuItiplied jy the quantity required for completion of the services will constitute a fixed price.

The Eixed-price rates subaitted siall be all inclusive (i.e., labo:, lajor overiead, general and adinistrative expense, and pIOEit) for receipt and disposal of the radioactive weste material.

\section{C-2-5 DISPOSAI REOUIREME:ITS}

The isposal facility shall subait the following infolaztion as

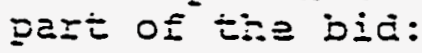

Genezal İiormaticn:

Facility rame asa E?a Identification riumber. Eacility locaticn.

Nare of responsiale contact for the facility.

Telepione number For the contact.

Sič: Istter o: agresment to accept wastes as specified. Unit of =easure uilizized at facility for costing purposes. Waste chazacterization requirerents. RCR Part 3 Per-i= Number (if different from EPA ID No.). Racicactione Haste License jumber.

$$
C-2-4
$$


Provide a report of the proposed facility's last state corpliance inspection.

Indicate what, if any, RCRA waste is or has been accepted at the facility.

Provide certification from the facility that it will accept the conforming waste material in total.

Erovide assurance that the site is capable of accepting tive waste year-round. As an alternative, show that tine iacility is licensed to stockpile tempozarily the waste curing inclement weather or other unsuitable geriods.

\section{C-2-6 HASTE CONTEMINANTS}

Provide copies of the waste description forms and other information that will be used to perform this contract.

It is the responsibility of the generator of the waste to deternine and obtain tie analytical services recessary to docuient the nature of the waste.

It is the responsibility of the disposal facility to ensure that the analytical results proviced aze acceptable and that tio waste contarinants identified are in compliance witi all applicajle pezits and licerses.

C-2-7 PRODUCTS

(NONE THIS SECTIOA)

\section{C-2-8 EXECUTION}

The disposal facility shall perford the services according to the scope of fiork issued linder tisis contract. The disposal facility Iist provice that level of services necessary to assure the facility is maintaining the requirements of their license.

The disposal facility shall delïer to the contracting oficicer the following reports in an original and four copies:

1. A wonthly repozt consisting o: an accounting of all waste material received. Ihe report shall contain as a minimum,

a. the volume and/cz weight handled curing the week fron each site o: origin inclidirs:

$$
c-2-5
$$


(1) Shipment/container number.

(2) Dates container was sampled for testing by disposal facility, and date of unloading at the disposal site.

(3) Containers returned for any reason.

(4) Copies of all documentation (such as manifiests).

(5) The locarion of each shipuent/container at the end of each Ecnth and whether it is (a) in staging at the disposal facility, or (b) placed in the disposal area.

2. An annual report to be submitted witinin 15 days after tre end of every calendar year accounting for containers and cubic yards of all waste material accepted and disposed 오.

3. A final report due 60 calendar days after completion of the delivery order which shall include the following:

a. In accounting of all waterials disposed of;

b. Certification that all vehicles and containers rere properly decontaninated prior to release for ot:er services; and

c. Description of the actual methods utilized for (1) disposal, and (2) iecontamination.

The disposal facility shall provide assurance to the corp of Engineers, Kansas City District, that upon completion of riaste disposal activities, the responsibility for short-term and iong-tern post-closure managezent of the disposal jacility iril ie in accoriance with the closure plan for the facility.

The licensee is responsible for site maintenance and monitcrirg "nder the short-term managemert phases. During this period, site cinersing reacins with the licensee. The long-ter managezent phase follows icense termination and site ownership trans zer to a governent agency responsible for custodial care of the waste aisposal upon closure of the site or receive an exemption to t:-e land transfe $=$ and have proper assurances that all custodial a=e of the facility is covered by the post-closure plan and prozer trust funds. This phase party is responsible for any monizc=ing and managenent that may be recuired.

$$
C-2-6
$$

DACH4I-93-D-9O0I 200003

:iove:Le= $15, \quad \geq \equiv 9$ : 


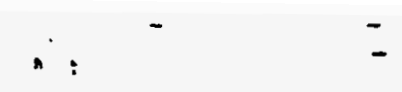

Such assurance shall also include documentation that the party will:

a. Be prepared to accept transfer and responsibility for disposed of radioactive contaminated and radioactive RCRA-hazardous materials.

b. Assume responsibilities under the license, and assume title to the land used for the waste disposal upon closure of the site; and

c. Assume responsibility for custodial care after site closure and observation and maintenance following closure.

END OE SECTION

(CH2305)

$C-2-7$

DÁCW41-93-D-9001 P00003

November 15, 1993 